\title{
PLANEJAMENTO \\ URBANO E \\ REGIONAL
}

\section{Marco Antônio Couto Marinho}

(Organizador)
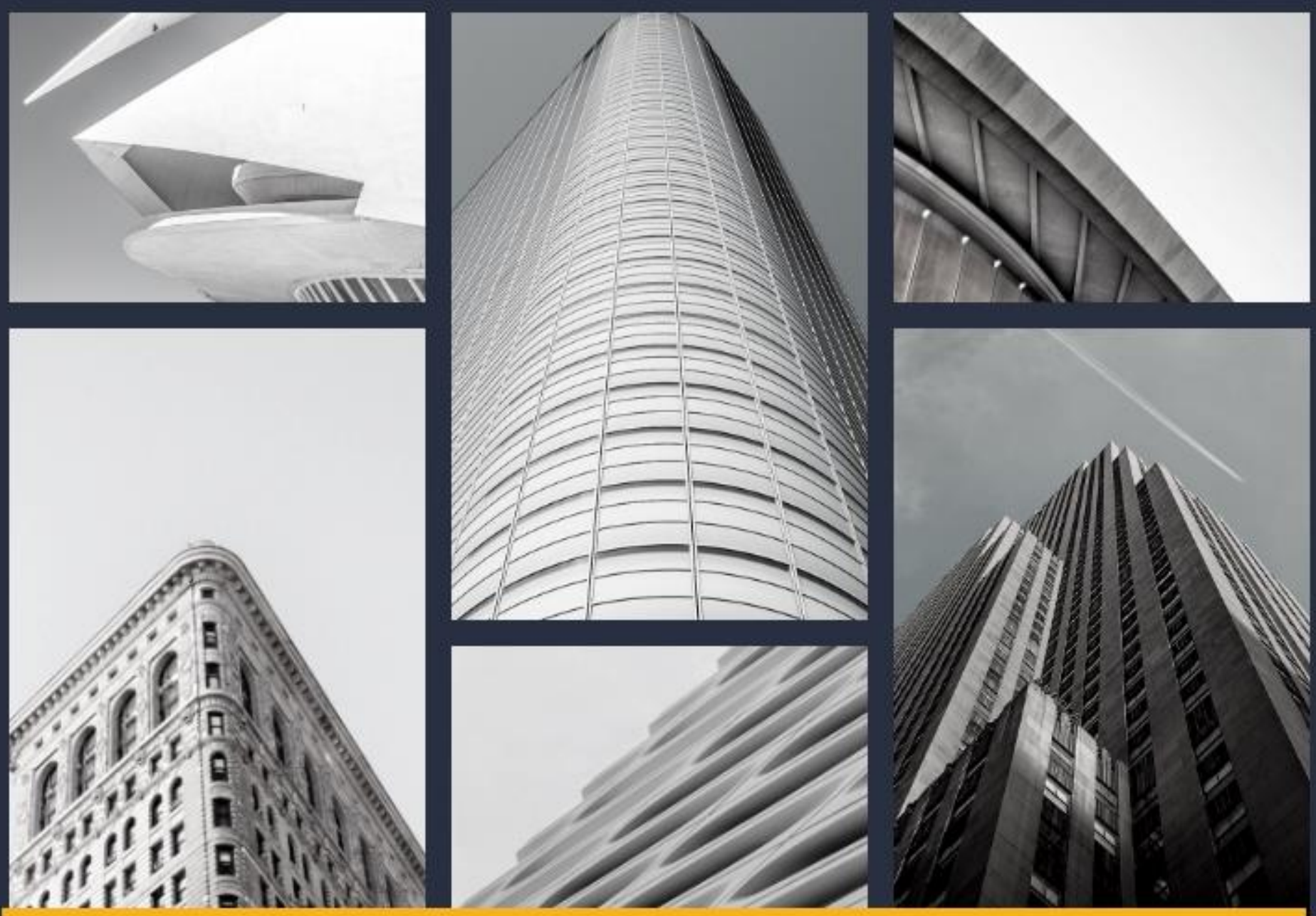

$\prec$ Editora Poisson 
Editora Poisson

\title{
Planejamento Urbano e Regional Volume 1
}

\author{
1a Edição
}

Belo Horizonte

Poisson

2018 
Editor Chefe: Dr. Darly Fernando Andrade

\section{Conselho Editorial}

Dr. Antônio Artur de Souza - Universidade Federal de Minas Gerais

Dra. Cacilda Nacur Lorentz - Universidade do Estado de Minas Gerais

Dr. José Eduardo Ferreira Lopes - Universidade Federal de Uberlândia

Dr. Otaviano Francisco Neves - Pontifícia Universidade Católica de Minas Gerais

Dr. Luiz Cláudio de Lima - Universidade FUMEC

Dr. Nelson Ferreira Filho - Faculdades Kennedy

Ms. Valdiney Alves de Oliveira - Universidade Federal de Uberlândia

Dados Internacionais de Catalogação na Publicação (CIP) P712

Planejamento Urbano e Regional - Volume 1/

Organização: Marco Antônio Couto Marinho

Belo Horizonte - MG: Poisson, 2018

$303 p$

Formato: PDF

ISBN : 978-85-7042-019-0

DOI : $10.5935 / 978-85-7042-019-0.2018 B 001$

Modo de acesso: World Wide Web

Inclui bibliografia

1. Cidade 2. Planejamento. 3. I. Título

CDD- 658

O conteúdo dos artigos e seus dados em sua forma, correção e confiabilidade são de responsabilidade exclusiva dos seus respectivos autores.

$\underline{\text { www.poisson.com.br }}$

contato@poisson.com.br 


\section{APRESENTAÇÃO}

A presente obra consiste numa coleção de textos, que trazem debates em torno da questão territorial no Brasil, produzidos por estudiosos de diferentes áreas do conhecimento como a Geografia, Planejamento Urbano e Regional, Arquitetura e Urbanismo, Direito, Política, Economia, Cultura, Ciências Sociais, Educação. Trata-se de um desafio epistemológico voltado para a reflexão sobre a produção do espaço urbano e rural, em suas diversas facetas, todas elas impactadas pela pós-modernidade e pelos fenômenos a ela associados tais como a supremacia da urbanização, a globalização, o advento das novas tecnologias de informação e comunicação e as mudanças nas relações entre territorialidades na sociedade contemporânea.

Historicamente, o Brasil teve sua formação territorial em torno de cidades litorâneas, o avanço das fronteiras ao oeste foi posterior e acompanhado do extermínio dos povos indígenas e também do desmatamento de vegetações nativas, sendo a urbanização um fenômeno mais recente, dos últimos 100 anos. Em um país de proporções continentais há uma vasta parcela de sua população que foi forçada a ocupar morros de forma clandestina, a residir em vilas e em favelas, ou mesmo quando em outras condições comprometidas por toda vida em financiamentos de imóveis populares com míseros metros quadrados, no aluguel ou em casas autoconstruídas nas periferias com pouca ou nenhuma estrutura urbana nem o acesso pleno aos serviços. Essa contradição entre o gigantismo do território nacional e a falta de acesso ao espaço por grande parte de sua própria população em função da discrepância entre os valores dos salários em relação ao valor do preço da terra e imobiliário, é apenas uma das facetas abarcadas pelo estudo do território.

Desde a dependência em relação à economia do café, à construção de paisagens sonoras, políticas e culturais em territórios agrários e urbanos, o território representa uma categoria de análise central entre os diversos campos do conhecimento supracitados, apresenta-se como o palco e ambiente onde se desenvolvem as relações humanas, estando submetido à confluência de forças e disputas. Contudo, essas disputas nem sempre se convertem em conflitos públicos, visíveis, pelo contrário podem ocorrer de forma pouco perceptível tornando-se invisível para a grande maioria dos habitantes de um determinado lugar ou cidade, que tenderam a naturalizar sua relação com o território. Nesse sentido, o livro consiste traz um amplo panorama sobre a complexidade a partir da qual o território materializa-se, dessa maneira, produz paisagens das quais estruturam-se as dinâmicas responsáveis pela própria reprodução da realidade, do espaço da vida.

Aproveite a leitura!

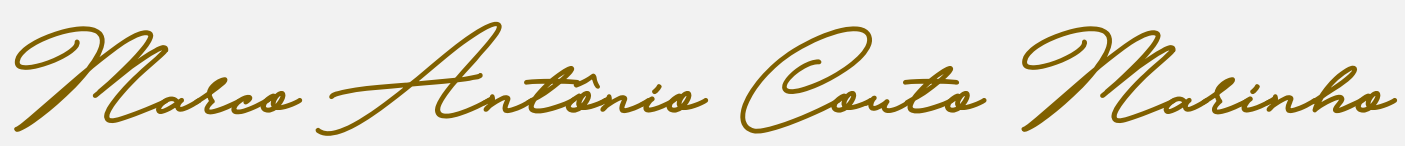




\section{Sumárīio}

Capítulo 1: Praça Presidente Vargas: relação entre espaço público e atores sociais

Jozieli Camila Cardenal, Hieda Maria Pagliosa Corona

Capítulo 2: A financeirização do capital imobiliário e a interiorização de Grandes Projetos Urbanos: o caso de Goiana-PE

Caroline Gonçalves dos Santos, Flávio Antônio Miranda de Souza

Capítulo 3: Estado, território e gestão da cidade: o caso da Operação Urbana Consorciada Nova BH

Reginaldo Magalhães de Almeida, Juliana Lamego Balbino Nizza, Amanda Pereira de Oliveira Diniz, Jorge Eulampio Monteiro Junior

Capítulo 4: Territórios sonoros do sertão alagoano.

Walcler de Lima Mendes Junior, Juliana Michaello Macêdo Dias

Capítulo 5: A confluência perversa e a questão agrária brasileira

Diná Andrade Lima Ramos, Carlos Frederico Bom Kraemer, Lamounier Erthal Villela

Capítulo 6: O Vale do Café no século XXI: comparação de indicadores de desenvolvimento rural sustentável e os desafios de escala geográfica

Gabriel Magalhães Rodrigues, Marcio Silva Borges

Capítulo 7: Coisas velhas, coisas do passado, mas sempre nossas:

Patrimônio cultural, educação no campo e desenvolvimento local

Shirlei Alexandra Fetter, Daniel Luciano Gevehr, Jacques Andre Grings

Capítulo 8: A dupla face da cidade: o Rio de Janeiro nas crônicas do início do século $X X$

Guilherme Mendes Tenório, Cesar Augusto Miranda Guedes

Capítulo 9: Máximo esforço, mínimo resultado: a poética urbana de Francis Alÿs 


\section{Sumárīio}

Capítulo 10: Narrativas da cidade: uma aproximação entre memória coletiva, cidade e literatura

Rodrigo Vitorino Assumpção, Jane Victal Ferreira

Capítulo 11: As 'fronteiras' da governança urbano-regional: reflexões sobre proximidades, ação coletiva e aprendizagem

Mariana Galacini Bonadio

Capítulo 12: Espaços de Humanização: simbolismo e apropriação no Parque José Affonso Junqueira.....

Esther Aparecida Cervini de Melo, Jane Victal Ferreira, Renata Baesso Pereira

Capítulo 13: Urbanismo Insurgente: ações recentes de coletivos urbanos ressignificando o espaço público na cidade de São Paulo

Maria Carolina Maziviero, Eneida de Almeida

Capítulo 14: Resistência e Melhoria Habitacional: reflexões sobre uma atuação dialógica junto à Comunidade Indiana na cidade do Rio de Janeiro ...

Maria Paula Gonçalves Lysandro de Albernaz, Fernando Cesar Negrini Minto, Malu França de Miranda, Huani Quintanilha Felinto, Bruna Garritano Ferreira

Capítulo 15: Campo dos Alemães em São José dos Campos / SP como campo de disputa simbólica: o que dizem os muros

Frederico Papali, Valéria Zanetti, Paula Vilhena Carnevale Vianna

Capítulo 16: Cidade cativa: estratégias de uma urbanização oligopolista em uma cidade mato-grossense.

Lívia Maschio Fioravanti

Capítulo 17: Habitação popular em Curitiba/PR: da criação da COHAB à implementação do Programa Minha Casa Minha Vida.

Fabiana Alves Monteiro 


\section{Sumárīio}

Capítulo 18: O reflexo da reestruturação produtiva nas cidades médias: o caso de Varginha/MG.

Helen Ribeiro Rodrigues, Teresa Cristina de Almeida Faria

Capítulo 19: Simulação de elevação do nível do mar na cidade de Joinville (SC)

Samara Braun, Juarês José Aumond

Capítulo 20: Percepção de idosos brasileiros sobre os fatores limitantes de interação com o espaço público: O caso das praças na cidade de Florianópolis/SC

Alba Valeria de Barros e Silva Pinheiro, Fernando Manuel Brandão Alves, Paulo Santos Conceição

Capítulo 21: Microurbanismo Efêmero: Táticas urbanas criativas 275

Tiago Balem

Autores 


\section{Gapítulo 1}

\section{PRAÇA PRESIDENTE VARGAS: RELAÇÃO ENTRE ESPAÇO PÚBLICO E ATORES SOCIAIS}

\section{Jozieli Camila Cardenal,}

\section{Hieda Maria Pagliosa Corona}

Resumo: A Praça Presidente Vargas, situada em Pato Branco, no Sudoeste do Paraná, é um espaço público constituído historicamente por relações sociais vinculadas ao desenvolvimento urbano da cidade, a partir de experiências desencadeadas por atores sociais, entre elas a mobilização pela construção da Igreja Matriz e o movimento social de 1957 pela regularização da posse de terra na região. Diante disto, o presente estudo abordará o protagonismo de atores e grupos em acontecimentos de relevância histórica e social ocorridos no local, evidenciando a relação entre o sujeito e o espaço urbano.

Palavras-chave: Atores Sociais; Espaço Urbano; Praça Presidente Vargas; Pato Branco; Desenvolvimento. 


\section{INTRODUÇÃO}

A percepção do lugar varia para cada indivíduo. Contudo, o lugar é construído coletivamente e, por mais que seja aparentemente inerte, não é inanimado, pois recebe influências da interação entre o homem, a sociedade e o ambiente. Assim, constituem-se os espaços públicos que, nas cidades, são transformados na medida em que os atores sociais os modificam a partir de suas experiências e necessidades.

As reflexões a seguir mostrarão que o espaço público é componente fundamental da história e do desenvolvimento urbano. Isso pode ser evidenciado a partir de exemplos significativos da "imaginária urbana", bem como por meio de ações de diferentes agentes/atores sociais - desde os pioneiros que, em suas distintas áreas de atuação e em diferentes contextos históricos, transformaram realidades e contribuíram para o desenvolvimento de suas cidades.

É justamente esse o percurso proposto por este estudo, que relaciona momentos emblemáticos da história de Pato Branco com a relação que a sociedade, através de seus agentes, mantém com a Praça Presidente Vargas - espaço público que, desde a década de 1930, compõe o ambiente e o tecido social local, e reflete transformações que ultrapassam dimensões meramente físicas.

Não estamos falando de um espaço inorgânico, pelo contrário, a praça em questão refere-se a um lugar significativo, que possui forte representatividade simbólica para a cidade, pois sediou movimentos marcantes para a construção histórico-social do município e recebeu importantes intervenções estruturais urbanas, acompanhando o crescimento da cidade.

Para tanto, o presente artigo partirá da intervenção de atores sociais no reconhecimento do espaço público urbano, relacionando a abordagem teórica com eventos de caráter histórico-sociais desencadeados na praça central de Pato Branco, buscando evidenciar assim a relação entre os sujeitos e o lugar, com base em noções de territorialidade a partir de aspectos do desenvolvimento local.

Esse conjunto de representações norteará, ainda, questões levantadas que traduzem traços da modernidade na prática social evidenciada nos diferentes contextos históricos e na vida cotidiana. Propõe-se elucidar que a ótica urbana meramente estrutural e física é falha, uma vez que a história de um lugar reconhecido como público, por representar a identidade cultural local, também está diretamente ligada à história e ao desenvolvimento da cidade onde o mesmo está inserido.

No caso da Praça Presidente Vargas, o espaço aberto, sem grades, indica que todos podem se aproximar. Além disso, são dezenas de bancos contornando o local, convidativos para o descanso ou para a prosa leve. É o palco da diversidade. Há também o playground para as crianças e a quadra de futebol. $O$ paisagismo com jardins e arborização, caracteriza o ar aconchegante. Destaque ainda para o chafariz que marca o coração da praça, além do memorial histórico, que relembra momentos emblemáticos do local, o que reforça a valoração que a população assume pelo espaço. Aliás, é nele onde foi edificada a matriz da cidade, na década de 1960, com a participação voluntária da população e relatos de pessoas que trabalharam 400 dias na obra. Alguns anos antes, em 1957, agricultores se uniram ao maior movimento agrário já realizado no Brasil, a Revolta dos Posseiros - o que também ocorreu na praça.

Assim, pretende-se apontar que o espaço físico é concebido por interações desencadeadas por fatos urbanos e que, enquanto reflexo de experiências humanas, assume o ritmo da dinâmica social, que está em constante movimento. Portanto, as reflexões a seguir apresentam um processo histórico onde o "lugar" adquire características que precisam ser observadas para além de suas formas físicas.

Para dar conta do objetivo que orienta o presente artigo, no item 1 será abordada a simbologia do espaço público "praça", relacionando com características específicas do objeto de estudo em questão, que é a praça central de Pato Branco. Ao apresentar fatos emblemáticos para a ótica do local, sobretudo para o desenvolvimento da cidade, propõe-se mostrar o papel dos agentes sociais na transformação da realidade local, onde o fio condutor será partilhado por Anthony Giddens e Pierre Bourdieu, com outros autores que contribuem para a reflexão.

Fica aqui o convite para um breve passeio pela história desta cidade, situada no 
Sudoeste do Paraná, e que certamente tem aspectos semelhantes a milhares de outras cidades de médio porte do Brasil, onde a população permanece próxima da praça central, seja no passeio despretensioso no entardecer, ou na união popular para reivindicar alguma mudança. Contudo, mesmo que viva a cidade e a praça, a comunidade nem sempre reflete sobre elas, ou reconhece a representatividade de movimentos sociais desencadeados em determinados momentos. É por isso que escrevemos este artigo.

\section{O ESPAÇO PÚBLICO URBANO E A ATUAÇÃO DOS AGENTES SOCIAIS}

Em uma cidade relativamente jovem como Pato Branco, com pouco mais de 60 anos de emancipação política, a vida pulsa no anel central. Prática cotidiana que começou nas primeiras décadas de colonização, pois 0 comércio, o lazer e os principais atrativos da vida urbana estão condicionados na mesma extensão física desde a década de 1930. De lá para cá, o perfil cultural, econômico e social da comunidade foi transformado - contudo, ainda preservam traços de sua colonização, estes que não estão tão no passado assim.

A constituição histórica de espaços públicos é definida por interações sociais, que refletem o desenvolvimento social, econômico e cultural de determinada localidade. Foi assim com a Praça Presidente Vargas. Nela, experiências desencadeadas por atores sociais enalteceram a ligação entre os sujeitos e o "lugar" - que não é apenas transitório, ou um mero ambiente de passagem; mais do que isso, integra o dia a dia da sociedade e, sobretudo, apresenta reflexos da vida moderna, como expressada pelas lógicas de uso e de infraestrutura que a praça fora tendo ao longo das últimas décadas.

O que configura um "espaço público" é, justamente, o conjunto de relações interpessoais atribuídas a ele. Portanto, é importante considerar a diferença entre "lugar" e "espaço", pois o segundo é uma variável praticável do primeiro. Ou seja, o espaço existe a partir da apropriação individual e coletiva do mesmo, em que constitui-se enquanto "um lugar praticado", formado por um sistema de signos (CERTEAU, 1994, p.202).

Quando um lugar passa a ser habitado, altera-se a relação entre sociedade e natureza. O natural ganha viés de artificial, recebe elementos e simbolismos do novo contexto que está prestes a ser formado. Processo que, conforme Milton Santos (2009, p.233), é "[...] sucessivamente instrumentalizado por essa mesma sociedade". A relação entre o "natural" e o "artificial" é alterada de acordo com cada novo contexto, em cada novo momento histórico (SANTOS, 2009, p.233).

processo de urbanização da Praça Presidente Vargas, a partir da prática dos atores/agentes sociais, evidencia tal percepção.

Não há registros que comprovem com exatidão o ano em que a Praça Brasil - antigo nome da Praça Presidente Vargas - começou a se formar enquanto espaço urbano, previamente delimitado. Há, por outro lado, a conotação simbólica do reconhecimento da população a partir da intervenção religiosa franciscana, ocorrida com a transferência da capela para esse local em 1935 (BODANESE, 1982, p.09).

Embora o primeiro traçado viário de Pato Branco já tivesse sido elaborado pelo Engenheiro Duílio Beltrão, na década de 1930, o conjunto de elementos típicos de uma colonização de descendentes europeus - que segue certa lógica em que a igreja, junto com os demais serviços, vai definindo o anel central, pois é em torno dele que vão se instalando as moradias e demais edificações/funções - conduziu a definição do anel central. Na época, já havia algumas casas e comércio no entorno do espaço, mas foi a transferência da capela para a área correspondente à praça que de fato consolidou a constituição simbólica e social do espaço público (VOLTOLINI, 2005).

Sabe-se, portanto, que foi a partir da transferência da igreja que a praça passou a ser reconhecida pela população. "E como, num povoado interiorano nos moldes de Villa Nova, tudo girasse em torno da igreja, mudouse também o ponto polarizador da vila, mantendo-se através dos anos e transformando-se no centro da cidade de Pato Branco", (VOLTOLINI, 2005, p.291). Neste período, muito antes da emancipação política da localidade, a mesma era conhecida como "Villa Nova".

Desde a constituição da Praça Presidente Vargas, fica evidente o papel dos atores sociais na consolidação física e simbólica deste espaço construído socialmente, através da intervenção da comunidade. Tal evidência 
está presente no conceito de "território" - este que, segundo Sarita Albagli (2004), é reconhecido enquanto um "[...] espaço apropriado por um ator, sendo definido e delimitado por e a partir de relações de poder, em suas múltiplas dimensões", (ALBAGLI, 2004, p. 26).

Assim, é possível evidenciar o papel dos atores sociais, pois o território é produto da intervenção desses sujeitos sobre o espaço a que pertencem ou estão inseridos. A partir dessa concepção, observa-se que o espaço não se limita apenas ao aspecto físico, ou a sua dimensão material, pois é construído historicamente a partir de diferentes contextos: a casa, o bairro, a cidade, a região, a nação, o planeta (ALBAGLI, 2004, p.26). Essa dinâmica relacional, ainda segundo Albagli (2004, p.27), pode ser observada em quatro dimensões: física, econômica, simbólica e sociopolítica - e este estudo, que tem como objeto central a Praça Presidente Vargas, transitará pelas quatro áreas.

Para tanto, é necessário considerar além da concepção de território e espaço, a definição social de "lugar", este que deve ser reconhecido não apenas pelo cotidiano ou pelo seu caráter transitório, mas "[...] como aquele no qual se situam as transformações e a reprodução das relações sociais de longo prazo, bem como a construção física e material da vida em sociedade" (ALBAGLI, 2004, p. 51). Sendo assim, o lugar deve ser reconhecido como um espaço onde a sociedade escreve a sua história, a partir das experiências e interações da prática cotidiana.

Nele, realiza-se o cotidiano, o momento, o fugidio, mas também a história, o permanente, o fixo, o correspondendo ao identitário, ao relacional e ao histórico, no âmbito da tríade habitante-identidade-lugar. O papel do lugar é determinante. Ele não é apenas um quadro de vida, mas um espaço vivido, isto é, de experiência sempre renovada, o que permite, ao mesmo tempo, a reavaliação das heranças e a indagação sobre o presente e o futuro. A existência naquele espaço exerce um papel revelador sobre o mundo. (ALBAGLI, 2004, p. 51)

Ao definirem a delimitação física da praça central de Pato Branco, os pioneiros enquanto atores sociais - deram início a uma sequência de relações que culminaram em diferentes aspectos característicos não apenas do anel central, mas que também refletiram no desenvolvimento da cidade. Afinal, a imaginária urbana, o espaço público e os agentes sociais representam a tríade que traduz a memória e a cultura urbana (FILHO, 2008, p.25).

Nesse contexto, o sujeito não é mero reflexo da ação social ou da organização do espaço físico: ele é atuante, protagonista no processo de formação social e na construção histórica. Tal concepção pode ser analisada a partir de Pierre Bourdieu (1996), que traz o papel do agente social, que pode atuar de forma singular ou juntamente com um grupo, uma classe de agentes. Essa atuação constrói o espaço social, ou seja, a "realidade invisível" que compõe o tecido de relações que aproximam os agentes por meio de um conjunto de interesses, posicionamentos, crenças e hábitos (BOURDIEU, 1996, p.24).

Sendo assim, o espaço social é construído coletivamente, uma vez que não resume-se a simples matéria inanimada, pelo contrário, "[...] é a realidade primeira e última já que comanda até as representações que os agentes sociais podem ter dele" (BOURDIEU, 1996, p.27).

Essa complexidade resulta do protagonismo dos agentes, que por vezes demonstram autonomia individual e coletiva diante da hierarquia política e econômica (BOURDIEU, 2001, p.31). Ao transformarem a realidade social, os atores (ou agentes), inferem no contexto histórico local, bem como na dinâmica relacional da comunidade.

[...] basta que os agentes se deixem levar por sua "natureza", isto é, pelo que a história fez deles, para estarem como que "naturalmente" ajustados ao mundo histórico com o qual se defrontam, para fazerem o que é preciso, para realizarem o futuro potencialmente inscrito nesse mundo em que eles estão como peixes dentro d'água. (BOURDIEU, 2004, p.130)

Afinal, a decisão de padres franciscanos pela transferência da igreja, que desde o início da década de 1930 estava situada na rua Tapir, nas proximidades da avenida Tupi, conduziu não somente a delimitação da praça, mas a formação do anel central, pois fomentou a instalação de estabelecimentos comerciais no entorno do espaço. Entre as famílias pioneiras que acompanharam o fluxo do anel central que começava a se formar, estava a do professor Juvenal Cardoso, reconhecido até os dias de hoje pelo pioneirismo na educação de Pato Branco. Como a escola situava-se 
junto à casa do educador, ganhava nova sede a cada mudança da família, por isso também se instalou no entorno da praça (VOLTOLINI, 2005).

Entre as décadas de 1930 e 1940, além da capela e da escola, a praça sediava outra importante construção: o primeiro hotel de Pato Branco, de propriedade do alemão Paulo Schmidt, que ocupava a área onde hoje é o edifício Severino Cavazzola, no início da rua Pedro Ramires de Mello. A estrutura era um casarão, em que o pátio era usado pela escola do professor Juvenal Cardoso como área de recreio e atividades (VOLTOLINI, 2005).
Ainda no ramo hoteleiro, entre as décadas de 1940 e 1950, o pioneiro Pedro Ramires de Mello transformou o armazém da família no Hotel Brasil, situado na avenida Tupi, onde hoje é a Caixa Econômica Federal. O estabelecimento, que levava o nome da praça, foi vendido para Clemente Pastro, em 1950. Contudo, "Pedro Xico" continuou no ramo e construiu, na esquina da rua Silvio Vidal e da avenida Tupi, o Hotel Rodoviária (hotel em cima e rodoviária embaixo), uma vez que Pato Branco já recebia linhas regulares de ônibus - algo de representatividade regional para a época (VOLTOLINI, 2005). A localização dos dois hotéis está ilustrada no mapa a seguir:

Mapa 1: Praça Presidente Vargas, Hotel Brasil, Hotel Rodoviária, Matriz São Pedro Apóstolo e ruas do entorno.

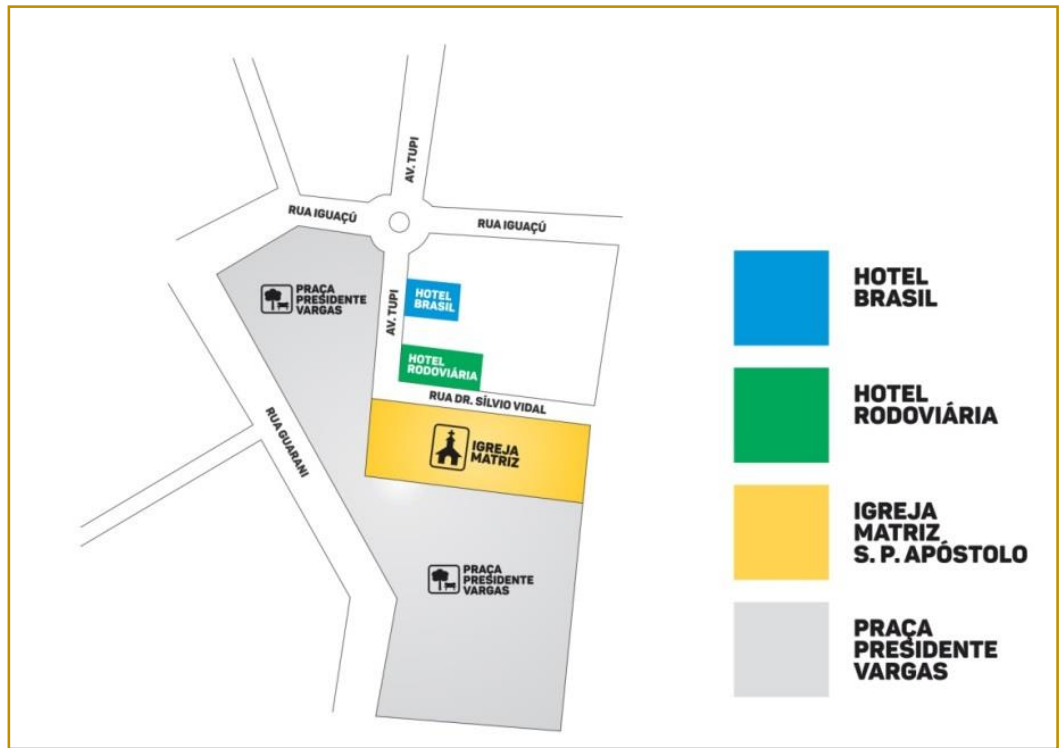

Fonte/descrição: Mapa criado pela autora, baseado no desenho atual da praça, ilustrando os dois hotéis em questão, conforme disposição da época.

Portanto, a delimitação geográfica de determinado espaço infere, sobretudo, nas relações de trabalho, de poder, de alteridade política, inclusive, de condições econômicas. Conforme Santos (2009, p.255), "nas cidades, a produção não é mais ação do trabalho sobre a natureza, mas do trabalho sobre o trabalho [...]". Assim, é preciso reconhecer que a dinâmica vivenciada no espaço configura-se enquanto base da vida econômica e social das comunidades (SANTOS, 2009, p.255).

As condições iniciais que caracterizam o desenvolvimento local estão diretamente ligadas à história, assim como direcionam o futuro de determinada comunidade. Neste sentido, a consolidação dos mercados está relacionada ao nascimento e formação das cidades, o que resulta do processo de desenvolvimento. Afinal, "[...] os mercados locais se desenvolveram a partir de atos individuais de permuta", (POLANYI, 1980, p.82).

Há lojas situadas no entorno da Praça Presidente Vargas há mais de 40 anos. Tal característica justifica-se uma vez que "[...] sinergias espacialmente localizadas muitas vezes mantêm relação com uma história de formas de reciprocidade no tecido social", (RADOMSKY; SCHNEIDER, 2007, p. 263). Essa proximidade reflete na dinâmica da cidade, pois resultam de ações que 
estimulam o desenvolvimento através dos atores sociais.

Hoje, Pato Branco é referência em diversos setores econômicos em âmbito regional, inclusive no comércio e na prestação de serviços. Destaque para $\mathrm{O}$ anel central pulsante, que dispõe de ampla variedade de produtos e que movimenta não apenas o município, mas também recebe consumidores de diversas cidades da região Sudoeste do Paraná e Oeste de Santa Catarina.

Assim, é possível relacionar o pioneirismo datado da década de 1930 ao crescimento vivenciado nos dias de hoje, pois é característica comum de pequenos negócios promoverem intensificações e estimularem a produção local (FILHO, 2001, p.268). Evidencia-se o papel das "antecipações" instituídas pelos agentes, que podem ecoar no futuro da economia (FILHO, 2001, p.265) como ocorreu em Pato Branco.

Afinal, o fortalecimento de territorialidades estimula laços de identidade e cooperação. Isso baseia-se "[...] no interesse comum de proteger, valorizar e capitalizar aquilo que um dado território tem de "seu" - suas especialidades econômicas", (ALBAGLI, 2004, p.63). Diante disso, as territorialidades são construídas a partir da doação inicial de "capital socioterritorial", que pode ser acumulado ou herdado em processos históricos (ALBAGLI, 2004, p.63).

Ainda sobre o nome "Praça Brasil", vale pontuar que foi em 25 de outubro de 1953quase dois anos após a emancipação política do Município -, que o então prefeito Plácido Machado sancionou a lei no 49/53, que previa a denominação de praças e ruas, entre elas a praça "Presidente Vargas". Plácido Machado era filiado ao Partido Trabalhista Brasileiro (PTB), fundado em 1945, sob inspiração e liderança de Getúlio Vargas. Além do contexto político, como a maioria dos colonizadores de Pato Branco eram do Rio Grande do Sul, o nome também configura-se como homenagem aos gaúchos.

Desde o seu reconhecimento enquanto espaço público, na primeira metade do século XX, a Praça Presidente Vargas passou a ser vista como um ponto polarizador da cultura e da interação social e do desenvolvimento local. Tal característica atende ao posicionamento de Antonio Colchete Filho (2008) que, neste sentido, aponta o significado social das praças:
Vista no conjunto de espaços da cidade, a praça reúne elementos históricos e formais que designam como um dos espaços mais importantes do meio urbano. [...] e históricos, porque, ao possuir características que permitem a concentração de pessoas, atrai atividades importantes para o seu próprio espaço e para o entorno, atuando como um cenário importante dos fatos sociais. (FILHO, 2008, p. 32)

Contudo, é preciso considerar que o percurso que traduz a atuação dos atores sociais nem sempre é amistoso. A praça central de Pato Branco sediou lutas, fervorosas missões, encontros religiosos. Um dos exemplos mais emblemáticos é a Revolta dos Posseiros, o maior movimento agrário do Sul do Brasil, que teve a Praça Presidente Vargas como palco da mobilização dos agricultores em outubro de 1957.

Para situar melhor a abordagem, é preciso pontuar que a colonização da região Sudoeste foi intensificada em 1938, quando o presidente Getúlio Vargas, durante o Estado Novo, viabilizou estratégias como a "Marcha para o Oeste" visando estimular a colonização de diferentes regiões do Sul do Brasil, na fronteira oeste com os demais países sulamericanos. Ocorreu que, no final da década de 1950, companhias passaram a reivindicar o uso e ocupação das terras, instaurando a violência por meio de barbáries cometidas por jagunços em diversas cidades do Sudoeste, com destaque para Capanema, Verê, Francisco Beltrão e Pato Branco (BONAMIGO; SCHNEIDER, 2007).

Em se tratando do contexto pato-branquense, a Rádio Colméia - a mais antiga da cidade, hoje denominada Celinauta, que juntas perfazem 62 anos de existência - na época estava situada na rua Iguaçu, no entorno da Praça Presidente Vargas. O lugar se tornou ponto de encontro dos agricultores, pois todas as informações circulavam a partir dali, sendo que no momento do conflito, o locutor Ivo Thomazoni foi um dos porta-vozes da luta dos colonos contra a violência das companhias e dos jagunços pela disputa de terras.

Tudo isso se passou diante da Praça Presidente Vargas, que recebia as reuniões dos agricultores, motivados por lideranças locais (VOLTOLINI, 1997, p.111). Diante da atuação de agentes sociais na Revolta dos Posseiros, e do reconhecimento dos agricultores da praça como ponto de 
encontro, é preciso considerar que os campos da vida e da atividade humana acompanham tradições expressas e verbalizadas. Essas manifestações são condicionadas pelos "senhores do pensamento", que detêm ideias determinantes, que são concebidas como fundamentais para a sociedade onde estão inseridas (BAKHTIN, 2011, p.294). De acordo com Bourdieu (1996), a percepção do espaço social refere-se a um ponto de vista, uma perspectiva, onde "[...] a realidade primeira e última já que comanda até as representações que os agentes sociais podem ter dele" (BOURDIEU, 1996, p.27).

O ponto crítico do conflito ocorreu em 09 de outubro de 1957, quando três crianças foram espancadas por jagunços em Pato Branco. Esta e outras atrocidades direcionadas a famílias do Sudoeste fizeram com que os agricultores se mobilizassem para a luta, no conhecido "levante". Foram quatro dias de tensão, pois o levante dos Posseiros, entre 9 e 12 de outubro de 1957, fez com que a Junta Governativa de Pato Branco montasse guarda especial em locais de possíveis ataques. Nesse período, mulheres e crianças não saíram de casa e o comércio parou de funcionar. Além disso, corriam boatos que, a qualquer momento, a cidade seria invadida por jagunços fortemente armados (VOLTOLINI, 1997) ${ }^{1}$.

Esses agricultores podem ser reconhecidos como "novos agentes sociais", surgidos em meio a um período de conflito, tensão e resistência popular. Esse episódio pode ser compreendido quando Bourdieu (2001) afirma que:

De fato, todos esses novos agentes sociais - a respeito deles talvez seja apropriado dizer que, cada qual em seu nicho, contribuirão para a invenção do universal do qual se tornarão os porta-vozes por meio dos "filósofos das Luzes" - acabaram cumprindo essa função histórica por estarem envolvidos em campos relativamente autônomos e cuja necessidade, que eles mesmos contribuíram

\footnotetext{
${ }^{1}$ Em 09 de outubro de 1957, foi definida a criação da Junta Governativa Provisória, para assumir o comando de Pato Branco durante os dias do levante da Revolta dos Posseiros. Formada por "intelectuais", suas deliberações por vezes não foram reconhecidas como legítimas por lideranças que lutavam no conflito. Além disso, o grupo formado por pouco mais de 20 pessoas, foi reconhecido como "ditatorial" pelo jornal o Estado do Paraná (PEGORARO, 2007).
}

para dar existência, não puderam se furtar. (BOURDIEU, 2001, p.31)

Os fatos desencadeados em 1957 resultaram em outro episódio emblemático sediado pela Praça Presidente Vargas. Em 17 de março de 1962, o então presidente da República, João Goulart, esteve no local para legalizar a situação dos colonos e entregar escrituras das terras ocupadas por pequenos agricultores. $\mathrm{Na}$ oportunidade, foi recepcionado por lideranças políticas e comunitárias. Em ato público realizado na praça, Goulart "fez justiça", conforme a grande faixa sustentada pela população que presenciou o ato (VOLTOLINI, 2005)².

Mobilizações sociais em busca de direitos como a Revolta dos Posseiros, bem como a relação que assumem com o espaço urbano, estão ligadas ao processo de desenvolvimento local, este que não refere-se apenas a variáveis ligadas à renda ou à acumulação de riqueza. Partindo do pressuposto defendido por Amartya Sen (2000), o desenvolvimento precisa ser reconhecido não somente por questões econômicas, mas também pelas condições de qualidade de vida, do exercício das liberdades básicas e dos direitos civis. Ao usufruirmos dessa liberdade, além de interagir com o mundo, é possível influenciá-lo (SEN, 2000).

Observa-se que a interação social contribui para constituir a significação de um espaço urbano, bem como dos agentes sociais. As experiências obtidas a partir desta perspectiva também são discursivas e refletem, sobretudo, a maneira como os sujeitos se posicionam perante a sociedade. Ou seja, conforme Bakhtin (2011), a forma como compartilhamos impressões sobre determinados aspectos cotidianos, além de possuir elementos que ocorreram anteriormente, também origina de enunciados emitidos por diferentes sujeitos que compõem o tecido social em que estamos inseridos.

A composição desse tecido social é apresentada por Ricardo Abramovay (2000,

\footnotetext{
${ }^{2}$ Em 19 de março de 1957, dois dias após a visita a Pato Branco, João Goulart criou o Grupo Executivo de Terras Para o Sudoeste do Paraná (Getsop), através do decreto 51.431, que durante 12 anos trabalho pela paz e bem-estar na região, legalizando as situações dos colonos (VOLTOLINI, 1997, p.190).
} 
p.06), que defende a representação do território que não resume-se apenas a uma base física para as relações, mas que é formado por uma organização complexa com "[...] raízes históricas, configurações políticas e identidades que desempenham um papel ainda pouco conhecido no próprio desenvolvimento econômico" (ABRAMOVAY, 2000, p.06).

Considera-se que, com a Praça Presidente Vargas, isso não é diferente, pois a experiência discursiva individual de cada pessoa não é inédita, ela é construída a partir da interação entre os sujeitos. Assim, a relevância e o valor desses enunciados parte do princípio de que deixamos de ser meros receptores para, a partir dessa interação, recriarmos outras formas de expressão social. É como se estivéssemos imersos em um ciclo que não é inerte, pois não somos meros repetidores - também construímos novas experiências a partir dessa coletividade (BAKHTIN, 2011, p.294-295).

Portanto, o mundo social é construído por meio da cooperação ou do conflito, onde a alternância de interesses ou os diferentes tipos de capital são considerados armas utilizadas em lutas que têm como propósito conservar ou transformar o espaço social, a partir da atuação de seus agentes (BOURDIEU, 1996, p. 27). Esses embates contribuem na constituição da estrutura social, que passa a ser caracterizada enquanto um campo de forças.

É isso que acredito expressar quando descrevo o espaço social global como um campo, isto e, ao mesmo tempo, como um campo de forças, cuja necessidade se impõe aos agentes que nele se encontram envolvidos, e como um campo de lutas, no interior do qual os agentes se enfrentam, com meios e fins diferenciados conforme sua posição na estrutura do campo de forças, contribuindo assim para a conservação ou a transformação de sua estrutura. (BOURDIEU, 1996, p.50)

Eventos históricos certamente contribuíram para o reconhecimento da Praça Presidente Vargas enquanto palco de sonhos e ideais, pois o local recebe, desde a sua formação, as principais mobilizações e manifestos populares de Pato Branco. Essa evidência foi apontada, por exemplo, na edição de 10 de fevereiro de 1995 do Jornal Gazeta do Sudoeste, hoje Diário do Sudoeste, na seguinte legenda: "Como a Boca Maldita em
Curitiba e a Praça da Sé em São Paulo, a Praça Presidente Vargas, guardadas (na legenda da foto originalmente publicada, a palavra indicada está como "guardas", cuja correção no presente artigo foi realizada pelas autoras.) as proporções, é o palco das grandes manifestações, como a que estará acontecendo logo mais". A foto, por sua vez, relembrava uma greve ocorrida em 1989, cuja manifestação também foi desencadeada na praça. Como num ciclo que se repete e se recria - conforme aponta Bakhtin (2011) -, a matéria de 1995 anunciava um manifesto de teor agrícola que ocorreria naquela manhã, no mesmo local. Tal perspectiva também está presente em Bourdieu (2001):

Todavia, ao obrigar esses agentes a mobilizar, a cada momento, em suas lutas presentes, os recursos específicos acumulados no decurso de lutas anteriores, a lógica dos campos eruditos em processo de constituição (qual seja a da concorrência interna viabilizada pela ruptura social com o universo da economia e o mundo da prática) levou-os a criar as regras e as regularidades específicas de microcosmos regidos por uma lógica social favorável a sistematização e a racionalização, fazendo progredir as diferentes formas (jurídica, cientifica, artística etc.) de racionalidade e de universalidade. (BOURDIEU, 2001, p.31-32)

Além de ser palco dos principais eventos históricos desencadeados pelos patobranquenses, elementos simbólicos que compõem a Praça Presidente Vargas também possuem representatividade para a comunidade e refletem aspectos da postura de cooperação que, na primeira metade do século $X X$, predominava nas atividades locais.

O exemplo mais expressivo de cooperação desencadeado na praça central de Pato Branco foi a construção do principal elemento que compõe o traçado do espaço público, a Igreja Matriz São Pedro Apóstolo. Iniciada em 1960, a obra foi conduzida por frei Gonçalo Orth e contou com a colaboração da população, que trabalhou e doou recursos financeiros, de forma voluntária, para garantir que a cidade tivesse uma igreja com o porte de município que já demonstrava se destacar regionalmente. Para tanto, houve casos de famílias que trabalharam 400 dias para concretizar a edificação (JUNIOR et al., 2009, p.04).

Por que essa cooperação mútua entre agentes sociais, sem a intervenção direta de 
agências ligadas ao estado, é tão incomum nos dias de hoje? Além da confiança na paróquia e nos frades franciscanos, a comunidade acreditava nos valores dos agentes humanos envolvidos na cooperação, onde a suposição de credibilidade estava diretamente relacionada à honra dessas pessoas (GIDDENS, 1991, p.35).

Nos dias de hoje, será que a comunidade se envolveria da mesma forma se fosse convocada a edificar um novo santuário para a cidade? Ou, ainda, será que as pessoas que transitam diariamente pela Praça Presidente Vargas, que frequentam o local com a família ou que participam das mobilizações sociais que ocorrem no espaço, se questionam sobre a atuação dos pioneiros na concretização da matriz que, muito mais do que um cartão postal ou símbolo do município, representa uma característica social presente em determinado espaçotempo?

Primeiramente, para que possamos compreender as consequências da modernidade, precisamos definir o que é modernidade. Segundo Giddens (1991), modernidade é "[...] o estilo, costume de vida ou organização social que emergiram na Europa, a partir do século XVII e que se tornaram mais ou menos mundiais em sua influência", (GIDDENS, p. 11, 1991). Na medida em que as sociedades passaram de "tradicionais" para "modernas", o que também refletiu nas práticas relacionais, alterou-se a consciência entre o espaço (o lugar) e o tempo.

Basta nos debruçarmos diante da história e reconhecermos como a criação do relógio mecânico, no final do século XVIII, mudou a forma com que nos relacionamos em sociedade, para então percebermos que a organização do tempo concebeu novas significações à forma com que enxergamos 0 mundo. E, desde então, estamos cada vez mais distantes da natureza (Giddens, 1991, p.27-28). Assim, Giddens (1991) nos leva a repensar a relação do homem com a natureza, a partir da noção de "espaço e tempo", nos colocando diante das transformações sociais desencadeadas a partir da era moderna.

Outra possível abordagem para a prática espacial e temporal dos agentes, pode ser observada a partir da concepção de "tradições culturais autênticas" apresentada por Roberto DaMatta (1987). O autor elucida que há um processo dialético entre as regras e o grupo de agentes que as pratica. $\mathrm{Na}$ medida em que a sociedade as vivencia, também concebe eventuais regras e práticas cotidianas, que definem a significação do tempo e a valorização de ocasiões desencadeadas pela prática social (DAMATTA, 1987, p.49).

A edificação da matriz foi concluída em 1965 e deu lugar à capela que, em 1935, contribuiu para o reconhecimento da área da Praça Presidente Vargas. Vale destacar que, assim como a anterior, a nova igreja permaneceu dentro dos limites da praça, integrando a dinâmica relacional desencadeada no espaço público. Todavia, vale frisar que a relação histórica entre religião e a Praça Presidente Vargas também refere-se a propriedade legal da área onde foi delimitado o logradouro.

Embora já estivesse legalmente reconhecida enquanto espaço público, a área da praça continuava sendo propriedade da paróquia até 1958, quando frei Honorato Brüggemann negociou a área com a Prefeitura Municipal para atender ao projeto de urbanização realizado na administração do terceiro prefeito de Pato Branco, Dr. Harry Valdir Graeff (VOLTOLINI, 2005, p.221). Na lei no $=30 / 58$, sancionada em 20 de dezembro de 1958, consta que o poder executivo investiu $\mathrm{Cr} \$$ $500.000,00$ na aquisição da área da Praça Presidente Vargas, valor repassado à Igreja Matriz de Pato Branco.

Atualmente, conforme a sociedade recebe os traços da modernidade, a presença física dos atores se torna dispensável, pois tal relação é mediada por fichas simbólicas (dinheiro) e sistemas peritos (meios tecnológicos e especialidades profissionais). Como consequência, essa independência da intervenção direta do "outro" infere a atividade social, onde "[...] instituições desencaixadas dilatam amplamente o escopo do distanciamento tempo-espaço e, para ter este efeito, dependem da coordenação através do tempo e do espaço", (GIDDENS, 1991, p.24).

Assim, a relação estabelecida com o outro pode ocorrer, facilmente, à distância. Aparentemente, a facilidade tecnológica não implica na finalidade das relações, pelo contrário, possibilita tal relacionamento. Contudo, permanece o sentimento de que, ao mesmo tempo em que permite uma proximidade que seria impossível num passado relativamente próximo, distancia os 
agentes, que estabelecem relações por vezes superficiais - o que também implica no reconhecimento no espaço público urbano, que por vezes é identificado como meramente transitório, sem ter a sua representatividade cultural e social reconhecida.

Ocorre então uma contínua geração de valores e autoconhecimento relacionada à reflexividade da modernidade. Para Giddens (1991), "[...] as práticas sociais são constantemente examinadas e reformadas à luz de informação renovada sobre estas próprias práticas, alterando assim constitutivamente seu caráter", (GIDDENS, 1991, p. 45). Ou seja, o tempo todo são recriadas significações sociais de acordo com diferentes interesses e percepções. Há uma inconstância na sociedade atual, o que vem de encontro com a ideia de que a "grande narrativa" é reconhecida como falha, cuja história da humanidade não pode ter um começo, um meio e um fim preconcebidos.

É a partir dessa inconstância que os atores têm o "poder" de alterar os acontecimentos. Ou seja, mesmo aqueles que assumem posição de subordinação têm capacidade de gerar a mudança (GIDDENS, 1989, p. 10). Assim, a agência humana é uma característica da reflexividade, esta que faz o agente refletir sobre suas ações e regras e que o conduz a transformar as práticas sociais (GIDDENS, 1991).

Nesse processo de contínua transformação, o valor simbólico da Praça Presidente Vargas permanece latente. Desde que começou a ser reconhecido enquanto logradouro público, na década de 1930, o local é palco dos principais eventos da cidade, inclusive de atrações turísticas. Então, por que a sociedade mantém essa relação de proximidade com este espaço público? Por que é uma relação tão peculiar se comparada com outros logradouros da cidade?

Conforme pontua Giddens (1991), essa evidência não possui conexão direta com o passado, tampouco refere-se apenas à prática da tradição local. Isso porque hábitos rotineiros estão internalizados na organização social - não denotam, necessariamente, aspectos tradicionais. Ocorre que o posicionamento desencadeado outrora pode coincidir com as significações renovadas pela sociedade.

Diferente de eventos da reflexividade moderna, "[...] nas culturas tradicionais, o passado é honrado e os símbolos valorizados porque contêm e perpetuam a experiência de gerações", (GIDDENS, 1991, p.38). Em sociedades onde a tradição ainda é perpetuada, símbolos que possuem valor social inferem na organização tempo-espacial da comunidade, onde presente, passado e futuro são estruturados por práticas sociais recorrentes.

Assim, quando imbuída de significado, a tradição relaciona-se ao ritual e "[...] mantém a confiança na continuidade do passado, presente e futuro, e vincula esta confiança a práticas sociais rotinizadas" (GIDDENS, 1991, p.95). Nesse processo, aspectos da tradição também são reinventados a cada nova geração, onde o vínculo com o passado é mantido. Assim, a identidade social, continua se reconhecendo, na medida em que é transformada

Não se sanciona uma prática por ela ser tradicional; a tradição pode ser justificada, mas apenas à luz do conhecimento, o qual, por sua vez, não é autenticado pela tradição. Combinado com a inércia do hábito, isto significa que, mesmo na mais modernizada das sociedades, a tradição continua a desempenhar um papel. Mas este papel é geralmente muito menos significativo do que supõem os autores que enfocam a atenção na integração da tradição com a modernidade no mundo contemporâneo. Pois a tradição justificada é tradição falsificada e recebe sua identidade apenas da reflexividade do moderno. (GIDDENS, 1991, p.39)

Ainda conforme Giddens (2012), processos de mudanças intencionais, que visam o abandono da tradição, estão diretamente relacionados à agenda da ciência social. O autor define esta como uma característica da "sociedade pós-tradicional", uma vez que a modernidade reconstruiu a tradição na medida em que absorvia seus reflexos. Essa recriação contínua da tradição, nas sociedades ocidentais, contribuiu para a legitimação do poder a partir da imposição do Estado diante de sujeitos passivos (GIDDENS; BECK; SCOTT, 2012, p.90-91). Afinal,

[...] nem "o passado" nem "o futuro" são um fenômeno discreto, separado do "presente contínuo", como no caso da perspectiva moderna. O tempo passado é incorporado às práticas presentes, de forma que o horizonte do futuro se curva para trás para cruzar com o que se passou antes. (GIDDENS, 1991, p.95)

É possível observar um exemplo deste "embate" entre modernidade e tradição, que 
infere diretamente na identidade social, nos projetos de urbanização direcionados à Praça Presidente Vargas. O primeiro prefeito a realizar intervenções estruturais significativas no local foi o Dr. Harry Valdir Graeff, cujo mandato ocorreu no período de 1956 a 1960. Desde então, inúmeras foram as transformações físicas e materiais que tiveram como intuito traduzir diferentes momentos sociais, culturais, políticos e econômicos da cidade. A população precisou reconhecer o

Fotografia 1: Praça Presidente Vargas, entre as décadas de 1960 e 1970. significado de cada novidade intencionalmente imposta por diferentes administrações.

Entre os exemplos está o projeto executado na gestão do prefeito Alberto Cattani, cuja gestão municipal ocorreu de 1969 a 1973. Na ocasião, foram extraídas todas as árvores que foram cultivadas na praça a partir da década de 1930, restando apenas uma araucária, conforme mostram as fotos abaixo. A praça ficou irreconhecível.

Fotografia 2: Praça Presidente Vargas, em 1972, após as intervenções estruturais executadas na gestão do prefeito Alberto Cattani.

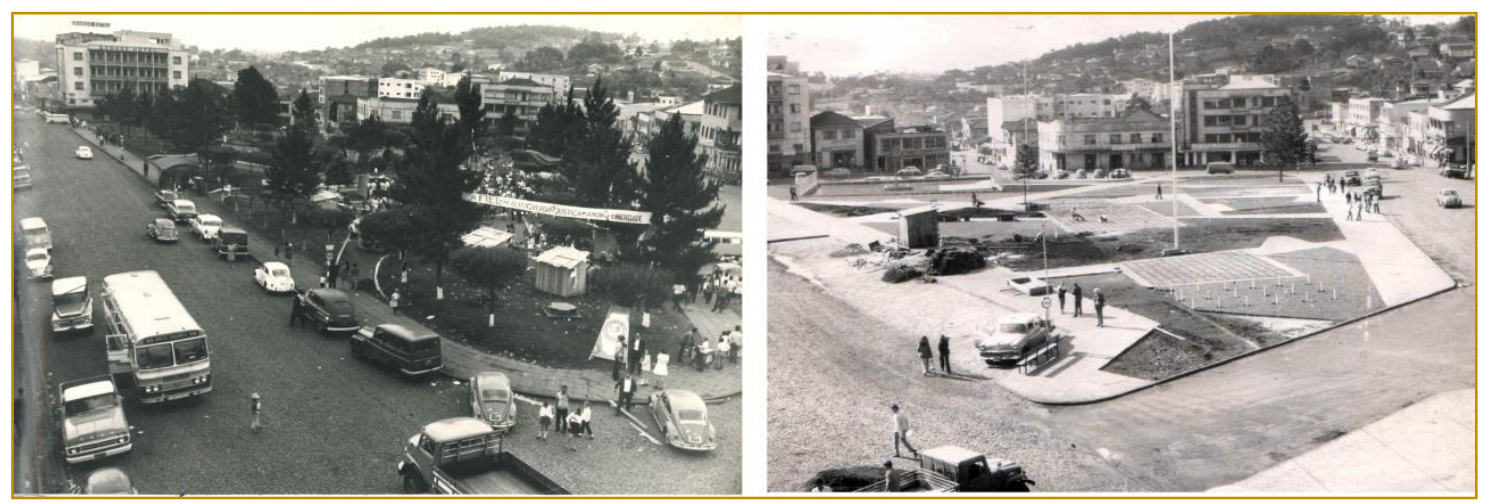

Fonte: Acervo do Departamento Municipal de Cultura de Pato Branco.

Fonte: Bodanese, 1982.

Antes da nova estruturação, a Praça Presidente Vargas assumia o modelo de praça ajardinada que, conforme apontam Fabio Robba e Silvio Soares Macedo (2010), se tornou padrão paisagístico do Brasil nas primeiras décadas do século XX. Neste período, reformas em praças centrais visando espaços ajardinados se tornaram mais comuns no país. Contudo, esse modelo refere-se a tradição meramente contemplativa dos jardins europeus característicos dos séculos XVII e XVIII (ROBBA; MACEDO, 2010). De espaço meramente contemplativo, usado por classes mais elitizadas, as praças brasileiras receberiam o hábito do passeio e da integração por parte da população apenas no final do século $X X$, o que permanece até os dias de hoje, com eventuais peculiaridades locais:

O hábito de passear na praça subsiste no final do século $X X$, mas compete em igualdade com outras atividades de lazer, como práticas esportivas e comércio. Por todo - país ainda podem ser encontrados logradouros onde permanecem o costume de "desfilar" em "praça pública" e o tradicional passeio aos sábados à noite em volta da praça (o footing), principalmente em bairros afastados ou cidades menores e mais conservadoras. (ROBBA; MACEDO, 2010, p.55)

Mesmo levando em conta a influência européia da praça ajardinada, isso nos remete a pensar, conforme Edgar Morin (2002), que "[...] não devemos esquecer que o homem é um ser biológico-sóciocultural, e que os fenômenos sociais são, ao mesmo tempo, econômicos, culturais, psicológicos etc.", (MORIN, 2002, p.177). Assim, quando a sociedade intervém na dinâmica estrutural do espaço público - no caso da Praça Presidente Vargas isso ocorreu em diferentes momentos sociais e políticos - fica evidente a relação entre o homem e a natureza, que pode ser tanto de proximidade quanto de separação. 
Giddens (1991) aponta as "descontinuidades" do período moderno que, segundo ele, nos afastam de aspectos tradicionais de uma forma sem precedentes (Giddens, 1991, p.14). Isso porque o evolucionismo social impede que a descontinuidade seja reconhecida. A sensação é que nada é feito para durar. Nesse contexto, as descontinuidades que separam as instituições sociais modernas das de ordem sociais tradicionais têm como características: o ritmo de mudança, o escopo da mudança e a natureza intrínseca das instituições modernas (Giddens, 1991, p. 16).

Neste ciclo onde o espaço físico está em constante transformação, pois não é acabado e recebe constantes interferências sociais, constata-se que não sendo transitório ele é produzido através das experiências dos sujeitos, em que a materialidade e imaterialidade por vezes se confundem. É possível perceber tal relação na definição do termo "dialógico" apresentada por Morin (2002). Segundo o autor, há duas lógicas e, consequentemente, dois princípios, que mesmo que estejam unidos, mantêm a dualidade na unidade concebida. A partir disso, surge a concepção de "unidualidade", onde "[...] o homem é um ser unidual, totalmente biológico e totalmente cultural a um só tempo", (MORIN, 2002, p.188). Afinal:

Uma sociedade é produzida pelas interações entre indivíduos e essas interações produzem um todo organizador que retroage sobre os indivíduos para co-produzi-los enquanto indivíduos humanos, o que eles não seriam se não dispusessem da instrução, da linguagem e da cultura. (MORIN, 2002, p.182)

A representatividade do lugar como espaço das relações humanas, deixou de ser reconhecida diante da globalização hegemônica. Conforme esclarece Boaventura de Souza Santos (2006), isso ocorre, pois:

[...] as relações de poder, de resistência, de dominação e de alternativas de hegemonia e de contra-hegemonia são constitutivas da globalização. Isto é assim porque a globalização é hoje o marcador hegemónico dos termos do conflito social histórico criado pelo capitalismo. A globalização é simultaneamente o conflito (a ideia da força) e os termos do conflito (a força da ideia). O capitalismo global, por um lado, e a diversidade e a globalização, pelo outro. (BOAVENTURA, 2006, p. 151-152)
Ou seja, é preciso estimular o reconhecimento das relações com o lugar, a partir de dinâmicas de interações, de trabalho e de eventuais vestígios de tradições. Isso porque "[...] a experiência de desenvolvimento significou para a maioria das pessoas um rompimento do lugar, mais profundo como jamais visto", (ESCOBAR, 2005, p.02). No entanto, diz Escobar (2005) que a modernidade contribui para o distanciamento das relações entre os humanos e o seu ambiente, entre homem e natureza, defendendo que "[...] os seres humanos estão arraigados na natureza e imersos em atos práticos, localizados", (ESCOBAR, 2005, p.07). Como as culturas e a natureza contêm a diversidade, é possível pensar as conexões dos lugares com o global em outros termos, pelo que é significativo para a interconexão em defesa dos lugares, logo da diversidade.

Neste sentido, Morin (2002) define como "medíocre" as posturas que não considerem a relação entre sociedade e ambiente:

Um pensamento de organização que não inclua a relação auto-eco-organizadora, isto é, a relação profunda e íntima com o meio ambiente, que não inclua a relação hologramática entre as partes e o todo, que não inclua o princípio de recursividade, está condenado à mediocridade, à trivialidade, isto é, ao erro. (MORIN, 2002, p.193).

É preciso evidenciar que as transformações físicas da praça central também interferem na identidade da cidade, bem como na relação entre os agentes e o espaço público. A percepção dos indivíduos perante a arquitetura urbana, bem como a influência da mesma na atividade rotineira da população, ocorre por que:

Esses contornos dizem respeito à individualidade dos monumentos, da cidade, das construções e, portanto, ao conceito de individualidade e a seus limites, onde ela começa e onde ela acaba; dizem à relação local da arquitetura, ao lugar de uma arte. E, portanto, aos vínculos e à própria particularização do "locus" como fato singular determinado pelo espaço e pelo tempo, por sua dimensão topográfica e por sua forma, por ser sede de acontecimentos antigos e novos, por sua memória. (ROSSI, 2001, p.152)

Quando a coletividade adere ao estilo de vida predominante, geralmente vinculado à tradição, eventualmente ocorre algum fenômeno que propõe mudar ou que questiona esses hábitos. Assim, a cada nova 
alteração no contexto da vida cotidiana da Praça Presidente Vargas, ocorreram alternâncias nas regras sociais. Essa gama de experiências permitiu a socialização, bem como a intepretação de regras e normas aderidas pelo grupo social. Contudo, novas regras, mesmo que sejam impostas, apenas se tornam viáveis por meio da aceitação e legitimidade por parte dos agentes (DAMATTA, 1987, p.49).

Um exemplo é a prática social estabelecida ao longo da história na Praça Presidente Vargas, onde a população precisou se habituar em relação às intervenções físicas feitas no local, assim como com as consequências dos eventos desencadeados no espaço. Houve, ainda, momentos de conflito onde a comunidade se reuniu na praça se mostrando disposta a resistir diante de mudanças impostas - um exemplo foi a Revolta dos Posseiros.

A partir da breve contextualização histórica apresentada até aqui, é possível considerar, ainda, a dinâmica relacional atribuída por Boaventura de Souza Santos (2003) ao espaço-tempo da cidadania, que contempla o conjunto de interações sociais que criam identidades coletivas, que além de refletir aspectos simbólicos como religião, etnias, entre outros, também "[...] vinculam os indivíduos a territórios físicos ou simbólicos e a temporalidades partilhadas passadas, presentes ou futuras", (SANTOS, 2003, p. 315).

A interação entre os pato-branquenses e a praça central da cidade foi desencadeada a partir de um processo histórico que, a cada novo evento de intervenção social, política ou econômica, recebeu novos simbolismos. Nesse contexto, a proximidade da população com o local permanece presente na imaginária urbana. Hoje, e foi assim ao longo da história, a praça é um dos principais pontos de encontro da comunidade, pois se configura enquanto área de lazer em virtude dos elementos que possui, especialmente a partir de intervenções recentes.

Portanto, essa relação entre os sujeitos e o espaço físico, a partir da construção histórica e social da Praça Presidente Vargas, pode ser concebida pela noção de pertencimento, que é definida pelas experiências entre o homem e a localidade. Essa relação denota certo grau de enraizamento da identidade do lugar e do indivíduo. Tal evidência está relacionada a dinâmicas sociais, culturais, econômicas e ecossistêmicas.

\section{CONSIDERAÇÕES}

Lugares como a Praça Presidente Vargas recebem aspectos da atividade cotidiana que condicionam a dinâmica urbana. A partir do estudo de caso proposto, verificou-se que o espaço público urbano acompanha e reflete o desenvolvimento local a partir da atuação dos atores sociais.

Afinal, há uma força intrínseca que eleva a forma meramente física dos espaços urbanos, pois espaço e vida social estão diretamente ligados, cujo elo é a atuação dos agentes, que têm capacidade de transformar realidades a partir da relação que assumem com os lugares. Não há limite, nem distanciamento dual, há interrelações.

Assim, propõe-se que o conhecimento e os modelos de desenvolvimento locais sejam repensados para enfraquecer a dicotomia que distancia a relação entre natureza e cultura, entre lugar e sociedade - postura que é evidenciada a partir da atuação dos atores em momentos emblemáticos da construção histórica e social, como vimos na análise teórica aqui proposta e colocada diante da Praça Presidente Vargas.

Ao reunir situações desencadeadas ao longo da história de Pato Branco, configurou-se a praça como palco das principais manifestações sociais da cidade - o que é uma característica de cidades de pequeno e médio porte e com aspectos tradicionais ainda presentes. Assim, buscou-se enaltecer a representatividade dos atores sociais no processo de desenvolvimento, a partir da relação estabelecida entre os sujeitos e o espaço urbano. Sendo assim, ficou evidente o papel social de indivíduos, lideranças de vanguarda, assim como de grupos imbuídos do mesmo ideal.

A partir disso, ficou evidente que os lugares são construídos por sonhos e ideais, mas também por ações concretas de sujeitos que os vivenciam. No caso da Praça Presidente Vargas, o espaço urbano constitui-se enquanto produto social de um processo histórico que traduz o contexto e o protagonismo da população local. Assim, a concepção histórica e social deste lugar demonstra a relação entre a comunidade e o espaço físico, que não deve ser encarada apenas pela ótica da materialidade. 
Afinal, dessa interação há vida e, sobretudo, há construção social que resulta em experiências de caráter transformador. Tal reflexão é de fundamental importância para repensarmos a atuação do homem sobre o ambiente em que ele está inserido, uma vez que a interferência na dinâmica urbana reflete na vida social e na direção da história.

\section{AGRADECIMENTO}

Agradecimento especial ao professor Anselmo Pereira de Lima, doutor em

\section{REFERÊNCIAS}

[1] ABRAMOVAY, Ricardo. O capital social dos territórios: repensando o desenvolvimento rural. Economia Aplicada. Vol. 4, $n^{\circ}$ 2, abril/junho 2000.

[2] AGRICULTORES em grande manifestação hoje no centro de Pato Branco. Gazeta do Sudoeste, Pato Branco, 10 de fevereiro. 1995.

[3] ALBAGLI, Sarita. Território e Territorialidade. In: LAGES, Vinícius; BRAGA, Christiano; MORELLI, Gustavo (Orgs.). Territórios em movimento: cultura e identidade como estratégia de inserção competitiva. Rio de Janeiro: RelumeDumará; Brasília, DF: SEBRAE, 2004.

[4] BAKHTIN, Mikhail. Estética da criação verbal. Trad. Paulo Bezerra. 4.ed. São Paulo: Martins Fontes, 1979/2003.

[5] BODANESE, RUDI. Lembranças de Vila Nova: a evolução de Pato Branco através de imagens fotográficas. Pato Branco: Darnol, 1982.

[6] BONAMIGO, Carlos Antônio; SCHNEIDER, Claídes Rejane (Orgs). Revisitando a história: a Revolta dos Posseiros de 1957 no Sudoeste do Paraná. Francisco Beltrão: Grafisul Gráfica e Editora Ltda., 2007.

[7] BOURDIEU, Pierre. Coisas ditas. São Paulo: Brasiliense, 2004.

[8] Rio de Janeiro: Bertrand Brasil, 2001.

[9] Razões práticas: sobre a teoria da ação. Campinas, SP: Papirus, 1996.

[10] CERTEAU, Michel de. A invenção do cotidiano. Petrópolis: Editora Vozes, 1994.

[11] DAMATTA, Roberto. Revitalizando: uma introdução à antropologia social. Rio de Janeiro: Rocco, 1987.

[12] ESCOBAR, Arturo. O lugar da natureza e a natureza do lugar: globalização ou pósdesenvolvimento? In: A colonialidade do saber: euricentrismo e ciências sociais. Perspectivas latino-americanas. Edgardo Lander (org).
Linguística Aplicada e Estudos da Linguagem, docente do Programa de Pós-Graduação em Desenvolvimento Regional - PPGDR, da Universidade Tecnológica Federal do Paraná - UTFPR, pela sua valiosa contribuição no reconhecimento da Praça Presidente Vargas enquanto objeto de pesquisa, e por nos apontar aspectos importantes do movimento que o espaço público urbano estabelece a partir da interação com a sociedade e com a sua história.

Colección Susr Sur, CLACSO, Ciudad Autónoma de Buenos Aires, Argentina, setembro 2005.

[13] GIDDENS, Anthony. As consequências da modernidade. São Paulo: Editora UNESP, 1991.

[14] A constituição da sociedade. São Paulo: Martins Fontes, 1989.

[15] BECK, Ulrich. SCOTT, Lash. Modernização Reflexiva: Política, tradição e estética na ordem social moderna. 2.ed. São Paulo: Editora Unesp, 2012.

[16] FILHO, Antonio Colchete. Praça XV: projetos do espaço público. Rio de Janeiro: 7Letras, 2008.

[17] JUNIOR, Nelson et al. Matriz São Pedro Apóstolo, uma história que o povo construiu. XVI Exposição da Pesquisa Experimental em Comunicação - Prêmio Expocom 2009.

[18] MORIN. Edgar. O desafio da complexidade. In. Ciência com consciência. 6 $6^{\underline{a}}$ ed. Rio de Janeiro: Bertrand Brasil, 2002.

[19] PARTIDO TRABALHISTA BRASILEIRO. In: WIKIPÉDIA, a enciclopédia livre. Flórida: Wikimedia Foundation, 2016. Disponível em: $<$ https://pt.wikipedia.org/w/index.php?title=Partido_ Trabalhista_Brasileiro\&oldid=46123899>. Acesso em: 24 jul. 2016.

[20] PEGORARO, Éverly. Dizeres em confronto: A Revolta dos Posseiros de 1957 na imprensa paranaense. Dissertação (Mestrado em História Social) - Programa de Pós-Graduação Interinstitucional em História UFF/UNICENTRO, 2007. Disponível em:

[21] <www.historia.uff.br/stricto/teses/Dissert2007_PEGORARO_Everly-S.pdf>. Acesso em: 28 out. 2016.

[22] POLANYI, Karl Paul. A grande transformação: as origens da nossa época. RJ .Ed. Campus, 1980.

[23] QUEREMISMO. In: WIKIPÉDIA, a enciclopédia livre. Flórida: Wikimedia Foundation, $2015 . \quad$ Disponível em: 
<https://pt.wikipedia.org/w/index.php?title=Queremi smo\&oldid=42502481 > . Acesso em: 24 jul. 2016.

[24] RADOMSKY, Guilherme; SCHNEIDER, Sergio. Nas teias da Economia: o papel das redes sociais e da reciprocidade nos processos locais de desenvolvimento. Sociedade e Estado, Brasília, v. 22, n. 2, p. 249-284, maio/ago. 2007

[25] ROBBA, Fabio; MACEDO, Silvio Soares. Praças Brasileiras: Public Squares in Brazil. 3.ed. São Paulo: Editora da Universidade de São Paulo, 2010.

[26] ROSSI, Aldo. A arquitetura da cidade. São Paulo: Martins Fontes, 2001.

[27] SANTOS, Boaventura de Sousa. Pela mão de Alice: o social e o político na pós-modernidade. 9.ed. São Paulo: Cortez, 2003.
[28] A ecologia de saberes. In. A gramática do tempo: para uma nova cultura política. São Paulo: Cortez, 2006.

[29] SANTOS, Milton. Do meio natural ao meio técnico-científico-informacional. In. A natureza do espaço: técnica e tempo, razão e emoção. 4.ed. São Paulo: Editora USP, 2009.

[30] SEN, Amartya. Desenvolvimento como liberdade. São Paulo: Companhia das Letras, 2000.

[31] VOLTOLINI, Sittilo. Retorno 1: origens de Pato Branco. 2.ed. Pato Branco: Imprepel - Gráfica e Editora Ltda, 2005.

[32]

Retorno 2: Pato Branco na Revolta dos Posseiros de 1957. 1.ed. Pato Branco: Artepres - Gráfica e Editora Ltda, 1997. 


\section{Eapítulo 2}

\section{A FINANCEIRIZACẼOO DO CAPITAL IMOBILIÁRIO E A INTERIORIZACCÃO DE GRANDES PROJETOS URBANOS: O CASO DE GOIANA-PE}

\section{Caroline Gonçalves dos Santos}

\section{Flávio Antônio Miranda de Souza}

Resumo: Na era da financeirização da economia, o Brasil reestrutura seu sistema financeiro e investe em instrumentos a fim de atrair capital, sobretudo estrangeiro. Entre os anos 2004 e 2014, o país passa por um momento de estabilidade econômica com um significativo crescimento e absorve um grande volume de investimentos, o qual se expande em rede alcançando municípios de menor importância nas hierarquias urbano regionais. Com isso, esses municípios têm dinamizado suas economias, ampliado o contingente populacional e, por conseguinte, demandado por moradias. Neste ponto, é importante salientar a confluência entre o capital financeiro e setor imobiliário, em que este último encontra no primeiro a oportunidade de obter retorno dos investimentos ainda mais rápido e lucros maiores. Sendo assim, este artigo discute a expansão dos circuitos imobiliários por meio de grandes empreendimentos da Região Metropolitana do Recife para municípios vizinhos, com destaque para o caso de Goiana e os impactos na reprodução socioespacial urbana. O município entrou nesse circuito global financeiro com a instalação da indústria automotiva FIAT, que estimulou a chegada de outras indústrias, o que aqueceu o mercado imobiliário para atender a possível demanda. No entanto, ainda que o município comece a se firmar como uma nova centralidade, os empreendimentos residenciais implantados têm sido adquiridos mais como investimento do que como moradia.

Palavras Chave: interiorização dos investimentos; expansão imobiliária; reconfiguração socioespacial. 


\section{A ERA DO CAPITAL FINANCEIRO E A FINANCEIRIZAÇÃO DO CAPITAL IMOBILIÁRIO}

Por financeirização, entende-se o aumento da dominância de atores, mercados, práticas, medidas e discursos financeiros em várias escalas, resultando em uma transformação estrutural do: setor privado - incluindo instituições financeiras - do estado e proprietários, conforme conceituação de Aalbers (2015). Em síntese, refere-se a um padrão de funcionamento da economia em que se visa obter lucro mais por canais financeiros, por meio de juros, do que através das atividades diretamente produtivas, diminuindo consideravelmente o tempo de giro do capital.

O que se observou nos anos 2000 foi que autoridades monetárias, como o FMI, vinham divulgando que o mundo estava inundado com excesso de liquidez, ou seja, existia um volume crescente de dinheiro à procura de algo rentável para colocar-se (HARVEY, 2011). E assim, como qualquer capital, independentemente de ser financeiro, o problema de se ter excedente é que se o crescimento não recomeça então o capital super acumulado se desvaloriza ou é destruído (Idem, 2011).

O capital então, utilizando-se do contexto de economia neoliberal e das possibilidades oriundas da globalização, expandiu a sua rede para outros países do mundo através da exportação de maior oferta de capital financeiro, no lugar de produtos (HARVEY, 2013). De modo que se pode dizer na atualidade que o mundo capitalista se apresenta sob uma conjuntura macroeconômica movida pelas finanças, promovendo a reestruturação desde as relações econômicas às relações sociais impactando, por conseguinte, na reprodução do espaço urbano.

Nesse contexto, o Brasil buscou modernizar seu sistema financeiro e melhor estruturar seus instrumentos, explorando a ideia de que era necessário conquistar de maneira definitiva a credibilidade dos investidores externos, segundo sinaliza Paulani (2010), sobre as políticas econômicas adotadas a partir de 2003. Com isso, observa-se um crescimento econômico bastante significativo no país, segundo dados do IBGE, a média da taxa anual de crescimento do PIB entre 2004 e 2013 foi de 3,8\%, sendo somente em 2004 a taxa anual de crescimento igual a 5,2\%. Para fins de comparação, Magalhães et al. (2011) aponta que nas duas décadas anteriores (1983-2003), esta média tinha sido de 2,4\%.

De acordo com Mattos (2007), na medida em que as nações estabilizam e modernizam suas economias, tornam-se lugares seguros para os investimentos globais. Assim, a partir daquele crescimento econômico, houve uma ampliação do volume de capital estrangeiro aportado no país, também atrelada à expansão de exportação de commodities (CARDOSO; ARAGÃO, 2013). A presença desse capital se revelou nas instalações de grandes empresas, sobretudo, nos setores: automobilístico, aeronáutica, eletroeletrônico, tecnologia e informação e de telecomunicações.

Ainda com vistas a melhor aproveitar a "euforia" do capital, citando De Souza e Cavalcanti (2013), verificam-se novas reconfigurações na política econômica do governo com ampliação de incentivos e uma liberalização dos gastos públicos, especialmente a partir de 2006, culminando em 2007 com o lançamento do Programa de Aceleração do Crescimento (PAC). O programa tem por objetivo a implantação de grandes obras de infraestrutura urbana, destinadas a estimular a contínua promoção do crescimento econômico.

Assim, os bancos que tiveram papel fundamental no período desenvolvimentista brasileiro, nos anos 1950 e 1960, voltam a investir forte no país, de modo que os desembolsos de recursos realizados pelo Banco Nacional de Desenvolvimento Econômico e Social (BNDES) ${ }^{3}$ passaram de $R \$ 51$ bilhões em 2006 para $R$ \$ 168 bilhões em 2010, alcançado os $R \$ 190$ bilhões em 2013. Ainda que boa parte dos investimentos estivesse concentrada na região Sudeste, convém destacar o volume aportado no

\footnotetext{
3 O BNDES é hoje um dos maiores bancos de desenvolvimento do mundo. Grande parte de suas operações é realizada de forma indireta, através de parceria com uma rede de instituições financeiras credenciadas que cobre o território nacional, composta pela maioria dos bancos brasileiros. Oferece ainda, desde 2009, o Fundo Garantidor para Investimentos (FGI), que tem por finalidade colaborar para ampliação de acesso ao crédito às empresas. Para tanto, o fundo complementa garantias apresentadas pelas empresas, assumindo parte do risco de crédito em operações de financiamento, aumentando, portanto, as chances de aprovação dos pedidos de crédito (BNDES, 2016).
} 
Nordeste, que em 2009 ocupa o segundo lugar entre as regiões com mais recursos recebidos, com $\mathrm{R} \$ 22,3$ bilhões em desembolsos (BNDES, 2016).
No Nordeste a evolução do desembolso mostra que os investimentos passaram de $R \$$ 4,83 bilhões, em 2006, para os referidos $R \$$ 22,3 bilhões, em 2009, chegando a $\mathrm{R} \$ 25$ bilhões no ano de 2013 (Figura 1).

Figura 1 - Evolução dos desembolsos para a região Nordeste em $\mathrm{R} \$$ bilhões.

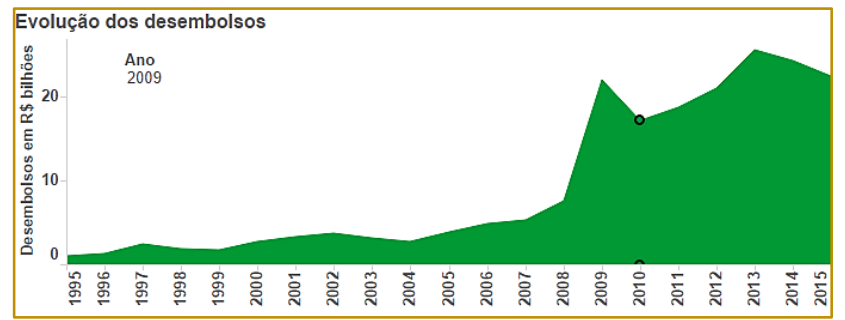

Fonte: Estatísticas e desempenho BNDES, 2016.

Por sua vez, na região nordestina os recursos estiveram concentrados nos estados da Bahia, Ceará e Pernambuco, com destaque para o grande volume aplicado em Pernambuco também em 2009, em que do total de $\mathrm{R} \$ 22,3$ bilhões direcionados a região, $\mathrm{R} \$ 13$ bilhões foram absorvidos pelo estado, o maior volume observado nos últimos anos. Embora, se tenha mantido um investimento contínuo em torno dos $\mathrm{R} \$ 4$ milhões no estado até 2015 após quase uma década (19952004) em que o volume de desembolso médio era de aproximadamente $\mathrm{R} \$ 300$ milhões (Figura 2).

Figura 2 - Evolução dos desembolsos para o estado de Pernambuco em $\mathrm{R} \$$ milhões

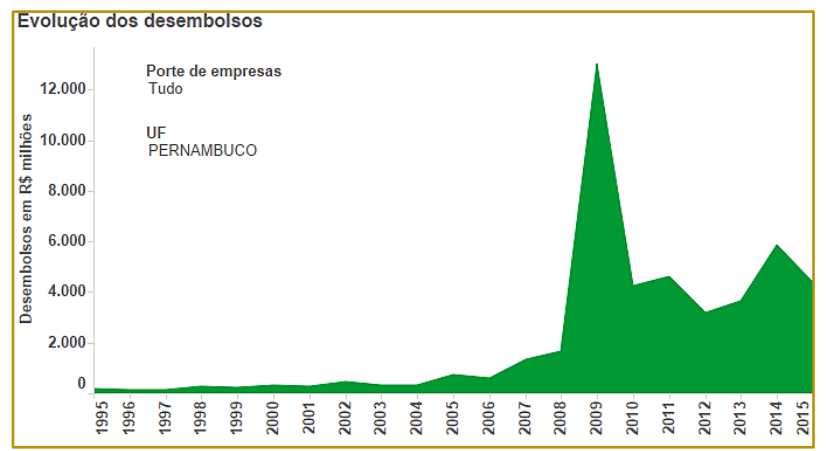

Fonte: Estatísticas e desempenho BNDES, 2016.

Esses investimentos possibilitaram a aplicação em ações de interiorização e de dinamização da economia por meio de atração de outros capitais privados para o estado, fazendo com que, em 2011, Pernambuco liderasse os indicadores econômicos no nordeste brasileiro e, em 2012, apresentasse um crescimento do PIB superior ao registrado nacionalmente, com destaque para o setor de serviços, especialmente na área de transporte, alugueis e intermediação financeira; e para o setor de indústria, alavancado pela construção civil, permitindo assim, a retomada da autonomia pernambucana no cenário econômico (GOVERNO DO ESTADO, 2016).
Com os novos investimentos e a interiorização dos mesmos, novas áreas e cidades despontam como centralidades, atraindo moradores em virtude da oferta de empregos, os quais demandam moradias, serviços e produtos diversos. Aquecendo, portanto, o mercado imobiliário que tem respondido essa demanda, no contexto de financeirização, por meio de Grandes Projetos Urbanos (GPUs) ${ }^{4}$.

\footnotetext{
4 Segundo conceituações trazidas por Lungo (2004) e Cuenya et al. (2012), são intervenções públicas ou privadas de grande escala, construídas com desenhos e padrões tecnológicos vanguardistas que por sua integração produzem impactos no desenvolvimento de uma cidade.
} 
Neste ponto, vê-se uma confluência entre capital financeiro e setor imobiliário, em que este último passa por uma reconfiguração a fim de se adequar a lógica financeira ${ }^{5}$, a qual oferece retorno dos investimentos ainda mais rápido em face da mobilidade do capital, possibilidade de lucros maiores em virtude dos juros e ampliação das ofertas tanto construídas quanto de ativos financeiros lastreados em imóveis. O que superaria algumas das principais dificuldades encontradas no setor imobiliário, que se tratava da imobilidade do capital em face da fixidez do imóvel. Dessa aproximação, tem-se o que chamamos aqui de capital imobiliário.

Essa confluência torna-se ainda mais evidente no cenário brasileiro com a abertura do capital de na bolsa de valores por incorporadoras, baseada na teoria de que os preços imobiliários investidos continuariam em alta, atraindo inclusive construtoras voltadas para baixa renda conforme citado. Ressalta-se, além disso, para esse período entre 2004 e 2013, o aumento de renda de uma camada da população e/ou de acesso ao crédito, o que viria a expandir o mercado consumidor e garantir a solvabilidade da demanda.

Diante do exposto, este artigo tem por objetivo discutir a expansão dos circuitos imobiliários por meio de GPUs, da Região Metropolitana do Recife (RMR) para municípios vizinhos, com destaque para o caso de Goiana, em um contexto de economia financeirizada e decisão de interiorização dos investimentos por parte do governo do estado. O município entrou nesse circuito global financeiro com a instalação da indústria automotiva FIAT, que estimulou a chegada de outras indústrias importantes e complementares. O que aqueceu o mercado imobiliário para atender a possível demanda decorrente das novas possibilidades de emprego.

Ainda que se vivencie uma mudança no cenário econômico brasileiro, observada a partir de 2014, que culminou em 2015, entende-se a relevância desse estudo de

Podem envolver desde um conjunto residencial até a renovação urbana de um centro histórico, zonas industriais, portuárias, ferroviárias, etc, construção de novas zonas turísticas ou recreativas, ou a construção de uma infraestrutura de transporte. Ou seja, possibilitam as condições ideais para a ${ }_{5}$ aplicação do capital financeiro. confluência entre setor financeiro e mercado imobiliário, haja vista que houve uma intensa produção nessa década, gerando novas centralidades e mudanças significativas nas hierarquias urbano regionais.

\section{AS MUDANÇAS NAS HIERARQUIAS URBANO REGIONAIS DA RMR A PARTIR DO RECENTE BOOM DE INVESTIMENTOS}

Atualmente a RMR é composta por 14 municípios $^{6}$, sendo responsável por aproximadamente $64 \%$ do PIB (Produto Interno Bruto a preços correntes) de Pernambuco $(\mathrm{R} \$ 89.726 .645$ bilhões do total de $R \$ 140.727 .616$ bilhões do estado, conforme dados do Instituto Brasileiro de Geografia e Estatística (IBGE, 2013)), além de ter apresentado índices econômicos crescentes nos últimos anos que ultrapassam o desempenho nacional. Em 2013, por exemplo, cresceu $3,5 \%$, enquanto a média nacional foi de $2,3 \%$, conforme apontamentos da agência Condepe/Fidem (2014). Desde a sua criação ao contexto recente passou por transformações significativas.

A Região Metropolitana do Recife foi institucionalizada ainda em 1973 juntamente com as regiões metropolitanas de São Paulo, Belo Horizonte, Porto Alegre, Salvador, Curitiba, Belém e Fortaleza, através da Lei Complementar no14 de 1973, na forma do art. 164 da Emenda Constitucional nํ1, 1969. O caráter de metropolização que Recife estabelecia, sobretudo, com Olinda e Jaboatão dos Guararapes, com grande circulação para trabalho, estudo e lazer entre os municípios, intensificado pelo direcionamento dos investimentos pelo governo do estado naquela época, justificam a decisão.

A partir de então foram elaborados planos de desenvolvimento para a região crescer e se desenvolver de maneira integrada, estabelecendo a setorização por nucleações para direcionar os investimentos, dos quais ressalta-se o Plano de Desenvolvimento Integrado (PDI), de 1976 que serviu de inspirações para os planos seguintes. As nucleações inicialmente foram realizadas em

\footnotetext{
${ }^{6}$ Os municípios são: Abreu e Lima, Araçoiaba, Cabo de Santo Agostinho, Camaragibe, Igarassu, Ipojuca, Ilha de Itamaracá, Itapissuma, Jaboatão dos Guararapes, Moreno, Olinda, Paulista, Recife e São Lourenço da Mata (Lei Complementar n-10/94).
} 
torno de municípios de destaque, a saber: Núcleo Metropolitano do Recife, Nucleação do II Polo Metropolitano, Núcleo Metropolitano do Cabo e Núcleo Metropolitano de Paulista e Igarassu. Posteriormente, os núcleos foram redefinidos como nucleações: Centro, Sul, Norte e Oeste.

Por meio dessas setorizações orientava-se o investimento e os tipos de atividades. De modo que desde a década de 1970, fomentou-se o desenvolvimento do Complexo Industrial Portuário de SUAPE (CIPS) no núcleo Sul - que ficou caracterizado pelo desenvolvimento e consolidação industrial; o núcleo Centro que começava a se consolidar como polo de atividades terciárias; a nucleação Oeste em que se almejava que pudesse receber a expansão do núcleo Centro, mas que terminou por se caracterizar ao longo dos anos, por uma ocupação de população de baixa renda em conjuntos habitacionais - ainda que se tenha direcionado investimentos para atrair moradores, como o Terminal Integrado de Passageiros, nos anos 1980 -; e a nucleação Norte, que teve os investimentos mais voltados à agroindústria e nas indústrias de gênero têxtil e vestuário, de química e produtos de matérias plásticas, e de extração de minerais (mineração de areias) (CPRH, 2016).

A década de 1990, no entanto, é marcada pela descentralização política e econômica e conferência de maior autonomia e protagonismo dos municípios na formulação e implementação de políticas públicas, orientada pela Constituição Federal de 1988, além de abertura comercial e financeira da economia brasileira, levando a um momento de transição para redefinição de papeis das várias esferas governamentais e das orientações de desenvolvimento econômico das cidades.

Nesse contexto, percebe-se que as experiências de gestão metropolitana do Recife perdem a força, sobretudo, em virtude da desarticulação do sistema de planejamento centralizado idealizado pelo Estado e da diminuição dos investimentos. Além disso, referida redução de investimentos diretos em Pernambuco, leva a dinâmica metropolitana do Recife a operar a partir dos recursos obtidos na fase anterior, já que não havia mais contrapartidas de políticas públicas que pudessem atender as demandas sociais de então, conforme apontaram Rosa e Oliveira (2015).
Nesse contexto, pode-se verificar mudanças estruturais e funcionais na hierarquia das cidades em virtude de sua maior autonomia. As cidades com melhor infraestrutura, maior nível de renda da sua população e maior potencial concentrador, a exemplo de Recife e Olinda, na RMR, assumiram posições no topo da hierarquia, passando a atrair os setores financeiros e produtores de serviços modernos com uso de tecnologia avançada que oferecem maior dinamismo econômico e deslocam atividades de menor rentabilidade, como a indústria $e$, por conseguinte, parte da população, para as cidades do entorno de posição subordinada na hierarquia da rede urbana (FERREIRA, MONTEIRO NETO, 2003).

O setor terciário que no ano de 1980 tinha participação de $55,9 \%$ do PIB do estado, em 1996, alcançava $72,4 \%$ do PIB. Na cidade do recife, nos mesmos anos de referência, os percentuais eram $75,1 \%$ e $88,8 \%$ respectivamente, revelando a transformação e consolidação dessa atividade na cidade polo da RMR (Ibidem, 2003). No que se refere ao terciário moderno, que se cristaliza com a globalização a partir dos anos 1970, representado por serviços de transporte, armazenagem e comunicações; comunicações; atividades financeiras e bens imóveis, observa-se um contínuo aumento nas décadas de 1970 a 1990, com a taxa de crescimento, ainda que menor nos anos 1990, sempre positiva (Figura 3).

Entretanto, é importante salientar que não foi um processo de transição entre setores simples e sem maiores impactos. Assim como no cenário brasileiro da década de 1990, observaram-se também antigos e prósperos centros industriais entrarem em declínio, bem como uma ampliação dos índices de desemprego e subemprego. É nesse cenário, que há uma busca ou disputa entre as cidades para se inserirem nas rotas para onde afluem a riqueza financeira, por meio de aportes de capital nacional e internacional a fim de tentar superar suas perdas. Para tanto, faziam-se necessários novos investimentos em infraestrutura e especialização na produção de serviços adequados às novas demandas (Ibidem, 2003). Mas além disso, os municípios recorreram aos incentivos fiscais.

De modo que novos planos foram formulados, salientando a elaboração em 1998, do Plano Diretor da Região Metropolitana do Recife (PDRMR) com vistas a direcionar o cenário pretendido da metrópole em 2010. Para tanto, 
foram redefinidas as funções e vocações dos municípios e suas territorialidades na RMR. Com isso, observa-se que no núcleo Centro e no seu entorno imediato predomina o incentivo ao setor terciário, com alguma ênfase ao terciário moderno. Reitera-se também a intenção em expandir para o Oeste as funções já estabelecidas no Centro, uma vez que o Oeste permanece com baixo grau de desenvolvimento socioeconômico apesar dos planos estabelecidos para a área. As atividades industriais cada vez mais se afastam da nucleação central e são levadas para o Norte, e, sobretudo, para o Sul.
As políticas de incentivos fiscais $e$ da descentralização do desenvolvimento, inclusive com uma maior interiorização dos investimentos, ainda na década de 1990, mas especialmente nos anos 2000, começaram a dar resultados, demonstrados pela recuperação do desempenho econômico relativo do estado (LIMA et al., 2007). Alavancado pela cada vez mais maior concentração de atividades do setor terciário moderno no Recife e da intensificação da industrialização nos municípios vizinhos.

Figura 3 - Tabela com a taxa média anual de crescimento do PIB setorial e por atividade econômica de Pernambuco - 1970-1999.

\begin{tabular}{|c|c|c|c|}
\hline \multirow{2}{*}{ ATIVIDADE ECONÔMICA } & \multicolumn{3}{|c|}{ TAXA MÉDIA } \\
\hline & $1970-80$ & $1980-90$ & $1990-99$ \\
\hline SETOR AGROPECUÁRIO & 6,0 & 0,8 & $-2,2$ \\
\hline Agropecuária, Silvicultura e Pesca & 6,0 & 0,8 & $-2,2$ \\
\hline SETOR INDUSTRIAL & 10,7 & 1,9 & 1,7 \\
\hline Indústria Extrativa Mineral & 16,3 & $-1,5$ & $-7,3$ \\
\hline Indústria de Transformação & 13,1 & $-1,2$ & $-1,3$ \\
\hline Energia Elétrica e Abastecimento de Água & 9,3 & 4,8 & 3,8 \\
\hline Energia Elétrica & 9,9 & 5,5 & 5,0 \\
\hline Abastecimento de Água & 6,1 & 2,0 & $-2,6$ \\
\hline Construção & 5,6 & 7,2 & 5,5 \\
\hline SETOR DE SERVIÇOS & 8,4 & 4,4 & 2,5 \\
\hline Comércio (inclusive Restaurantes e Hospedagem) & 10,7 & $-0,6$ & 3,6 \\
\hline Transportes, Armazenagem e Comunicaçōes & 5,4 & 6,2 & 7,9 \\
\hline $\begin{array}{l}\text { Transporte Rodoviário } \\
\text { S }\end{array}$ & 4,0 & 3,4 & $-2,2$ \\
\hline Transporte Ferroviário & 7,9 & $-5,9$ & 0,2 \\
\hline Transporte Aéreo & 11,8 & 4,4 & 2,9 \\
\hline Transporte Maritimo & & - & - \\
\hline $\begin{array}{l}\text { Comunicaçōes } \\
\text { - }\end{array}$ & 9,9 & 11,4 & 10,2 \\
\hline Atividades Financeiras & 14,2 & 6,8 & 2,1 \\
\hline Bens Imóveis & 8,8 & 7,0 & 3,8 \\
\hline Administração Pública & 5,7 & 5,0 & $-0,7$ \\
\hline TOTAL & 8,6 & 3,5 & 2,0 \\
\hline
\end{tabular}

Fonte: LIMA et al., 2007.

Dados sobre os investimentos anunciados entre 2004 e dezembro de 2012 para o estado de Pernambuco registram um volume total de R\$ 104,319 bilhões. Ao todo, foram setecentos e vinte nove projetos aprovados com vistas ao período de implementação entre os anos de 2007-2016. Desse total, $R \$$ 78,5 bilhões se concentraram na RMR, dos quais quase $R \$ 58,3$ bilhões foram anunciados para cinquenta empreendimentos localizados somente na cidade de Ipojuca e outros $\mathrm{R} \$ 11,6$ bilhões no município do Cabo de Santo Agostinho (ROSA; OLIVEIRA, 2015).

A tabela a seguir apresenta a distribuição dos recursos e o quantitativo de projetos aprovados com ênfase nas cidades da região metropolitana e nos municípios de Goiana e Vitória de Santo Antão. Alguns dos projetos já estão em operação, outros em curso e alguns ainda não foram iniciados, possivelmente, em virtude dos reveses na economia, sobretudo, a partir de 2015 (Tabela 1). 
Tabela 1 - Investimentos anunciados entre 2004 e dez/2012 para o estado de Pernambuco com ênfase nos municípios da RMR, Goiana e Vitória de Santo Antão para implementação entre 20072016.

\begin{tabular}{|c|c|c|c|}
\hline \multirow[t]{2}{*}{ Unidade territorial } & \multirow{2}{*}{$\begin{array}{l}\text { Número de projetos } \\
\text { aprovados }\end{array}$} & \multicolumn{2}{|c|}{ Volume de investimentos } \\
\hline & & $\mathrm{R} \$$ milhões & Distribuição \% \\
\hline Abreu e Lima & 14 & 63,8 & 0,06 \\
\hline Araçoiaba & -- & -- & -- \\
\hline Cabo de Santo Agostinho & 51 & $11.646,0$ & 11,16 \\
\hline Camaragibe & 6 & 232,1 & 0,22 \\
\hline Igarassu & 14 & 166,5 & 0,16 \\
\hline Ipojuca & 50 & $58.260,0$ & 55,85 \\
\hline Itamaracá & -- & -- & -- \\
\hline Itapissuma & 11 & $1.080,6$ & 1,04 \\
\hline Jaboatão dos Guararapes & 70 & 955,1 & 0,92 \\
\hline Moreno & 5 & 46,7 & 0,04 \\
\hline Olinda & 11 & 40,6 & 0,04 \\
\hline Paulista & 38 & 852,2 & 0,82 \\
\hline Recife & 153 & $4.039,8$ & 3,87 \\
\hline São Lourenço da Mata & 7 & 774,3 & 0,74 \\
\hline Vários municípios* & 2 & 394,0 & 0,38 \\
\hline RMR (total) & 432 & $78.551,7$ & 75,3 \\
\hline Goiana & 29 & $11.576,3$ & 11,1 \\
\hline Vitória de Santo Antão & 34 & $1.144,2$ & 1,1 \\
\hline Outros municípios de PE & 234 & $13.047,4$ & 12,5 \\
\hline Pernambuco (total) & 729 & $104.319,6$ & 100 \\
\hline
\end{tabular}

Fonte: Federação das Indústrias do Estado de Pernambuco. In ROSA, OLIVEIRA, 2015.

Nota: Foram contabilizados apenas os investimentos cujo valor declarado superou R\$100 mil.

${ }^{*}$ ) Corresponde aos investimentos que perpassam mais de um município da RMR.

A cidade do Recife concentrou o maior número de projetos aprovados, mas que correspondem em valores a $\mathrm{R} \$ 4$ bilhões, ou $5,14 \%$ do total aportado na RMR. Os dados confirmam o que discutem Rocha e Diniz (2014), quando afirmam que a capital deixa de ser a única centralidade da RMR. Observase que com os novos investimentos, abre-se espaço para a intencionada maior dinamização de outros municípios, que passam a assumir características de centralidade, gerando outros polos de desenvolvimento mais significativos, e consolidam-se municípios que já tinham esse atributo.

Como se pode perceber, o maior volume de investimentos, quase 90\%, se concentrou na nucleação Sul por meio de aportes em torno do Complexo Industrial Portuário de Suape a fim de melhor explorar as potencialidades e capacidade do complexo e o consolidar como centralidade daquela nucleação. No que se refere aos novos direcionamentos, chama-se atenção para os identificados ao Norte, sobretudo, com a concentração de $R \$ 11,5$ bilhões em investimentos no município de Goiana, o qual não faz parte da RMR. O valor é mais que o dobro do investido no Recife e ocuparia a terceira posição entre os municípios que receberam maior aporte de capital, se fizesse parte da RMR. Com isso, a expectativa é de que a cidade de Goiana se transforme em uma nova centralidade ao Norte da RMR, o que possivelmente impactará nas suas relações intermunicipais, como salientam Rosa e Oliveira (2015).

A Oeste salienta-se a realização dos megaeventos Copa das Confederações em 2013 e Copa do Mundo em 2014, que levou investimentos, sobretudo, a São Lourenço da Mata, município sede da Arena Pernambuco, para a implantação do estádio e da infraestrutura de serviço e transporte que demandava a realização de eventos como esses, bem como, investimentos na área de habitação em virtude dos reassentamentos realizados.

Além disso, destaca-se outro município que também não pertence à RMR, Vitória de Santo Antão, que faz limites com os municípios de Moreno, São Lourenço e Cabo de Santo Agostinho, e recebeu um shopping center, uma unidade do Instituto Federal de Educação Ciência e Tecnologia e o Centro Acadêmico de Vitória da Universidade Federal de Pernambuco, bem como, projetos na área de habitação (ROSA; OLIVEIRA, 2015).

Desde os anos 1990, quando Pernambuco deixou de receber maiores investimentos, viuse perder espaço para as economias de estados como a Bahia e o Ceará, de modo que se intencionava recuperar a característica 
de centralidade do estado. Para tanto, o estado assume a formulação de políticas públicas em prol da diversificação das atividades e interiorização da economia, de maneira tal que no momento em que o cenário econômico tornou-se favorável já havia um claro direcionamento para aplicação do volume de capital aportado, que foi aproveitando outras oportunidades que foram surgindo.

Nesse contexto, é importante salientar que com todas essas novas possibilidades, amplia-se a expectativa de demandas por moradias, especialmente, nos municípios que mais receberam investimentos em projetos com capacidade de dinamizar a economia, tais como Ipojuca, Cabo de Santo Agostinho, Jaboatão dos Guararapes, Paulista, Goiana, São Lourenço da Mata, Camaragibe e Vitória de Santo Antão.

Até o ano de 2008, observava-se que o mercado imobiliário na RMR se concentrava nos municípios de Olinda, Jaboatão dos Guararapes, além da capital Recife, em virtude da densa ocupação, sobretudo na porção orla, e da forte integração e conurbação entre esses municípios. A partir de 2009, no entanto, em resposta a intensificação da interiorização dos investimentos, verifica-se gradativamente a ampliação da participação de demais municípios (Figura 4).

Figura 4 - Gráficos ilustrando a evolução da participação dos municípios da RMR sobre o total de lançamentos imobiliários.

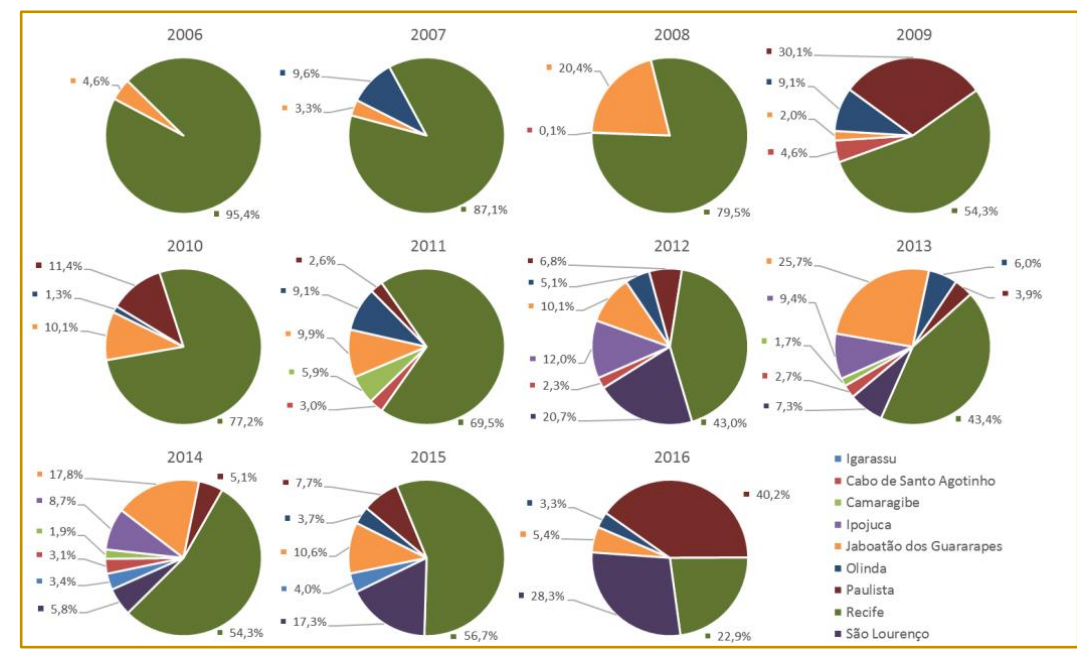

Fonte: Pesquisa de índice de Velocidade de Vendas. FIEPE (2006-2016). LACERDA BERNARDINO, 2014. Adaptado e atualizado pela autora, 2016.

Destaca-se que nos anos de 2012 e 2013 a construção civil em Recife teve menos da metade dos lançamentos que nos demais municípios da RMR, chegando nos anos de 2013 e 2014 com a participação de 8 municípios na produção imobiliária. Em 2016, incita-se atenção para uma participação de $23 \%$ da cidade do Recife, com um aumento significativo da construção civil no município de Paulista, o qual tem atraído o mercado imobiliário, em virtude das dinamizações na nucleação Norte da RMR.

Convém salientar ainda que não constam nesses gráficos os municípios fora da RMR, mas que provocam e sofrem grande influência da mesma e que também têm atraído novos empreendimentos residenciais após a realização de intensos investimentos. Como os municípios de Goiana e Vitória de Santo Antão. Com isso, vê-se confirmar o surgimento pretendido das novas centralidades e as nucleações vão se consolidando não apenas como polos industriais, mas como polos de desenvolvimento com dinamismo de atividades e possibilidades diversas de uso.

Para além do aumento significativo da participação de outros municípios nos lançamentos imobiliários, ressalta-se também o tamanho e as características dos novos empreendimentos. Ora pautados pelo modelo de bairro/ cidade planejada, com multiuso, ora em condomínios verticais envoltos de vários itens de lazer, recreação e amenidades 
naturais, ora aproveitando-se dos recursos do MCMV para a construção de inúmeras unidades.

Dessa maneira, entende-se que há um grande impacto na reprodução do espaço social e urbano nas cidades que passam a receber esses projetos urbanos de grande porte, de modo que se justifica o estudo aprofundado, sobretudo para o município de Goiana, que ainda que não faça parte da região metropolitana, tem recebido grandes investimentos em infraestrutura urbana, aporte de capital de grandes empresas e, por conseguinte, atraído fortemente o mercado imobiliário, de modo a passar por uma intensa transformação na hierarquia urbano regional com vistas a se consolidar como uma nova centralidade.

\section{TRANSFORMAÇÕES URBANAS EM GOIANA}

O município de Goiana localiza-se ao Norte do estado de Pernambuco, na microrregião da Zona da Mata Norte, limitando-se ao Norte com o estado da Paraíba, ao Sul com os municípios de Itaquitinga, Igarassu, Itapissuma e Itamaracá (e toda RMR), ao Leste com o Oceano Atlântico e ao Oeste com os municípios de Condado e Itambé (Figura 5).

Figura 5 - Localização de Goiana e seus limites.



Fonte: Elaboração própria, 2016.

Goiana conta com uma população de 78.618 habitantes, segundo estimativa do IBGE (2015), em uma área territorial de 501,881 $\mathrm{km}^{2}$, sendo sua densidade demográfica, portanto, de 156,92 hab/ $\mathrm{km}^{2}$, o que é considerada baixa, se comparada a Recife, por exemplo, que é de 7.039,64 hab/ $\mathrm{km}^{2}$.
Aproximadamente, a 13 metros acima do nível do mar, é formada por relevo de tabuleiros costeiros na maior parte da sua extensão e uma área menor de baixadas costeiras, com predominância de restingas, mangues e dunas (IBGE, 2015) (Figura 6). 
Figura 6 - Caracterização de Goiana com seus três distritos.

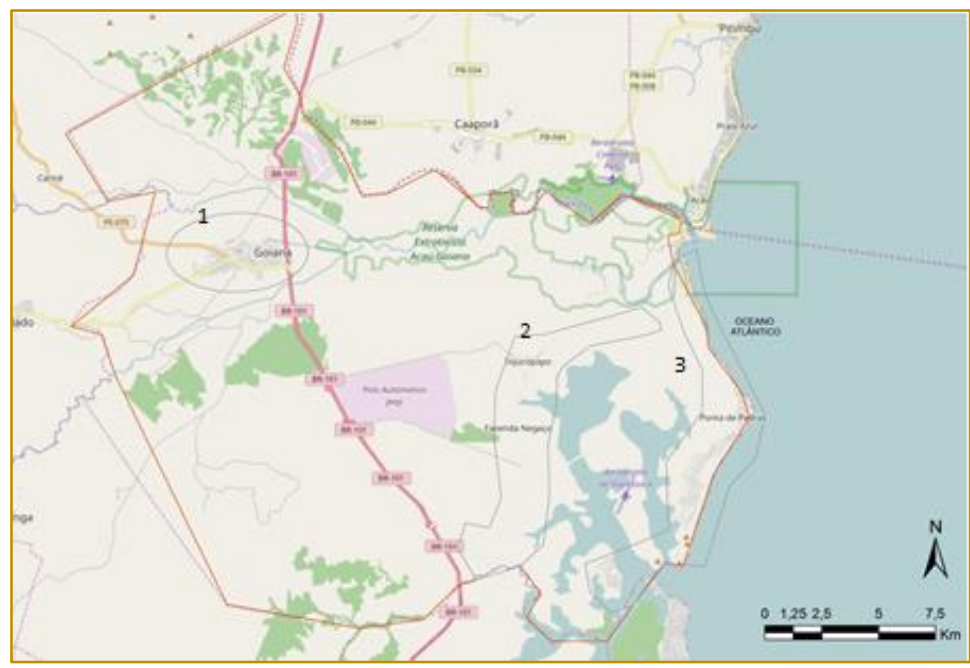

Fonte: Elaboração própria, 2016.

Como se pode observar na imagem acima, trata-se de uma área com a manutenção ainda de extensas áreas verdes que se concentram em diversas partes do território. Demonstra ainda a permeabilidade dos corpos d'água na extensão do município, revelando um município com muitos recursos naturais, ao mesmo tempo que, com muitas fragilidades ambientais.

Sua área divide-se, desde 1979, em três distritos (Figura 6): 1) o Distrito Sede, conhecido como Goiana, que possui o maior território e concentra a maior parte da população; 2) Tejucopapo, caracterizado pela população dispersa no território, bem como, pela riqueza de ambientes naturais, e 3) Ponta de Pedras, que compreende toda a extensão do litoral do município, de aproximadamente $18 \mathrm{~km}$ de extensão, formada por seis praias: Carne de Vaca, Tabatinga, Ponta de Pedras, Catuama, Barra de Catuama e Atapuz (IBGE, 2015). A ocupação se configura bastante dispersa e fragmentada pelo território.

Goiana passou a categoria de Vila em 1865 e começou a ganhar maior prestígio no cenário da economia estadual, de modo a se tornar, no século XIX, a cidade mais importante de Pernambuco depois do Recife. O que se deveu ao crescimento da importância das atividades comerciais em torno, principalmente, da cana-de-açúcar, em função sobretudo do movimento do seu porto, pelo qual podiam ser facilmente escoadas as mercadorias oriundas do interior (IBGE, 2015).

No final do século XIX, o município de Goiana era um grande centro agrícola, comercial e industrial, tinha um total de 47 engenhos, usina de açúcar e fábrica de tecidos. Como não haviam ainda as estradas de ferro, havia uma relação de dependência dos municípios vizinhos que precisavam se abastecer e tinham Goiana como a principal opção, dinamizando o movimento comercial da cidade com compradores que vinham tanto do interior de Pernambuco e da Paraíba ( $A D$ GOIANA, 2016).

Naquele período, já se observava cristalizar também uma sociedade estruturada em classes e bastante desigual, oriunda da formação econômica, composta pelos: grandes comerciantes e altos funcionários no topo, que ocupavam área central do distrito Sede; seguidos por pequenos proprietários e prestadores de serviços, no entorno imediato; depois, por pessoas pobres dispersos no território; na base, por uma grande massa de trabalhadores escravizados, que formaram quilombos na região, como exemplo, o do bairro São Lourenço, no distrito de Tejucopapo (ANDRADE, 2001).

No século $X X$, porém, as mudanças urbanas oriundas do processo de industrialização, que possibilitou a instalação da rede ferroviária do Nordeste e, por conseguinte, a facilidade de transporte de mercadorias, levaram a perda de hegemonia que o município detinha no cenário econômico estadual e nordestino, uma vez que as cidades vizinhas deixaram de depender das vantagens locacionais de Goiana. Data desse período então, o início do declínio vivenciado pela cidade, que não acompanhou a dinamização das atividades econômicas alcançadas por outros 
municípios, mantendo-se naquele século, bastante atrelada as atividades do setor agrícola, o qual sofre interferência de inúmeros fatores, além do cenário econômico e político, condições do clima, do solo (períodos de secas), e ainda, não confere o retorno de capital observado nos outros setores (LADOSKY, 2015).

O início do século XXI, entretanto, como vem sendo discutido neste artigo, trouxe novas perspectivas. Observa-se que desde os anos 2000 o município passou a procurar dinamizar suas atividades econômicas. Alterações no Plano Diretor municipal e incentivos fiscais, permitiram 0 interesse e a posterior implantação de indústrias importantes, como a Vivix Vidros Planos (VVP), a única de produção de vidros planos com capital 100\% nacional e já em atividade, e a Empresa Brasileira de Hemoderivados e Biotecnologia (Hemobrás), com uso de alta tecnologia voltada para pesquisa e desenvolvimento e prevista para entrar em pleno funcionamento em 2018, apesar de parte estar em operação; além de outras fábricas de suporte a essas atividades (HEMOBRÁS, 2013).

Salienta-se também a inauguração, em 2012, do Distrito Industrial Empresário José Albino Pimentel, que possui incentivos fiscais e já contemplou a instalação de várias empresas, seja de reciclagem, confecções, cerâmicas, pré-moldados, entre outras. Mas foi a instalação da indústria automobilística da FIAT, anunciada pela imprensa pernambucana em agosto de 2011, que permitiu a entrada oficial de Goiana no circuito global financeiro, impactando consequentemente na dinâmica urbana, conforme será abordado a seguir.

Com isso, a cidade de Goiana que vinha com crescimento populacional estável no início dos anos 2000, variando de 71.177 hab. em 2000 para 71.796 hab. em 2007, aumentando apenas 0,87\% em 7 anos, passou a ter um crescimento demográfico mais significativo a partir de 2010, passando para 75.644 hab. e 78.618 hab. em 2015, um aumento de 9,5\% nos últimos 8 anos. Esses fatores, tais como: investimentos públicos e privados e, aumento populacional, aqueceram $\mathrm{o}$ mercado imobiliário com vistas a atender a essa demanda decorrente das novas atividades, que assim como no contexto observado de financeirização da economia e do capital imobiliário, tem respondido por meio de projetos urbanos de grande porte.

\section{OS GRANDES PROJETOS URBANOS EM GOIANA}

Ainda, em agosto de 2011, com a divulgação da implantação da Fiat e movimentações de outras empresas, pode-se observar um crescimento vertiginoso dos preços de vendas e aluguéis de imóveis. O que se justifica em virtude de uma oferta pequena para a demanda que começava a surgir, e para demanda futura que se assinalava, de modo que o mercado imobiliário se viu estimulado a se aproximar do município com vistas a oferecer uma maior oferta, anunciando rapidamente vários empreendimentos de grande porte para o município (Tabela 2).

Tabela 2 - Grandes empreendimentos anunciados para Goiana.

\begin{tabular}{|c|c|c|c|c|}
\hline \multicolumn{2}{|r|}{ Empreendimento } & Responsáveis & Uhs & Status \\
\hline 1 & Northville & $\begin{array}{c}\text { Consórcio Paradigma - AWM Engenharia, CA3 } \\
\text { Construtora, São Bento Empreendimentos e Malus } \\
\text { Incorporadora }\end{array}$ & 406 & Oferta \\
\hline 2 & Cidade Atlântica & $\begin{array}{l}\text { Consórcio Atlântica - Queiroz Galvão, Grupo Moura, } \\
\text { GL Empreendimentos, Grupo Cavalcanti Petribu }\end{array}$ & 18000 & Projeto \\
\hline 3 & Novo Horizonte & Grupo de Investimentos Bom negócio & 559 & Oferta \\
\hline 4 & Portal do Mar & $\begin{array}{c}\text { AMP empreendimentos, Aparauá Ecoaventura e } \\
\text { Carvalheira Soluções Imobiliárias }\end{array}$ & 450 & Oferta \\
\hline 5 & Mirante do Mar & Imobi Desenvolvimento Urbano & 310 & Oferta \\
\hline 6 & $\begin{array}{l}\text { Goiana Beach } \\
\text { Life }\end{array}$ & Imobi Desenvolvimento Urbano & 500 & Oferta \\
\hline 7 & Caminho da Praia & Patrimônio Incorporações LTDA & 522 & Oferta \\
\hline
\end{tabular}


Os responsáveis pelos grandes projetos são desde construtoras com tradição nesse mercado, a antigos usineiros que mudam de setor passam a investir no mercado imobiliário, bem como formação de consórcios para compor o capital necessário.
Os novos sete grandes empreendimentos estão dispersos no território de Goiana, ora se localizando próximo ao distrito industrial, e da Hemobrás e VVP; ora no entorno da fábrica da Fiat ou no Distrito Praias (Figura 7).

Figura 7 - Localização dos novos empreendimentos e empresas em Goiana.

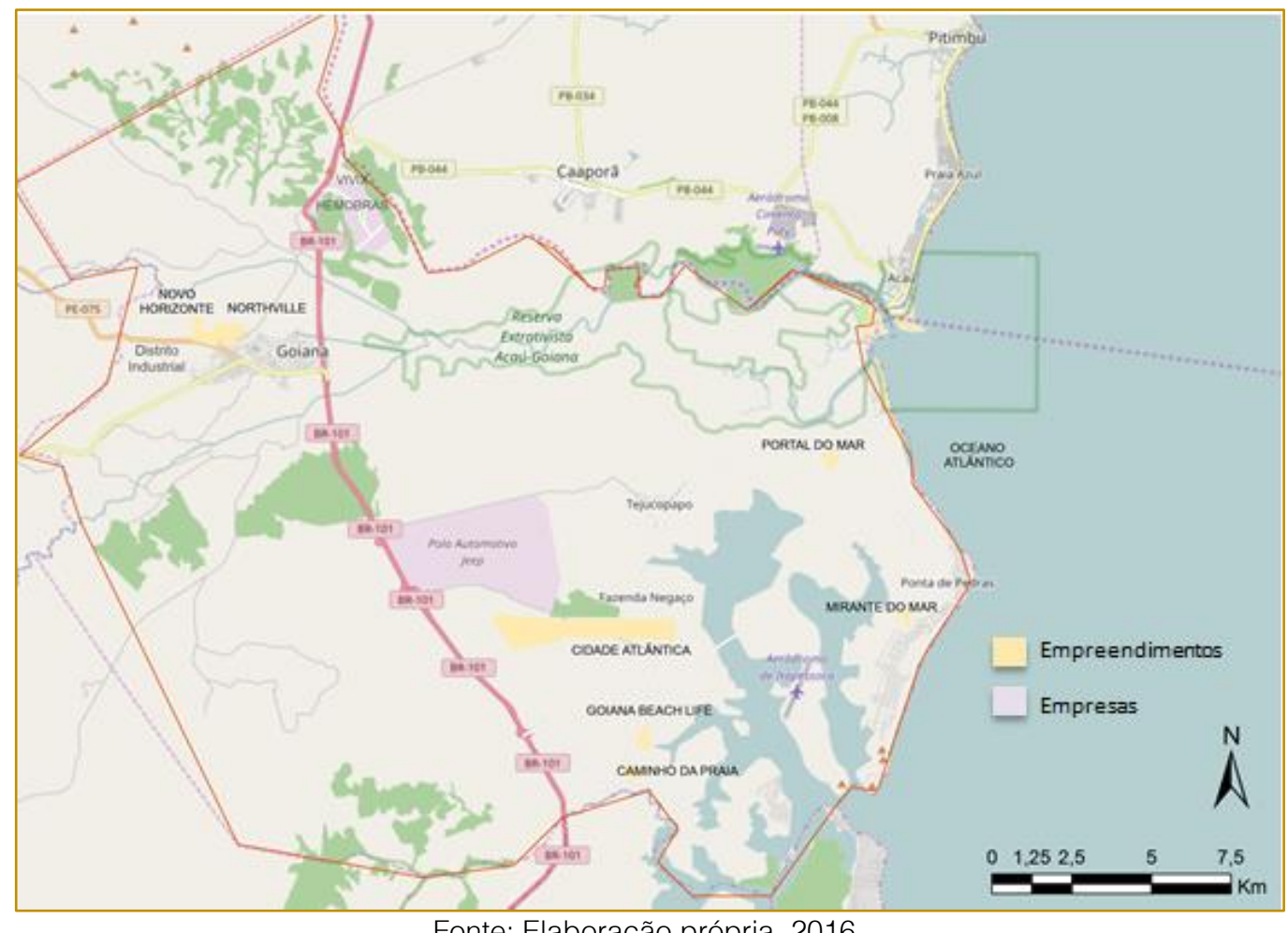

Ao todo seriam 20.747 unidades sob um modelo de tendência global: cidade/bairro planejado, abrangendo na maioria dos casos, além do uso residencial, o uso de comércio e serviços, e uso institucional, ocupando grandes extensões do território, mas sem maiores integrações (Figura 8).

Figura 8 - Northville, Novo Horizonte, Cidade Atlântica, Portal do Mar, Caminho do

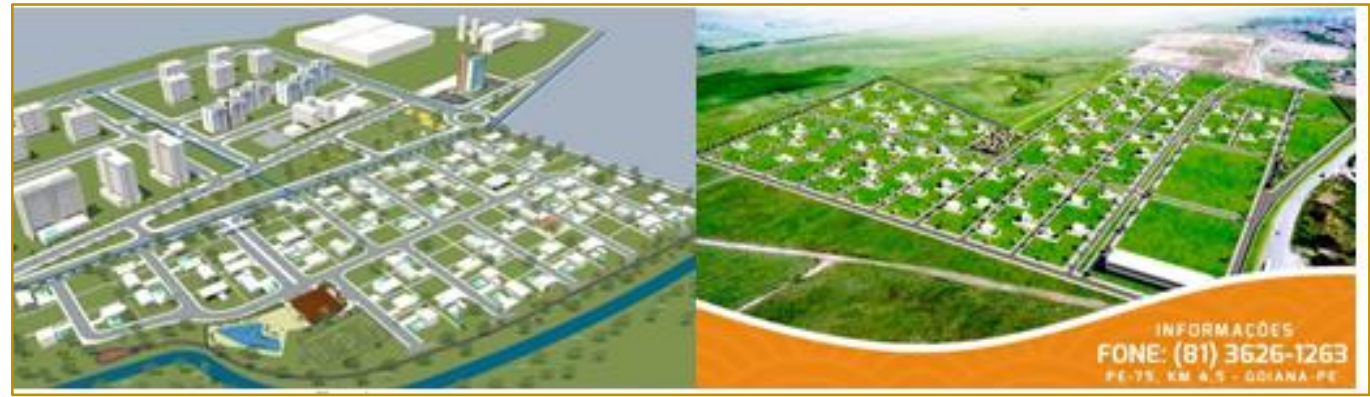


Praia, Goiana Beach Life e Mirante do Mar (em sequência).
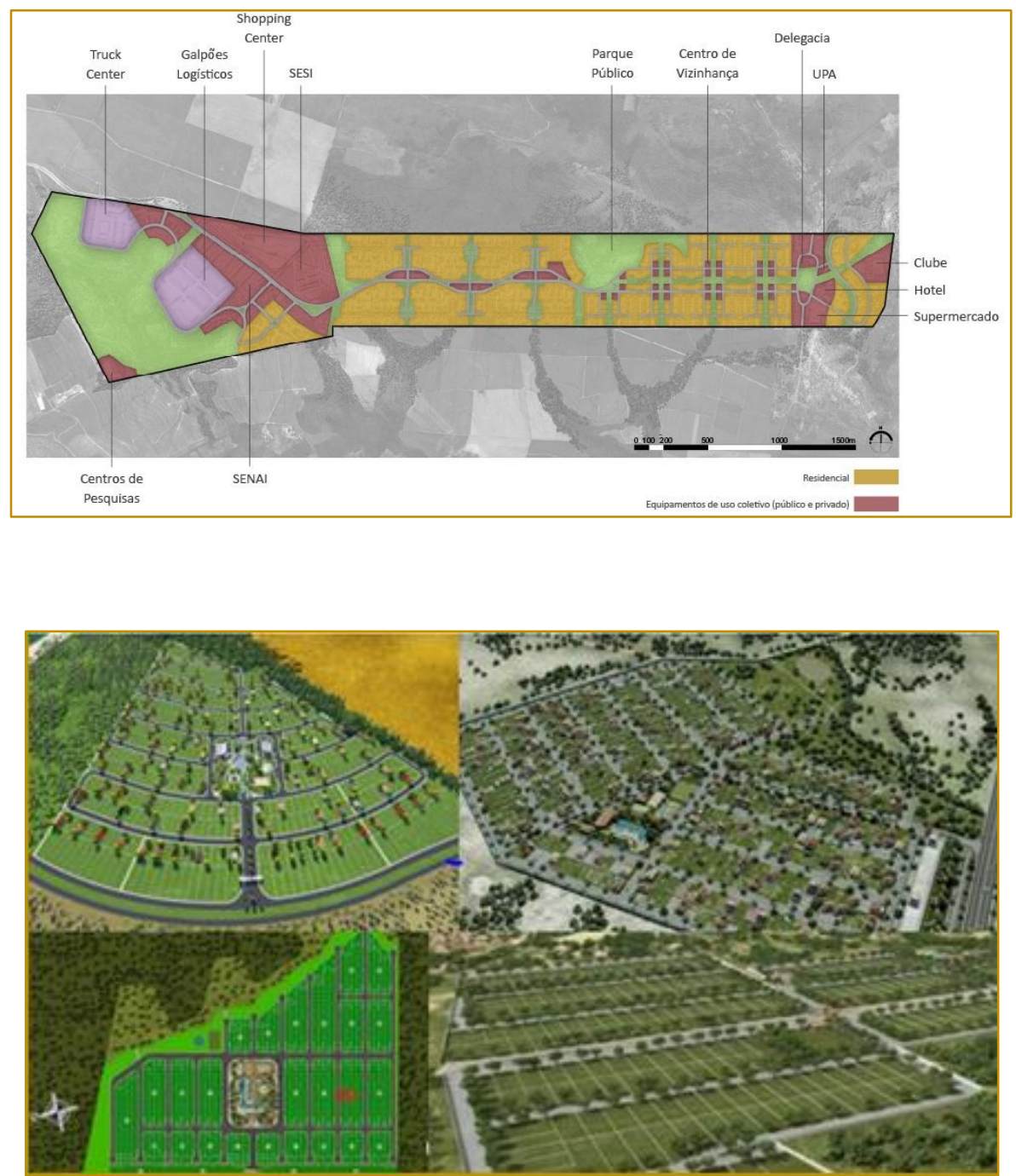

Fonte: Elaboração própria (2016)

Com algumas poucas unidades contempladas pelo programa Minha Casa, Minha Vida - como no caso do Northville Residence, parte destinada aos edifícios verticais -, os empreendimentos são voltados para o público de renda média a alta. Além disso, ao adotar o modelo de cidade/bairro planejado, muitas vezes, os responsáveis se utilizam dos condomínios murados, como é o caso da parte do Northville que é voltada para casas (o Northville Houses - que conta com 105 lotes), e dos loteamentos: Caminho da Praia, Goiana Beach Life e Mirante do Mar, o que amplia a fragmentação observada no município desde sua origem e cria ainda espaços segregados.

A maioria dos empreendimentos foi entregue - Northville Houses, Caminho da Praia e Mirante do Mar - ou está em vias de ser Novo Horizonte, Goiana Beach Life e Portal do
Mar. No entanto, o maior empreendimento proposto, o Cidade Atlântica não chegou a sair do papel e deverá ser deslocado para outro município. O grande projeto urbano realizado pela De Fournier \& Associados se localizaria no distrito de Tejucopapo, ao lado da Fiat, em um terreno de 600 hectares $^{7}$, com área residencial para aproximadamente 63 mil habitantes.

O projeto previa a divisão da área em quatro módulos distintos: dois bairros, contando com 18 mil moradias ao todo; e dois centros de comércio e serviços, sendo: um chamado de centro local, focado no público da Cidade Atlântica, com supermercados, posto de gasolina, escolas, e outros serviços; e outro regional, focado na população da cidade de

\footnotetext{
${ }^{7}$ Extensão territorial comparável ao de um grande bairro como Boa Viagem, em Recife-PE, que conta 753 hectares de área
} 
Goiana e em extensão a Mata Norte, com shopping center, hospital, hotel, centro empresarial e centro de logística.

Entretanto, o Consórcio Atlântica e o grupo Fiat-Chrysler Automobilies (FCA) entraram em conflito de interesses, e a supremacia foi do grupo FCA da empresa Fiat que já estava em construção e viu na implantação desse grande projeto imobiliário vizinho a possibilidade de afetar suas futuras pretensões de desenvolvimento e expansão na área.

A Cidade Atlântica, em função da sua magnitude, iria proporcionar um impacto ainda maior na malha urbana de Goiana e consequentemente nas demandas e necessidades futuras de integração e conexão. Com a mesma, previa-se um incremento populacional ao todo de 72 mil novos moradores, o que quase dobraria a população atual. Ainda assim, com a expectativa de um incremento de 9 mil habitantes, observa-se no contexto atual o início da conformação de uma outra cidade dentro de Goiana, ou de vários novos bairros, esses genéricos e que podem conduzir a formação de cenários urbanos globalizados compostos por uma arquitetura homogênea $e$ globalizada que além de possuir uma baixa integração com a malha urbana existente, tende a ter pouca relação com o estilo de vida dos moradores tradicionais.

Atraídos pelas novas possibilidades oferecidas pela financeirização da economia e, especialmente, do capital imobiliário, esse boom de novos empreendimentos em um município - que até a década passada não se vislumbrava grandes oportunidades de expansão - foi acompanhado por um sucesso de vendas dos lotes, nos anos de 2011 a 2014. O que a princípio, poderia sugerir que essa mudança de acréscimo populacional seria tão rápida quanto 0 esperado, no entanto, observa-se que não está ocorrendo uma confirmação dos usos propostos ${ }^{8}$, nem as residências estão sendo construídas nos lotes, nem os serviços incentivados (clínicas, escritórios de advocacia e contabilidade) estão se implantando no local.

Esse fato pode ter várias razões: a aquisição do lote como investimento com intenção de

\footnotetext{
${ }^{8}$ Visitas realizadas em abril de 2016 reveleram que dos empreendimentos entregues, apenas no Northville Houses há uma construção paralisada ainda na etapa de execução da alvenaria.
}

repasse ou de arrendamento, o atual cenário econômico de instabilidade do país momento em que é preferível poupar a gastar -, ou ainda, a carência de serviços atrativos e essenciais em Goiana, tais como saúde e educação de qualidade, além de infraestrutura básica de saneamento, por exemplo.

As três razões juntas podem ser a grande justificativa para o cenário que se apresenta, mas a última especificamente já pode ser observada quanto a escolha de moradia dos novos funcionários de alto escalão que optaram ou por residir em Recife ou João Pessoa - capital do município vizinho. Ambas cidades estão equidistantes de Goiana e contam melhor infraestrutura e serviços, sobretudo, Recife, que possui um Polo Médico de destaque no âmbito regional e escolas de referência. Por outro lado, é sabido que os novos funcionários que não têm poder de compra que ofereça maiores opções de escolha, estão indo morar de aluguel nas áreas periféricas ou até mesmo em cidades vizinhas, em virtude do crescimento vertiginoso de preços nas localidades mais próximas aos postos de trabalho.

Desse modo, discute-se os impactos espaciais já evidentes pela euforia do capital percebida até o ano de 2014 no que se refere a construção de empreendimentos de grande porte associados a lógica recente do capital imobiliário, mas dissociados da realidade em que se implanta, em um município com ares interioranos e fora do contexto metropolitano até os anos 2010. Entretanto, maiores impactos sociais poderão ser percebidos com a confirmação desse modelo a longo prazo ou até mesmo, pela não confirmação do mesmo, haja vista que o estoque de terrenos foi vendido e pode ser readaptado para outras funções, uma vez que o capital precisa girar, pois se o crescimento não recomeça, ele pode ser desvalorizado ou destruído.

\section{GOIANA COMO UMA NOVA CENTRALIDADE? REFLEXÕES À GUISA DE CONCLUSÃO}

A política de interiorização dos investimentos do governo de Pernambuco produziu resultados significativos e tem possibilitado a dinamização da economia por meio de novas atividade, com ofertas de emprego, mesmo em um contexto de inflexão da economia 
brasileira, em que há uma clara retração de investimentos.

Salienta-se que para atrair a instalação de novas fábricas, empresas e o próprio mercado imobiliário, o governo do estado e o município de Goiana, desde o ano de 2011, têm entrado com recursos próprios, promoveram inovações nos arranjos institucionais, traçaram Parcerias PúblicoPrivadas (PPPs), estabeleceram incentivos fiscais e alteraram inclusive, parâmetros e diretrizes do plano diretor ${ }^{9}$. Ou seja, trata-se de um processo que proporcionou grandes alterações na política e economia do município e do estado, apostando nas novas possibilidades oferecidas pelo capital financeiro e imobiliário, e está ainda em andamento, podendo colher outros frutos a longo prazo.

Como se pode observar nessa discussão, Goiana passa por uma reestruturação quanto

9 Foram estabelecidos novos arranjos institucionais, com destaque para a criação da autarquia Agência de Desenvolvimento de Goiana (AD Goiana), atrelada ao Gabinete do Prefeito, tendo por missão a promoção do desenvolvimento econômico sustentável do município, com ênfase na ampliação das oportunidades de trabalho, emprego e renda para a população economicante ativa, tanto do setor forma quando do setor informal da economia (AD GOIANA, 2016). Quanto às PPPs, aponta-se a inclusão de Goiana no programa cidade saneada, uma parceria entre a Companhia Pernambucana de Saneamento (COMPESA) e um consórcio formado pelas empresas Foz do Brasil, do Grupo Odebrecht e Lidermac Construções que objetiva universalizar o sistema de esgotamento da RMR e já incluiu o muncípio de Goiana, haja vista, os novos interesses. Por fim, no que se refere às mudanças no plano diretor, salienta-se a criação da Lei no 2.196/2012 que altera dispositivos da Lei no $1.987 / 2006$ e dá outras providências, incidiu especialmente no zoneamento do município, redefinindo zonas de uso agrícola e turismo para zonas de expansão urbana, e diminuindo, em alguns casos, zonas de recuperação ambiental, ampliando áreas para a urbanização. Em agosto de 2012, dois meses depois dessa, já havia uma nova Lei de no 2.204/2012, a qual cria uma nova Macrozona, a Macrozona Especial de Dinamização Econômica (MZEDE) - Goiana. A MZEDE se insere no setor de Tejucopapo e passa a se configurar com área urbana, sendo anteriormente rural. Tem a função de permitir a implantação de atividades logísticas, industriais e tecnológicas, necessárias ao atendimento de demandas decorrentes da instalação de grandes empreendimentos industriais, viabilizando a estratégia de desenvolvimento do município a sua hierarquia urbana regional, com a possibilidade de se firmar como uma nova centralidade para o estado, recuperando sua autonomia de outrora. De modo que atentos a esta oportunidade, viu-se uma expansão dos circuitos imobiliários para a localidade, com a implantação de grandes projetos urbanos e um bom índice de vendas. No entanto, a expectativa de novos moradores ainda não se confirmou.

Assim, destaca-se que para se consolidar como centralidade, não é suficiente em Goiana apenas ampliar a oferta de moradia, é preciso melhorar e modernizar a infraestrutura do município, aumentando também a oferta de serviços essenciais, como saúde e educação, as também chamadas infraestruturas sociais, e que têm peso fundamental na decisão de escolha de lugar para morar dos executivos e dos funcionários com renda que permite fazer opções.

Ademais, a demanda por moradias a preços baixos persiste, revelando a urgência de atendimento a esse público e desperta atenção para as reais necessidades sociais oriundas dos investimentos no município, que vai muito além dos interesses do capital imobiliário que permanece visando apenas o retorno rentável, pouco aproveitando das mais valias-urbanas oriundas do bom momento econômico vivenciado.

\section{REFERÊNCIAS}

[1] Aalbers, Manuel B. Corporate financialization. In: Castree, N. et al. (eds) The International Encyclopedia of Geography: People, the Earth, Environment, and Technology. Oxford: Wiley, forthcoming in 2015.

[2] $A D$ Goiana. Sítio da Agência de Desenvolvimento de Goiana. Disponível em http://adgoiana.pe.gov.br/. Acesso fev./mar. 2016

[3] Andrade, Manuel Correia de. Espaço e tempo na agroindústria canavieira de Pernambuco. Estudos Avançados, vol.15 no.43 São Paulo Sept./Dec. 2001

[4] Bndes/Banco Nacional de Desenvolvimento Econômico e Social. Disponível em:

http://www.bndes.gov.br/wps/portal/site/home/trans parencia/estatisticas-operacionais/. Acesso 18 out. 2016.

[5] Cardoso, Adauto Lúcio; Aragão, Thêmis A. Do fim do BNH ao programa Minha Casa Minha Vida: 25 anos da política habitacional no Brasil. In: CARDOSO, Adauto Lúcio (Org.). O programa 
Minha Casa Minha Vida e seus efeitos territoriais. Rio de Janeiro: Letra Capital, 2013.

[6] Condepe/Fidem. Desafios metropolitanos - cidade metropolitana: realidade e utopia. 10 Jun. $2014 . \quad$ Disponível em http://www.condepefidem.pe.gov.br/c/document_li brary/get_file?p_l_id=3104136\&folderld=13991739 \&name=DLFE-67524.pdf. Acesso em 14 out. 2016.

[7] Cprh. Sítio da Agência Estadual de Meio ambiente. Disponivel em http://www.cprh.pe.gov.br/home/42697\%3B38548 \%3B10\%3B0\%3B0.asp. Acesso em 14 out. 2016.

[8] Ferreira, G. D.; Monteiro Neto, Aristides. Transformações Estruturais na RM de Recife: notas sobre a década de 90. Leituras de Economia Política: Revista do Instituto de Economia da UNICAMP, Campinas/SP, v. 10, p. 125-145, 2003.

[9] Governo do Estado. PIB de Pernambuco apresenta crescimento superior ao do Brasil. Disponível

em http://www.pe.gov.br/blog/2013/03/11/pib-depernambuco-apresenta-crescimento-superior-aodo-brasil/. Acesso 17 de out. 2016.

[10] Harvey, David. O enigma do capital e as crises do capitalismo. São Paulo: Boitempo, 2011.

[11] Harvey, David. Os limites do Capital. São Paulo: Boitempo, 2013.

[12] Hemobras. Análise Participativa da Realidade Socioambiental de Goiana/PE, 2013. Disponível em: <http://www.hemobras.gov.br/site/downloads/Socio _Ambiental.pdf>. Acesso em: 28 jan. 2016.

[13] IBGE. Síntese de indicadores. Rio de Janeiro: Instituto Brasileiro de Geografia e Estatística, 2013.

[14] IBGE. Síntese de indicadores. Rio de Janeiro: Instituto Brasileiro de Geografia e Estatística, 2015.

[15] Lacerda, Norma; Bernardino, lana. L. Fragmentação e integração nas metrópoles brasileiras: retorno a unidade espacial. In: Limonad, E.; Castro, E. R. (Org.). Um Novo [23]
Planejamento para um Novo Brasil. 1ed. Rio de Janeiro: Letra Capital, 2014.

[16] Ladosky, Mário Henrique Guedes. Tradição e modernização das relações de classes em Goiana (PE). In: Anais do 39ํEcontro Anual da Anpocs. Caxambu, MG, 2015.

[17] Lima, J. P. R.; SICSU, A. B.; Padilha, Maria F. G. Economia de Pernambuco: Transformações Recentes e Perspectivas no Contexto Regional Globalizado. In: Revista Econômica do Nordeste, v. 38, p. 525-541, 2007.

[18] Magalhães, Felipe; Tonucci Filho, João; SILVA, Harley. Valorização Imobiliária e produção do espaço: novas frentes na RMBH. In: MENDONÇA, Jupira Gomes; COSTA, Heloisa Soares M. (Org.). Estado e capital imobiliário: convergências atuais na produção do espaço urbano brasileiro. Belo Horizonte: C/Arte, 2011.

[19] Mattos, Carlos A. de. Globalización, negocios inmobiliarios y transformación urbana. Nueva Sociedad. №. 212, pp.82-96., nov.- dez. 2007.

[20] Paulani, Leda Maria. Capitalismo financeiro, estado de emergência econômico e hegemonia às avessas no Brasil. In: OLIVEIRA, Francisco; BRAGA, Ruy; RIZEK, Cibele (orgs.). Hegemonia às avessas: economia, política e cultura na era da servidão financeira. São Paulo: Boitempo, 2010.

[21] Rocha, Daniele; Diniz, Fabiano. Arenas de decisão, arranjos institucionais e reconfiguração socioespacial ao sul da RMR: o polo Suape no cerne das políticas de desenvolvimento de Pernambuco. In: Maria Ângela de Almeida Souza; Jan Bitoun. (Org.). Recife: transformações na ordem urbana. 1ed.Rio de Janeiro: Letra Capital, v. 1, p. 459-501, 2015.

[22] Rosa, Jurema Regueira Arayban M.; OLIVEIRA, Fábio L. Pimental. Tendências de reestruturação territorial na Região Metropolitana do Recife: Economia e Mercado de Trabalho. In: Maria Ângela de Almeida Souza; Jan Bitoun. (Org.). Recife: transformações na ordem urbana. 1ed.Rio de Janeiro: Letra Capital, 2015. 


\title{
Capítulo 3
}

\section{ESTADO, TERRITÓRIO E GESTÃO DA CIDADE: O CASO DA OPERAÇÃO URBANA CONSORCIADA NOVA BH.}

\author{
Reginaldo Magalhães de Almeida \\ Juliana Lamego Balbino Nizza \\ Amanda Pereira de Oliveira Diniz \\ Jorge Eulampio Monteiro Junior
}

Resumo: Alguns instrumentos de política urbana regulamentados no Estatuto da Cidade, apesar de transcorridos mais de 15 anos de sua aprovação, merecem uma maior análise. Entre esses instrumentos destaca-se a Operação Urbana Consorciada, a qual vem sendo bastante utilizada em diversas cidades no Brasil para viabilizar, principalmente, grandes empreendimentos imobiliários. Em Belo Horizonte, a Operação Urbana Consorciada começou a ser utilizada, desde meados da década 1990. Procurando a interação dos campos da Arquitetura e do Direito e concentrando-se na experiência de Belo Horizonte, apresenta-se neste artigo parte dos resultados de uma pesquisa, apoiada pela Universidade FUMEC/MG e pela FUNADESP em 2015/2016. O objetivo central desse artigo é analisar a atuação do poder público municipal no processo de implantação das Operações Urbanas Consorciadas, desenvolvendo uma análise crítica dos caminhos percorridos pela Prefeitura de Belo Horizonte no processo de gestão dos interesses da participação da população. Como recorte de estudo, estudou-se a Operação Urbana Consorciada denominada primeiramente como Nova BH, proposta pela Prefeitura de Belo Horizonte e que está em processo de implantação. Posteriormente, ela passou a ser chamada Operação Urbana Antônio Carlos/Pedro I/Leste-Oeste. Para a realização do artigo, utilizaram-se dados disponibilizados em órgãos públicos e uma extensa revisão bibliográfica de renomados autores do Direito Urbanístico. Ao final, conclui-se que a coordenação do poder público municipal, do processo de implementação das operações em Belo Horizonte, necessita de avançar mais, tanto na defesa e garantia quanto na participação da população como um todo, e não apenas de certos agentes específicos, como os investidores privados e os proprietários dos terrenos.

Palavras Chave: Belo Horizonte. Gestão pública. Operação Urbana Consociada 


\section{INTRODUÇÃO}

O instrumento urbanístico de política urbana denominado Operação Urbana Consorciada, regulamentado pelo Estatuto da Cidade (Lei Federal $n^{\circ}$ 10.257/2001), cada vez mais presente no planejamento e gestão do uso do solo urbano nas grandes e médias cidades no Brasil, caracteriza-se por um conjunto de intervenções urbanísticas e estruturais coordenadas pelo poder público municipal.

Em Belo Horizonte, capital de Minas Gerais, esse instrumento vem sendo utilizado desde 1996, ano no qual foi aprovado o primeiro Plano Diretor municipal da cidade (Lei $\mathrm{n}^{\circ}$ 7.165/96). A partir de então, foram implantadas e implementadas várias Operações Urbanas Consorciadas na cidade, que viabilizaram grandes empreendimentos imobiliários, regularização fundiária, construção de equipamentos públicos, reabilitação de áreas urbanas, preservação do patrimônio histórico da cidade, dentre outros. Até os dias atuais, muitos foram os caminhos percorridos por esse instrumento na capital de Minas Gerais e que merecem um aprofundamento maior.

A implantação de uma legislação é um processo que se inicia com a idealização da lei, passa por sua redação, apresentação ao Poder Legislativo, discussão, votação, aprovação, promulgação e publicação em Diário Oficial. Já a implementação da lei só começa depois que ela estiver implantada. Com relação à análise da implantação de uma legislação, o jurista José Afonso da Silva (2000) destaca que cabe verificar se o poder público está observando as normatizações que orientam o processo jurídico, desde a redação até a publicação da legislação, com destaque para a participação e defesa dos interesses da população.

O objetivo deste artigo é analisar a atuação do poder público municipal de Belo Horizonte na efetivação da garantia dos interesses da população nas Operações Urbanas Consorciadas, prevista na regulamentação desse instrumento urbanístico no Estatuto da Cidade. Pretende-se descortinar se o poder público municipal tem procurado, durante a implantação da Operação Urbana Consorciada, exercer o papel que lhe cabe na gestão dos interesses da população, garantido, assim, a participação de todos os agentes que participam da produção da cidade.
Como estudo de caso, pretende-se analisar a Operação Urbana Consorciada Nova BH, proposta apresentada pela Prefeitura de Belo Horizonte (PBH) em outubro de 2013 e que pretendia ser a maior Operação Urbana da capital. Em 2014, após uma série de questionamentos, ela passou a ser denominada pela $\mathrm{PBH}$ como a Operação Urbana Consorciada Antônio Carlos/Pedro I/Leste/Oeste, mantendo parte dos objetivos anteriormente propostos.

A Operação Urbana Consorciada Nova BH e/ou Antônio Carlos/Pedro I/Leste/Oeste envolve importantes vias de ligação regional da cidade, abrangendo toda a extensão do Vale do Arrudas, envolvendo diversos bairros da cidade e totalizando uma área de influência direta de aproximadamente $9 \%$ da extensão territorial de Belo Horizonte (PBH,2016).

Os estudos para realização deste artigo foram baseados em ampla pesquisa e análise documental, fundamentadas nos documentos arquivados pela Prefeitura de Belo Horizonte $(\mathrm{PBH})$ e pelo Ministério Público Estadual (Coordenação de Urbanismo e Meio Ambiente) e que estão disponíveis ao acesso público. A análise envolveu também pesquisa em jornais, livros nos campos do Direito, da Arquitetura e do Urbanismo, reportagens, teses e dissertações.

Os dados e as análises apresentadas aqui fazem parte de uma pesquisa iniciada em 2015 que conta com o apoio do Programa de Pesquisa e Iniciação Científica da Universidade FUMEC (ProPic/FUMEC) e da FUNADESP, sendo o grupo de pesquisadores formado por professores e alunos dos cursos de Arquitetura e Urbanismo e do Direito.

\section{O ESTATUTO DA CIDADE E AS OPERAÇÕES URBANAS CONSORCIADAS: BREVES CONSIDERAÇÕES}

Estatuto da Cidade (2001) prescreve, no artigo 32, $1^{\circ} \stackrel{\circ}{ }$, que a Operação Urbana Consorciada é um tipo especial de intervenção urbana que objetiva a realização de transformações estruturais, com melhorias sociais e valorização ambiental. Por transformações urbanísticas estruturais, compreende-se a implantação dos serviços públicos, a pavimentação de vias, sistemas de saneamento, os transportes, dentre outros. Como melhorias sociais, entende-se a implantação de equipamentos comunitários 
como postos médicos e escolas, a construção de centros habitacionais para a população de baixa renda e o estímulo à oferta de bens e serviços de consumo. Por fim, na valorização ambiental considera-se a preservação do meio ambiente e dos recursos naturais, a implantação de praças e parques, bem como, a valorização arquitetônica do patrimônio histórico. (Brasil, 2001).

Esse instrumento urbanístico partiu de quatro diretrizes, sendo elas: a falta de recursos públicos para realizar investimentos de transformação urbanística de determinadas áreas; a convicção de que investimentos públicos geram valorização imobiliária, que pode ser captada pelo poder público; a convicção de que o controle do potencial construtivo era a grande 'moeda' que o poder público poderia contar para entrar na operação; e a crítica às estratégias correntes de controle de uso e ocupação do solo no sentido de sua incapacidade de captar singularidades e promover o redesenho ou, em outras palavras, o urbanismo. (Brasil, 2001: 82).

Os Professores e Urbanistas Ermínia Maricato e João Sette Whitaker Ferreira (2002) consideram que a Operação Urbana Consorciada, mesmo sendo regulamentada nacionalmente em 2001 no Estatuto da Cidade, já era conhecida e vinha sendo aplicada em diversos planos diretores das cidades brasileiras, e até mesmo entendida por outras configurações e nomenclaturas.

De acordo com a Professora e Urbanista Mariana Fix (2001), a Operação Urbana Consorciada começou a ser utilizada pelas administrações municipais, a partir da década de 1990, servindo, em cidades como São Paulo, como solução para renovação ou modernização de trechos da cidade, que supostamente seria custeada pela arrecadação entre seus beneficiários.

$\mathrm{Na}$ área jurídica, cada vez mais, tem-se estudado esse instrumento. Para o advogado João Carlos Castellar (2010), a Operação Urbana é uma forma de parceria público privada, que funciona como um sistema de troca no qual o setor privado investe em melhorias urbanas em uma área delimitada por uma lei municipal específica e, em contrapartida, garante flexibilidade nas leis edilícias em seus empreendimentos.

Estudioso da gestão pública, o professor e jurista Toshio Mukai (2007) conceitua a Operação Urbana Consorciada como um tipo especial de intervenção urbana que objetiva a transformação sobre a gestão do poder público, onde há o redesenho deste setor, podendo seu espaço ser público ou privado, receber investimentos públicos e privados a fim de realizar a execução, alteração, manejo e transação dos direitos de uso e edificabilidade do solo e as obrigações de urbanização.

Outro professor e jurista José dos Santos Carvalho Filho (2009) define a Operação Urbana Consorciada como sendo um instrumento de política urbana, que representa um instituto criado e desenvolvido com base no regime de parceria, cujo modelo auxilia inúmeras formas de atuação do poder público no processo de gestão das cidades. É imperioso ressaltar que o regime de parceria exige a cooperação mútua entre o poder público municipal e o setor privado. Para o autor, o intuito cooperativo é a base da Operação Urbana Consorciada.

Os requisitos para a realização de uma Operação Urbana Consorciada estão delimitados no artigo 32 do Estatuto da Cidade. Esse dispositivo legal define exigências ao poder público municipal na implantação da legislação regulamentadora do instrumento das OUC, tais como, a delimitação da área de aplicação do instrumento, que esteja explícito qual será a sua finalidade, as transformações estruturais que fomentarão e a projeção de melhorias sociais e ambientais que serão atingidas na área demarcada. Já o artigo 33 do Estatuto da Cidade, complementando o anterior, prescreve que cabe ao poder público definir quais são os objetivos específicos a serem concretizados com a aplicação do instrumento, respeitando, como afirma a jurista Betânia de Moraes Alfonsi (2005), o princípio da publicidade, observância indispensável ao poder público municipal.

Assim, trata-se a Operação Urbana Consorciada de um instrumento de produção do espaço urbano, que conta com a parceria entre o setor público e investidores privados, permitindo a participação de diversos agentes, visando à realização de transformações urbanísticas estruturais, melhorias sociais e a valorização ambiental de uma determinada cidade.

Ainda sobre o tema, o geógrafo Roberto Lobato Corrêa (2011) classifica e elenca o papel que cabe aos agentes que produzem o espaço urbano. O autor os identifica como 
sendo: os proprietários dos terrenos, os moradores, os usuários permanentes, os investidores privados e o poder público.

Os proprietários dos terrenos ou imóveis envolvidos na Operação Urbana Consorciada atuam de forma a obter a maior renda possível de suas propriedades, aproveitandose das melhorias públicas em infraestrutura para valorização dos terrenos (Corrêa, 2011). Carvalho Filho (2009) afirma que os proprietários podem ser os maiores beneficiários das operações urbanísticas, pois tais proprietários são titulares do direito de propriedade sobre os imóveis e poderão adquirir determinado benefício.

Já na categoria pertencente aos moradores, tem-se os residentes no local em que será realizada a Operação Urbana Consorciada, podendo ser ou não proprietários. Ademais, os moradores do entorno da área da intervenção podem ter um voto de peso na negociação, quando, a partir do estudo de impacto de vizinhança, se verificar que estes sofrerão impactos positivos e negativos em razão dos empreendimentos que serão realizados. Já os usuários permanentes são aqueles que, mesmo não residindo no local afetado, utilizam o espaço, como por exemplo os comerciantes, e também poderão ter uma posição no acordo.

Os investidores privados exercem grande pressão política na elaboração, aprovação e implementação das Operações Urbanas, pois são os principais financiadores, possuem interesse em imóveis estrategicamente localizados de acordo com seus objetivos e asseguram-se disto ao bancar as obras de infraestrutura pública.

Por fim, o poder público aparece, de acordo com a lei, como intermediador da operação, sendo o agente que coordena a implantação e implementação das Operações Urbanas Consorciadas, buscando um acordo entre os agentes envolvidos. Esta responsabilidade do poder público será discutida no próximo item do artigo.

\section{AS RESPONSABILIDADES DO PODER PÚBLICO MUNICIPAL NA GESTÃO DA CIDADE}

Constituição Federal de 1988 (Brasil, 1988) reparte a competência urbanística para legislar entre os três entes federativos, competindo, assim, à União, aos Estados e aos Municípios criar normas jurídicas urbanísticas (artigos 21, 30 e 182, da Constituição Federal). Segundo Silva, (2000: 62):

Em verdade, as normas urbanísticas municipais são as mais características, porque é nos Municípios que se manifesta a atividade urbanística na sua forma mais concreta e dinâmica. Por isso, as competências da União e do Estado esbarram na competência própria que a Constituição reservou aos Municípios, embora estes tenham, por outro lado, que conformar sua atuação urbanística aos ditames, diretrizes e objetivos gerais de desenvolvimento urbano estabelecidos pela União e às regras genéricas de coordenação expedidas pelo Estado.

Da análise do artigo 182 do texto constitucional, regulamentado pelo Estatuto da Cidade, depreende-se que "a política de desenvolvimento urbano, executada pelo poder público municipal, conforme diretrizes gerais fixadas em lei, tem por objetivo ordenar o pleno desenvolvimento das funções sociais da cidade e garantir o bem-estar de seus habitantes".

Assim, muito embora a atuação mais concreta e perceptível na prática seja realizada pela municipalidade, já que esta exerce o papel de executora da política de desenvolvimento urbano, verifica-se que a função de legislar sobre a atividade urbanística compete às três esferas do poder público, de forma concorrente, cabendo-Ihes definir procedimentos e normas acerca do regime jurídico da propriedade urbana.

Segundo o professor e jurista Hely Lopes Meirelles, na obra Direito Administrativo Brasileiro (2006: 66), a União, os Estadosmembros, os Municípios e o Distrito Federal são pessoas jurídicas de Direito Público integrantes da estrutura constitucional do Estado, possuindo poderes políticos e administrativos. A competência de tais entidades estatais está expressamente prevista na Constituição Federal (Brasil, 1988), discorrendo o texto constitucional especificamente sobre o que compete a cada uma delas.

Em relação ao papel dos Municípios, objeto de análise neste artigo, Meirelles (2001: 339) afirma que "a competência do Município para organizar e manter serviços públicos locais está reconhecida constitucionalmente como um dos princípios asseguradores de sua autonomia administrativa (art. 30)". Assim, 
caberá ao poder público municipal, atuar sobre serviços públicos em que o interesse é local, isto é, aos interesses mais afetos e predominantes àquele município do que ao Estado e à União.

O papel do poder público municipal, no que se refere à matéria urbanística, encontra previsão constitucional no artigo 30 , incisos I, II e VIII, bem como, no artigo 182 (Brasil, 1988). O poder público possui atuação direta e perceptível em assuntos de interesse local, promovendo adequadamente a ordenação do território, através do planejamento e controle do uso, do parcelamento e da ocupação do solo urbano. Tal atuação é feita fundamentalmente através de um instrumento básico de política de desenvolvimento e de expansão urbana, denominado de plano diretor.

O jurista Edésio Fernandes (1998) discorre sobre o papel do poder público e do plano diretor da seguinte forma:

Ora, é fácil perceber que a ordenação da cidade através de normas urbanísticas é assunto predominantemente local, e tal ideia se reforça-se ainda mais diante da explicitação da natureza do Plano Diretor, verdadeiro instrumento de planejamento estratégico do próprios Município, que, aplicado por sua legislação correlata - Lei do Uso, Ocupação e Parcelamento do Solo, Código de Obras e Código de Posturas deve conter diretrizes das mais diversas, desde as relacionadas às condições de acesso dos cidadãos aos seus direitos sociais e fundamentais, como emprego, habitação e serviços, passando pela proteção ao meio ambiente e patrimônio natural e cultural, até aquelas que digam respeito ao perfil econômico do Município, entre outras (1998: 21).

A função de planejamento urbanístico local está prevista no artigo 30, VIII, da Constituição Federal (Brasil, 1988), que dispõe que compete ao poder público municipal planejar e gerir a cidade através de uma política urbana, buscando atender à função social da propriedade e ao bem-estar de seus habitantes. Tal planejamento, que incluirá os critérios de utilização do solo, será estabelecido no Plano Diretor de cada cidade, que deverá ser aprovado pela Câmara Municipal, conforme previsto pelo artigo 182, da Constituição Federal.

Para o professor e geógrafo Marcelo Lopes de Souza (2002), planejamento e gestão são questões mais políticas do que técnicas, sendo ações coletivas com bases teóricas e com um ponto de vista autonomista, ou seja, saberes políticos por excelência e conduzidos de forma democrática, e não inspirada por intelectuais tecnocráticos e impostas pelo poder público. Ainda assim, o autor defende que a participação dos técnicos no planejamento e gestão das cidades é relevante, mesmo entendendo que o conhecimento técnico é obtido por uma minoria e que isso é insuficiente para a construção de um bem geral, como seria possibilitado democraticamente.

Silva (2000: 86) ainda disserta que "(..) o processo de planejamento passou a ser um mecanismo jurídico por meio do qual o administrador deverá executar sua atividade governamental na busca da realização das mudanças necessárias à consecução do desenvolvimento econômico-social". Dessa forma, promover o planejamento do uso do solo urbano deixou de uma mera faculdade do Município, posto que, constituiu uma previsão constitucional e uma provisão legal, por meio da qual deve o poder público municipal estabelecer os objetivos e as estratégias definidoras do processo de utilização do solo urbano. O autor prossegue assim dissertando:

Compenetrando-se da realidade a ser transformada e das operações de transformação que consubstanciam o processo de planejamento, sob pena de ser mera abstração sem sentido, o plano urbanístico adquire, ele próprio, por contaminação necessariamente dialética, as características de um procedimento jurídico dinâmico, ao mesmo tempo normativo e ativo, no sentido de que os anteprojetos elaborados por técnicos e especialistas adquirem a categoria de diretrizes para a política do solo e sua edificação, ao mesmo tempo em que, em seus desdobramentos, se manifesta como conjunto de atos e fundamentos para a produção de atos de atuação urbanística concreta. (Silva, 2000: 91-92)

Lado outro, contudo, e não menos importante, está o dever de implementação da legislação urbanística pelo Município, isto é, deve o poder público buscar efetivar que os instrumentos legais alcancem os objetivos previstos na legislação. Para tanto, é imprescindível que o poder público municipal, ao atuar como gestor dos interesses da população, garanta a participação efetiva deste agente na elaboração da legislação 
instituidora de determinada Operação Urbana Consorciada. Dessa forma, durante a implantação das normas e sua posterior implementação, sobre a coordenação do poder público, parte dos efeitos almejados e previstos na legislação da Operação Urbana Consorciada poderão ser alcançados e sentidos pela população local, posto que, seus interesses reais foram perseguidos e contemplados em planejamentos correspondentes aos anseios da realidade urbana.
4. OPERAÇÃO URBANA CONSORCIADA NOVA BH OU OPERAÇÃO URBANA ANTÔNIO CARLOS/PEDRO I, LESTE/OESTE.

Operação Urbana Consorciada Nova $\mathrm{BH}$ foi apresentada pela primeira vez no início de 2013 pelo poder público municipal de Belo Horizonte, sendo a maior operação da capital mineira até os dias atuais, abrangendo os corredores das Avenidas Antônio Carlos/Pedro I como eixos principais, e incluindo também trechos das Avenidas Andradas, Tereza Cristina e Via Expressa, que pertencem a bacia do Ribeirão Arrudas. Envolveria 58 bairros, divididos em 10 setores, com cerca de $25 \mathrm{~km}^{2} \mathrm{e}$ afetando aproximadamente 170 mil moradores da região (PBH, 2016) (Fig. 1).

Figura 1 - Operação Urbana Consorciada Nova BH

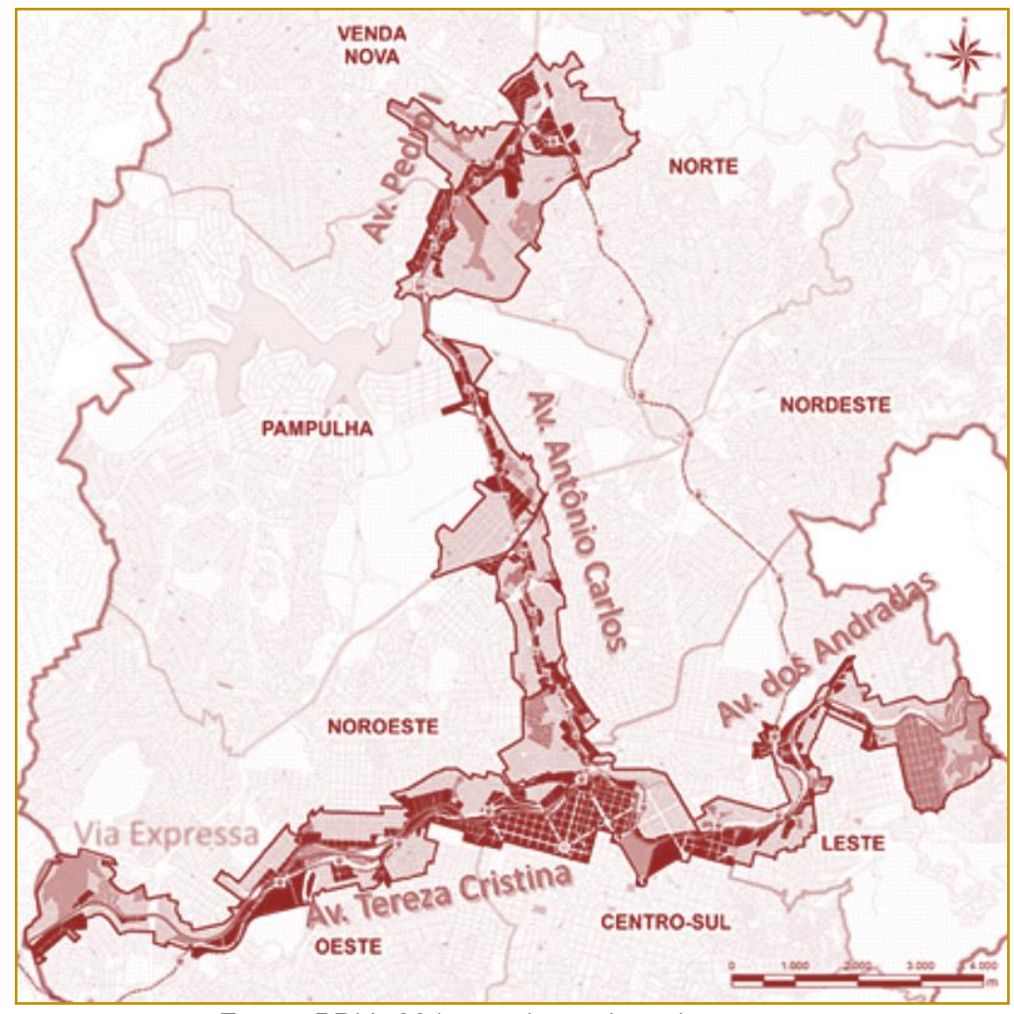

Fonte: PBH, 2014 - adaptado pelos autores.

A ideia da proposta da Operação Urbana Consorciada surgiu após análise apresentada na $3^{a}$ Conferência de Política Urbana em 2009, onde a PBH mostrou a possibilidade de uso desse instrumento nas regiões da cidade citadas anteriormente, já que tais áreas estavam passando por grandes intervenções viárias, como a implantação do BRT (transporte de ônibus rápido), as quais, segundo a $\mathrm{PBH}$, gerariam melhorias estruturais, principalmente na mobilidade, direcionando o desenvolvimento da cidade nessas regiões, que passariam a ter, assim, maior capacidade de suporte e, no entendimento dos técnicos, teria grande estrutura para receber mais potencial construtivo (PBH, 2015). 
Os objetivos previstos para a Operação Urbana Consorciada Nova BH, conforme proposta da $\mathrm{PBH}$, dividiam-se em três eixos: estrutural, socioambiental e econômico. No eixo estrutural, os objetivos seriam: permitir que a Prefeitura ordenasse/direcionasse 0 crescimento da cidade para regiões próximas aos principais corredores de transporte público coletivo (Metrô e BRT) - ocupando áreas com melhor infraestrutura viária e capacidade de transporte; criar novos centros de serviços e comércio na cidade, aumentando a oferta de serviços e trabalho mais próximos das residências das pessoas, reduzindo os deslocamentos e desafogando o trânsito da cidade; garantir a geração de mais espaços livres de uso público e de mais qualidade de vida para a população que reside ou trabalha no território da operação, por meio de investimentos de caráter urbanístico, ambiental e social.

Como objetivos do eixo econômico, pretendiase promover uma renovação construtiva em terrenos desocupados ou subutilizados, localizados em áreas com melhor infraestrutura e capacidade de transporte coletivo, atraindo e incentivando o crescimento de empresas voltadas para setores estratégicos da economia da cidade, como, saúde, tecnologia da informação e turismo, desenvolvendo, dessa forma, a economia da cidade e gerando mais renda e oportunidades de emprego. (PBH, 2013). (Fig. 2)

Figura 2 - Centro de Serviços avançados previsto na OUC Nova BH.

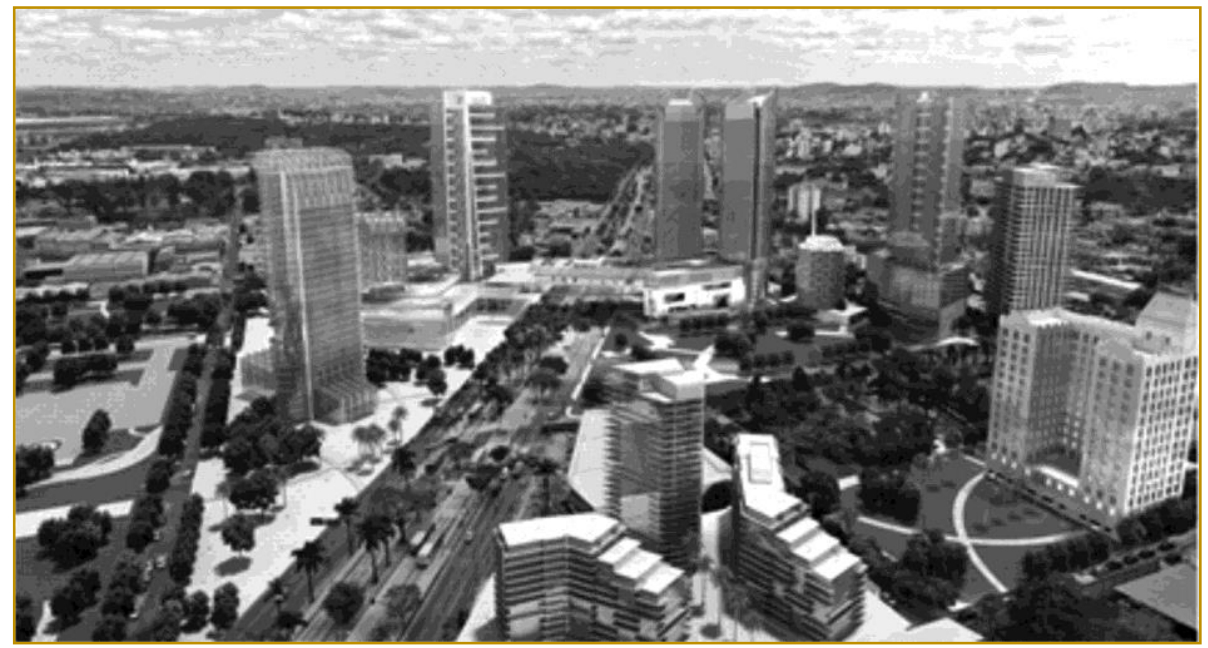

Fonte: PBH, 2013 - adaptado pelos autores.

Já como objetivos do eixo socioambientais, previa-se a qualificação da infraestrutura urbana das vilas e aglomerados localizados no território da Operação, o estabelecimento de incentivos para a construção de habitação de interesse social; a promoção do renascimento urbano e a recuperação do patrimônio em áreas de importância histórica para a cidade, como a Lagoinha e o Centro; a implantação de novos equipamentos de educação, saúde, cultura e lazer no território da Operação; a criação de novas áreas verdes e a expansão de outras, com parques, praças e corredores verdes; e, por fim, a promoção de melhorias nas condições de mobilidade, com foco no pedestre e no transporte coletivo.
O valor das obras previstas nos eixos citados anteriormente foi estimado em 04 bilhões de reais e, para financiar tamanho investimento, o governo utilizaria a arrecadação através da venda de Certificados de Potencial Adicional Construtivo (CEPACs). Foi a primeira operação urbana proposta em $\mathrm{BH}$ que teria a finalidade de gerar esses certificados $(\mathrm{PBH}$, 2013). Os CEPACs, segundo a professora Mariana Fix (2009, p. 52), são "certificados emitidos pela prefeitura e utilizados para pagamento de obras ou leiloados na Bolsa de Valores". Para Operação Urbana Consorciada Nova $\mathrm{BH}$, os CEPACs seriam convertidos em metragem quadrada de acordo com a localização do empreendimento: em áreas menos valorizadas, seriam convertidos em mais metros quadrados. Já em áreas mais 
valorizadas, seriam convertidos em menos metros quadrados.

A proposta Nova BH estava, desde o início, sendo elaborada por técnicos da $\mathrm{PBH}$ e por empresas privadas através da Manifestação de Interesse da Iniciativa Privada (MIP), sem participação direta da população na elaboração do plano urbanístico, como exigido pelo Estatuto da Cidade e analisado no item anterior deste artigo. Tal falta de participação acabou provocando a mobilização de outros agentes, como intelectuais, arquitetos urbanistas, estudantes e moradores das áreas afetadas, em prol de esclarecimentos e melhorias do projeto, principalmente no que se refere ao problema da retirada das famílias das vilas e aglomerados da região e até a provável gentrificação que a implementação da legislação poderia causar. Essa grande mobilização, noticiada nos veículos de comunicação da época, fez com que o Ministério Público iniciasse uma investigação sobre irregularidades no processo de implantação da Operação Urbana Nova BH (O Tempo, 2013).

Mesmo com grande rejeição, comprovada pelas manifestações nos jornais, a $\mathrm{PBH}$ conseguiu aprovar em outubro de 2013, o Estudo de Impacto de Vizinhança (EIV) da Operação Urbana Consorciada Nova BH no Conselho Municipal de Política Urbana

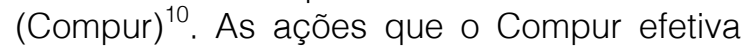

${ }^{10}$ O Compur é uma instância de discussão e deliberação de políticas de planejamento urbano e gestão do território de Belo Horizonte instituída em 1996 pelo Plano Diretor do Município. O Compur agrega funções como acompanhar as ações de intervenção pública na estrutura urbana do município, manifestar-se sobre temas afetos à política urbana e propor intervenções e soluções a eles relacionadas, monitorar a implementação das normas contidas no Plano Diretor e na Lei de Parcelamento, Ocupação e Uso do Solo - LPOUS, decidir premissas para regulamentação de instrumentos de política urbana, deliberar sobre a instalação e funcionamento de empreendimentos de grande porte, por meio da avaliação de EIV. As reuniões do Conselho são abertas à comunidade, podendo a população acompanhar e manifestar (PBH, 2014). O Compur é composto por 16 membros. Oito são representantes da sociedade civil, escolhidos entre entidades ou cidadãos de destacada atuação na cidade, na área de arquitetura e urbanismo. Conta ainda com 7 representantes do poder público municipal (incluindo o legislativo) e um pesquisador, cientista, tecnólogo ou pessoa de notório saber, de livre escolha do prefeito. Aspecto importante a ressaltar para estimular e proporcionar a participação popular em seu funcionamento e estrutura deliberativa são: realização de audiências públicas; realização de reuniões sempre abertas à participação do público interessado; a presença e a participação de representantes comunitários e demais agentes envolvidos nos temas em discussão; representação da sociedade civil organizada na composição do conselho. Segundo estudos realizados sobre a atuação do Compur, durante as reuniões que ocorreram entre 2010 e 2015, destaca-se que a maioria dos participantes na plenária era representante dos assuntos em pauta, com grande participação do setor empresarial. Por outro lado, uma pequena parcela da população atingida, representada por associações comunitárias e entidades do terceiro setor, fez-se presente na reunião para defender seus interesses. Constata-se, assim, pela análise da composição do Compur, que dos conselheiros, poucos representam os interesses de associações mais populares. Isto apresenta a grande disparidade de interesses dentro das vagas no conselho da sociedade civil organizada (Almeida: 2015).

No Compur, constata-se uma forte pressão oriunda dos representantes governamentais, bem como a crescente pressão exercida pelos proprietários dos terrenos e, principalmente, pelos investidores privados. Os Conselheiros que se identificam com a parte mais técnica e menos política do conselho, apresentam posições mais imparciais; entretanto, acabam votando na proposta defendida pelo poder público (Almeida: 2015).

Logo após a aprovação do EIV pelo Compur e quando o poder público municipal estava prestes a encaminhar o projeto para a Câmara Municipal, a implantação da Operação Urbana Consorciada Nova BH foi paralisada. Segundo o jornal "O Tempo" (2014), a prefeitura deu um passo atrás para corrigir um erro: "Fizemos uma avaliação, com autocrítica, e vimos que realmente faltou a participação da sociedade no processo. Agora queremos ouvir o morador de cada área que será afetada e mostrar que estamos sensibilizados com o posicionamento de cada

é que a presidência do conselho sempre fica a cargo do Secretário Municipal de Desenvolvimento Urbano, portanto, a direção é sempre do poder público, que possui, de acordo com o regimento interno, grandes poderes dentro do Compur $(\mathrm{PBH}$, 2015). 
um", afirmou o Secretário Municipal de Planejamento Urbano, em entrevista ao jornal citado.

Sendo noticiado na imprensa que o EIV da Nova BH seria, após a sua aprovação pelo Conselho Municipal de Política Urbana, enviado na forma de Minuta de Lei para apreciação pela Câmara Municipal de BH, para início das obras em 2014, e que o referido projeto não foi precedido de audiência pública, o Ministério Público de Minas Gerais (MPMG), através da Promotoria de Justiça de Habitação e Urbanismo, em 25 de novembro de 2013, após a abertura do Inquérito Civil no 002413.009688-6 e, por meio da Recomendação no 008/2013, se insurgiu contra a implantação da OUC Nova BH. O MPMG considerou falho o processo de dar publicidade ao estudo de impacto de vizinhança, conforme determina o Estatuto da Cidade, sem promover amplo debate com a sociedade civil, o que implicaria a violação ao princípio da gestão democrática da cidade, também previsto no Estatuto. No mencionado documento afirmou o MPMG:

Tratando especificamente dos instrumentos da política urbana, entende-se que a implantação da Operação Urbana Consorciada é um instrumento de participação, uma vez que deverá ser dada publicidade de seu teor e questionada pela população residente, podendo obstar a instalação de equipamentos que causem impacto negativo. Assim, restou demonstrado nos autos que tais previsões normativas, a princípio, não estão sendo integralmente cumpridas; isto é, a Municipalidade não ofertou a possibilidade de gestão participativa aos representantes da sociedade civil (população, bem como as associações representativas) sobre a Operação Urbana Consorciada [...]. Ademais, o mero informa dos acontecimentos, como aduz a Municipalidade agravante em suas razões recursais [...], não é suficiente para atender o que a lei determina, uma vez que a mesma prevê efetiva participação popular. Outrossim, para haver a participação efetiva, a população e as entidades representativas têm que estar instruídas, tendo pleno acesso prévio aos elementos que conduzem a decisão política pública, bem como participar da própria política de ordenamento urbano como dita a Lei. (Larcher, Souza, 2016).

Assim, o MPMG requereu que fosse dada à Operação Urbana Consorciada Nova BH ampla publicidade aos planos urbanísticos, ao EIV e que fossem promovidos debates com a sociedade, senão vejamos:

(...) se abstenha de encaminhar projeto de lei referente à Operação Urbana Consorciada à Câmara Municipal de Belo Horizonte, sem antes observar o que determina as Constituições Federal e Estadual, o Estatuto da Cidade, a Lei Orgânica do Município de Belo Horizonte e seu Plano Diretor, no que refere-se à realização de debates e audiências, com prévia e ampla publicidade do estudos técnicos pertinentes (Larcher, Souza, 2016).

O planejamento participativo, a partir da Constituição da República e do Estatuto da Cidade, conforme analisado neste artigo, submete a vontade do poder público à dos demais agentes da produção do espaço e não apenas de pequenos grupos, sendo tal submissão requisito obrigatório em todas as fases do processamento da implantação e implementação dos instrumentos de planejamento da cidade. $\mathrm{O}$ artigo 33 do Estatuto da Cidade estabelece um conteúdo mínimo para que a lei autorize a operação e, dentre eles e especialmente "[...] forma de controle da operação, obrigatoriamente compartilhado com representação da sociedade civil" (Brasil, 2001). Por sua vez, o artigo $2^{\circ}$, incisos I e XII, do Estatuto da Cidade, prevê uma "gestão democrática da cidade por meio da participação popular e de associações representativas" e "audiência do poder público municipal e da população interessada (...)" (Brasil, 2001).

Com relação a essa participação, o geógrafo Marcelo Lopes de Souza (2014:33) afirma que:

[...] sob pena de inconstitucionalidade e ilegalidade da ação governamental, não há dúvida de que a participação da população e das associações representativas de vários segmentos da comunidade é norma geral da qual o administrador municipal não pode se esquivar na formulação, na execução e no acompanhamento de planos, projetos e programas de desenvolvimento urbano [...]

Assim, considerando as pressões da população e do MPMG, em meados de novembro de 2013, a $\mathrm{PBH}$ paralisou o processo implantação da Operação Urbana Consorciada Nova BH, não enviando a Minuta de Lei para a Câmara Municipal (O Tempo, 2014). Porém, no início de 2014, a PBH apresentou a Operação Urbana Consorciada Antônio Carlos/Pedro I e Leste Oeste, 
recomeçando o processo de discussão. Segundo a $\mathrm{PBH}$, tratava-se de uma nova operação (PBH, 2014).

Para possibilitar a participação popular, a $\mathrm{PBH}$ criou um cronograma de oficinas e audiências que foram realizadas em cada regional de Belo Horizonte, em uma espécie de miniconferência de política urbana. Realizaram-se debates, tiraram-se dúvidas, e visitas foram feitas aos locais onde eram previstas obras e intervenções, bem como, foram realizadas oficinas em que os cidadãos puderam opinar sobre o projeto e apresentar propostas que foram ouvidas, sendo muitas delas implantadas na proposta. Todo o processo foi relatado e as audiências foram publicadas no site da prefeitura. (PBH, 2015).
Durante essas audiências para apresentar a proposta de implantação, os técnicos da prefeitura destacaram pontos de mudança na Antônio Carlos/Pedro I e Leste/Oeste. Dentre elas, pode-se destacar a inserção do Cemitério do Bonfim na proposta para receber obras com recursos oriundos da operação urbana; bem como a retirada do bairro São José, na Pampulha. Apenas quadras que estão voltadas para a Avenida Antônio Carlos foram incluídas. Já os bairros Califórnia e Pindorama, na região Noroeste, passaram a fazer parte da Operação Urbana Consorciada, assim como, um trecho da Avenida Belém, no extremo Leste da capital (EM, 2015). (Fig. 3).

Figura 3 - Cartaz convocando a população a participar das Audiências Públicas.

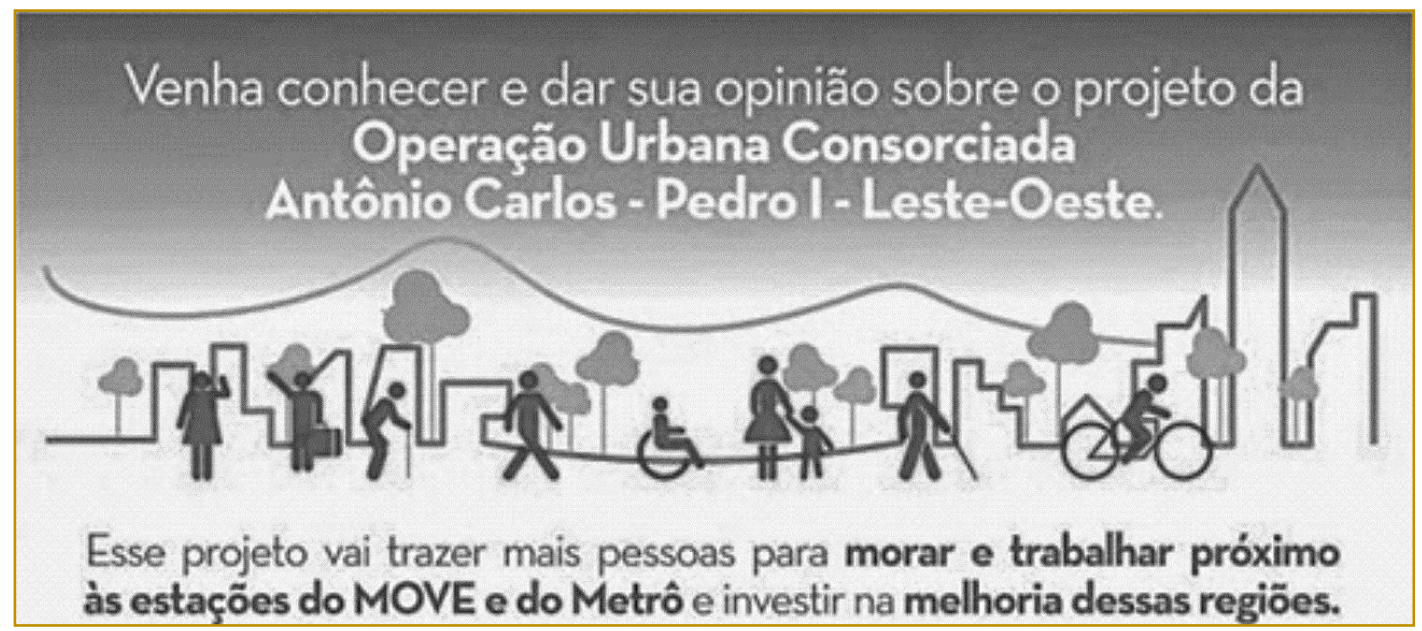

Fonte: PBH, 2016

Outra novidade da Operação Urbana Consorciada Antônio Carlos/Pedro I, Leste/Oeste e que não existia na Operação Urbana Consorciada Nova $\mathrm{BH}$, foi a maneira como seria formado o conselho de gestão dos recursos da operação urbana. Segundo a proposta da $\mathrm{PBH}$, o conselho funcionaria como um detalhamento do projeto a longo prazo, garantindo que, com a divisão de tarefas por grupos de visões distintas, poderiam ser tomadas decisões mais positivas para todos os envolvidos. O órgão que decidiria os investimentos seria formado por 36 membros - 15 da prefeitura, 12 das associações de moradores, três de movimentos sociais e entidades técnicas, dois proprietários, dois comerciantes e dois investidores imobiliários. Esse grupo teria que definir as obras prioritárias, seguindo as diretrizes das intervenções já apontadas no plano inicial e o investimento destinado à habitação de interesse social (PBH, 2016).

$\mathrm{Na}$ proposta de implantação, os moradores das áreas afetadas pela Operação Urbana Consorciada Antônio Carlos/Pedro I, Leste/Oeste poderiam ter que pagar um tributo pelas melhorias infraestruturais previstas no projeto (PBH, 2015). O tributo da contribuição de melhoria é previsto na Lei Orgânica do Município, mas pouco utilizado até então. Acredita-se, contudo, que se houver outra forma de arrecadação, como os CEPACs, seu valor pode reduzir. Apesar disso, a possibilidade de pagamento do tributo não foi bem aceita pela população, gerando grande resistência. Além da contribuição de melhoria e dos CEPACs, é citado no projeto da Operação outras formas 
de arrecadação, como a utilização do dinheiro público.

Desenvolvendo uma comparação da Operação Urbana Consorciada Antônio Carlos/Pedro I, Leste/Oeste com a Nova BH, destacam-se algumas alterações, sendo: ampliação da abrangência da operação para 99 bairros; ampliação da área para $29 \mathrm{~km}^{2}$, o que corresponde a $9 \%$ do território municipal; as áreas de Diretrizes Especiais (ADEs) e tombamento dentro da Operação Urbana Consorciada Antônio Carlos/Pedro I, Leste/Oeste serão respeitadas; arrecadação de verba para investimentos através dos CEPACs cai para $\mathrm{R} \$ 3,1$ bilhões, $\mathrm{R} \$ 600,00$ por $\mathrm{m}^{2}$ construído além do permitido (houve um redimensionamento do potencial da operação urbana, com a realização de menos construções de grande porte); incentivo de construção de habitações sociais, no mínimo $20 \%$ de tudo que for arrecadado será destinado à habitação social. Para incentivar esse tipo de moradia, foram criados dois mecanismos: o aluguel social e a política de incentivos para apartamentos menores ao longo dos corredores. A previsão é criar 5.211 moradias sociais em 20 anos. (Audiência, 2015).

Ainda se tratando de habitação, propostas temáticas foram pensadas, tendo como público alvo os usuários do transporte público. Para tanto, surgiu a tipologia incentivada (apartamentos de cerca de $50 \mathrm{~m}^{2}$, com um banheiro e, no máximo, uma vaga de garagem). Parte do estoque disponível é para a produção da tipologia incentivada e a outra é para tipologias livres. Há também o plano de implantação do aluguel social para famílias com renda de até 10 salários mínimos, com o valor do aluguel proporcional à renda. O objetivo do aluguel social é levar a construção de unidades habitacionais públicas para a região, de forma a atrair as camadas sociais para essas áreas, além de atuar indiretamente no controle do valor dos alugueis, impedindo, assim, a especulação imobiliária e gentrificação. Haverá também incentivos para a construção de habitação social pelo mercado, buscando-se reduzir o reassentamento de famílias já existentes no local, de forma que as remoções já previstas sejam apenas casos estritamente necessários e ocorrerão dentro do perímetro da própria operação urbana. As ZEIS serão mantidas e receberão investimentos para melhorias. (Audiência, 2015).
Pode-se considerar que, pelo menos no discurso, a Operação Urbana Consorciada Antônio Carlos/Pedro I, Leste/Oeste é uma versão mais voltada ao social em comparação ao projeto anterior, visto que, na OUC Nova $\mathrm{BH}$ havia uma atuação privada na elaboração do projeto, o que influenciou um foco mais imobiliário na Operação e excluiu a participação popular. Já a Operação Urbana Consorciada Antônio Carlos/Pedro I, Leste/Oeste possui mínima participação privada na elaboração, obteve cooperação popular que acrescentou informações mais profundas dos moradores a respeito das peculiaridades de cada região e formou um projeto mais completo, funcional e social, em confronto com $\mathrm{O}$ da Nova $\mathrm{BH}$, e ainda baseado no projeto de lei do novo Plano Diretor a ser votado.

A proposta de alteração do atual Plano Diretor surgiu a partir da $4^{\mathrm{a}}$ Conferência de Política Urbana, onde foram discutidas a reestruturação, alteração de todo o zoneamento, redefinição das categorias de ocupação do solo, dentre outras propostas. Em 2015, as propostas foram transformadas em projeto de lei, que foi encaminhado à Câmara; contudo, tal projeto aguarda votação até o presente momento. A decisão por adaptarem a Operação aos parâmetros do projeto de lei do novo Plano Diretor veio após a constatação de que o plano vigente tem uma série de problemas, estando em desacordo com o ordenamento urbanístico, com a lei de uso do solo, por possibilitar o adensamento de áreas que não são adequadas para tal fim, sendo necessário o direcionamento do adensamento e a ampliação de áreas de melhoria social e proteção ambiental. Para tanto, um dos parâmetros do projeto do novo Plano Diretor aplicados na Operação Urbana Consorciada Antônio Carlos/Pedro I, Leste/Oeste refere-se às áreas de amortecimento, que são pontos de transição até locais fora da OUC, que exigem adensamento mais moderado.

O projeto da Operação Urbana Consorciada Antônio Carlos/Pedro I, Leste/Oeste já foi aprovado pelo Compur e enviado para apreciação da Câmara no ano passado. Contudo, por conter parâmetros baseados no projeto do novo Plano Diretor ainda não votado, mesmo com o envio do projeto de lei para a Câmara, a Operação Urbana Consorciada Antônio Carlos/Pedro I, Leste/Oeste só poderá ser votada após a aprovação do referido Plano Diretor, o que 
poderá demorar a ocorrer, em razão da mudança na administração municipal após as eleições em 2016. Tal demora foi notificada à Câmara pelo MPMG, que entende que as mudanças políticas não deveriam interferir no processo de aprovação do projeto de lei. Estima-se que as votações dos projetos do novo Plano Diretor e da Operação Urbana aconteçam este ano. Assim, a implementação da Operação Urbana Consorciada Antônio Carlos/Pedro I, Leste/Oeste poderá ocorrer no próximo ano.

\section{CONSIDERAÇÕES FINAIS}

Instrumento Operação Urbana Consorciada é geralmente estabelecido na lei de forma abrangente, necessitando, assim, de normas específicas para sua implantação e implementação. Para tanto, há requisitos mínimos previstos no artigo 33 do Estatuto da Cidade, que explicita os parâmetros básicos para aprovação da lei da Operação Urbana e têm por finalidade conferir maior eficácia ao instrumento.

Deve o poder público buscar efetivar que os instrumentos legais alcancem os objetivos previstos na legislação. Para tanto, é imprescindível que o poder público municipal, ao atuar como gestor dos interesses da população, garanta a participação efetiva desse agente na elaboração da legislação instituidora de determinada Operação Urbana Consorciada. Dessa forma, a partir da implantação e/ou implementação das normas, os efeitos almejados e previstos serão alcançados e sentidos pela população local, posto que, seus interesses reais foram perseguidos e contemplados em planejamentos correspondentes aos anseios da realidade urbana.

A Constituição Federal de 1988, atenta ao valor da participação social na elaboração da política urbana dos municípios, conferiu, em seu artigo $245, \S 1^{\circ}$, significado à regra constitucional da intervenção da população no planejamento urbano municipal ao determinar as diretrizes que deverão constar nos planos diretores, dentre elas, a participação das entidades comunitárias no planejamento e o controle da execução dos programas a ela pertinentes.

O Estatuto da Cidade, norma geral cogente em direito urbanístico, de observância obrigatória pelo Município, estabelece que a política urbana siga, dentre outras, a diretriz geral consistente na gestão democrática da cidade por meio da participação da população e de associações representativas dos vários segmentos da comunidade na formulação, execução e acompanhamento de planos, programas e projetos, em sintonia com os princípios constitucionais do planejamento urbano, e a democracia participativa. Para garantir a gestão democrática da cidade, deverão ser utilizados, entre outros instrumentos, os debates, audiências e consultas públicas. Estabelece também, na implantação das Operações Urbanas Consorciadas, a efetiva participação popular e das entidades representativas, as quais muitas vezes, não vêm sendo cumpridas pelo poder público municipal. $\mathrm{O}$ artigo 44 do Estatuto da Cidade indica a gestão participativa aqui desatendida pelo agravante como "condição obrigatória" para a aprovação do projeto pela Câmara Municipal.

Existem inúmeras formas do poder público cumprir suas funções. Uma delas é garantir à população e associações representativas acesso e tempo hábil para fazerem a necessária análise dos estudos, relatórios, documentos e informações sobre o objeto do encontro. A participação não se limita apenas a receber panfletos e assistir à apresentação em power point, não é somente ser espectador. A participação da comunidade e das associações representativas, na formulação dos projetos (garantia prevista no artigo $2^{\circ}$, inciso II, do Estatuto da Cidade), significa permitir à sociedade civil interferir diretamente no seu resultado.

Gestão participativa não se coaduna com o tipo de audiência pública meramente auricular, como praticada muitas vezes pela esfera publica municipal e verificada neste artigo na implementação do instrumento das Operações Urbanas. Entende-se que Gestão Participativa, que deve acompanhar a implantação das Operações Urbanas Consorciadas, deve ter como eixo central a transparência, matizada de uma interação eclética, vivaz, sinérgico-colaborativa e, por isso mesmo, democrática, entre os círculos do poder e as forças predominantes na teia social.

A Operação Urbana Consorciada Carlos/Pedro I/Leste-Oeste, embora tenha segundo o poder público um enfoque mais social, ao manter a maioria dos objetivos da Operação Urbana anterior, acaba sendo uma continuidade da Nova BH. Embora algumas 
áreas da cidade tenham sido incorporadas, tenham sido realizadas audiências públicas, continua na Operação Urbana Consorciada Carlos/Pedro I/Leste-Oeste as propostas da Operação Urbana Consorciada Nova BH, sendo ambas as propostas apresentadas pelo poder público municipal e encaminhadas, já definidas, para discussão pública, ou seja, não foram construídas junto aos demais agentes que participam da produção da cidade, como os moradores.

Este artigo preza enfatizar a atuação do poder público no instrumento urbanístico da Operação Urbana Consorciada, na defesa do interesse popular, no papel primordial na coordenação do instrumento urbanístico e na garantia da população como principal beneficiária do projeto. Entretanto, o Estatuto da Cidade define o papel do poder público de forma geral, sem restrições quanto a outras formas de participação, o que pode agregar mais funções, sendo que, neste caso, a Operação Urbana Consorciada Nova BH aproveita-se dessas lacunas para utilizar o dinheiro público na operação. A medida é prevista no projeto, sendo alegado que a verba pode ser utilizada, pois os investimentos a serem implementados são de interesse social, cabendo as responsabilidades ao poder público municipal. Esse também falha no interesse dos agentes como os moradores, quando se diz respeito à aprovação do Estudo de Impacto de Vizinhança pela Compur, conselho formado em sua maioria por integrantes de dentro da prefeitura, técnicos, vereadores e setores privados. A população, ou seja, os moradores, entram com uma pequena parcela no conselho. As decisões ali tomadas estão sujeitas a influências partidárias e, principalmente, dos agentes ligados ao mercado imobiliário, fragilizando o alcance dos interesses sociais.

Sendo assim, os conhecimentos dos setores técnicos envolvidos na formação da Operação Urbana são insuficientes na

\section{REFERÊNCIAS}

[1] Alfonsin, Betânia de Moraes. Operações Urbanas Consorciadas como instrumentos de captação de mais valias urbanas: um imperativo da nova ordem jurídico-urbanística brasileira. Revista de Ciências Jurídicas, vol.6, n.2, Canoas, Ed. ULBRA, p. 301-318, 2005.

[2] Almeida, Reginaldo Magalhães de. Participação social e gestão pública: o caso do Conselho Municipal de Meio Ambiente de Belo promoção de um bem comum pleno, necessitando da participação popular com papel importante na formação do projeto, de maneira que estabeleça um instrumento urbanísitico mais democrático e com a finalidade de conseguir o melhor para toda a população. Entretanto, pode-se questionar se os moradores realmente foram ouvidos durante o processo de implantação e se as obras foram repensadas e adaptadas de acordo com o contexto social da área.

A Operação Urbana Consorciada Nova BH tem por sua definição a entrada do poder privado em investimento de obras de interesse social, restando claro, então, que o interesse popular deve ser visto como foco. Entretanto o CEPACs que será usado para viabilizar as obras sociais, pode ser insuficiente em comparação à abrangência de impacto causado nas camadas sociais afetadas em toda a área da Operação Urbana.

Diante desse cenário da Operação Urbana Consorciada Nova $\mathrm{BH}$, da análise do caminho percorrido da gestão pública desse instrumento até os dias atuais, verifica-se que o poder público se faz ineficaz na defesa e garantia quanto à participação da população como um todo e precisa de avanços. Nesse artigo verificou-se que a população, quando da implantação da Operação Urbana, não foi ouvida, principalmente quando da elaboração das necessidades sociais. Assim, a análise do caminho percorrido pelo instrumento urbanístico de política urbana, Operação Urbana Consorciada em Belo Horizonte demonstra como é necessário o seu aperfeiçoamento, principalmente no que se refere à gestão do poder público municipal, bem como a participação e defesa dos interesses de todos os agentes que participam da produção do espaço urbano, e não de apenas um grupo especifico como os investidores privados e os proprietários dos terrenos.

Horizonte. Artigo. VIII Congresso Brasileiro de Direito Urbanístico. Direito Urbanístico e Conflitos Urbanos: a efetividade da ordem jurídicourbanística na promoção do direito à cidade. Fortaleza/CE - 04 a 07 de outubro de 2015

[3] Brasil. Constituição Federal de 1988. Brasília: Câmara dos Deputados, Coordenação de Publicações, 1988.

[4] Brasil. Estatuto da Cidade - guia para implementação pelos municípios e cidadãos: Lei 
n.10.257, de 10/07/2001, que estabelece diretrizes gerais da política urbana. Brasília: Câmara dos Deputados, Coordenação de Publicações, 2001.

[5] Carvalho Filho, José dos Santos. Comentários ao Estatuto da Cidade. $3^{a}$ edição. Rio de Janeiro, Editora Lumen Juris, 2009

[6] Castellar, João Carlos. Operações Urbanas Consorciadas e Estado de Exceção. Rio de Janeiro: Revista de Direito da Unigranrio, v. 3, 2010.

[7] Corrêa, Roberto Lobato. Sobres Agentes Sociais, Escala e Produção do Espaço: Um Texto para Discussão. In: A produção do espaço urbano: agentes e processos, escalas e desafios/ Ana Fani Alessandri Carlos, Marcelo Lopes de Souza; Maria Encarnação Spósito (organizadores). São Paulo, Contexto, 2011.

[8] EM. Jornal Estado de Minas. Operação Urbana Antônio Carlos/Nova BH. Disponível em: http://www.em.com.br/app/noticia/gerais/2015/04/0 8/interna_gerais,635542/pbh-comeca-a-apresentaroperacao-urbana-consorciada-antonio-carlospedro-i-leste-oeste.shtml - Consultado em 01 de março de 2015.

[9] Fernandes, Edésio, organizador. Direito urbanístico. Belo Horizonte: Del Rey Editora, 1998.

[10] Filho, Vicente Greco. Direito Processual Civil Brasileiro. São Paulo: Saraiva, 2007

[11] FIX, M. Parceiros da exclusão. Duas histórias da construção de uma "nova cidade" em São Paulo: Faria Lima e Água Espraiada. São Paulo: Boitempo, 2001.

[12] Indisciplinar. Blog Indisciplinar. Disponível em: http://blog.indisciplinar.com/lutas-territoriais-2/. Consultado em 01 de março de 2016

[13] Larcher, Marta Alves; Souza, Cláudia Ferreira de. Agravo de Instrumento - Ação Civil Pública. Operação Urbana Consorciada (OUC) Vila Sônia - Pretensão do Ministério Público em compelir a Municipalidade a abster-se de toda e qualquer tramitação administrativa e legislativa. 21/11/2013 Disponível em: http://www.mpmg.mp.br/comunicacao/noticias/cerc a-de-200-pessoas-participaram-de-audienciapublica-promovida-pelo-mpmg-para-discutir-oprojeto-nova-bh.htm\#.V-g4wPArLIU. Acesso em 26/09/2016.

[14] Maricato, Ermínia; Ferreira, José Sette Whitaker. Operação urbana consorciada: diversificação urbanística participativa ou aprofundamento da desigualdade?. In: Osório, Letícia Marques. Estatuto da Cidade e reforma urbana: novas perspectivas para as cidades brasileiras. Porto Alegre: Sérgio Antônio Fabris, 2002

[15] Meirelles, Hely Lopes. Direito Administrativo Brasileiro. São Paulo: Malheiros Editores, 2006.
[16] Mukai, Toshio. Operações Urbanas Consorciadas. Revista Magister de Direito Ambiental e Urbanístico, 2007

[17] O Tempo, 2014. Jornal o Tempo. Operação Urbana Antônio Carlos/Nova BH Disponível em: http://www.otempo.com.br/cidades/nova-bh-volta\%C3\%A0-estaca-zero-1.943079. Consultado em 01 de março de 2014

[18] O Tempo, 2015 a. Jornal o Tempo. Operação Urbana Antônio Carlos/Nova BH prioriza moradia. Disponível em: http://www.otempo.com.br/cidades/novo-projetopara-opera\%C3\%A7\%C3\%A3o-urbana-priorizamoradia-social-1.1115207. Consultado em 01 de março de 2015.

[19] O Tempo, 2015 b. Jornal o Tempo. Operação Urbana Antônio Carlos/Nova BH Disponível em: http://www.otempo.com.br/cidades/opera\%C3\%A7 $\%$ C3\%A3o-urbana-ser\%C3\%A1-conhecida-emfevereiro-1.961046. Consultado em 01 de março de 2015

[20] O Tempo, 2015 c. Jornal o Tempo. Nova Operação Urbana Antônio Carlos. Disponível em: http://www.otempo.com.br/cidades/moradores-debh-podem-pagar-taxa-por-melhorias-

urban\%C3\%ADsticas-1.1115913. Consultado em 05 de março de 2015.

[21] PBH. Prefeitura de Belo Horizonte. Políticas Urbanas. Disponível em: http://portalpbh.pbh.gov.br/pbh/ecp/comunidade.d o? evento=portlet\&pldPIc=ecpTaxonomiaMenuPorta I\&app=planejamentourbano\&lang=pt_BR\&pg=884 $3 \& \operatorname{tax}=39582$. Consultado em 01 de novembro de 2014

[22] PBH. Prefeitura de Belo Horizonte Audiência Publica sobe a Operação Urbana Nova $\mathrm{BH}$. Disponível em: http://portalpbh.pbh.gov.br/pbh/ecp/comunidade.d o? evento=portlet\&pldPIc=ecpTaxonomiaMenuPorta I\&app $=$ pbh\&tax $=53757 \&$ lang $=$ pt_. Consultado em 01 de nov. de 2015.

[23] $\mathrm{PBH}$. Prefeitura de Belo Horizonte. Operação Urbana da Avenida Antônio Carlos. Disponível em: http://portalpbh.pbh.gov.br/pbh/ecp/comunidade.d o? evento=portlet\&pldPlc=ecpTaxonomiaMenuPorta I\&app $=$ pbh\&tax $=53757 \&$ lang $=$ pt_BR\&pg $=5120 \&$ ta $\mathrm{xp}=0$ \& . Consultado em 20 de set. de 2016.

[24] Silva, José Afonso da. Direito Urbanístico Brasileiro. São Paulo: Malheiros Editores, 2000.

[25] Souza, Marcelo Lopes de. Mudar a Cidade: uma introdução crítica ao planejamento e às gestões urbanas; Ed. Bertrand Brasil, São Paulo, 2014. 


\section{Bapítulo 4}

\section{TERRITÓRIOS SONOROS DO SERTÃO ALAGOANO}

\section{Walcler de Lima Mendes Junior}

Juliana Michaello Macêdo Dias

Resumo: O artigo apresenta os resultados da pesquisa intitulada Mapeamento sonoro do Sertão alagoano, discutidos à luz dos conceitos de paisagem sonora (Schafer, 2011) e territórios sonoros (Obici, 2008). A pesquisa citada foi desenvolvida entre os anos de 2017 e 2018 e produziu cartografias sonoras do território estudado através do cruzamento interdisciplinar das áreas da antropologia, da arquitetura e do urbanismo, da sociologia e da comunicação social. O artigo foca em aspectos teóricos e metodológicos da pesquisa, buscando apresentar os direcionamentos adotados como forma de contribuir para a discussão da interface entre sonoridades e territorialidades culturalmente constituídas.

Palavras-Chave: mapeamento sonoro, sertão, paisagem sonora, território sonoro 


\section{INTRODUÇÃO}

As questões que fomentaram este artigo surgiram a partir de inquietações trazidas à tona no trabalho de campo do Projeto de Salvaguarda do Patrimônio Imaterial de Alagoas, desenvolvido pelo Grupo de Pesquisa Nordestanças no território do Sertão Alagoano. Tal pesquisa respondeu a uma demanda do IPHAN e da Secretaria de Cultura do Estado de Alagoas para produzir um mapeamento das práticas culturais referenciadas pelas populações do território do estado marcado pela noção de referências culturais e utilizando a metodologia do Inventário Nacional de Referências Culturais INRC.

Durante 0 desenvolvimento do projeto chamou a atenção do grupo a diversidade $e$ complexidade das paisagens sonoras do sertão, que englobam sons de animais silvestres como pássaros, primatas, felinos, pequenos mamíferos, o roçagar das folhas e das copas das árvores sacudidas pelo vento e pela chuva, passando por sons específicos da presença humana como o badalo no pescoço dos bois, carneiros e cabras, o sino no campanário da igreja matriz, os fogos das festas sacro-profanas, o galope das cavalgadas e pegas-de-boi por estradas, veredas e na mata fechada da caatinga. Uma vez que o projeto citado tinha um escopo amplo de mapeamento geral e não poderia se deter com mais especificidade à coleta e análise destes dados sonoros, entendemos como relevante o desenvolvimento de um projeto de pesquisa especificamente para tratar destas diferentes territorializações sonoras. São os resultados e reflexões deste projeto, intitulado "Mapeamento sonoro do Sertão alagoano" que discutiremos neste capítulo, enfatizando as relações entre esta cartografia sonora e aspectos ligados à cultura em transformação nos territórios sertanejos.

Tomando por base três territorialidades preliminares - territórios naturais, territórios transformados por ação, ocupação e presença humana de baixo impacto e territórios transformados por ação, ocupação e presença humana de alto impacto sonoro, ao longo do projeto percebemos outras tantas paisagens e territorialidades que remarcam o sertão em sua contemporaneidade. Quando em meio à caatinga o som dos pássaros, insetos e lagartos é subitamente cortado pelo motor rangente de uma moto invisível e de sinos de bois igualmente invisíveis, a paisagem sonora nos fala da introdução das motos no sertão, substituindo o jumento e o cavalo na lida diária com os bois. Quando o ranger do carro de boi vem acompanhado do som estridente de uma música sendo tocada a partir de um aparelho celular, podemos ler uma mescla entre territórios da tradição e da modernidade. É desse sertão, marcado por sonoridades tradicionais, mas também atravessado pela contemporaneidade, que falaremos aqui.

Marcado por um olhar atento aos aspectos culturais das territorialidades humanas, o grupo não buscou uma caracterização do som a partir de seus aspectos físicos (como frequência, timbre, volume), mas antes, a partir de uma análise daquilo que a escuta permite perceber dos hábitos, costumes, paradoxos e enfrentamentos locais. Propusemos, então, uma interface interdisciplinar para abordar o sertão e suas sonoridades a partir do conceito de "paisagem sonora" (SCHAFER, 2011), interpelado por reflexões contemporâneas que rediscutem o mesmo, propondo através de uma releitura deleuziana, o conceito de "território sonoro" (OBICI, 2008).

\section{CONCEITOS DE PARTIDA}

\subsection{PAISAGEM SONORA E TERRITÓRIOS SONOROS}

O termo soundscape [paisagem sonora] apareceu na língua inglesa em fins do século $X X$ e se refere à totalidade dos sons que chegam a nossos ouvidos em determinado momento, constituindo certa noção de lugar. A criação do termo é atribuída ao compositor canadense Murray Schafer, entusiasta e estudioso da sonoridade de diversos hábitats. Schafer estabeleceu o que seria o ponto de partida para as pesquisas em torno das sonoridades em transformação na sociedade moderna, compreendendo a importância da paisagem sonora como parte constituinte das construções identitárias das sociedades.

Como um dos pioneiros nos estudos de ambientes sonoros, Schafer criou em 1969 o projeto Paisagem Sonora Mundial, cujos objetivos eram: produzir um estudo interdisciplinar sobre os ambientes acústicos e suas relações com o homem; propor um ambiente acústico mais saudável e propor uma espécie de "pedagogia de escuta", que será disseminada pelo pesquisador em suas aulas. Essa pesquisa, conjuntamente com as 
reflexões oriundas das aulas, resultou em várias publicações que foram compiladas em 1977, no livro "A afinação do Mundo".

Por paisagem sonora, o autor compreende os eventos acústicos componentes de um lugar. "O termo pode referir-se a ambientes reais ou a construções abstratas, como composições musicais e montagens de fitas, em particular quando consideradas como um ambiente" (SCHAFER, 2011, p. 366). Desta forma, o ambiente sonoro como um todo comporá a paisagem sonora, incluindo sons desejáveis ou não, contínuos ou esporádicos.

Nos termos discutidos no projeto, o conceito de paisagem sonora foi operativo num primeiro momento, ao nos colocar diante da necessidade de escuta de diferentes lugares, compondo contextos de sons, já que não nos interessava uma espécie de identificação de sons isolados. A paisagem sonora, enquanto recorte de pesquisa nos permitiu atentar para as interpelações entre diferentes sons, e o quanto certos conjuntos aparecem recorrentemente nos territórios sertanejos, como por exemplo os sinos amarrados nos pescoços dos animais de criação, que ao serem soltos na mata para se alimentar muitas vezes compõem a paisagem sonora junto com aves e pequenos animais, mas sem sons humanos diretos. Discutiremos mais a fundo essas questões, uma vez que é claro que o agrupamento de animais em rebanhos e o próprio chocalho são marcas humanas na paisagem genericamente chamada de natural.

Se a atenção à sonoridade surge para Schafer em meio à percepção de uma perda da qualidade das experiências sonoras, as críticas a ele surgem especialmente pelo olhar positivista que o autor emprega ao caracterizar "boas" e "más" paisagens sonoras, baseado na ideia da separação entre som e ruído. O autor entenderá que

A mais satisfatória definição de ruído para uso geral é ainda a de 'som não desejado'. Isso torna ruído um termo subjetivo. (...) Mas mantém aberta a possibilidade de haver, em determinada sociedade, mais concordâncias do que discordâncias a respeito de que sons se constituem em interrupções não desejadas (SCHAFER, 2011, p.367).

Ainda que abra o conceito de ruído para uma classificação subjetiva, por trás dos estudos de Schafer há um desejo de instituir uma "pedagogia auditiva", onde o silêncio e a clauriaudiência - "literalmente, audição clara"
(SCHAFER, 2011, P. 363) - são valorados enquanto experiências auditivas "superiores". O autor irá inclusive classificar as paisagens sonoras em hi-fi e low-fi, considerando necessária a experiência de ambientes sonoros considerados de alta qualidade como modo de "limpar" os ouvidos para uma escuta mais atenta.

O ambiente silencioso da paisagem sonora hifi permite o ouvinte escutar mais longe, a distância, a exemplo dos exercícios de visão a longa distância no campo. A cidade abrevia essa habilidade para a audição (e visão) a distância, marcando uma das mais importantes mudanças na história da percepção". (Schafer, p.71)

Parte da necessidade de ampliar este escopo teórico nasceu do incômodo que essa valorização do silêncio nos impôs ao escutar - sertão alagoano. Não se trata definitivamente de um território de silêncio e clauriaudiência e percebemos que do ponto de vista antropológico e sociológico essa questão sequer parecia plausível como ponto de partida analítico, uma vez que produz um juízo de valor prévio, balizado por uma visão civilizacional etnocêntrica. Optamos assim, ao longo do projeto, por utilizar o conceito de paisagem sonora como referência preliminar, mas imbuídos de evitar a classificação das sonoridades em desejáveis ou não, mas sim atentos às composições que rasuram certas marcas territoriais visuais e nos permitem ler arranjos socioculturais a partir das texturas sonoras.

Além da perspectiva positivista implicada na ideia de um ambiente sonoro saudável e de ouvidos educados, o conceito de paisagem sonora pode também ser deslocado a partir da crítica deleuziana, substituindo o conceito de paisagem (que implica um recorte geralmente constituído pelo observador/ouvinte) pelo de territorialização (em que o ouvinte atua em diálogo com o meio, territorializando-o ao mesmo tempo em que é territorializado por ele). É nessa perspectiva que Obici agenciará o conceito de território sonoro.

Um TS [Território Sonoro] não existe de antemão, ele se constrói e é fabricado, levantando muros sônicos, que podem proteger, mas também aprisionar. A dinâmica do ritornelo, de territorializar e desterritorializar o som, está imbricada na produção dos TSs. (...)Um TS está sempre prestes a se desterritorializar (OBICI, p. 100). 
Esta condição deleuziana dos territórios de se (des)(re)constituírem pressupõe uma percepção do território enquanto marca expressiva. "O território não é primeiro em relação à marca qualitativa, é a marca que faz o território. As funções de um território não são primeiras, elas supõem antes uma expressividade que faz território" (DELEUZE E GUATTARI, p. 121). Desta forma, as territorializações que foram elencadas e cartografadas neste projeto serão sempre discutidas a partir da premissa de que não preexistem ao mapeamento, mas o constituem sendo por ele constituídas. Desta forma, mapear as sonoridades do sertão alagoano é instituir com o mesmo territorializações do nosso encontro com paisagens sonoras que conseguimos escutar.

\subsection{ACUSMÁTICA, ESCUTA ATIVA E OUVIDO PENSANTE}

Se os conceitos de paisagem sonora e território sonoro permitem delinear o campo de interesse, os conceitos de acusmática e ouvido pensante nos permitiram tecer reflexões sobre o como ouvir. Longe de buscarmos uma audiência "limpa", como propõe Schafer, no projeto discutimos justamente as interferências que uma escuta interessada e permeada por questões técnicas e culturais produzem no processo de escuta que a pesquisa incentivou.

O conceito de acusmática surge em meio a experiências com músicas eletrônicas nas décadas de 1960 e 1970 e de modo geral refere-se à música composta em estúdio e tocada por caixas de som em concertos, destacando a não identificação da fonte sonora quando da experiência de escuta. Em certa medida uma caracterização da música acusmática é também a experimentação com os sons, não diferenciando música e ruído.

No âmbito desta discussão, a acusmática é pensada em sua contribuição sobre a interferência e disjunção entre som e fonte sonora possibilitados pelos meios técnicos de alta fidelidade. Como um binóculo, os microfones e os fones de ouvido trazem o som para um âmbito próximo e íntimo, revelando uma gama de detalhes nítidos que são inteiramente desconhecidos. Alguns pássaros cruzam o espaço estereofônico e a ondulação das asas produz uma cadência lenta, uma mistura diáfana de silvos e silêncios. Com uma aparelhagem portátil de gravação, o pesquisador não se sente escutando como um observador distante; pelo contrário, se sente lançado a um espaço novo e se transforma em parte integrante da própria experiência. Muitas das texturas acústicas sutis se agigantam através dos fones estéreo, cujo controle de volume se coloca no máximo para não perder nenhum detalhe. O impacto é imediato e poderoso. A impressão de leveza e amplidão é esplêndida e sedutora. O ambiente se transforma, revelando sutilezas mínimas que jamais se percebe de ouvidos desarmados.

Com os novos dispositivos de gravação (fonógrafo, fita-magnética e atualmente os suportes de mídias digitais) surge a possibilidade de armazenar, repetir e examinar sons efêmeros que, antes, só eram passíveis de serem escutados diante da presença da fonte mecânica que o produziu. "A dissociação da vista e do ouvido favorece aqui uma outra maneira de escutar" (Schaeffer, 1966, p. 57). Trata-se aí da escuta acusmática para Schaeffer, que se dissocia de uma relação causa-efeito (localização imediata da fonte sonora). A escuta passa a ocupar uma dimensão nova, estabelecendo uma ruptura com a maneira tradicional de nos relacionarmos com o som, seja no plano da música, da comunicação ou dos sons cotidianos.

A acusmática contribui justamente naquilo em que se relaciona às alterações na escuta produzidas pelos meios técnicos de captação de áudio, isolamento do mesmo em faixas e escuta em fones de ouvido. A ausência e/ou a não identificação da fonte sonora é frequente nas experiências de audição de paisagens sonoras das mais diversas, mas ganha novos contornos quando ao longo da pesquisa utilizamos microfones de alta fidelidade que permitem ouvir frequências e timbres normalmente inaudíveis à escuta não permeada pela tecnologia.

Embora o som nos chegue por meios físicos, o reconhecimento de que ele não pode ser visto, tocado ou cheirado levou o sonoplasta Walter Murch, ganhador de um Oscar, a falar em um "sentido fantasma", que habita sozinho um reino etéreo e sem forma. Em seu ofício de engenharia de som, Murch e seus colegas fazem uma ponte entre essa dimensão fantasmagórica - manifesta sob a forma de diálogos, efeitos ou música - e a realidade visual bem mais concreta das imagens, acrescentando contexto e, assim, transformando ambos os elementos. Seres humanos de audição perfeita são capazes de 
ouvir frequências compreendidas entre os extremos de 20 ciclos por segundo, ou $20 \mathrm{~Hz}$, e de $20.000 \mathrm{~Hz}$. A sensibilidade dos meios técnicos contemporâneos por vezes ultrapassa essas barreiras e comprimem sons dificilmente audíveis ao seres humanos, ou percebidos apenas como ruídos, trazendo-os à tona.

A questão se tornou especialmente relevante ao longo de nossa discussão exatamente porque nos interessava não a caracterização dos sons em seus aspectos de frequência e timbre, mas o embate entre sons e aspectos da percepção cultural dos mesmos. Nessa perspectiva entender as deformações geradas a essas percepções ao usar ferramentas tecnológicas diversas era de extrema importância, levando-nos a discutir a questão da escuta ativa do pesquisador.

Embora presentes em todo e qualquer sinal acústico - seja ele gerado por animais, homens, instrumentos musicais ou máquinas , os elementos do som constituem apenas uma parte do que constitui a percepção da sonoridade coletiva de determinada localidade. Se partimos da ideia de uma escuta ativa ou de um ouvido pensante, a percepção sonora aparece entrelaçada com subjetividades e construções semânticas coletivas dos sons.

Schaeffer, a partir de uma abordagem fenomenológica, compreenderá que "não se trata mais de saber como uma escuta subjetiva interpreta ou deforma a 'realidade', estudar as reações aos estímulos; é a escuta, ela mesma, que torna-se a origem do fenômeno a estudar" (SCHAEFFER, 1966, p. 92). Mas interessa ao autor não uma abordagem subjetiva individual, mas antes as relações intersubjetivas da escuta: "a questão será, desta vez, saber como encontrar, no confronto das subjetividades, qualquer coisa sobre a qual será possível a vários sujeitos (expérimentateurs) entrarem em acordo" (SCHAEFFER, 1966, p. 92).

No entanto, para além e complementando essa escuta coletiva, devemos focar numa certa condição de escuta, visto que é pela função da escuta que mais diretamente estabelece-se a relação ouvinte e fonte sonora, cuja dissociação é produzida pela acusmática. Condição de escuta que não seria jamais passiva ou apenas receptiva, considerando que o próprio ato de ouvir já configura uma ação seletiva.
A música para Deleuze e Guattari territorializa e desterritorializa em ritornelo constante, précondição de uma escuta não passiva que se deixa contaminar pelo território do outro, interferindo, traduzindo, interpretando esse território. Trata-se de escuta como um ato de criação $(\mathrm{OBICl}, 2008)$ e de afirmação de certo lugar político e estético em que ouvinte e fonte sonora se predispõem de forma ativa e atuante.

Assumimos que o ato de mapear a audição é mais do que inventar escuta, mas, inventar pela escuta, uma escuta que cria ao interpretar/traduzir o que ouve para além da condição de ouvinte cristalizado do qual se espera uma resposta dentro do padrão mapeado pelo dialogismo na contingência da relação estabelecida. Antes de ir mais a fundo nas possibilidades do jogo expresso na relação entre ouvintes e fontes sonoras que vão se desconstruindo ou desterritorializando, já haveria uma indecisão mesmo a nível contextual que afeta internamente o dizer sonoro. Uma vez que o contexto determinaria os limites estéticos do que deve ser classificado por som, música, ruído e silêncio, essas construções devem, por sua vez, responder à construção contextual (social, político, cultural, construída por um discurso) ora desafiando o limite ora subordinando-se a ele.

O campo sonoro é palco de uma constante batalha de destruições de paradigmas e conceitos que definem o que é o musical, o ruído e o silêncio. Todas as categorias do sonoro precisam ser inventadas constantemente, "o que não se faz sem alguma perda e com um grande exercício inventivo" (OBICl, 2008, p.95). Como diria Wisnik (2006), ao falar da separação eurocêntrica entre música e ruído, problemática ao tratar da música modal oriental e tribal:

(...) A escuta está polarizada pela repetição do mercado, mas outros modos de escuta estão latentes nela como ressonâncias harmônicas. À medida que nos aprofundamos no tempo da dessacralização, toda a história dos símbolos, que vibra num acorde oculto (modal, tonal, serial), fica paradoxalmente mais exposta na sua simultânea contemporaneidade (WISNIK, 2006, p.56).

É, pois, no tensionamento da escuta que inventamos, com ela, ao escutar, som, ruído, murmúrio e música. O sonoro, tal qual a música, se desloca entre o silêncio e o ruído, 
não sem drama, sem conflito, mas, é preciso pensar o quanto o ouvido não é também personagem atuante desse mesmo drama, produzindo e destruindo territórios, por ato auditivo ativo e afirmativo. Assim, propõe-se o jogo entre música (como expresso pelo ritornelo deleuziano) e escuta estabelecendo uma dupla possibilidade de rasura, atuando no deslizamento do que se quer dizer música, do que se quer dizer ruído e do que se quer dizer silêncio.

\section{CARTOGRAFIA SONORA DO SERTÃO}

\subsection{TERRITORIALIZAÇÕES PRELIMINARES E BORRAMENTO DE FRONTEIRAS}

Como base preliminar de pesquisa, o projeto partiu de uma caracterização geral dos territórios sertanejos em "naturais" (ou pouco influenciados pela ação humana), "rurais" (transformados pela ação, ocupação e presença humana de baixo impacto sonoro) e "urbanos" (transformados pela ação, ocupação e presença humana de alto impacto sonoro). Tal caracterização foi em certa medida importante para a ordenação das coletas e evidenciou certas tessituras preliminares no mapeamento.

A região de realização da pesquisa foi o sertão alagoano (Ver Fig1), compreendendo os municípios de Delmiro Gouveia, Piranhas, Pão de Açúcar, Belo Monte, Água Branca, Canapi, Inhapi, Mata Grande, Pariconha, Carneiros, Dois Riachos, São José da Tapera, Santana do Ipanema, Senador Rui Palmeira, Ouro Branco, Poço das Trincheiras e Maravilha (total de 17 municípios). A captação dos ambientes sonoros se deu tanto nos municípios sede, localidades e povoados quanto nas áreas rurais, fazendas, sítios, assim como nas paisagens naturais, serras, lajedos, resquícios de mata nativa, resquícios de caatinga, etc.

Figura 1: Mapa de Alagoas, evidenciando a área de pesquisa

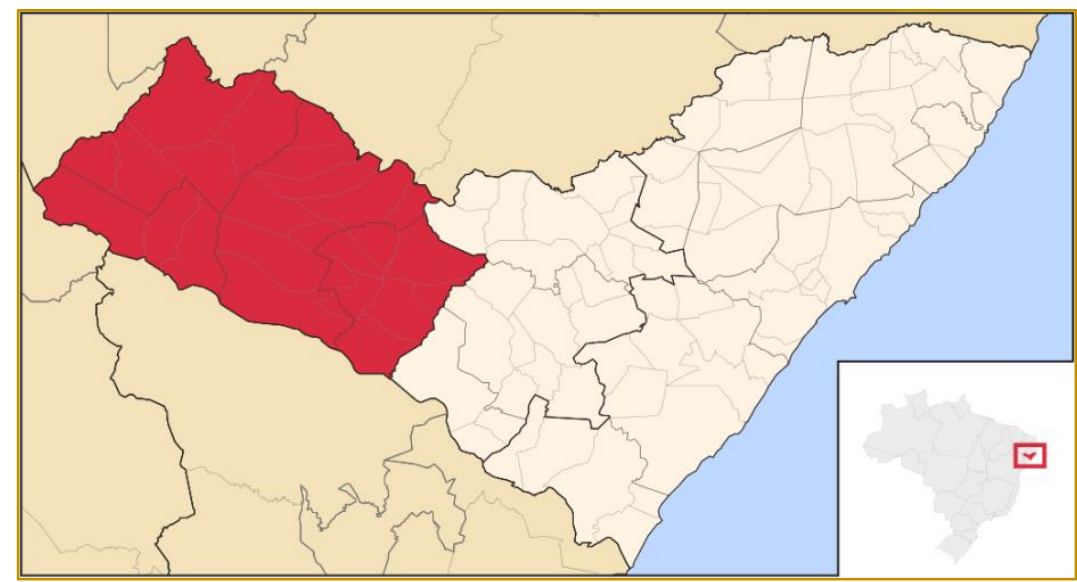

Fonte: Wikicommons, 2018.

Em termos epistêmicos a pesquisa fundou-se sobre uma base pós-estruturalista, considerando o mapeamento da região, no caso o sertão alagoano, a partir de uma leitura deleuziana, em que os limites, fronteiras e separações entre território natural, rural e urbano não se apresentam de forma alienada entre si, com bordas e beiras nitidamente descriminadas, mas, ao contrário, se comunicando e produzindo estratégias de adaptação, linhas de fuga, zonas de interseção, corredores e veredas por onde elementos típicos de cada território se manifestam e são localizados em outro. Logo não se trata de um mapeamento que parte do princípio que carcarás, bugios, gambás e preás estarão restritos aos territórios naturais enquanto motos estarão restritas aos ambientes urbanos e os carros de boi, por extensão, aos ambientes rurais, mas, uma forma de catalogação sensível e atenta a essas contaminações entre territórios que certa forma de produzir ciência classifica como nitidamente separados.

As transformações e rearranjos dos territórios sertanejos produzem deslocamentos e novos agenciamentos sonoros, e desta forma partimos da compreensão de que não se produz um mapa taxonômico dos territórios sonoros, mas uma cartografia aberta que se constitui enquanto constitui territórios em devir. "Há linhas de articulação ou 
segmentaridade, estratos, territorialidades, mas também linhas de fuga, movimentos de desterritorialização e desestratificação" (DELEUZE \& GUATTARI, 1995, p. 11).

À medida em que adentramos sertão adentro, a escuta foi rasurada pelas interpenetrações dos sons e optamos por tratar os conjuntos a partir também de outros recortes, que dizem respeito a temporalidades e espacialidades específicas do sertão e que não se encerram nas categorias apresentadas. Desta forma, não há propriamente um mapa resultante, mas como acentuariam Deleuze e Guattari (1997), uma cartografia, "conectável, desmontável, reversível, suscetível de receber modificações constantemente" (p. 21).

\subsection{MODOS DE NOTAÇÃO - MAPA DE SONORIDADES}

Uma vez que não há aqui uma tentativa de esgotamento das territorializações, apresentamos na Tabela 1 uma síntese das anotações de campo dos pesquisadores com finalidade de ilustrar o primeiro sistema de notação, ainda estruturado a partir do conceito de paisagem sonora, que se mostrou insuficiente por não conseguir explicitar as tessituras entre os elementos sonoros e suas espacializações, temporalizações e seus aspectos socioculturais.

Tabela 1: Notação preliminar utilizada nos diários de escuta dos pesquisadores. Essa metodologia de representação foi abandonada pelo grupo ao longo do processo, tendo sido dada preferência aos registros audiovisuais explicitados no mapa de sonoridades e nos documentários sonoros.

\begin{tabular}{|c|c|c|c|}
\hline & Onde & Temporalidades & o que escutamos \\
\hline 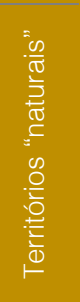 & $\begin{array}{c}\text { Caatinga } \\
\text { Lajedos } \\
\text { Serras } \\
\text { Resquícios de mata } \\
\text { nativa }\end{array}$ & $\begin{array}{l}\text { Amanhecer } \\
\text { Alvorada } \\
\text { Meio-dia } \\
\text { Dia chuvoso }\end{array}$ & $\begin{array}{c}\text { Canto de aves } \\
\text { Revoadas } \\
\text { Zumbidos de insetos } \\
\text { Vento } \\
\text { Riacho correndo } \\
\text { Cachoeira } \\
\text { Gotas de chuva na pedra } \\
\text { Farfalhar de folhas } \\
\text { Galhos contorcidos pelo vento }\end{array}$ \\
\hline 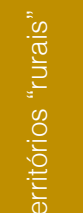 & $\begin{array}{l}\text { Fazendas } \\
\text { Sítios } \\
\text { Pequenos povoados } \\
\text { Estradas de terra }\end{array}$ & $\begin{array}{l}\text { Jornadas diurnas } \\
\text { Fim de tarde } \\
\text { Amanhecer } \\
\text { Dia de festas religiosas } \\
\text { Dia de feira }\end{array}$ & $\begin{array}{c}\text { Carros de boi } \\
\text { Sinos amarrados em pescoço de animais } \\
\text { Passos } \\
\text { Músicas tradicionais cantadas } \\
\text { Músicas amplificadas pelos rádios } \\
\text { Carroças puxadas a tração animal }\end{array}$ \\
\hline 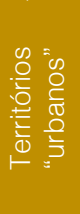 & $\begin{array}{l}\text { Sede dos municípios } \\
\text { Estradas secundárias }\end{array}$ & $\begin{array}{l}\text { Jornadas diurnas } \\
\text { Fim de tarde } \\
\text { Amanhecer } \\
\text { Dia de festas religiosas } \\
\text { Dia de feira }\end{array}$ & $\begin{array}{c}\text { Som de autofalante de automóveis } \\
\text { Motos } \\
\text { Conversas } \\
\text { Anúncios de comércio em autofalante } \\
\text { Sinos eletrônicos } \\
\text { Missa }\end{array}$ \\
\hline 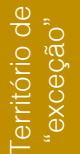 & Barrragem de Xingó & $\begin{array}{c}\text { Manhã } \\
\text { Fim de tarde } \\
\text { Período de seca }\end{array}$ & $\begin{array}{c}\text { Jorro de água } \\
\text { Turbina } \\
\text { Conversas em alto volume de voz } \\
\text { Sirene }\end{array}$ \\
\hline
\end{tabular}

Além disto, compreendemos que a transposição dos sons para uma descrição escrita ou mesmo gráfica dos mesmos, seja ela de base técnica ou perceptiva, não permitia perceber certas tessituras gerais mais diretamente vinculadas aos objetivos do projeto. Optamos assim por utilizar a notação escrita apenas como referência geral de campo, mas aprofundar métodos de registro, análise, depuração e apresentação dos resultados da pesquisa que exigissem, eles mesmos, a escuta.

Construímos, assim duas ferramentas de notação sonora: o Mapa de Sonoridades e os Documentários Sonoros. Ainda que já previstos desde o planejamento da pesquisa, tais ferramentas eram inicialmente pensadas apenas em suas possibilidades de publicação dos resultados finais, mas ao longo do processo eles evidenciaram potencialidades 
analíticas próprias e foram utilizadas como ferramentas de registro, organização e análise.

O Mapa de Sonoridades, utilizando ferramentas de georreferenciamento em base livre do GoogleMaps, foi utilizado em campo para marcar caminhos percorridos, localizar espacialidades perdidas em meio às paisagens naturais e oferecer publicamente acesso às sonoridades registradas. Desta forma, o mapa permite a escuta de diferentes sonoridades registradas de modo interativo. No mapa utilizamos parcialmente as camadas propostas no projeto, classificando as territorialidades em "naturais, periurbanas e urbanas", mas é possível rasurar tal classificação, já que a sequência de escuta é livre.

Figura 2: Interface do Mapa de Sonoridades, disponível na página do projeto

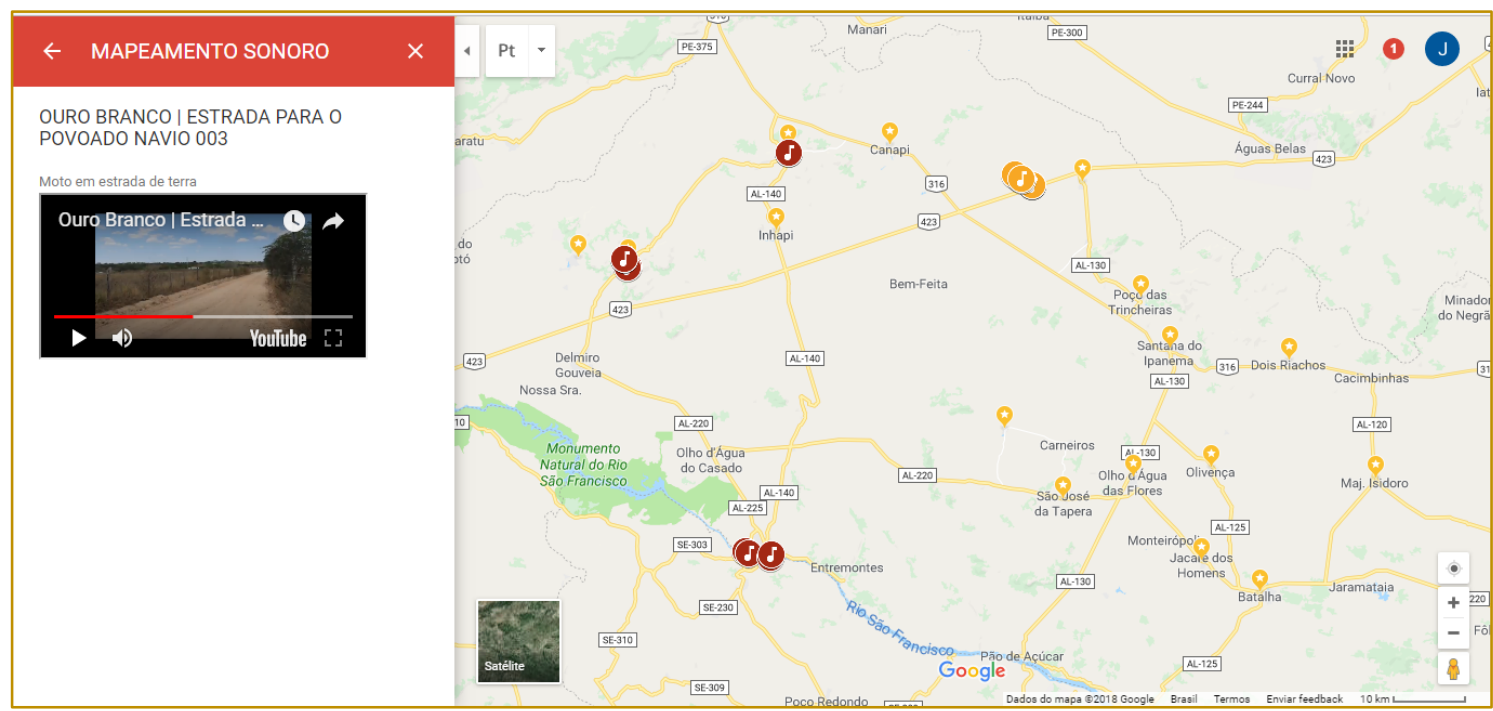

Fonte: Site do projeto (não divulgado para evitar a identificação dos autores)

\subsection{PAISAGENS SONORAS ENQUANTO EXPRESSÕES CULTURAIS}

Para além do mapa das sonoridades, o grupo produziu leituras aproximativas de territorializações sonoras que perpassam o sertão e complexificam a identificação de zonas sonoras definitivas e generalizantes. Tais leituras foram sendo configuradas pelo grupo inicialmente em fragmentos agenciadores, analisados à luz de questões socioculturais, que se articulam como agenciamentos territoriais preliminares. Tais paisagens foram sendo percebidas e evidenciadas ao longo do desenvolvimento da pesquisa em fragmentos sonoros que se colocam entre as sonoridades contingenciais apresentadas no mapa de sonoridades e os agenciamentos propostos nos documentários. Apresentaremos a seguir, a título de exemplo, algumas destas análises imbricadas a uma leitura ampliada que as caracteriza como índices de modos de vida e relações territoriais próprias ao sertão.

O silêncio da rua dos municípios ao meio dia em janeiro. - Esse silêncio em meio às cidades em pleno verão e sobre o calçamento quente de pedra ao sol escaldante do meio dia foi um dos poucos momentos de silêncio escutados nas sedes dos municípios. Rasurado sazonalmente pelo ruído de motos ou pelo volume mais alto de uma televisão, trata-se de um silêncio em mormaço, que indica a inospitalidade momentânea das cidades, sempre repletas de gente. Em dia de feira, esse silêncio não atravessa o centro das cidades, já que ao meio dia dos dias de feira o som é de barracas desmontando, feirantes anunciando a xepa, CDs piratas tocando em alto falantes ruidosos e com o volume estourado, bêbados cantarolando e as vezes brigas apartadas pelo ôô dos transeuntes.

O ruidoso nascer do sol no lajedo. Boa parte da vida animal do sertão é composta por aves diversificadas, cujo canto inclusive faz parte do imaginário do sertanejo. O canto do Acauã ou da Asa Branca indicam a chegada da seca ou da chuva e a escuta desse falar das aves é fundamental para a leitura das temporalidades amplas, dos ciclos anuais. Mas o som dos animais marca também os 
horários do dia, com uma vasta gama cromática de revoadas, cantos, zumbidos, chiados.

\begin{abstract}
Veredas em estradas de terra e a invasão das motos.- Uma das territorialidades mais presentes ao longo da pesquisa foram as estradas de terra que ligam as sedes dos municípios aos povoados, sítios e elementos naturais. De condição precária em sua maioria, a maior parte dos sons são das carroças puxadas por burros e carros de boi que transportam as famílias moradoras das zonas rurais para a feira, os aboios de vaqueiros tangendo pequenos rebanhos. Esses sons se caracterizam pela sua continuidade, deslocamento e permanência já que falamos aí de ritmo lento. Reconfigurando essa paisagem sonora, assimilada como bucólica e tradicional, percebemos de modo cortante o som de numerosas motos, as vezes invisíveis ao entorno imediato, mas que pela sua caracterização sonora tende a dominar a paisagem por alguns segundos, de tempos em tempos. Devido à sua velocidade contrastante com os ruídos das carroças, poderíamos compreender o som das motos como uma rasura da velocidade modernizante do ciclo econômico da década de 2000 chegando até os trabalhadores das zonas rurais. O quase ausente som de automóveis dá a ler a difícil condição das estradas e a condição econômica dos moradores das áreas mais distantes.
\end{abstract}

Sinos eletrônicos e missas amplificadas no autofalante.- Nas sedes dos municípios ainda são presentes de modo marcante as sonoridades relativas às práticas religiosas, especialmente as católicas. Em horário de missa ouve-se o som de sinos eletrônicos, gravados a partir da internet e amplificados em autofalantes onipresentes nas portas das igrejas matrizes. Como se não bastassem os badalos eletrônicos, um membro da congregação ou por vezes o próprio padre recorre aos amplificadores para reforçar o chamado para a celebração, que em alguns lugares é toda ela jogada de dentro do espaço da igreja para a praça imediatamente à sua frente. Durante uma missa de finados, a equipe surpreendeu-se com o período de cerca de meia hora de chamado de nomes de pessoas falecidas, cuja intenção para oração foi inscrita por seus familiares na celebração, enquanto o bar lotado na praça abaixava o som em sinal de respeito.

A chegada do carro-pipa e as cisternas. - Nos pequenos povoados, após a descontinuidade parcial do programa de cisternas em alguns municípios que se estabeleceu em 2017, o barulho de um caminhão pipa chegando na rua barrenta, os gritos das crianças e mulheres se amontoando ao seu redor e a água sendo despejada em algum reservatório plástico improvisado configuram sonoridades que pensamos que estariam em vias de extinção, mas se fizeram presentes, denunciando desmontes de políticas públicas que pareciam estar consolidadas.

A barragem e o ensurdecimento.- Como marca do desenvolvimentismo, o som da barragem de Xingó se impõe e remodela o som do Rio São Francisco correndo em seu curso regular. Imergindo no som da turbina, a água corre de modo violento e paralisa os sons naturais de pássaros e da água batendo nas rochas. Tudo é turbina, som mecânico, contínuo, grave. Nada mais se escuta. Vivenciamos a sonoridade da barragem, no entanto, com menos força do que o comum, já que apenas uma comporta se encontra aberta atualmente - reflexo da seca e do assoreamento do rio.

\subsection{DOCUMENTÁRIOS SONOROS}

A partir das análises exemplificadas no item anterior, e numa dicção que se constitui como mediadora de experiências fenomenológicas e estéticas e chaves de leitura de certa textura sonora sertaneja, constituímos o que chamamos de Documentários Sonoros. É certo que o termo documentário, derivado da noção de documento, carrega em sua rede semântica uma ideia de "verdade". Entretanto, assim como Paul Ricoeur (2007) evidencia em "A memória, a história, o esquecimento", a noção de documento é problemática em si, já que pressupõe que o documento não existe em si, mas através do interesse que se investe sobre ele. A título de exemplo, no Brasil o termo "documentário sonoro" é mais conhecido para tratar de conjuntos de registros documentais sonoros, usualmente captados a partir de uma perspectiva folclórica. Esses acervos documentais tendem a ser lidos como registros, mas demonstram olhares próprios às primeiras décadas do século XX, em suas buscas pelos "saberes populares".

Ainda que a questão sonora esteja presente como aspecto fundamental da linguagem ficcional e documental desde os primórdios do cinema (mesmo na fase do cinema mudo a preocupação com o som estava presente e era 
comum o acompanhamento com piano nas salas de cinema), há certa prevalência da imagem sobre o som na maior parte dos discursos produzidos através das narrativas audiovisuais. "Embora o cinema, assim como o vídeo ou a televisão sejam indiscutivelmente meios audiovisuais, em geral nos referimos a eles como meios baseados na imagem", afirma Arlindo Machado (2011, p. 15) em artigo que discute novas formas do cinema documental, destacando os documentários sonoros como formato em expansão recente. No artigo o autor citará diversos filmes documentais nos quais a imagem é secundária ao som, que comporiam para Machado o campo do documentário sonoro. Em nossas experimentações, tentamos discutir essa lógica e colocar a sonoridade em destaque, ainda que não partamos da compreensão de que se deveria isolar o som dos apelos visuais.

No tratamento dado ao material mapeado ora o som é ampliado pelas fontes de captação, como falamos ao nos referir à interferência de microfones, fones e equalização na percepção auditiva, ora é colocado para o ouvinte de maneira próxima em contraste a imagens distantes de um mesmo local. Há portanto, desde disjunções a mudanças de foco, ampliações, contrastes e simbioses entre imagens e sonoridades, numa tentativa de compor um discurso sobre o audível através das experiências sensíveis. Se elencamos o conceito de território sonoro a partir de uma perspectiva deleuziana em que a cartografia se constitui enquanto agencia teritorializações que por sua vez a conformam, os documentários sonoros seriam modos não de esgotamento dos territórios sonoros sertanejos, mas de sua

\section{REFERÊNCIAS}

[1] Deleuze, Gilles \& Guatari, Felix. Mil Platôs: capitalismo e esquizofrenia. Rio de Janeiro: Ed. 34, 1995.

[2] Guattari, Félix. As três ecologias. Campinas: Papirus, 2004.

[3] Caosmose: um novo paradigma estético. Ed.3. São Paulo: Editora 34, 2000.

[4] Krause, Bernie. A grande orquestra da natureza. São Paulo: Zahar, 2013

[5] Machado, Arlindo. Novos territórios do documentário. Doc On-line, n. 11, dezembro de 2011. Disponível em: www.doc.ubi.pt. Acesso em 12 de novembro de 2017. territorialização, reterritorialização.

desterritorialização e

\section{CONSIDERAÇÕES FINAIS}

Através das reflexões teóricas e as experimentações metodológicas apresentadas, tentamos neste artigo contribuir para a problematização dos territórios sonoros ao registrar e agenciar sonoridades do sertão alagoano. Além disto imagina-se que o mesmo poderá inspirar e incentivar ações políticas em torno da ecologia acústica. Parte-se de uma convicção de que aguçar percepções sonoras, nossa sensibilidade auditiva, para determinadas manifestações naturais e artificiais, contribui no enriquecimento de aspectos relacionados a sociabilidade e a memória, aguçando compromissos éticos, históricos e políticos do indivíduo em constante processo de construção e negociação de aspectos e signos relacionados às marcas de identidade e território.

Não pretendemos, como já foi dito, esgotar as paisagens e territorialidades sonoras do sertão alagoano. Se paisagens e territórios se fazem junto ao fazer humano, caracterizam-se por mudanças, indefinições, paradoxos. O mapeamento aqui apresentado e desenvolvido ao longo de cerca de dois anos permitiu delimitar aspectos teóricos e metodológicos e registrar uma gama variada de sonoridades sertanejas, mas compreendemos que trata-se de um projeto inesgotável. A cartografia proposta, portanto, é uma cartografia em aberto, multiplicável, que dobra-se sobre si mesma e que permite ler relações de identificação e permanência, mas também de mudança e transitoriedade.

[6] Obici, Giuliano. Condição da escuta. Rio de Janeiro: 7letras, 2008.

[7] Schaeffer, Pierre. Traité des objets musicaux [Nouvelle Édition]. Paris: Éditions du Seuil, 1966.

[8] Schafer, Raymond Murray. O ouvido pensante. São Paulo: UNESP, 1991.

[9] A A afinação do mundo. São Paulo: Editora Unesp, 2011.

[10] Wisnik, José Miguel. O som e o sentido: uma outra história da música. Ed. 2. São Paulo: Cia das Letras / Círculo do Livro, 1999. 


\section{Capítulo 5}

\section{A CONFLUÊNCIA PERVERSA E A QUESTÃO AGRÁRIA BRASILEIRA}

Diná Andrade Lima Ramos

Carlos Frederico Bom Kraemer

Lamounier Erthal Villela

Resumo: O objetivo deste artigo é analisar a questão agrária a partir da confluência entre as políticas neoliberais adotadas desde os anos 1990 e as propostas democráticas para o meio rural desde a reabertura política até maio de 2016. Para tanto, realiza-se um ensaio teórico. Essas políticas têm o potencial de impactar a forma de opupacão do espaço rural. Mesmo com a aparente incompatibilidade das condições do modelo do agronegócio, crescente, predador e degradador; com um modelo mais inclusivo de desenvolvimento para o meio rural, buscava-se, mais recentemente, conduzir e possibilitar a convivência entre ambas as propostas, mediante uma agenda mais progressista. Nas políticas que contrapõem o modelo conservador, pelo menos em seu desenho, têm como foco os trabalhadores rurais sem terra, os agricultores familiares e os assentados. Nesta perspectiva, era adotado um enfoque territorial nas ações para o desenvolvimento rural como um meio de contrabalançar as desigualdades socioeconômicas do campo. Na análise, conclui-se que os modelos tanto das políticas neoliberais, quanto das políticas de cunho social estavam convivendo com algum ganho social, antes que assumisse um governo de direita, com suas intenções mais conservadoras. Ao mesmo tempo em que o Estado buscava atender aos interesses da elite agrária brasileira ligada ao agronegócio, implementava-se, ainda que de forma tímida, parte das demandas suscitadas nas lutas sociais para o campo, sobretudo condições de permanência de sua população.

Palavras Chave: Questão agrária; Políticas públicas para o campo; Território. 


\section{INTRODUÇÃO}

A década de 1980 foi o cenário de transformações econômicas, sociais, políticas no Brasil. O período testemunhou o fim do regime autoritário e um esforço de democratização a partir de diferentes esforços nacionais, gerando muitas expectativas por parte da sociedade, que ansiava por maior participação nas decisões políticas.

Tanto no campo, como na economia Brasileira como um todo, foram sentidos os impactos causados pelos constrangimentos econômicos externos diante de uma economia globalizada. Com frequência, as exportações agrícolas têm sido tomadas como estratégica para de geração de riqueza e divisas, atendendo e corroborando, com as condições necessárias ao agronegócio.

Era muito esperado pelos diferentes movimentos e instituições sociais que atuavam na luta pelo acesso à terra e condições de permanência no campo, que, com a eleição de Luiz Inácio Lula da Silva, houvesse um rompimento mais profundo com os preceitos neoliberais, o que não se verificou. Ainda assim, foi possível encontrar alguns indicativos, quanto às políticas para o meio rural,da adoção de novas abordagens metodológicas para se pensar o seu desenvolvimento, principalmente no que atende a população mais vulnerável do campo.

O objetivo deste trabalho é analisar a questão agrária a partir da confluência perversa entre as medidas neoliberais adotadas desde os anos 1990 e as propostas democráticas para o meio rural, desde a reabertura política e desde a reabertura política até maio de 2016, em especial no que concerne à luta pela reforma agrária. Trata-se de uma análise a partir de uma pesquisa bibliográfica. Propõese organizar esta análise dividindo-a em seis seções, contando com esta introdução. $\mathrm{Na}$ segunda seção discute-se a questão agrária no Brasil, partindo do embate teórico em torno dela e destacando a opção pela via prussiana como resposta às necessidades de aumento da produtividade para atender o mercado interno e externo com produtos agropecuários, a chamada modernização conservadora, e que demonstra orientar as políticas agrícolas contemporâneas. $\quad \mathrm{Na}$ seção três será discutida a confluência perversa de que trata Dagnino (2004), por meio de um rearranjo político entre dois ideais políticos aparentemente conflitantes que operaram até, pelo menos, o fim do governo Dilma Rousseff: o neoliberal e o democratizante e seus efeitos sobre a capacidade de mobilização dos protagonistasque buscam uma sociedade mais democrática e igualitária. Na seção quatro salienta-se que, mesmo com a aparente incompatibilidade das condições necessárias ao agronegócio com um modelo mais inclusivo de desenvolvimento para o meio rural, buscava-se, contando com a legitimação e participação da sociedade civil, conduzir e possibilitar a convivência entre ambas as propostas. Uma discussão quanto aos caminhos alternativos que atenda aos habitantes do rural brasileiro, não incluídos no agronegócio, é apresentada na seção cinco. $\mathrm{Na}$ seção seis são apresentadas as discussões finais.

\section{QUESTÃO AGRÁRIA: DA MODERNIZAÇÃO CONSERVADORA AO AJUSTAMENTO CONSTRANGIDO}

A reforma agrária é um veículo estratégico de desenvolvimento socioeconômico e sustentável para o meio rural (Leite, 2007). De acordo com o autor, o acesso à terra leva a implicações positivas em relação ao crescimento agrícola e econômico e possibilita a homogeneização social, promovendo justiça social e cidadania. Mas, para que ela seja promovida, é necessária a atuação conjunta de atores estratégicos, sobretudo o Estado, e que "[...] seja problematizado $\mathrm{o}$ próprio padrão de desenvolvimento que tem pautado a trajetória dos últimos 50 anos dos países em desenvolvimento, questionando a prioridade conferida ao modelo agroexportador." (Leite , 2007, p.5).

O embate teórico em torno da questão agrária no Brasil tem destaque no pós-guerra, quando duas grandes correntes se fazem representar: uma em prol da reforma agrária, e outra que entendia que os problemas existentes no meio rural poderiam ser solucionados sem a necessidade de haver distribuição fundiária.

Enquanto os primeiros focalizam as chamadas relações internas de produção acentuando o papel da estrutura de propriedade fundiária e das relações de trabalho predominantes, e seus efeitos econômicos e extra-econômicos -, os conservadores estão observando pela lente 
das funções da agricultura. Atendidas as funções básicas ${ }^{11}$, imaginadas para uma agricultura genérica, sem pressões estruturais sobre o Índice Geral de Preços, a balança comercial e a produção industrial não haveria porque falar em crise do ou no setor primário. (Guilherme Delgado, 2005, p.56)

A proposta da reforma agrária foi vencida pelo pensamento econômico conservador, sob o discurso da modernização técnica agrícola $^{12}$. Como afirma Ramos (2007, p.33), as formulações de inspiração neoclássica, indicavam que a solução para a questão agrícola "[...] deveria vir de uma adequação do funcionamento dos mecanismos de mercado, auxiliado e não distorcido pelas políticas agrícolas." Essa tese orientou as políticas agrícolas no regime militar, quando as propostas modernizantes ${ }^{13}$ de Delfim Netto e seu grupo da Universidade de São Paulo (USP) foram adotadas como projeto de governo. Isto fica mais explícito em 1967, quando é implementado o sistema Nacional de Crédito Rural (SNCR), objetivando o aumento da produção e produtividade para atender a demandas internas e externas.

Ramos (2007, p.34) citando o trabalho de Ignácio Rangel (1978) diz que, enquanto leitor de Marx e Lenin, Rangel sabia que havia alternativas para resolver o desenvolvimento no meio rural.

Ignácio Rangel [...] sabia que havia duas vias de desenvolvimento do capitalismo no campo: a via democrática ou americana, na qual ocorre uma expansão e modernização das atividades agropecuárias com mudança da estrutura fundiária pretérita e com ocupação parcelada de novas terras; e a via prussiana, na qual é mantida uma estrutura fundiária

\footnotetext{
11 A imaginação dos economistas conservadores da época, e também de alguns críticos do sistema, está impregnada das chamadas cinco funções da agricultura: i) liberar mão-de-obra para a indústria; ii) gerar oferta adequada de alimentos; iii) suprir matérias-primas para indústrias; iv) elevar as exportações agrícolas; e v) transferir renda real para o setor urbano."(DELGADO, 2005, p.56)

12 Pensamento desenvolvido por um grupo de economistas da Universidade de São Paulo (USP), liderado por Antonio Delfim Netto, refutando a tese cepalinada correlação positiva entre a rigidez da oferta agrícola e a estrutura fundiária concentrada.

13 Leia-se aumentar o nível técnico da mão de obra; investimentos em novas tecnologias (máquinas,equipamentos, fertilizantes e defensivos agrícolas) e eficiência na estrutura agrária.
}

concentrada e, portanto, moderniza-se o latifúndio.

O papel desempenhado pela agricultura no Brasil tem sido, com afirma Nelson Delgado (2010, p.28) "[...] de alguma forma adaptado, e primeiro lugar para responder aos estímulos do mercado externo ou para enfrentar as crises recorrentes do balanço de pagamentos" pelas elites e formuladores de políticas.

Não resta dúvida a via adotada no Brasil. As políticas promovidas nos anos 1970 assumiram que 0 desenvolvimento rural deveria ser entendido como modernização agrícola. De acordo com Guilherme Delgado (op. cit., p. 58) a modernização agrícola, do período 1965-1981 significou o auge "[...] do desenvolvimento de uma agricultura capitalista em integração com a economia industrial e urbana e com o setor externo, sob forte mediação financeira do setor público.". O autor afirma que ela teria incorporado mais uma de demanda para a agricultura brasileira "o aprofundamento das relações técnicas da agricultura com a indústria e de ambos com o setor externo ${ }^{14}$, isso tudo fortemente subvencionado pela política agrícola e comercial do período".

A modernização conservadora, como ficou conhecida a modernização da agricultura sem reforma na estrutura fundiária brasileira, resultou na subordinação da agricultura à indústria. Ela passou a comandar "a direção, as formas e o ritmo da mudança na base técnica agrícola." (Kageyama et al., 1990, p.113).

A modernização da agricultura é um processo antigo, que se intensificou na escala nacional no pós-guerra. Segundo Kageyamaet al. (op. cit., p.113), ela significou "uma mudança na base técnica da produção que transforma a produção artesanal do camponês, à base da enxada, numa agricultura moderna, intensiva, mecanizada, enfim, numa nova maneira de produzir". Ao longo dessa modernização culmina a industrialização da agricultura, que foi um processo se intensificou pós 1965, e que, segundo a autora "[...] envolve a ideia de que a agricultura acaba se transformando num ramo de produção semelhante a uma indústria, como uma "fábrica"15 que compra determinados insumos e produz matériasprimas para outros ramos de produção".

\footnotetext{
${ }^{14}$ Grifo no original

${ }^{15}$ Grifo no original
} 
Por outro lado, as medidas econômicas e políticas assumidas nessa modernização, além de preservar, aprofundaram as heterogeneidades econômicas e sociais regionais na agricultura brasileira quanto à inserção tecnológica e às relações de trabalho, inclusive privilegiando antigas oligarquias rurais ligadas ao latifúndio. Assim, o processo de industrialização da agricultura levou a transformações no meio rural que afetaria de forma irreversível as relações socioeconômicas no campo. Até meados dos anos 1960, havia segundo Kageyama et al. (op. cit.), lugar para a pequena produção independente e artesanal, ainda que utilizasse insumos modernos.

A partir da industrialização, há uma divisão social do trabalho, em que o trabalhador passa a ser um assalariado "que trabalha coletivamente ou cooperativamente dentro de uma atividade". Outro aspecto da industrialização é o salto qualitativo que ocorre quando se usa fertilizantes $e$ defensivos químicos e se mecaniza todo o processo produtivo, do plantio à colheita, e não se usa somente, como antes, o trator, que embora fosse um substituto da tração animal força física, ainda prescindia a habilidade do trabalhador. Nesse período o Brasil já havia endogenizado o D1, ou seja, já era capaz de produzir bens de capital, por meio da implantação de indústrias de base, viabilizando para a agricultura, insumos modernos (fertilizantes, defensivos, corretivos do solo, sementes melhoradas etc.) e máquinas e equipamentos industriais (tratores, colhedeiras, implementos, equipamentos de irrigação etc.). As desigualdades no campo foram também salientadas por Palmeira e Leite (1998 apud Leite , 2007, p.6), que destacaram os "efeitos perversos" da modernização agrícola:

[...] a propriedade tornou-se mais concentrada, as disparidades de renda aumentaram, o êxodo rural acentuou-se, aumentou a taxa de exploração da força de trabalho nas atividades agrícolas, cresceu a taxa de auto exploração nas propriedades menores, piorou a qualidade de vida da população trabalhadora do campo, agravaram as condições ambientais.

O fato é que a agricultura passou a ser apenas um elo na cadeia produtiva comandada pela indústria. Através da ação de setores industriais distintos, a montante e a jusante da agricultura, conformaram-se os complexos agroindustriais (CAls). Por isso se afirma que a agricultura é atingida por uma "tesoura preços" como salienta Graziano da Silva (1991, p.11), a partir do trabalho de Alberto Passos Guimarães (1976), "para trás a agricultura se relaciona com uma indústria fortemente oligopolizada que consegue impor preços aos insumos adquiridos pelos agricultores; e para frente com a agroindústria processadora, também oligopolizada."

Os CAls se concretizaram nos anos 1970, se beneficiando da internalização do D1para a agricultura em 1965 e da estruturação da agroindústria processadora. Guilherme Delgado (1985, apud Kageyama, 1990, p.123) diz que esse padrão é integrador de capitais de diferentes ordens "[...] industriais, bancários, agrários etc., que por sua vez fundir-se-iam em sociedades anônimas, condomínios, cooperativas rurais e, ainda, empresas de responsabilidade limitada integradas verticalmente (agroindustriais ou agrocomerciais)". Reforça essa afirmação os dados apresentados pela autora a atuação de diferentes ramos, empresas industriais, financeiras e comerciais, ou seja do grande capital, investindo na atividade agrícola e no mercado de terras. Neste cenário, o Estado também desempenhou papel importante regulando de forma a "financiar, patrocinar e administrar as expectativas e a captura das margens de lucro na agricultura, no sentido de beneficiar os capitais integrados e garantir sua valorização." (Kageyama et al., op. cit., p. 124).O novo padrão agrícola passa a ter, então, sua base nos CAls e pela fusão dos diferentes capitais citados acima por meio capital financeiro, cujo elo foi o já citado SNCR.

Findo o regime militar e com a chegada da Nova República brasileira, retoma-se a discussão da reforma agrária. Os protagonistas foram tanto os diferentes movimentos e instituições sociais, propiciado por um ambiente de abertura política, quanto o Estado, refletida no Primeiro Plano Nacional de Reforma Agrária (PNRA), concebida em 1985, no governo Sarney; e na Constituição cidadã de 1988. Essa constituição, dentre outros avanços sociais, legitimou a função social da terra e consagrou a participação da sociedade civil. Foram importantes os movimentos sociais para o alcance dessas conquistas. Contudo, o PNRA gerou controvérsias entre os atores favoráveis à reforma agrária e a forte oposição dos representantes das elites agrárias, que chegou a criar a União Democrática Ruralista 
(UDR), tendo como alguns dos objetivos, evitar a aprovação do Plano e impedir a reforma agrária. A UDR teve êxito, pois o PNRA foi abandonado.

No âmbito internacional, a partir da moratória do México em 1982, houve no Brasil uma crise da dívida externa, levando o país a um "processo de ajustamento constrangido à ordem econômica globalizada." (Guilherme Delgado, op. cit., p.62). Tal situação, segundo Nelson Delgado (op. cit., p.50) obrigou "o país a um ajustamento econômico unilateral, que desestruturou a economia e fragilizou inteiramente a capacidade do Estado formular políticas públicas ativas", dado o alto endividamento público, dependência externa, a aceleração inflacionária, o fracasso dos planos de estabilização. Como agravante, o autor salienta ainda que o fracasso dos sucessivos planos de estabilização gerou grande instabilidade entre os agentes econômicos, gerando "comportamentos altamente especulativos quanto aos estoques e ativos agropecuários, intensificando o caráter especulativo da formação dos preços das commodities agrícolas, o que redundou [...] numa crise agrícola no início dos anos 1990."

A estagnação interna ocorrida a partir da necessidade desse ajustamento facilitou, segundo Nelson Delgado (op. cit., p.51), a inserção das propostas neoliberais, já ensaiadasno governo Collor e aprofundadas nos os dois governos Fernando Henrique Cardoso, onde se destaca pelo menos uma: "do papel estratégico das exportações agrícolas para enfrentar o estrangulamento recorrente da balança de pagamentos especialmente em uma economia que se estava tornando mais aberta e desregulada e para alavancar a retomada do crescimento da economia."

As exportações agrícolas passaram a ser consideradas essenciais para cobrir os déficits em conta corrente do balanço de pagamentos. Segundo Guilherme Delgado (op. cit., p.51), "a forma como a política econômica externa incorporará o setor agrícola na "solução" do endividamento externo reforça a estratégia de concentração e especulação fundiária no mercado de terras."Isto faz com que se acirrem pressões e conflitos no meio rural.

Assim, a reforma agrária é novamente sufocada, agora sob a ordem econômica mundial neoliberal e globalizada em que, na opinião de Guilherme Delgado (op. cit., p.51), "[...] obsta o papel que o Estado precisaria exercer para cumprir os direitos sociais agrários inscritos na Constituição, que prescreve a função social da propriedade fundiária." Mais do que nunca, a economia internacional estaria influenciado a questão agrária no Brasil, atendendo aos interesses históricos das elites agrárias em defesa da vocação agroexportadora do país.

A existência de um abundante capital estrangeiro disponível ao Brasil como resultado da conjuntura internacional, associada a estabilização monetária com a implementação do Plano Real em 1994, levou a um abandono à política de geração de saldos comerciais promovidas no período anterior e a à adoção de medidas liberais, no primeiro governo de Fernando Henrique Cardoso (FHC). Com a economia ancorada no tripé "câmbio sobrevalorizado, tarifas ultra mitigadas e desregulamentação no campo das políticas de fomento agrícola e industrial"(Guilherme Delgado, op. cit., p.64), logo se observa déficit em conta corrente, resultando num grande passivo externo entre 1994 e 1999, que será servido por um novo endividamento externo. $O$ resultado de tais medidas foi sentido com a queda na renda agrícola e, como consequência, no preço da terra.

O curioso, como aponta Guilherme Delgado (op. cit., p.65), é que esse efeito sobre o preço da terra pode ser encarado tanto como um facilitador, como também pode dificultar as políticas de reforma agrária. Com a terra mais barata seria possível incorporá-la ao processo distributivo de terras. Por outro, se o preço da terra caiu em função da queda dos preços agrícolas, os efeitos são extremamente negativos sobre da renda da produção quando não se pode contar com políticas de preços mínimos. "No âmbito da agricultura familiar, verifica-se abandono de atividades, desmobilização de estabelecimentos ou sua conversão à atividades de subsistência". Como salienta Nelson Delgado (op. cit., p.46), o comportamento e as condições de produção da agricultura, em especial a familiar, foi influenciado pelas medidas da década de 1990: redução dos recursos destinados às políticas agrícolas e de estoques públicos de alimento, redução das tarifas de importação, aumentos dos custos financeiros em função do aumento nas taxas de juros e escassez de crédito, aumento das importações agrícolas em função do câmbio 
valorizado, evolução desfavorável dos preços reais e da produção.

Afetado por uma segunda crise de liquidez internacional em 1998, a política macroeconômica no segundo governo FHC precisa novamente se ajustar, em especial o câmbio, e lidar com o passivo acumulado das contas externas. A responsabilidade de gerar o saldo comercial necessário ficou novamente a cargo do setor primário-exportador, agora autodenominado de agronegócio. Essa estratégia foi muito bem sucedida. Só de 2000 para 2003 as exportações agropecuárias brasileiras aumentaram em quase $50 \%$.

Segundo Guilherme Delgado (op. cit., p.66) o agronegócio é um termo entendido no Brasil como sendo "uma associação do grande capital agroindustrial com a grande propriedade fundiária. Essa associação realiza uma estratégia econômica de capital financeiro, perseguindo o lucro e a renda da terra, sob patrocínio de políticas de Estado". Quanto à origem do termo agronegócio, Graziano da Silva (1991, p.6), afirma que ele deriva do conceito complexo industrial, que "[...] nada tem a ver com a teoria do desenvolvimento ou com a ideia de dinâmica de crescimento" contido nele. O complexo agroindustrial, o "complexão", segundo o autor:

[...] tem uma origem "estática" que se destinava tão somente ampliar o conceito de agricultura uma vez que, nos EUA dos anos 50 , já não se podia mais tratá-lo como "setor primário" [...] nem ignorar sua crescente interligação com o restante da economia, em especial com os serviços financeiros - daí "agribusiness"

Heredia et al. (2010, p.160) afirmam que o conceito de agronegócio seria "[...] uma espécie de radicalização dessa visão, em que o lado "agrícola" perde importância e o lado "industrial" é abordado tendo como referência não a unidade industrial local, mas o conjunto de atividades do grupo que a controla e suas formas de gerenciamento".

Nos últimos anos do segundo governo FHC travou-se um embate político entre a reforma agrária e a modernização agrícola, sob um novo rearranjo político, cuja dialética Dagnino (2004, p.195) chamou de confluência perversa. A atual política agrícola tem priorizado o agronegócio, com sua lógica maximizadora da renda fundiária. Isso fez emergir novamente pressões e conflitos no meio rural diante da especulação do mercado de terras e da ausência de uma política efetiva de mudança na estrutura fundiária, resultando em algumas conquistas que serão analisadas mais adiante. Os saldos comerciais gerados pelo agronegócio, embora atenda aos serviços do passivo interno, "não desencadeiam demanda interna e emprego, mas repercutem na renda da terra e na especulação fundiária" como bem alertou Guilherme Delgado (op. cit., p.69) ao analisar a expansão constrangida.

Não obstante a questão agrária deva ser tratada sob circunstâncias histórica e política diferentes, Guilherme Delgado observa no debate em que se discute a questão agrária no Brasil "[...] uma linha de continuidade, qual seja a reprodução da estrutura altamente desigual da posse e uso da terra ao longo de todo o ciclo industrial (1930-1981) e também no período subsequente de relativa estagnação (1982-2003)" (Id., Ibid, p.52).

O Governo Lula, embora possa ser visto como uma vitória do projeto democratizante, não significou um rompimento com os preceitos neoliberais. Em seu primeiro governo houve preocupação como os gastos públicos, elevadas taxas de juros, controle cambial, abertura econômica e livre mobilidade de capitais, manutenção dos estímulos ao agronegócio como instrumento equilibrador das transações correntes, ocasionando novas expansões da fronteira agrícola pondo em risco, dessa vez, a região Amazônica, além da permissão para o cultivo de transgênicos. No que concerne à reforma agrária, as diretrizes estabelecidas no II Plano Nacional de Reforma Agrária (PNRA), elaborado em 2003, em seu governo, foram consideradas tímidas por Nelson Delgado. Para o autor, as ações do governo ficaram muito aquém das expectativas. Usando os dados do Instituto de Pesquisa Econômica Aplicada (IPEA), Nelson Delgado (op. cit., p.63) ressaltou que "a participação das terras desapropriadas no total das terras arrecadadas para a reforma agrária caiu de $40 \%$ no segundo governo FHC para $5 \%$ no governo Lula". Além disso, no segundo governo o número de famílias assentadas teve queda contínua. Para o autor "É destacável, por exemplo, a ausência, quase geral, do tema reforma agrária nas proposições de política pública decorrentes da nova institucionalidade criada para a gestão social dos territórios rurais, identidade adotada pela Secretaria de Desenvolvimento Territorial (SDT)." A governança dos territórios rurais, se fundamentada nos princípios da 
gestão social é entendida "como um meio para que as organizações sociais possam alcançar um desenvolvimento disseminado, igualitário e participativo" (Villela et al., 2012, p.129).

Carter (2015) afirma que houve uma quebra da histórica promessa petista de fazer reforma agrária. Para ele, o movimento nacional de reforma agrária no Brasil teria sofrido sua terceira derrota, tendo sido a primeira o golpe militar de 1964 e a segunda a decisão do presidente Sarney a abandonar o plano de reforma agrária adotado em 1985.

Estendo a análise para o governo da Dilma Rousseff, Carter (op. cit.), usou os seguintes argumentos para evidenciar a quebra de compromisso dos governos petistas como a reforma agrária. Em primeiro lugar o autor mostrou ter havido um acentuado declínio na redistribuição da terra, visto que o número de famílias beneficiadas aumentou sob o primeiro mandato de Lula, sofreu uma queda significativa em seu segundo mandato e o governo de Dilma beneficiou menos famílias do que qualquer outro governo brasileiro desde 1979. O mais impressionante foi o autor ter constatado que o primeiro governo de FHC foi aquele que mais beneficiou famílias por meio da distribuição de terras comparativamente aos partidos de esquerda. Em segundo lugar, O PT demonstrou relutância para distribuir vastas áreas de terras agrícolas disponíveis para a reforma agrária. Segundo o autor, o governo do PT não teria feito esforço de fato para fazer cumprir a exigência constitucional da função social da terra e nem mesmo tentou recuperar os 86,4 milhões de hectares de terra que estavam sob o domínio da elite agrária do país e deixando de beneficiar cerca de 4,2 milhões de famílias. Na sequência, Carter ressaltou os generosos subsídios e concessões que estavam sendo destinados aos grandes proprietários do agronegócio. Ele ressaltou que, entre 2003 e 2012, as empresas agrícolas se beneficiaram de $88 \%$ de todos os créditos agrícolas federais. Além disso, essas administrações prestaram assistência financeira e de infraestrutura às associações dirigidas pela elite agrária do Brasil, muitas vezes superiores às verbas canalizadas para projetos relacionados com o Movimento dos Trabalhadores Rurais sem Terra (MST) no que diz respeito ao ensino, cooperativas, direitos humanos e cuidados de saúde, além dos incentivos fiscais, do sobre lucro de compensação do governo pela desapropriação de terras para a Reforma Agrária, as grandes concessões de terra à elite agrária no segundo mandato de Lula.

Em quarto lugar, o autor chamou a atenção para a frouxidão do Estado na aplicação de leis que afetam aos interesses dos grandes proprietários haja vista a não implementação de leis agrárias, trabalhistas e ambientais, além da cobrança irrisória de imposto de propriedade da terra, mantendo assim os privilégios e impunidade das elites rurais tradicionais. Para finalizar, Carter critica a submissão do PT à elite econômica do Brasil alinhando suas políticas com o capital financeiro e às grandes corporações, incluindo as do agronegócio. Esse conjunto de evidências levou o autor a afirmar que o partido de esquerda estaria assim praticando o socialismo voltado para os ricos.

Por outro lado, pesa positivo, segundo Nelson Delgado (op. cit.), o fato de o governo Lula ter consolidado um conjunto de equipamentos em apoio à agricultura familiar e outras populações do meio rural. Essas medidas explicitariam o reconhecimento de que há outro tipo de agricultura no Brasil. São exemplos: a Lei da Agricultura Familiar e os novos papéis assumidos pelo Ministério do Desenvolvimento Agrário (MDA) instituído no governo de Fernando Henrique Cardoso (FHC) e agora extinto pelo atual presidente Michel Temer. Além disso, o governo Lula resgatou e ampliou algumas políticas existentes consideradas importantes de desenvolvimento rural, dentre elas: o Programa Nacional de Fortalecimento da Agricultura Familiar (PRONAF) instituído também no governo FHC, Plano Safra para a agricultura familiar, a reestruturação do programa de assistência técnica e extensão rural para os agricultores familiares resultando na Lei de Assistência Técnica e Extensão Rural (ATER) de 2010, criação do Programa de Aquisição de Alimentos (PAA) e a política de desenvolvimento territorial rural, como o Programa Territórios da Cidadania (PTC).

Carter (op. cit.) também reconheceu que o PT buscou dirigir alguma atenção e recursos à população pobre rural, destacando: a resistência do governo em criminalizar atividades do MST, seu o esforço para estender a eletrificação rural, a melhora nos serviços de extensão agrícola, os programas para a alfabetização de adultos, a oferta de cursos universitários para assentados da reforma agrária e o fornecimento de água para comunidades rurais no interior do 
Nordeste. Em adição o PT aumentou os recursos para a expansão da assistência social e fomentar oportunidades econômicas no meio rural. Os recursos destinados foram bem pequenos em comparação com os montantes previstos para os agricultores corporativos, mas já representava, segundo o autor, um conjunto de novos benefícios tangíveis destinados à população pobre rural. Por outro lado, não houve significativa alteração da realidade social dessa população. Carter destacou que em 2012, o Brasil ainda tinha 42 milhões de pessoas vivendo na pobreza, 9,4 milhões delas em áreas rurais. Nestas áreas o coeficiente de Gini alcançou 0,727, segundo o autor.

\section{A CONFLUÊNCIA PERVERSA ENTRE PROJETOS POLÍTICOS}

Nelson Delgado (op. cit., p.30) indica a década de 1990 com sendo uma demarcadora da atual disputa na sociedade brasileira "em relação ao rumo das relações economia e agricultura [...] e sobre a apropriação do significado do Brasil rural e do desenvolvimento rural.". Dagnino (2004, p.196) chamou atenção para a confluência perversa, neste período, entre dois projetos: o neoliberal e o democratizante. A autora a chama essa situação de perversa porque a convivência desses dois conjuntos de princípios não revela imediatamente seus efeitos negativos, principalmente aos atores da sociedade civil, que são peça "ativa e propositiva" em ambos os projetos.

O restabelecimento da democracia formal criou um ambiente favorável à aposta de que seria possível que o Estado e a sociedade atuassem em uma ação conjunta para o aprofundamento das concepções democráticas da política no Brasil. Segundo Dagnino (Ibid., p. 197):

Essa aposta deve ser entendida num contexto onde o princípio de participação da sociedade se tornou central como característica distintiva desse projeto, subjacente ao próprio esforço de criação de espaços públicos onde o poder do Estado pudesse ser compartilhado com a sociedade. Entre os espaços implementados durante esse período destacam-se os Conselhos Gestores de Políticas Públicas, instituídos por lei, e os Orçamentos Participativos, que, a partir da experiência pioneira de Porto Alegre, foram implementados em cerca de 100 cidades brasileiras, a maioria governadas por partidos de esquerda, principalmente $\mathrm{o}$ Partido dos Trabalhadores (PT)

A utilização das referências comuns: Sociedade Civil, Participação e Cidadania e Democracia, podem, segundo a autora obscurecer as diferenças quanto ao verdadeiro intuito dos dois projetos aqui analisados.

[...] a linguagem corrente, na homogeneidade de seu vocabulário, obscurece diferenças, dilui nuances e reduz antagonismos. Nesse obscurecimento se constroem subrepticiamente os canais por onde avançam as concepções neoliberais, que passam a ocupar terrenos insuspeitados. Nessa disputa, onde os deslizamentos semânticos, os deslocamentos de sentido, são as armas principais, o terreno da prática política se constitui num terreno minado, onde qualquer passo em falso nos leva ao campo adversário. (Dagnino, op. cit., p.196)

Dessa maneira, a construção de um ambiente democrático, inspirador de criação de novas instituições, tem sido atravessada pelo projeto neoliberal que impõe a política do Estado Mínimo e a consequente transferência das responsabilidades do Estado para a sociedade. Os movimentos sociais e os representantes da sociedade civil nos conselhos gestores, segundo a autora, têm o receio de acabar servindo ao um projeto que não Ihe favorece ao participarem das instâncias decisórias tidas como um equipamento de aprofundamento democrático.

Por outro lado, Dagnino (op. cit., p. 201) salientou que, no caso brasileiro, o projeto político democratizante se encontra no Brasil "[...] amadurecido desde o período de resistência da ditadura militar, fundado na ampliação da cidadania e na participação da sociedade civil." Assim, o projeto democratizante funcionaria como um freio ao projeto neoliberal, constituindo assim campo de disputa.

A existência desse contendor e dessa disputa determina, na nossa perspectiva, direções específicas às estratégias e formas de atuação das forças vinculadas ao projeto neoliberal em nosso país que, se não se afastam das direções adotadas no nível global, adquirem especificidade própria na medida em que são forçadas a estabelecer relações de sentido e um terreno de interlocução com o campo adversário. A necessidade dessa interlocução se acentua 
no interior dos espaços públicos de participação do Estado e da sociedade civil quando se defrontam face a face esses dois projetos.

Dada a importância dos espaços públicos como arena política, é essencial que ele garanta uma participação plural e a equivalência entre informação, conhecimento e poder. Longe de se ter alcançado ainda tal equivalência, a partir da Constituição de 1988 consolidaram-se instituições públicas que proporcionam a representação da sociedade civil, possibilitando o controle social e a descentralização de algumas políticas públicas setoriais. Contudo, após o impeachment conturbado e controverso da ex-presidente Dilma, a ainda embrionária experiência de participação da socieadade civil na política parece ameaçada. Para ilustrar algumas dessas instituições, citam-se aquelas destacadas por Nelson Delgado (op. cit., p. 52-56):

Conselho Nacional de Segurança Alimentar e Nutricional (CONSEA) - criado no Governo Itamar Franco, extinto pelo Governo FHC e recriado no Governo Lula - e o Conselho Nacional de Desenvolvimento Rural Sustentável (CNDRS), surgido no primeiro Governo FHC e passando a assumir a sigla CONDRAF no Governo Lula [...], além disso, que a prática das conferências nacionais, estaduais e municipais foi sendo fortalecida a partir da década de 1990, até chegar a seu auge no Governo Lula, como um instrumento indispensável de aprendizado e de mobilização em torno da construção de agendas de reivindicações da sociedade civil com vistas a influenciar a formulação e a implementação de políticas públicas setoriais (saúde,educação, meio ambiente, cidades, desenvolvimento rural etc.)

O modelo alternativo para o meio rural, considerando o projeto democratizante, tem sido focalizado nas três identidades que ganharam força ao longo dos anos 1990, os trabalhadores rurais sem terra, os agricultores familiares e os assentados. Um exemplo de conquista em resultado das lutas desses atores foi o PRONAF de 1996 e o Sistema de Previdência Social Rural a partir de 1992.

\section{A EXPANSÃO DO AGRONEGÓCIO E A QUESTÃO AGRÁRIA}

Como discute Guilherme Delgado (op. cit., p.71), as atuais condições criadas para a sustentação do agronegócio brasileiro, que associa acumulação produtiva como acumulação fundiária, não é compatível com outras perspectivas mais atuais de desenvolvimento no meio rural voltadas para os seguimentos mais frágeis como os trabalhadores rurais sem terra, a agricultura familiar e assentamentos de reforma agrária, impedindo a expulsão do dos povos do campo. A acumulação produtiva e fundiária tem sido características essenciais do agronegócio no Brasil.

A forma de captura da renda da terra se dá pela elevação do seu preço, que está, por sua, vez refletindo a elevação da renda (ou do lucro) agrícola. A elevação da renda da terra e a obtenção de ganho patrimônio pelos grandes proprietários incidem sobre a totalidade do estoque de terra produtiva que controlam. (Guilherme Delgado, Ibid.).

Embora tenha observado novas estratégias de desenvolvimento para o meio rural, como verificado no início do primeiro mandato do governo Lula, ainda há frouxidão na política fundiária brasileira, diante de sua incapacidade ou falta de vontade de fiscalizar e regular o mercado de terras. Quanto a isso, Guilherme Delgado (op. cit., p.76), considerando o aparato jurídico em torno do assunto demonstra que a legislação agrária e fiscal sobre a função social da terra no Brasil se situa no âmbito da "ficção".

No início do governo Lula, o Estado indicou retomar seu papel enquanto indutor estratégico do desenvolvimento nacional. De fato, as políticas territoriais de desenvolvimento tiveram avanços, inclusive seu significado quanto à retomada da capacidade de planejamento do Estado, ainda que não se possa afirmar a existência de "[...] uma política de atuação territorializada do Estado nacional." (Senra , 2007, apud Leite et al., p.91). O Plano Plurianual de 20042007, constituído no governo petista, demonstrava priorizar a promoção da igualdade social e espacial, chegando mesmo a organizar debate público nacional. A premissa do Programa de Desenvolvimento Sustentável dos Territórios Rurais (PDSTR), de 2003, tinha, conforme salientam Leite et al.:

[...] o objetivo geral do programa consistiu na construção e no desenvolvimento das capacidades locais para a articulação das políticas públicas e dos atores sociais em torno das principais demandas e 
potencialidades percebidas nos territórios como obstáculo ou como contribuição para seu desenvolvimento [...]. (Leite et al., 2008, p.110)

Por outro lado, a associação entre o grande capital financeiro e a grande propriedade fundiária atua na contramão de um desenvolvimento que se quer mais autônomo. Os movimentos sociais supracitados, especialmente àqueles mais ligados à esquerda política, sentiram-se traídos, de certa forma desmobilizando e até mesmo desvirtuando a luta em favor da reforma agrária. Os líderes que ora estavam em comum acordo com seus ideais, de repente pareciam comprometidos em administrar políticas macroeconômicas frente aos constrangimentos econômicos externos.

\section{OUTROS CAMINHOS PARA DESENVOLVIMENTO RURAL}

Diante do caráter concentrador de propriedade e de renda e ainda, predador e poluente do agronegócio, fica evidente a necessidade de se pensar em novos modelos de desenvolvimento rural. Guilherme Delgado (op. cit., p.81) indica que seria necessário o desmonte das seguintes condições estratégicas em que opera o agronegócio: "i) frouxidão da política fundiária; ii) restrição à expansão da demanda interna do conjunto da economia; e iii) restrição à incorporação da massa de trabalhadores do setor de subsistência ao projeto de desenvolvimento rural."

Como observa Ramos (op. cit., p.45), um novo referencial teórico e analítico tem sido utilizado estudar o heterogêneo rural brasileiro. Ele analisa a opinião de estudiosos no assunto:

[...] o Brasil possui tanto uma "agricultura patronal" como uma "agricultura familiar". Como se percebe, a primeira teve sua existência preservada e mesmo ampliada com a implementação da modernização conservadora na sociedade brasileira, vale dizer, com a adoção da via denominada por Lenin de "prussiana". O segundo tipo, que tem merecido maior atenção nos últimos anos, diz respeito a uma agricultura de pequeno e de médio porte, fundamentalmente praticada por agricultores proprietários e seus familiares. Neste segundo caso, cabe alertar para o fato de que os estudiosos afirmam haver "tipos" de agricultura familiar, ou seja, reconhecem que não existe uma única situação, especialmente em termos de sua sustentação/viabilidade econômica.

A identidade de agricultor familiar, que se tornou então o foco para políticas alternativas de desenvolvimento no campo, ganhou força na década de 1990, substituindo, segundo Nelson Delgado (op. cit., p.55), a categoria de pequeno produtor dos anos 1980. Como principais motivos para o fortalecimento dessa categoria o autor destaca:

A perda de relevância política dos assalariados rurais; (2) a maior complexidade social e política dos pequenos agricultores, tanto em termos de suas demandas e mobilizações, como de suas lideranças, que passam a ganhar maior peso no sindicalismo em todo o país, através principalmente das chamadas "oposições sindicais"; (3) a progressiva decepção com a modernização da agricultura e sua incapacidade de atender às demandas desses agricultores, bem como o surgimento de várias "questões" correlatas, como a das tecnologias alternativas, da organização produtiva, da comercialização, da agroindustrialização, do meio ambiente etc., o que acelerou a percepção em torno da necessidade de um novo modelo de desenvolvimento; e (4) a intensificação da reflexão intelectual e do debate sobre a permanência, o significado e a importância econômica e social da agricultura familiar para um desenvolvimento rural mais democrático e inclusivo, tomando principalmente como referência o conhecimento da experiência européia, que muitas assessorias e lideranças sindicais passaram a ter acesso através de intercâmbios promovidos pelas Igrejas Católica e Luterana e por ONGs.

Em continuidade e avanço às políticas para a população pobre do campo, o Programa Territórios da Cidadania (PTC), instituído em 2008, reforça a abordagem territorial e a identidade de agricultura familiar. Segundo Wanderley (2014, p.340) este é um método de ação que "favorece a articulação das políticas públicas $[\ldots]$ e $\quad$ o reconhecimento da capacidade dos atores locais de formular e expressar, com legitimidade, suas demandas.", o que a aproximaria da ideia de processo em que os atores locais são mobilizados em prol do desenvolvimento rural.

Com a ascensão do governo do ex-presidente Lula, há setores dos movimentos sociais assim como ONGs, sindicatos e acadêmicos 
passam a ter mais influência nas discussões acerca das políticas públicas voltadas para a agricultura familiar. Desta forma, neste período é adotado um enfoque territorial sobre as ações voltadas para o desenvolvimento rural com o objetivo de romper com os movimentos restritamente localizados nas prefeituras inclusive ampliando os canais de participação dos conselhos municipais para os colegiados e fóruns territoriais, envolvendo um conjunto de municípios (Caniello; Piraux; Bastos, 2013). Nesta estratégia, em 2003 é criada a Secretaria de Desenvolvimento Territorial (SDT), no âmbito do MDA. Com isso, foi lançado o Programa de Desenvolvimento Sustentável dos Territórios Rurais (PRONAT) no qual são criados os Territórios Rurais e, em 2008, no segundo Governo Lula, o Programa Territórios da Cidadania (PTC).

O PTC tem em seu objetivo expandir o acesso às políticas públicas, em especial, para as populações rurais excluídas. Em seu modelo tem como referência um modelo de gestão social. O programa em seu desenho pretende superar a pobreza e as desigualdades sociais em territórios essencialmente rurais, por meio de estratégia de desenvolvimento territorial sustentável, buscando a integração de políticas públicas, a ampliação dos mecanismos de participação social na gestão das políticas, a disponibilização dos programas básicos de cidadania, ações inclusão e integração produtiva das populações pobres e dos segmentos sociais mais vulneráveis (Benson; Allebrandt, 2014). Atualmente são 164 Territórios Rurais. E destes, 120 são Territórios da Cidadania (SIT, 2016).

Os critérios que determinam a seleção dos territórios de cidadania são: (I) menor índice de desenvolvimento humano (IDH); (II) maior concentração de agricultores familiares e assentados da reforma agrária; (III) maior concentração de populações quilombolas e indígenas; (IV) maior número de beneficiários do Programa Bolsa Família; (V) maior número de municípios com baixo dinamismo econômico; (VI) maior organização social; (VII) pelo menos um território por estado da federação (Zimmermann, 2014).

Sobre diversas análises no âmbito do das políticas para os Territórios Rurais e Territórios da Cidadania pode-se apontar algumas discussões preliminares. Para Zani e Tenório (2014) o marco normativo do PTC contempla a pluralidade dos atores, mas apresenta dificuldades na inserção de representações empresarias. Os autores apontam que esta inserção deve ser com cautela devido aos riscos possíveis por causa da assimetria de poder, no que tange recursos que possam ser disponibilizados assim como diferenças nos próprios objetivos, valores e cultura. No entanto, para a consecução das metas estabelecidas pelo o programa se faz necessário o envolvimento dos empresários locais.

Segundo Grisa (2013) as políticas voltadas para a questão fundiária têm apresentado pouca expressão. Com isso, a reforma agrária não vem sendo contemplada na política territorial, apresar de estar inserida com uma de suas ações. Precisando de investigação para o entendimento dessa limitação.

Já Maluf (2013) expõe que apesar do programa ter como intuito chegar à parte da população mais vulnerável das áreas rurais, este enfrenta dificuldades, pois muitas famílias somente são contempladas pelas políticas a partir do cadastro da Declaração de aptidão ao PRONAF (DAP). No entanto, é provável que tenha um número expressivo de famílias rurais que ficam "invisíveis" nas ações do Estado e são justamente as que mais apresentariam dificuldades.

De qualquer forma, há de se apontar que a abordagem territorial é nova nas políticas brasileiras, assim como sua institucionalidade e mesmo salientando algumas dessas limitações percebem-se ganhos para o meio rural brasileiro, pois vem possibilitando a articulação dos atores locais e a descentralização da ação pública (Zimmermann, 2014). Todavia, o governo de Temer não indica apoiar esta abordagem. Com a extinção do Ministério do Desenvolvimento Agrário, as políticas que até então estavam em vigor estão sendo pouco a pouco desestruturadas. Hoje a Secretaria de Desenvolvimento Territorial está lotada na Casa Civil como subpasta da nova Secretaria Especial de Agricultura Familiar e Desenvolvimento Agrário. Além disso, as parcerias que vinham sendo feitas junto às Universidades, intermediadas pelo $\mathrm{CNPq}$, para coordenar os nos Núcleos de Extensão em Desenvolvimento Territorial (NEDETs) estão em vias de encerramento. A equipe do Laboratório de Pesquisas em Desenvolvimento Territorial e Políticas Públicas (LPDT) da Universidade Federal Rural do Rio de Janeiro (UFRRJ), por exemplo, vinha buscado, por meio do 
referencial teórico da gestão social, explicar os fenômenos e as transformações econômicas e sociais por que têm passado o território da Baía da Ilha Grande (BIG), bem como levar à população rural, projetos de extensão ${ }^{16}$ como capacitações e construção do Plano Territorial de Desenvolvimento Rural Sustentável (PTDRS). Daí a importância, por exemplo, da continuidade dos NEDETs.

Ao tratar de formas de agricultura de base familiar, é necessário, como vinha sendo abordado nos programas territoriais, promover a inclusão produtiva, estimulando, para além da categoria sociopolítica agricultor familiar, "aos agricultores pobres, os assentados de reforma agrária, as comunidades tradicionais e os trabalhadores assalariados." (Wanderley, Ibid, p.351), a fim de consolidar o desenvolvimento do campo. Como afirma a autora, a inclusão produtiva é capaz de gerar dois efeitos positivos: de um lado permite gerar a "acumulação primitiva" necessária ao capital social das famílias rurais, por outro, promove a valorização das potencialidades locais. Este tipo de política tem o potencial de prevenir o esvaziamento do campo e a pobreza rural. Além disso, se contrapõe ao contínuo e crescente processo de concentração fundiária, em função da expansão do agronegócio, que promove efeitos perversos sobre o pequeno produtor, inclusive a pressão quanto à permanência em suas terras ou nas que trabalha. A atividade agrícola será sempre, como afirma Wanderley (op. cit., p. 342), "o esteio da vida rural, mesmo que, cada vez mais, não seja a única atividade nele exercida". As atividades não agrícolas, que se inserem no meio rural, segundo a autora, não o desqualificam como tal, "antes, alimentam-no, na medida em que enriquecem a vida das comunidades, por meio da multiplicação dos serviços de proximidade, e favorecem a interdependência entre os habitantes do campo e da cidade."

Poertanto, para Wanderley (op. cit., p.345), essa inclusão produtiva não deveria interferir no modo de funcionamento da agricultura familiar, sob a proposta de modernização. O apoio monetário, proveniente da concessão de crédito subsidiado, deveria, ao invés, proporcionar acesso ao conjunto dos recursos

\footnotetext{
${ }^{16}$ Em agosto de 2014 e em setembro de 2015 -, no âmbito do processo da ação cível colocada pela Defensoria contra a prefeitura municipal, para suspender a demolição das casas desocupadas na Indiana cujos moradores haviam acordado pelo reassentamento.
}

produtivos e aos bens e serviços necessários à manutenção de uma boa qualidade de vida e conformação de um patrimônio, a começar pela propriedade da terra.

De acordo com a lógica econômica, destinar recursos públicos a atividades com pouca produtividade significa destruir poupança. $\mathrm{O}$ dinamismo da vocação produtiva brasileira ficaria a cargo da agricultura moderna, tecnificada e mercantilizada e capitalizada, restando aos pobres rurais, as políticas sociais. Por outro lado, como afirma Maluf (2004, p.301), os caminhos escolhidos para desenvolver o país, sob os aspectos socioeconômicos, culturais, espaciais e ambientais, podem ser percebidos pela forma como se organiza a produção agroalimentar "[...] bem como determina as condições em que os alimentos são ofertados à população em termos de disponibilidade, qualidade e preço e, portanto, não devem estar limitados à lógica da eficiência econômica. Maluf (op. cit., p.300), tratando da agricultura de base familiar, considera que "os empreendimentos de pequeno e médio portes constituem componente central para uma estratégia de desenvolvimento assentada em atividades econômicas promotoras de equidade e de inclusão social, em bases sustentáveis."

A inclusão produtiva da população rural, por seu turno, pode se dar por diferentes caminhos: pela inclusão dos pobres rurais via mercado de trabalho fora da agricultura, por meio de novas políticas de modernização agrícola e pela formas familiares de agricultura, capazes de articular estratégias mais autônomas e a capacidade de inovar.

Ao incorporarem estratégias inovadoras de produção, distribuição e consumo dos produtos, a formas familiares de agricultura surgem como uma alternativa viável, porque agregariam valor simbólico ao produto ao refletirem 0 enraizamento territorial das populações rurais, como, por exemplo, os produtos: caipiras, coloniais, indígenas, de identificação geográfica, etc..

Quanto ao aspecto modernizante com especialização produtiva, Maluf (2004, passim) entende que "a agricultura familiar torna-se a vítima da receita comumente formulada para a sua redenção", devido a "armadilha da modernização", termo cunhado pelo autor. A especialização do agricultor familiar em um ou dois produtos, alterando, portanto, seu perfil diversificado de produção, pode acarretar maior "[...] vulnerabilidade 
econômica frente aos insucessos da safra, às oscilações de mercado e às rupturas dos compromissos de aquisição do produto", além dos impactos ambientais que esse tipo de cultura provoca. A não disponibilidade de recursos financeiros e expansão da oferta de alguns produtos levaram ao desaparecimento, segundo o autor, de um grande número de pequenos estabelecimentos rurais. Como estratégia, o autor propõe "[...] uma combinação de atividades desenvolvidas nas unidades familiares rurais, base para a implementação de iniciativas autônomas pelos agricultores de agregação de valor ao produto primário, em forma individual ou associativa" proporcionando a essas famílias "maior parcela do valor do produto final de consumo."

Os novos circuitos de mercados onde circulam os alimentos e produtos da agricultura familiar funcionariam como espaços de inclusão produtiva, ao mesmo tempo em que guardam relação com aspectos da segurança alimentar, redução de desperdícios e da degradação ambiental. Tais circuitos se diferenciam de acordo com a forma da agricultura. Já os pequenos produtores de alimentos orgânicos têm encontrado espaço nas feiras livres, lojas especializadas, vendas pela internet, criação de grupos de consumidores, como rede alternativa a sua inclusão. Os mercados institucionais estariam impulsionando, segundo Maluf (Ibid.), não apenas a produção agroecológica diversificada, mas também a criação de novos circuitos de mercado.

O estudo realizado pela equipe da pesquisa do qual resulta o trabalho de Cazella et al. (op. cit., p. 49-50), permitiu analisar como as quatro funções da agricultura multifuncional se manifestavam no contexto brasileiro nas regiões estudadas. A produção agrícola própria cumpre papel importante na função de reprodução socioeconômica das famílias rurais, mas a renda monetária teria contribuição secundária para seu bem-estar. Essa produção seria capaz de promover a segurança alimentar das famílias rurais, especialmente no que concerne à disponibilidade, ao acesso e à qualidade dos alimentos, mas não da sociedade. Para além da segurança alimentar, essa atividade possui o potencial de manter o tecido social e cultural das famílias rurais, pois "a agricultura continua sendo o principal fator definidor da identidade e condição de inserção das famílias rurais brasileiras." Não obstante esta forte relação identitária como o campo, os autores salientaram que há "conflitos generalizados entre o objetivo de preservação dos recursos naturais e a prática da agricultura familiar." Já a possibilidade de preservação da paisagem rural, seria um tema pouco tratado no Brasil.

Contudo, adotar o enfoque da Multifincionalidade da Agricultura Faliliar (MFA), juntamente com o de território torna necessária a elaboração de programas que equacionem as atividades agrícolas com suas demais funções, ao mesmo tempo em que possibilita um avanço nas políticas de desenvolvimento territorial ao promover a agricultura familiar. Para Wanderley (op. cit., p. 342)

Apoiar a agricultura de base familiar implica construir um mundo rural, povoado, baseado em comunidades de proprietários, cujos membros vivam no campo por livre escolha e não por falta de alternativas, e em simbiose com as pequenas cidades, com as quais formam um tecido social municipal. Isto é, sem dúvida, o oposto de uma perspectiva setorial, dominante no Brasil, que supõe a concentração fundiária, esvazia o campo de seus habitantes e gera pobreza rural.

Como salientaram Leite et al. (op. cit., p.74) as políticas territoriais buscaram "soluções inovadoras, com respeito às políticas setoriais, frente aos novos ou antigos desafios da sociedade e da economia nacional, tais como a pobreza, a desigualdade regional ou, ainda, a emergência do desenvolvimento sustentável [...]. Mas ainda precisam extrapolar o entendimento de que a pobreza e a desigualdades rurais se solucionam mediante pequenas transferências de renda ou concessão de crédito segunda as regras clássicas e a lógica econômica do sistema financeiro. O apoio monetário, segundo Wanderley (op. cit., p.345) deve considerar o indivíduo como agricultor, "[...] que se apoiado convenientemente, tem potencialidade para assegurar, em melhores condições, a sobrevivência de sua família e participar da produção da riqueza de sua comunidade local". Para isso são necessários, segue a autora, acesso à recursos produtivos e bens e serviços adequados. Cazella (2007 apud Leite et al., op. cit., p.158) aponta ainda a necessidade da criação de um sistema financeiro capaz de atender adequadamente as propostas alternativas de desenvolvimento, além do contínuo investimento em pesquisas na área de gestão do território. 


\section{CONCLUSÃO}

As políticas agrícolas dos governos, após a reabertura política brasileira, sejam dos ditos partidos de direita ou de esquerda conceberam, gradativamente, um rearranjo político. Esse rearranjo foi capaz de convergir, sob circunstâncias econômicas externas e internas, e legitimidade popular, diferentes em um mesmo cenário. Nele, passaram a conviver projetos para meio rural aparentemente incompatíveis.

Desse modo, estavam convivendo até pelo menos o fim do governo Dilma, em agosto de 2016, as políticas neoliberais e as de cunho social. Ao mesmo tempo em que se buscava atender aos interesses da elite agrária brasileira e do agronegócio, implementava-se, ainda que de forma tímida e decrescente,

\section{REFERÊNCIAS}

[1] Benson, A.; Allebrandt, S. L. Comunicação e Informação no Programa territórios da Cidadania: - caso do Território da Cidadania Noroeste Colonial. Organizações Rurais \& Agroindustriais, Lavras, v. 16, n. 2, p. 247-261, 2014. Disponível em:

<http://revista.dae.ufla.br/index.php/ora/article/view File/825/446>. Acesso em: 25 nov. 2016.

[2] Brasil. Decreto de 25 de fevereiro de 2008. Medida provisória no 1.569-9, de 11 de dezembro de 1997. Institui o Programa Territórios da Cidadania e dá outras providências. Presidência da República. Casa Civil. Subchefia para Assuntos Jurídicos. Disponível em: $<$ http://www.mds.gov.br/acesso-a-

informacao/legislacao/assistenciasocial/decretos/2 008/Decreto,20de,P2025,P20de,P20fevereiro,P20d e,P202008.pdf.pagespeed.ce.uQ6epoxsDo.pdf>. Acesso em: 15 jul. 2015.

[3] Caniello, M.; PIRAUX, M.; Bastos, V. V. de S. Identidade e participação social na gestão do programa Territórios da Cidadania: um estudo com-parativo. Estud. Soc. e Agric.,Rio de Janeiro, v. 21, n. 1, p. 84-107, 2013: 84-107. Disponível em: <http://r1.ufrrj.br/esa/V2/ojs/index.php/esa/article/vi ew/360>. Acesso em: 24 nov. 2016.

[4] Carter, M. Broken Promise: The Land Reform Debacle Under the PT Governments (Epílogo). In. Carter, M. (Ed.) Challenging Social Inequality: The Landless Rural Workers Movement and Agrarian Reform in Brazil. Durham: Duke University Press, 2015.

[5] Cazella, A. A., Bonnal, P. e Maluf, R.S. (Org.). Agricultura familiar: multifuncionalidade e desenvolvimento territorial no Brasil. R. Janeiro: Mauad X, 2009. parte das demandas suscitadas nas lutas sociais para o campo. Contudo, a convivência entre os atores envolvidos nos diferentes projetos políticos não significava passividade por parte das lutas sociais. Considerando as diferentes concepções metodologias para tratar de desenvolvimento rural, não parecia que a sociedade civil e a academia, ao interagirem e colaborarem com políticas inovadoras para o campo, estavam fortalecendo o projeto neoliberal. Estavam jogando com as regras do jogo, de modo a conquistar, passo a passo, a igualdade historicamente negada. Infelizmente, os avanços e conquistas sociais no campo, cujas bases ainda são frágeis, correm risco de retrocesso. A extinção do MDA é a expressão mais emblemática de que o atual governo federal não tem interesse em manter os projetos sociais que lhes dava apoio e suporte.

[6] Dagnino, E. Confluência perversa, deslocamentos de sentido, crise discursiva In: Grimson, A.La Cultura em lãs Crisis Lationamericanas. Buenos Aires: CLACSO, $1^{\text {a }}$ ed, 2004. Disponível em:.http://bibliotecavirtual.clacso.org.ar/ar/libros/gr upos/grim_crisis/11Confluencia.pdf>. Acesso em: 15 jul. 2015.

[7] Delgado, G. A questão agrária no Brasil, 1950-2003. Jaccoud, L.(ed.). Questão social e políticas sociais no Brasil contemporâneo. 1a.ed. Brasília: IPEA, 2005.p. 51-90.

[8] Delgado, N. G. O papel do rural no desenvolvimento nacional: da modernização conservadora dos anos 1970 ao Governo Lula. In: Delgado, N.G. (Coord.). Brasil rural em debate: coletânea de artigos. Brasília:CONDRAF/MDA, 2010.

[9] Grisa, C. Projetos estratégicos e ações para o desenvolvimento territorial: uma análise do Pronat e do programa territórios da cidadania. In: LEITE, Sérgio (org.) Políticas de desenvolvimento territorial e enfrentamento da pobreza rural no Brasil. Série Desenvolvimento Rural Sustentável. v.19, p. 149-176. Brasília: IICA, 2013. Disponível em: $\quad<$ http://www.iicabr.iica.org.br/wpcontent/uploads/2014/03/S\%C3\%A9rie-DRS-vol19.pdf. Acesso 26 nov. 2016>.

[10] Heredia, B., Palmeira, M., LEITE, S. P. Sociedade e economia do agronegócio no Brasil. Revista Brasileira de Ciências Sociais, n.74, out. 2010.

[11] Kageyama, A. et al.O novo padrão agrícola brasileiro: do complexo rural aos complexos agroindustriais IN: DELGADO, G.et al.Agricultura e Políticas Públicas. Brasília, IPEA, 1990, p 113-223. 
[12] Leite, Sérgio P. A reforma agrária como estratégia de desenvolvimento: uma abordagem a partir de Barraclough, Furtado, Hirschman e Sen. Boletim de Ciências Económicas, Coimbra, v. XLX, p. 3-38, 2007

[13] Leite, S. P. et al.Desenvolvimento territorial: articulação de políticas públicas e atores sociais. In: Miranda, C. e Tiburcio, B. (Org.). Articulação de políticas públicas e atores sociais. Brasília: IICA, 2008. p. 69-169 (Série Desenvolvimento Rural Sustentável; 8 v.)

[14] Maluf, R. S.J. Elementos para uma agenda pública de enfrentamento da pobreza e inclusão sócioprodutiva no meio rural na ótica do desenvolvimento territorial sustentável. In: LEITE, Sérgio (org.) Políticas de desenvolvimento territorial e enfrentamento da pobreza rural no Brasil. Série Desenvolvimento Rural Sustentável. v.19, p. 57-88. Brasília: IICA, 2013. Disponível em: $<$ http://www.iicabr.iica.org.br/wpcontent/uploads/2014/03/S\%C3\%A9rie-DRS-vol19.pdf>. Acesso 26 nov. 2016.

[15] Maluf, R. S. Mercados agroalimentares e a agricultura familiar no Brasil: agregação de valor, cadeias integradas e circuitos regionais. Ensaios FEE, Porto Alegre, v. 25, n. 1, p. 299-322, abri. 2004.

[16] Ramos, P. Referencial teórico e analítico sobre a agropecuária brasileira. In: Ramos, $\mathrm{P}$. (Org.). Dimensões do agronegócio brasileiro: políticas, instituições e perspectivas. Brasília: NEAD, 2007.p.18-52.
[17] Sistema de Informações Territoriais. Ministério A. Disponível em: $<$ http://sit.mda.gov.br/mapa.php?opcaomapa=TR\& modo=0 $>$. Acesso em: 28 nov. 2016.

[18] Villela L. E.; Guedes, C. A. M. ; Santana, J. S. ; BRITO, E. B. R. Crescimento Econômico versus Gestão Social e Desenvolvimento Territorial Sustentável - Análise dos Impactos de Megaempreendimentos nos Municípios de MacaéRJ e de Itaguaí-RJ. Desenvolvimento em Questão, v. 10, p. $119-145,2012$

[19] Wanderley, M. N. B. Que territórios, que agricultores, que ruralidades? In: Cavalcanti, J.S.B. et al. (Org.). Participação, território e cidadania: um olhar sobre a política de desenvolvimento territorial no Brasil. Recife: UFPE, 2014. p. 338-353.

[20] Zani, F. B.; Tenório, F. G. Gestão social do desenvolvimento: o desafio da articulação de atores sociais no Programa Territórios da Cidadania Norte-RJ. Revista O\&S, Salvador, v. 21 n. 68, p. 97-118, Janeiro/Março, 2014. Disponível em:

<https://portalseer.ufba.br/index.php/revistaoes/arti cle/view/9966>. Acesso em: 20 nov. 2016.

[21] Zimmermann, S. A. A Abordagem territorial nas políticas públicas brasileiras e a pobreza rural: um olhar a partir de estudos de casos. CAMPOTERRITÓRIO: revista de geografia agrária, Uberlândia, v.9, n.18, p. 1-23, jun., 2014. Disponível em: <http://www.seer.ufu.br/index.php/campoterritorio/a rticle/view/26893/14603>. Acesso em: 26 nov. 2016. 


\section{Capítulo 6}

\section{O VALE DO CAFÉ NO SÉCULO XXI: COMPARACẼ̃ DE INDICADORES DE DESENVOLVIMENTO RURAL SUSTENTÁVEL E OS DESAFIOS DE ESCALA GEOGRÁFICA}

\section{Gabriel Magalhães Rodrigues}

\section{Marcio Silva Borges}

Resumo: Este trabalho consiste em comparar indicadores relacionados ao desenvolvimento rural sustentável (demografia, rendimentos, produto agropecuário, alfabetização e saneamento) entre os municípios do Vale do Café fluminense, especialmente a partir dos anos 2000, para constatar quais municípios aparentam propiciar melhores condições de vida para suas populações. Além disso, serão apresentadas instituições que atuam no planejamento e gestão desses territórios rurais, e os desafios de escala geográfica para a realização de ações nesses municípios. Dessa forma, primeiramente foram brevemente apresentados conceitos relacionados ao estudo do desenvolvimento (centro-periferia, sustentável, rural). Utilizando esses conceitos como norteadores, foram apresentados e comparados dados referentes às zonas rurais dos treze municípios participantes. Ainda foram apontadas algumas instituições, os âmbitos em que atuam, a forma em que se organizam e a escala politico/geográfica compreendida por suas políticas. Merecem destaque os municípios de Piraí e Engenheiro Paulo de Frontin que possuem meios rurais dotados de rendimentos relativamente altos e das condições básicas de educação e saneamento conforme os dados analisados. Foi identificada, a respeito dos desafios institucionais, uma clara necessidade de haver maior articulação entre os agentes locais, regionais e estaduais, para o planejamento e gestão de ações coordenadas, que geram ganhos transescalares

Palavras Chave: Desenvolvimento rural sustentável; Vale do Café; Escala geográfica; 


\section{INTRODUÇÃO}

O Estado do Rio de Janeiro viveu o auge de sua atividade agropecuária entre os séculos XVIII e XIX com a cultura do café, especificamente em alguns municípios do Vale do Café. Essa região, tomando como base a divisão político administrativa nacional, é composta por treze municípios distribuídos geograficamente em duas mesorregiões: a Sul-fluminense (que abrange os municípios de Valença, Rio das Flores, Barra do Piraí, Pinheiral, Piraí, Volta Redonda, Barra Mansa) e a Metropolitana do Rio de Janeiro abrangendo Engenheiro Paulo de Frontin, Mendes, Miguel Pereira, Paracambi, Paty do Alferes, Vassouras (CEPERJ, 2011).

Com a crise do café na economia brasileira, que tem seu ápice no início do século XX, o Estado do Rio de Janeiro bem como o Vale do Café caminharam para a diversificação agrícola, abrindo caminho para transformações significativas na economia regional. No entanto, hoje o que movimenta a economia rural da região é o turismo histórico/rural, pequenas e médias fazendas com agricultura familiar ou produtores rurais, a gastronomia, a pecuária leiteira, além da monocultura do tomate em Paty do Alferes.

O objetivo deste artigo é comparar indicadores relacionados ao desenvolvimento rural sustentável, considerando os municípios da região do Vale do Café, a partir dos anos 2000. Para isso primeiramente serão apresentados de maneira sucinta, conceitos de desenvolvimento rural e sustentável e também será realizada uma breve caracterização da região incluindo a história, geografia e a realidade socioeconômica. Depois serão observados dados correspondentes ao meio rural da região em questão, que dizem respeito à demografia, rendimentos, produto agropecuário, alfabetização e saneamento, disponibilizados pelo Centro Estadual de Estatísticas, Pesquisas e Formação de Servidores Públicos do Rio de Janeiro (CEPERJ) e pelo Instituto Brasileiro de Geografia e Estatística (IBGE), e também os desafios das instituições atuantes no meio rural regional.

\section{REFERENCIAL TEÓRICO}

\subsection{AS FACETAS DO DESENVOLVIMENTO}

O processo de desenvolvimento, seja qual for a escala geográfica, envolve múltiplas perspectivas (econômica, política, social, ambiental) que estão interligadas na prática e devem ser tratadas com atenção. A desigualdade na distribuição de recursos em nível mundial faz com que os países que não detêm a produção de tecnologia (subdesenvolvidos) tenham que vender produtos dotados de uma baixa relação capital/trabalho levando a uma exploração cada vez maior desses trabalhadores, e/ou vender seus recursos naturais a preços competitivos.

Países periféricos, ou em desenvolvimento, são assim chamados por não conseguirem distribuir seus recursos de forma eficiente e equitativa de maneira a ofertar saúde, educação, trabalho, lazer e, de uma maneira geral, qualidade de vida para a maioria da sua população. Essa incapacidade advém principalmente de razões históricas inerentes a cada território, mas também da própria estrutura capitalista, tornando-os praticamente dependentes das economias desenvolvidas ou centrais (Furtado, 1974).

A incapacidade de alcançar o desenvolvimento advém ainda de uma má formação institucional que dificulta a fluidez das relações políticas, econômicas e sociais ou que privilegiam mais interesses particulares ou setoriais do que coletivos em suas atribuições. A relação centro-periferia também pode ser notada em outras escalas espaciais, por exemplo, entre regiões, estados e até mesmo municípios, todavia sem deixar de perceber a relação dessas escalas micro com as macro escalas. Furtado (1974) afirma que a maioria absoluta da população dos países menos desenvolvidos não se apropria dos ganhos advindos do crescimento econômico, e além do mais a industrialização (no modelo do pósguerra/centro-periferia) não proporciona a melhoria dessa situação, trazendo uma modernização, mas não o desenvolvimento.

Para Furtado (1974), outro empecilho aos menos desenvolvidos, ou em desenvolvimento, é um fator de ordem física, ou seja, os padrões de produção e consumo dos países "desenvolvidos" não são condizentes com a disponibilidade de recursos naturais da Terra. Mesmo que as ideias do autor tenham sido expostas na década de 1970, esses argumentos ainda são, em partes, válidos; Como aponta Padilha (2003) o primeiro e mais importante limite dessa cultura do consumo, que estamos testemunhando hoje, são os próprios limites ambientais. O planeta não suportaria se cada 
habitante tivesse um automóvel, por exemplo. Uma ressalva a se fazer é que avanços tecnológicos podem possibilitar o aumento do nível de produção e consumo sem necessariamente aumentar o nível de degradação ambiental, todavia necessitam de grandes montantes de investimento, muitas vezes restritos.

Essa concepção se aproxima das ideias básicas trazidas nas teorias de desenvolvimento sustentável, termo controverso que passou e ainda passa por embates políticos e ideológicos. Em geral o desenvolvimento sustentável traz consigo a ideia de desenvolvimento econômico com proteção ambiental e equidade social. É necessário ter em mente que a sustentabilidade é um processo sem regras fixas, ou seja, diferente em cada situação, relacionado ao planejamento do espaço, da economia e da demografia. Ser sustentável é reduzir vulnerabilidades, resíduos (o que se faz além do necessário) e avaliar riscos e impactos, sem necessariamente mercantilizar a natureza.

Acselrad (1999) aponta algumas questões diretamente ligadas à noção de sustentabilidade: eficiência, escala, equidade, autossuficiência e ética. A questão da eficiência está ligada ao não desperdício da base material do desenvolvimento (espaço não-mercantil planetário, ou meio ambiente), ao passo que a escala seria um determinante de limites quantitativos para o crescimento econômico dadas as pressões ambientais. A equidade diz respeito à justiça e igualdade no processo de desenvolvimento, já a autossuficiência é apontada como estratégia adequada para a regulação comunitária das condições para o desenvolvimento, e por fim a ética estaria ligada à existência de recursos para a continuidade da vida planetária.

A perspectiva do desenvolvimento sustentável deve levar em conta espaços urbanos e rurais, uma vez que cada um desses espaços possuem suas particularidades e por isso devem ser tratados de maneira diferente. $\mathrm{Na}$ atualidade é difícil mensurar os limites do urbano e do rural, uma vez que eles se mostram complementares e indissociáveis, devido aos meios de transporte, comunicação e à integração produtiva e social de uma maneira geral. Hoje o urbano já conta com atividades agrícolas, o rural com atividades industriais, e a urbanização chega a todos os lugares, mesmo que seja de maneira virtual (rádio, televisão, celular, internet, computador) (Floriani, Rios e Floriani, 2013).

Atualmente ainda existem muitas maneiras de entender o termo desenvolvimento rural, que podem levar em conta diversos aspectos do ambiente, tais como um maior nível de bem estar social, produto e renda; diversidade de atividades econômicas; maior tecnificação; preservação do ecossistema e da agrobiodiversidade; permanência da população no campo; distribuição e uso de terras; educação rural, etc. O desenvolvimento rural também pode estar relacionado às atitudes e práxis direcionadas à redução da pobreza nesses territórios, buscando, na perspectiva da gestão social, estimular a participação dos habitantes para que eles decidam as prioridades para a mudança (Ellis, 2001).

Kageyama (2004) realizou uma revisão bibliográfica sobre o tema do desenvolvimento rural e concluiu que dentre as diversas definições apresentadas para o termo, uma ideia comum a todas era a de que o desenvolvimento rural deve levar em consideração o aspecto econômico estabilidade e elevação da renda familiar - e social - obtenção de um nível de vida socialmente aceitável - buscando a diversificação das atividades geradoras de renda em uma dada base territorial, local ou regional.

O desenvolvimento do meio rural também passa pelas questões agrícolas (produção agropecuária), agrárias (regulação e distribuição de terras), territoriais (participação popular, cultura e identidade, arranjos produtivos locais), ambientais (conservação e preservação), e sociais (previdência, benefícios, habitação, povoamento, saneamento). Alguns elementos podem ser considerados chave na atual discussão do desenvolvimento rural como os mercados abertos, intensificadores da competitividade, as cadeias agroalimentares, mas também uma diversidade de iniciativas alternativas ao padrão técnico dominante. A complementaridade setorial, a mudança no papel do poder público e das instituições que atuam no mundo rural e a ênfase nas dimensões ambientais e sustentáveis também são aspectos relevantes para o debate do desenvolvimento rural (Schneider, 2004).

Fica claro que os termos desenvolvimento sustentável e rural apresentam entre si muitas semelhanças, com destaque para os 
aspectos sociais e ambientais. Ambos apontam para uma gestão do território baseada na participação popular, respeitando o equilíbrio e a diversidade, e objetivando a equidade na distribuição dos recursos entre as populações. O termo desenvolvimento rural trata de forma mais incisiva algumas particularidades da maioria dos espaços rurais, tais como menor densidade demográfica e concentração da população, menor complexidade social (menor diversidade política e cultural) e maior integração social (vínculos fortes). Entretanto é necessário estar atento à atual dinâmica dos espaços rurais que contam com muitos produtores residentes em espaços urbanos densamente povoados, que se vinculam facilmente a estas áreas e contribuem para trazer novas características ao rural.

O entendimento destas facetas do desenvolvimento facilita a análise dos territórios, uma vez que elas apontam as condições básicas para a melhoria da qualidade de vida da população fazendo um uso justo e consciente dos recursos naturais.

\section{METODOLOGIA}

Caracterizado como pesquisa exploratória, este trabalho apresenta as características das zonas rurais dos treze municípios do Vale do Café com a finalidade de concluir quais demonstram um meio rural mais desenvolvido. Como suporte teórico inicial foram apresentados conceitos pertinentes ao campo do desenvolvimento, necessários para o entendimento das questões relacionadas ao desenvolvimento rural e ao desenvolvimento sustentável.

Em seguida são apresentados dados socioeconômicos referentes ao meio rural da região do Vale do Café, no Estado do Rio de Janeiro, tais como, população urbana e rural, densidade demográfica, rendimentos urbanos e rurais, adequação das instalações sanitárias e alfabetização, extraídos do Censo Demográfico de 2000 e 2010 do IBGE. O produto agropecuário por município no ano de 2013 foi obtido no portal do CEPERJ. Esses dados serão analisados e comparados à luz dos conceitos apresentados no referencial teórico.
Por meio da comparação serão apontados, entre os treze municípios analisados, aqueles que praticam um desenvolvimento rural sustentável. Por fim, serão explicitadas algumas instituições que colaboram para o desenvolvimento rural sustentável da região, mostrando em qual âmbito elas atuam, a maneira em que se organizam, as escalas politico/geográficas compreendidas por suas políticas e os desafios para a implementação de ações coordenadas.

\subsection{HISTÓRIA, GEOGRAFIA E REALIDADE SOCIOECONÔMICA DO VALE DO CAFÉ}

O Vale do Café fluminense está localizado em um país em desenvolvimento, ou semiperiférico considerando a economia mundial, mas em uma região central considerando a economia nacional. Os treze municípios analisados, em destaque na Figura 1, foram delimitados com base em uma divisão sugerida pela Secretaria de Turismo do Estado do Rio de Janeiro. A delimitação geográfica do Vale do Café é tangenciada à sudoeste pela BR-116 (Rodovia Presidente Dutra) e cortada pela BR-393 (Antiga RioBahia), duas importante vias de escoamento e entrada de produtos e serviços diversos. Seus municípios, situados mais ao sul, fazem parte da bacia hidrográfica do Rio Guandu, e os demais, da bacia do Rio Paraíba do Sul, que atravessa a região.

Originalmente a região do Vale do Café é composta pelo bioma da Mata Atlântica. Abreu (2012) afirma que ela foi habitada por índios Puris e que durante o século XVIII a região fez parte do caminho do ouro para escoar a produção proveniente do Estado de Minas Gerais. Já no século XIX a região tem seu apogeu com as plantações de café, principal produto exportado pelo Brasil entre os séculos XIX e XX. Os barões do café e as fazendas precursoras trouxeram riquezas que proporcionam o surgimento de núcleos urbanos. Em 1820 Paty do Alferes se torna vila, mas o desenvolvimento se manifestou acentuadamente em Vassouras, que atraia fazendeiros vindos de São João Del Rey e Mariana, por exemplo. 
Figura 1- Mapa do Estado do Rio de Janeiro, divisão Secretaria de Turismo, Região do Vale do Café.



Fonte: Portal Rio Turismo, editado pelo autor, 2016.

A importância do período ferroviário no desenvolvimento da região pode ser verificada pela dinamização promovida no município de Miguel Pereira, predominantemente ocupado por trabalhadores da Rede Ferroviária Nacional, assim como pelo Engenheiro Paulo de Frontin, um dos construtores das estradas férreas no Brasil, que dá nome a um dos municípios do Vale. Hoje as ferrovias estão desativadas ou são utilizadas para transporte logístico de carga e passeios turísticos.

O manejo não sustentável da produção cafeeira levou à exaustão dos solos do Vale do Café, provocando a transferência dessa cultura no sentido do Vale do Paraíba Paulista. Além disso, a crise de superprodução da cafeicultura brasileira do século XX traria consigo, de acordo com Furtado (2009), algumas medidas, sendo uma delas a retenção dos estoques esperando a revalorização do produto. Mendonça (2008) argumenta que no caso do Estado do Rio de Janeiro, diante dos baixos níveis de produtividade, produção e exportação, foi a diversificação agrícola que representou uma reação à crise cafeeira regional, aproveitando fatores de produção subtilizados e abrindo caminho para transformações significativas na economia regional, voltando-se para o mercado doméstico. Houve também muita produção de cana de açúcar, ficando a cachaça, a rapadura e o açúcar mascavo como um elemento da cultura local.
Quanto ao Produto Interno Bruto (PIB) da região, o PIB de Volta Redonda atingiu quase nove milhões de reais em 2013, seguido por Barra Mansa com $\mathrm{R} \$ 4,4$ milhões ou praticamente a metade, Barra do Piraí com $\mathrm{R} \$ 1,5$ milhão e Piraí com $\mathrm{R} \$ 1,1$ milhão. Essa alta produção advém principalmente do setor de serviços e industrial/siderúrgico, e está relacionado à proximidade desses municípios à rodovia Presidente Dutra. A Companhia Siderúrgica Nacional (CSN), constituída como um grande investimento público com recursos do governo federal no ano de 1941, atuou como uma instituição polarizadora de renda e emprego no município de Volta Redonda, além do mais a expansão urbano/industrial da territorialmente pequena Volta Redonda chegou a Barra Mansa (CEPERJ, 2013).

Os menores PIB's estão em Rio das Flores (R\$ 156,5 mil), Engenheiro Paulo de Frontin $(\mathrm{R} \$ 173,5$ mil) e Mendes ( $R \$ 216,5 \mathrm{mil})$, comparativamente municípios com baixa atividade econômica, mais voltada para a agricultura e serviços. Vale ressaltar que nos municípios com menor PIB total o setor da administração pública exerce importante papel na economia (CEPERJ, 2013). A próxima subseção aborda mais especificamente as características do meio rural dos municípios abrangidos pelo Vale do Café, observando dados que representam a demografia, participação agropecuária no produto, rendimentos, educação e saúde. 


\section{O MEIO RURAL DO VALE DO CAFÉ}

\subsection{CARACTERÍSTICAS DEMOGRÁFICAS, ECONÔMICAS, SOCIAIS E AMBIENTAIS}

O meio rural dos municípios do Vale do Café pode parecer insignificante num primeiro olhar, mas é incontestável a necessidade de analisa-lo de modo aprofundado para favorecer a construção de medidas promotoras de desenvolvimento, uma vez que o meio rural é habitado, produz, está diretamente relacionado a questões ambientais e suas populações demandam educação e saúde de qualidade, como será demonstrado adiante.

Observando a população total dos treze municípios é possível observar que a maior concentração populacional ocorre nas zonas urbanas dos três municípios, que apresentam como visto os maiores PIB's: Volta Redonda, Barra Mansa e Barra do Piraí. Entretanto, muitos municípios da região preservam meios rurais vivos e ativos. Segundo dados do Censo Demográfico do IBGE (2010), a população rural tem uma participação significativa na população total nos municípios de Vassouras (33\%), Paty do Alferes (30\%), Rio das Flores (30\%), Engenheiro Paulo de Frontin (28\%), e Piraí (20\%).

Apesar do município de Valença possuir somente $14 \%$ de seus habitantes na zona rural, ele possui a segunda maior população rural da região estudada (9619 habitantes), ficando atrás somente de Vassouras (11211 habitantes). Paty do Alferes possui a terceira maior população rural dentre os municípios do Vale do Café. As menores populações rurais estão em Volta Redonda, Barra Mansa, Barra do Piraí e Mendes, todos eles com menos de 5\% da população total (IBGE, 2010) .

Entre os anos de 2000 e 2010 Paracambi foi o município do Vale do Café que atraiu, proporcionalmente, o maior número de pessoas para a zona rural, seguido por Piraí. Os municípios são vizinhos, ambos cortados pela BR 116 e com rendimentos rurais relativamente altos, como será mostrado adiante. Outros municípios que tiveram aumentos na sua população rural entre esses anos foram Pinheiral, Rio das Flores, Engenheiro Paulo de Frontin, Mendes, Volta Redonda e Valença (IBGE, 2000; IBGE, 2010).

Todos os demais municípios apresentaram redução de suas populações rurais, destacando-se Vassouras, Paty do Alferes e Miguel Pereira. Uma variação percentual positiva da população rural entre 2000 e 2010, possivelmente, é reflexo das melhorias na qualidade de vida dos espaços rurais desses municípios, que atraíram população principalmente com infraestrutura (estradas, meios de comunicação, saneamento) educação, e melhores rendimentos (IBGE, 2000; IBGE, 2010).

No que diz respeito à densidade demográfica Rio das Flores apresenta o menor valor (18 hab. $\left./ \mathrm{km}^{2}\right)$, ao passo que o município de Volta Redonda (1413 hab. $/ \mathrm{km}^{2}$ ) concentra uma grande população urbana em uma pequena área, população esta que possivelmente se espraiou para Barra Mansa (325 hab./km²), provocando pressões de escala e deixando poucas alternativas ao desenvolvimento rural, fato que pode ser explicado por fatores históricos como a implantação da CSN em 1941 (IBGE, 2010).

Outros municípios que apresentam, relativamente, baixa densidade demográfica são Piraí (52 hab./km²), Valença (55 hab./km²), Vassouras (64 hab./km²), Paty do Alferes (83 hab. $/ \mathrm{km}^{2}$ ), Miguel Pereira (85 hab. $/ \mathrm{km}^{2}$ ) e Engenheiro Paulo de Frontin (100 hab./km²), todos eles municípios com características bastante rurais. Nota-se que a baixa densidade demográfica atribuída aos municípios de Piraí e Valença, principalmente, tem relação com a grande extensão territorial destes. (IBGE, 2010).

Esses dados demográficos estão relacionados ao desenvolvimento rural sustentável, uma vez que podem revelar ineficiências na distribuição da população, problemas de escala relacionados às pressões ambientais advindas das aglomerações urbanas não planejadas, subordinação do espaço rural ao urbano e não preocupação com as questões ambientais e de qualidade de vida para gerações futuras.

Quanto aos dados econômicos, a agropecuária apesar de representar pouco para o produto da região como um todo (revelando ineficiências na alocação dos meios de produção regionais e dependência a outros mercados), tem os maiores valores monetários nos municípios de Barra Mansa (principalmente devido à pecuária leiteira), Valença, Paty do Alferes (principalmente devido à cultura do tomate, que é majoritariamente escoada para a região metropolitana do Rio de Janeiro) e Vassouras. $A$ atividade agropecuária representa cerca de 
$10 \%$ do produto de Paty de Alferes e $7 \%$ do PIB de Rio das Flores, $4 \%$ do PIB de Vassouras e $3 \%$ do PIB de Valença (CEPERJ, 2013).

De acordo com Mattos e Sant'ana (2010) $60 \%$ das fazendas históricas da região têm produção própria de alimentos e comercializam esses produtos (doces, queijos, conservas e café) nos mercados locais e regional. Apesar disso, grande parte das populações rurais do Vale do Café ainda aproveita pouco esse potencial, devido à dificuldade de comunicação/transporte e comercialização dos produtos, bem como pela dificuldade de se adequar às normatizações sanitárias, entre outras restrições.

Passando à análise da diferença entre os rendimentos medianos mensais rurais e urbanos (rendimentos do trabalho e outras fontes que uma pessoa de dez anos ou mais recebeu no período de um mês), disponibilizados no Censo Demográfico do IBGE (2010), os municípios que apresentaram os maiores rendimentos rurais foram Engenheiro Paulo de Frontin, Piraí, Rio das Flores e Pinheiral com R $\$ 1020,00 /$ pessoa e Vassouras, Valença, Barra do Piraí e Paracambi com $\mathrm{R} \$ 1000,00 /$ pessoa. Em todos os 13 municípios o rendimento mediano mensal urbano supera o rural, exceto no município de Engenheiro Paulo de Frontin em que são iguais.

O curioso é que Paty do Alferes apesar de possuir um produto agropecuário significativo e 30\% de sua população rural (uma das maiores da região analisada), possui um rendimento mediano mensal rural proporcionalmente baixo ( $\mathrm{R} \$ 800,00 /$ pessoa), o que indica condições ruins de distribuição de renda. Os rendimentos rurais mais baixos são encontrados em Mendes (R\$ 650,00/pessoa) e Volta Redonda ( $R \$ 734,00 /$ pessoa), cidades que também possuem baixas populações rurais. Quando se trata dos rendimentos, a sustentabilidade pode ser analisada pelo aspecto da equidade, tanto observando as diferenças entre rendimentos rurais e urbanos em cada município, quanto observando a diferença dos rendimentos rurais entre os diversos municípios que compõe a região. Maiores disparidades entre os rendimentos, e/ou menores rendimentos são características que apontam para um desenvolvimento desigual e desequilibrado.
A respeito da educação nas áreas rurais dos municípios do Vale do Café, dentre os municípios que possuem significativas populações rurais, Engenheiro Paulo de Frontin possui quase $90 \%$ de sua população rural alfabetizada e Piraí próximo de $85 \%$. Vassouras e Rio das Flores têm $80 \%$ de sua população rural alfabetizada, ao passo que Paty do Alferes tem apenas $75 \%$. Valença, que apesar de não ter grande percentual de sua população na zona rural possui o segundo maior numero de habitantes rurais da região, assim como Vassouras tem cerca de $80 \%$ de sua população alfabetizada. Um estudo mais aprofundado deve levar em conta - grau de escolaridade dessas populações rurais, no entanto os dados anteriormente explicitados fornecem uma imagem preliminar sobre as condições educacionais nas zonas rurais dos municípios abordados (IBGE, 2010).

Quanto às instalações sanitárias dos domicílios rurais desses municípios, Engenheiro Paulo de Frontin conta com quase 99\% dos domicílios com instalações sanitárias adequadas ou semi-adequadas. Pinheiral e Vassouras também tem elevada parcela dos domicílios rurais com instalações sanitárias adequadas ou semi-adequadas (cerca de 95\%) e Miguel Pereira e Mendes têm quase 90\% dos domicílios rurais também nessas condições sanitárias. Os números mais preocupantes são os de Valença e de Paty do Alferes, que apresentam apenas $70 \%$ de seus domicílios rurais com instalações sanitárias em condições adequadas ou semiadequadas (IBGE, 2010).

Para tornar mais clara a discussão, instalações sanitárias são consideradas adequadas quando os domicílios contam com dutos ligados à rede-geral ou fossa séptica, abastecidos com água proveniente de rede geral e com destino do lixo coletado diretamente ou indiretamente pelos serviços de limpeza; Nas instalações semi-adequadas os domicílios possuem, pelo menos, um dos serviços de abastecimento de água, esgoto ou lixo classificados como adequado; Já nas instalações sanitárias inadequadas os domicílios possuem escoadouro ligados à fossa rudimentar, vala, rio, lago ou mar e outro escoadouro; servidos de água proveniente de poço ou nascente ou outra forma com destino de lixo queimado ou enterrado, ou jogado em terreno baldio. A falta de instalações sanitárias adequadas é diretamente 
responsável pelo aumento da incidência de esquistossomose, amarelão e teníase, doenças que afetam a saúde e consequentemente o orçamento das famílias rurais carentes de infraestrutura.

Os dados relativos à alfabetização e às instalações sanitárias dos habitantes e domicílios rurais, respectivamente, se relacionam também a questão da equidade, por revelarem condições preocupantes em alguns municípios, mas, sobretudo estes dados estão relacionados à questão ética, por demonstrarem que muitos municípios, em pleno século XXI, ainda possuem mais de $20 \%$ de sua população rural analfabeta e vivendo em domicílios com instalações sanitárias inadequadas, estimulando assim o esvaziamento do espaço rural e a desterritorialização ou (re)territorialização (Haesbaert, 2013).

Para que seja possível notar melhorias nesses indicadores, é necessário criar condições e referências para que os mecanismos de mercado e sociais possam atuar de maneira mais eficiente, possibilitando as liberdades de escolha individuais por meio, pelo menos do suprimento das necessidades básicas de reprodução da vida. A ação individual dos agentes tem se mostrado ineficiente para a promoção de melhorias na renda, na educação, na saúde e no bem estar coletivo. Daí a importância do Estado atuar como mecanismo promotor e coordenador de esforços, bem como regulador de práticas, podendo ser representado por meio de instituições que atuam em diferentes escalas territoriais.

Essas instituições devem buscar diagnosticar o meio rural dos territórios em que atuam (como proposto nesta pesquisa, por exemplo) para realizarem o planejamento de ações promotoras de desenvolvimento. Tanto o planejamento quanto a execução dessas ações também deve levar em conta as múltiplas escalas de atuação das instituições e as relações entre os diversos entes federativos representados por cada uma delas, uma vez que as questões abordadas são de interesse intra e interestadual.

A próxima subseção trata de citar e contextualizar algumas instituições públicas ou de interesse público presentes na região, que buscam estimular o desenvolvimento rural sustentável nos campos da hidrografia, turismo e gastronomia, agricultura orgânica e agroecologia, todos elas, mais ou menos, legitimados pela participação social.

\subsection{INSTITUIÇÕES E O DESAFIO DAS ESCALAS TERRITORIAIS}

Para se pensar no desenvolvimento rural sustentável, como já dito, é preciso levar em conta os fatores ambientais, econômicos, sociais e culturais, e ainda como esses fatores interagem com a politica e a sociedade. Por exemplo, a questão da delimitação de territórios em diferentes escalas geográficas para a implementação de políticas públicas, os agentes gestores dessas políticas, e o planejamento coordenado entre esses gestores, são assuntos que devem ser tratados com atenção. Atualmente, não apenas no Vale do Café, mas no Brasil e no mundo, os formuladores e gestores de políticas públicas são agentes individuais ou representantes de instituições que atuam em diferentes áreas e escalas geográficas (local, municipal, regional, estadual, interestadual, nacional...).

A respeito dessas instituições, North (1981) afirma que podem ser interpretadas como organizações físicas (escolares, de saúde, políticas) que definem e executam as regras de certo jogo, ou as próprias regras (legislação), determinando 0 que os jogadores podem e não podem fazer. Essas instituições devem conduzir a uma organização eficiente da sociedade, levando em conta fatores como o contexto histórico e a busca por bem estar social.

Uma iniciativa de nível estadual, relativa à extinta Secretaria de Agricultura em parceria com uma organização multilateral, que realiza ações coordenadas por meio de algumas instituições em diversos municípios da região estudada é o Programa Rio Rural. Este programa criado em 2005 pretende promover o desenvolvimento rural sustentável em micro bacias hidrográficas, por meio da gestão democrática e transparente; da inclusão e participação social dos agentes rurais, principalmente agricultores familiares e pequenos agricultores, mulheres e jovens rurais; e da sustentabilidade financeira das ações. Diversas entidades estão em conjunto para realizar o planejamento, execução e avaliação dessas propostas, dentre elas a Embrapa, a Emater, e os Conselhos Municipais de Desenvolvimento Rural Sustentável (CMDRS), por exemplo. 
Iniciativas como o CMDRS podem colocar prefeitos, secretários de agricultura e meio ambiente, vereadores, representantes de instituições de apoio e fomento, agricultores e moradores das zonas urbana e rural para dialogar sobre questões relevantes para a melhoria da qualidade de vida não só dos moradores da zona rural. Apesar da importância desses conselhos, muitas vezes eles não atuam alinhados aos conselhos dos municípios vizinhos, que possuem experiências e demandas comuns.

O Vale do Café, que já foi o maior produtor mundial do grão, ainda conta com um vasto patrimônio (histórico e cultural) deixado por aquele período. No ano de 1994 foi fundado o Instituto Preservale, como forma de unir fazendeiros, pesquisadores, ambientalistas, arquitetos, agentes de viagem e historiadores preocupados com o patrimônio pertencente ao Vale do Café. Abarcando os 13 municípios estudados, o Conselho Regional de Turismo do Vale do Ciclo do Café (CONCICLO) objetiva integrar Estado e sociedade para executar ações de desenvolvimento regional sob o motor do turismo, cultura e fortalecimento da identidade. O CONCICLO em especial, por realizar ações nos mesmos municípios delimitados por esta pesquisa (que apresentam uma diversidade de conexões internas e externas) é uma instituição fundamental ao desenvolvimento rural do Vale do Café, pois pode servir como um nó na rede de formuladores de políticas públicas. Além do mais, instituições como estas são importantes na promoção do desenvolvimento rural sustentável, uma vez que estão relacionadas a questões éticas (preservação de memórias) e de autossuficiência econômica para a região, buscando pautar suas ações na participação social.

Para se pensar em desenvolvimento sustentável é necessário também levar em conta os recursos hídricos e sua influência em diferentes populações. A água é um recurso de extrema importância nos meios rurais (e urbanos), uma vez que, em condições adequadas, proporciona a irrigação de lavouras e a produção, o abastecimento dos domicílios e a pesca. A preservação de matas ciliares e nascentes, juntamente com uma diversidade de medidas que visam a sustentabilidade ambiental, proporcionam água em abundância que é sinônimo de resiliência e autossuficiência frente a crises de abastecimento e até mesmo crises energéticas.

No que diz respeito à hidrografia, alguns municípios do Vale do Café fazem parte do Comitê Guandu, que desenvolve projetos de acordo com planos de aplicação plurianuais, voltados para conservação e recuperação dos recursos hídricos. Esse comitê existe desde 2002 e possui uma diretoria colegiada que conta com representantes dos segmentos público e privado. Já outros municípios inseridos na bacia do Paraíba do Sul se articulam principalmente por meio do Comitê de Integração da Bacia Hidrográfica do Rio Paraíba do Sul (CEIVAP), que foi criado em 1996. Este é também um espaço democrático que mescla poder público e privado para debater questões relacionadas ao uso das águas da bacia. Uma particularidade da bacia do Paraíba do Sul é que ela contempla tanto municípios do Estado do Rio de Janeiro quanto do Estado de São Paulo, o que significa maiores dificuldades para tratar de questões indiretamente relacionadas à hidrografia, mas ao mesmo tempo potencialidade de reunir esforços interestaduais para uma questão de interesse comum (CEIVAP, 2016).

Todas estas instituições são promotoras do desenvolvimento, quando buscam realizar suas ações de forma socialmente planejada, sem desperdício de recursos, colaborando para a dinamização das economias em que atuam para alcançar maior autossuficiência e equidade social. Considerando o desenvolvimento rural regional, nota-se a necessidade da melhoria da qualidade das ações governamentais, atuando de fato em conjunto com a sociedade para 0 planejamento do território, ações essas que precisam ser realizadas de maneira coordenada entre as diferentes instituições que atuam em diferentes âmbitos e escalas geográficas, mas que visam melhorias para os mesmos municípios.

As questões ambientais, econômicas, políticas e sociais, na prática, estão entrelaçadas e dessa forma necessitam de políticas públicas que contemplem todas elas em suas respectivas escalas, sem ignorar que estas escalas estão interconectadas. Por exemplo, nessa mesma região existem instituições atuando em escalas físicas (bacias hidrográficas), territoriais (Vale do Café), político administrativas (municipio e estado), etc. Em outras palavras, é necessário, como afirma Brandão (2004), 
romper com a endogenia exagerada local, e reconhecer a complexidade político/social, e a existência de uma coesão orgânica extra localizada (correlação de forças hegemônicas, posta em determinado tempoespaço), sendo que constranger as principais cláusulas desse pacto é tarefa que pode e deve ser travada no local, nos espaços regionais, em âmbito nacional e até internacional.

É importante enfatizar que um grande desafio para a adoção de políticas públicas para o desenvolvimento rural da região estudada é que o Vale do Café não se constitui como uma mesorregião e nem como região de planejamento ou de governo, o que dificulta ações regionais por parte do governo do Estado do Rio de Janeiro. Todavia todas as instituições apresentadas anteriormente atuam nos municípios da região e possuem a capacidade de realizar esforços coletivos para tornar efetivas ações regionalizadas o que seria muito positivo para a promoção do desenvolvimento rural sustentável da região, uma vez que os municípios estabelecem uma diversidade de vínculos (estradas, rios, redes de comunicação e comércio, instituições comuns)... Uma dificuldade para tornar concreta essa governança é a postura competitiva e individualista adotada pelos representantes de algumas instituições (prefeituras, conselhos) e outros agentes que não dão a devida importância a estas questões trans escalares.

\section{CONSIDERAÇÕES FINAIS}

Conforme dito, os conceitos de desenvolvimento rural e desenvolvimento sustentável apresentam muitos pontos em comum, levando em conta aspectos ambientais, econômicos, sociais e políticos, que na prática se misturam e implicam em um processo dialético. Por exemplo, o município de Volta Redonda apesar de possuir uma posição econômica e politica central, sediando a CSN e um polo comercial, e ainda com acesso à via Dutra, possui uma inexpressiva população rural, e uma grande população urbana prejudicada pelos altos níveis de poluição do ar e da água e pela dependência de alimentos vindos de outros mercados externos ao município.

Tomando como base os dados e as informações apresentadas, e relacionando-os aos conceitos utilizados como fundamentação teórica é possível notar que dentre os municípios do Vale do Café, os que se destacam por apresentarem um meio rural habitado, que dispõe de rendimentos mais dignos, saneamento e educação são Piraí, Engenheiro Paulo de Frontin, Vassouras, Rio das Flores, Valença, Paty do Alferes, Paracambi, Miguel Pereira e Pinheiral, nessa ordem.

Piraí merece destaque, município de baixa densidade demográfica, e que possui a quarta maior população rural da região, tem boa parte dessa população alfabetizada, e ainda demonstrou atrair pessoas para seu meio rural entre os anos de 2000 e 2010. Além disso, apresenta números favoráveis ao desenvolvimento rural no que diz respeito aos rendimentos, ao saneamento e à produção agrícola, considerando que o setor agropecuário não é tão expressivo no produto da região.

Engenheiro Paulo de Frontin apresenta os melhores valores quando se observa os dados relacionados à educação, saneamento e rendimentos. Esse município também atraiu pessoas para seu meio rural entre os anos de 2000 e 2010. Apesar das atividades agrícolas não representarem muito no produto municipal, os dados levam a crer que este município tem melhorado a qualidade de vida de suas populações rurais, o que reforça a ideia da diversidade produtiva do "novo rural". Todavia, o potencial turístico e agrícola do município é pouco explorado, uma vez que este conta com algumas cachoeiras aptas para banho, e tem terras propícias para o cultivo de banana, mamão, manga e jaca, o que poderia impulsionar a gastronomia e o comércio local (geleias, bolos, doces, receitas diversas).

O município de Vassouras possui a maior população rural, em termos absolutos, e também o maior percentual de população rural, dentre todos os 13 municípios em questão. A respeito da educação e do saneamento Vassouras também está entre os três melhores desempenhos, quando se observa os dados anteriormente mostrados. Fato curioso é que entre os anos de 2000 e 2010 esse mesmo município demonstrou uma grande queda de sua população rural, indicando que nesses anos o meio rural desse município se tornou menos atrativo, talvez impulsionado pelos baixos rendimentos ou pelo declínio da atividade turística.

Merece destaque também o município de Rio das Flores, que apesar de não possuir 
elevado contingente populacional, possui o segundo maior percentual de população rural. Esse município que possui a menor densidade demográfica da região, tem rendimentos rurais mais elevados do que os de Vassouras, e apresentou também uma elevação na sua população rural entre os anos de 2000 e 2010.

Paty do Alferes é também um município com características interessantes. Possui a terceira maior população rural em termos absolutos e o terceiro maior percentual de participação rural frente à população total. Seu produto agropecuário é o terceiro maior da região, (menor que Barra Mansa e Valença) advindo principalmente da produção de tomate. Apesar das primeiras informações serem positivas, os dados referentes à educação, saneamento e rendimentos não parecem ser muito favoráveis, o que pode indicar má distribuição de renda. Um reflexo desses dados negativos é a diminuiu da população rural entre os anos 2000 e 2010.

Por fim, o município de Valença também será destacado, este que possui a segunda maior população rural (atrás da vizinha Vassouras), tem também a segunda maior produção agropecuária dentre os municípios da região, no ano analisado. O nível de alfabetização e os rendimentos rurais são razoáveis, no entanto o saneamento parece deixar a

\section{REFERÊNCIAS}

[1] Abreu, Regina. Colecionando museus como ruínas: percursos e experiências de memória no contexto de ações patrimoniais. Rio de Janeiro, Unirio, 2012.

[2] Acselrad, Henri e Leroy, Jean P. Novas premissas da sustentabilidade democrática. Revista Brasileira de Estudos Urbanos e Regionais, 1, 1999.

[3] Brandão, Carlos. O processo de subdesenvolvimento, as desigualdades espaciais e o "jogo das escalas". Superintendência de Estudos Econômicos e Sociais.(Org.). Desigualdades Regionais. Salvador: SEI, p. 9-37, 2004.

[4] Centro Estadual de Estatísticas Pesquisas e Formação de Servidores Públicos do Estado do RIO de Janeiro (CEPERJ).Divisão regional, segundo as mesorregiões, microrregiões geográficas e municípios, Estado do Rio de Janeiro, 2011. Disponível em: <www.ceperj.rj.gov.br/ceep/info_territorios/Div_reg/ Quadro_MesoeMicrorregioes_Geograficas.XLS>. Acesso em 02 de outubro de 2016.

[5] Estado do Rio de Janeiro, desejar. Mesmo assim, sua população rural aumentou razoavelmente no primeiro decênio do século XXI.

Observando os meios rurais da região como um todo, torna-se clara a necessidade de melhorias na mobilidade (recuperação das estradas e transporte coletivo), na comunicação (redes de telefonia e internet), no saneamento (adequação das instalações sanitárias domiciliares, tratamento do esgoto), na educação (alfabetização e metodologias adaptadas ao campo), na distribuição de renda (entre as populações rurais e urbanas e entre os municípios) e incentivos à atividade agropecuária.

Estas melhorias serão conquistadas por meio de ações de organização dos agricultores e trabalhadores habitantes do meio rural e urbano, em conjunto com as empresas e instituições locais, mas, sobretudo, com Estado em suas múltiplas escalas. A atuação de forma mais integrada e regional no sentido de planejar ações, políticas públicas, e buscar formas de investimentos para os municípios pertencentes, rompendo com o neo-localismo competitivo, seria um alternativa interessante à permanência de um meio rural habitado de forma equilibrada e equitativa, para a promoção do desenvolvimento em suas múltiplas formas.

<http://www.ceperj.rj.gov.br/ceep/info_territorios/div is_regional.html>. Acesso em: 19 de outubro de 2016.

$[6]$ atividade econômica, Produto Interno Bruto, Produto Interno Bruto per capita e Impostos sobre produtos, segundo as Regiões de Governo e municípios, Estado do Rio de Janeiro, 2013. Disponível <http://www.ceperj.rj.gov.br/ceep/pib/pib.html> Acesso em: 08 de outubro de 2016.

[7] Comitê de Integração da Bacia Hidrográfica do Rio Paraíba do Sul (CEIVAP). Apresentação CEIVAP. Disponível em: <http://www.ceivap.org.br/apresentacao.php>. Acesso em: 05 de novembro de 2016.

[8] Ellis, Frank. Biggs, Stephen. Evolving themes in rural development - 1950s-2000s. Development Policy Review. Oxford, UK: Blackwell publishers, 19 (4): 437-448, 2001.

[9] Floriani, N; Rios, F T; Floriani, D. Territorialidades alternativas e Hibridismo no mundo rural: resiliência e reprodução da sociobiodiversidade em comunidades tradicionais do Brasil e Chile meridionais. In Polis: revista 
latinoamericana, vol 12, n 34, 2013. Disponível em: http://www.scielo.cl/pdf/polis/v12n34/art05.pdf

[10] Furtado, Celso. Formação econômica do Brasil: edição comemorativa : 50 anos / Celso Furtado ; organização Rosa Freire d'Aguiar Furtado. São Paulo : Companhia das Letras, $2009.567 \mathrm{p}$.

[11] Furtado, Celso. O mito do desenvolvimento econômico. Rio de Janeiro: Paz e Terra, 1974. $117 \mathrm{p}$.

[12] Haesbaert, Rogério. Da desterritorialização à multiterritorialidade. Anais: Encontros Nacionais da ANPUR, v. 9, 2013.

[13] Instituto Brasileiro de Geografia e Estatística (IBGE). Censo Demográfico 2000. Disponível em: <http://www.ibge.gov.br/home/estatistica/populaca o/default_censo_2000.shtm>. Acesso em: 05 de outubro de 2016

$\begin{array}{rr}{[14]} & \text { Censo Demográfico } \\ \text { Disponível em: } & \end{array}$ <http://www.ibge.gov.br/home/estatistica/populaca o/censo2010/indicadores_sociais_municipais/defau It_indicadores_sociais_municipais.shtm>. Acesso em: 05 de outubro de 2016.
[15] Kageyama, Ângela. Desenvolvimento rural: conceito e medida. In: Cadernos de Ciência \& Tecnologia. Brasília, v. 21, n. 3, p. 379-408, set./dez. 2004.

[16] Mattos, Sônia; Sant'ana, André. Relatório final. Ações estratégicas de revitalização do Vale do Café. 2 2a edição. 2010. Disponível em: <http://www.preservale.com.br/files/relatorio01.pdf >. Acesso em: 15 de setembro de 2016.

[17] Mendonça, Sônia Regina de. O Convênio de Taubaté e a agricultura fluminense. Revista Brasileira de Gestão e Desenvolvimento Regional. Vol. 4, n. 3, Taubaté, SP, 2008.

[18] NORTH, Douglas Cecil. Structure and change in economic history. New York: Norton, 1981. $240 \mathrm{p}$.

[19] PADILHA, Valquíria. Shopping Center: a catedral das mercadorias e do lazer reificado. São Paulo: Universidade de Campinas, 2003.

[20] Portal Rio Turismo. Mapa das regiões do Estado do Rio de Janeiro. Disponível em: <http://www.rio-turismo.com/mapas/regioes.htm>. Acesso em: 05 de outubro de 2016.

[21] Schneider, Sergio. A abordagem territorial do desenvolvimento rural e suas articulações externas. Sociologias, v. 6, n. 11, p. 88-125, 2004. 


\section{Capítulo 7}

\section{COISAS VELHAS, COISAS DO PASSADO, MAS SEMPRE NOSSAS: PATRIMONNIO CULTURAL, EDUCAÇÃO NO CAMPO E DESENVOLVIMENTO LOCAL.}

\section{Shirlei Alexandra Fetter}

\section{Daniel Luciano Gevehr}

\section{Jacques Andre Grings}

Resumo: O objetivo do presente estudo é discutir a Educação no Campo como patrimônio cultural e, sua colaboração ao incremento do desenvolvimento local. A temática ganha relevância pelos conceitos pontuados sobre a escola rural, como patrimônio cultural, evidenciado suas características e a sua contribuição ao desenvolvimento local. A metodologia do estudo vem ao encontro de reflexões qualitativas, sobre o conceito de escola do campo, como valorização do Patrimônio Cultural Local. Os resultados encontrados baseiam-se nas relações que se apresentam entre Patrimônio Cultural e a realidade, em que a escola se encontra inserida, como cultura imaterial, manifestando seu comprometimento com aquilo que tem de particular, dentro de seu contexto/âmbito local. As experiências educativas, voltadas ao presente debate, enaltecem a contribuição educacional de práticas culturais, exercitadas no campo, que ressaltam o desenvolvimento local e a especialização sociocultural das populações do campo.

Palavras-chave: Instituição de Ensino. Patrimônio Cultural. Desenvolvimento. Ruralidade. 


\section{CONSIDERAÇÕES INICIAIS}

A presente discussão parte, inicialmente, de reflexões realizadas no campo patrimonial cultural fazendo parte do percurso investigativo durante a produção do presente artigo. Partindo do interesse em se investigar práticas educativas no caminho da valorização das identidades culturais, compreendendo-se o patrimônio histórico material e imaterial, a partir das escolas de campo como percurso produtivo na discussão dos referidos aspectos.

Assegurados pela Constituição Federal de 1988, em seus artigos 215 e 216, que ampliam o conceito de patrimônio cultural ao confirmar a presença de bens culturais de origem material e imaterial (BRASIL, 1988), partimos de uma retrospectiva sobre 0 processo que define o patrimônio histórico cultural no Brasil e, suas possibilidades de ações que orientadas, subsidiam um trabalho de conscientização e preservação do patrimônio cultural no âmbito das instituições escolares.

Segundo Tomaz (2010) tal trabalho se concretiza pela proposta da Educação Patrimonial, na perspectiva pedagógica que visa um processo de valorização, conhecimento e preservação cultural da identidade e dos valores locais. A fim de se apontar a função da escola nesta harmonização cultural, enfatiza-se a Educação do Campo como caminho de efetivação e desenvolvimento do trabalho com a Educação cultural, uma vez que, a grandiosidade do tema acaba por não ser refletida. Isso acontece pelo desconhecimento e visões restritas sobre o assunto que ainda se mostra, em muitos aspectos, longe da articulação com os conteúdos significativos à realidade local, bem como com as vivências culturais dos alunos (MALTÊZ, 2010).

A Educação do Campo vem abrangendo um espaço político cada vez maior na sociedade contemporânea, como uma conquista dos movimentos sociais e, fomentadas pelas iniciativas governamentais. A Lei de Diretrizes e Bases da Educação Nacional de 1996, ressalta aspectos que apontam a escola de campo inserida na comunidade local, favorecendo o desenvolvimento no sentido de considerar o campo como espaço voltado não só à economia, mas também como elemento fundamental para garantir qualidade de vida daqueles que vivem no meio rural (BRASIL, 1996).

Compreendemos que a escola do campo ao atuar pela qualidade, responsabilidade e pelo desenvolvimento do local onde se faz presente, faz uma ponte de ligação entre o sujeito e o ambiente, pois através da educação contextualizada resguarda aquilo que é cultural, isto é, conserva os valores próprios da cultura vivida pelos sujeitos do campo. Acreditamos que, ao proporcionar ações práticas dentro da realidade cultural do campo, os alunos entram em contato com algo concreto e não somente com conceitos teóricos típicos de uma educação bancária e descontextualizada. Dessa forma, afirma-se a possibilidade da escola de campo como trabalho de cunho cultural, elevando o nível de compreensão da realidade e desenvolvendo a localidade através da contextualização da prática e do fazer educativo.

\section{PATRIMÔNIO CULTURAL LOCAL E ESCOLA DE CAMPO}

Faz-se necessário um esboço histórico sobre a concepção de Patrimônio, para entender o que está assim proposto pelo desenvolvimento deste trabalho. Segundo Tomaz (2010), o conceito de Patrimônio, refere-se, excepcionalmente ao legado paterno, isto é, aos bens transmitidos de uma geração a outra. $O$ autor também define 0 Patrimônio como bens que perpassam a sociedade atribuindo significado à história vivenciada pelos ancestrais de cada povo. Segundo Maria (2003), Patrimônio Histórico: "Pode-se conceituar como as diferentes maneiras de viver de um povo, transmitidas de geração a geração recebidas por tradição". (MAIA, 2003, p. 39)

Logo, torna-se importante observar que, em seu sentido peculiar, o conceito de Patrimônio inclui não apenas os pertences materiais, mas também os imateriais de um povo. Compreende desde construções, acervos destinados à consultas e visitações; documentos e objetos, bem como os valores, costumes e tradição de um determinado grupo social.

Perante a necessidade de fortalecer a história e a tradição dos povos, afirma-se o patrimônio cultural como a identidade de um povo. As definições que caracterizam o patrimônio cultural apresentam tendências mais 
especificas e abrangentes a partir de dos anos 80 , passando a tomar para si a visão mais significativa sobre cultura. Esta perspectiva vem ao encontro de políticas culturais de preservação e olhar atento e respeitoso ao Patrimônio Cultural (TOMAZ, 2010).

Ao falar em patrimônio cultural, busca-se entender a abrangência do termo a partir da Constituição Federal de 1988. O Artigo 216 da referida constituição, dispõe sobre este apontando que, hoje suas características se referem tanto ao ambiente cultural quanto ao ambiente natural (BRASIL, 1988). Assim sendo, duas linhas sustentarão este texto: as questões de valores culturais de referências à comunidade e a questão que se constitui sobre o que chamamos de educação na perspectiva de desenvolvimento local.

Ao se constituir o processo de preservação do patrimônio cultural busca-se a preservação do abstrato enquanto identidade constituinte de uma nação (TOMAZ, 2010). Entretanto, há controvérsias sobre como se reedificar o processo histórico, ou ainda, qual o problema do lugar e o significado de culturas populares no contexto da cultura nacional ou ainda daquilo que se torna oficial dentro do estado. Consequentemente, a constituição do Patrimônio Cultural representa diferentes características, enfatizadas por diferentes políticas públicas. Ao transpor essas identidades à comunidade, ela o define como aquilo que a identifica e que respeita.

Segundo Peralta e Anico (2006), patrimônio cultural se constitui como identidade por suas variadas relações com a sociedade. Sua coletividade está na construção homogênea da identidade social e cultural e, pela concretização perante o grupo. Como vimos, patrimônio cultural é um conjunto material e imaterial, que pertence ao interesse coletivo de uma comunidade. Através dele se recorda - passado com manifestações (re) memorativas sobre os acontecimentos mais importantes, com efeito, de relação ao conceito de memória social, autenticando a identidade de um grupo, expressando a identidade histórica e as vivências de um povo pela legitimação social e política do que é ou não património (MAIA, 2003).

Baseado nesse olhar é que se pretende pautar as ações deste trabalho, valorizando a cultura regional e mostrando a necessidade de incorporar patrimônios que possam ser reconhecidos e trabalhados desde a escola enquanto instituição educativa e social, de transmissão e fomentação da cultura. Para tanto, faz-se necessário apresentar à discussão sobre o conceito de patrimônio, sobretudo a ênfase em Educação do Campo ${ }^{17}$.

A educação do campo vem contemplar o ensino voltado à realidade de seus alunos, onde o conteúdo curricular e as metodologias de ensino do professor devem ser adequados às necessidades e interesses dos alunos de zona rural, os quais necessitam de um ensino que valorize, dentre outros aspectos, a cultura da criança que vive no campo e seu modo de vida (ARROYO, 2004).

Desta forma, trabalhar os conceitos abordados por conteúdos e disciplinas como comumente é feito nas escolas, limita-os pelas normas oficiais estabelecidas. O conceito sobre o patrimônio cultural local, que valoriza as questões sociais, está além de ser um conteúdo fechado, fragmentado e descontextualizado (TOMAZ, 2010). O fato de que somente os bens materiais são valorizados repercute na ocorrência imaterial e natural dos objetos patrimoniais, tais como os monumentos, sítios e centros históricos.

Neste caso, patrimônios imateriais e naturais são considerados recursos educacionais imprescindíveis para a escola, pois permitem ultrapassar os limites disciplinares sobre o aprendizado, enfocando os conteúdos que fazem parte da realidade significativa que serão considerados importantes para a vida dos alunos, harmonizando e contribuindo para o crescimento do mesmo desde o local onde vive (VARINE, 2013).

Compreende-se, aqui, a importância do patrimônio da humanidade, porque nele se reconhece que em uma determinada cidade ou região há tanta riqueza cultural preservada. Os conceitos de patrimônio cultural acrescentam o meio ambiente, aqui denominado meio ambiente cultural, que pode afirmar-se como as - "riquezas" culturais de um local. Não se pode excluir o

\footnotetext{
${ }^{17}$ Educação do Campo é alicerçada no Movimento Camponês, na perspectiva da construção de uma educação humana e emancipatória, articulada à vida, ao trabalho, à cultura, e aos saberes das práticas sociais dos camponeses. Ela promove a formação integral do indivíduo, de forma que valorize o local e as vivências ali desenvolvidas, considerando seus saberes como conhecimento adquirido historicamente (CHAVES E FOSCHIERA, p. 78, 2014).
} 
meio ambiente da abrangência do patrimônio cultural, sendo esse considerado como uma derivação dos estudos e conhecido como meio ambiente cultural de vivências e do desenvolvimento comunitário local (VARINE, 2013).

A escola que se pretende como espaço de transformação, tem por desafio ir à busca da prática educativa manifesta na e pela educação do campo. Ao analisar a prática educativa do campo, encontramos um referencial simbólico e prático imprescindível para a qualificação da educação com um todo; uma educação contextualizada e comprometida com a realidade à qual pretende qualificar e transformar.

Nesta perspectiva de educação voltada à cultura local do campo, encontra-se uma natureza imaterial que diz respeito às práticas de domínios sociais que se manifestam em saberes e expressões que fazem parte da vida do campo. A Organização das Nações Unidas - UNESCO - para a Educação, a Ciência e a Cultura, define como patrimônio imaterial as práticas representativas, que expressam conhecimentos que as comunidades, os grupos e, em alguns casos os indivíduos, reconhecem como parte integrante de seu patrimônio cultural.

Na década de 1990 são iniciados debates pelos movimentos sociais organizados sobre Educação do Campo, enfatizando a importância e a função da escola do campo para a sociedade. Esse debate foi importante para buscar resultados de uma escola que atendesse às ambições de qualificação da realidade dos povos que vivem no campo. Com os movimentos organizados passou-se a solicitar novas políticas públicas que garantissem o ingresso à educação própria, bem como uma estrutura curricular própria para escolas do campo, condizentes com uma proposta educacional que tenha como princípios os valores próprios da cultura do campo. (BLAKA, 2010).

Diante do processo de discussão que surgiram ao logo dos anos sobre a educação do campo, priorizou-se a valorização dos seus saberes enquanto patrimônio cultural, na perspectiva sustentável local, entrelaçando o fazer pedagógico às raízes do patrimônio cultural. Os conhecimentos produzidos relacionam-se com o incremento da escola participativa na comunidade e nas relações com outras instituições de ensino, valorizando os saberes do campo que fortalecem e aproximam os sujeitos da comunidade.

A escola do campo recepciona sujeitos que se caracterizam pelo trabalho rural, desde onde, se valoriza os saberes da vida no campo no ambiente escolar e, prioriza-se à aprendizagem significativa para a comunidade do campo (ARROYO, 2004).

Sua definição enquanto instituição - situada no espaço rural - é definida pelo Instituto Brasileiro de Geografia e Estatística (IBGE), como identidade e referencia ao lugar à que pertence. Por isso, seu currículo é conciliável aos saberes e às necessidades da cultura local. Entretanto, a maior parte das escolas rurais só oferecem os anos iniciais do Ensino Fundamental e, quanto a etapa seguinte e o Ensino Médio são despercebidos dos espaços rurais.

Por estas razões, os alunos que residem na zona rural e objetivam a conclusão do Ensino Médio precisam se deslocar até a zona urbana para terem acesso às instituições que ofertam esta modalidade de ensino. Daí a necessidade de fortalecer e expandir a educação do campo em todos os níveis.

Os princípios que norteiam a Educação do Campo demonstram alguns aspectos, ainda distante deles (CHAVES E FOSCHIERA, 2014). Precisa-se empreender um processo amplo e profundo de reflexão sobre como a Educação do Campo pode desenvolver um novo paradigma que assegure a permanência das pessoas no campo, comprometidas com as atividades e o desenvolvimento local.

É importante frisar que, não se pode cair no risco de criar uma escola no campo a partir do julgamento urbano; uma escola pensada desde o gabinete para os cidadãos que habitam esta localidade. É necessário que a escola do campo seja pensada pelos sujeitos que ali vivem, para que efetivamente sintamse pertencentes a este ambiente, como protagonistas de sua cultura $^{18}$. A educação precisa ofertar a capacidade de inferir as

\footnotetext{
18 A educação do campo é a luta do povo do campo por políticas públicas que garantam o seu direito à educação, e a uma educação que seja no e do campo. No: o povo tem o direito a ser educado no lugar onde vive; Do: o povo tem direito a uma educação pensada desde o seu lugar e com a sua participação, vinculada à sua cultura e às suas necessidades humanas e sociais. [...] não pode ser tratada como serviço, nem como política compensatória; muito menos como mercadoria (CALDART, 2000, p. 26).
} 
particularidades, entre os modos de vida, os espaços e a vivência destes sujeitos da cidade e do campo (CHAVES E FOSCHIERA, 2014).

Para o IPHAN - Instituto do Patrimônio Histórico e Artístico Nacional - os saberes são considerados significativos quando são gerados no cotidiano das pessoas comuns, das empresas e das comunidades, sendo geralmente disponíveis em ambientes não formais. Dessa forma, fortalecem desenvolvimento das pessoas, enquanto requisito essencial para o desenvolvimento de toda a comunidade. Com efeito, estendendose para fora dos muros da escola, a educação faz com que todos se sintam como protagonistas das ações que envolvem as raízes de preservação do patrimônio cultural com destino ao desenvolvimento local sustentável (PERALTA e ANICO, 2006).

Segundo Galdart (2002) na educação do campo é preciso refletir sobre como se ajuda a construir, desde a infância, uma visão de mundo crítica e histórica, como se aprende e como se ensina nas diferentes fases da vida a olhar para a realidade enxergando seu movimento, sua historicidade e as relações que existem entre uma coisa e outra, como se aprende e como se ensina a tomar posição diante das questões do seu tempo, como se aprendem e como se ensinam valores sociais e como se educam valores humanistas, como se educa o pensar por conta própria e o dizer a sua palavra e como se respeita uma organização coletiva. Atesta Peralta e Anico (2006) que a escola de campo precisa não deixar desflorar o cultivo de suas identidades culturais.

Uma das funções da escola de campo é trabalhar a identidade cultural, no sentido de ajudar a construir a visão que a pessoa tem de si mesma - autoconsciência de quem é e com o que ou com quem se identifica identidade campesina de trabalhador, identidade de gênero, de cultura, de povo, de nação (GALDART, 2000). Compreende-se que este é um aprendizado humano essencial, assumir a identidade pessoal, social e cultural.

Educação do campo com raízes é, considerada por Arroyo (2004) como a constituição e o fortalecimento das identidades culturais, isto é, valores, modo de vida e memória. Em consequência, a escola do campo será tanto mais significativo se ela estiver em sintonia com os processos e as realidades vivenciados pelos seus educandos - se ela mesma consegue constituir um processo social - cumprindo a tarefa da socialização de que tratamos antes - capaz de ajudar a construir e fortalecer identidades.

Pensando sobre a intencionalidade política e pedagógica da educação do campo, a escola ao trabalhar com ênfase no cultivo de identidades, memória e resistência cultural (MALTÊZ, 2010). A mesma tem como finalidade - que não pode ser subestimado na formação de seus educandos importância da educação do campo, já que em comunidades camponesas existe 0 traço cultural que a escola assume, além de todo um trabalho ligado à memória, à cultura, aos valores culturais locais.

A escola do campo ao enraizar as pessoas em sua cultura, recriada a interação com valores locais de sua comunidade, através da formação humana ao trabalhar com raízes e vínculos de sua realidade. Isto quer dizer, precisa-se trabalhar suas raízes culturais a partir de sua intencionalidade local de acordo padrões culturais que se manifestam em sua realidade (SOUZA, 2006).

\section{O DESENVOLVIMENTO DA LOCALIDADE NA PERSPECTIVA PATRIMONIAL}

$\mathrm{Na}$ atualidade pensar em desenvolvimento regional e local é pensar num contexto geral, como estratégias para a civilização social e convivências culturais que estimulem a propagação local (FURTADO, 2000). Pensar neste cenário de propagação é pensar num processo de abertura econômico-política local. Visto que, a região desenvolvida tende a apresentar maiores possibilidades, no entendimento de Boisier (1996) este processo como uma organização estruturada entre a divisão de regiões e localidades, associa as forças que se mantém centralizadas pelo poder econômico e da política local.

Promover o progresso local não significa voltar às costas para os processos mais amplos, ao contrário, significa utilizar as diversas dimensões territoriais, entre elas à educação do e no campo, de acordo com os interesses da comunidade (CHAVES E FOSCHIERA, 2014). Sobretudo, as iniciativas locais compreendem como natural, que da educação se espere não só competências gerais, mas as compreensões de como esses entendimentos se materializam em possibilidades de ações de intervenção no 
espaço e contexto local. Considerar a educação como uma necessidade de transformação local, é adquirir os experimentos para transformar as estruturas culturais, afetivas e cognitivas em posturas de comprometimento com a realidade local (MALTÊZ, 2010).

O desenvolvimento cultural enquanto qualificação do educando e a sua persistência no campo apresentam-se à sociedade como espaço para o desenvolvimento do conhecimento e da consciência, da convivência, moradia, cultura, produtividade. Entretanto, é preciso ter cuidado para que esse protagonismo não seja desrespeitado e manipulado socialmente, político e economicamente por políticas públicas elaboradas de cima para baixo, dentro de gabinetes, direcionadas para interesses neoliberais e do mercado globalizado.

Observa-se que os conhecimentos sobre o patrimônio cultural em relação à comunidade que o acolhe são, por vezes, descuidado na própria Escola. Neste caso, quando na instituição não se impõe a importância e a necessidade de valorização do patrimônio cultural, acaba perdendo a oportunidade de cumprir com o seu compromisso e função social. Encontra-se na escola o lugar mais apropriado para se refletir sobre assuntos de interesses coletivos, que objetivam o desenvolvimento local, por meio do aprofundamento dos conhecimentos, partindo dos contextos socioculturais e ambientais da sua realidade (TOMAZ, 2010).

As Diretrizes Operacionais da Educação Básica do Campo reconhecem o papel da educação para o desenvolvimento rural dos estados e municípios reafirmando, como prioridade a Educação do Campo, como uma estratégia fundamental para o desenvolvimento do meio rural (BRASIL, 2002).

O desenvolvimento é entendido como a possibilidade de qualificar o solo, a paisagem, a memória e o modo de vida dos habitantes, bem como contribuir para as construções, a produção de bens e serviços adaptados às demandas e às necessidades das pessoas. São as pessoas que dão essência, o exercem, moram nele, ou em seus arredores ou, são as pessoas para as quais esse patrimônio tem significado direto, por estar intrínseco às suas vidas (VARINE, 2013).
Ao valorizar as singularidades históricas e culturais da localidade, através da educação, através do resgate de memórias que potencializam o sentimento pertencimento, os representantes locais podem produzir princípios impulsionadores de geração de trabalho e renda desde localidade e, ao mesmo tempo, o patrimônio cultural local passa a ser reconhecido como elemento estruturante da identidade própria e local. Em consequência, o patrimônio cultural passa a ser visto como um dos recursos essenciais para a afirmação dos valores culturais e ambientais no quadro renovado das teorias de desenvolvimento (CARVALHO, 2003).

A ligação da educação desde escola de campo e a conservação do patrimônio cultural são fundamentais para a formação do indivíduo. A escola como local de conhecimento torna-se indispensável para a concretização da valorização do conhecimento cultural do aluno, pois ela permite socializar a valorização dos elementos que compõem este patrimônio cultural. Nesse sentido, compreender o valor da identidade e do conhecimento da história, bem como a preservação do patrimônio tornase um fator importante na formação escolar visando o desenvolvimento local (DIAS e MACHADO, 2009). Daí a necessidade de pautar a pedagogia escolar para a Educação Patrimonial.

O IPHAN entende como Educação Patrimonial os processos educativos formais ou nãoformais que têm como objeto de estudo patrimônio cultural material ou imaterial, com a finalidade de colaborar para $\mathrm{O}$ seu reconhecimento, valorização e preservação. A escola de campo enquanto patrimônio histórico oferece oportunidades de qualificação da educação patrimonial. Nesse sentido, falar na necessidade de preservar os valores da cultura local implica projetar o futuro e o desenvolvimento local passando por uma ressignificação do presente (HORTA et al, 1994).

Pensar na educação para o desenvolvimento local está diretamente vinculado à compreensão e a necessidade de se formarem pessoas que amanhã possam participar de forma ativa das atividades de seu meio, que sejam capazes de converter seu entorno, de produzir dinâmicas construtivas e produtivas (CARVALHO, 2003). Assim, a identidade da escola do campo é definida pela sua vinculação às questões inerentes a sua realidade, ancorando-se na 
riqueza de seus saberes próprios, gerados e produzidos desde o meio rural.

Promover o desenvolvimento local faz menção à capacidade de integração da comunidade com a escola. Através da fomentação das relações de complementaridade a comunidade e a escola podem melhor atender as necessidades sociais, econômicas, culturais, políticas e ambientais para o seu próprio desenvolvimento. O desenvolvimento da comunidade deve ser pensado a partir da riqueza que a localidade possui no que diz respeito à cultura herdada, às atividades que prevalecem na região, as possibilidades existentes, e, nesse sentido, através da escola buscar os recursos necessários para qualificar as relações e os recursos disponíveis (DIAS e MACHADO, 2009).

O patrimônio é usado não apenas para simbolizar, representar ou comunicar. Patrimônio cultural não existe apenas para representar ideias e valores abstratos e para ser contemplado. O patrimônio de certo modo, constrói e forma as pessoas ao mesmo tempo em que é moldado por elas. A compreensão profunda da realidade por parte do indivíduo faz com que ele passe a dar valor a sua história e em consequência, à sua memória. Despertando sua consciência sobre si, nessa perspectiva, o patrimônio cultural local se encobre de grande notoriedade.

\section{CONSIDERAÇÔES FINAIS}

Nestas reflexões considera-se a importância de preservar, os aspectos que engrandecem a presença da escola no campo enquanto fomentadora do patrimônio cultural do campo. Tendo em vista a Educação do Campo como potencializadora da articulação e (re) construção da cultura rural, considerando os aspectos de vida, os significados e saberes das pessoas que vivem nesta localidade, buscando valorizar suas relações culturais e econômicas, evidencia-se a sua importância na construção de valores que sejam significativos à humanidade, tais como: solidariedade, democracia, justiça e transformação social da sua realidade.

Procurando aprofundar o debate em questão, - estudo apresentou algumas questões educacionais que consideram propostas de educação do campo condizentes com a preservação de patrimônio cultural que enaltecem o desenvolvimento da localidade.
Entretanto, para preservar o patrimônio serão necessárias ações sólidas e eficazes entre escola e vida real da comunidade escolar, de forma que é primordial que cada indivíduo tenha consciência da importância do patrimônio cultural herdado e, ao mesmo tempo, se comprometa em qualificá-lo.

Para a garantia dessas ações é fundamental a ampliação de trabalhos de pesquisa envolvendo a realidade educacional do campo patrimonial, desde onde a comunidade poderá ter acesso ao conhecimento do seu passado, para que a partir de então, aprenda a valorizar e respeitar as suas raízes.

Preocupar-se com os bens patrimoniais e culturais é uma questão essencial para a qualificação da sociedade como um todo. Apesar de a legislação brasileira ser bastante ampla e de boa qualidade, ainda não se efetiva na prática da forma como se faz necessário, e, até que isso ocorra, ainda será comum a perda de elementos culturais praticados em função dessa ineficiência legislativa.

Entender o patrimônio como um bem, não só de interesse público, mas no intuito de mobilizar a comunidade para a necessidade de preservá-lo e qualificá-lo através da educação e da prática cidadã é fundamental para a qualificação da comunidade humana. Pois, o desenvolvimento local não está relacionado unicamente com crescimento econômico, mas também com a melhoria da qualidade de vida das pessoas e com a conservação do meio ambiente cultural e natural ao qual elas permanecem.

O patrimônio imaterial é fundamental à comunidade que o produziu e o reproduz. Se a comunidade souber reconhecer, valorizar e preservar o patrimônio cultural no seu entorno, terá dado um gigantesco passo para garantir o bem-estar social. Para isso é imprescindível que, desde a escola, se promovam ações e atividades que qualifiquem 0 desenvolvimento, em especifico da região e da localidade, objetivando a melhoria da qualidade de vida da comunidade e a garantia do exercício da memória e da identidade regional e local.

Pensar a educação vinculada à cultura significa construir uma visão de educação em uma perspectiva de longa duração - isto tem a ver, especialmente, com a educação de valores culturais - a educação do campo, além de se preocupar com o cultivo da 
identidade cultural camponesa, precisa recuperar os veios da educação dos grandes valores humanos e sociais, buscando emancipação, justiça, igualdade, liberdade, respeito à diversidade, bem como a integração das novas gerações o valor da utopia e do engajamento pessoal a causas coletivas e humanas.

O vínculo com as matrizes de trabalho e cultura nos remete a pensar em outro traço muito importante para a educação do campo, neste sentido o trabalho e a cultura são produções e expressões necessariamente coletivas e não individuais. Raiz cultural, que inclui o vínculo com determinados tipos de processos produtivos, significa pertença a um grupo, identificação coletiva.

Compreender o lugar da escola na educação do campo é ter claro que ser humano ela precisa ajudar a formar e como pode contribuir com a formação dos novos sujeitos sociais que se constituem no campo. A escola

\section{REFERÊNCIAS}

[1] Arroyo, Miguel. G. A Educação Básica e o Movimento Social do Campo. In: ARROYO, M.G, Caldart, R.S., Molina, M.C (orgs.) Por uma Educação do Campo. Petrópolis: Vozes, 2004.

[2] Blaka, Rosimari de Fátima Cubas. Avanços e desafios no desenvolvimento da qualidade do ensino na educação do campo de Canoinhas, SC. Dissertação de Mestrado apresentada ao Programa de Mestrado em Desenvolvimento Regional da Universidade do Contestado/UnC. Canoinhas, SC, 2010.

[3] Brasil. Constituição da República Federativa de 1988. Disponível em: http://www.planalto.gov.br/ccivil_03/Constituicao/C onstituicao.htm. Acesso em: 12 out. 2017.

[4] . Lei de Diretrizes e Bases da Educação $1996 . \quad$ Disponível em: http://www.planalto.gov.br/ccivil_03/leis/L9394.htm. Acesso em: 17 out. 2016.

[5] . Diretrizes Operacionais para a Educação Básica do Campo. Brasília/DF, 2002. Disponível em:

http://portal.mec.gov.br/index.php?option=com_co ntent\&id=12992 Acesso em: 22 out. 2017.

[6] Boisier, Sergio. Em Busca do Esquivo Desenvolvimento Regional: entre a caixa-preta e o projeto político. Planejamento e Políticas Públicas, n. 13, jun. 1996.

[7] Caldart, Roseli Salete. Pedagogia do Movimento Sem Terra: escola é mais do que escola. Petrópolis, RJ: Vozes, 2000. precisa cumprir a sua vocação universal de ajudar no processo de humanização, com as tarefas específicas que pode assumir nesta perspectiva. Ao mesmo tempo é chamada a estar atenta à particularidade dos processos sociais do seu tempo histórico e ajudar na formação das novas gerações.

Em síntese, considerar o desenvolvimento local pressupõe uma transformação consciente de sua realidade. Suas implicações se apresentam pela implicação coerente entre a geração presente e a futura, e neste aspecto, o fator ambiente local é quem assume fundamental importância. O aspecto mais relevante do desenvolvimento local é aquele que implica sua articulação entre diversos atores, seja a sociedade civil, as organizações não governamentais, as instituições privadas e publicas (entre elas a escola), sendo que, cada um desses atores, têm papel fundamental no fortalecimento do desenvolvimento local.

a. , Roseli Salete. Por uma educação do campo: traços de uma identidade em construção. Caderno 4. Brasília: Articulação Nacional Por Uma Educação do Campo, 2002.

[8] Chaves, Kênia Matos da Silva; Foschiera, Atamis Antonio. Práticas de Educação do Campo no Brasil: Escola Família Agrícola, Casa Familiar Rural e Escola Itinerante. revista pegada - vol. 15, n.2, p.76-95, dez. 2014.

[9] Carvalho, Paulo. Património e (re) descoberta dos territórios rurais. Boletim Goiano de Geografia. V.23(2), p. 173- 196, 2003.

[10] Dias, Reinaldo; Machado, Gilmara de Cássia. Patrimônio Cultural e Turismo: Educação, Transformação e Desenvolvimento Local. Revista Patrimônio: Lazer \& Turismo, v. 6, n. 8, out.-nov.dez./2009, p.1-11.

[11] Furtado, Celso. Introdução ao desenvolvimento. 3. ed. São Paulo: Paz e Terra, 2000.

[12] Horta, Maria de Lourdes Parreira. et al. Guia Básico de Educação Patrimonial. Brasília: Iphan/ Museu Imperial, 1999.

[13] Ibge. Instituto Brasileiro de Geografia e Estatística. Disponível em: $<$ http://www.ibge.gov.br/home/>. Acesso em: 19/10/2017.

[14] Iphan. Patrimônio natural do Brasil: Brasília, 2009. Disponível em: < http://portal.iphan.gov.br/pagina/detalhes/234 > Acesso em: 16 out. 2016. 
[15] Maia, Felícia Assmar. DIREITO À Memória: O Patrimônio Histórico, Artístico e cultural e o Poder Econômico. Movendo Ideias, Belém, v8, n.13, p.3942, jun. 2003.

[16] Maltêz, Camila Rodrigues. Et al. Educação e Patrimônio: O papel da Escola na preservação e valorização do Patrimônio Cultural. Pedagogia em ação, v.2, n.2, p. 1-117, nov. 2010.

[17] Peralta, Elsa e Anico, Marta. (orgs). Patrimónios e Identidades: ficções contemporâneas. Oeiras, Celta 2006.
[18] Souza, Maria. Antônia. Educação do campo: propostas e práticas pedagógicas do MST. Petrópolis: Vozes, 2006.

[19] Tomaz, Paulo Cesar. A Preservação do Patrimônio Cultural e sua Trajetória No Brasil. Fênix - Revista de História e Estudos Culturais. v. 7, no 2, Maio/ Junho/ Julho/ Agosto de 2010. Disponível em: www.revistafenix.pro.br. Acesso em: 12 out. 2017.

[20] Varine, Hugues de. As Raízes do Futuro: O Patrimônio a Serviço do Desenvolvimento Local. Porto Alegre: Medianiz, 2013. 


\section{Capítulo 8}

\section{A DUPLA FACE DA CIDADE: O RIO DE JANEIRO NAS CRONNICAS DO INÍCIO DO SÉCULO XX}

\section{Guilherme Mendes Tenório}

\section{Cesar Augusto Miranda Guedes}

Resumo: No início do século XX, a cidade do Rio de Janeiro passou por um conjunto de reformas empreendido pelo prefeito Pereira Passos em conjunto com o governo federal. Tais reformas compreenderam seja a abertura de avenidas como a Avenida Beira-Mar e a Avenida Central seja a adaptação do porto para embarcações de maior calado. Articuladas a este processo esta a adoção de novos hábitos como a freqüência a salas de cinema e os passeios pela cidade à noite. Neste contexto, as crônicas funcionam como modos de expressão subjetiva e simultaneamente social das conseqüências do planejamento urbano bem como do desejo de construir uma cidade moldada nos padrões europeus, ressaltando as tensões entre a cidade real e a cidade ideal como quer o critico uruguaio Angel Rama. Deste modo, este texto objetiva captar novos sentidos para um período da história da cidade do Rio de Janeiro fecundo de interpretações.

Palavras-chave: Rio de Janeiro, crônicas, urbanização. 


\section{INTRODUÇÃO}

Esta é uma versão revista de um artigo enviado para a edição do Encontro Nacional de Planejamento Urbano e Regional (ENANPUR) realizado em Maio deste ano na cidade de São Paulo. Sem abandonar o cerne do texto anterior, que consistia da análise de crônicas publicadas no início do século XX, o texto que ora se inicia agrega outros recortes teóricos àqueles utilizados anteriormente.

Entre estes recortes teóricos, destaco as ponderações de Carlos Brandão e Ivo Theis. Os dois autores incidem seu olhar sobre a dimensão territorial tanto da acumulação de capital como da distribuição do desenvolvimento científico pelas diferentes regiões do Brasil e sua articulação com o desenvolvimento econômico-social. Na obra de Carlos Brandão sobre Território e Desenvolvimento, por exemplo, nos deparamos com a lição de que não é possível olhar para as transformações de uma cidade sem darmos conta de outras escalas.

No que nos interessam, as observações de Brandão nos levam a pensar que as reformas encetadas por Pereira Passos no início do século XX não dizem respeito exclusivamente à história da cidade do Rio de Janeiro. Mesmo por que elas foram realizadas em parte pelo governo federal na figura de Rodrigues Alves, o qual ficou responsável pela obra que aumentou o calado do porto do Rio de Janeiro. Deste modo, a escala local deve ser lida a luz de processos emanados das escalas nacional e global, como reflete o economista

Por sua vez, a pesquisa de Theis alerta para o fato de que o processo de urbanização ocorrido no século XX foi bastante acelerado e levou aquilo que ele chama de metropolização. Com a chegada de imigrantes e depois de migrantes vindos do campo as cidades brasileiras tomaram outras proporções transformando-se em metrópoles cujos problemas levam à necessária articulação entre os prefeitos, muitas vezes com a participação dos governadores dos estados.

Estes pontos justificam porque o trabalho saltará um século, entre o início do século do século XX e o início do século XXI. Deste modo, acreditamos, será possível entender melhor as dimensões das reformas urbanas capitaneadas pelo prefeito Pereira Passos em conluio com o governo federal no contexto da Primeira República.

\section{UMA CIDADE EM CONSTANTE} TRANSFORMAÇÃO

Conforme dito acima, a então Capital Federal atravessou um período de transformações iniciado com a eleição de Rodrigues Alves em 1902. Tais transformações somaram-se aquelas que vinham afetando a vida urbana do Rio de Janeiro pelo menos desde a chegada da corte portuguesa em 1808, quando foram instalados o Jardim Botânico e a Biblioteca Nacional, transformando a cidade na sede do reino lusitano.

Por sua vez, na segunda metade do século XIX o Município Neutro e depois sede da corte imperial conheceu a introdução de serviços como a iluminação a gás e elétrica, as linhas de bondes, o telegrafo e o esgoto. Isto para não falar da construção de 4 ramais de linha férrea que expandiram a cidade para o que viria a ser denominado de subúrbio e a conexão férrea com estados de Minas Gerais e São Paulo.

Porém, estas mudanças não eram suficientes para dissipar a imagem de uma cidade colonial assolada por doenças como a varíola, a febre amarela e a peste bubônica e com ruas mal planejadas. Além destas questões, faz-se necessário olhar para a inserção da cidade no desenvolvimento do capitalismo no quadro da segunda revolução industrial.

Seguimos, portanto as sugestões do historiador Nicolau Sevcenko ${ }^{19}$ no primeiro capítulo do livro Literatura como Missão, a qual traz uma série de referências factuais em relação aos aspectos socioeconômicos brasileiros no início do século passado. Entre outros pontos, o autor cita a inadequação do porto brasileiro para receber os navios de maior calado, problema solucionado pelas reformas comandadas por Rodrigues Alves e pelo engenheiro Lauro Miller, que então estava à frente do Ministério da Viação. Essas transformaram o porto no terceiro maior da América perdendo apenas para Nova York e Buenos Aires e o décimo quinto do mundo.

Lógico também que o porto do Rio de Janeiro não exercia o mesmo papel que o porto de Santos nas exportações de café, ainda mais depois que o Vale do Paraíba entrara em decadência e fora substituído pelo Oeste

19 SEVCENKO, Nicolau. "A inserção compulsória do Brasil na Belle Epoque. In: SEVCENKO, Nicolau. Literatura como missão: tensões sociais e criação cultural na Primeira República. São Paulo: Companhia das Letras, 2003. 
Paulista. Contudo, o porto do Rio de Janeiro ainda era central na navegação de cabotagem e por meio desta articulava-se a praças comerciais no Nordeste e no Norte.

Da mesma forma, a cidade era um centro político e financeiro que abrigava o poder executivo, seus ministérios, embaixadas, a sede do Banco do Brasil, da Bolsa de Valores e de uma série de instituições estrangeiras e nacionais. Aqui aportavam navios com mercadorias originárias dos quatro cantos do mundo, notadamente da França.

A cidade ainda recebeu um montante significativo dos capitais exportados pela GrãBretanha. Esses foram investidos na infraestrutura urbana e principalmente naquilo que facilitasse a exploração de produtos como o café, o cacau, açúcar e a borracha. Assim, o Brasil ainda era nitidamente uma economia agroexportadora cujo papel dentro da divisão internacional do trabalho era o de fornecer alimentos e matérias-primas. Nessa perspectiva, a sociedade e a economia brasileiras eram constituídas de arquipélagos modernizados se comparados às regiões rurais. Além do Rio de Janeiro, São Paulo, Recife e Belém eram pólos de modernização interessantes. São Paulo crescia impulsionada pelo café do Oeste Paulista, Recife tinha importância cultural devido a sua Faculdade de Direito e Belém apareceu ao mundo a partir do ciclo da borracha e do Museu Emilio Goeldi. Nada que contrariasse o fato de que a população brasileira ainda era predominantemente rural ou mesmo o peso das oligarquias regionais.

No plano demográfico, as tabelas veiculadas no livro do urbanista Marcelo $\mathrm{Abreu}^{20}$ indicam que em 1906 o Rio de Janeiro era uma cidade de 800.000 habitantes e em 1920 este total ultrapassou a marca do um milhão. Estes números faziam da então Capital Federal a maior cidade do país, posto que perdeu para a cidade de São Paulo a partir dos anos 1960. Para efeito de comparação, cite-se que atualmente somos a segunda maior metrópole do Brasil com seis milhões de habitantes, mas que chegam a 12 milhões se contamos com a região metropolitana. Enquanto isso, São Paulo perfaz um total de 12 milhões de habitantes que se transformam em 20 milhões tomando em perspectiva a área metropolitana.

\footnotetext{
${ }^{20}$ ABREU, Maurício de Almeida. A evolução urbana do Rio de Janeiro. Rio de Janeiro: IPP, 2013. p. 80
}

Não devemos esquecer também das inúmeras instituições culturais e científicas sediadas na cidade do Rio de Janeiro. A primeira delas, ainda no final do século XIX, foi a Academia Brasileira de Letras. Com as reformas de Pereira Passos, foram construídos ainda uma nova sede para a Biblioteca Nacional, outra para a Escola Nacional de Belas Artes e o Teatro Municipal. Ademais, na Avenida Central e nas ruas adjacentes situavam-se prédios de periódicos como o Jornal do Commercio, o Paiz, Correio da Manhã e a Gazeta de Notícias. Sem esquecermos o Instituto Manguinhos, hoje Fundação Oswaldo Cruz. Inaugurado em 1900, pelo médico e sanitarista Oswaldo Cruz, o Instituto foi fundamental no sentido do combate as epidemias da febre amarela e da peste bubônica.

Os elementos elencados acima justificam porque o Rio de Janeiro era caracterizado como a caixa de ressonância do Brasil, espécie de cidade-modelo que atraia todos os olhares. Se Lima Barreto e João do Rio eram nascidos na Capital Federal, aqui também vieram aportar intelectuais de outros estados e mesmo do estado do Rio de Janeiro, que na época era uma entidade política distinta com capital na cidade de Niterói. Para a cidade do Rio de Janeiro, vieram o sergipano Gilberto Amado, o maranhense Arthur Azevedo e o cantagalense Euclides da Cunha. Esta fusão entre o espaço urbano carioca e as questões nacionais, aliás, acarretaram problemas para a formação de um campo político autônomo, como demonstram os historiadores Américo Freire ${ }^{21}$ e Marly Motta 22 .

\section{ENTRE A CIDADE IDEAL E A CIDADE REAL: O RIO DAS CRÔNICAS.}

De acordo com o que foi dito anteriormente, nosso interlocutor será o critico literário uruguaio Angel Rama ${ }^{23}$. Dissertando sobre as cidades latino-americanas, Rama pontua que desde o inicio da colonização as cidades instaladas pelos espanhóis se caracterizaram por apresentar a ordenação do espaço urbano como se fosse um tabuleiro de damas

\footnotetext{
${ }^{21}$ FREIRE, Américo. Sinais trocados: o Rio de Janeiro e a República. Rio de Janeiro: 7Letras, 2012.

22 MOTTA, Marly da Silva. Rio de Janeiro: de cidade-capital a Estado da Guanabara. Rio de Janeiro: Editora FGV, 2001

${ }^{23}$ RAMA, Angel. Op.cit, 1982.
} 
no qual as hierarquias sociais organizavam-se em círculos concêntricos.

Portanto, as cidades coloniais representavam, segundo Rama, um ideal de ordem e racionalização, ou melhor, esta seria a intenção dos planejadores de todos os tempos. Pois na verdade existiria um abismo entre a cidade real, palmilhada pelos habitantes em seu cotidiano; e a cidade ideal, concebida na cabeça dos planejadores. Neste contexto, os intelectuais teriam sido fundamentais enquanto porta vozes desta perspectiva ordenadora e racional.

Entretanto, cronistas como João do Rio, Olavo Bilac e Lima Barreto vivenciaram cotidianamente a cidade do Rio de Janeiro no início do século XX. Freqüentavam ambientes como o Café Java e a Confeitaria Colombo. Visitavam cortiços e os morros. Pegavam o trem entre o subúrbio e o centro como fazia todo dia Lima Barreto. Trata-se pois de uma tensão entre a cidade ideal e a cidade real.

E por que tensão? Pois foi justamente neste período que a cidade do Rio de Janeiro atravessou um conjunto de reformas capitaneado pelo presidente Rodrigues Alves e pelo prefeito Pereira Passos. Tais reformas dialogam com o desejo das elites coloniais em construir espaços da ordem a partir da racionalização das cidades. É difícil na verdade separar os planos do real e do ideal, visto que a cidade concebida no mundo das idéias acaba por se imiscuir na cidade que todos vivenciavam nem é possível traçar uma fronteira rígida entre a cidade das letras e a cidade do cotidiano.

No entanto, a análise de Rama sugere que a história das reformas urbanas na América Latina é anterior ao final do século XIX e desconstrói a vinculação automática que geralmente traçamos entre o que aconteceu no Rio de Janeiro e o que se deu em Paris com as reformas de Haussman. Com Pereira Passos, a ordem continuava a ditar a cabeça daqueles que intervinham na cidade, basta que pensemos nas posturas que visavam à correção de hábitos anteriores como andar descalço e os quiosques.

Por outro lado, cabe pensar as reformas do Rio de Janeiro em um contexto específico, na medida em que no século XIX cidades como Barcelona, Florença, Paris, Viena e Buenos Aires passaram por transformações. Ademais não nos esqueçamos de que o período colonial não assistiu ao desenvolvimento de novas tecnologias como o cinema, a luz elétrica, o bonde e o automóvel, as quais as cidades modernas passariam a estar atreladas. Tecnologias essas que, por sua vez, evidenciavam uma nova etapa no desenvolvimento capitalista, vinculada aos desdobramentos da segunda Revolução Industrial.

Entre todos os cronistas citados, Olavo Bilac foi o mais favorável à modernização empreendida por Pereira Passos. Para ele, portanto, a cidade real surgida a partir das picaretas de Pereira Passos como que se iguala a cidade ideal. Antes mesmo de a Avenida Central ficar pronta, ele coloca: "A Avenida...Parece-me que a vejo acabada, ampla e formosa, com as suas arvores, os seus palácios, as suas lâmpadas elétricas, os seus "refúgios", e cheia de uma multidão contente e limpa. (Bilac, 1903)

No ano seguinte, a Avenida foi inaugurada e sobre ela Bilac escreve:

Mas o meu sonho animou tudo aquilo: comecei a ver, ao longo da cidade derramada aos meus pés, rasgar-se a grande Avenida; diante dos meus olhos deslumbrados relampejavam jatos de luz elétrica, e vi desenhar-se a cidade futura, resplandecente e rica, mais bela de que todas as suas irmãs, irradiante na gloria da civilização. (BILAC; 1903)

Em muitas das outras crônicas, Bilac repete o tom alvissareiro com que tratou a abertura da Avenida Central hoje Avenida Rio Branco. Tal fato constitui uma sumula da chegada da civilização a então Capital Federal. Se valendo de recursos poéticos como "relampejavam jatos de luz elétricos", o cronista confere um tom alegórico a abertura da Avenida. Nesta mesma crônica, aliás, Bilac descreve uma personagem que representaria a "Tradição", o "Progresso", "a Produção", que em certo momento diz:

Oh! o progresso! Pobre desta cidade! Pobres destas boas casas que morrem! Pobres destas boas ruas que desaparecem! Pobres das minhas alegrias que se esvaem! Esta Avenida, menino, vai ser o caminho da Perdição! O caminho do céu é estreito e feio como o Escorrega; o caminho do inferno é que é amplo, rasgado, cômodo e bonito! Pelas veredas apertadas só passam as almas puras, mas pelas avenidas largas passam todas as multidões pecadoras... (BILAC; 1904) 
A personagem acima alude ao problema do descompasso entre a cidade real e a cidade ideal por outra perspectiva, qual seja: a cidade ideal não era aquela que se projetava com a abertura da Avenida e sim aquela do passado, provavelmente do século XIX. Do mesmo modo, é interessante assinalar como a personagem se vale de um tropo bíblico para advertir sobre os perigos das avenidas largas, transformando o Rio de Janeiro numa futura Babilônia.

Ainda este mesmo trecho pode ser analisado a partir das sugestões de Raymond Williams em seu clássico sobre as representações do campo e da cidade na Inglaterra, pois o autor afirma que um suposto campo ideal seria um mito que sempre recuaria no tempo, cada vez mais remotamente. Podemos transpor isso para as representações das cidades e supor, por exemplo, que um viajante do tempo que chegasse ao Rio de Janeiro no século XIX pensaria que a cidade colonial fora um época dourada em comparação aquela.

Deste modo, a imagem de um Rio de Janeiro com vielas tortas e estreitas acabou passando a memória como representação fidedigna do que era a Cidade Maravilhosa antes das obras de Pereira Passos, fazendo-nos esquecer das transformações anteriores que a atingiram. Assim, não haveria distinção significativa entre a cidade dos tempos de Estácio de Sá e da Capital Federal. Logo, afirma-se mais uma vez o que foi ressaltado por Angel Rama acerca do papel da cultura letrada diante da cidade física: as crônicas sobre o Rio de Janeiro do início do século XX acabam por construir uma memória sobre o que teriam significado as reformas de Pereira Passos no sentido de uma ruptura total com que o era a cidade anteriormente, como que eternizando aquele momento para todo sempre. Portanto, o Rio de Pereira Passos ganhou muito da sua importância em virtude do talento de escritores como João do Rio e Olavo Bilac.

Bilac reparte com Arthur Azevedo a representação alegórica do passado em personagens como o "Carrancismo". Basta olhar para o texto da peça Guanabarina como sugere a pesquisa de Tatiana Oliveira Siciliano $^{24}$ e verificamos que no inicio do espetáculo Carrancismo solicita a Satanás que impeça o progresso da cidade invocando

\footnotetext{
${ }^{24}$ SICILIANO, Tatiana Oliveira. O Rio de Janeiro de Artur Azevedo: cenas de um teatro urbano. Rio de Janeiro: Mauad X: Faperj, 2014.
}

uma série de calamidades nomeadas como Politicagem, Interesse Pessoal e Descrença que agirão pelas mãos de um gênio de nome Andrade, o qual lutará contra a fada Guanabarina, que conta com as alegorias do Progresso, da Indústria, da Civilização, do Patriotismo para impedir os planos malignos de Andrade. Não é a toa que os dois autores, Bilac e Arthur Azevedo, partilhavam a crença no trabalho de Pereira Passos como fator de progresso.

João do Rio, pseudônimo mais famoso do jornalista Paulo Barreto, foi outro adepto das transformações urbanas promovidas por Pereira Passos. Mas João do Rio foi além, dando a conhecer outro lado da cidade, aquele dos fumadores de ópio e das meninas que namoravam as vitrines. Era, no dizer de Julia O' Donnell, um etnólogo da cidade real ${ }^{25}$, permitindo que visualizemos as conseqüências do furor modernizante liderado por Pereira Passos e Rodrigues Alves. Primeiro, vejamos como ele se vale dos recursos da linguagem para descrever a nova paisagem urbana:

A praia de Botafogo apresenta um aspecto maravilhoso. A grande e esplendorosa avenida cintila de toiletes raras, de jóias coruscantes e de belezas admiráveis. Passam, sem cessar, automóveis caros, carros de luxo numa fila interminável. Sob o sol de inverno, o mar achamolata-se. (Rio, João do, 1907)

Na passagem acima, o cronista descreve a nova Avenida Beira Mar, via que ligava a Zona Sul ao Centro e que fazia parte do conjunto de reformas promovido por Pereira Passos. É interessante como João do Rio se vale de metáforas relacionadas à joalheria e a moda para ressaltar a fusão da elegância das pessoas que passeavam na avenida com o próprio espaço. O próprio mar, aliás, ganha a textura de um tecido, na medida em que a palavra "achamolatar" remete a chamalote, um tecido de origem oriental feito de pele de cabra ou camelo.

O quadro pintado por João do Rio na crônica citada acima lembra muito as fotografias publicadas em revistas ilustradas daquele momento como o Malho, a Fon-Fon e a Kosmos. Este era o mundo no qual as pessoas procuravam imitar as últimas

\footnotetext{
25 O' DONNELL, Julia. De olho na rua: a cidade de João do Rio. Rio de Janeiro: Jorge Zahar Ed, 2008.
} 
tendências de moda do mundo europeu, que à época era sinônimo de mundo civilizado.

Esse era 0 ambiente pretendido pelos planejadores de uma cidade ideal, oposta àquela cidade real, formada pelos hábitos populares. A ordem, portanto, não estava apenas nas avenidas retilíneas, mas dependia da aquisição de novos comportamentos, vendidos como se fossem os mais elegantes, ou para usar o linguajar da época, "smart". Era uma nova disposição do corpo descrita em termos poéticos por João do Rio, ou melhor, o treinamento do corpo para se adaptar a outra configuração do espaço urbano.

Neste caso, João do Rio serviria de exemplo às discussões travadas por Angel Rama no sentido do papel desempenhado pela cidade das letras diante da cidade física, constituída pelas transformações sinalizadas pela abertura de novas avenidas. Lembremos que para Rama os intelectuais seriam um dos encaminhadores da cidade ideal, servindo de suporte simbólico para o planejamento e ordenamento do espaço urbano.

Porém, João do Rio não se limitou a ser um "pedagogo" da cidade ideal. Seu livro, "a Alma encantadora das Ruas", traz retratos de uma série de outras cidades possíveis, como aquela dos "comedores de ópio":

As lâmpadas tremem, esticam-se na ânsia de queimar o narcótico mortal. Ao fundo um velho idiota, com as pernas cruzadas em torno de um balde, atira com dous pauzinhos arroz à boca. O ambiente tem um cheiro inenarrável, os corpos movem-se como as larvas de um pesadelo, e estas 15 caras estúpidas, arrancadas ao balsamo que Ihes cicatriza a alma, olham-nos com o susto covarde de coolies espantados. E todos murmuram medrosamente, com os pés sujos, as mãos sujas (...) (RIO, João do; 1908)

Temos, pois, um contraste entre a cidade que circula que pela avenida de automóvel e aquela que se esconde para fazer uso do ópio. Contraste este que se faz notar pelas palavras utilizadas pelo cronista para se referir aos chineses como "caras estúpidas", "susto covarde", "velho idiota". Sumiram a avenida cintilante e o mar em formato de tecido. Agora prevalece a sujeira, o cheiro putrefato, uma serie de características ambientais descritas em tom negativo,

Nesta crônica, se evidencia a distância entre a cidade ideal e a cidade real. Essa é, como vimos, aquela vivenciada por seus habitantes no dia-a-dia, nem sempre correspondendo ao planejamento dos seus idealizadores. E que ficava, aliás, bem próxima a cidade inserida no plano de Pereira Passos. A bem dizer, os limites entre a cidade real e a ideal não são dos mais fáceis a serem definidos, sendo a literatura a grande responsável pela constante ultrapassagem das fronteiras, pois nem está apenas imaginando um espaço urbano ideal nem se restringe a descrição daquilo que o cronista vê ao flanar, isto é, caminhar sem objetivo definido.

Como estamos ressaltando constantemente ao longo do texto, as crônicas de João do Rio e Olavo Bilac eternizariam o momento fugaz das reformas promovidas por Pereira Passos e todas as conseqüências daí advindas. Como disse Angel Rama: os intelectuais da cidade das letras dão sentido aos significantes produzidos pelas transformações urbanas e é a partir deles que lemos os múltiplos vieses do mesmo processo.

Em outro, "As Mariposas de Luxo", João do Rio incide seu olhar sobre algumas jovens que namoram uma vitrine da Rua do Ouvidor, uma das artérias mais importantes do Rio "civilizado". Vejamos dois trechos:

São duas raparigas, ambas morenas. A mais alta alisa instintivamente os bandos, sem chapéu, apenas com pentes de ouro falso. A montra reflete-lhe o perfil entre as plumas, as rendas de dentro; e enquanto a outra afunda - olhar nos veludos que realçam toda a espetacularização do luxo, enquanto a outra sofre aquela tortura de Tântalo, ela mira-se, afina com as duas mãos a cintura, parece pensar coisas graves. Chegam, porém, mais duas. A pobreza feminina não gosta dos flagrantes de curiosidade invejosa (...)

(...) Quanta coisa! Quanta coisa rica! Elas vão para casa acanhada jantar, aturar a rabugice dos velhos, despir a blusa de chita - a mesma que hão de vestir amanha ... E estão tristes. São os pássaros sombrios no caminho das tentações. Morde-lhes a alma a grande vontade de possuir, de ter o esplendor que se Ihes nega na polidez espelhante dos vidros. (Rio, João do; 1908)

Anteriormente, havíamos dito que a abertura de novas avenidas teve, entre outras motivações, o ensejo de facilitar a circulação de mercadorias. É também consenso afirmar que a iluminação destes novos espaços facilitou o habito de passear pela cidade à noite. Tais emblemas da nova cidade estão 
sintetizados na crônica cujos trechos foram transcritos acima, na medida em que João do Rio poderá os significados de um passeio por uma das ruas mais elegantes do Rio de Janeiro de então.

A crônica chama atenção para os efeitos da formação da sociedade de consumo sobre a psique dos indivíduos. Fala da tristeza com que as moças encaram a impossibilidade de consumir um objeto desejado ou que foram levadas a desejar. É, pois, o choque entre a cidade ideal dos hábitos elegantes de consumo e a cidade real dos "pássaros sombrios no caminho das tentações", o que remete mais uma vez a metáfora da cidade moderna como Babilônia.

Vamos ao nosso último cronista, Afonso Henrique de Lima Barreto. Dos três, Lima Barreto foi o mais crítico ao processo de modernização que atingiu o Rio de Janeiro no inicio do século XX, seja aquele promovido por Pereira Passos seja aquele desenvolvido por Carlos Sampaio já na década de 1920, simbolizado pela derrubada do Morro do Castelo.

Ainda nos valendo do diapasão fornecido por Angel Rama, Lima Barreto seria o intelectual mais próximo da cidade real. Seus textos conferem uma perspectiva negativa às transformações do espaço urbano, tocando no que seriam os limites daquela ordem visada pelos planejadores. Vejamos como ele trabalha, por exemplo, o problema das enchentes:

O Rio de Janeiro, da Avenida, dos squares, dos freios elétricos, não pode estar à mercê de chuvaradas, mais ou menos violentas, para viver a sua vida integral.

O Prefeito Passos, que tanto se interessou pelo embelezamento da cidade, descurou completamente de solucionar esse defeito do nosso Rio.

Cidade cercada de montanhas e entre montanhas, que recebe violentamente grandes precipitações atmosféricas, o seu principal defeito a vencer era esse acidente das inundações.

Infelizmente, porém, nos preocupamos com os aspectos externos, com as fachadas, e não com o que há de essencial nos problemas de nossa vida urbana, econômica, financeira e social. (BARRETO; 1915)

Diferentemente de João do Rio, Lima Barreto não enxerga nas reformas urbanas promovidas por Pereira Passos nenhum traço de profundidade. Para ele, apesar de terem afetado vertiginosamente o cotidiano dos cariocas, seriam mudanças de fachada na medida em que não lograram resolver o problema das enchentes, entre outros. Portanto, não é que Lima Barreto rejeitasse a civilização ou o progresso, mas sim que estes valores adquiriam em sua perspectiva outra feição.

Da mesma forma, se o autor também pensava em termos de uma cidade ideal esta não seria aquela planejada por homens como Pereira Passos, Rodrigues Alves e Carlos Sampaio. A partir das indicações biográficas de Francisco Assis Barbosa ${ }^{26}$, infere-se que uma suposta cidade ideal para Lima Barreto seria aquela que atenderia aos anseios das classes populares, às quais sempre esteve ligado por origem social. O autor de Vida e Morte de Gonzaga Sá matinha em perspectiva crítica os desdobramentos das práticas ordenadoras ensejadas pela cidade das letras, formada não só pelos administradores como também pelos intelectuais.

Também não seria correto dizer que Lima Barreto seja um mero passadista. Leiamos, por exemplo, o que o autor escreveu a respeito da demolição do Convento da Ajuda para dar lugar ao novo prédio da Cruz Vermelha:

Não sei bem que vantagens trará tal coisa. Se, ao menos, fossemos levantar ali um Louvre, um Palácio dos Doges, alguma coisa de belo e grandioso arquitetonicamente, era de justificar todo esse contentamento que vai pela alma dos estetas; mas para substituí-lo por um hediondo edifício americano, enorme, pretensioso e pífio, o embelezamento da cidade não será grande e a satisfação dos nossos olhos não há de ser de natureza artística. Uma coisa vale a outra.

Não é que eu tenha grande admiração pelo velho casarão, mas é que também não tenho admiração nem pelo estilo nem pela gente, nem pelos preceitos americanos dos Estados Unidos. (BARRETO; 1911)

Fica claro pela leitura dos trechos acima que o problema da demolição do Convento da Ajuda é simultaneamente estético e de ideológico. Estético porque, para Lima Barreto, edifícios americanos não teriam a beleza de um Louvre, museu parisiense. E

\footnotetext{
${ }^{26}$ BARBOSA, Francisco de Assis. A vida de Lima Barreto. Rio de Janeiro: Jose Olimpio, 1975.
} 
ideológico porque seguiria princípios norteamericanos, com os quais não demonstra simpatia. Sobre isso, o biografo de Lima Barreto assinala que nosso autor não era fã dos Estados Unidos por duas razões: a situação do negro na República do Norte e suas práticas imperialistas.

Escrita em 1911, a crônica se refere à substituição do modelo francês de civilização pelo norte-americano, simbolizada pela adoção dos arranha-céus e nos anos 1920 pelo Jazz. Lima Barreto indicia como a cidade real estava em constante processo de adequação a um suposto modelo de cidade. Processo esse, como sugere Renato Cordeiro Gomes $^{27}$, marcado pela esfuziante Idea de um rompimento com o passado. Para lembrar Marx e um dos seus analistas, Marshall Berman, tudo que é solido desmancha no ar.

Se a cidade real está em constante transformação, a cidade ideal não se volatiza facilmente no tempo. Lima Barreto, por sua vez, eternizou uma reforma Pereira Passos excludente, visível pela derrubada dos cortiços e pelo controle de certos hábitos como andar descalço. Assim, quando estudamos mais uma vez as reformas ocorridas no inicio do século temos sempre em mente tanto a imagem de uma radical mudança no espaço citadino como a face excludente do processo.

\section{CONSIDERAÇÕES FINAIS.}

Escritos como os de Olavo Bilac, João do Rio e Lima Barreto têm impulsionado estudos sobre o Período Pereira Passos. Tanto é assim que mesmo analises críticas e embasadas nas teorias sociais corroboram para considerar o início do século XX como um período de radical transformação na então Capital Federal. A cidade que existia antes é quase sempre assumida como colonial em contraposição a cidade moderna construída por Passos.

Como já afirmamos anteriormente, não se negam aqui as dimensões das transformações produzidas pela reforma levada a cabo por Pereira Passos. Elas atingiram vários bairros da cidade, como Copacabana, Botafogo, Catete, Glória, Tijuca e mesmo Santa Cruz. Permitiram ainda aos

\footnotetext{
${ }^{27}$ GOMES, Renato Cordeiro. Todas as cidades, a cidade: literatura e experiência urbana. Rio de Janeiro: Rocco, 1994
}

cariocas a aquisição de novos hábitos de lazer como os passeios noturnos. No entanto, é sempre importante relativizar a profundidade da ruptura que provocaram, visto que a cidade já se transformava pelo menos desde a chegada da família real.

Deste modo, seguimos as sugestões de Angel Rama no sentido de enquadrar as reformas de Pereira Passos num espectro ideológico mais amplo do que aquele sintetizado pela palavra "modernidade". $\mathrm{Na}$ verdade, a implementação de núcleos urbanos na América Latina adquiriu um aspecto ordenador já na colonização européia, o que problematiza segundo indica Barbara Freitag $^{28}$, a tese de Sergio Buarque de Holanda segundo a qual, ao contrário do colonizador espanhol, o português não teve maiores preocupações ao instalar suas cidades no novo mundo.

Se for assim, por que as reformas de Pereira Passos ganharam tamanha fama? Para responder a esta questão, chamamos Rama ao debate novamente e seguimos sua sugestão no sentido de que a cidade das letras tem a força de controlar a passagem de tempo, conferindo aura a determinados momentos da história e ajudando a construir uma memória dos mesmos. Isso aconteceu com o Período Passos.

Acontecerá com o período atual, no qual a cidade do Rio de Janeiro se transformou novamente para adequar-se a Copa do Mundo e principalmente aos Jogos Olímpicos de 2016? Qual será o comportamento da cidade das letras diante da cidade física? Zuenir Ventura, Aldir Blanc, Arthur Dapieve, Joaquim Ferreira dos Santos serão aqueles que perpetuarão a memória dos dias atuais ou já passou o tempo no qual a cidade das letras ainda conversava com o burburinho das ruas?

Além das questões concernentes ás relações entre espaço urbano e literatura, devemos lembrar que o Rio de Janeiro faz parte de uma megalópole com mais de 12 milhões de habitantes dentro da qual os municípios componentes apresentam condições socioeconômicas dispares e que, no entanto, precisam coordenar-se a fim de solucionar problemas como o saneamento básico, a

\footnotetext{
${ }^{28}$ FREITAG, Barbara. Capitais migrantes, poderes peregrinos: o caso do Rio de Janeiro. Campinas, SP: Papirus, 2009.
} 
mobilidade urbana e os impactos ambientais sobre a Baia de Guanabara.

Somam-se a isto a herança e o ônus de ter sido capital nos períodos colonial (17631822), imperial (1822-1889) e republicano, pois apesar do Poder Executivo ter sido transferido para Brasília em 1960 aqui se manteve estrutura institucional vinculada ao governo federal, como algumas das principais

\section{REFERÊNCIAS}

[1]. Abreu, Maurício de Almeida. A evolução urbana do Rio de Janeiro. Rio de Janeiro: IPP, 2013.

[2]. Barbosa, Francisco de Assis. A vida de Lima Barreto. 5트 Ed. Rio de Janeiro: José Olimpio, 1975.

[3]. Barreto, Lima. Toda crônica. Rio de Janeiro: Agir, 2004.

[4]. Brandão, Carlos. Território e desenvolvimento: as múltiplas escalas entre o local e o global. Campinas: Ed. Unicamp, 2007.

[5]. Dimas, Antonio. Bilac, o Jornalista: Crônicas: Volume 1. São Paulo: Imprensa Oficial do Estado de São Paulo, Editora da Universidade de São Paulo, Editora da Unicamp, 2006.

[6]. Freire, Américo. Sinais trocados: o Rio de Janeiro e a República. Rio de Janeiro: 7LETRAS, 2012.

[7]. Freitag, Barbara. Capitais migrantes e poderes peregrinos: o caso do Rio de Janeiro. Campinas, SP: Papirus, 2009.

[8]. Gomes, Renato Cordeiro. Todas as cidades, a cidade: literatura e experiência urbana. Rio de Janeiro: Rocco, 1994.

[9]. Lessa, Carlos. O Rio de todos os Brasis. Rio de Janeiro: Record, 2000.

[10]. Motta, Marly da Silva. Rio de Janeiro: de cidade-capital a Estado de Guanabara. Rio de Janeiro: FGV, 2001. empresas estatais, a Biblioteca Nacional, o Museu Histórico Nacional, sem falar dos hospitais (Hospital dos Servidores, Bonsucesso e Andaraí) e dos órgãos administrados pelas Forças Armadas. Portanto, Machado de Assis não estava tão errado ao apontar que o Rio de Janeiro, ainda que perdesse o status de sede administrativa da nação, não seria totalmente alijado de sua importância simbólica.

[11]. Novaes, Aline da Silva. João do Rio e seus cinematógrafos: o hibridismo da crônica na narrativa da belle époque carioca. Rio de Janeiro: Mauad: FAPERJ, 2015.

[12]. O' DONNELL, Julia. De olho na rua: a cidade de João do Rio. Rio de Janeiro: Jorge Zahar Ed, 2008.

[13]. Paoli, Paula de. Entre relíquias e casas velhas: a arquitetura das reformas urbanas de Pereira Passos no centro do Rio de Janeiro. Rio de Janeiro: Rio Books, 2013.

[14]. Rama, Angel. A cidade das letras. São Paulo: Brasiliense, 1982

[15]. Rezende, Beatriz. Lima Barreto e o Rio de Janeiro em fragmentos. Rio de Janeiro: Editora UFRJ; Editora Unicamp, 1993.

[16]. Ribeiro, Luiz Cezar de Queiroz. (Coord). Rio de Janeiro: Transformações da ordem urbana. Rio de Janeiro: Letra Capital; Observatório das Metrópoles, 2016.

[17]. RIO, João do. Melhores crônicas. 1 ed. São Paulo: Global, 2009.

[18]. Sevcenko, Nicolau. Literatura como missão: tensões sociais e criação cultural na Primeira República. São Paulo: Companhia das Letras, 2003.

[19]. Siciliano, Tatiana Oliveira. O Rio de Janeiro de Artur Azevedo: cenas de um teatro urbano. Rio de Janeiro: Mauad X: Faperj, 2014.

[20]. Theis, Ivo Marcos. Desenvolvimento científico e tecnológico e território no Brasil. Chapecó, SC: Argos, 2015. 


\section{Capítulo 9}

\section{MÁXIMO ESFORÇO, MINIMO RESULTADO: A POÉTICA URBANA DE FRANCIS ALŸS}

\section{Germana Konrath}

Paulo Edison Belo Reyes

Resumo: O presente artigo trata do potencial de transformação que trabalhos desenvolvidos pelo artista belga-mexicano, Francis Alÿs, apresentam em relação à nossa forma de pensar e de ocupar a cidade, tanto de um ponto de vista espacial quanto temporal. O estudo aborda a vivência nas cidades atuais modulada por tempos acelerados ou determinados por padrões de produtividade e por espaços públicos programáticos. Partimos de quatro ações poéticas de Alÿs realizadas no México e em Cuba, entre 1994 e 2006, para discutir a "burocratização do amanhã" presente nos discursos e práticas neoliberais que tomam lugar na urbe contemporânea. O artigo fundamenta-se na noção de "direto à cidade" desenvolvida por Lefebvre, que é atualizada através de autores contemporâneos a Francis Alÿs: Deleuze e Guattari, Rancière e Canclini. Destes autores, interessam alguns conceitos que serão operacionalizados para a análise dos projetos artísticos, como: alisamento/estriamento, de Deleuze e Guattari; estética e política, de Rancière; e encapsulação/transgressão, de Canclini. Muitas das ações realizadas por Alÿs têm o espaço público como território de atuação, questionando seus limites físicos e conceituais. A intenção deste artigo é identificar possíveis plataformas de pensamento crítico que proponham novos modos de pensabilidade e de articulação de nossa vida urbana, fugindo à linearidade e ao pragmatismo dos discursos dominantes.

Palavras Chave: Francis Alÿs, espaço público, arte contemporânea, política. 


\section{FORÇA MOTRIZ}

A pesquisa da qual este artigo é extraído, desenvolvida no âmbito de pós-graduação em planejamento urbano e regional, trata da criação de espaços de resistência em urbanismo através da arte contemporânea. $O$ estudo justifica-se, de forma mais abrangente e sob o ponto de vista das ciências sociais aplicadas, no atual contexto histórico, classificado por muitos autores ${ }^{29}$ como pósutópico, marcado pelo capitalismo mundial integrado e por sentenças como a proferida por Margaret Tatcher "There is no alternative" ${ }^{30}$. Buscando fazer frente a essa postura, temos vozes como a de David Harvey, ao pontuar que "não há uma única região do mundo onde as manifestações de raiva e descontentamento com o sistema capitalista não podem ser encontradas" (Harvey, 2004).

Em meio a essa discussão, torna-se essencial identificar, na contemporaneidade, movimentos e possibilidades de ruptura com o status quo, respondendo criticamente ao sistema hegemônico que parece repetir incessantemente que não há outro modo de vida possível além daquele que já está dado. Essa necessidade se agudiza frente às atuais circunstâncias políticas em nosso país e aos eficientes discursos de crise e de falência generalizados, estrategicamente disseminados em todas as esferas de nossas vidas.

Nossos sistemas altamente refinados e introjetados de controle e de vigilância, de parcelamento do tempo em atividades programáticas, de narrativas impregnadas pela ideologia do sucesso balizando nossas relações mais íntimas e subjetivas e de mecanismos de falsa participação (ou de figuração), são parte de uma estrutura dominante à qual parece não haver escapatória. O espaço público onde se projetam nossas ações cotidianas reflete esta

29 Lucia Santaella, Haroldo de Campos, Flávio Carneiro, entre outros autores, usam o termo pósutópico em contraposição a pós-moderno ou mesmo a utópico, indicando que vivemos um período de princípio-realidade e não mais princípio-esperança (referência à obra de Ernst Bloch).

30 There is no alternative" foi um slogan político usado pela primeira ministra britânica Margaret Tatcher, ao afirmar que não havia alternativa (ou nenhuma alternativa melhor) para o progresso da sociedade moderna além da abertura de mercados e do capitalismo globalizado. negação do direito à cidade. A significativa porcentagem de abstenções, votos brancos e nulos nas urnas municipais de grandes capitais brasileiras no último mês de outubro (10/2016), evidencia este descolamento ou não identificação dos cidadãos com a política urbana, pelo menos do ponto de vista da democracia representativa.

A partir deste cenário, surgem questionamentos sobre plataformas alternativas e possibilidades de participação que resgatem o direito à apropriação da urbe por seus habitantes em seus aspectos fundamentais. Propomos a seguinte pergunta para nortear este artigo: quais são as possíveis contribuições de projetos artísticos, como os de Francis Alÿs aqui analisados, para repensarmos a maneira como articulamos hoje nossos discursos e práticas sobre o espaço público urbano? O objetivo é lançar mão de provocações presentes nos trabalhos de Alÿs que permitam ampliar nosso entendimento sobre o espaço público, seus limites conceituais e físicos.

A relevância da discussão proposta é evidenciada pela multiplicação de manifestações artísticas da contemporaneidade que abordam essa temática, como prescreveu Lefebvre, mas parece até hoje apartada ou secundária na agenda das cidades ou do planejamento urbano. Encontramos, ao longo da pesquisa, estudos similares a este, sendo relevantes suas contribuições para o meio acadêmico, como a desenvolvida em nível de graduação por Clara Laurentiis. No entanto, há diversos pontos ainda inexplorados, visto que proposições poéticas, como as aqui analisadas, têm a qualidade de não se esgotar e de seguir gerando novos valores, justamente por serem processuais, abertas. Seguir buscando, assim, produções atuais que interrompem os gestos maquínicos, a esteira dos clichês e o sentimento de apatia generalizada em relação à nossa cidade, justificam tanto este artigo como a investigação da qual ele deriva.

A pesquisa empírica, da qual esse artigo se alimenta, fundamenta-se na análise de diversos materiais e fontes: documentação de projetos de Alÿs em fotos e vídeos através de seu site oficial, em catálogos de exposições e de bienais; textos escritos por críticos e demais profissionais relacionados ao campo da arte; entrevistas com o artista disponibilizadas em sites, revistas e livros, e 
textos escritos por Alÿs acerca de seus trabalhos.

No estudo já realizado, as informações coletadas foram avaliadas dentro de uma abordagem qualitativa. A intenção foi fazer uma varredura de sua obra, procurando identificar padrões recorrentes, tendências, repetições e variações, que tornassem a análise consistente. Apesar do enfoque não ser numérico, a revisão de todos os projetos de Alÿs a que se têm acesso, através das fontes buscadas, permitiu um aprofundamento na discussão proposta.

A escolha por este artista, especificamente, deve-se ao profundo diálogo estabelecido entre as práticas de Alÿs com o contexto urbano. O espaço público para ele representa a possibilidade de criar, no local de encontros sociais da cidade, situações escultóricas, entendidas aqui como as esculturas sociais às quais o artista Joseph Beuys se referia ${ }^{31}$. Alÿs cria narrativas ou fábulas, como ele as chama, a partir dos elementos presentes no espaço público, evidenciando situações políticas e sociais, muitas vezes características de países "em crise" ou em eterna busca pelo desenvolvimento, como aqueles da América Latina, onde muitos de seus projetos se desenvolvem.

Sua postura crítica frente ao sistema político e socioeconômico é elaborada através de uma produção poética não banal ou literal, pelo contrário, o artista se vale de alegorias, mitos e símbolos que permitem diversas interpretações, jogos e aberturas, dando à sua produção um caráter permeável e processual. Supomos que estas características estabeleçam um profundo diálogo com as teorias caras à pesquisa, que buscam abrir outras possibilidades de pensamento, ocupando-se daquilo que ainda não tem forma pronta, que existe apenas como iminência. É uma atitude contrária à da maior parte dos projetos em arquitetura e urbanismo, marcados por processos teleológicos que geram resultados previsíveis.

\footnotetext{
31 A Escultura socialpode ser definida em como nós moldamos e damos forma ao mundo em que vivemos. É a escultura vista como um processo evolucionário onde todo ser humano é um artista" (Durini, 1997). Beuys entendia a escultura de forma ampliada, a partir da percepção de que estamos constantemente criando formas para nos relacionarmos, visto que todo conteúdo, toda linguagem, tem sua forma de expressão, e que podemos moldá-la como a uma escultura.
}

Alÿs intervém no espaço público de forma efêmera e suas obras podem ser vistas e lidas de modo autônomo e pontual, porém o motivo de fundo que as une é contínuo, quase circular, conectando forma e conteúdo, essência e aparência. Como previu Lefebvre "deixando a representação, o ornamento, a decoração, a arte pode se tornar práxis e poiesis em escala social: a arte de viver na cidade como obra de arte" (Lefebvre, 2001). $\mathrm{Na}$ mesma página, o autor segue ainda afirmando que "o futuro da arte não é artístico, mas urbano". Essa é a premissa na qual se baseia o artigo que aqui se propõe, trazendo projetos artísticos como produtores de pensamentos, pensabilidades, ações e transformações sobre o espaço público urbano.

Acreditamos que Alÿs entabule uma conversa direta com Lefebvre em sua defesa à (re)apropriação das cidades pós-industriais por seus habitantes; avance em consonância com o entendimento de Rancière que vincula a base da política com estética; desenvolva ações diretamente relacionadas às acepções de agenciamento, alisamento e estriamento de Deleuze e Guattari e ainda tensione o binômio encapsulação/transgressão de Canclini, com sua produção poética de difícil classificação e apreensão pelo mercado da arte.

Este universo constrói a seguinte matriz teórica: 1. Derivando do direito à cidade de Lefebvre, pretende-se verificar como Alÿs cria situações que retomam um sentido de pertencimento à coisa urbana; 2. Partindo de Rancière, busca-se identificar a vinculação entre ações poéticas e ações políticas propostas pelo artista, baseados no entendimento do regime de pensamento das artes: os modos de fazer, as formas de visibilidade dessas maneiras de fazer e os modos de pensabilidade de suas relações; 3. Desdobrando os conceitos de alisamento e estriamento de Deleuze e Guattari, propomos uma leitura da trajetória poética analisada frente ao efeito de inversão que esse binômio propõe e de sua essência disruptiva; 4. A partir de Canclini, visamos problematizar não apenas a apreensão pelo mercado de projetos de Alÿs, mas sua capacidade de transpor limites e romper fronteiras no campo da arte através do binômio encapsulação/transgressão.

Para fomentar essa discussão, foram selecionados quatro trabalhos do artista, de diferentes momentos de sua carreira: Turista 
(Cidade do México, 1994); Paradoja de la praxis 1 - Algunas veces el hacer algo no lleva a nada (Cidade do México, 1997); Barrenderos (Cidade do México, 2004) e Puente (Keywest, EUA e Havana, Cuba, 2006). O recorte corresponde a pautas que interessam a este artigo: índices de produtividade e parâmetros de sucesso, mecanismos de aceleração de processos, artifícios de circunscrição dos espaços púbicos e de seu uso pela população, delimitações territoriais e conceituais que determinam nosso modus operandi urbano.

\section{PONTO DE PARTIDA}

\subsection{O DIREITO À CIDADE DE LEFEBVRE}

Henri Lefebvre, ao analisar o percurso histórico das cidades pós-industriais, passando pela sociedade dita de consumo, que ele reinterpreta como "sociedade burocrática de consumo dirigido" argumenta que "o ser humano tem necessidade de acumular energias e a necessidade de gastálas, e mesmo de desperdiçá-las no jogo" (Lefebvre, 2001). Segue ainda declarando que muito além das necessidades específicas, atendidas minimamente pelos equipamentos urbanos funcionais, persiste e sobressai uma necessidade não prevista no planejamento, ausente nos projetos, uma necessidade fundamental de atividade criadora, lúdica, geradora de obras de arte e de bens simbólicos, de imaginário, e não apenas de bens materiais, objetivos e consumíveis.

Para Lefebvre o direito à cidade era, na verdade, um direito à liberdade, um direito à obra como atividade participante na urbe (e não falsamente democrática, onde todos são apenas figurantes) e um direito à apropriação que vai muito além do direito à propriedade. É relevante para este texto não apenas um entendimento sobre os elementos que constituem as necessidades do homem urbano e de seu direito à cidade (que incluem o direito à criação e à obra), mas também a ideia de Lefebvre, para quem a cidade não era um objeto fixo, estático. A cidade, defende o autor, é um objeto virtual em constante atualização e seus processos não podem estar restritos apenas ao planejamento urbano ou a índices e parâmetros quantitativos, objetivos.

Segundo ele, urbanistas, arquitetos, sociólogos, políticos, não são capazes de criar relações sociais; no máximo, podem facilitar ou dificultar sua formulação. Essas relações, quando são produzidas, se dão a partir da práxis cotidiana, promovidas por todos nós em nossos espaços-tempos de convívio, em nossa vida social, no espaço público. Nesse ponto, o autor aponta para uma possível função para os profissionais que normalmente são encarregados do planejamento das cidades. Indica que, individualmente ou em grupo, eles poderiam "limpar o caminho, propor, tentar, preparar formas e (...) inventariar a experiência obtida, tirar lições dos fracassos, ajudar o parto do possível através da maiêutica nutrida da ciência" (Lefebvre, 2001).

Lefebvre aqui nos coloca frente à frente com o conceito de fracasso, assim como Alÿs que, ao jogar, em sua produção, com o mito de Sísifo ${ }^{32}$, ironiza o projeto de Modernidade imposto aos países latino-americanos, que parecem estar sempre em busca de seu auge, sem nunca atingi-lo. Essa ironia parecenos evidente em projetos como Paradoja de la práxis I, Barrenderos e Puente, como veremos a seguir. Que contribuição podemos esperar, do ponto de vista do urbanismo, de trabalhos artísticos cujo pano de fundo esteja atrelado à ideia de "fracasso" ou do "parto do possível" como prescreveu Lefebvre? Essa questão permeará a análise do objeto empírico.

\subsection{A NOÇÃO DE ESTÉTICA E DE POLÍTICA EM RANCIËRE}

Contrariamente à posição de Gilles Lipovetsky e Jean Serroy (2015) acerca da estetização como um processo muitas vezes superficial e feito a posteriori, como um verniz ou máscara que recobriria a realidade, Rancière defende que a estética é a base da política. O autor afirma ainda que a estética não é a teoria da arte e sim "um regime específico de identificação e pensamentos das artes: um modo de articulação entre maneiras de fazer

\footnotetext{
32 Sísifo é um personagem mitológico grego condenado a empurrar uma pedra até o topo de uma montanha de forma cíclica e contínua. Toda vez que está prestes a atingir o cume, a rocha rola novamente para o sopé da montanha, num movimento repetido, movido por forças irresistíveis e invisíveis que tornam o trabalho e o esforço de Sísifo vão. Alÿs evoca a narrativa grega em obras como Rehearsal e Politics of rehearsal, The last Clown, entre outras, além daquelas mencionadas no artigo.
} 
e os modos de reflexão de suas relações" (Rancière, 2009).

Rancière nos fala acerca dos atos estéticos como provocadores e indutores de novas experiências de subjetividade política, retomando a fusão entre arte e vida proposta por distintos filósofos e por artistas como Allan Kaprow, Joseph Beuys e alguns situacionistas, por exemplo, cuja contribuição para o trabalho de Francis Alÿs é notável. O autor traz a "arte como testemunho do encontro com 0 irrepresentável que desconcerta todo pensamento" (Rancière, 2009). Nos fala ainda que o regime estético das artes é responsável por determinar possíveis (possíveis maneiras de fazer, modos de visibilidade e modos de pensabilidades) e seus modos de transformação.

O filósofo parte da premissa de que todo ato é político (lembrando que a raiz etimológica de política é pólis) e que antes de qualquer racionalidade existe uma sensibilidade. A estética, portanto, permearia todo processo político e a arte seria o campo mais afeito a esta exploração dos possíveis, da criação de contornos para aquilo que até então é inominável para o inteligível e para o racional, sendo uma antecipadora do que pode vir a ser e daquilo que a sensibilidade já intui.

Rancière defende ainda a existência de duas formas de entendimento político: a primeira como uma construção pelo acordo e a segunda como um desenvolvimento baseado em dissensos. O autor coloca em xeque a noção de política como consenso e de que partimos todos de uma sensibilidade comum. Segundo ele "a estética e a politica articulamse ao dar visibilidade ao escondido, reconfigurando a divisão do sensível e tornando o dissenso evidente" (Rancière, 2009). Aqui o filósofo abre a discussão sobre dissenso, indicando que não se trata apenas da falta de objetivos ou de afinidades compartilhados, mas sim de um passo anterior, em que os próprios dados da situação, os sujeitos envolvidos, as formas de inclusão ou exclusão, o que é sensível a uma situação, afinal, é passível de desacordo.

Neste sentido, ações quixotescas como as propostas por Alÿs seriam capazes de criar contornos e evidenciar dissensos ou mesmo de suspender acordos? De que forma? As ações que veremos podem ser consideradas não filtradas pela forma-fim e pelo pensamento inteligível ou seriam obras que apenas utilizam o vocabulário do processo e da iminência permanecendo, no entanto, limitados por um direcionamento do artista elaborado a prior?

\subsection{O BINÔMIO ALISAMENTO/ESTRIAMENTO DE DELEUZE E GUATTARI}

De Deleuze e Guattari interessam à pesquisa os conceitos de agenciamento, processos de territorialização e o binômio liso/estriado. A dupla de pensadores ressignifica esses últimos termos, colocados em tensão constante e complementaridade dinâmica. No intuito de não deturpar o sentido aplicado a ambos ou reduzir sua complexidade, copiamos aqui algumas palavras dos autores retiradas do livro Mil Platôs - Capitalismo e esquizofrenia.

"No espaço estriado, as linhas, os trajetos têm uma tendência a ficar subordinados aos pontos: vai-se de um ponto a outro. No liso, é o inverso: os pontos estão subordinados ao trajeto. É a subordinação do habitat ao percurso, a conformação do espaço do dentro ao espaço do fora: a tenda (nômade), o iglu, o barco. (...) O espaço liso é ocupado por acontecimentos ou hecceidades, muito mais do que por coisas formadas e percebidas. É um espaço de afetos mais do que de propriedades. É uma percepção háptica, mais do que óptica. É um espaço intensivo mais do que extensivo, de distâncias e não de medidas. O que ocupa o espaço liso são intensidades, os ventos e ruídos, as forças e qualidades tácteis e sonoras, como no deserto, na estepe ou no gelo. O que cobre o espaço estriado, ao contrário, é o céu como medida (astronômica), e as qualidades visuais mensuráveis que derivam dele" (Deleuze e Guattari, 1997).

Os autores procuram caracterizar aquilo que identifica o liso e o estriado sem circunscrevêlos em limites prévios ou significados e exemplos estanques. É possível reconhecer processos libertários sendo estriados por forças hegemônicas, mas, sobretudo, é no contra-fluxo do discurso e das organizações estruturadas a priori, chamadas estriadas, que haveria a possibilidade de seu alisamento, através de operações que escapam ao controle e às regras estabelecidas. O alisamento e o estriamento só existem um em função do outro.

Ao buscar modelos que ilustrem essa teoria, Deleuze e Guattari recorrem à passagem do sentido físico-científico de trabalho para um 
sentido socioeconômico de trabalho. Segundo os autores, essa apropriação conceitual se deu no século XIX a partir da necessidade do Estado em estabelecer uma medida, uma moeda mecânica, transformada em financeira, relacionada ao esforço ou força física despendida pela sociedade nas atividades diárias que sustentavam a economia. Era necessário criar um modelo abstrato que permitisse atribuir valor ao esforço e desempenho de cada sujeito em suas rotinas, desempenhadas da forma mais uniforme e homogênea possível.

Neste ponto, os autores identificam como o modelo trabalho estriou o tempo livre das sociedades em industrialização, implementando regras e medidas para estruturar ações lisas até então. Essa percepção parece-nos compartilhada por Alÿs, que mina com suas ações delicadas e precisas, a máxima de que "tempo é dinheiro". Alÿs inverte esse lema, propondo axiomas como o que dá título a este texto "máximo esforço, mínimo resultado", seguido de outros títulos de obras suas como: "algunas veces el hacer algo no lleva a nada". O artista suspende os acordos e os clichês estabelecidos, criando paradoxos. Que valores podemos depreender de ações poéticas absurdas, como as que veremos a seguir, onde o sentido de trabalho parece substituído pelo de desperdício? Que relações podemos estabelecer com outros modos de vida não pautados pelo modelotrabalho e quais tensionamentos neste binômio alisamento/estriamento podem ser identificados na obra de Alÿs?

\subsection{A OPOSIÇÃO ENTRE ENCAPSULAÇÃO E TRANSGRESSÃO EM CANCLINI}

A tensão de forças entre encapsulação e transgressão proposta por Canclini designa uma posição paradoxal da arte que busca garantir a independência de seu campo através de práticas e vocabulários específicos, ao mesmo tempo em que passa a influenciar e a se alimentar de outras disciplinas. O autor ressalta a ruptura de barreiras que separavam o campo da arte de outros campos do conhecimento, indicando que, cada vez mais, verdade e simulacro confundem-se e tornam-se estratégias não apenas de obras de arte, mas são absorvidas pela publicidade, pela economia e política, onde a forma ganha cada vez mais relevância sobre a função. Segundo o antropólogo a arte tornou-se pós-autônoma.
Se o campo da arte tem o mérito de ter se aberto a novas linguagens e suportes, destacadamente a partir da década de 1960, por outro lado, tem sido também, cada vez mais, alvo da lógica de mercado. Este mercado busca apreender a produção artística dentro de seus parâmetros de consumo e assim encapsular um espaço potencialmente transgressor, aplicando suas estratégias de controle à arte, inclusive à arte conceitual.

A partir da década de 1960, com a ruptura da arte autônoma e autocentrada, seu extravasamento para além do próprio campo, sua difusão em termos de linguagens e suportes, seu transbordamento para fora dos espaços tradicionais (como museus e galerias), muitos artistas passaram também a refutar o objeto como produto mercadológico e fim último de seus projetos. O processo e, principalmente, o pensamento, passaram a ser os elementos estruturadores de trabalhos artísticos a partir da chamada arte conceitual (Freire, 2006).

Entende-se que as transformações que permitiram a ampliação dos suportes e, consequentemente, do horizonte de atuação das artes visuais, foram fundamentais para a atualização desse campo e para uma oxigenação salutar de ideias que, nas décadas subsequentes, afetaram e seguem afetando o espaço urbano. A cidade passou a ser protagonista da produção de vários artistas, não apenas servindo de local de apresentação de suas obras, mas como tema em si. É a realização do que previa Lefebvre, por um lado, mas que, ao longo dos últimos anos, vem passando por diversos processos de estetização e captura pelo sistema e pelo mercado da arte, como sinaliza Canclini.

A persistência de forças transgressoras nos sinaliza a existência, mesmo que em níveis menos evidentes ou declarados, de sistemas opressores e de estruturas às quais se contrapor, de discursos ou relatos institucionalizados, que ainda justificam esse binômio encapsulamento/ transgressão. Segundo Canclini, o esforço feito por artistas desde o século XIX no sentido de garantir a autonomia da arte garantiu um espírito "rebelde" ao campo. O autor postula que "entre a inserção social inevitável e o desejo de autonomia, está em jogo o lugar da transgressão criadora, do dissenso crítico e desse sentido da iminência que faz do estético algo que não termina de se produzir, não procura se transformar em um ofício 
codificado nem em mercadoria rentável" (Canclini, 2012).

Aqui nos interessa localizar a produção poética de Alÿs, buscando compreender sua inserção no sistema das artes e, ao mesmo tempo, discutir seu potencial de transgredir ou atravessar fronteiras de seu campo. Mais do que isso, queremos, através das obras analisadas, explorar a contribuição de fatos estéticos como os produzidos por Alÿs capazes de expressar revelações em iminência que alteram nossa sensibilidade sobre o espaço e o tempo que ocupamos nas cidades em que vivemos.

\section{CORPOS EM DESLOCAMENTO}

Francis Alÿs nasceu em 1959 na Bélgica, estudou arquitetura e desenvolveu sua tese de doutorado no Istituto di Architettura di Venezia na primeira metade dos anos 80. Em 1986, escapando do serviço militar belga, optou por participar de um projeto de seu governo para ajudar o México após o terremoto que atingiu gravemente a capital do país, em 1985. Desde então, Alÿs mora na Cidade do México, onde desenvolve sua carreira artística, iniciada aproximadamente em 1989. Naquele ano, Alÿs, após ter dificuldades legais para voltar à sua terra natal e tendo terminado seu serviço no programa no qual tinha se inscrito, busca sua função e seu lugar na imensa e caótica Cidade do México.

Alguns de seus projetos têm como pano de fundo o sentimento de não pertencimento, a figura do estrangeiro, remetendo ao fato de Alÿs ser sempre o "outro" na metrópole latinoamericana que escolheu para viver. Alÿs parte não apenas da sua necessidade de identificação, mas observa como os demais habitantes da cidade criam "personagens" para este fim, buscando diferenciar-se e, ao mesmo tempo, identificar-se na urbe. A ideia de deslocamento e de dissenso estão presentes, assim, na base de muitos de seus trabalhos, e estas questões tomam lugar, em geral, no espaço público. Sua produção é, em larga escala, baseada em territorializações e agenciamentos ou ainda outras táticas relacionadas ao ato de posicionar-se no espaço público urbano, de forma individual ou coletiva.

Alÿs não parece interessado em transformar seus projetos em obras de arte (entendidas aqui como produtos acabados) e declara que para ele os processos são o núcleo do trabalho. O mote do eterno ensaio, de projetos não teleológicos, estão por trás de toda sua poética. O artista reforça uma posição de não trabalhar por resultados, por fins dados ou pela conclusão de suas proposições. Seus trabalhos distanciam-se de obras de arte facilmente capturáveis pelo mercado.

Mesmo com uma produção reconhecida internacionalmente, com exposições solo sediadas na Tate de Londres e no MoMa de Nova Iorque, por exemplo, Alÿs parece repetir em sua trajetória a frase do personagem Bartebly 33 "Prefiro não". Prefiro não entrar no sistema que demanda resultado, prefiro não me adaptar, prefiro me ocupar de outra coisa. É uma postura ativa, de escolha, mesmo que seja uma escolha negativa: Alÿs não se conforma e não se resigna, cria espaços de resistência e de atrito, no território e no tempo que ocupa através de seus trabalhos. Mais do que uma resposta negativa ou transgressora em relação ao sistema das artes, Alÿs está interessado em processos que desencadeiam outros processos, como mitos e fábulas, cujo conteúdo não é apreensível nem circunscrito a um único relato ou a uma narrativa conclusiva.

As inquietações de Alÿs o impulsionam em seus deslocamentos, que hoje se encontram inseridos no meio artístico, talvez, justamente por não encontrarem outro lugar ou campo onde se abrigar. Para Canclini, além da compreensão interna às obras, é fundamental encará-las como "experiências epistemológicas que renovam as formas de perguntar, traduzir e trabalhar com 0 incompreensível ou o surpreendente" (Canclini, 2012). O autor segue ainda indicando, de forma alinhada à Rancière, que a liberdade permitida ao artista é maior do que a um cientista social e que assim a arte consegue dizer, através de "metáforas condensações e incertezas de sentido o que não encontramos como formular em conceitos e leva a reconsiderar as articulações entre estes dois modos de abarcar o que nos escapa no presente" (Canclini, 2012). O próprio artista argumenta que "o principal

\footnotetext{
${ }^{33}$ No conto do autor Herman Melvilles, Bartebly, o escrivão, de 1856, o personagem utiliza a expressão "prefiro não" como uma forma de posicionar-se ativamente (preferir) contra algo (não). É uma escolha pelo não ao invés de uma negação de ação. Ou seja, a postura do personagem é ativa e não passiva. Ele se coloca, declara sua preferência.
} 
motor por trás de muitos de meus projetos é uma profunda incapacidade de compreender" (Alÿs in Thornton, 2015).

\subsection{AÇÕES POÉTICAS}

\subsubsection{TURISTA, 1994}

Em um dia qualquer, no ano de 1994, mais um desses dias chamados "úteis", um gringo instala-se na maior e mais antiga praça da Cidade do México, chamada Zócalo. Escorase no gradil em frente à Catedral, disputando espaço entre os demais presentes, com uma placa indicativa à sua frente onde se lê: turista. Durante todo aquele dia, neste emblemático espaço público da capital mexicana - antiga sede do império Asteca Francis Alÿs se posiciona, em meio a trabalhadores informais que oferecem seus serviços a céu aberto, todos sinalizados por placas diminutas e domésticas, quase como se portassem crachás. Entre encanadores, eletricistas, gesseiros e pintores, o artista joga com seu status de estrangeiro. Sublinha as diferenças presentes na situação que são, para ele, parte de uma vivência pessoal, iniciada por sua mudança de habitat e de ocupação, mas também parte de um processo coletivo e cotidiano de identificação na urbe

Turista, 1994. Francis Alÿs. Documentação fotográfica de uma ação

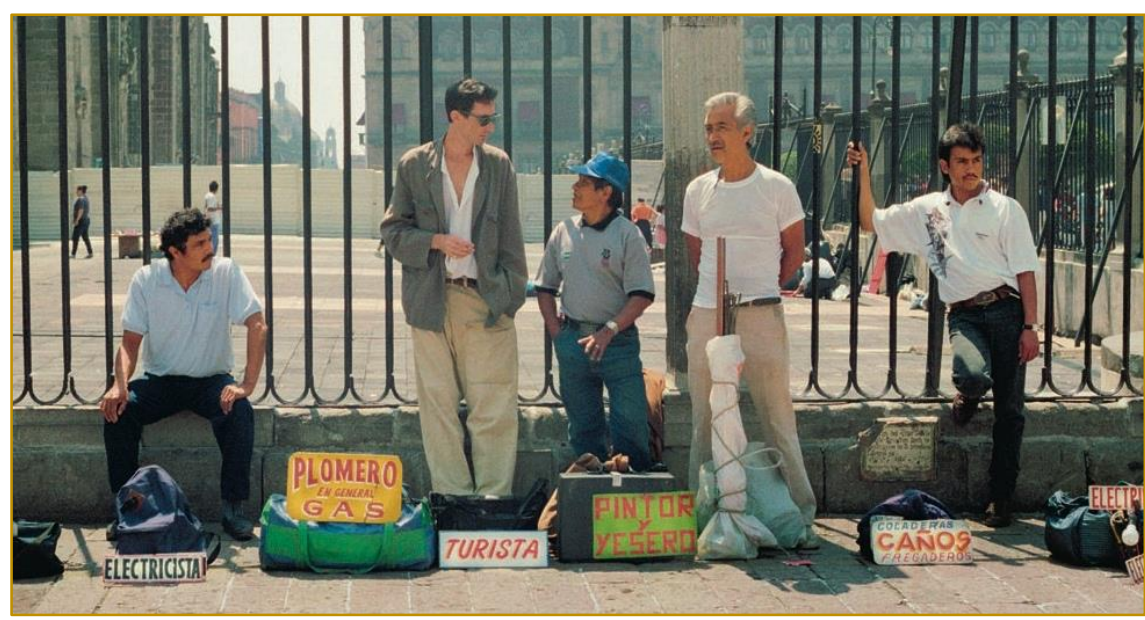

Fonte: FERGUSON; FISHER; MEDINA, 2007, p. 10. @)Francis Alÿs.

"México (D.F.) é uma cidade que te obriga constantemente a responder à sua realidade, (...) a te reposicionar frente a essa entidade urbana desmesurada. Toda essa gente que não deixa de se reinventar: gente que um dia sente a necessidade de construir uma personalidade, uma identidade para afirmar seu sítio neste caos urbano" (Alÿs, 2006). O artista discorre, assim, sobre os processos de identificação e pertencimento, de agenciamento e territorialização a partir de sua vivência no centro da capital mexicana, onde escolheu instalar seu estúdio. Segundo Lefebvre, a manutenção destes antigos núcleos urbanos deve-se a qualidades estéticas como a presença de monumentos e de sedes institucionais de poder, mas também por configuraram-se como espaços destinado originalmente a festas, desfiles, celebrações e passeios. Hoje tornando-se, por esses mesmos motivos, focos de interesse e produto de consumo para turistas e estrangeiros. $\mathrm{O}$ autor atesta que tais centros "sobrevivem graças a este duplo papel: lugar de consumo e consumo do lugar" (Lefebvre, 2001).

Sob o ponto de vista do direito à cidade, a credencial de turista portada por Alÿs opõe-se a dos trabalhadores ordinários ali presentes. Ironicamente, apesar de estarem ocupando a praça pública, aos trabalhadores o direito à cidade é cada vez mais restrito e condicionado. Espaços como o da histórica praça el Zócalo são, cada vez mais, destinados aos turistas, a quem o sistema capitalista concede o direito de permanência, desde que participem das redes de consumo. Processos de negação do direito à cidade, iniciados com as cidades pós-industriais e seus cinturões e subúrbios, são hoje 
acentuados com as políticas de gentrificação, impelindo massas populacionais à periferia não apenas no sentido geográfico, mas também do ponto de vista simbólico, em relação à participação na urbe.

Na perspectiva do regime estético das artes proposto por Rancière, ao se colocar como "um trabalhador - o turista" Alÿs produz um ruído na cotidianidade mexicana; manipula as formas de fazer, de dar visibilidade e de, consequentemente, produzir um pensamento político que já na sua base é estético. O artista não está preocupado em estetizar uma ação política, justamente ao contrário: ao articular corpos no nível do sensível, produz um ato totalmente político e dissensual por natureza. O autor da ação provoca uma leitura comparativa que evidencia o dissenso e o reducionismo da situação, onde uma pessoa é lida por sua função no sistema socioeconômico. Não apenas o artista destoa fenotipicamente dos que o cercam, mas sua função naquele local gera perturbação. $\mathrm{O}$ artista desconcerta os acordos, nos levando a refletir sobre os conceitos de função, ocupação e trabalho, bem como o uso do tempo e do espaço na cidade.

Acerca dessa concepção vale resgatar palavras de Deleuze e Guattari, para quem "o trabalho efetua uma operação generalizada de estriagem do espaço-tempo, uma sujeição da ação livre, uma anulação dos espaços lisos" (Deleuze e Guattari, 1997). Poderia-se dizer que Alÿs, com essa intervenção, está chamando a atenção para o estriamento do tempo livre, hoje já absorvido pelas estruturas de lazer e estratégias de entretenimento que não mais permitem espaços não preenchidos em nossas vidas. Cada hora de nosso dia e cada metro quadrado de nossa cidade precisam enquadrar-se dentro de alguma função, muitas das vezes tendo o trabalho como referência, mesmo que seja por oposição (espaços-tempos de ócio, férias ou turismo). A situação, mesmo antes da ação de Alÿs, poderia ser encarada como um alisamento do espaço público através das táticas que nele tomam lugar, à revelia do planejamento urbano e das políticas de higienização presentes e atuantes naquele momento na capital mexicana. O trabalho informal que diariamente se estabelece no local, através de agenciamentos e processos de territorialização, recebe uma segunda camada de intervenção. Alÿs percebe que, mesmo dentro de uma ação que burla a dominação formal e a gramática do planejamento urbano, existem normas tácitas e posturas já estabelecidas entre os corpos ali presentes, estriando novamente um espaço alisado, remetendo assim à complementaridade e simultaneidade entre esses dois movimentos.

Ao identificar-se como turista, o artista faz ainda outras operações, agindo como se tomasse um enunciado e o colocasse à prova pelo seu inverso, elevando-o a menos 1. Evidenciamos que sua crítica vai além da superfície visto que, ao invés de portar o crachá de artista, Alÿs aprofunda questionamentos, inscrevendo-se como turista. O próprio autor indica que sua ação se situa entre o trabalho e o ócio, entre a observação e a participação. Não se trata de tensionar o próprio campo e de refletir sobre a função do artista na sociedade; Alÿs questiona a noção de ocupação em si. Temos aqui um sinal da transgressão sobre a qual Canclini nos fala. Alÿs suspende 0 entendimento comum sobre ocupação, do tempo e do espaço, ao disponibilizar seu dia e fazer uso do espaço público ao sabor do acaso.

Ao invés de deixar seu tempo ser estriado por uma agenda de atividades, coloca-se à mercê de quem quiser contratar seus "serviços" de turista, gerando reações de incredulidade, surpresa, suspensão de certezas. O artista corporifica perguntas: qual é sua função naquele local? O que pode ser considerado uma ocupação? Qual é o papel do turista naquele contexto? Que elementos geram identidade na coisa pública?

O meio em que está inserido e a soma de sujeitos a ponto de a obra só fazer sentido dentro de uma coletividade e contexto urbano é outro fator presente neste e em outros projetos de Alÿs. Aspecto que nos remete tanto à transgressão ou ruptura da arte com seu campo (pós-autônoma, como defenderia Canclini), como à participação democrática e política potencializada por fatos estéticos. Nesse caso, o corpo do artista é um corpo político, que força sua entrada num sistema ao qual não pertence, criando uma narrativa absurda que acaba por abalar nossas convicções (tão frágeis quanto arraigadas) sobre os modos de produção e de consumo que envolvem os espaços públicos da cidade e as relações sociais nele tecidas. 


\subsubsection{PARADOJA DE LA PRÁXIS 1 - ALGUNAS VEZES EL HACER ALGO NO LLEVA A NADA, 1997}

Alÿs desloca, pelas ruas da Cidade do México, um grande bloco de gelo maciço, usando para isso toda a força de seu corpo. Avança sem rumo por nove, quase dez horas a fio, traçando caminhos cujo rastro é ainda mais efêmero que a ação. O cubo é grande demais e só pode ser empurrado. A passagem do tempo vai desfazendo sua massa e o sólido vai cedendo ao atrito e ao calor, se perdendo no movimento que perfaz. Torna-se pequeno a ponto de poder ser chutado. Derrete-se por completo. O percurso encerra-se no momento em que todo gelo se liquefaz, evapora. O movimento cessa. O trabalho acaba.

Paradoja de la práxis I, 1997. Francis Alÿs. Documentação fotográfica de uma ação.

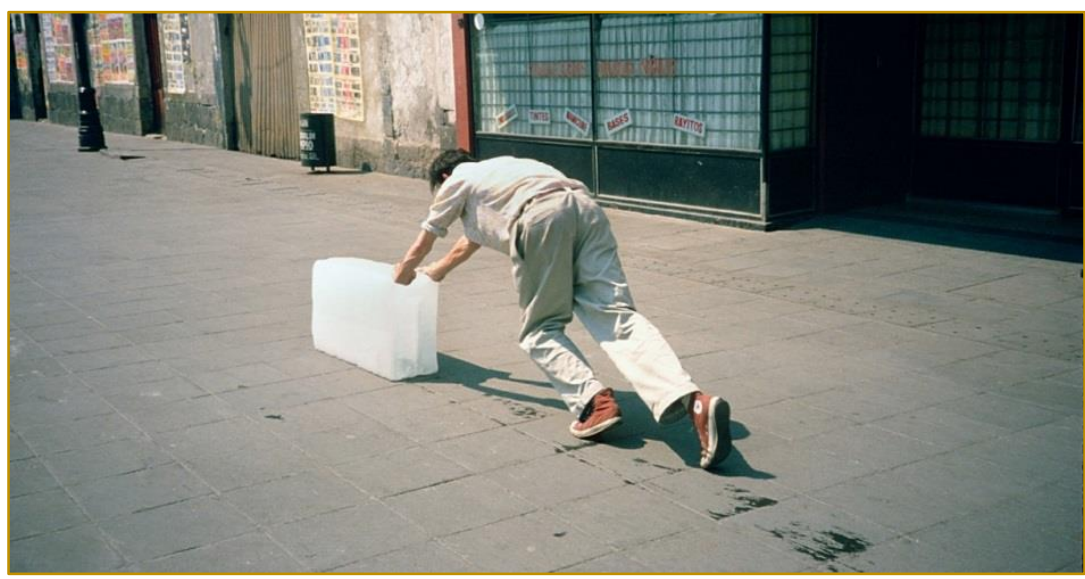

Fonte: FERGUSON; FISHER; MEDINA, 2007, p. 46. @@Francis Alÿs

Em Paradoja de la práxis 1, torna-se ainda mais evidente um aspecto da poética de Alÿs: a provocação em relação ao modo como ocupamos nossa vida urbana e a percepção do artista frente à história latino-americana de eterna busca pelo progresso. Lefebvre defende que, já a partir da metade do século XIX, a burguesia "progressista" toma para si o papel de desenvolver a economia, através de um discurso de crescimento racional. Neste caminho, avança substituindo a opressão pela exploração e, segundo ele, "esta classe enquanto tal não mais cria; substitui a obra pelo produto" (Lefebvre, 2001). A ação de Alÿs vai na contramão desse sistema de valores que coloca o produto no mais alto patamar e olvida-se da obra. Paradoja de la práxis 1 desfaz o produto. O que permanece é apenas a obra em seu entendimento mais amplo. O trabalho de Alÿs se contrapõe ao domínio progressista trazido por agentes externos. Alÿs foca no axioma "máximo esforço, mínimo resultado", enunciado por ele ao comentar a alusão que a obra faz ao processo de modernização sempre incompleto e cíclico das cidades latinoamericanas. Nelas, anacronismos e espaços de resistência parecem surgir na mesma medida em que padrões norte-americanos ou europeus são impostos à população local, visando o desenvolvimentismo rumo ao "primeiro mundo". Como dizia Lefebvre, o ser humano tem a necessidade de acumular energias e a de desperdiça-las, inclusive em atividades lúdicas. É o que realiza Alÿs, contrariando a lógica racionalista de produtividade a que estamos subjugados em nossas rotinas. O artista se apropria da cidade, passeando por suas avenidas, fazendo uso do espaço público conforme the convém, através de suas narrativas e ficções, seus jogos, transformando o acúmulo (de gelo, de energia, de tempo) em puro "desperdício".

O tempo dos habitantes da cidade aparece atrelado a indicadores de produtividade e remete ao jargão de que "tempo é dinheiro", sendo parcelado em atividades funcionais, muitas vezes ligadas às necessidades de consumo criadas por um sistema que parece intangível ao cidadão comum. A eficiência da urbe, expressa pelo pensamento modernista, racionalista, é posta em suspensão, através 
da proposição do artista. O significado de desperdício ou de falência gera desacordos e, através de sua proposição no nível do sensível, Alÿs cria contornos que evidenciam esse dissenso. A atitude é política desde sua concepção, coadunando com o entrelaçamento entre estética e política postulado por Rancière. Alÿs inaugura aqui um tema que será desenvolvido ao longo de sua carreira, atrelando o mote de suas ações ao mito de Sísifo, a falência e ao eterno ensaio que nunca chega ao fim. O absurdo da ação nos remete ao entendimento de Rancière sobre o que é irrepresentável e que precede a racionalidade. Trata-se de uma sensibilidade posta em evidência através de um acontecimento estético, que provoca diferentes formas de pensar e de articular os pensamentos. Aqui não podemos partir de nosso parâmetros e acordos para analisar a obra. A ação suspende o inteligível, desestabiliza nossas certezas.

Para Deleuze e Guattari alisamentos são secretados e produzidos justamente onde o estriamento chega a seu ápice. Segundo eles "habitar a cidade como nômade, ou troglodita. Às vezes bastam movimentos, de velocidade ou de lentidão, para recriar um espaço liso. Evidentemente, os espaços lisos por si só não são liberadores. Mas é neles que a luta muda, se desloca, e que a vida reconstitui seus desafios, afronta novos obstáculos, inventa novos andamentos" (Deleuze e Guattari, 1997). Alÿs alisa, com seu movimento, parâmetros de sucesso, completude e eficiência; desacelera o ritmo ao criar um obstáculo contrário ao seu deslocamento. O artista não traz respostas prontas nem apresenta soluções ao projeto de modernização ou à forma como ocupamos nosso tempo ou nossos espaços na cidade. Aponta, contudo, para fissuras neste sistema, nos indica outros tempos possíveis, distende a ideia de presente através de sua ação continuada e não balizada por uma meta ou futuro previsível, e sim por um possível devir. Como escrevem os filósofos "talvez seja preciso dizer que todo progresso se faz por e no espaço estriado, mas é no espaço liso que se produz todo devir" (Deleuze e Guattari, 1997).

Canclini disserta que uma boa pergunta deve evitar, a todo custo, uma resposta. Alÿs, em suas entrevistas, alinha-se a essa visão. Mantém sempre presente 0 espírito questionador de suas obras, que provocam mais do que esclarecem. Problematiza, além disso, os próprios cânones artísticos, como a importância - praticamente um fetiche garantida pelo sistema das artes ao objeto, especialmente ao cubo. Essa forma representa a quintessência da arte minimalista. Ao criar um cubo de gelo, que desmaterializa-se durante a ação, Alÿs ironiza a relevância do produto e do enquadramento de ações poéticas em classificações prédeterminadas, facilmente manejáveis pelo mundo da arte, com seu vocabulário próprio. $\mathrm{O}$ artista segue assim gerando transgressões, não se deixando encapsular, pelo menos não totalmente. Não se trata aqui de afirmar - o que seria no mínimo ingênuo - que Alÿs não participe e não se beneficie do sistema e do mercado da arte. Afinal, esta é sua profissão. No entanto, é importante identificarmos a capacidade de seus projetos em seguir criando tensões e iminências que forçam, sempre para mais além, as fronteiras da arte. Canclini afirma que "a arte é o lugar da iminência" e que "seu atrativo procede, em parte, do fato de anunciar algo que pode acontecer, prometer o sentido ou modifica-lo com insinuações (...) Deixa o que disse em suspense" (Canclini, 2012).

A partir do trabalho Paradoja de la práxis 1, Alÿs parece nos lançar perguntas: destinar grande parte de nosso tempo, espaço e energia, buscando alcançar um padrão importado de sucesso e progresso que nunca chega é menos absurdo do que realizar tarefas sem um propósito definido, como empurrar um bloco de gelo? A forma como ocupamos nosso tempo pode interferir na forma como o sentimos, como o pensamos ou como o articulamos com os acontecimentos e suas durações? Que transformações podem ocorrer quando invertemos a lógica da meta, ao subordinar o ponto de chegada ao trajeto?

\subsubsection{BARRENDEROS, 2004}

Todos os dias centenas de ambulantes e camelôs ocupam as ruas centrais da capital mexicana. Sua presença é massiva e suas práticas fazem parte de uma tradição de comércio de rua arraigada na cultura local. Todas as noites esses ambulantes e camelôs saem do centro, levando consigo seus carrinhos, barracas, tendas e produtos. Deixam, porém, resíduos, restos, cascas, lixo atrás de si, como um testemunho de sua existência. Entram em ação os garis que, nas madrugadas, transformam os resíduos em limpeza, em ausência. Mais um dia começa, a 
cena se repete: presença-resíduo-limpezaausência. O ciclo é interrompido quando, numa noite, um convite é lançado aos varredores encontrados no caminho, aleatoriamente. A proposta, feita por Alÿs, é que os garis se organizem em grupo e o grupo em uma linha, empurrando os restos com suas vassouras, formando um bloco de lixo, único, grande e denso, até o ponto de não mais conseguirem movê-lo.

Barrenderos, 2004. Francis Alÿs em colaboração com Julien Devaux. Still de vídeo.

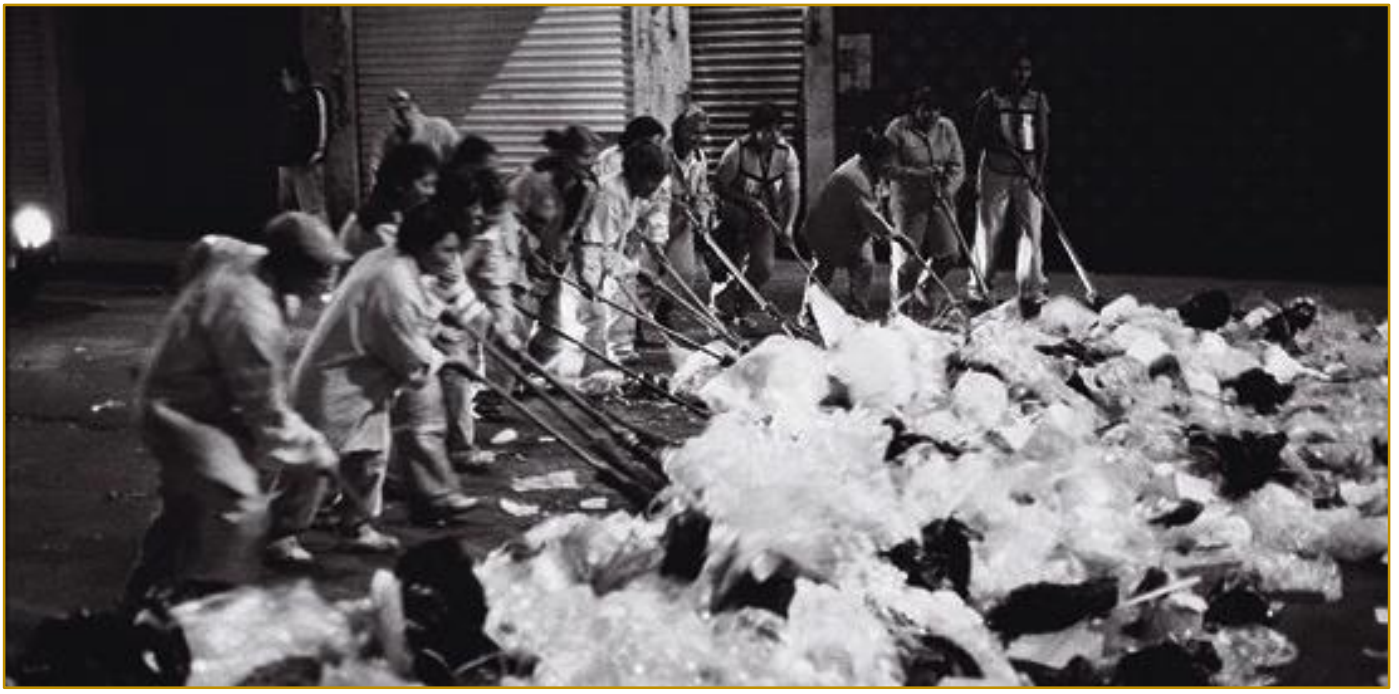

Fonte: FERGUSON; FISHER; MEDINA, 2007, p. 50. OOFrancis Alÿs

Podemos pensar na proposta em relação ao direito à cidade a partir de uma leitura que aponta para os processos de expulsão do proletariado e de "biscates" da vida urbana e de seus centros de poder. Fica evidente, em Barrenderos, a falência das instituições governamentais em implementar seu projeto de "revitalização" do centro da capital mexicana - um eufemismo para o processo de gentrificação ali iniciado na década de 1980 e comum a várias cidades latinoamericanas. A adoção do nome centro histórico, no lugar de centro, naquele período, denota este tipo de processo que, no início do século XX, atendia por nomes como plano de melhoramentos, saneamento ou embelezamento urbano. De forma irônica, Alÿs nos mostra o avesso deste processo, através do acúmulo de lixo nas ruas do coração da cidade, atestando não apenas a presença dos que se pretendia excluir, mas de seus resíduos indesejáveis. A mobilização, que acaba por formar uma barricada, nos endereça, por exemplo, às revoluções do século XIX, quando, grosso modo, as camadas oprimidas reivindicavam seu direito à cidade e à participação política. As barricadas que tomaram as ruelas medievais da França naquela época são, ainda hoje, um símbolo de resistência e de disputa pelo poder daqueles que se sentem excluídos do sistema, escanteados na política e na vida pública. Coincidência ou não, o filme encerra com a passagem do carro da polícia pelos garis, após o fim da ação, nos lembrando da constante disputa pelo domínio do espaço público entre o poder constituído, com suas estratégias de controle e repressão e as táticas que burlam esse sistema, como as criadas pelos trabalhadores informais. Seja através do registro em fotos e vídeos realizado por Alÿs neste e em outros trabalhos - como ferramenta de persistência e de memória dos ambulantes e camelôs no centro urbano; seja através da alusão às barricadas, - artista toca em pontos fundamentais relativos ao direito à cidade.

Alÿs contribui para apontar os dissensos presentes naquele cenário, ao criar uma ficção que se realiza no espaço público, expondo suas idiossincrasias e revelando sujeitos, usos e formas de expressão ocultas ou ainda não exploradas neste locus político. Aqui a ficcionalidade é, como afirma Rancière, "uma potência de significação inerente às coisas mudas" (Rancière, 2009). Gera com os garis e demais participantes da 
ação um modo de compartilhamento do sensível, em torno de um proposta que poderia ser consideradas quixotesca ou, no mínimo, despropositada, mas que revela-se, ao final, extremamente política em sua beleza deslocada.

A operação é inicialmente orquestrada por Alÿs, mas aberta o suficiente para que seja coordenada pelo próprio coletivo a partir de um certo ponto, a partir do qual perde-se a noção de sujeito ou hierarquia. É organizada numa partilha comum, no agenciamento dos corpos ali presentes, que vão se conformando ao longo do tempo. Ao final do vídeo, Alÿs comenta que a ação teve um desenrolar muito mais bonito do que ele tinha imaginado em seu projeto. Essa estrutura aberta, incompleta e imprevisível, alinha-se às ideias defendidas também por Deleuze e Guattari e fazem parte dos processos poéticos de Alÿs. Percebemos ainda outro ponto de encontro entre a ação e os dois teóricos quando, ao analisar as cidades, indicam que o espaço estriado não cessa de criar espaços lisos, ou que as redes de ordem da estratégia produzem permanentemente o oposto a seus objetivos: assim o lucro e a produtividade geram desperdício no sistema e miséria fora dele. Alÿs revela esta tensão através do conceito de desperdício e dos resíduos gerados pelo sistema. Poderia-se dizer, inclusive, que ao fazer uma proposição formal, criando uma espécie de escultura com o lixo, Alÿs estria um espaço dantes liso. Ao mesmo tempo, alisa a ação de trabalhadores ao propor uma atividade que escapa completamente à função para a qual foram contratados. Brinca, assim, com outros possíveis modelos de ocupação do tempo que fogem ao do trabalho, nos lembrando das sociedades indígenas da América Latina, muitas vezes chamadas erroneamente de sociedades da preguiça. Eram sociedades de ação livre, de espaço liso, que desprezavam a noção de excedente ou de acúmulo e que, por vezes, preferiam deixar-se morrer a realizar trabalhos forçados. Preferir deixar-se morrer, assim como Bartleby, o escrivão, é uma postura de alisamento extrema frente a um sistema opressor que impõe suas regras sem deixar espaço para atividades criadoras como a proposta por Alÿs.

O artista cria as condições necessárias para que a forma resulte de tensões internas ao processo em si e não de um desenho feito $a$ priori, dissolvendo a noção de autoria tão cara ao campo da arte. O potencial transgressor do trabalho reside não somente neste aspecto, mas também, na enorme capacidade da ação em gerar diferentes chaves de leitura tanto dentro de seu campo como fora dele. Podemos, por exemplo, identificar vínculos com a ideia de escultura social, de Beuys, visto que não artistas são incitados a dar forma ao objeto de seu trabalho, ao coreografarem uma dança expressiva, que culmina com a conformação de um corpo intransponível. Em Alÿs percebemos $\mathrm{o}$ ato político na base do fato estético. Para melhor entender a diferença, podemos contrapor esta ação a algumas obras do artista Vik Muniz realizadas a partir de resíduos, como na série Lixo extraordinário. À diferença de Muniz, que utiliza restos para compor imagens préconcebidas, Alÿs não estetiza o lixo, não cria um produto pronto, não se deixa encapsular pelo sistema da arte nem pelo apelo do mercado. Grande parte de suas obras sequer podem ser consumidas, e mesmo seus registros estão, em geral, disponíveis online gratuitamente para download. Canclini identifica nesta postura o potencial transgressor, de iminência, que lhe interessa nos artistas que não se limitam a um ofício codificado ou à produção de mercadorias rentáveis.

\subsubsection{PUENTE, 2006}

Imagine uma negociação proposta a diferentes grupos de barqueiros, pescadores, turistas e velejadores para criarem, a partir do enfileiramento de seus barcos, casco a casco, uma linha o mais longa possível, mar adentro. Imagine recrutar diversos voluntários para essa ação em dois países separados por alguns quilômetros de oceano, no intuito de formarem, na união de suas linhas, uma ponte. Agora imagine que estes países são Cuba e Estados Unidos. Neste projeto Alÿs utiliza os canais de fluxo e de trânsito que estão à disposição da população de Havana e de Keywest, que são públicos de certa forma, para questionar as linhas arbitrárias e muitas vezes invisíveis, nem por isso, menos difíceis de cruzar, entre fronteiras. Alÿs trabalha com a noção de barreira, propondo quebras nesses limites impostos, possibilidades de escapar ao sistema ou, no mínimo, de evidenciar seu absurdo. Expande, com isso, o conceito de espaço público para além das ruas e praças urbanas, alcançando as praias públicas, as águas de domínio público, o mar. 
Bridge/Puente, 2006. Francis Alÿs em colaboração com Tayana Pimentel e Cuauhtémoc Medina. Documentação fotográfica de um evento.

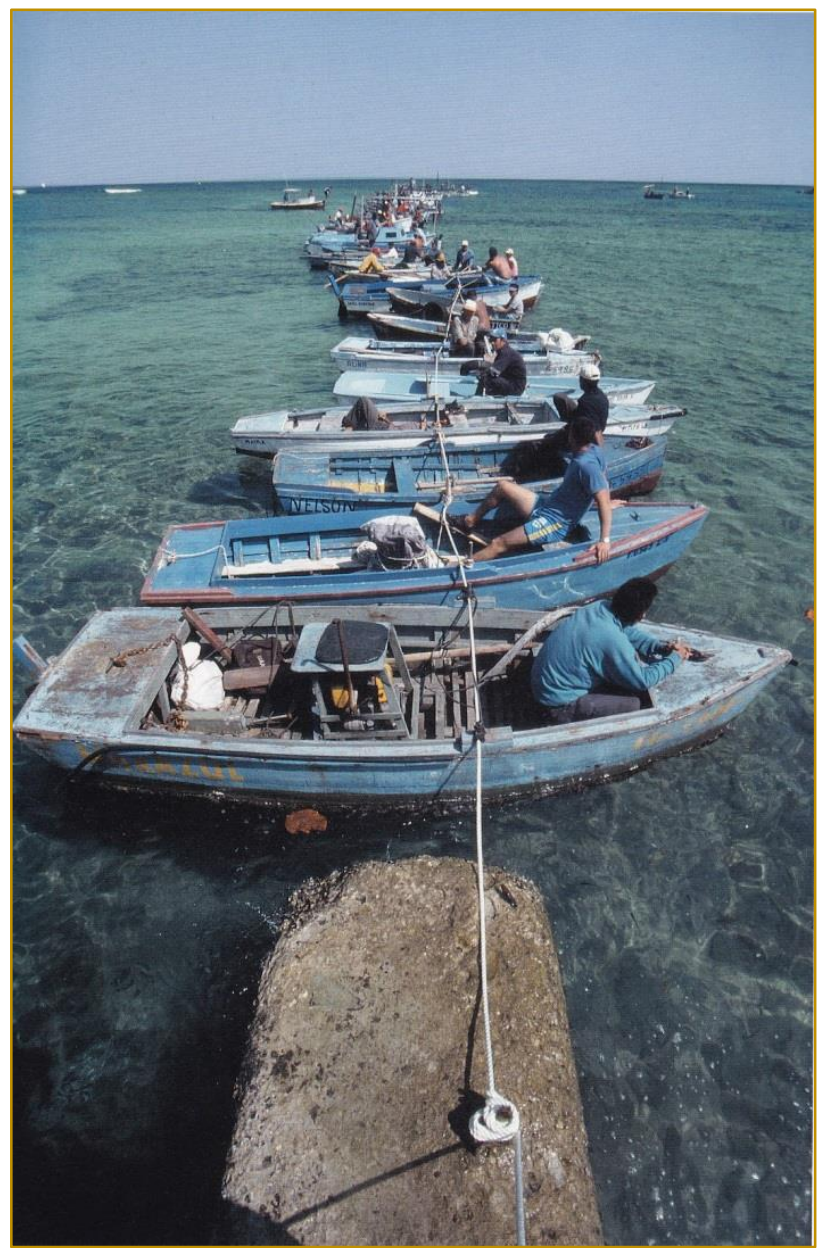

Fonte: FERGUSON; FISHER; MEDINA, 2007, p. 107. (C)Francis Alÿs

Lefebvre nos fala de direito ao acesso, ao público, ao heterogêneo, à apropriação. Alÿs nos propõe maneiras de atualizar esse discurso, realizando-o através de ações poéticas. A ponte a ser construída coletivamente representa uma união tida por impossível, entre dois mundos de acentuadas diferenças culturais, políticas e, obviamente, econômicas. O autor afirma, ao falar de arte, que esta "restitui o sentido de obra; oferece múltiplas figuras de tempos e espaços apropriados: não impostos, não aceitos por uma resignação passiva, mas metamorfoseados em obra" (Lefebvre, 2001). Alÿs incita a população local de cada margem a não se resignar, a lutar contra as barreiras invisíveis que separam os dois países, que limitam seu direito de acesso e de apropriação. Trata-se, inicialmente, de uma ficção, algo não palpável ou concreto, mas que toma forma na vida real, assim como as fronteiras. Através de uma proposta disruptiva, o artista nos defronta com a criação de possibilidades não filtradas pela razão. Segundo Lefebvre "não há dúvida nenhuma que o conhecimento da realidade urbana possa incidir sobre o possível (ou sobre as possibilidades) e não apenas sobre o acabado ou sobre o passado" (Lefebvre, 2001).

Alÿs corrobora assim na geração de outros possíveis que determinam modos de transformação, através do regime estético da arte, criando um posicionamento político. Toda proposta parte do dissenso. No vídeo registro da ação, percebemos, por exemplo, a assimetria entre a quantidade de voluntários participando do lado norte-americano (menos de uma dezena), do expressivo número de participantes cubanos. Não existem acordos e a negociação de onde parte o artista evidencia essa necessidade política em lidar 
com sujeitos plurais, não apenas em seus objetivos, mas em suas visões, identidades e papéis no projeto proposto. Rancière discorre que o conceito de vanguarda artística só faz sentido quando temos a "invenção de formas sensíveis e dos limites materiais de uma vida por vir" (Rancière, 2009). Criar pontes é o que fazem nossos pensamentos, gerando novas associações e significados possíveis para conceitos existentes. O mesmo procedimento é incentivado por Alÿs, buscando novas formas de pensabilidade sobre uma situação já não mais questionada em seus fundamentos.

Ao propor ações processuais em que o percurso torna-se mais importante do que o ponto de partida ou o de chegada, Alÿs nos remete à diferença entre liso e estriado proposta por Deleuze e Guattari, quando afirmam que um e outro se diferenciam, antes de mais nada, pela relação inversa do ponto e da linha: no espaço estriado parte-se de dois pontos entre os quais desenha-se uma linha, enquanto no liso o que importa são os pontos que resultam do cruzamento das linhas, o entre. Alÿs propõe a criação de duas linhas, mas o que interessa é a possibilidade de uma intersecção entre elas, um cruzamento, uma ponte, um entre.

Canclini diria ainda que "a tarefa da arte não é dar um relato à sociedade para organizar sua diversidade, mas valorizar o iminente onde o dissenso é possível" (Canclini, 2012). O autor postula ainda que trabalhos poéticos não apenas suspendem a realidade, mas é como se estivessem posicionados num momento anterior, onde e quando o real ainda é possível, onde tudo está a ponto de ser. O antropólogo encontra eco na ação de Alÿs, mas também em suas palavras, quando afirma que "não se mudou nada, mas se introduziu por algumas horas a possibilidade de mudança" (Alÿs, 2007). É um pensamento transgressor e recorrente na trajetória de Alÿs, que defende que essas experiências têm muito mais valor por suas múltiplas tentativas do que por sua conclusão. A respeito de sua produção, Alÿs segue ainda, lançando as seguintes perguntas:

"É possível uma intervenção artística verdadeiramente trazer uma maneira imprevista de pensar ou é mais uma questão de criar uma sensação de 'falta de sentido' que mostra o absurdo da situação? Pode uma intervenção artística traduzir tensões sociais em narrativas que, por sua vez, intervêm na paisagem imaginária de um lugar? Pode um ato absurdo provocar uma transgressão que faça você abandonar os pressupostos padrão sobre uma situação, como as fontes de conflito? Podem estes tipos de atos artísticos trazer possibilidades de mudança? Como a arte pode permanecer politicamente significativa sem assumir um ponto de vista doutrinário ou que aspira a tornar-se ativismo social? No momento, eu estou explorando o seguinte axioma: Às vezes fazer algo poético pode se tornar político e às vezes fazer algo político pode se tornar poético" (Alÿs, 2007).

\section{MOVIMENTOS CIRCULARES}

Seria difícil e incoerente buscar, em um símbolo único, uma síntese do pensamento de Alÿs ou das ações apresentadas neste artigo; não é este nosso intuito. Mesmo assim, arriscamos trazer aqui a figura de movimentos circulares ou de ondas, amparados num depoimento do próprio artista ao sugerir que "se mover em círculos pode ser uma forma de avançar" (Alÿs, 2006). Se boa parte dos projetos aqui discutidos remetem ao conceito físico de trabalho, tendo guiado, inclusive, a separação do artigo em seus capítulos, este conceito não ajuda a traduzir os pensamentos formulados a partir das ações poéticas analisadas. Estamos mais próximos, assim, da sentença trazida pelo artista, quando argumenta que "não se pode traçar uma reta em um espaço curvo" (Alÿs, 2007).

Partimos então do entendimento de que este artigo não avança em linha reta, não tem uma progressão ou uma meta. Mas constrói um caminho, uma trajetória que de alguma forma, avança. Talvez a imagem de propagação em ondas, através de círculos concêntricos, seja válida para entendermos como uma obra artística pode gerar contribuições em outros campos. Assim, ao criar fábulas que se dissipam através da multiplicação das fontes de narração, ao tentar repetir ações poéticas que partem de uma ideia comum, Alÿs intensifica seu efeito e dilata seu raio de alcance. Cria ruídos que afetam o ambiente à sua volta, como ondas sonoras, de forma mais ou menos intensa. Busca explorar os efeitos de proximidade ou afastamento, inclusão ou exclusão dos centros, em seus aspectos físicos e simbólicos.

O entendimento de espaço de intervenção e o raio de atuação de suas ações parecem se ampliar, ao longo de sua trajetória. Inicialmente percebemos um artista muito próximo à sua formação de arquiteto e 
urbanista, trabalhando no centro da cidade do México, buscando compreender seus espaços públicos. Logo a dimensão de espaço público ganha as ruas, avança rumo à periferia (em trabalhos como Cuando la fe mueve montañas, de 2002, em Lima), transpondo os limites da cidade e chegando às margens e fronteiras. Alcança os espaços que seriam, a princípio, de domínio público, mas cuja ultrapassagem ou transposição pode demandar um esforço hercúleo, considerado absurdo. Assim como Lefebvre, Alÿs parece expandir o conceito de urbano para além dos limites da cidade, estendendoo para todos os espaços onde existe condensação de processos sociais e relações de produção.

O artista transborda o sentido de espaço e ocupa a cidade também em sua dimensão temporal. Lefebvre já havia alertado para a circunscrição não salutar, realizada pelo urbanismo moderno, que especializou o tempo, subordinando-o a suas métricas. Através de desacelerações, mudanças de ritmo, interferências nas agendas e no cotidiano da cidade e de seus habitantes, Alÿs cria outros tempos no tempo. Alisa o estriamento de nossa vida em dias úteis e atividades programáticas. Recorre ao absurdo e aos movimentos da física para nos lembrar que existe sempre um momento, o ápice, quando um corpo já parou de subir, mas ainda não começou a descer, quando a velocidade é igual a zero e todo movimento está a ponto de ser invertido.

Outra expansão na trajetória de Alÿs é declarada pelo próprio artista ao afirmar que

\section{REFERÊNCIAS}

[1] Alÿs, Francis. Sometimes doing something poetic can become political and sometimes doing something political can become poetic. Nova Iorque: David Zwirner, 2007.

[2] Alÿs, Francis. (Contemporary Artists). Londres: Phaidon, 2007.

[3] Alÿs, Francis; Medina, Cuauhtémoc. Diez cuadras alrededor del estudio / Walking Distance From the Studio. Cidade do México: Antiguo Colegio de San Ildefonso, 2006.

[4] Canclini, Néstor García. A Sociedade sem Relato: Antropologia e Estética da Iminência. São Paulo: Editora da Universidade de São Paulo, 2012.

[5] Certeau, Michel de. A invenção do cotidiano. Petrópolis: Vozes, 1994. em seus trabalhos iniciais a mensagem era "às vezes fazer algo não leva a nada" e que, num segundo momento, passou a ser "às vezes fazer algo pode se transformar em outra coisa". Assim, as alegorias ao mito de Sísifo, à ideia de falência ou à identificação com o conceito de estrangeiro, servem como uma postura questionado, porém ativa, engajadora. Alÿs nos impulsiona e nos move contra a inércia e a passividade, cria fábulas, constrói pontes, descompassa o tempo, vinculando poética e política, ética e estética.

As ações identificam-se com o que Certeau (1994) chama de microrresistências e, mesmo através de uma pequena amostragem de suas obras, como a apresentada neste artigo, podemos entrever sua potência desestabilizadora. Suas proposições encontram-se na contramão da sentença de Tatcher, arranham os discursos hegemônicos e escapam ao encapsulamento de práticas artísticas pelo mercado. Se contrapõem aos processos de estetização característicos de nossa época e também à leitura conformista de que somos todos consumidores dentro de um sistema capitalista (como profetizada pelos Situacionistas e reatualizada por Lipovetsky e Serroy, 2015). A hipótese que permanece é de que a potência na trajetória de Francis Alÿs está em seguir buscando novos possíveis, causando estranhamentos e instabilidades no espaço urbano, apontando para aquilo que está a ponto de se tornar, e dessa forma, às vezes fazer algo poético se tornar político e às vezes fazer algo político se tornar poético...

[6] Deleuze, Gilles; Guattari, Felix. Mil Platôs: Capitalismo e esquizofrenia. São Paulo: Editora 34, 1997.

[7] Durini, Lucrezia de Domizio. The Felt Hat A Life Told. Milão: Charta, 1997.

[8] Ferguson, Russel; Fisher, Jean; Medina, Cuauhtémoc. Francis Alÿs. Londres: Phaidon, 2007.

[9] Freire, Cristina. Arte Conceitual. Rio de Janeiro: Zahar, 2006.

[10] Harvey, David. Espaços de Esperança. São Paulo: Loyola, 2004.

[11] Laurentiis, Clara Barzaghi de. Francis Alÿs Percursos e desvios. Trabalho Final de Graduação. São Paulo: FAU-USP, 2014.

[12] Lefebvre, Henri. O direito à cidade. São Paulo: Centauro, 2001. 
[13] LIPOVETSKY, Gilles; SERROY, Jean. A estetização do mundo: viver na era do capitalismo artista. São Paulo: Companhia das Letras, 2015.

[14] Rancière, Jaques. A partilha do sensível: estética e política. São Paulo: Editora 34, 2009.
[15] Thornton, Sarah. O que é um artista. Rio de Janeiro: Zahar, 2015.

[16] Site oficial do artista: http://www.francisalys.com 


\section{Gapítulo 10}

\section{NARRATIVAS DA CIDADE: UMA APROXIMACÃO ENTRE MEMÓRIA COLETIVA, CIDADE E LITERATURA.}

\section{Rodrigo Vitorino Assumpção}

Jane Victal Ferreira

Resumo:Esse artigo elabora uma reflexão sobre a memória coletiva e a formação das identidades urbanas na cidade de São Paulo, utilizando a obra literária de Alcântara Machado como fonte primária de pesquisa. Para tanto, dividimos o trabalho em duas partes. Em primeiro lugar apresentaremos uma discussão sobre narrativas literárias e narrativas urbanas, conforme aspectos tratados em obras de Paul Ricouer, Walter Benjamin e Bernardo Secchi. Posteriormente faremos uma reflexão sobre a memória coletiva de Mauricie Halbwachs e o resgate das narrativas apresentadas na obra de Alcântara Machado para o estudo da cidade de São Paulo.

Palavras Chave: Memória Coletiva, Cidade, Literatura. 


\section{INTRODUÇÃO}

A cidade como sedimentação de signos ao longo do tempo e espaço constitui o registro indelével no território, conforme sugere Bernardo Secchi (2006). O espaço urbano é o resultado direto da ação do homem, seja por meio de leis que ordenam os usos da cidade, ou por uma constituição arquitetônica mais informal de técnicas vernáculas, que moldam a morfologia urbana. Os registros podem ser associados como parte de um todo ou em pequenos fragmentos, que auxiliam na interpretação de um determinado fato marcante para a História Urbana daquele local. Nesse caso, esses registros - pautados por documentos oficiais - reconstroem uma "História Oficial", ou seja, uma historiografia associada aos fatos que produzem uma identidade nacional, ou regional. No caso da cidade de São Paulo, muitos desses documentos são encontrados na Assembléia Legislativa ou em arquivos históricos públicos.

São documentos que, por possuírem um caráter político e social significativo para a compreensão da História Urbana, muitas vezes se sobrepõem a outros registros que, a princípio, podem parecer de menor valor histórico. Entretanto, quando esses registros são observados mais atentamente, eles apresentam fatos que os documentos oficiais não conseguem transparecer. Isso não significa que, na essência do fato, temos duas ou mais Histórias conflitantes sobre a mesma cidade, nem tão pouco há uma importância maior entre elas. Na realidade são metodologias narrativas distintas e por consequência possuem fontes de pesquisa distintas, bem como resultados e análises distintos. Nesta dualidade epistemológica destacamos duas análises pertinentes ao trabalho do historiador: a memória coletiva e a memória individual, ambas descritas na obra de Maurice Halbwachs.

A História enquanto ciência é, na sua essência, uma narrativa. Mas o que nos interessa, nesse artigo, é uma reflexão sobre histórias do cotidiano paulista do início do século XX. Nesse sentido, encontramos na obra de Antônio Alcântara Machado um meio de resgate da memória coletiva relativa à formação dos bairros operários de São Paulo: Brás, Bexiga e Barra Funda. A leitura do espaço urbano e a construção das narrativas fazem parte da formação das Identidades Urbanas. A cultura que emerge nas ruas estabelece relações diretas entre o tempo e o espaço, assim como as relações entre memória e lugar são constituídas por diversos fatores sociais, políticos, econômicos e culturais. A literatura se encarrega de estabelecer uma outra narrativa, onde reafirma a consciência de identidade e memória coletiva apresentados por grupos sociais que constituíram a cidade ${ }^{34}$. Diferentemente do historiador das cidades, que baseia sua narrativa nos documentos históricos, ou do cronista histórico que constrói sua narrativa a partir da topologia das ruas e dos homens e fatos importantes que constituiram a cidade, a obra de Alcantara Machado apresenta sua narrativa por meio das vivencia do espaço urbano de um grupo social de imigrantes que ocupam uma nova porção territorial e concebem novos bairros na cidade. A vida cotidiana desses imigrantes são narrativas urbanas, que trabalham em um plano individual, ao mesmo tempo em que abrangem o aspecto coletivo da sociedade, possibilitando a constante elaboração da sua identidade local.

Nesse trabalho exploramos justamente a importância da literatura para uma rafiticação da identidade urbana. A narrativa literária se entrelaça à narrativa da própria cidade a fim de salientar as questões de memória coletiva e identidades. Para tanto, abordamos nesse artigo as questões sobre narrativas e posteriormente a narrativa literária de Antônio Alcantara Machado como método para discussão sobre a identidade urbana.

\section{AS NARRATIVAS E A EXPERIÊNCIA}

Para Benjamin a arte de narrar um fato está em vias de extinção, pois poucos são aqueles que sabem fazê-lo devidamente (Benjamim,1987). A narrativa está vinculada diretamente com a experiência vivida, isto é, com o conhecimento vivenciado em sua plenitude, e para o autor, vivemos em um tempo sem experiência. Essa afirmação de Benjamin decorre do conhecimento sobre a essência da narrativa que tem como função transmitir uma mensagem, codificada através da linguagem e compreensível a um determinado grupo cultural. Coloca-se como uma ligação comunicativa entre um sujeito emissor e um sujeito receptor. Entretanto,

\footnotetext{
34 Um exemplo de historiador de cidades que podemos destacar é Benedito Lima de Toledo com seu livro São Paulo: três cidades em um século; enquanto um crostista histórico que merece atenção é Paulo Cursino de Moura com a obra São Paulo de outrora: evocações da metrópole.
} 
diferentemente da informação, a narrativa possibilita diversas interpretações do fato narrado. É também uma relação entre o homem, o tempo e as imagens, na medida em que aquele que emite a mensagem - tal qual o que recebe - cria diversas imagens em tempos distintos. Ao se estabelecer a narrativa de um fato - seja aquele que emite ou o recebe - cria imagens distintas do evento narrado.

Ricouer (1994) aponta que o mundo apresentado pela obra narrativa é sempre um mundo temporal, e ressalta que o tempo torna-se tempo humano visto que se articula de modo narrativo, assim como a narrativa esboça traços da experiência temporal. O tempo humano é oposto ao tempo cronológico na medida em que o primeiro carrega na sua essência o tempo como experiência de vida, enquanto o segundo é um passar do tempo sem relação direta com a experiência. A narrativa possui a premissa de transmitir a experiência vivida e, portanto, é uma qualificação da existência temporal o que, para a Ricouer, remete a discussão sobre o tempo como "ruminação inconclusiva" e réplica da atividade narrativa.

Diferentemente da construção da poesia, onde a sublimação da palavra tem a função de representar o instante do tempo, tornandoo instante poético, a narrativa se constrói no tempo existencial do narrador, que só finda com a sua ausência. Portanto, há um campo homogêneo do tempo entre narrador e fato narrado, onde o tempo do narrador é simultâneo ao fato narrado, sendo que um complementa o outro. Assim, o próprio fato narrado é parte do narrador, ou seja, é a sua representatividade na experiência existencial.

A crítica sobre o tempo sem experiência em Benjamin é retomada por Olgária Matos ${ }^{35}$. Em ambos os autores o declínio de experiência provém do surgimento da cidade industrial, quando ocorre a substituição dos modos de ser do homem tradicional - àqueles vinculados as atividades da terra - por aqueles do homem moderno. As narrativas de Benjamin acontecem na passagem da cidade tradicional para a industrial europeia, semelhantemente a obra de Alcântara Machado que é escrita no início da industrialização paulista. Nestes dois contextos, a cidade se transforma, tornandose metrópole, mas na obra literária o autor expõe a formação das identidades urbanas

\footnotetext{
${ }^{35}$ Ver também vídeo da CPFL sobre o assunto.
}

dos bairros paulistas, pautada pela relação com a memória coletiva do grupo de imigrantes italianos.

A narrativa presentifica 0 passado com imagens anteriormente vividas e assim coloca-se no campo da memória. Para Ricouer, a narrativa implica em memória enquanto o futuro é uma espera contida no presente por coisas que estão porvir (Ricouer, 1994).

A espera é assim análoga à memória. Consiste numa imagem que já existe no sentido que precede o evento que ainda não é(...); mas essa imagem não é uma impressão deixada pelas coisas passadas, mas um sinal e uma causa das coisas futuras que assim são antecipadas, pre-percebidas, anunciadas, preditas, proclamadas antecipadamente (...) (Ricouer , 1994)

A espera do futuro é o silencio, a pausa no tempo narrativo. É também o instante que inaugura o futuro, mas que faz da memória um fator recorrente na espera. Só é possivel medir o tempo quando no passado ou no futuro, enquanto o presente é incomensurável e indivisível. Mas se é possível mensurar a passagem do tempo, é certo que o tempo possui um espaço, isto é, uma medida do tempo. Isso porque Ricouer considera o "passar do tempo" no sentido de transitar (transitare), o que suscita uma quase espacialidade, mas as relações entre intervalos de tempo são também espaços de tempo $^{36}$ (Ricouer ,1994). O instante de suspensão é a própria apresentação do tempo presente. A síntese do tempo está contida no fato narrado. É ela que contrai diversos acontecimentos ocorridos anterior e posteriormente à narrativa, como causas, efeitos ou consequências subentendidas a ela. É nesse sentido que dois objetos do nosso estudo se apresentam e se correlacionam de forma mais clara: a literatura e a cidade.

Pensamos a cidade de São Paulo na dualidade de ser narrada por um literato onde seus personagens vivenciam os fatos e 0 tempo narrados; e o espaço urbano criado pelos urbanistas. $O$ fato narrado pela literatura é também um documento, um registro que o literato explora, a fim de apresentar um tempo

\footnotetext{
${ }^{36}$ Essa é uma discussão apresentada por Ricouer quando questiona o tempo sob o olhar de Santo Agostinho, que segundo o autor é um grande enigma (aenigma) investigado pelo religioso.
} 
vivido. Esse tempo vivido e explorado como registro histórico só se constituiu na contemporaneidade do literato, pois ele percebe, por meio dos sentidos, o espaço e a passagem do tempo, portanto esta experiência sensível é passível de uma análise histórica.

Da mesma forma, a cidade é a síntese de tempos, tanto do passado, com seus traços sócio culturais, representados por patrimônios - como expectativa ${ }^{37}$ do futuro - apresentado por possíveis planos urbanísticos, visando à constituição urbana futura. Esses traços são elementos visíveis em qualquer sociedade, e se apresentam na própria cidade através dos espaços urbanos e da arquitetura. Os traços sociais e culturais da cidade podem ser compreendidos como vestígios e ou fragmentos. Nesse sentido literatura e cidade são acúmulos de conhecimento, depositários do saber cultural e possuem o caráter de transmissão de experiências vividas se partirmos do princípio de que ambos são artefatos humanos construídos e interpretados em tempos e espaços distintos.

Por sua vez, a cidade é o resultado do trabalho coletivo em diferentes instancias, os quais serão vivenciados pela sociedade como um todo. Produzir cidades é também o ofício do urbanista, na medida em que ele cria espaços urbano. O trabalho coletivo da sociedade, bem como do urbanista têm como resultado final a constituição da paisagem. Além de ser fisicamente produzida, a cidade é um conjunto de manifestações sócio culturais constituídas na duração do tempo, se apresenta em imagens de tempos distintos, simultaneamente construída por meio da sobreposição de significados. Entretanto, há uma transformação contínua do território, dada pela reconstrução e modificação de signos que ocorrem devido à pluralidade dos sujeitos que vivenciam o espaço e nesse sentido a cidade também é narrativa. Discorrendo sobre isso, Bernardo Secchi elabora uma reflexão sobre a importância da narrativa na ciência moderna, como uma estrutura discursiva para constituir um conjunto de enunciados relacionados a fatos. Essencialmente, é a idéia de progresso que supera o obscuro e a ignorância. Nesse contexto, por muito tempo a ação do urbanista é apresentada como a finitude do processo de agravamento das condições da

\footnotetext{
${ }^{37}$ No sentido etimológico de "spectare", olhar ou espera o futuro
}

cidade e do território por ele analisado além um início virtuoso de um processo de melhoria. (Secchi, 2006).

$\mathrm{Na}$ narrativa, as Figuras ${ }^{38}$ sempre estão presentes como parte da estrutura discursiva. Frequentemente, as figuras não possuem apenas um sentido descritivo, mas também "um papel construtivo, de organização do nosso pensamento"(Secchi, 2006). É uma concepção metafísica que unifica e orienta o pensamento, relacionando aspectos diferentes da percepção do real. As figuras, enquanto parte das narrativas urbanas referem-se ao modo de observar, interpretar e construir a cidade, não apenas no discurso sobre a cidade, mas também na sua constituição física, isto é, na configuração do espaço urbano.

Enquanto narrativa, a cidade coloca-se como uma recomposição intencional de fatos, espaços e tempos que merecem ser explorados para transmitir experiências construídas no decorrer da História. Olhar a narrativa literária e sobrepor a uma narrativa urbana tem o sentido de explorar duas possibilidades de transmissão concomitantes de experiência. Nesse contexto, a memória coletiva que estabelece relações afetivas com um determinado fato, um tempo e um espaço, representadas ora na literatura, ora na própria cidade, tornam-se ambas, narrativas.

\section{LITERATURA: VIÉS DA MEMÓRIA COLETIVA DE SÃO PAULO}

É possível uma aproximação entre as idéias de Halbawchs (2006) sobre memória coletiva e individual com as premissas sobre as narrativas de Benjamin (1987). Se para Halbawchs o homem se apoia em memórias individuais para promover a memória coletiva de um grupo social; por sua vez, Benjamim afirma que as melhores narrativas escritas são as que menos se distinguem da narrativa oral contada por narradores anônimos. É exatamente no anonimato dos personagens que Alcântara Machado tece suas narrativas. Em sua obra, são as memórias individuais de cada personagem que reconstroem a

\footnotetext{
${ }^{38}$ As figuras descritas por Secchi indicam, em um nível abstrato, formas de pensamento, formas de cidades, suas partes ou até mesmo a arquitetura. Como dissemos, é uma percepção do real. Portanto, é uma imagem que se constitui a partir do real. O autor reserva um capítulo inteiro para esmiuçar essa questão. Vide capítulo "Figuras"
} 
memória coletiva desse grupo de imigrantes, em seus primeiros anos na cidade de São Paulo. Não é possível afirmar categoricamente a existência literal de cada personagem do texto de Alcântara Machado, mas isso não tem severa importância na narrativa. Entretanto, se o livro surge a partir de escritos como notícias extraídas de jornais, a priori podemos supor que os fatos possivelmente ocorreram. O mais significativo para nosso contexto é que as vivências desses habitantes constituíram valores culturais que mereceram ser narrados e sua importância está no fato de manifestarem certa identidade urbana criada entre o grupo social e o espaço da cidade.

A cidade é construída em tempos e espaços distintos. Muitas vezes, vemos nas cidades as sobreposições de tempos e espaços. O espaço urbano construído no passado ainda é vivenciado na contemporaneidade. É a própria cidade que narra sua história com marcas indeléveis no espaço urbano. As memórias do passado estão presas, imóveis em um tempo que não existe mais, entretanto ao rememorá-las elas reconstroem um espaço vivenciado.

O que articula o tempo narrativo literário e a cidade é justamente a memória coletiva. Halbwachs deixa claro em sua obra que o homem vivencia a memória coletiva e a memória individual, concomitantemente. Entretanto, muitas vezes a memória individual se apoia na memória coletiva para apresentar um fato com maior clareza. O autor esclarece que a reconstrução das imagens de um acontecimento é a aproximação dos fragmentos de memórias individuais, só possível na instância coletiva e enquanto aqueles membros do mesmo grupo social continuarem a fazer parte daquela coletividade. A memória individual depende do lugar que o indivíduo ocupa no grupo social e as suas relações com o ambiente. (Halbwachs, 2006). Ela é passível de mudança, pois é um ponto de vista sobre a memória coletiva. A percepção dos fatos e dos espaços são atos individuais. Cada vez que essas percepções individuais do espaço e tempo emergem como imagens através de narrativas, elas passam a fazer parte da memória coletiva. Quanto mais se ouve ou lê sobre determinados fatos, melhor a percepção sobre os fatos e essa memória individual se torna mais a memória dos outros membros do grupo, ou uma "memória tomada de empréstimo, que não é minha"(Halbwachs, 2006). Portanto, é possível que obras literárias, na sua experiência narrativa que reúne narrador e temporalidade, possam recompor modos de vida e paisagem urbana de tempos passados, tornando-se nesse sentido fontes de pesquisa histórica.

Ao registrar a vida cotidiana desse grupo de imigrantes italianos na cidade de São Paulo, Alcântara Machado simula uma experiência da memória coletiva, por meio de personagens individuais, que a priori, não possuem características próprias de protagonistas ou coadjuvantes. Todos os personagens fazem parte de uma narrativa social. Como figura de linguagem, os personagens são metonímias, ou seja, partes de um todo, inseridos em uma História Urbana. Mas também representam a concentração dos imigrantes italianos em uma porção do território paulista: Brás, Bexiga e Barra Funda. É interessante pensar na relação que essa narrativa social, composta pelas figuras da metonímia na narrativa literária, tem com a narrativa urbana e os registros de signos indeléveis no território descritos por Secchi. Há entre estas duas experiências de narrativa uma diferença na produção: o literato é único autor, enquanto a cidade é obra da ação de vários agentes. Este aspecto torna a obra ainda mais relevante para o nosso estudo. Na medida em que o literato vai buscar em jornais seu material de trabalho, sua intenção é expor contar com a interferência de vários autores, diminuindo a relevância da visão centrada no autor, tal como a diversidade de atores sociais que constroem a cidade.

A obra de Antônio de Alcântara Machado apresenta a vida cotidiana, a experiência da rua, o homem tradicional que migra de seu país para uma nova cidade e se fixa em bairros como Brás, Bexiga e Barra Funda. É uma obra totalmente distinta daquela que constituem as narrativas da história urbana, história social, ou história econômica. A obra literária em questão é mais do que uma narrativa, é um simulacro em escala reduzida da experiência vivida na cidade.

Defendemos que, no caso de estudar bairros tão tradicionais como Brás, Bexiga, Barra Funda, é possível detectar a memória coletiva através de relatos como da obra de Alcântara Machado. Mas na medida em que esse autor narra um tempo literário, ele também recria paisagens urbanas que emergem da memória coletiva de cada uma das comunidades desses bairros. Halbwachs tem uma explicação para isso. Segundo ele, a 
consciência individual cria imagens e pensamentos que resultam de diversos ambientes vivenciados, que se sucedem sobre uma ordem, e por assim dizer uma história individual de cada um que vivenciou esses tempos e espaços (Halbwachs, 2006).

\section{CONSIDERAÇÕES FINAIS}

A memória coletiva contém memórias individuais onde ambas são limitadas no espaço e no tempo (Halbwachs, 2006). Nesse artigo demonstramos que essas memórias se apresentam como parte da constituição da identidade urbana. O tempo e o espaço vividos, seja na rua ou nos comércios desses bairros em formação, também fazem parte dessa memória coletiva. Como a cidade faz parte da narrativa, ela é por vezes, a síntese do espaço onde as memórias são constituídas. Não se trata aqui da cidade

\section{REFERENCIAS}

[1] Benjamin. Walter. Obras escolhidas: Magia e técnica, Arte e política. São Paulo: Brasiliense, 1987.

[2] Obras Escolhidas II: Rua de mão única. São Paulo: Brasiliense, 2000.

[3] Careri, Francesco. Walkscapes: o caminhar como prática estética. Tradução: Frederico Bonaldo. São Paulo: Gustavo Gili, 2013.

[4] Halbwachs, Maurice. A memória coletiva. São Paulo: Vértice,1990. enquanto Patrimônio, até porque muitos dos espaços descritos na obra do literato já não existem mais. Temos, portanto, a cidade como parte da memória daqueles que ali viveram, mas também daqueles que puderam, através da narrativa, vivenciar a imagem de uma cidade que já não existe.

Sendo assim, a memória coletiva sobrevive por meio das imagens criadas das narrativas, tanto de Alcântara Machado, como das famílias que transformaram o espaço urbano em lugar, ou seja, estabeleceram uma relação simbólica com o espaço urbano reconhecendo-se como parte de um grupo social. Vale lembrar que essas relações simbólicas com o espaço urbano ainda persistem em bairros mais tradicionais da cidade de São Paulo contemporânea. A memória reconstrói na imaginação os espaços que foram fundamentais na nossa experiência urbana, durante toda nossa vida.

[5] Machado, Antônio de Alcântara. Novelas Paulistanas: Brás, Bexiga e Barra Funda; Laranja da China, Mana Maria, contos avulsos. Rio de Janeiro: José Olympio, 1978.

[6] Ricouer, Paul. Tempo e narrativa. Campinas: Papirus, 1994.

[7] Secchi, Bernardo. Primeira lição de arquitetura. São Paulo: Perspectiva, 2006.

[8] Silva, Isabel dos Santos. Bras, Bexiga e Barra Funda de Alcantara Machado: uma narrativa registro da cidade de São Paulo. São Paulo: Pontificia Universidade Católica de São Paulo. Puc SP. Dissertação de Mestrado em Literatura. 2010. 


\section{Bapítulo 11}

\section{AS 'FRONTEIRAS' DA GOVERNANCA URBANO- REGIONAL: REFLEXÕES SOBRE PROXIMIDADES, AÇÃO COLETIVA E APRENDIZAGEM.}

\section{Mariana Galacini Bonadio}

Resumo A partir de uma crítica a noção de espaço e planejamento como sempre já territorializados - particularmente pela lógica do Estado - que se perpetuam no Estatuto da Metrópole na institucionalização de entidades metropolitanas, o presente artigo se propõe a uma reflexão a cerca dos desafios da configuração contemporânea dos arranjos de poder para a compreensão epistemológica na gestão dos territórios. Para tratar da crescente tensão entre o espaço funcional e o espaço da legitimidade da ação, pública e coletiva, da escala urbano-regional, partimos de um olhar teórico-analítico sobre dinâmicas de proximidade e agentes em rede, em um esforço de entendê-los sob a luz dos processos de aprendizagem e da produção do conhecimento. Ao encontro de um debate sobre o planejamento pelo viés da gestão territorial, estes aportes nos permitem argumentar por uma governança como um sistema de aprendizagem complexo, pressupondo uma atitude politica relacional por meio de processos dialógicos e de uma hermenêutica diatópica, capaz de reter os múltiplos sentidos dos devires coetâneos e potencializar os imaginários sociais emancipatórios. 


\section{INTRODUÇÃO}

As reflexões em torno dos processos de metropolização no Brasil não são, definitivamente, atuais. Contudo, a normatização do Estatuto da Metrópole ${ }^{39}$, nos convida a uma reflexão sobre os constrangimentos e voluntariedades presentes na construção da escala urbanoregional. Dada a heterogeneidade das problemáticas que caracterizam as dinâmicas metropolitanas, assim como dos processos de institucionalidade territorial, o esforço aqui realizado não tratará da dimensão propriamente estratégica ou operacional da governança interfederativa - proposta pelo recente Estatuto - mas pretende-se como contribuição a cerca dos desafios da configuração contemporânea dos arranjos de poder, para a compreensão epistemológica na gestão dos territórios.

Dada a tensão entre o que seria o espaço funcional metropolitano e o espaço da legitimidade das ações, pública e coletiva, apresentam-se pertinentes os postulados teórico-metodológicos que consistem a utilizar os vetores de proximidade como ferramentas analíticas para apreender o conjunto de processos coletivos, sócio relacionais, que produzem territorialidade. Argumentaremos, no presente artigo, que a assimilação do território ao conhecimento produzido por meio de redes de proximidade, constitui, potencialmente, um dos fatores que participa na construção dos espaços das ações socioespaciais. Jogando com as proximidades e utilizando as representações que estas veiculam $e$ as trocas que favorecem, as dinâmicas de proximidade modulariam as condições subjetivas e objetivas da existência e da capacidade da ação, ao mesmo tempo em que tais vetores são modulados pelas possibilidades relacionais.

Para mais, o entendimento das dinâmicas de proximidade como potencialidades de agência, nos permitem direcionar a reflexão para os sistemas de governança territorial, entendidos não em sua institucionalidade, mas como sistemas complexos de aprendizagem e produção de conhecimento, no qual poderíamos pressupor o enquadramento de uma "outra" entidade metropolitana; especialmente uma protagonizada por ações coletivas pautadas

\footnotetext{
${ }^{39}$ Lei no 13.089 , de 12 de janeiro de 2015. (BRASIL, 2015)
}

pela contestação a injustiça cognitiva e aos processos (re)produtores das desigualdades socioespaciais.

Partiremos de um olhar sobre os vetores de proximidade, enquanto canais de aprendizagem e conhecimento da ação coletiva, para alimentar reflexões ao encontro de um debate sobre governança: iniciamos com uma exposição sobre a hibridização das lógicas na produção das escalas territoriais, a partir do entendimento das fronteiras jurídicoadministrativas enquanto construções voluntárias e políticas; a partir de tais reflexões, recuperaremos abordagens teóricoanalíticas de proximidades e organização de redes, em um esforço de entendê-los a partir dos processos de aprendizagem e da produção do conhecimento, imbricados em geometrias de poder; estes aportes nos permitem pensar a governança como um sistema de aprendizagem complexo, pressupondo uma atitude politica relacional a partir de processos dialógicos e de uma hermenêutica diatópica; para, enfim, finalizarmos com o que consideramos, a partir das reflexões, uma das contradições essenciais dos atuais processos de territorialização: as noções de espacialidade e de planejamento, como sempre já territorializados, que se perpetuam na condução de nossas relações politico territoriais.

\section{CONSIDERACOÕES INICIAIS: EXPONDO OS ELEMENTOS QÜE GUIAM NOSSA REFLEXÃO}

As aglomerações metropolitanas, denominadas por Rosa Moura (2012) de arranjos urbano-regionais, particularizam-se por dinâmicas que transcendem as fronteiras municipais, configuradas pela complexidade da abrangência regional. Ainda que cobrindo realidades distintas, os arranjos engendrados pelos processos de metropolização e pela avançada divisão social do trabalho da versão contemporânea do capitalismo, pautado por uma agenda neoliberal, configuram novas morfologias urbanas: adensadas e mais articuladas; descontínuas ou contínuas; absorvendo em uma unidade espacial centros urbanos e áreas intersticiais urbanas e rurais de unidades vizinhas; extenso raio de polarização econômico - institucional; confluência de uma multiplicidade de fluxos multidirecionais de pessoas, mercadorias, conhecimento e de relações de poder; e, ao mesmo tempo, sem limites territoriais 
precisos. (Moura, 2012).

Em sua complexidade, as aglomerações de dimensão metropolitana materializam o paradoxo do lócus privilegiado para a concentração de riqueza ao mesmo tempo em que lócus de (re)produção das disparidades socioespaciais, que caracterizam o abismal deficit social brasileiro. Fato é que, atualmente, esses arranjos adquirem maior relevância na ampliação geográfica do processo de acumulação, elevadas à localização preferencial para a valorização do capital. (Klink, 2013; Smith, 2000). Apenas esse fato já nos permitiria supor certa discursividade nos debates em torno da institucionalização dos arranjos metropolitanos, por trás do Estatuto da Metrópole, que remete a retomada da importância da escala regional na organização do Estado. Soma-se que, passados mais de vinte anos da descentralização político-administrativa do Estado brasileiro - deflagrada pela Constituição Federal de 1988 - a municipalização de diversas funções de planejamento e de gestão territorial mostramse, na prática, limitadas para responder às questões das disparidades socioespaciais, especialmente as de dimensão urbanoregional.

Dotadas, pois, de contradições - que transitam pelo institucional, social, cognitivo, econômico, político ... - uma característica que fundamenta os arranjos urbano-regionais é a multiplicidade escalar (Moura, 2012), elemento simultaneamente potencial e constrangedor da ação coletiva. Partimos, então, de uma crítica inicial ao desenvolvimento metropolitano pautado pelo Estatuto da Metrópole. Ao retomar o debate da institucionalização de entidades metropolitanas, centrada principalmente em alterações no entendimento do optimum dimensional das fronteiras jurídicoadministrativas, o Estatuto da Metrópole subjaz uma rigidez do território; uma visão exclusiva e exaustiva de território, feito de limites e fronteiras.

O que nos parece estar em discussão é apenas o tamanho do território relevante para a ação pública, uma mudança de identificação de um reduto territorial para outro maior. E, ainda assim, mesmo a partir do Estatuto da Metrópole, apenas transferiu-se da União para os Estado-membro a competência para a institucionalização da escala metropolitana e da governança interfederativa, via leis estaduais; aos municípios participes de uma aglomeração ou região criada, cabe a compatibilização e articulação dos planos diretores municipais no planejamento e na execução das funções de interesse comum, incluso o desenvolvimento urbano integrado (art. 10요 $\S 3^{\circ}$, Brasil, 2015). Ou seja, o plano diretor permanece enquanto referencia de planejamento, pela autonomia municipal, na intervenção de ordenamento territorial metropolitano, e não é proposta uma autonomia funcional para a organização metropolitana.

Se uma governança interfederativa poderia amortecer o municipalismo das políticas urbanas, evidencia-se dependente da tratativa da escala metropolitana dada pelos planos diretores para a execução e decisão sobre as formas que, na prática, concretizam a dinâmica entre a escala municipal e a metropolitana (Gorsdorf, 2009). Assim, o Estatuto da Metrópole reitera os espaços de decisão política nas escalas municipal e estadual, não transferindo responsabilidades de ordenamento territorial para a organização metropolitana; que, independente de suas diretrizes, dependerá das voluntariedades e capacidades municipais e estaduais para sua implementação.

O primeiro efeito: os agentes com maior capacidade de agenciamento podem continuar a avançar em função dos seus projetos estratégicos, geralmente com primazia de força decisória do município polo e de grupos econômicos, dada que o agenciamento das áreas metropolitanas manifesta-se, de forma seletiva nos municípios (e em certas regiões metropolitanas, mais do que em outras), sem irradiar potencialidades, agravando um quadro de "metropolização ex-post" (Rolnik e Klink, 2011). O segundo efeito: a complexidade e riqueza do território são reduzidas ao beneficio do que é considerado essencial, para alguns, produzindo um referencial pobre de construção de ações de curto prazo; próprias da competitividade, do marketing territorial e das desregulações estatais para atrair investimentos externos (Schiavo, Vera e Gelfuso, 2015).

Não nos parece exagero, então, no sentido da gestão territorial, falar na crescente tensão entre o espaço funcional e o espaço da legitimidade da ação, à medida que os procedimentos jurídico-administrativos se sobrepõem aos processos socioespaciais. De um ponto de vista espacial, a gestão da 
organização territorial permanece determinada, de fato, por uma divergência entre os territórios políticos e os espaços de vida urbano-regionais; em que o último funciona em uma configuração espacial complexa de interconectividade e expansão geográfica de relações em rede (Lencioni, 2006; Massey, 2009), e o espaço da ação pública mantêm-se limitado àquele da circunscrição jurídica - onde o ordenamento territorial permanece interrompida nas fronteiras das unidades municipais, principalmente por meio do plano diretor.

Se deveria ser um instrumento de mudança, o Estatuto da Metrópole aparece muito mais como uma ferramenta de reprodução, uma vez que subestima ou simplifica a dimensão territorial do poder. Mesmo ao possibilitar uma alteração na escala de intervenção, não modifica as formas de mediação do ordenamento territorial e de elaboração de políticas públicas. Esta manutenção da organização politica e jurídica clássica do território, finalmente, pode produzir mais distância do que conexões e trocas.

Em resposta à multiplicidade, temos respondido com fronteiras jurídicoadministrativa: ao complexo à simplificação. Estas respostas demonstram os seus limites, em um momento em que as relações sociais, econômicas e políticas, em redes de proximidade relativa possuem uma força de influência mais evidente (Lencioni, 2006). Não é apenas a questão de autonomia no ordenamento territorial que se põem como um problema: ela exprime a necessidade de outra qualificação das organizações territoriais, de pesquisa de novos meios de negociação e de dispor de novos instrumentos de ação. Questões para as quais não temos respostas; ao contrário, muitas perguntas.

Então, não seria uma das prioridades da gestão territorial desembaraçar as passagens e os passantes dessas sobrepostas fronteiras e escalas? Reduzir distâncias, facilitar a passagem de uma rede a outra, para fluidificar a inscrição espacial das organizações sociais... Face a esses desafios, e diante das restrições inerentes às atuais territorialidades politicas para responder às complexidades das relações socioespaciais, que se desdobram em geometrias de poder expandidas (Massey, 2009), como, então, não falar do domínio do conhecimento?
E falar de conhecimento trata-se, precisamente, de resistir ao reducionismo das redes de tecnologias de informação e comunicação, que constituem parte das redes de proximidade relativa. Os pontos fortes anunciados destas ferramentas são sedutores para explicar os processos contemporâneos de metropolização e globalização; contudo, são as estratégias humanas que delimitam os modos de realização da ação, e até agora nenhum sinal tangível nos autoriza a defender que o comportamento humano será transformado por técnicas do domínio tecnológico. Empregando contribuições de Jean-Pierre Jambes (2001), ainda que as tecnologias de informação e comunicação ofereçam uma paleta de funcionalidades, nos parece importante refutar 0 determinismo tecnológico, uma vez que a própria tecnologia é profundamente marcada pelo contexto, sócio relacional e de poder, em que é usada e explorada.

Argumentamos, então, que são os processos de aprendizagem e de produção do conhecimento que constituem as relações em redes, e que se apresentam, potencialmente, com capacidade para transformar significativamente os fatores constitutivos das proximidades e do afastamento. Nos parece que um dos caminhos para o debate de ressignificação das organizações territoriais, pode se utilizar dos princípios teóricoanalíticos de constituição de proximidades, que permitam desafiar a visão clássica de território pelo Estado; e caminhar para a concepção de espacialidade como uma organização cognitiva relacional. Trate-se, de fato, de passar de um território estrutural, que canaliza, retarda e empobrece a circulação de conhecimento, a um território cognitivo, concebido como um sistema de aprendizagem, plural, de epistemologias e ações coletivas.

\section{A QUESTÃO DAS ESCALAS E DAS "FRONTEIRAS" URBANO-REGIONAIS}

Uma suposição inicial é de que não existe a priori combinação ideal para um arranjo institucional, dado que não existe nada inerente a uma escala territorial precisa (Klink, 2013). A institucionalização das fronteiras do Estado - União, Estados e Municípios, na divisão espacial de poder brasileira - já materializa um processo sócio politico de territorialização. Objeto de um limite discursivo significativo, as fronteiras de tais 
escalas expressam ou revelam o exercício de um projeto político que se propõem assertivo e, para tal, constitui-se ao enfatizar sua distinção de outras estruturas espaciais, de distinção pela autonomia ou de soberania (Groupe Frontiére, 2004; Smith, 2000). Esta primeira suposição nos permite questionar as escalas em que o planejamento territorial pressupõem intervir, como se essas contivessem processos socioespaciais, ao contrário de serem produzidas por estes; e produzidas, também, pela tendenciosidade inerente ao processo de planejamento determinado na estrutura funcional do Estado.

Desta primeira suposição, pressupõem-se que a escala é uma construção social, política, simbólica e discursiva, articulada por meio de projetos, estratégias e ações dos agentes sociais que a constroem (Klink, 2013; Smith, 2000). São, portanto, objeto de confronto e negociação, arena de disputa de poder, discursivo e material, antes de serem os campos legítimos da ação estatal. A limitação de uma fronteira jurídicoadmnistrativa para a incidência do planejamento se dá no âmbito da negociação política e da capacidade de agência dos atores envolvidos em sua construção. Importante destacar que, como processo de disputa e conflito, esse pode ocorrer sem qualquer responsividade à efetivação da função social da cidade e da propriedade que, em teoria, deveria balizar a política territorial brasileira.

Podemos observar, então, uma justaposição de lógicas territoriais numa hibridação de, ao menos, dois processos na construção escalar dos territórios. A primeira, pela delimitação de escalas para o exercício do poder do Estado, concebida pelos agentes públicos e referente a uma escolha política, a partir de uma coerência preconcebida entre as modalidades de ação estatal e a resolução de determinadas questões sociespaciais. A partir desta lógica, estabelecem-se as formalizações fronteiriças jurídicoadministrativas, precisando entidades territoriais com status legal e funções específicas dentro da estrutura funcional do Estado.

A segunda lógica, dá-se pela construção do território pela ação de uma pluralidade de agentes sociais, em constante disputa e negociação por hegemonia. Neste segundo processo, a partir das colocações de Jeroen Klink (2013), as ações coletivas tanto podem se realizar em articulação com a ação estatal, a partir de uma estratégia proativa dos agentes sociais para dispor e influenciar as oportunidades ofertadas pelo Estado, ou, de forma inversa, construir-se em contraposição ao Estado, objetivando um certo grau de autonomia. É importante ressaltar que, a esta lógica, que tanto pode corresponder aos movimentos sociais transnacionais (Castells, 1999), corresponde mais intensamente a dinâmica atual da reprodução do capital, que acentua 0 poder dos grandes grupos econômicos (e, progressivamente, os de capital financeiro internacional) que,

"ao submeterem como nunca antes o poder do Estado-nação, emergem com força hegemônica na reestruturação do território, deixando na lembrança um planejamento centralizador por parte do Estado e trazendo a tona a necessidade de desenvolvimento de aportes teóricos para dar conta da compreensão da atual dinâmica territorial." (Lencioni, 2006, p. 69)

Em face a emergência de processos contemporâneos de reestruturação produtiva, fundamentada numa dinâmica global de reprodução e de circulação do capital, os aportes de Sandra Lencioni (2006) alimentam a reflexão da hibridização de lógicas territoriais, ao discorrer sobre a limitação de pensar a relação entre as escalas por meio de hierarquias piramidal. A contribuição da autora quanto a multiplicidade e diversidade de relações estabelecidas por meio de redes que fluem em variadas escalas, demonstram que a constituição de forças produtivas fundamentais para uma economia cada vez mais globalizada não se situam propriamente na transformação para uma economia flexível ou na configuração das redes de fluxos, mas na expressão dialética da ação recíproca entre a forma global de organização da produção e a conformação dessas redes.

Cabe-nos observar, entretanto, que o processo atual de metropolização, conformando novos arranjos territoriais, revela um aprofundamento das desigualdades: cognitivas, materiais e socioespaciais, entre grupos sociais tanto quanto entre as unidades que compõem o Estado. Como elucida Sandra Lencioni (2006), o processo de metropolização - impulsionado por geografias expandidas das redes de proximidade relativa - é descontinuo: embora, ao olharmos para as semelhanças da reestruturação do capital em diversas cidades, a homogenização é apenas uma tendência, pois persistem e são criadas fragmentações; especialmente entre cidades 
integradas em um mesmo arranjo urbanoregional, em que algumas cidades são capazes de se aproximar de circuitos globais, enquanto outras permanecem a margem do processo de metropolização. A abertura da pretensa globalização é estritamente seletiva: alguns pontos do território estão abertos, enquanto outros permanecem fechados, nas formas que interessam ao atual projeto de globalização capitalista. (Massey, 2009).

Em muitos aspectos, a problemática do desenvolvimento urbano-regional oscila entre a prática do planejamento definido na estrutura funcional do Estado (a primeira lógica) e a racionalidade dos agentes envolvidos na territorialização pelo exercício do poder (a segunda lógica); e que se traduzem em predisposições ou constrangimentos à multiplicidade de ações coletivas. Utilizado o senso político de desenvolvimento, nos parece possível interpretar a institucionalização atual de governanças interfederativas, no Brasil, como uma ação voluntária, um processo que evoca a intenção de estabelecimento proposital de estratégias responsivas a mobilidade geográfica do capital, acompanhando as "exigências" de transformação nas condições gerais ${ }^{40}$ para a reprodução social do mesmo. A maioria dos projetos políticos e das agendas de governo, até então estruturadas nas escalas metropolitanas, evidencia a fragilidade da capacidade de controle social sobre o ordenamento territorial de dimensão urbano-regional; afastadas das exigências da função social da cidade e pervasiva à atuação do capital financeiro, do mercado imobiliário, dos interesses econômicos (Klin, 2013; Franzoni, 2015; Gorsdorf, 2009).

Ainda assim, a escala de vida urbano-regional não é dada funcionalmente, mas está continuamente a ser construída, não designando apenas uma contingência de dinâmicas socioespaciais da ordem de coerência entre ação estatal e resolução de problemas. Ao contrário, acompanhando as

\footnotetext{
40 Segundo Sandra Lencioni (2006, p. 69), "as condições gerais dizem respeito as condições necessárias a reprodução do capital em geral e, nesse sentido, não se constituem em condições que interessam especificamente, a um capitalista, mas que são importantes para vários capitalistas, ou seja, ao capitalista em geral, como, por exemplo, a instalação de redes de fibra ótica, a implantação de escolas técnicas fornecedoras de trabalhadores qualificados e especializados e o desenvolvimento de infraestruturas"
}

reflexões de Doreen Massey (2009), é um empreendimento das relações sociais (ou da falta de relações), construído por uma complexidade de redes de proximidade, geograficamente expandidas, de vínculos, ações e práticas, em torno de escolhas, discursos, atos conscientes e inconscientes dos agentes sociais, inscritos em geometrias de poder. Se até o momento, no Brasil, poderíamos interpretar a institucionalização da entidade metropolitana, mais inscrito na ordem do agir estratégico, conformado na funcionalidade do Estado e em resposta às transformações macroeconômicas; não deveria significar a negação de outros devires, comunicacionais e das relações de saber-poder na territorialização.

\section{ASSIMILAÇÃO DO TERRITÓRIO ÀS ABORDAGENS DE PROXIMIDADE: CONHECIMENTO E PODER NA AÇÃO COLETIVA}

A reflexão até aqui apresentada sobre as lógicas de produção dos territórios na contemporaneidade, revelam uma transformação profunda, de complexificação, dos sistemas de agentes em redes. Tais processos contemporâneos, nos remetem a falar (mais na literatura do que na prática política), de uma abertura da ação pública à ação coletiva, no plural (Lefèbvre et al.,2013). A abordagem por proximidades, como ferramenta analítica para apreender a dinâmica de construção de territórios, enriquece a compreensão do espaço em termos da ação da multiplicidade de agentes. A partir dessa abordagem teórico-analítica, de acordo com Jean-Pierre Gilly e Yannick Lung (2005), a territorialidade não poderia existir sem uma dose de qualquer uma das proximidades: geográfica, organizacional e institucional.

A proximidade geográfica expressa a distância que separa a materialidade do espaço em unidades distintas. Isto implica duas dimensões relativas: a existência de infraestrutura de mobilidade (para pessoas, bens etc.) e o julgamento subjetivo que os indivíduos fazem da relação tempo-distância (Torre e Rallet, 2005). Estes vetores corresponderiam à rede de proximidade territorial, apontada por Sandra Lencioni (2006), formada por redes materiais, a exemplo da circulação viária. É a densidade destas redes, somada a sua capacidade de fluidez - que define o tempo-distância 
percorrida - que redimensiona as distâncias entre os lugares, mas do que a métrica quantitativa que separa uma unidade espacial de outra.

De acordo com Gabriel Colletis e Bernard Pecqueur (2005) a necessidade da proximidade geográfica na produção de territorialidade explica-se, em grande parte, pela diferença entre fluxo de informação e produção do conhecimento. Com as tecnologias de informação e comunicação contemporâneos, o fluxo de informação não depende necessariamente da proximidade geográfica. No entanto, esta proximidade é altamente relevante para a produção de conhecimento. A elucidação oferecida por David Rooney et al. (2003), sugere que o conhecimento resulta de um "processo de conhecer", resultante de uma aprendizagem. O conhecimento, por si só, não tem uma existência independente fora do processo de aprendizagem, e o aprender implica a evolução de diversas variáveis - conceitual, intelectual, cognitiva, intuitiva, emocional que emergem das relações sociais, e constituem as bases para a ação coletiva, permitindo o entendimento do conhecimento como o processo que leva do reconhecer um problema a agir sobre ele.

Duas facetas do conhecimento devem ser enfatizadas, a fim de explicitar a importância das dinâmicas de proximidade geográfica na sua produção, conformando o contexto social e interpretativo relacional do conhecimento: suas dimensões tácita e explícita. Enquanto a primeira não está prontamente articulada, consistindo em sistemas de pensamento não verbais, e mais intensamente elaborados nas relações sociais, a última é articulada de forma simbólica, por meio de textos, números, e outros semelhantes. (Rooney et al., 2003). Em particular, a interação humana permanece altamente dependente de sistemas nãoexplícitos, com base em contextos tácitos que incluem não só as intuições e emoções individuais, mas também suposições de grupos, valores e ideologias coletivas. A aprendizagem, como base para a ação coletiva, produzida na interação humana, é um processo de intensidade tácita, especialmente quando um problema precisa ser resolvido e as formas de resolvê-lo não são conhecidas com antecedência.

Assim, a proximidade geográfica pode ser um trunfo para catalisar processos de aprendizagem por meio das interações sociais face a face, facilitadas pelas redes geográficas que aproximam os agentes; relações mais intensamente carregadas pela afetividade e subjetividade, o que contribui significativamente para representações sociais compartilhadas, como, por exemplo, nas formas de cooperação, de solidariedade e de articulação social. (Laclau e Mouffe, 1987). No entanto, ser "vizinho" pode tanto levar os agentes a promoverem relações, tanto quanto à rejeitá-las, uma vez que a proximidade geográfica também pode ser experimentada como uma restrição por agentes que enfrentam externalidades negativas. Como discutido por Damien Talbot (2006), os conflitos sobre o uso e a apropriação do solo, por exemplo, na partilha de recursos ambientais, como bacias hidrográficas, a poluição difusa, disputas de grilagem de terras etc., estão no cerne das interações negativas que emanam da proximidade geográfica.

É este aspecto paradoxal de aproximações e/ou tensões promovidos pela proximidade geográfica, que demonstra a importância das dinâmicas de proximidades organizacional e institucional, entendidos, aqui, como conformando as redes de proximidade relativa, apontada por Sandra Lencioni (2006). Esta rede diz respeito as redes imateriais, como as redes de fluxo de informação e comunicação (sem esquecer que estas requerem infraestrutura material), e é a densidade dos fluxos imateriais que permitem que agentes e unidades territorialmente distantes se aproximem, enquanto vizinhos podem manter poucas relações entre si. Para a autora, em consonância com as contribuições de Saskia Sassen (1998), de Manuel Castells (1999), entre outros, seriam as redes de proximidade relativa que estruturariam o sistema mundial de cidades em rede, diante da nova lógica globalizada de reprodução do capital.

Há, contudo, outros aspectos importantes a serem destacados em relação aos vetores de proximidades organizacional e institucional, que nos parecem auxiliar a tatear a complexidade na conformação das redes de proximidade relativa, produtoras de territorialidade pela ação coletiva. A proximidade organizacional tem uma natureza relacional, sendo a capacidade de uma rede de ter os seus membros interagindo uns com os outros. Esta facilita a coordenação dos agentes por duas razões: por um lado, a lógica de pertencimento a uma unidade induz a uma interação "fluida" entre os seus 
membros; por outro lado, a lógica da semelhança gerada por sistemas de representação compartilhada, como crenças e símbolos, aumenta a possibilidade de cooperação entre eles. (Torre e Rallet, 2005).

Portanto, a essência da proximidade organizacional não é geográfica e pode atravessar fronteiras. As ações dos agentes coletivos vão muito além e fortes laços afetivos e de lealdade, assim como de posições éticas potenciais, podem ser desenvolvidos desde as dimensões locais à transnacionais, seja no âmbito das relações econômicas como dos movimentos sociais (Torre e Rallet, 2005; Castells, 1999). Esta proximidade organizacional define o espaço de possibilidade das ações e estratégias dos agentes. No entanto, fará a partir de um conjunto de regras estabelecidas pelas instituições, principais responsáveis por gerar a lógica de pertencimento a um determinado espaço (Gilly e Lung, 2005). Assim, para ativar a proximidade organizacional, é necessário uma certa proximidade institucional. Neste sentido, estes dois tipos de proximidades são diferentes, mas em níveis analíticos estão inter-relacionadas: o nível institucional consiste em regras necessárias para qualquer ação acontecer; o nível organizacional consiste nas formas de coordenação em que as interações e ações ocorrem.

De acordo com Geoffrey Hogson "as instituições são os tipos de estruturas que mais importam na vida social: elas fazem as coisas da vida social" (2006, pg 02.). Estas são sistemas de regras, de ética e de moral prevalecentes e normatizadores, socialmente construídas por processos de aprendizagem interativa, ao longo do tempo. Este sistema de regras assume formas múltiplas, como da linguagem, do dinheiro, da lei, da religião, de entidades públicas e dos diferentes tipos de organizações sociais. A legitimidade das instituições encontraria raízes na sua capacidade de criar expectativas estáveis dos comportamentos individuais e coletivos, reduzindo a incerteza nas interações sociais, possibilitando que os grupos possam trabalhar de forma coerente e agir coletivamente. Esta característica da proximidade institucional é contextual, precisada pela característica relacional do conhecimento, que oferece o quadro para a condução das ações por meio de um pano de fundo fenomenológico compartilhado; comumente chamado de cultura, que encontra suas raízes também na produção epistêmica.

Fato é que, não há conhecimento fora do processo de aprendizagem, que ocorre se não no interior das relações sociais por meio de práticas relacionais, mediado por variadas instituições. Mas se todo conhecimento é contexto, todo contexto é uma produção social dinâmica (Souza Santos, 2011); ou seja, diferentes tipos de relações sociais darão lugar a diferentes epistemes, produzindo múltiplas proximidades institucionais e organizacionais, muitas vezes em conflito umas com as outras na produção de territorialidade. Conforme Boaventura de Souza Santos (2009) nos apresenta, a construção de hierarquias de conhecimento, e consequentemente das ações, se sustenta por um pensamento abismal, que traduz a dominação econômica, política e cultural de alguns grupos sobre outros. O pensamento abismal opera mediante a definição unilateral, pela epistemologia dominante, de linhas que dividem as experiências e as ações de agentes sociais entre os que são uteis e inteligíveis, e os que são inúteis, até mesmo perigosos, sujeitos silenciados e subalternizados por práticas institucionais hegemônicas.

Reiteradamente, são favorecidas as praticas que predominam o conhecimento científico, associadas a uma pretensa neutralidade. Esta exclusividade do conhecimento valido se traduz em um vasto aparato institucional, no qual a produção acadêmica e teórica do planejamento urbano e regional atual se encontra, seja nas universidades, nos centros de investigação e na prática de ordenamento territorial. A epistemologia dominante que se firmou na ciência moderna, a partir de uma pretensão de universalidade, é o resultado de uma intervenção epistemológica possível graças a força com que a dominação multifacética do capitalismo moderno se impôs sobre a multiplicidade cultural, silenciando determinadas práticas sociais e ações coletivas, também, de territorialização (Souza Santos, 2011). Esta intervenção tem sido tão profunda que desacredita e, sempre que necessário, suprime todas as formas de experiências subversivas aos seus interesses, ocultando que, tanto o conhecimento como as instituições, são parte de uma concepção intersubjetiva da realidade, socialmente produzida, compartilhada por agentes em proximidade institucional e organizacional.

A importância de assimilar a injustiça 
cognitiva no processo de planejamento, justifica-se a partir do entendimento que a injustiça entre conhecimentos, funda e contamina todas as demais formas de injustiça que conhecemos: socieconômica, de gênero, cor, sexual, histórica, geracional etc. (Foucault, 2008; Souza Santos, 2011) Estas questões são relevantes para pensar as relações urbano-regionais, pois tratam-se de territorialidades de tempos-espaços muito diferentes: urbanos, periurbanos, rurais etc, compostos por multiplicidades de comunidades urbanas, agrícolas, indígenas, ribeirinhas, quilombolas..., e que concebem representações espaciais e de ação coletiva diferentes entre si - que raramente, para não dizer nunca, são consideradas no planejamento urbano e regional.

Portanto, as interações em um território estão incorporadas pelas relações de saber-poder (Foucault, 2008), que conformam as interações entre vetores de proximidades, uma vez que os recursos materiais, cognitivos e discursivos são valorados e distribuídos de forma desigual entre os agentes. Para mais, os agentes - entendidos como "conhecedores" e atuando em redes - ao serem também, em grande parte, intencionais, agem propositadamente para atingir objetivos de curto e longo prazo. A atuação do conhecimento é, portanto, também de natureza intencional, tática e/ou estratégica, levando à ação, em que os agentes são capazes de usar o conhecimento a partir da posição de poder dos papéis que assumem nas redes em que estão inseridos, sujeitos às ideologias, laços de lealdade e interesses específicos. (Rooney e Schneider, 2005)

Neste sentido, as posições dos agentes em redes somadas às suas proximidades institucionais, são capazes de reiterar tanto o status quo como impedir possíveis transformações do mesmo, com base nas possibilidades de interpretação e de traduções práticas dos conceitos de liberdade, de democracia, de direitos individuais e coletivos, de desenvolvimento, de planejamento etc. Logo, a direção no planejamento territorial, com o objetivo de transformação (ou não), é também um ato de poder. Este nos parece ser um ponto-chave, levantando questões sobre como as geometrias de saber-poder podem moldar 0 tipo de conhecimento, de informações e de valores, que os agentes sociais podem utilizar nos processos de territorialização, no caso, urbano-regionais. Enquanto o domínio 'território' for em parte confiscado por determinados agentes, performado a partir de uma apreensão epistemológica jurídicoadministrativa de território, aumenta-se o poder de controle exercido por uma minoria, empobrecendo a capacidade de ação coletiva de uma multiplicidade de agentes sociais. (Jambes, 2001).

As dinâmicas de proximidades ainda possuem uma dimensão histórica: as relações entre os vários atributos que as produzem variam ao longo do tempo e são continuamente transformados, frutos de processos de aprendizagem cumulativos. Em cada contexto, em cada situação temporal/espacial/histórica se formam práticas sociopolíticas, que são também as que fazem emergir as redes de agentes sociais e políticos e a precisar a potencialidade de suas ações. (Massey, 2009). Isto significa que um determinado sistema de gestão territorial manifesta-se a partir das sinergias de cooperação e negociação produzidas ao longo do tempo, não implicando necessariamente um carácter duradouro (Colletis e Pecqueur, 2005). Ao mesmo tempo, significa que as proximidades estarão sempre abertas a construção, indicando o potencial para mudanças.

\section{GOVERNANÇA: SISTEMA DE APRENDIZAGEM QUE EMANA DAS PROXIMIDADES?}

Governança é um conceito polissêmico apropriado nos últimos vinte anos tanto em economia como nas ciências políticas e ciências sociais, de modo que é possível falar de governança de forma plural. Considerando a pluralidade de definições de governança, proporemos aqui um entendimento de governança territorial como um sistema de aprendizagem pela e para a ação coletiva, que emana da combinação de proximidades e, portanto, em constelações de possíveis múltiplas, que definiriam "fronteiras" singulares para a governança. A dimensão relacional do conhecimento e do poder convida a pensar um sistema de governança capaz de expandir sua capacidade, de esfera de concertação da ação estatal, para tradutor, mobilizador e instrumentalizador de ações coletivas.

De modo geral, a literatura sobre governança territorial centra-se na ação coletiva consciente e intencional, ou seja, voluntária, 
considerada como um processo fundamental para a construção dos espaços da ação política. Não obstante, de acordo com Fabienne Leloup et al. (2005), governança territorial não é apenas um processo de coordenação de agentes em um dado território, mas também um processo de construção contínua de territorialidade pela multiplicidade de agentes sociais, ao longo do tempo.

A mobilização e concretização das ações de territorialização, a partir de um sistema de governança não é apenas um ato de cooperação, mas de negociação e, seguindo Damien Talbot (2006), só pode ser concretizada por meio da regulação dos conflitos. Em qualquer dado território, os interesses e entendimentos de bem comum dos agentes divergem e tal processo de negociação pode resultar no fortalecimento da ação de alguns e exclusão de outros. Consideradas as situações de disputa de poder, habituais, às instâncias públicas de maior abrangência, até então, é destinado um papel crucial no âmbito da governança, responsáveis por exercer uma função reguladora das ações coletivas, a fim de mediar as tensões e favorecer, em teoria, os interesses da coletividade (Benko, 1996). Dado este papel regulador, as instâncias públicas - que seria o caso da governança interfederativa - são comumente sinonimizadas enquanto governança territorial. Talvez por isso, grande parte do debate nessa arena, tem focado mais nos aspectos de governabilidade do sistema e capacidade de governo na construção técnico política de governança, do que propriamente na negociação dos conflitos das ações coletivas produtoras de territorialidade.

A questão proposta, neste ponto, não é uma negação ao estabelecimento de um optimum territorial adequado à governabilidade interfederativa, ou da importância da discussão quanto ao grau de isomorfia entre a capacidade de governo e a aglomeração urbano-regional a qual suporia responder. Não se trata de um simples fetichismo espacial: de fechamento, a partir do Estado, e de abertura, a partir dos agentes sociais em redes de proximidade relativa. O Estado, e as estruturas institucionais que o conformam, podem também ser um meio importante para efetuar o avanço social e político. Contudo, a questão é que regras, no sentido de uma política territorial totalizante de unidades abstratas em categorias topográficas, não existem (Laclau e Mouffe, 1987); o que nos posiciona criticamente quanto à discussão sobre a governabilidade do sistema de governança, sem o questionamento da produção conflitiva da escala de atuação pela ação pública e da implementação do sistema em si.

Antes de uma coerência territorial preconcebida, há praticas sociais e relações de poder social, espacializadas - e que são, inclusive, (re)produtoras de variadas formas de dominação (Laclau e Mouffe, 1987). A problemática da governança trata-se mais de uma tomada de posição politica que se dirija diretamente as questões das geometrias de poder, do que da aplicação de uma fórmula fronteirada preconcebida sobre o espaço. Aproveitando das colocações de Rosalyn Deutsche sobre a arte pública (1996, apud Massey, 2009), o que estaria em jogo não é propriamente o que é legítimo ou ilegítimo nos fundamentos da vida social e em suas materializações espaciais, mas a própria legitimidade do debate nessa arena. Um outro debate poderia partir do reconhecimento do conflito, em que não há possibilidades de definição de regras trasladáveis de um lugar ao outro (conformado pela lógica unilateral do Estado), mas que as negociações serão sempre improvisações singulares (Massey, 2009), exigindo aprendizagem contínua na ação política.

E o desafio da negociação é significativo, dado que a injustiça cognitiva é usada ativamente na produção da desigualdade, com práticas de exclusão, repetidas exaustivamente até se estabelecerem institucionalmente. Portanto, é também o confronto das forças diferenciais (epistemológicas e de recursos) no processo de negociação que devem ser trazidos ao debate da política, fazendo-os visíveis para que também sejam contestados (Laclau e Mouffe, 1987); em vez de apagar os traços de saber-poder desiguais que permeiam, até então, a governança governamental (ou corporativa pública), silenciados até mesmo por formas de planejamento participativo, dissimulados. A questão sociopolítica, talvez, diga menos respeito ao grau de abertura/fechamento do sistema espacial da governança (ou ao seu grau de isomorfia) do que aos termos em que tais aberturas e fechamentos são produzidos por meio das relações sociais: as sempre móveis geometrias de poder (Massey, 2009), em redes de proximidade geográfica e múltiplas 
redes de proximidade relativa.

Este debate é, definitivamente, mais profundo do que aqui elaboramos. Fato é, que, os processos de transição nas configurações socioespaciais contemporâneos, do qual os arranjos urbano-regionais fazem parte, motivam o despertar de outras bases epistemológicas de planejamento - ou contraplanejamento (Randolph, 2015), em rompimento paradigmático com a universalidade moderna - capazes de imaginar o espaço como devires coetâneos (Massey, 2009). E neste sentido, a perspectiva de governança como sistema de aprendizagem, enquanto possibilidade de movimento de sentidos dos devires, nos aproximam de algumas pistas; que, podem ser trabalhadas, por exemplo, a partir dos pressupostos comunicativos de Jugen Habermas (1989; Randolph, 2015) e, mantendo a ideia de processo dialógico mas afastando-se, de certa forma, da proposição de universalidade ética e da racionalidade do consenso, a partir da hermenêutica diatópica de Boaventura de Souza Santos (2009; 2011).

Assumir a aprendizagem como abordagem pré-operacional para um sistema de governança - capaz de levar a cabo a definição de um perímetro flexível e pertinente para a ação pública, mobilizado pelas ações coletivas - é também assumir o caráter incompleto de todos os conhecimentos vetoriais de proximidades institucionais $e$ organizacionais. A assunção da impossibilidade de completude, que nos desvia, parcialmente, da racionalidade consensual-comunicativa Habermasiana (1989), é entendido como condição para um processo dialógico horizontal entre conhecimentos. Não se trata de relativismo, mas certamente nos obriga a análises mais complexas quanto a inteligibilidade e intencionalidade dos diferentes tipos de ações coletivas, produzidas a partir da pluralidade epistemológica dos agentes sociais (Boaventura, 2011). O reconhecimento da pluralidade, dos conflitos entre saberes, como das relações de saber-poder, a partir das quais as territorialidades são produzidas (Foucault, 2008), nos convida a ampliar o horizonte de inteligibilidades no processo de planejamento, como oportunidade para ampliar o campo de possibilidades democráticas e de emancipação na intervenção territorial.

A hermenêutica diatópica, proposta por Boaventura de Souza Santos (2009; 2011), parte da ideia de tradução entre distintos universos de sentido, entendida como um procedimento de interpretação que permite criar inteligibilidade recíproca entre os saberes, ações e seus agentes, sem atribuir a nenhum conjunto de experiências o estatuto de totalidade exclusiva. O trabalho de tradução entre diferentes ações coletivas e projetos emancipatórios, têm como objetivo identificar preocupações isomórficas entre elas e as diferentes respostas que proporcionam na solução de problemas; e, distante de um relativismo, a partir de uma confrontação pragmática das ações com seus resultados. Não visa atingir a completude, mas, pelo contrário, visa ampliar ao máximo a consciência da incompletude mutua, por meio do diálogo e, porque não, de um agir comunicativo no sentido de Habermas (1989).

A partir do reconhecimento da diferença e da incompletude, pelo procedimento de tradução, seria possível a formulação de múltiplas narrativas de emancipação social e de devires coetâneos, espacial-temporais. Moira Gatens e Genevieve Lloyd (1999), a partir de uma leitura contemporânea da filosofia de Baruch Espinoza, também fazem emergir o conceito de tradução, expressa por uma ontologia relacional, como capaz de expandir os imaginários sociais de devires, o que potencializaria os poderes de ação coletiva, ao prover novos fundamentos para nossos sentimentos de pertencimento e nossas reivindicações de direitos sociais, políticos e éticos.

A potencialidade é para que o movimento, para além das escalas de atuação da ação pública, seja antes um movimento de expansão e encontro de linhas de equivalência entre redes de proximidades relativa, construídas com componentes das multiplicidades de imaginários. A potencialização de tais equivalências, por meio de um processo dialógico de tradução, é em si mesma um processo de negociação, um envolvimento de ações coletivas, em que o fundamento é buscado através do que podem construir conjuntamente na abertura do futuro de outros devires, no reconhecimento de suas incompletudes.

Os sistemas de governança territorial, entendidos não em sua possibilidade institucional ou normativa, mas como sistemas complexos de aprendizagem coletiva, não nega a proposição de tais estruturas na esfera pública, se promotoras de instrumentos para a inscrição e operacionalização das ações 
coletivas dos diferentes agentes sociais. Tal entendimento evidencia que são cruciais novas formas de organização do poder, (re)significando a democracia: é uma questão de explorar outras formas de (contra)planejamento, capazes de reter os sentidos dos múltiplos devires contemporâneos, na articulação e envolvimento entre práticas, ações e agentes em redes, para o qual a redistribuição do poder é exigência mínima.

\section{PARA ALÉM DAS ABORDAGENS TEÓRICO-ANALÍTICAS: RESSIGNIFICAÇÃO DA ESPACIALIDADE E DA POLÍTICA}

A contradição entre os processos socioespaciais urbano-regionais $e$ os procedimentos adotados institucionalmente, pelo Estatuto da Metrópole e na proposta de governança interfederativa, confirma, de uma parte os limites do instrumento território, considerado no senso estrito da acepção jurídica politica - dominado pelo conceito moderno de Estado -, e reforça de outra parte, a hipótese sobre a qual a epistemologia do planejamento deveria se pautar por um processo de reinvenção das expressões espaciais das sociedades. Se nossa política formal de planejamento tem-se organizado a partir de uma concepção de espacialidade de coerência preconcebida, os laços das proximidades relativas mostram que as redes contemporâneas são mais complexas para continuarmos a nos ater a um dualismo entre fechamento territorial do "bom" governo ou abertura total para um mundo, tão frequentemente, chamado de espaço de fluxos.

Como argumentado, a lógica da prática do planejamento definido na estrutura funcional do Estado não pode ser tomada como garantia, partindo de um pressuposto de governança apenas como um procedimento de formalização jurídico-administrativa. Isto implica se apoderar do fato de que arranjos urbano-regionais detém múltiplas capacidades organizacional e institucional, com base nos diversos vetores de proximidade presentes; e que a construção territorial pelo Estado é hibridizada com a lógica da ação coletiva de uma pluralidade de agentes sociais, em conflito e negociação.

Dinâmicas de proximidades, ação estatal e coletiva, governança... Noções que retornam a dois conceitos centrais: poder e território. A construção de novas "fronteiras" de aglomerações ou regiões metropolitanas em entidades da ação pública, em que o planejamento urbano-regional é estabelecido, colocam a questão da performance do poder ao centro das reflexões sobre tais arranjos. $\mathrm{E}$ nos parece justo falar em territorialidade do poder na dimensão urbano-regional, no sentido que o território delimitado por fronteiras jurídico-administrativas não é apenas um dos princípios fundadores da ação estatal, mas também o veículo pelo qual o poder do Estado transita, materializa-se, perpetua-se e evolui, num conjunto de práticas territorializadas. (Jambes, 2001). O tema da governança territorial refere-se, sobretudo, a espacialidade do poder e da política: ao mesmo tempo em que podem reforçar a lógica funcional do projeto político do Estado, convidam a expandir os imaginários sociais, em formas inovadoras de interação e de linhas de equivalência dos vetores plurais de proximidade geográfica, organizacional e institucional.

A partir das contribuições teórico-analíticas das dinâmicas de proximidades, conformando relações em redes de geografias expandidas, a imaginação da espacialidade sugere o espaço como uma produção relacional específica. E, se o espaço é relacional, e esfera da multiplicidade de ações e epistemologias, é com as relações distintas, porém interligadas, de geometrias de poder de sua construção que a política precisa se engajar. Acompanhando as reflexões de Doreen Massey (2009), assumir a espacialidade relacional reivindica uma política relacional e, ainda mais, uma política de negociação das relações, que enfatize a conformação e a inevitabilidade da singularidade e do conflito. O que está em questão, ao final de contas, é o processo constante, não-linear, e conflituoso da constituição do social e das negociações de poder no interior das decisões que territorializam as múltiplas expressões espaciais das sociedades.

Então, o desafio é a reinvenção dos mecanismos de construção da espacialidade no exercício do poder e na política do território; de uma parte, uma interrogação sobre as condições atuais deste exercício, e de outra, da prefiguração de novas formas de legitimidade democrática; que subvertam os fundamentos da democracia ocidental, excessivamente baseada na territorialidade do Estado-Nação. Neste sentido, uma das questões centrais para um outro (contra) 
planejamento consistiria em elaborar, experimentar e avaliar modos renovados de legitimação das ações coletivas, a partir de um esforço de requalificação da espacialidade; ultrapassando o conceito de espacialidade concebido estritamente sobre a imaginação modernista do espaço, como sempre já territorializado, ao encontro de um conceito de espaço-tempo, sempre multiplamente sendo feito e jamais intrinsecamente coerente.

Ao aproximarmo-nos do território não mais como um instrumento de controle, mas como uma alavanca de socialização relacional dos

\section{REFERÊNCIAS}

[1] Benko, Georges. Géographie économique et théorie de la régulation. Finisterra, XXXI, Vol. 62, p. $7-28,1996$.

[2] Brasil. Lei federal $n^{\circ} 13.089$, de 12 de Janeiro de 2015. Institui o Estatuto da Metrópole, altera a Lei $n^{\circ} 10.257$, de 10 de julho de 2001, e dá outras providências.

[3] Castells, Manuel. A sociedade em rede - a era da informação, economia, sociedade e cultura v.1. São Paulo: Paz e Terra, 1999

[4] Colletis, Gabriel. e Pecqueur, Bernard. Révélation de ressources spécifiques et coordination située. Revue Economie et Institution, No 6-7, p. 1-17, 2005

[5] Foucault, Michel. Segurança, Território, População: curso dado no Collège de France (1977-1978). São Paulo: Ed. Martins Fontes, 2008.

[6] Franzoni, Julia Ávila. Dos arranjos metropolitanos: as inovações legislativas, os desafios institucionais e de gestão, e a experiência da RMBH. Curitiba: Terra de Direitos, 2015.

[7] Gatens, Moira e Lloyd, Genevieve. Collective Imaginins: Spinoza, past and present. Londres: Routledge, 1999

[8] Gilly Jean-Pierre. e Lung Yannick. Proximités, secteurs, territoires. Cahier du GRES: Groupement de Recherches Economiques et Sociales, 2005.

[9] Gorsdorf, Leandro Franklin. A dimensão Metropolitana nos Planos Diretores Municipais da Região Metropolitana de Curitiba. Em: Dinâmicas intrametropolitanas e produção do espaço na Região Metropolitana de Curitiba / Moura, R e Firkowski, O. L. C. (org). Observatório de Políticas Públicas Paraná; Curitiba: Letra Capital Editora, 2009 .

[10] Groupe Frontière. La frontière, un objet spatial en mutation. Em: Dictionnaire de la géographie et de l'espace des sociétés/ LÉVY, J. e LUSSAULT, M. (org), Paris: Belin, 2004. agentes, sua operacionalização, enquanto domínio do político, poderia se alicerçar num entendimento do planejamento a partir de uma governança de paradigma do tipo comunicacional, de tradução entre múltiplas redes de proximidades relativa; uma governança que se apresenta como uma constelação de processos, e não uma coisa em si, sempre em construção, de emancipação política e social. Dentre as muitas perguntas, a com que terminamos: como transformarmos o planejamento na ressignificação dos princípios políticos da espacialidade?

[11] Habermas, Jürgen. A Teoría de La Acción Comunicativa: Complementos y estudios previos. Madri: Cátedra, 1989

[12] Hogson, Geoffrey. What Are Institutions? Journal of Economic Issues, Vol. XL, No. 1, p. 1-25, 2006.

[13] Jambes, Jean-Pierre. Territoires apprenants. Esquisses pour le développement local du XXIe siècle. Paris: L'Harmattan, 2001.

[14] Klink, Jeroen. Por que as Regiões Metropolitanas continuam tão ingovernáveis? Problematizando a reestruturação e o reescalonamento do Estado SocialDesenvolvimentista em espaços metropolitanos. Em: Território metropolitano, políticas municipais: por soluções conjuntas de problemas urbanos no âmbito metropolitano / Furtado, B. V.; Krause, C.; Karla França, K.C.B. (org). Brasília: Ipea, 2013.

[15] Laclau, Ernesto; Mouffe, Chantal. Hegemonía y estrategia socialista: hacia una radicalización de la democracia. Madrid, Siglo XXI, 1987.

[16] Lefèbvre, Christian; Roseau, Nathalie e Vitale, Tommaso. Introduction. Les défis de la gouvernance metropolitaine. Em: De la ville à la métropole : les défis de la gouvernance./ LEFĖBVRE, C.; ROSEAU, N. e VITALE, T. (org) Paris: L'oeil d'or, Collection critiques et cités. 2013.

[17] Leloup, Fabienne.; Moyart, Laurence.; Pecqueur Bernard. La gouvernance territoriale comme nouveau mode de coordination territoriale? Revue Géographie Économie Société, Vol. 7, p. 321-332, 2005.

[18] Lencioni, Sandra. Da cidade e sua região à cidade-região. Em: Panorama da geografia brasileira I, p. 65-75. / Silva, J. B.; Lima, L. C.; Elias, D. (Org.). São Paulo: Annablume, 2006.

[19] Massey, Doreen. Pelo Espaço: Uma nova Política da Espacialidade. Rio de Janeiro: Bertrand Brasil, 2009.

[20] Moura, Rosa. A dimensão urbano-regional na metropolização contemporânea. EURE 
(Santiago. Impresa), v. 38, p. 5-31, 2012.

[21] Randolph, Rainer. A origem estrutural da subversão em sociedades capitalistas contemporâneas, suas práticas baseadas na vivência cotidiana e um novo paradigma de um contraplanejamento. Em: Teorias e práticas urbanas: condições para a sociedade urbana, p. 103-128/ COSTA, G.M; MOURA COSTA, H.S.; MONTE-MOR, R.L.M (org). Belo Horizonte: C/Arte, 2015.

[22] Rolnik, Raquel.; Klink, Jeroen. Crescimento econômico e desenvolvimento urbano. Por que nossas cidades continuam tão precárias? Novos estudos CEBRAP, v. 89, p. 89110, 2011

[23] Rooney, David.; Hearn, Gregory.; Mandeville, Thomas.; Joseph, Richard. Public Policy in Knowledge-Based Economies: Foundations and Frameworks. Cheltenham UK: Edward Elgar, 2003

[24] Rooney, David e Schneider, Ursula. The material, mental, historical and social character of knowledge. Em: Handbook on the Knowledge Economy p. 19-36/ Rooney, D.; Hearn, G.; Ninan, A. (org). UK: Edward Elgar Publishing Limited, 2005
[25] Sassen, Saskia. As cidades na economia mundial. São Paulo: Studio Nobel, 1998.

[26] Schiavo, Ester; Vera, Paula; Gelfuso, Alejandro. El derecho a la ciudad desde una perspectiva latinoamericana. Em: I Congreso Latinoamericano de Teoría Social Lugar: Buenos Aires, 2015

[27] Souza Santos, Boaventura de. Epistemologias del Sur. Em: Utopía y Praxis Latinoamericana, Año 16, № 54, p. 17-39, 2011.

[28] Sousa Santos, Boaventura de. Mas allá del pensamiento abismal: de las líneas globales a una ecología de saberes. Em: Pluralismo Epistemológico. La Paz: MueladelDiablo, 2009.

[29] Smith, Neil. Contornos de uma política espacializada. Veículos dos sem-teto e produção de escala geográfica. Em: O espaco da diferença/ Arantes, A. (org). Campinas: Papirus. 2000.

[30] Talbot, Damien. La gouvernance locale, une forme de développement local et durable? Une illustration par les pays. Développement durable et territoires, Dossier 7: Proximité et environnement, 2006.

[31] Torre, André. e Rallet, Alain. Proximity and Localization. Regional Studies, Vol. 39 (1) p. 47 59, 2005.exto das Referências 


\section{Gapítulo 12}

\section{ESPACCOS DE HUMANIZAÇÃO: SIMBOLISMO E APROPRIAÇÃO NO PARQUE JOSÉ AFFONSO JUNQUEIRA}

\section{Esther Aparecida Cervini de Melo}

\section{Jane Victal Ferreira}

\section{Renata Baesso Pereira}

Resumo: Este artigo trata do estudo do Parque José Affonso Junqueira em Poços de Caldas MG, no que se refere as suas apropriações atuais sob o olhar da memória, da psicologia e da fenomenologia. Num primeiro momento, sustentando a poética de um jardim e o papel que ele oferece à população poçoscaldense, procurou-se teorizar sobre o conceito de humanização da cidade relacionada ao aspecto da subjetivação dos seus habitantes. Depois parte-se para uma análise dos aspectos de referência que constituem as memórias e o sentido de lugar que revelam seus vestígios de significação. Finalmente conclui-se com uma consideração sobre as manifestações e recentes eventos realizados neste local dentro de uma perspectiva da diferença, da participação e da potencialização do espaço urbano, buscando- se desenhar as experiências e as novas aspirações da sociedade contemporânea.

Palavras Chave: urbanismo, humanização, memória, identidade, psicologia. 
1. INTRODUÇÃO - ESPAÇOS DE HUMANIZAÇÃO

Atualmente, em várias áreas do conhecimento, o termo humanizar vem sendo retomado, na saúde, na educação, na arquitetura. Mas, também no urbanismo, o conceito humanizar vem aparecendo voltado à busca da escala humana como referência para projetos e para a construção da cidade. Humanizar (Houaiss, 2001) pode significar tornar-se humano, dar ou adquirir condição humana; humanar-se; tornar-se benévolo, ameno, tolerável; humanar-se (a cidade se humanizou com a criação de novos parques); tornar-se mais sociável, mais tratável. Humanizar também tem o sentido de socializar-se dentro de uma visão do processo civilizatório, civilizar-se.

A humanização na arquitetura é colorida pelos aspectos do humanismo clássico, com uma preocupação com a natureza e com a estética, bem como a emoção e o entusiasmo pela melhoria do homem e a sua relação com o ambiente físico (Kowaltowski, 1989). Às vezes a definição do termo humanização vem acompanhada de seu oposto, que é a desumanização. E este processo parece atingir grande parte das cidades contemporâneas em virtude do planejamento moderno. Entre alguns autores, como Jane Jacobs, encontra-se uma das primeiras vozes de resistência e participação cidadã ante os excessos de um urbanismo desumanizado, e em seu livro "Morte e vida das grandes cidades" ela resgata as ricas pré-existências da cidade funcional, compacta e densa onde a rua, o bairro e a comunidade são vitais (Marcos, 2016).

Mais recentemente, e considerando estes valores da humanização, da cidade como lugar de encontro, aparece o arquiteto Jan Ghel, que propõe novamente a dimensão humana como tópico da reorganização das cidades atingidas pelo processo de verticalização, pelo aumento de tráfego de automóveis e pela baixa prioridade ao espaço público. A boa qualidade ao nível dos olhos deve ser considerada como direito humano básico sempre que as pessoas estejam nas cidades (Ghel, 2013).

Humanização, aqui, relaciona-se também aos valores subjetivos que a cidade é capaz de evocar, ligados à memória dos lugares, e muitas vezes, no presente, um determinado espaço está carregado de historicidade, como um substrato inconsciente existente que nos faz sonhar, alimentando a vida psíquica de seus habitantes.

Nesse contexto, este artigo traz um estudo do Complexo Hidrotermal de Poços de Caldas, composto pelo Parque José Affonso Junqueira, os edifícios de Palace Hotel, do Palace Cassino, as Thermas Antonio Carlos e a Praça Pedro Sanches. Será trabalhado, no entanto, o parque José Affonso Junqueira em Poços de Caldas, que desde a sua origem, está ligada à presença das águas termais e tem como metáfora o microcosmo da sociedade burguesa que desde os finais do século XIX buscava refúgios de cura e de prazer (Marrichi, 2015). Existia uma textura social viva e latente que nos faz pensar no jardim como uma área de transição entre o físico e o social, onde a subjetividade do indivíduo pode emergir dando sentido à cidade e seu simbolismo de centralidade como um lastro de permanência, num conjunto amplo de mudanças.

A capacidade de o jardim se constituir como um lugar de transição entre subjetividade do homem e o espaço externo, fortalece a identidade do conjunto e proporciona a existência de um espaço potencial. O espaço potencial é aquele que permite a criação e a estruturação das novas linguagens. Durante a existência do jardim, ele parece recriar-se não em seu desenho, mas na sua relação com a cidade, sendo palco desde o surgimento das preocupações higienistas e de aformoseamento no início do século $X X$, até hoje, como cenário de eventos midiáticos e lugar físico de encontros estabelecidos pelas redes sociais propociado pela tecnologia.

O jardim, no seu cotidiano, para seus frequentadores e habitantes pode representar um ponto de integração com a própria identidade como coletivo e do ser humano como pessoa. Os espaços integradores seriam aqueles voltados à qualidade de vida (Gehl, 2013), que se dá na pequena escala, bons para caminhar, bons para permanecer, bons para encontrar pessoas, bons para auto expressão e atividades físicas, com ótima escala, de bom clima ao nível dos olhos, belos e que proporcionem boas experiências, enfim espaços de vida.

Fazendo uma adaptação da cartilha de Ambiência do Programa Humaniza SUS do Ministério da Saúde, referente à humanização na área da saúde, o conceito de integração envolveria as noções de ambiência e seguem primordialmente três eixos: 
- $\quad$ O espaço que visa à confortabilidade focada na privacidade e individualidade dos sujeitos envolvidos, valorizando elementos do ambiente que interagem com as pessoas cor, cheiro, som, iluminação, morfologia...-, e garantindo conforto dos habitantes.

- $\quad$ O espaço que possibilita a produção de subjetividades - encontro de sujeitos - por meio da ação e reflexão sobre os processos urbanos.

- O espaço usado como ferramenta facilitadora do processo de socialidade, favorecendo a otimização de recursos, a disposição humanizada, acolhedora e resolutiva. É importante ressaltar que esses três eixos devem estar sempre juntos na composição de uma ambiência, sendo esta subdivisão apenas didática.

\section{ARQUEOLOGIA DE UM JARDIM}

A arqueologia proposta se refere à metodologia de análise, pois indica a existência de diversas camadas de significação para um mesmo espaço. A escavação arqueológica se dá como metáfora e procedimento a partir do espaço como hoje se apresenta, buscando-se a profundidade dos seus significados. $O$ presente e 0 passado se encontram. Secchi (2006) em sua visão da cidade como depositária de signos, nos fala:

O jardim, ornamento do solo, cidadela do otium, do céu ou lugar do mito, sempre foi a metáfora da cidade e da sociedade, lugar investido como prefiguração e ideologização por uma sociedade bem organizada.

O jardim é a figura urbanística que estrutura a análise, e diversas narrativas sobre o jardim coabitam no complexo hidrotermal composto pelo Parque Afonso Junqueira e pela Praça Pedro Sanches em Poços de Caldas, MG. O parque pode ser definido como área que constitui unidade de conservação, destinadas à proteção de áreas representativas dotadas de atributos naturais ou paisagísticos notáveis, sítio de interesse histórico e urbanístico. Trata-se de um lugar originário, e que ao mesmo tempo contém o que se pode chamar de figuras do urbanismo (Secchi, 2006): no jardim se expressam e são postos à prova, a importância teórica e os limites das novas ideias.

No caso de Poços de Caldas, o parque e a praça formam um espaço urbano que teve como pressuposto inicial a "esfera" pública, devido ao uso intenso por uma sociedade, presente desde o final do século XIX, que se desenha no início do século XX e continua no século XXI a ser sítio de vários eventos de ordem simbólica. O urbanismo de Poços de Caldas evoca a circulação de ideias do urbanismo sanitarista e da modernização das cidades na passagem do século XIX para o século XX. O que se põe aqui em discussão, observando seus estratos de memória, como o jardim vai sendo construído conforme se estrutura também 0 desenho urbano humanizado como potencializador do espaço público e também o locus segundo o qual torna-se possível os processos singularizados das subjetividades de seus habitantes.

A construção de uma identidade tem um papel central nesta discussão aqui apresentada, na medida em que se faz uma "escuta" do lugar, e a partir daí tenta-se resgatar o papel da subjetividade dentro da pesquisa histórica e nas análises urbanas, fazendo interface com a psicologia e a filosofia.

Mais contemporaneamente, com a comunicação digital e as redes sociais, com uma abrangência virtual, a esfera pública parece ainda necessitar de um espaço físico que exista na realidade e que seja capaz de sustentar a humanização com a criação de uma nova linguagem.

$\mathrm{Na}$ cidade de Poços de Caldas o espaço público não se estrutura por um largo com uma igreja, mas se constitui a partir das águas termais, daí o nome de "Hydrothermópolis", termo usado por Dr. David Benedito Ottoni no início do século XX. A água termal, desde os seus primeiros registros por volta de 1786 , teve a sua origem envolta num imaginário de lendas demoníacas muito em virtude da fumaça e cheiro de enxofre do local. O medo dessas lendas só foi abrandado com a descoberta das características curativas das águas e a partir de então, o campo misterioso passa a ser identificado como "Vale Milagroso" (Pozzer, 2001). O vale apresentava assim, uma paisagem rudimentar e de barracos e cabanas provisórios construídos por doentes que se aventuravam em difíceis viagens para conquistar a cura de seus males.

Em 1826 o doutor Agostinho de Souza Loureiro visita o local para averiguar o aproveitamento das águas termais e é realizado o primeiro levantamento do lugar. 
Figura 1: Análise dos lugares. A primeira planta do local de Poços é datada de 5 de março de 1826. In Ottoni, Homero Benedito. Poços de Caldas, 1960.

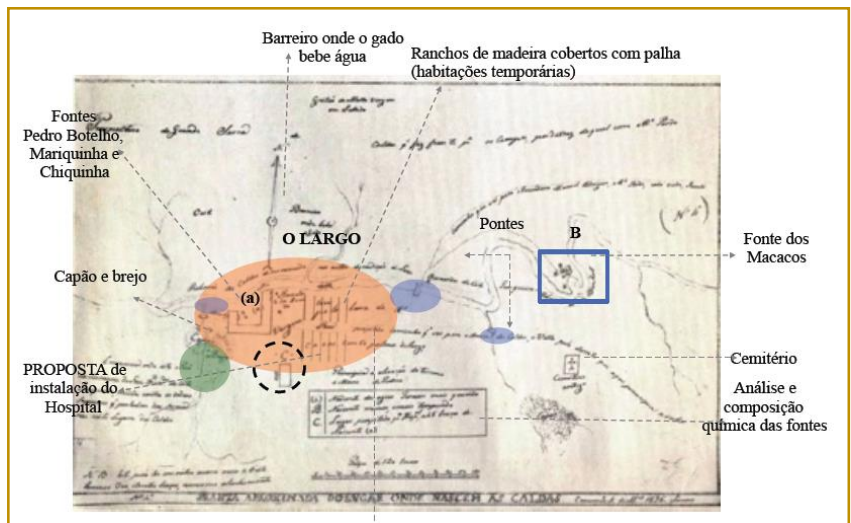

Fonte: MATTHES, Adriane de Almeida. Arquitetura e Permanências. Dissertação de Mestrado. Campinas: POSURB, 2005.

O mapa de 1826 deixa bem claro o desenho de um largo, que ao longo da história, vai sofrer diversas intervenções, no sentido de qualificar esse espaço dando a ele um aspecto de urbanidade e civilidade, sempre ligado aos assuntos do corpo e do mundo, mas nunca ligado ao sagrado e ao espírito. $\mathrm{O}$ povoado recebe o nome de Nossa Senhora da Saúde das Águas de Caldas.

Figura 2: Vista do largo para o Balneário, 1900.

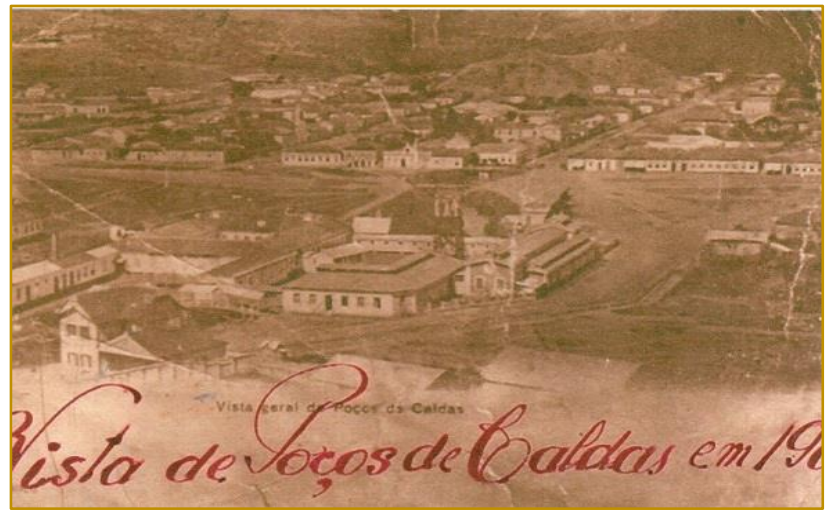

Fonte: Acervo do Museu Histórico e Geográfico de Poços de Caldas.

Em 1873, o governo da Província de Minas Gerais vê a necessidade de várias obras e concede à empresa concessionária a construção de um balneário sobre as fontes Pedro Botelho, Mariquinha e Chiquinha. Mas os atrasos nas obras fizeram com que em 1880 passasse para a "Sociedade Anônima Empresa Balneária" a construção de um balneário, que foi realizado na Praça Senador Godoy (hoje Praça Pedro Sanches), sendo inaugurado em 1884 o "Hotel da Empresa". Paralelamente às construções do balneário e hotéis, o grande público se dirigia ao núcleo urbano. Em 1882 se instalou a Cia Mogiana de Estradas de Ferro, com a conclusão do Ramal de Caldas, facilitando não só o acesso à localidade, mas, também, o escoamento da produção agrícola e cafeeira da região.

No final do século XIX, o potencial curativo e científico das águas minerais despertou o interesse dos governantes e vários melhoramentos passam a ser executados nas estâncias minerais. Nesse período a medicina brasileira tinha como referência os conceitos da educação médica europeia, que acreditava no termalismo, disciplina que era ensinada nas escolas médicas, como um instrumento eficaz para o tratamento de algumas doenças específicas, dentre elas o reumatismo e a sífilis. (Pozzer, 2001). Associase ao tratamento a paisagem agradável 
cercado de montanhas. O contato com a natureza, o distanciamento das cidades de origem representavam um fabuloso coadjuvante do processo de cura.

A análise de uma prática urbanística na cidade de Poços de Caldas, desde o final do século XIX, período chamado de "milagre urbanístico", passaram por importantes obras, como as do Prefeito Francisco Escobar e do importante Plano de Avenidas de 1905 do Dr. David Benedito Ottoni, chegando até as grandes obras da década de 30.

A planta abaixo inaugura a definição da área do parque e das termas que viriam a constituir o coração da cidade e inaugura também a hierarquia urbana que no traçado proposto por Maywald praticamente não existia. O espaço público é privilegiado.

Figura 3: Proposta do arquiteto Piffer, pela Cia Melhoramentos para Poços de Caldas, em 1912. A estação ficaria quase no centro do mapa, um pouco abaixo, em frente a um jardim que existe do outro lado do Hotel das Termas. A linha viria do oeste e faria uma curva para o norte na entrada da estação.

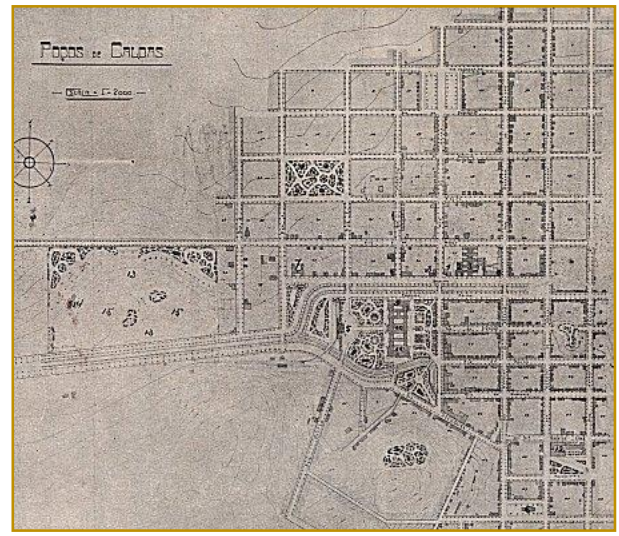

Fonte: Museu Histórico e Geográfico de Poços de Caldas.

No início do século XX, Poços de Caldas se tornou a mais importante estância hidromineral brasileira. Sua reputação acabou atraindo políticos, escritores, artistas famosos, a burguesia emergente, e a sua imagem sendo transformada numa cidade do jogo e do lazer. A cidade vai sendo conhecida por suas águas sulfurosas com propriedades curativas, mas também vai sendo reconhecida como território aprazível onde os frequentadores abastados podiam desfrutar de vários hotéis, passeios, bailes, shows e cassinos.

De 1920 a 1922 o Eng ${ }^{\circ}$ Lourenço Baeta Neves foi prefeito de Poços de Caldas e administrou a situação financeira do município e deu continuidade as obras iniciadas. Pretendia ainda empreender uma regularização no sistema sanitário municipal.

Nas cidades novas, nenhum problema excede de importância ao do estabelecimento ou regularização do aparelho hygienico do meio urbano, problema, cuja solução deve preparar o progresso local e nunca por este esperar, conforme o pensamento elevado da máxima de Saturnino de Brito, o mestre incomparável da engenharia sanitária (NEVES, 1922).

Baeta Neves propôs a obrigatoriedade do uso do sistema municipal de água e esgotos nos prédios servidos pela rede pública, a utilização de aparelhos sanitários e reformas nas instalações de higiene, criação de lavanderias públicas. Ele criticava a monotonia da tipologia dos chalets e sugeriu a adoção de tipologias com casas ajardinadas como as americanas.

Em 1925, a Companhia Melhoramentos, procurando cumprir as exigências contratuais, inaugurou o Palace Hotel, no entanto sem os critérios estéticos necessários a um hotel de estância hidromineral. Em 1926, um novo contrato com a Cia Melhoramentos obrigava melhorias no Palace Hotel, com a utilização de materiais e mobiliários adequados. Mas a não observação das exigências contratuais fez com que em 1927 a prefeitura de Poços de Caldas viesse administrar as águas, sendo prefeito então Carlos Pinheiro Chagas. A expectativa da população pela construção de uma cidade bela e salubre foi incrementada 
pala visita do Presidente Antônio Carlos Ribeiro de Andrada neste ano.

O Plano Geral de Melhoramentos compreendia as seguintes obras: reforma dos serviços de energia elétrica e iluminação pública, reforma geral da rede de esgotos e captação de mananciais, calçamento da cidade, construção de parques e jardins, receptação das fontes hidrominerais e construção de um novo hotel, de um cassino e um novo balneário. A expectativa sobre a remodelação da estância possibilitou a construção da mais importante estação de cura da América do Sul (LEME, 1999).

Carlos Pinheiro Chagas realizou uma viagem à Europa tendo como objetivo conhecer algumas estâncias termais em Portugal, na Alemanha, Tchecoslováquia, França e Itália. Nessa viagem foram contratados os serviços do médico hidrologista Paul Schoeber de Widband e do engenheiro Engen Maurer de Baden-Baden. Para o saneamento da estância foram contratados o Engenheiro Sanitarista Francisco Saturnino de Brito e o paisagismo e arborização dos parques, praças, ruas e avenidas à empresa Dierberger e Cia. Para projetos de edificações foi escolhido o arquiteto Eduardo Vasconcelos Pederneiras.

\section{SANITARISMO MODIFICANDO PAISAGEM: SATURNINO DE BRITO}

Em 1927, Saturnino de Brito e seu filho Saturnino de Brito Filho, estudaram a cidade de Poços de Caldas, resultando num projeto e obras de saneamento, abastecimento de água e sistema de drenagem das águas pluviais.

Ele criticava a adoção da malha reticulada para as vias públicas urbanas, recomendando esta tipologia às áreas planas e não a encostas. Propunha uma adequação à topografia, de modo a facilitar as obras de saneamento. Também defendia "tirar partido do pitoresco natural, aformoseando a cidade tornando-a mais atraente aos milhares de visitantes que vêem anualmente procurar a cura dos seus males pelas águas medicinais e pelo clima, deixando em troca valiosas quantias e para as rendas do Município e do Estado" (BRITO, 1944).

Os ribeirões que cortam a cidade foram considerados eixos estruturadores da futura expansão urbana e onde está o núcleo urbano, numa pequena planície onde ocorria a confluência dos ribeirões a leste estava a Avenida Francisco Sales, margeando o Ribeirão da Serra, a sudoeste o Ribeirão das Caldas e a oeste seguindo o troco das águas a Avenida João Pinheiro.

O desenho urbano da nova paisagem deveria acompanhar os Ribeirões e a topografia, cabendo ao "urbanista" a adoção dos traçados a serem adotados.

Nesse sentido, o conceito de aformoseamento não se limitava a obras de embelezamento, mas também a uma estética que estabelecia diretrizes técnicas para a expansão urbana. Para a construção dessa cidade bela e salubre, criando uma imagem urbana moderna, Saturnino de Brito teve vários problemas a enfrentar, desde a existência de quintais junto às águas nos quais se lavavam as roupas tantos dos sãos quanto dos doentes, até a execução de obras contra enchentes e melhoramentos nos balneários.

Saturnino de Brito indicava para a preservação dos mananciais da cidade, a desapropriação das bacias hidrográficas. Localizou os principais mananciais e sua captação, analisou os sistemas de esgoto e propôs a correção das irregularidades. $\mathrm{Na}$ análise das enchentes, foi considerada a grande inundação de 1926, que deixou a área central sob um metro de água. Com a conclusão dos estudos e dos projetos, uma série de obras de saneamento de grandes proporções foi realizada, e compreendiam também a construção das redes de água e esgotos, regularização dos cursos d'água e a canalização dos ribeirões, saneamento e redesenho da cidade contribuindo para a construção de uma nova paisagem urbana (Pozzer, 2001).

\section{A CONSTRUÇÃO DA IMAGEM ARQUITETÔNICA: EDUARDO VASCONCELOS PEDERNEIRAS}

Coube a Eduardo Vasconcelos Pederneiras a realização da reforma do Palace Hotel, os edifícios do Cassino e a reforma da Praça Pedro Sanches. Em 1927 são iniciadas as obras de demolição do Hotel da Empresa, do cassino e do antigo balneário. Ele dizia do conjunto de obras a serem realizadas:

O Palace Hotel será transformado em sua fachada e no seu interior. Do styloactual, próprio para um quartel, passará a ter o agradável aspecto dos hotéis da Suissa, com bonitas sacadas em balanço, jardineiras 
floridas, largos alpendres sustentados por arcadas graciosas, enfim terá o stylo apropriado a um hotel de uma cidade de águas situada na montanha.

Sobre o projeto do novo parque Pederneiras comentava no jornal Vida Social de 07 de julho de 1927:

...ocupara grande área de terreno actualmente abandonada, em frente do hotel de forma triangular, tendo dois dos seus lados limitados por um rio, sendo o terceiro lado paralelo à fachada do hotel. É uma área de cerca de quatrocentos metros quadrados, admiravelmente situada, e cuja situação será tirado o maior partido architectonico, Tratando-se de um parque, em uma cidade de águas, em que o aquático precisa passear ou descansar à sombra das árvores, escolhi como typo, o dos parques ingleses, com muito bosque e portanto, bastante sombra.

O projeto de reforma do Palace Hotel foi pensado conjuntamente com a proposta do novo parque urbano, com grande eixo lesteoeste construído como eixo estruturador que se prolonga da Rua São Paulo, demarcando o centro da praça Pedro Sanches, atravessa o hall de entrada do Palace Hotel, prolonga-se pelo parque, por uma fonte luminosa chegando ao pavilhão do chá.

Os projetos do Cassino e o das Thermas vão estabelecer uma relação tipológica com as formas propostas para a reforma do Palace Hotel, formando um conjunto cênico emoldurado pela cidade e pelas montanhas (a Serra de São Domingos).

Criava-se, assim, uma paisagem eclética que se destacava pela sua singularidade, no contexto urbano local. O arquiteto eclético estabelecia referências novas naquela paisagem em edificações como o hotel, o cassino e a thermas, caracterizada por telhados, pérgolas e sacadas que apresentavam certa familiaridade morfológica que contrastava com a implantação em ângulo e 0 rigor da linguagem clássica empregada na composição da casa de banhos.

\section{O DESENHO DOS JARDINS: DIERBERGER E CIA}

Um elemento fundamental de importância para emoldurar dos projetos do Palace Hotel, do Cassino e da Thermas foi a proposição eclética dos jardins elaborados por João e Reynaldo Dierberger. Tinham como características básicas:

...o tratamento do espaço livre dentro de uma visão romântica e idílica, que procura recriar nos espaços a imagem de paraísos perdidos, de campos bucólicos ou de jardins de palácios reais, incorporando no seu ideário uma concepção pitoresca de mundo típica da sociedade europeia do século XIX (MACEDO, 1999).

Em Poços de Caldas, Dieberger segue as sugestões de projeto de Eduardo Paderneiras, com jardins que estabeleciam um contraste entre as linguagens clássicas e românticas dos edifícios existentes. Os jardins que envolviam as novas Thermas apresentavam uma organização mais livre caracterizada pela irregularidade das formas propostas (Pozzer, 2001).

Figura 4 : Proposta para o novo parque em Poços de Caldas, autoria de Dierberger.

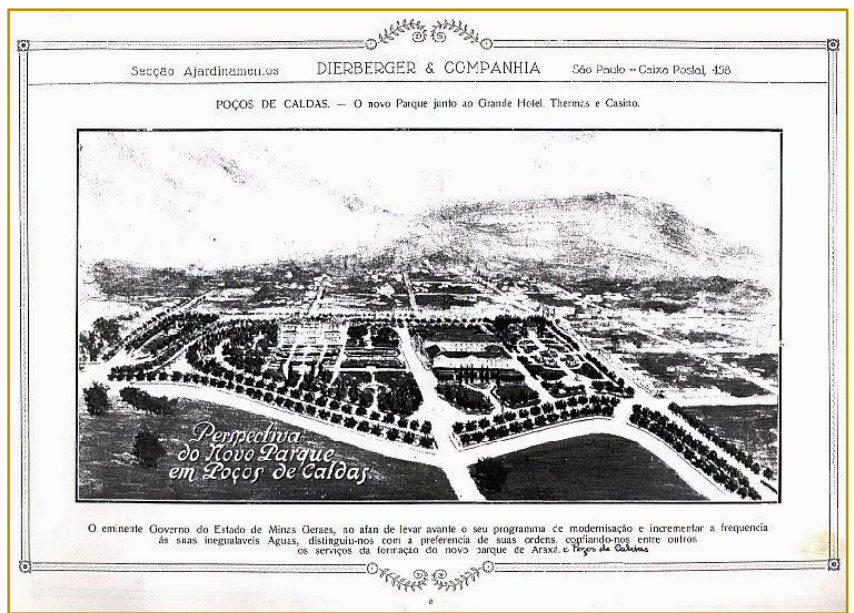

Fonte: Acervo do Museu Histórico e Geográfico de Poços de Caldas. 
Figura 5: Parque José Affonso Junqueira, Praça Pedro Sanches e praça Getúlio Vargas.

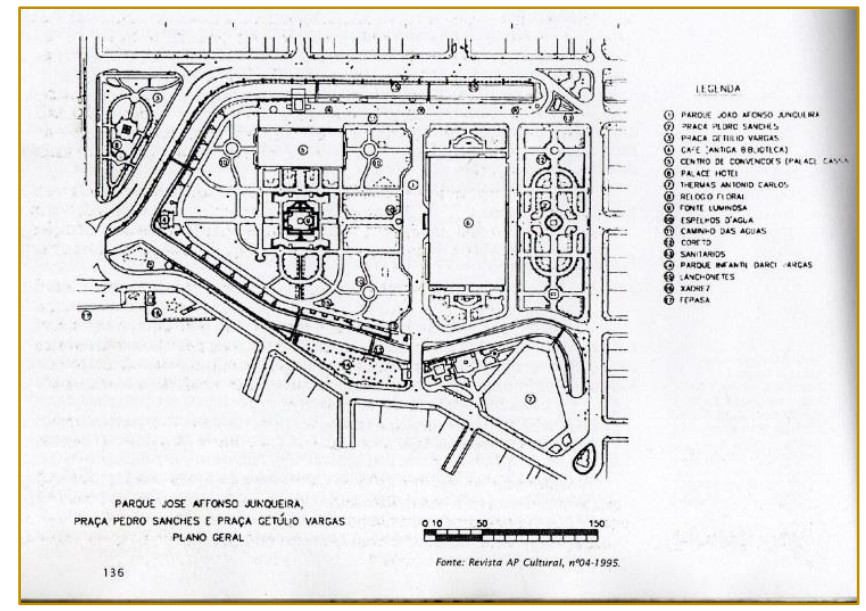

Fonte: Revista AP Cultural ํo 04, 1995.

Figura 6: Área atual do Parque José Affonso Junqueira.

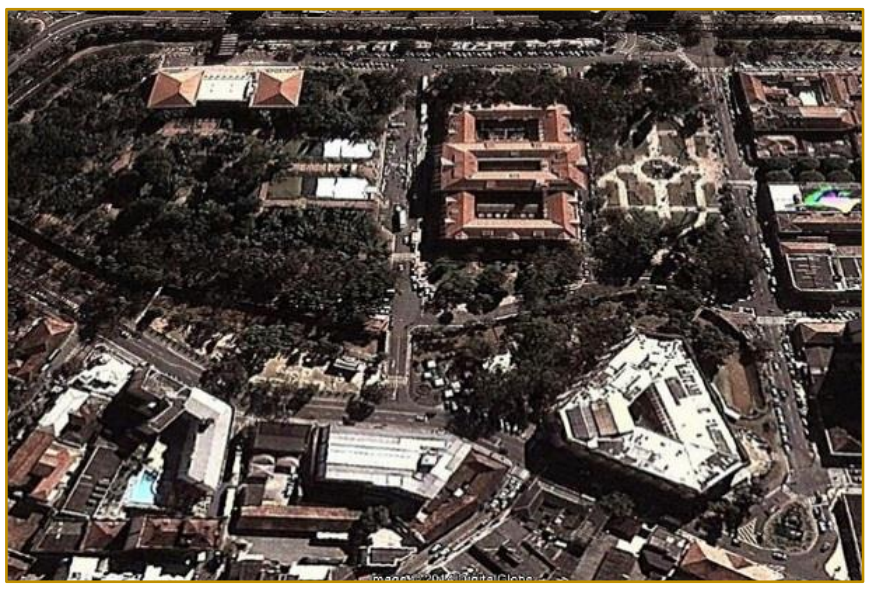

Fonte: http://www.memoriadepocos.com.br/2014/02/os-jardins-de-dierberger.html

Ao considerar todos os elementos do conjunto de intervenção: eixos estruturadores, dos canteiros, os tratados "clássicos" e "românticos", esculturas, coreto, fonte luminosa, pergolado, novos edifícios monumentais, os Dierberger acabam propondo uma composição de árvores, arbustos e forrações, que proporcionaram uma unidade estética para a grande obra. Em 1931 são finalmente inaugurados o Cassino e as Thermas.

Posteriormente, as vizinhanças de Poços vão sofrer com a Revolução de 1932. Muitas batalhas são travadas na divisa do estado com São Paulo. Com a turbulência da guerra, as grandes obras realizadas em Poços de Caldas tiveram seu movimento diminuído. Em 1933, a Prefeitura Municipal levanta fundos para a pavimentação e arborização da cidade, e também o escritório do Eng ${ }^{\circ}$
Saturnino de Brito dá a solução final da construção de uma represa de contenção para controlar as cheias na área central.

Durante os anos 40 a cidade desfruta de uma estabilização das atividades econômicas advinda do turismo e da prática dos jogos, com um aumento de obras de cassinos e outros empreendimentos. Em 1945, a guerra mundial eclode, e o termalismo passa a ser menos recomendado, perdendo terreno para a "medicina científica" desenvolvida nos EUA, com a descoberta da penicilina. No mesmo ano abre-se o período de campanha eleitoral, com a deposição de Getúlio Vargas. Eurico Gaspar Dutra vence então as eleições presidenciais. Em 1946 o novo presidente decreta o fim dos jogos de azar, determinando o fechamento de todos os cassinos no Brasil. 
A cidade de Poços de Caldas teve, por sua vez, sua economia abalada, passando um grande período de recessão. O município vai dedicar-se a partir da década de 50, às atividades extrativas de minérios e ao incremento do processo de industrialização com a chegada de multinacionais ao município. Inicia-se a construção de bairros de interesse social e conjuntos habitacionais na periferia da cidade. Ainda na década de 60 o perfil do turismo acaba se consagrando com a cidade desenvolvendo o circuito de "lua de mel" tendo o Parque José Affonso Junqueira com seu jardim como cenário muito propício. Novas alternativas para o turismo são implementadas culminando na década de 70 com o seu perfil voltado à classe popular.

Com vistas à preservação do patrimônio histórico da cidade, foi decretado o tombamento do complexo Hidrotermal de Poços de Caldas em 1985 pelo DPHTAM Diretoria do Patrimônio Histórico, Turístico e Artístico Municipal. Em 1992, com a realização do Plano Diretor da cidade, para área de turismo foram recomendadas diretrizes de revitalização da área central, com critérios a serem adotados no sentido de restabelecer-se a identidade do conjunto. Em 1993 a prefeitura municipal lança o Concurso Nacional para Revitalização da área Central "Poços Centro Vivo" que tinha como objetivos a reestruturação da paisagem urbana, a ordenação do tráfego de veículos, a ordenação das atividades urbanas, a dinamização dos usos e atividades urbanas e a proposição de formas de gestão urbana. Também, procurou-se reestabelecer o desenho originário para o jardim, que durante todos estes anos foi se tropicalizando pelo adensamento de espécies vegetais. A proposta de projeto procurou: 0 remanejamento das espécies vegetais; a recuperação do piso, a implantação de novo sistema de iluminação que possibilitasse maior segurança e conforto aos usuários e criação de efeitos cênicos para valorizar o patrimônio arquitetônico e paisagístico e a instalação de novo sistema de mobiliário urbano.

\section{A PAISAGEM INTERIOR: ALGUNS ELEMENTOS DE PSICOLOGIA AMBIENTAL}

O interesse em relacionar a história de um jardim e os processos de apropriação e identificação do lugar, parece configurar um campo de estudo interdisciplinar muito importante para a estruturação subjetiva da memória dos habitantes de Poços de Caldas. O simbolismo decorrente deste espaço vinculado à utilização das águas termais atraía no passado uma grande quantidade de visitantes cujo tratamento com banhos vinha acompanhado também pelo cuidado do ambiente: o repouso, o passeio no jardim sombreado, o controle das emoções (Marrichi, 2015) favoreciam, do ponto de vista social, uma nova postura e convivência afastada do cotidiano doméstico. Neste tempo em suspenso, representa uma janela na percepção do ser, de onde possível se ver a busca ontológica que o jardim evocava.

Proshansky (1978), na década de 60, inaugurou nos Estados Unidos, uma escola de Psicologia Ambiental na linha dos movimentos ambientalistas e além de preocupação com o meio ambiente natural, dedica-se também ao estudo do meio ambiente urbano. Para ele o processo de apropriação se relaciona com a identidade de lugar (placeidentity). Assim o lugar tem uma significação para o sujeito que o incorpora à própria identidade, ou seja, a identidade do "eu".

Para cada 'rol' de identidade, existem dimensões e características do entorno físico. Nesse sentido, a identidade de lugar (seu significado) é um componente específico do próprio 'eu' do sujeito, forjado por meio de um complexo processo de ideias conscientes e inconscientes, sentimentos, valores, objetivos, preferências, habilidades e tendências (Gonçalves, 2007, p. 27)

O processo de apropriação atua em dois sentidos: um em direção à conquista do espaço, e outro para si. Isto implica o sujeito adaptar um espaço as suas próprias necessidades, dar-lhe características próprias. A relação pessoa/ sociedade/ meio ambiente tem sempre uma dimensão da vivência e simbolismo. Essa dimensão tem aparecido muito nas conceituações de qualidade de vida, bem estar social e comunidade, e também naquilo que se refere à percepção e valorização da paisagem. Para a Psicologia, paisagem refere-se ao mundo intrapsíquico enquanto que para a arquitetura consiste na organização de imagens no mundo externo. Paisagem está diretamente ligado ao conceito de habitat e de espaço, levando em conta que o gerador dessa paisagem são as comunidades inseridas nesses habitats e que ocupam aquele determinado espaço (MACEDO, 1999). 
Essa interação pessoa - ambiente é assegurada pelo fato de ser o meio físico circundante, onde se assenta os espaços culturais, o local em que o sujeito vive e constrói a sua subjetividade. A apropriação do espaço é a de lugares repletos de significados, ou de signos que se acumulam em camadas. Estes são a "pousada" do espaço que se define como sendo um movimento tanto externo quanto interno (Gonçalves, 2007). Assim, o espaço não é só o meio circundante físico uma vez que por meio da dimensão sociocultural o sujeito internaliza e representa.

A apropriação, como processo de identificação, é em certa medida, um agente transformador, pois ao apropriar-se do espaço o sujeito deixa sua marca ao transformá-lo, iniciando, assim, um processo de reapropriação contínuo, que vai desde a cidade, a casa até seu interior. A partir das cores, das formas, dos odores, das sensações de prazer, o sujeito vai modificando as paisagens concretas do lugar, deixando sua marca e ao mesmo tempo, vai transformando sua paisagem interna, as paisagens do seu mundo interno.

\section{SUBJETIVAÇÃO E CONTEMPORANEIDADE}

Embora Poços de Caldas seja uma cidade de pequeno porte, em certos aspectos ela não está imune às forças da globalização. Subjetivação contemporânea e globalização (Montagna, 2001) andam conjuntamente. A metrópole seria a representação mais aproximada da contemporaneidade na caminhada da globalização. Paira a experiência de aceleração do tempo e a integração do espaço, permeando suas feições.

Mas o Parque José Affonso Junqueira, na contemporaneidade, continua a atrair formas de representação social e da vida pública. $A$ experiência deste espaço resguarda uma memória afetiva e sua decorrente preservação. O espaço interno e o externo seriam criados pelo próprio indivíduo de acordo com uma dinâmica do "incorporar atirar para fora". As realidades externas reais e independentes ou relativamente independentes influem o mundo interno do indivíduo, modificando-o pessoalmente.

Para Montagna (2001) Winnicott foi provavelmente o psicanalista que mais se ateve sobre a interação eu-mundo externo.
Ocupa-se do espaço de origem do jogo, da cultura e da espontaneidade. O mundo só existe para o bebê na medida em que ele próprio o cria, e ele só pode criar na medida em que ele exista, é sua proposição.

A subjetivação se dá a partir da realidade externa palpável, mas que só existe na medida em que de maneira particular vem a ser apropriada e feita existir pelo próprio indivíduo, a um tempo autor e personagem passivo de sua história pessoal. (Winnicott, 1988) Se há uma falha da adaptação materna, há uma distorção no processo de vida do bebê.

Para Damergian (2001), o sujeito constrói seu mundo interno na relação com o mundo social que, nos iniciais momentos de vida, é representado pela mãe. A primeira experiência de interação do ser humano é o ponto de partida da construção da subjetividade.

Pensar o social é refletir sobre a relação da criança com sua mãe que é, no momento de seu nascimento, todo o seu mundo. A mãe traz consigo o meio representado, e nele estão os modelos de identificação. São os modelos que, ao serem internalizados pela criança, vão orientar a estruturação de sua personalidade. Deste modo, a mãe, com ser psicológico desejante, é também representante do social, transmitindo aquilo que incorporou em sua história. A sociedade dispõe, portanto, de outra condição vital para o ser humano: nela estão os objetos das necessidades e desejos humanos.

$\mathrm{Na}$ discussão sobre a construção da subjetividade na metrópole, Damergian (2001) faz uma comparação analógica mãe/sociedade. A sociedade deve ser a valência positiva para o sujeito. Nesta visão, mãe-sociedade seria a valência positiva, em que a pulsão de vida seria predominante.

Harvey situa a questão da identidade na modernidade como uma celebração móvel, ou seja, o sujeito não tem uma identidade fixa, essencial ou permanente. Se o espaço urbano é o lócus de encontros e trocas sociais, num tempo tão acelerado, é difícil reconhecer marcos concretos que possibilitam contemplar e evocar nossa presença humanizada, nossa vida reconhecida, e não caída no anonimato da metrópole. Para Peter Sloterdijk (1999), "no individualismo-quitinete das metrópoles pós-modernas a capacidade de ilhar-se se torna definição do próprio indivíduo". O termo insularização foi definido 
como sucessão da humanidade-horda da Velha Natureza, a segunda insularização como a utilização, nas grandes civilizações, do homem pelo homem e a terceira insularização como pós-social, como aquela que precisa cada vez menos da sociedade.

Na relação dialética entre eu-mundo externo, Montagna nos fala sobre os caminhos intermediários de como trabalhar esta relação. Subjetividade na cultura do narcisismo, a sociedade de consumo como sistema simbólico dominante da subjetividade e do inconsciente apresenta uma crise da representação na modernidade. No caso de Poços de Caldas, o jardim resiste em sua presença como um oásis, frente a esta crise de representação.

\section{SUBJETIVIDADE E SENTIMENTO DE IDENTIDADE}

O sentimento de identidade, substância da subjetivação, define a unidade resultante de todos os processos identificatórios pelos quais o sujeito passa (e continua a passar) tendo assim uma natureza dinâmica e relacional. É por meio das introjeções e projeções, que o processo cultural, se consolida e trabalha a subjetivação através da identidade. É esta troca incessante com o meio externo que nos delimita através de uma camada virtual, o que Montagna chama de envelope de transicionalidade, realçando a plasticidade e o dinamismo implícito na adaptação do sujeito ao mundo. Winnicott e Anzieu seriam dois autores que compartilham deste conceito de espaço transicional. Por extensão, nossa apropriação de um espaço urbano também contém semelhante movimento.

O sentimento de identidade é fundamental para o ser humano. Ser reconhecido como pessoa faz parte dos sentimentos humanos e algumas vezes ele se sobrepõe à necessidade de prazer. É diferente do sentimento de existência, de estar vivo mesmo que este esteja no sentimento de identidade.

Para Montagna a marca dos ideais e de sua construção é importante no processo de amalgamento da identidade, e portanto, da subjetivação. Assim, assinala a importância do enraizamento em um lugar como possibilidade de aí voltar, um refúgio onde recolher consolo, uma morada para viver ou também os lugares revisitados e este ambiente pode ser também a cidade, repleta de lugares familiares que resistem ao sujeito, nas reviravoltas da vida, o sentimento de sua identidade. O desafio da contemporaneidade é o de manter nossas identidades face às mudanças, sem nos des-historicizar.

"Caminhamos em direção aos muros da cidade, e no temor da memória, não se sabe bem quem era a criança que ali brincava, que prazeres encerram. Então o súbito desígnio das casas, das ruas, das formas, do espaço dá às lembranças um contorno e consistência. É assim que o espaço ajuda a estruturar o tempo e que o olhar vem em socorro da memória. O olhar que outrora desempenhou um papel de suporte narcísico... é reconhecido e aí o ego reconhece suas fronteiras. O retorno à casa natal é um movimento de identificação consigo mesmo". (Berry apud Montagna, 2001, p. 78)

\section{FENOMENOLOGIA DE UM JARDIM: UMA BREVE NARRATIVA}

É possível dizer que a fenomenologia, enquanto terminologia ou nomenclatura está presente na história da filosofia e das ciências humanas há muitos séculos. No entanto, a proposta fenomenológica é consideravelmente mais jovem. Cunhada por Husserl em 1900, na obra "Investigações lógicas", a fenomenologia enquanto ciência dos fenômenos, aquela que por meio daquilo que se mostra a partir de si mesmo pretende o acesso ao ser. (MARCELLO, 2009).

Heidegger, discípulo de Husserl, adota o método de investigação fenomenológico em sua obra, sendo que em "Ser e Tempo", o filósofo promove uma ontologia acerca da existência humana, e, para tanto, a fenomenologia é empregada enquanto método. Heidegger considera que a fenomenologia é o "deixar e fazer ver por si mesmo aquilo que se mostra, tal como se mostra a partir de si mesmo. É este o sentido formal da pesquisa que traz o nome de fenomenologia (...)" (Heidegger apud Marcello, 1999). Com isso, o filósofo aprimora a definição inicial, apresentando, então, a fenomenologia como sendo a ciência dos fenômenos, a qual deve apreender os objetos.

É muito raro nos dias atuais, encontrar lugares que resistiram às mudanças dos tempos, e que guardam ou testemunham a memória de 
seus habitantes. As crianças ainda andam de charrete, as noivas ainda fotografam seus álbuns no jardim, a banda ainda toca no coreto (figura 8) todo o final de semana e, em sua roda, casais idosos vão dançar, a fonte luminosa (figura 9) ainda brilha ao som de músicas clássicas, ainda se marcam encontros na praça, ainda se passeia com cachorros, se brinca no parquinho, a Chalana dos Artistas (figura 13) ainda anima o Carnaval na praça. E se incorporaram novas tradições como a Sinfonia das Águas (figura 10), a mostra de Carros Antigos, as manifestações públicas, os shows, a queima de fogos na passagem de ano.

Figura 6 e 7: O Bosque e o jardim. Parque José Affonso Junqueira, 2008.

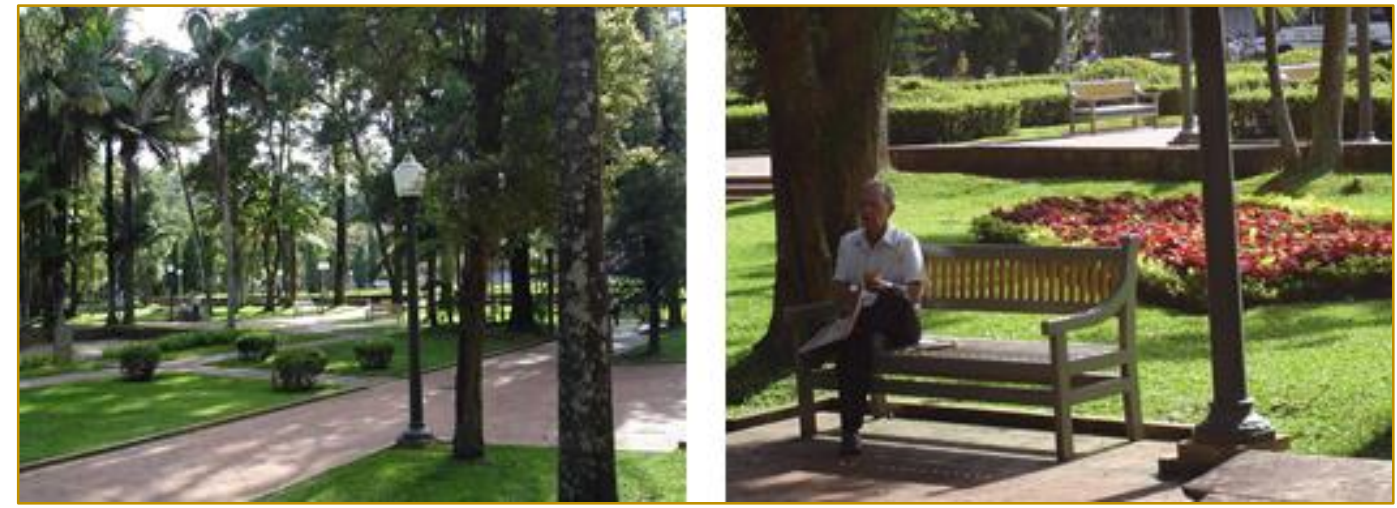

Fonte: Acervo Esther Cervini.

Figura 8 e 9: O coreto na Praça Pedro Sanches e fonte luminosa no Parque José Affonso Junqueira, 2008.

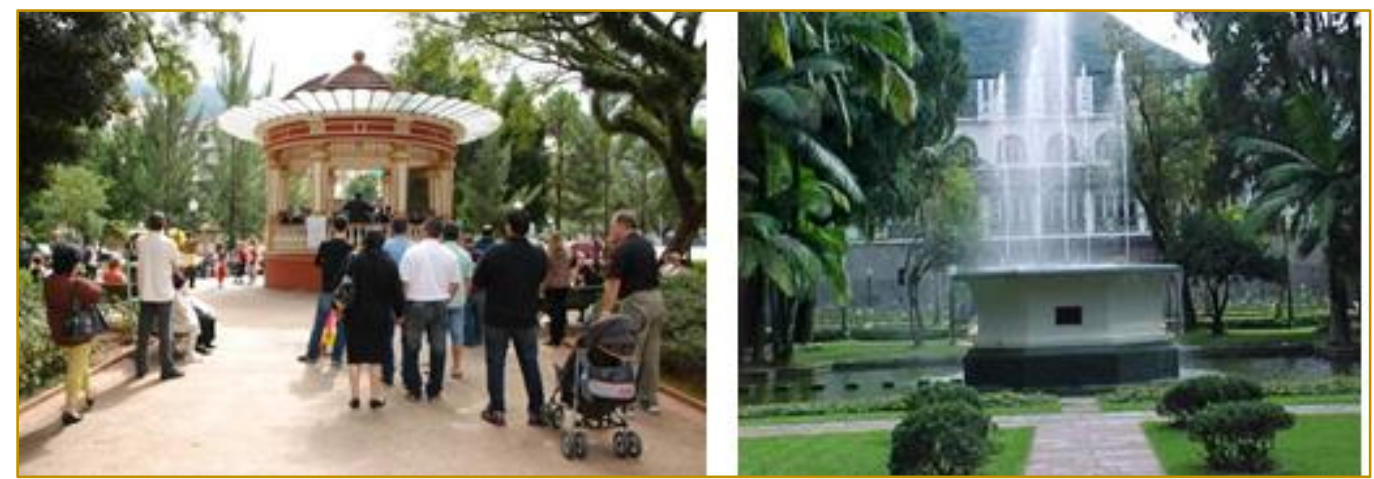

Fonte: Acervo Esther Cervini.

O jardim guarda vários lugares na Praça Pedro Sanches e no Parque Affonso Junqueira: o bosque, as fonte, os chafarizes, o pergolado, a casa de chá, antes biblioteca e agora o café, o jardim de azaléias, o gramado, o bondinho, "o palácio", o cassino, as termas.

A poética seria uma dimensão humana comum a todos os homens em que a pessoa transcende a própria história e o próprio tempo. Seria o "instante consagrado" a que Paz (1973) fala: faz-se homem ao fazer-se poeta, e assim, recuperar em si, naquele instante, a humanidade de todos os homens. O tempo (Gonçalves, 2007) é conduzido pelo objeto estético, capturado na obra estética, quer dizer, a captura poética é involuntária.

O potencial de se ofertar como espaço de humanização depende da apreensão sensível. Cada elemento arquitetônico do Parque José Affonso Junqueira representa um elemento poético que faz ancoragem material no espaço, porque a poética se estrutura por intermédio da experiência com o objeto poético e este é sempre evocativo. A poética perpassa as fronteiras da determinação do sujeito e no instante poético há a transformação do sujeito. Ele recria a si ao recriar concretamente o seu mundo. O sujeito se expressa e se revela no objeto poético. 
Com as transformações ocorridas durante 0 século XX e XXI, o jardim continua a preservar a aura do pitoresco e romantismo, mas também vem ocupar o lugar da experiência. O jardim torna-se palco de eventos e manifestações públicas de diversos grupos da cidade desde o hip-hop dos jovens até as atuais manifestações e ocupações políticas por grupos de ativistas na cidade.

\section{CONSIDERAÇÕES FINAIS}

Como observa Matthes (2006) estas seriam intervenções e organizações de uma estrutura urbana pensada para se constituir um espaço público coletivo.

A produção de um espaço social, construído com uma intenção que resultou numa dinâmica social com fluxos até hoje muito intensos. Um espaço que se construiu ao redor de equipamentos públicos de saúde, de serviços e de lazer, e que se configurou em espaços de contemplação, onde o desenho urbano sempre teve papel marcante e estruturador de um cenário para a promoção e convívio sociais.

Figura 10 e 11: Palace Hotel e Parque José Affonso Junqueira no espetáculo Sinfonia das Águas, 2016
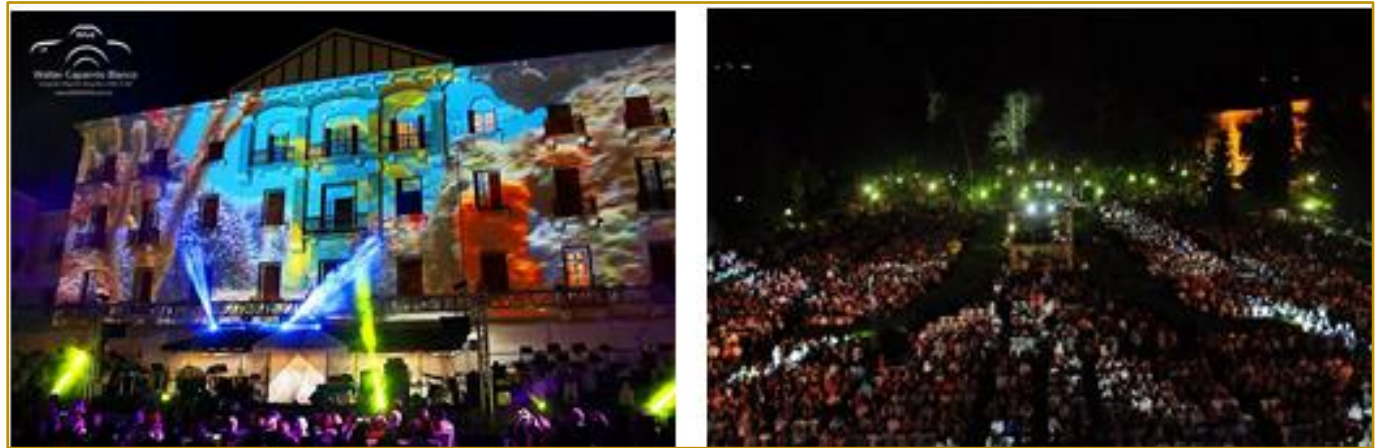

Fonte:https://www.google.com.br/search?q=sinfonia+das+\%C3\%A1guas\&biw=1366\&bih=673\&source=Inms\&t bm=isch\&sa=X\&ved=0ahUKEwilqciHndfPAhWIEpAKHd_2CgEQ_AUIBygC\#imgrc=wQAXCnImQ0vmZM\%3A . Acessado em 10/11/2016.

Não há como negar a incorporação de novos paradigmas à análise das condições de vida e do desenvolvimento no momento atual. A intersubjetividade como $\mathrm{O}$ mais novo paradigma da Ciência, (Habermas apud
Gonçalves, 2007) contribui para os processos simultâneos do conhecimento do mundo e a auto-subjetivação humana pela razão comunicativa.

Figura 12: A Chalana dos Artistas, Carnaval de 2016. Acervo: Esther Cervini. Figura 13: Manifestações em 2015.

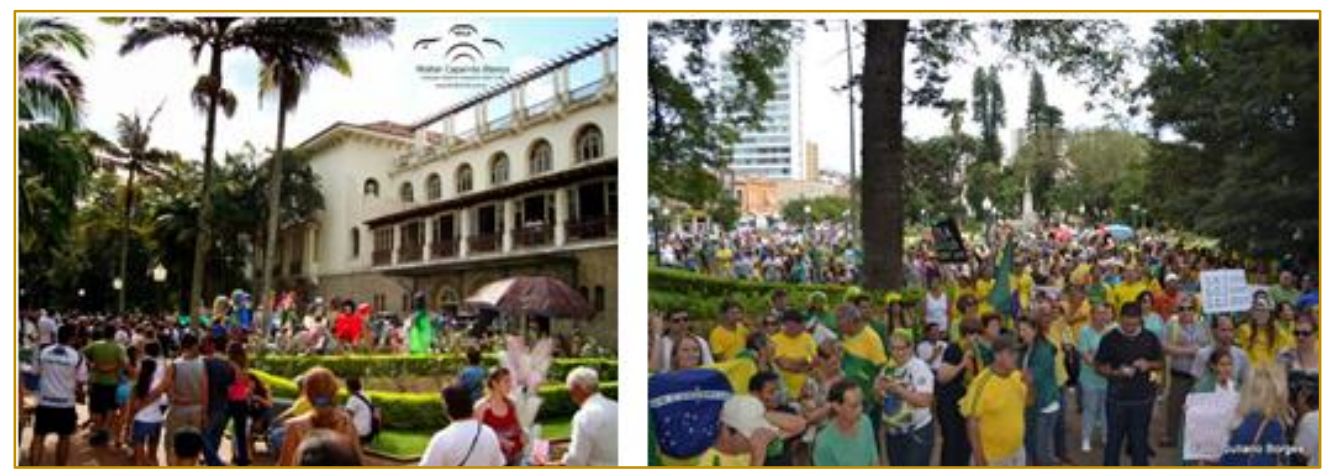

Fonte: Juliano Borges 
O potencial de se ofertar como espaço de humanização depende da apreensão sensível. Cada elemento arquitetônico do Parque José Affonso Junqueira representa um elemento poético que faz ancoragem material no espaço, porque a poética se estrutura por intermédio da experiência com o objeto poético e este é sempre evocativo. A poética perpassa as fronteiras da determinação do sujeito e no instante poético há a transformação do sujeito. Ele recria a si ao recriar concretamente o seu mundo. O sujeito se expressa e se revela no objeto poético.

Figura 14: Instalação do coletivo Trama Ação Urbana, 2016.

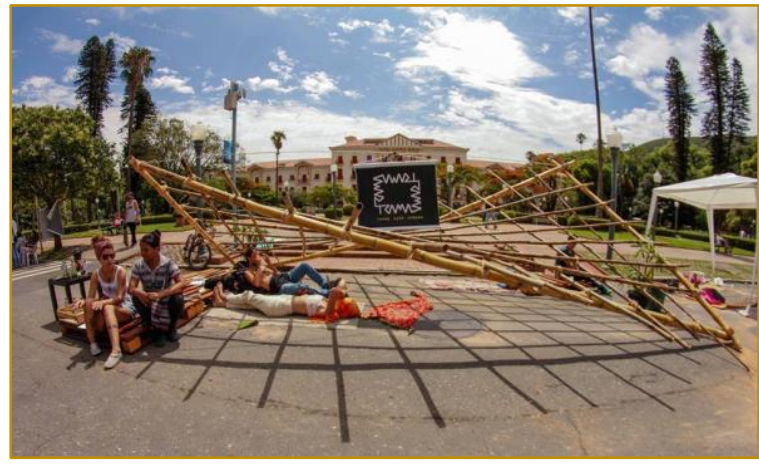

Fonte:https://www.facebook.com/tramaacaourbana/photos/pb.307514239415313.2207520000.1476344338./673699652796768/?type=3\&theater. Acessado em 10/11/2016.

A transmissão dos significados da cidade se faz pela consolidação da identidade no jardim e se engendra pela intersubjetividade, capaz de ser acessada pela memória dos lugares. O espaço não é, portanto, apenas uma localização físico-geográfica, é também

\section{REFERÊNCIAS}

[1] Andrade, Carlos Roberto Monteiro de. A Peste e o Plano: O urbanismo sanitarista do engenheiro Saturnino de Brito. Dissertação de mestrado. São Paulo: FAU -USP, 1992.

[2] Anzieu, Didier. O Eu pele. Rio de Janeiro: Casa do Psicólogo, 1989.

[3] Bollas, C. A Arquitetura e o Inconsciente. In: Revista Latinoanericana de Psicopatologia Fundamental, VollI I no 1 .São Paulo:Escuta, 2000, p. 21-46.

[4] Brito, Saturnino. Obras Completas. 23 volumes, Rio de Janeiro: Imprensa nacional, 1943/1944. Volume XIII.

[5] Choay, Françoise. O Urbanismo. São Paulo: Perspectiva, 1997

[6] Damergian, Sueli. A construção da subjetividade na metrópole paulistana: desafio da contemporaneidade. São Paulo: PUC, 2001.

[7]

A construção da subjetividade na metrópole paulistana: desafio da contemporaneidade. In: Tassara, Eda. T. de O. Panoramas interdisciplinares para uma Psicologia Ambiental do Urbano. São Paulo: EDUC, 2001. sociocultural e simbólico. A flexibilidade está relacionada a este espaço potencial uma vez que a qualidade de sustentar a subjetividade de seus habitantes proporciona a relação dos lugares com a vivência.

[8] Ferrara, Lucrécia D’Alessio. Os significados urbanos. São Paulo: ED. USP/ FAPESP, 2000.

[9] Freire, Cristina. Além dos mapas: Os monumentos no imaginário urbano contemporâneo. São Paulo: Annablume/ SESC, 1997.

[10] Gehl, Jan. Cidades para pessoas. São Paulo: Perspectiva, 2013.

[11] GONÇALVES, Teresinha Maria. Cidade e poética: Um estudo de psicologia ambiental sobre o ambiente urbano. ljuí: Ed. Unijuí, 2007.

[12] Habermas, J. Teoria de la acción comunicativa.Madrid: Taurus, 1987.

[13] Harvey, David. A condição pós- moderna. São Paulo: Loyola, 1998.

[14] Heidegger, M. Introdução à Metafísica;trad. Emmanuel C. Leão. - Rio de Janeiro: Tempo Brasileiro, 1987.

[15] "Sobre o Humanismo", in Conferências e Escritos Filosóficos; trad. Ernildo Stein. São Paulo: Abril Cultural, 1983.

[16] Houaiss, Antônio; Villar, Mauro Salles. Dicionário Houaiss da Língua Portuguesa. Rio de Janeiro: Objetiva, 2001. 
[17] Leme, Maria Cristina da Silva. Urbanismo no Brasil 1895-1965. São Paulo: FUPAN, Studio Nobel, 1999.

[18] Lynch, Kevin. A imagem da cidade. São Paulo: Martins Fontes, 2000.

[19] Macedo, Silvio Soares de. Quadro do Paisagismo no Brasil. São Paulo: Coleção Quapá, 1999.

[20] Maercello, Guilherme Conti. Origens e conceitos básicos da Fenomenologia.

[21] http://www.redepsi.com.br/2009/02/05/orig em-e-conceitos-b-sicos-da-fenomenologia/ Acessado em 27/ 11/2016

[22] Marrichi, Jussara Marques Oliveira. A cidade termal: Ciência das águas e sociabilidade moderna entre 1839 a 1931. São Paulo: Annablume, 2015.

[23] Montagna, Plínio. Subjetivação contemporânea na metrópole. In: Tassara, Eda. T. de O. Panoramas interdisciplinares para uma Psicologia Ambiental do Urbano. São Paulo: EDUC, 2001.
[24] Matthes, Adriane de Almeida. Arquitetura e Permanências. O projeto urbano na constituição da esfera pública. Dissertação de Mestrado. Campinas: POS URB PUC Campinas, 2005.

[25] Neves, Lourenço Baeta. Relatório do ano de 1912 do Conselho Deliberativo, Prefeitura Municicpal de Poços de Caldas, 1922.

[26] Pozzer, Carlos Eduardo. Poços de Caldas: A construção da paisagem urbana. Dissertação de mestrado, Campinas: FAU PUCCAMP, 2001.

[27] Proshansky, H. M. The city and selfidentity. Environment an behavior, 10, 1978.

[28] Rancière, Jacques. A partilha do sensível: estética e política.Rio de Janeiro: Editora 34, 2005.

[29] Secchi, Bernardo. Primeira Lição de Urbanismo. São Paulo: Pesrpectiva, 2006.

[30] Sloterdijk, Peter. No mesmo barco: ensaio sobre a hiperpolítica. São Paulo: Estação Lierdade, 1999.

[31] Winnicott, D. W. O Brincar e a realidade.Rio de Janeiro: Imago, 1975.

[32] O ambiente e os processos de maturação.Porto Alegre: Artes Médicas, 1990. 


\section{Gapítulo 13}

\section{URBANISMO INSURGENTE: ACÕES RECENTES DE COLETIVOS URBANOS RESSIGNIFICANDO O ESPAÇO PÚBLICO NA CIDADE DE SÃO PAULO}

\section{Maria Carolina Maziviero,}

\section{Eneida de Almeida}

Resumo :Discute-se as ações recentes de coletivos urbanos na cidade de São Paulo que, através de proposições alternativas de usar, olhar, planejar, discutir, construir e habitar, vem lançando luz sobre sociabilidade e construção coletiva da cidade. Tomando como ponto de partida o esvaziamento do espaço público a partir da conjuntura histórico-política brasileira dos anos 60 aos 80, em concomitância com a supressão dos direitos constitucionais e a repressão às manifestações políticas e culturais, o trabalho reúne elementos para construção de uma narrativa que explique a dinâmica urbana brasileira, desde a luta pela reforma urbana até a apropriação da cidade, a partir das manifestações de 2013. A recuperação de espaços públicos pelos cidadãos representa a relevância dos principais movimentos de insurgência, especialmente em uma cidade de grandes proporções como São Paulo. Contudo, os grupos atuantes na periferia ainda são pouco conhecidos porque esse tipo de ação é mais difundida no vetor centro-sudoeste. Os coletivos mais conhecidos são compostos por profissionais ligados à produção artística, arquitetônica e urbana, atuando no território que os circundam. Assim, o trabalho, ainda em desenvolvimento, procura entender como o "urbanismo insurgente" acontece nas franjas da cidade, onde as dinâmicas são muito diferentes. Busca-se entender sua dinâmica organizacional, lógica de gestão, comunicação e viabilização das atividades e o modo como atuam nas zonas norte e leste. Através do estudo sobre novas formas de se fazer política, busca-se colaborar para o debate sobre a ressignificação da fronteira centro $\times$ periferia, mediada pela experiência coletiva de apropriação espacial do espaço público.

Palavras Chave: espaço público, ativismo, experiência coletiva, formas de apropriação espacial, mobilização política, centro x periferia 


\section{INTRODUÇÃO}

O ano de 2011 ficou marcado mundialmente por conta dos levantes populares, fenômenos de dimensões políticas, sociais e tecnológicas que ocorreram em diversas cidades do globo. A condição econômica mundial, permeada pelo aumento do desemprego e pela relação desfavorável entre receitas e despesas, que resultou em medidas de austeridade da maioria dos governos, pode ser apontada como a razão fundamental dos protestos (WALLERSTEIN, 2012). No Brasil, em junho de 2013, milhares de pessoas foram às ruas de doze capitais brasileiras e diversas outras cidades de médio porte, em um protesto multifacetado, iniciado contra o aumento das passagens de ônibus municipais, mas que depois se transmutou em outras reivindicações (GOHN, 2014). A partir da visibilidade dessas manifestações públicas, os coletivos se propagaram em proporção geométrica pelo Brasil, pautados notadamente por trabalhos de intervenção no espaço urbano com caráter de denúncia social. Por sua postura crítica ao status quo e às formas limitadoras de acesso ao urbano, essas formas associativas têm conduzido suas ações regidas pelo lema da cultura maker "Faça-Você-Mesmo", defendendo o protagonismo cidadão para produzir, colaborativamente e com criatividade, atitude crítica e autonomia, a transformação da realidade (GERSHENFELD, 2012).

Este trabalho, ainda em desenvolvimento, tem como enfoque central a análise das ações recentes de coletivos urbanos na cidade de São Paulo que, através de proposições alternativas de usar, olhar, planejar, discutir, construir e habitar, vem lançando luz a temas sobre sociabilidade e construção coletiva da cidade. Tomando como ponto de partida o esvaziamento do espaço público a partir da conjuntura histórico-política brasileira dos anos 60 aos 80, em concomitância com a supressão dos direitos constitucionais e com a repressão às manifestações políticas e culturais, o artigo procura reunir elementos para constituir um aparato crítico para construção de uma narrativa que explique a dinâmica urbana brasileira, desde a luta pela reforma urbana até a produção e a apropriação da cidade, a partir das manifestações de 2013.

Apoiando-se em contribuições de autores dedicados à investigação das relações sóciopolíticas e econômicas da sociedade global contemporânea, do uso das tecnologias digitais, entrecruzando-as com as reflexões de estudiosos interessados na conjuntura social e política nacional, e seus reflexos na produção e apropriação do espaço urbano, espera-se contribuir para a ampliação do entendimento sobre a produção recente da cidade, desvendando a relação existente entre tecnologia e território, entre memória e representação social, enfatizando a importância dessas relações para apontar alternativas positivas e possíveis para as cidades.

\section{DO ESVAZIAMENTO DO ESPAÇO PÚBLICO À ORIGEM DOS COLETIVOS URBANOS NO BRASIL}

No Brasil, durante a década de 1980, houve um aprofundamento das desigualdades sócio espaciais, fruto da política dos anos 70 e da reestruturação produtiva mundial. A modernização desenvolvimentista dos anos 50 acabou estrangulada pelo arrocho da dívida e a inflação brasileira intensificou-se como nunca ocorreu antes. A alta dos juros internacionais, desde 1979, e os problemas ligados à administração da dívida externa marcaram um crescimento nunca visto das taxas inflacionárias no país, e continuaram a crescer ano a ano. Este período ficou conhecido no Brasil como a "década perdida", caracterizada pela queda nos investimentos e no crescimento do PIB, pelo aumento do déficit público, pelo crescimento da dívida externa e interna, e pela ascensão inflacionaria (BANCO MUNDIAL, 1993; CRUZ 1983). Ressalta- se que o país vivia sob governo militar.

A Ditadura Militar no Brasil teve seu início com o golpe de 31 de março de 1964, resultando no afastamento do Presidente da República, João Goulart, e tomando o poder o Marechal Castelo Branco. Este golpe de estado instituiu no país uma ditadura militar, justificada pelo discurso de uma ameaça comunista. Tais condições adversas de governabilidade se constituíram em obstáculos à formação de um projeto de nação que levasse em conta os interesses coletivos, sempre rechaçados. Tornaram-se, também e principalmente, entraves à constituição de um projeto de Modernidade, que abarcasse a formação de um Estado de direito e da cidadania como sustentação de um projeto democrático de país. Além disso, a cultura política do regime militar transformou a reunião no espaço público em uma ameaça à ordem pública, 
convertendo o encontro de pessoas na rua em um ato subversivo, "em caso de ameaça, a primeira imposição do poder é a interdição à permanência e à reunião na rua" (LEFEBVRE, 2002, p. 31). O fechamento e o esvaziamento do espaço público, assim, contribuíram para a interrupção do processo de estruturação da construção democrática nas décadas de 1960 e 70.

Nos últimos anos desse regime, o Brasil apresentava vários problemas econômicos que, somados ao fortalecimento das reivindicações sociais, desde meados dos anos 1970, culminou no desenvolvimento de uma ampla variedade de movimentos populares de base. Assim, a partir de 1974, a crise de legitimidade do regime teve como reflexo a luta pela volta do estado de direto e o início do debate em torno da questão dos direitos humanos, tornando inviável a continuação do governo militar. Em 1983, inicia-se então uma campanha pelas eleições diretas para a Presidência da República e, ainda que a emenda constitucional tenha sido derrotada no Congresso Nacional, em 1985, iniciou-se uma nova forma de governar o país, com um presidente eleito de forma indireta. Em 1988, foi aprovada uma nova constituição para o Brasil, vigente até os dias atuais e que buscou apagar os rastros da ditadura militar, estabelecendo princípios democráticos no país.

A agregação das lideranças dos movimentos sociais urbanos em prol da luta pela redemocratização na década de 1980 se dá, entretanto, ao mesmo tempo em que o país passava por um acirramento das condições de vida nos grandes aglomerados urbanos. A recessão econômica somada à desindustrialização e à expansão das atividades terciárias, ao empobrecimento das camadas trabalhadoras, ao deslocamento de parte da classe média e alta para fora do centro urbano, e a ampla difusão do crime, acentuou a desigualdade em cidades como São Paulo. Ao longo dos anos 1970, a cidade experimentou um intenso processo de favelização, e este passa então a ser a expressão espacial das desigualdades que marcam a sociedade brasileira. A taxa de crescimento da população favelada, por exemplo, entre os anos de 1973 e 1980 em São Paulo é maior do que a taxa de crescimento do município neste período.

A significativa concentração da pobreza nas metrópoles brasileiras tem como expressão um espaço dual: de um lado, a cidade formal, que concentra os investimentos públicos e, de outro, o seu contraponto absoluto, a cidade informal relegada dos benefícios equivalentes e que cresce exponencialmente na ilegalidade urbana que a constitui, exacerbando as diferenças socioambientais. A precariedade e a ilegalidade são seus componentes genéticos e contribuem para a formação de espaços urbanos sem atributos de urbanidade. (GROSTEIN, 2001, p.02)

Nesse quadro, a emergência dos movimentos populares, especialmente nas periferias, tinha como pauta determinante a luta por melhorias nas condições de vida contra o crescente processo de exclusão dos benefícios urbanos. A articulação de moradores reivindicando seu direito à cidadania perpassava por diferentes frentes de luta, como a regularização de loteamentos clandestinos, movimentos por infraestrutura básica, por equipamentos de saúde, etc. Esses movimentos, que se multiplicaram a partir dos anos 1970, estavam estreitamente relacionados a problemas de produção, distribuição e gestão dos meios de consumo coletivos necessários à vida cotidiana. A cidadania, reivindicada por penalizados e indignados pelas instabilidades de uma sociedade ainda em processo de constituição do povo, conseguiu de fato ampliar-se ancorada, sobretudo, pelos direitos constitucionais de igualdade e participação. A formação dos Conselhos Populares, na década de 80, como porta-vozes legítimos da população representaram o estabelecimento de um espaço efetivo de negociação em oposição a uma concepção de confronto (SOUTO e PAZ, 2012).

Já quando o neoliberalismo globalizante atingiu o país, nos anos 1990, o Estado brasileiro aderiu à receita internacional de governo mínimo, dando maior espaço à ideologia e às políticas privatistas, e declinando em investir em infraestrutura ou em políticas de atendimento social. A instauração do neoliberalismo provocou um aumento da concentração de renda da elite, restaurando, no cenário mundial, os privilégios dos grupos que tiveram poder e renda diminuídos após a Grande Depressão e a II Guerra Mundial (HARVEY, 2003). Localmente, dada a conjuntura históricopolítica brasileira, a entrada neoliberal e a abertura econômica acarretaram não só transformações no processo produtivo, na gestão e organização do trabalho, mas 
também no espaço construído, acentuando ainda mais os contrastes socioculturais.

Neste período, cresceu expressivamente o número de shoppings centers, condomínios fechados, segurança privada e controle de circulação. A instauração de uma cidade fragmentada resultou na desqualificação e abandono do espaço público, aprofundando a segregação e reduzindo as pessoas a uma vida simplificada em núcleos homogêneos. Os mecanismos de controle e vigilância, as grades e os muros que separam a propriedade privada da rua "criam lugares privados dentro da cidade pública" (CALDEIRA, 2000, p. 4). A rua, como espaço de encontro e diálogo entre os diferentes, é algo fundamental para a construção de uma cultura de tolerância. Esse distanciamento tende a subtrair aspectos positivos da sociabilidade urbana, que são estabelecidos no convívio comum, no contato com o outro no domínio da vida pública. Para Sennett (1999), a impossibilidade do encontro com o desconhecido e com a diferença, condição criada nas microcidades intramuros, "[...] tira da pessoa a chance de enriquecer as suas percepções, a sua experiência, e de aprender a mais valiosa de todas as lições humanas: a habilidade para colocar em questão as condições já estabelecidas de sua vida" (SENNETT, 1999, p. 360).

Entretanto, no final dos anos 1990, com os novos arranjos participativos conquistados a partir da nova constituinte, há uma retomada da reconstrução e da ressignificação dos espaços públicos das grandes cidades brasileiras, sobretudo em São Paulo, agora pelo viés da heterogeneidade e da diferença como forças libertadoras contra os resquícios do autoritarismo e do conservadorismo (SANTOS \& AVRITZER, 2002). Há uma redefinição da luta em favor da democracia e da cidadania através de iniciativas culturais e políticas de distintas orientações e naturezas, agora despidas dos modelos narrativos anteriores, universais e totalizantes, das certezas absolutas (JAMESON, 2004). Para Harvey (2003), na pós-modernidade nada de eterno configura qualquer atividade humana. Nas suas bases estão a fragmentação e a efemeridade, que constituem o caos e uma certa irracionalidade ditada pelo múltiplo, pelo nomadismo e pela diferença.

É nessa chave que se dão as novas formas de apropriação do espaço público por meio de ações autogeridas e transversais às ações governamentais, comandadas por arranjos descentralizados, organizados de forma anárquica e horizontal, flexíveis e situacionais, chamados de "coletivos urbanos". Munidos de um vocabulário conceitualmente voltado para a proposição de caminhos mais imaginativos, sensíveis e dinâmicos para a vida urbana, os coletivos se apropriam da cidade opondo-se ao processo de formulação do território a partir da projeção do medo e da violência. Desta forma, os levantes populares, a retomada das ruas e do espaço público aparecem como um busca pelo direito à cidade, por uma cidade mais humana, viva, inclusiva, segura e saudável (GEHL, 2013).

\section{A MEMÓRIA COMO INSTRUMENTO DE ARTICULAÇÃO ENTRE A IDENTIDADE PESSOAL E A COLETIVA.}

Agrega-se à investigação das ações participativas voltadas à ressignificação dos espaços públicos, a compreensão de diferentes abordagens ligadas ao estudo do espaço público a partir do entrelaçamento de distintos campos disciplinares que, associados entre si, possibilitam revigorar um sentido de lugar compartilhado no panorama da cidade contemporânea. Interessa especialmente analisar contribuições de autores, dentre os quais destacam-se Alois Riegl, Franco La Cecla e Giorgio Agamben e, sobretudo, articulá-las a uma compreensão de cidade que se apoia na imagem do palimpsesto, tal qual um papiro cujo texto primitivo foi raspado para dar lugar a outro, e que ao se transformar, produz e sobrepõe distintos significados. Esta abordagem, que se desenvolve tendo a memória como um dos fios condutores da complexa estrutura urbana, possibilita reconhecer um território de pertencimento através da partilha dos espaços comuns. Atentando-se aos legados do passado à luz do presente, apreende-se a noção de identidade ancorada no território reconhecido em sua espessura histórica, assegurando-se, assim, a possibilidade de se reconhecer como indivíduo atrelada à experiência de compartilhamento com os outros.

São Paulo, em sua escala metropolitana, como um imenso texto a ser mapeado e reorganizado na perspectiva do reconhecimento de legados do passado e da apreciação de estratégias compatíveis de intervenção, admite uma análise que envolve as diferentes apreensões do espaço no tempo, as dinâmicas sobrepostas da memória 
individual e coletiva, as relações entre as pessoas e delas com os suportes materiais que, ao mesmo tempo em que constituem a materialidade do ambiente urbano, povoam o imaginário e alimentam uma dimensão simbólica construída coletivamente. A aproximação entre memória e história alude a uma compreensão menos rigorosa $e$, por consequência, mais livre e fluída desses termos que não mais se opõem, mas se mesclam, perdem suas especificidades para adquirir uma conotação híbrida, distanciandose de uma esfera técnico-científica para enfatizar uma raiz mais humanística, deslocando-se do saber especializado, para se aproximar de uma apreensão mais sensível, própria dos cidadãos da metrópole.

Estudos empíricos propiciam discorrer a respeito da sobreposição de camadas de tempo a configurar diferentes espacialidades e, consequentemente, diferentes apreensões de cidade. $O$ exame desses objetos presta-se igualmente a estabelecer relações entre as posições teóricas dos autores aqui indicados e as premissas adotadas em determinados projetos, correlacionando experiências concretas do universo da arquitetura articuladas ao contexto urbano, a partir de prismas variados, reconfigurando resíduos do passado em espaços vivos da cidade do presente.

A noção de patrimônio, aqui contextualizada ao ambiente da metrópole paulistana, não remete exatamente à conotação do patrimônio oficial, do bem tombado. Ao invés disso, como quer Alois Riegl (2011), alude a uma compreensão mais próxima da sensibilidade do cidadão. Nessa perspectiva, o exercício da memória coloca-se como meio de assegurar não só a identidade do indivíduo, mas também sua ligação com a coletividade atual e histórica, para afirmar a ideia de pertencimento - que une indivíduos distintos e configurar o enraizamento não apenas no tempo, mas também no espaço.

À abordagem que se atém à memória impressa no território e à sua reedição para incorporá-la a uma nova proposta, associa-se a contribuição do antropólogo italiano Franco La Cecla, que compõe uma síntese ancorada na literatura antropológica perpassando experiências em diálogo com a reflexão heideggeriana, ao correlacionar a faculdade do habitar à capacidade de perder-se, à possibilidade de desorientar-se. Em seus escritos, sustenta que a condição de pertencimento a um horizonte, como experiência de integração, é indissociável da possibilidade de desorientação. Segundo La Cecla (1993), a capacidade humana de habitar, denominada mente locale, tem hoje alguma chance de reencontrar-se a si mesma, e com a sua capacidade de perder-se, precisamente nos limites da existência metropolitana. Não se trata, portanto, de um exercício nostálgico de recuperar um tempo perdido, uma dimensão originária, idealizada, da experiência espacial. Para La Cecla, são as zonas de indisciplina da metrópole aquelas nas quais se delineia uma possibilidade de habitar autenticamente, construindo os espaços baseados em um conhecimento local inseparável de uma experiência de vida comum participada, uma experiência de diálogo em ato. Segundo o autor, a faculdade do habitar corresponde a uma atividade de conhecimento que se dá com a apropriação do espaço que nos rodeia, uma atividade que se aproxima com a da linguagem, como retomar uma conversa interrompida entre a nossa presença e a dos lugares, uma construção coletiva. Tornar próprio um lugar, ambientar-se, é exercitar uma forma de conhecimento, semelhante à realização de uma descoberta, equivalente a fazer uso da palavra para se comunicar como os outros. Nesse sentido, sugere La Cecla, a territorialidade humana tem a ver com o aprendizado e a cognição, com a sobrevivência social e cultural, como um processo contínuo de alargamento e retorno (LA CECLA, 1993). Frequentar assiduamente os espaços habitados permite não apenas familiarizar-se com sua dimensão física, mas acessar o imaginário cotidiano.

As formulações do filósofo Giorgio Agamben são oportunas para refletir acerca da contemporaneidade. O contemporâneo, sustenta o filósofo, "é aquele que percebe o escuro do seu tempo como algo que the concerne e não cessa de interpelá-lo" (AGAMBEN, 2013, p.64), por isso mesmo é capaz de "transformá-lo e de colocá-lo em relação a outros tempos, de nele ler de modo inédito a história". Para o autor, "a via de acesso ao presente tem necessariamente a forma de uma arqueologia que não regride, no entanto, a um passado remoto, mas a tudo que no presente não podemos em nenhum caso viver e, restando não vivido, é incessantemente relançado para a origem, sem jamais alcançá-la" (AGAMBEN, 2013, p. 70). Assim, o presente, segundo Agamben, pode ser apreendido como parte do não vivido no vivido e a vida contemporânea como 
uma atenção dirigida a esse não-vivido. Através dessa compreensão, Agamben posiciona-se por uma atitude de resistência, de deslocamento à lógica do presente e aos mecanismos de sujeição, sugerindo des-criar e re-criar o que existe, para fazer aflorar uma dimensão poética em que se articula memória e invenção, apostando-se na estética da existência, no esculpir a própria experiência sem se esquivar do compartilhamento com o outro.

Compartilhar, mais do que partilhar espaços comuns permite, portanto, reconhecer um território de pertencimento, adensado pela memória de seus usos, em associação com certas experiências vivenciadas. Desse modo, a memória e a travessia do tempo nos espaços é considerada, menos pela abstração do que é tido como patrimônio stricto sensu e mais pelo que se transforma em patrimônio comum à medida que se reconhece como parte da história pessoal no compartilhamento da experiência com os outros.

\section{A CIDADE INSURGENTE: AS RECENTES ESTRATÉGIAS DOS COLETIVOS URBANOS.}

Segundo Castells (1999), a revolução tecnológica, centrada nas tecnologias da informação, começou a remodelar a base material da sociedade e, portanto, do espaço urbano. É por meio do uso e apropriação de ferramentas da Internet e outras novas tecnologias de informação e comunicação que os coletivos se articulam e fazem política, ou seja, há uma articulação potente entre o chamado ciberespaço e o mundo real (físicoterritorial) nas formas de atuação e de organização dos coletivos (LEVY, 1999). A lógica de rede, construída colaborativamente e sem lideranças evidenciadas, dirige a produção e a atuação desses grupos; "o projeto da inteligência coletiva supõe o abandono da perspectiva do poder. Ele quer abrir o vazio central, o poço de clareza que permite 0 jogo com a alteridade, a quimerização e a complexidade labiríntica" (LEVY, 1998, p. 211).

Essa forma de agrupamento, ainda que típica do trabalho dos artistas visuais jovens, vem realizando intervenções no espaço urbano e modificando, de forma gradual e colaborativa, o espaço da cidade. Esse caráter fortemente urbano de suas ações, entretanto, diferenciase da expressão tradicionalmente utilizada pela cultura do hip-hop. A forma de atuação dos coletivos é significativamente distinta daquelas do século passado, sobretudo em função da condição pós-moderna como uma nova versão da experiência do espaço e do tempo, segundo Harvey (2003). Essa onda de compressão do tempo-espaço implica uma inevitável aceleração dos modi vivendi, ou seja, há um caráter volátil e efêmero na produção, nos processos de trabalhos e, inclusive, nas ideias. A volatilidade constitui seu fluxo e, portanto, os grupos rejeitam a ideia de projetos a longo ou médio prazos. Há um certo nomadismo nessas estruturas e por isso o participante pode migrar para outro coletivo quando terminado o projeto a que se propôs, porque os coletivos não se configuram por seus integrantes, mas por suas ações. Assim, sua formação é simultaneamente fixa e móvel, pois se estruturam em um núcleo central, em torno do qual outros parceiros são agregados a partir do projeto em execução. Segundo Paim (2009), outros agrupamentos de artistas já trabalhavam nessa perspectiva desde o início do século, como os Grupos Dadaístas em Berlim e Zurique (1916); e, sobretudo, a partir dos anos de 1960, como os grupos Fluxus (Alemanha, 1962); Group de Recherche d'Art Visuel - GRAV (Paris, 1960); Art and Language (Estados Unidos e Inglaterra, 1968) ou ainda o Guerrilha Girls, de 1985 (Estados Unidos). Contudo, segundo Hollanda (2013), a partir do final da década de 1990, o espaço urbano torna-se o foco das intervenções dos coletivos.

O caráter rizomático e nômade dos coletivos somado à sua forma de organização independente, possibilita conexões inusitadas pela co-criação, pela justaposição e pela colisão, que redesenham outras dimensões possíveis da existência, ressaltando a preocupação com a alteridade e com outros mundos, coexistentes. No mundo fragmentado e estilhaçado é possível que todos os mundos aconteçam, sem privilégio de um sobre o outro (Deleuze \& Guattari, 1996)). Assim, seu processo constitutivo aberto ocasiona uma explosão de singularidades, distantes da concepção moderna de um caminho único como forma de resistência aos poderes dominantes, ou melhor, da dimensão da unidade. A efemeridade e a fragmentação conduzem essas uniões, pois os agrupamentos entendem que são necessárias ações imediatas e táticas no contexto da intervenção pública. Distanciam-se, assim, da configuração de um partido ou de qualquer 
estrutura fixa de organização, ainda que essa forma ininterrupta de relação aberta, de singularidades em movimento - que conformam a multidão (Negri, 2005), componham estratégias para minar propostas autoritárias, através da ação comum diante da crise. Para Negri (2014), esse estreitamento entre o ser social e o poder político ocorre por conta das condições dadas pela própria natureza da crise contemporânea, na passagem à pós-modernidade política, sem que a destruição dessa separação resulte em uma unidade. Diferem, portanto, das ações dos anos 60 e 70, quando os grupos se organizavam em cooperativas de produção ou sindicatos, guiados estreitamente por motes encerrados e bem delineados.

"A multidão se organiza em torno dos eventos do momento, nos quais uma linguagem comum se expressa. Uma linguagem comum que nasce da indignação e do protesto, do cansaço de sempre se encontrar em situações que não têm saída. É exatamente como antes era com a classe operária. A multidão se organiza à base de paixões que caminham junto com a resistência e com tentativas de construções de uma perspectiva de uma nova via de solução dos problemas. Não há muita diferença do ponto de vista entre a multidão e todos os outros movimentos que nascem da base de necessidades ou anseios fundamentais de se viver e produzir. Mas há um outro elemento que é a singularidade. Quando a multidão se move, nunca é simplesmente uma massa, é uma riqueza plural de elementos de questionamentos de vida. É claro que aqui nasce um problema de organização. Há um grande problema de unidade, de articulação dos movimentos, em meio a muitas singularidades. Mas esta é também a riqueza, a beleza do processo que vivemos." (NEGRI, 2014)

As intervenções espontâneas ou arquiteturas efêmeras, isto é, as microintervenções urbanas propositivas promovidas por esses grupos representam demandas e urgências, tendo como mote o cidadão como agente essencial no processo de produção e de apropriação da cidade (ROSA, 2011). É o chamado urbanismo tático, de guerrilha ou insurgente, que sugere outras perspectivas para a cidade e seus problemas cotidianos contemporâneos. O entendimento da cidade como plataforma aberta a ser constantemente resignificada a partir da perspectiva do interesse público, guia essa mistura de ações, comportamentos e significados atípicos para desenvolver uma espacialidade distinta daquelas previstas pela lei e pelas práticas tradicionais (LYNDON \& GARCIA, 2015). Os marcos regulatórios que dispõem sobre o uso e a ocupação do solo - e do espaço público, muitas vezes acabam por atravancar o surgimento de iniciativas inovadoras para a produção e apropriação do espaço construído. Isso porque entendem o espaço a partir da perspectiva única do mundo moderno, entrincheirado em fortes convicções, e não contemplam a dialética provocada por ações que percebem o espaço a partir das multiplicidades de camadas possíveis. Muitas vezes, as práticas de governo fixadas em processos burocráticos atávicos favorecem o ciclo de abandono e cerceamento de atividades dos espaços livres públicos, colaborando para a manutenção do medo e da violência urbana. Segundo Jacques (2011), essas ações no espaço público funcionam como microrresistências aos projetos urbanos homogeneizadores, realizados no mundo todo contemporaneamente; "tem o objetivo de ocupar, apropriar-se do espaço público para construir e propor outras experiências sensíveis e, assim, perturbar essa imagem tranquilizadora e pacifica do espaço público que o espetáculo do consenso tenta forjar" (JACQUES, 2011, p. 172).

Justamente por conta desse viés do desafio ao modelo cultural e espacial vigente, os coletivos se apropriam da cultura hacker, ou do hacking, entendido como a criação de um atalho inteligente que resulta em um novo recurso para uma ferramenta. $O$ termo, que se solidificou na década de 60 para definir especialistas de computadores envolvidos num tipo de subcultura de programação, vem ao encontro das intervenções ativistas contemporâneas no espaço público de caráter inventivo, rápido e alternativo que visam estimular o convívio cívico. Assim, o modo de resistência dos hackers age sobre os mecanismos de gerenciamento protocolares e reforça a necessidade da construção de novos saberes por indivíduos autônomos e colaborativos (SILVEIRA, 2010).

Os coletivos atuam dentro dessa perspectiva, criando a partir da recombinação e da reconfiguração dos códigos vigentes para produzir movimento, escapando às territorialidades. Nesse sentido, podem ser associados à ideia de resíduo desenvolvida por Lefebvre, como aquele elemento que 
escapa aos sistemas e que contém o poder criador inesgotável (LEFEBVRE, 1967). Em muitos aspectos, suas táticas são respostas para o lento processo de construção da cidade convencional, pois trabalham a partir da urgência do real. Atuam por meio de uma adaptação pontual de forma invasiva ou não do espaço público e, partindo do princípio de que a rua representa o espaço de todos, em geral essas ações não pedem autorização ou permissão à prefeitura. Essas reivindicações, redesign ou reprogramação do espaço se dão em pequena escala e buscam respostas flexíveis e reversíveis ou ajustáveis a condições inevitáveis de mudança, tendo em vista que os lugares não são estáticos.

Figura 1 - Parque de Diversões Minhocão, por Basurama. Em 2013, o coletivo construiu um parquet no meio da área central para ser usado livremente, e ser replicado em qualquer lugar. I

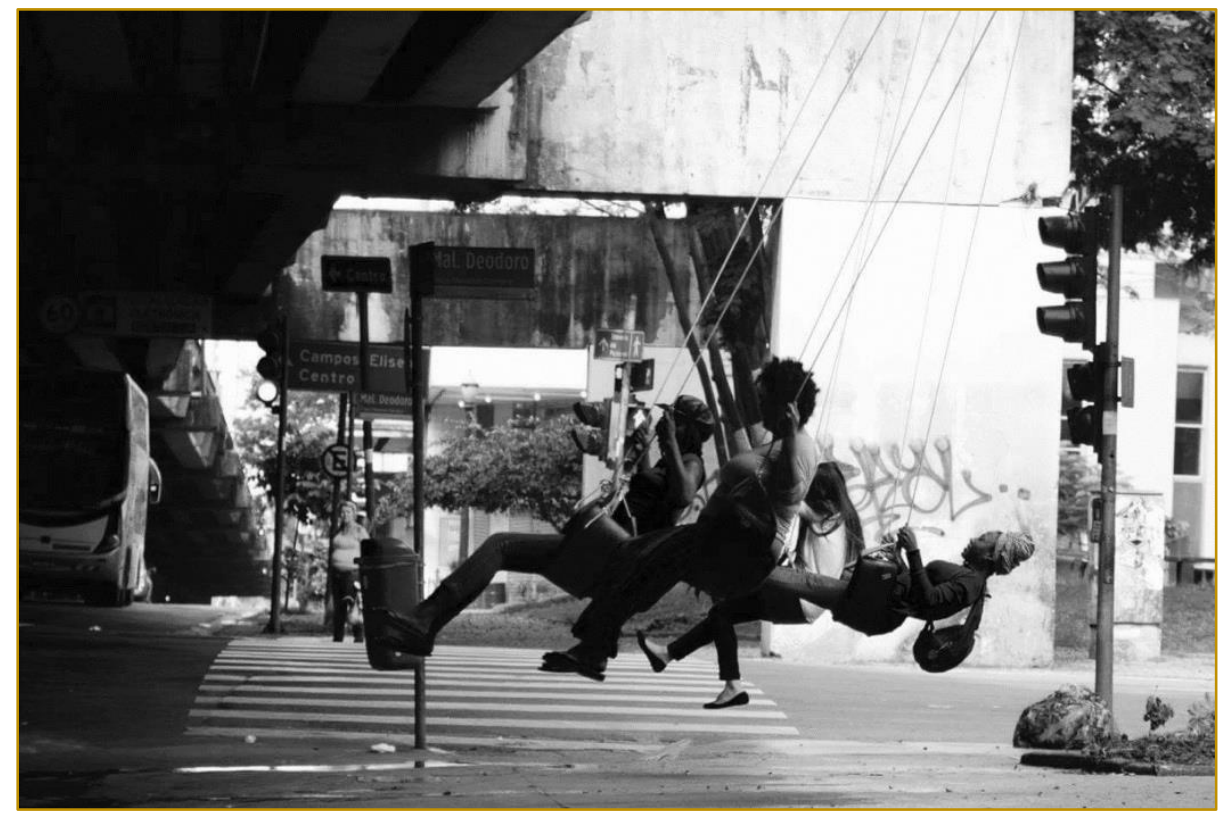

Fonte: Basurama, 2016.

Os coletivos, em geral, promovem iniciativas de cunho pedagógico, oferecendo cursos e realizando serviços vinculados a produção artística, não só a fim de promover o empoderamento e a capacitação da comunidade, mas também como forma de buscar patrocínio para a realização das atividades. Um exemplo disso é o coletivo Basurama, atuando desde 2007 em São Paulo, e que trabalha com materiais descartados, articulando urbanismo e ecologia com ações educativas. Outro aspecto dessa autogestão é que ela tende a eliminar a autoridade que tradicionalmente centraliza a seleção e a decisão sobre a produção artística, representada pela figura do curador. O Baixo Centro, por exemplo, movimento colaborativo, horizontal e independente, que surgiu em 2011 com a proposta de ressignificar a região central de São Paulo, sobretudo em torno do Minhocão (que compreende os bairros de Santa Cecília, Vila Buarque, Campos Elísios, Barra Funda e Luz). O movimento se estrutura em torno de um festival de rua realizado por uma rede aberta de produtores interessados nessa região da capital de São Paulo e traz como mote "as ruas são pra dançar". Por conta do seu caráter autogestionado, o Festival abre chamadas públicas para pessoas e coletivos inscreverem suas ideias e o que necessitarão para realizá-las e depois fazem a "cuidadoria", ou seja, cuidam dos projetos enviados, procurando formas de viabilizá-los colaborativamente, através de financiamento coletivo e associativo, via crowdfunding e/ou outras formas independentes de arrecadação.

Todas essas experimentações da prática urbana a partir do cotidiano convidam para um debate sobre resiliência local, entendida como a capacidade dos cidadãos em lidar com os problemas e superar os obstáculos em conjunto, considerando a importância da história e dos símbolos do lugar para aquela comunidade. Ajudam ainda a pensar uma abordagem ágil e barata para a produção do espaço, que pode resultar em transformações a longo prazo ou em políticas urbanas de maior abrangência. 
Figura 2 - Festival Baixo Centro. A foto mostra a ocupação das ruas durante o festival, que promoveu uma série de atividades no Minhocão usando intervenções artísticas como pintar as ruas e cobri-las com grama artificial.

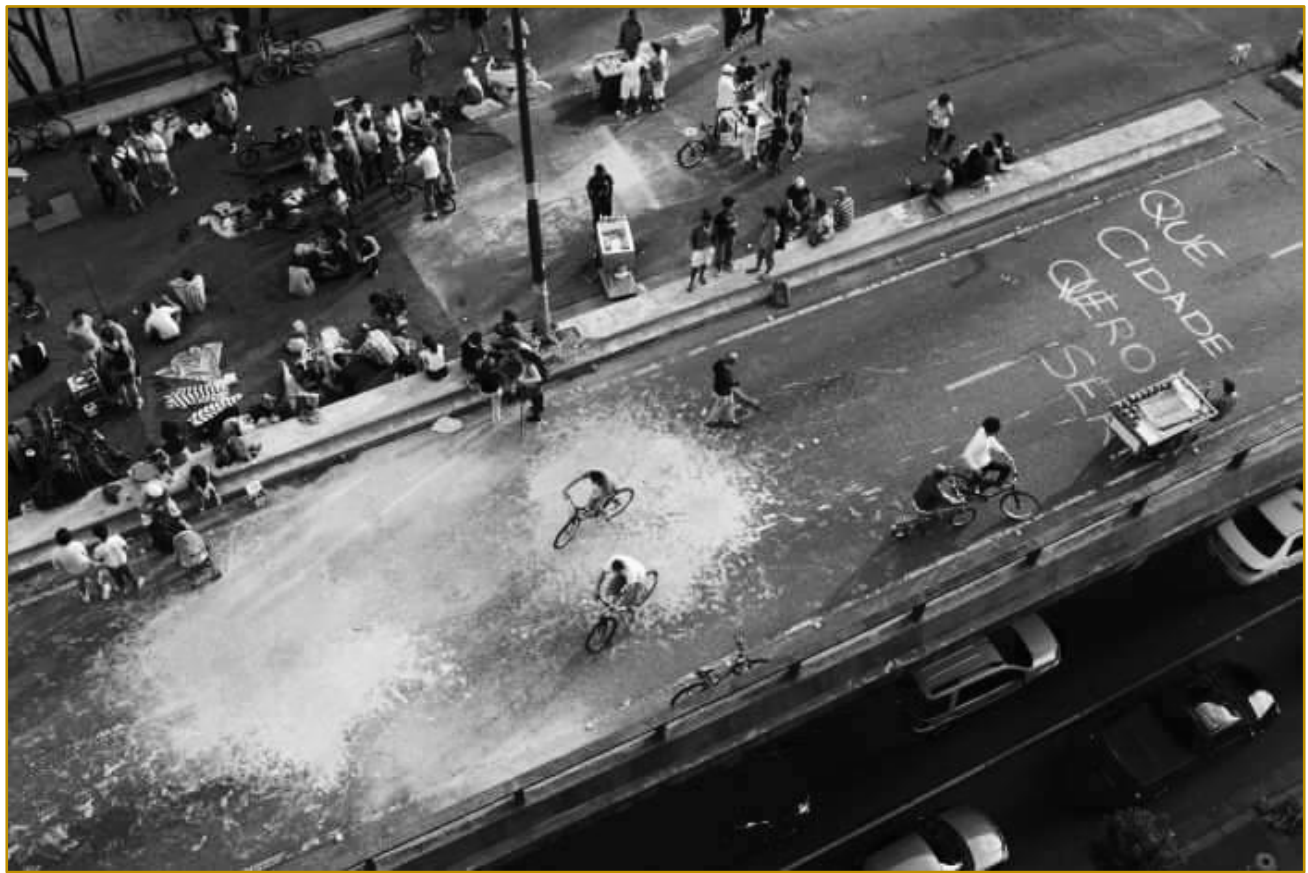

Fonte: foto de Tiago Queiroz, portal R7 notícias.

\section{AÇÕES TÁTICAS EM SÃO PAULO.}

Em São Paulo, o "urbanismo tático" vem sendo praticado majoritariamente por designers, artistas e arquitetos, que dão prioridade à visualização nos projetos de intervenção (LYNDON \& GARCIA, 2015). Por isso, suas ações são mais encontradas no eixo Centro - Zona Oeste de São Paulo, local de moradia ou trabalho da maior parte dessas pessoas. Entretanto, percebe-se um crescimento desses movimentos nas regiões mais periféricas da cidade, como as zonas norte e leste, comandados por grupos que estão à margem dos grandes investimentos, sobretudo, culturais. Nessas áreas, o elemento fundamental é a funcionalidade, bem como o potencial de organização para lutar, discutir e reivindicar políticas públicas para as comunidades da periferia. Vale ressaltar que a periferia sul da cidade de São Paulo, por volta de 1995, destacou-se no cenário nacional por conta do ativismo liderado por grupos de rappers que tratavam da condição do negro no Brasil e do crime na favela. Áreas como o bairro Capão Redondo foram consideradas centros de difusão da cultura hip-hop, e propulsoras da reconfiguração política e cultural da periferia de São Paulo. Por isso, essa porção da cidade continua, ainda hoje, a partilhar de um intenso movimento ativista, compondo a consciência prática dos moradores da região. Portanto, esta pesquisa optou por não envolver essa área já bastante mapeada e onde 0 ativismo parece consolidado, centrando o estudo na Zona Leste e Norte da capital paulistana. 
Figura 3 - Zonas leste e norte de São Paulo. Esta pesquisa enfoca as áreas fora do eixo governamental de investimento em cultura. Este mapa fornece um panorama dos grupos encontrados na área. Elaboração do grupo de pesquisa, 2016.

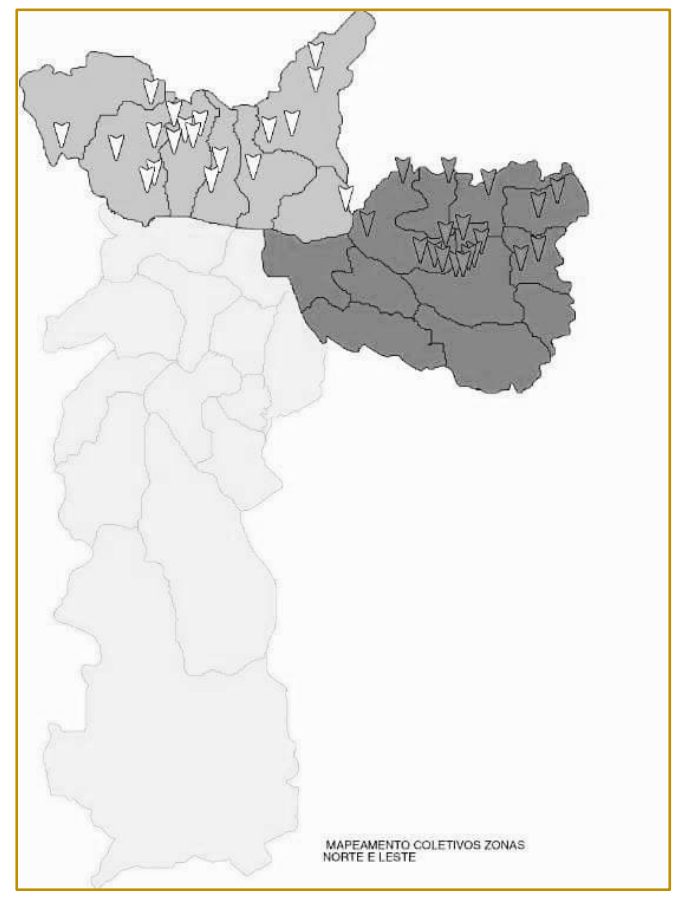

Os coletivos atuantes na periferia são pouco conhecidos, sobretudo porque esse tipo e ação é mais difundida em bairros como Vila Madalena, Pinheiros, ou até mesmo no Centro da cidade. Essas ações possuem o caráter de denúncia urbana, como tentativa de apropriação e melhoria desses espaços. Por outro lado, a lógica urbana, econômica e social nas franjas da cidade é diferente e singular, tendo inclusive movimentos artísticos pertencentes ao território. Uma das características dos coletivos atuantes nessa áreas é a de prover para a comunidade espaços que ofertem e divulguem atividades culturais, de educação, esportes e lazer. O mapa a seguir evidencia esta constatação, mostrando os equipamentos culturais existentes em 2016, divulgados pela
Prefeitura do Municipal de São Paulo, como bibliotecas, centros culturais, museus, cinemas e teatros. Observa-se que esses equipamentos estão concentrados no centro e no vetor sudoeste, criando uma grande defasagem nos extremos da cidade. Embora a relação existente entre tecnologia e território amplie e ressignifique o entendimento sobre a cidade, diluindo os limites e divisas consolidados nas últimas décadas (LEVY, 2000), a diminuta presença do Estado e de equipamentos públicos culturais nas franjas urbanas ainda mostra-se substancial e evidente na tentativa emergente dos coletivos em mitigar o déficit cultural dessas áreas, tema recorrente nas pautas das ações e debates desses grupos que agem fora do eixo mais valorizado da cidade. 
Figura 4 - Equipamentos Culturais em São Paulo, 2016.

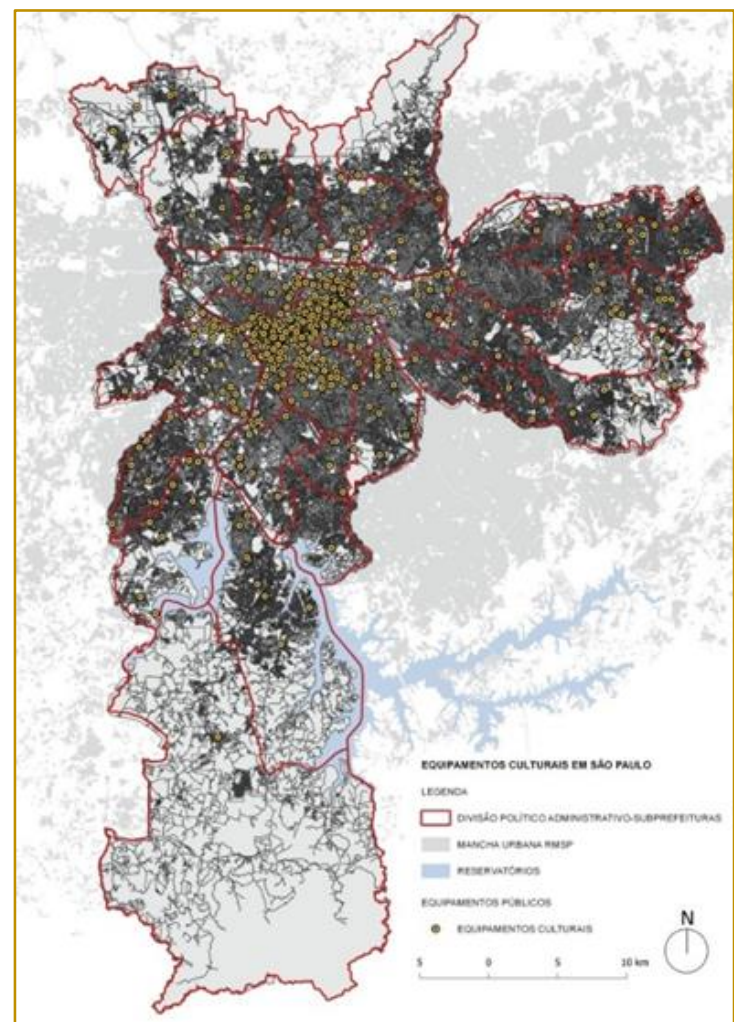

Fonte: PMSP, Base Cartográfica do Mapa Digital da Cidade, disponível em <geosampa.prefeitura.sp.gov.br>. Elaboração própria.

Assim, o interesse em mapear esses coletivos nas áreas periféricas da cidade é entender suas motivações conceituais, suas ações e táticas, para tecer aproximações e diferenças em relação às ações no eixo mais valorizado da cidade, centro-zona oeste, território tradicional da cultura alternativa paulistana. Soma-se a isso, o entendimento e a discussão das dimensões de espaço público, privado e coletivo nessas regiões, bem como do tema violência e segregação socioespacial, para entender o contexto relacionado à criação, apropriação e manutenção do território, de modo a colaborar, efetivamente, para o debate sobre a ressignificação da fronteira centro x periferia, mediada pela experiência coletiva de apropriação espacial do espaço público.

A partir do referencial teórico, encontrou-se um conjunto de elementos ou componentes, que podem ser resumidos nos seguintes aspectos, a saber: i) Funcionais, em termos do seu funcionamento como elemento de articulação do convívio cívico; ii) Sociais, em relação ao uso efetivo da ação por parte da comunidade local, incluindo as dimensões da gestão, dos usos e da autonomia; iii) Formais, em termos da dimensão física da intervenção; iv) Simbólicos, envolvendo a importância da história e das narrativas do lugar retomadas pela ação. Essas perspectivas de compreensão abertas apontam para problemáticas associadas, a saber: a) o entendimento do papel da tecnologia como meio de articulação e/ou como processo de trabalho; b) o modo de intervenção no espaço público em relação ao tempo de permanência e à escala da ação; c) o campo de ação do coletivo, se local ou itinerante. O desenvolvimento da pesquisa, ao final, relacionará os mapeamentos com os aspectos apontados acima. 
Figura 5 - Levantamento inicial de Coletivos das Zonas Norte e Leste de São Paulo.

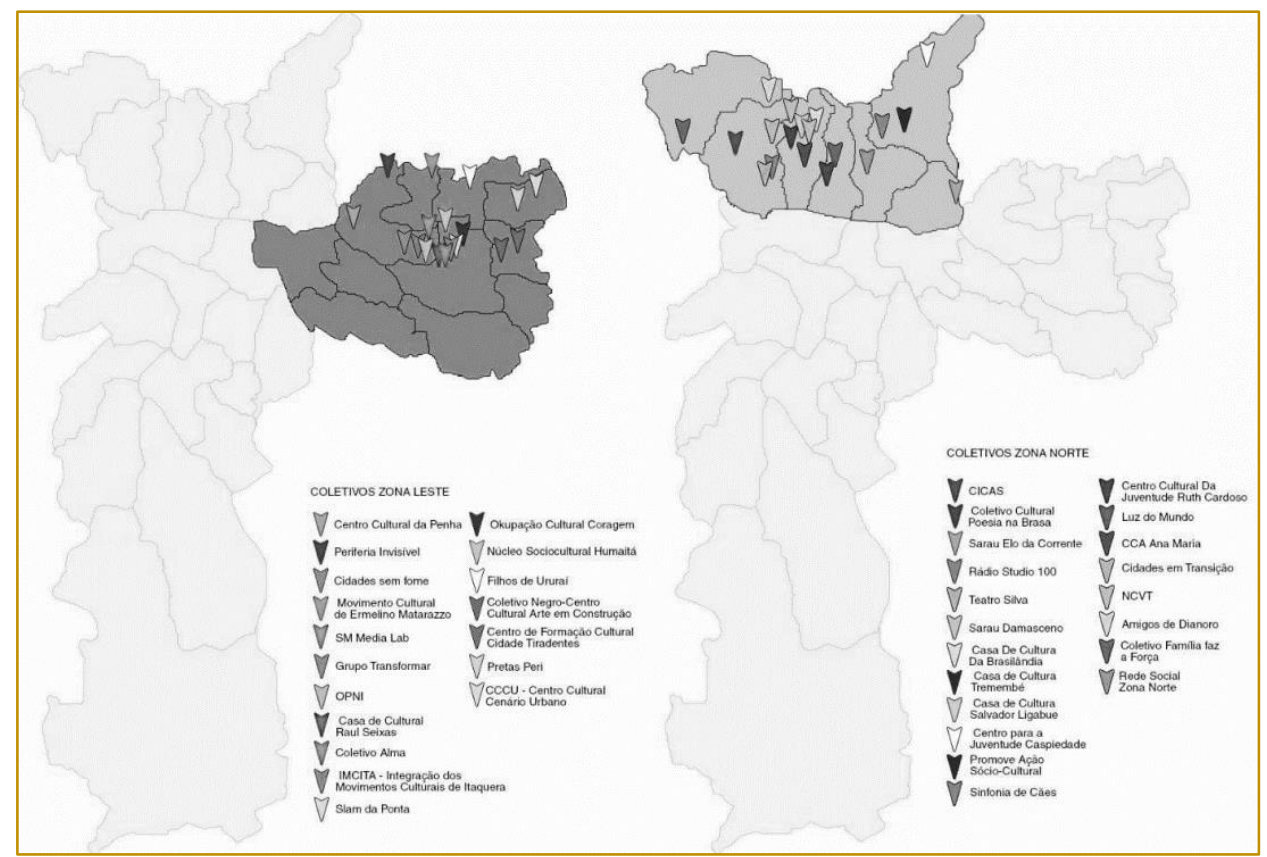

Fonte: Elaboração do grupo de pesquisa, 2016.

Os primeiros resultados apontam que as atividades dos coletivos na Zona Norte e Leste abordam temas como: educação ambiental, literatura/poesia, gastronomia vegetariana/vegana, dança, teatro, música e arte urbana. Trabalham com intervenções espontâneas ou efêmeras com base na experimentação, tratando a cidade como um laboratório para revelar o potencial de espaços até então desacreditados. De modo geral, a cultura funciona como o elemento de articulação política nessas experiências. Um exemplo disso é a elaboração da Lei de Fomento à Periferia - PL 624/2015, formulada pelo Movimento Cultural das Periferias, a partir de discussões com a comunidade, a fim de pleitear maior investimento em cultura nas regiões periféricas. Segundo essa articulação, os programas de subsídio público aos artistas na periferia não são insuficientes para atender à demanda existente. Para ampliar os recursos aplicados, o grupo elaborou uma lei para tornar o fomento uma política pública municipal. A luta vem sendo encabeçada pela articulação de movimentos culturais da zona Leste, e eles organizaram um levantamento sobre quais eram as diretrizes mais urgentes na periferia. Recém aprovada na Câmara dos Vereadores de São Paulo, o Projeto de Lei de Fomento à Periferia (PL 624/15) busca incentivar e financiar as ações culturais na periferia, como os próprios grupos reconhecem seu território, e nos "bolsões de pobreza" existentes no centro da cidade de São Paulo. A aprovação dessa lei é importante para que os coletivos saiam de uma fragilidade financeira para poder financiar as suas atividades, além de colocar em pauta a periferia como produtora e consumidora de arte e cultura, trazendo à tona as ações que vem sendo desenvolvidas nesses territórios.

\section{CONSIDERAÇÕES FINAIS}

O movimento é internacional e o tema vem ganhando força desde os anos 1990. O conceito de "urbanismo tático" popularizou-se nos EUA, em 2010, quando foi usado em um debate sobre a transformação da Times Square (NY) para um espaço destinado somente a pedestres. Em 2011, a UN-Habitat adotou uma resolução sobre desenvolvimento urbano sustentável através do acesso a espaços públicos de qualidade. Desde então, vem constantemente discutindo iniciativas urbanas voltadas para a promoção da urbanidade (HOLANDA, 2003). No Brasil, o Instituto de Arquitetos (IAB) realiza, desde 1993, o Prêmio Gentileza Urbana, para premiar pequenas atitudes dos cidadãos que colaboram para deixar a vida nas cidades cada dia melhor. A conferência da UNHABITAT de 2015 teve como tema Public Spaces, focando exatamente nas microações 
de coletivos. Atesta-se, portanto, a importância da discussão sobre o tema proposto nesta pesquisa, uma vez que a retomada do espaço das ruas pelas pessoas de forma transversal às ações governamentais torna-se tendência mundial. A recomendação da conferência vem no sentido de entender a capacidade de contribuição desses movimentos para o desenvolvimento local, revelando o potencial de espaços até então desacreditados.

Como apontado, nós não temos uma longa história de uso do espaço público, e estar em áreas comuns requer prática e hábito. Por isso, a recuperação de espaços públicos pelos cidadãos no Brasil, hoje em dia, representa a relevância dos principais movimentos de insurgência e questionamento nas cidades, especialmente em uma cidade de grandes proporções e tão complexa quanto São Paulo. Assim, esse levantamento de dados é imprescindível não só para o entendimento dessas experiências nas zonas periféricas de São Paulo, mas principalmente para servir de subsídio ao trabalho do arquiteto urbanista a fim de gerar soluções que realmente atendam à demanda da população, respeitando as diferenças culturais e os projetos já em andamento.

Representações de cidade remetem a vivências e conceitos assimilados, como uma

\section{REFERÊNCIAS}

[1] Agamben, G. O que é o contemporâneo? E outros ensaios. Chapecó, SC: Argos, 2009.

[2] Almeida, E. A memória e a dimensão pública do espaço. In: III Encontro da Associação Nacional de Pesquisa e Pós-Graduação em Arquitetura e Urbanismo, 2014, São Paulo. Anais do III Enanparq. São Paulo: ANPARQ, 2014.

[3] Banco Mundial. Poverty and income distribution in Latin America: the story of the 1980s. Washington, D.C., 1993. (Report no27).

[4] Caldeira, T. P. do R. Cidade de Muros: Crime, Segregação e Cidadania em São Paulo. São Paulo: Editora 34/Edusp, 2000.

[5] Castells, M. A sociedade em rede. São Paulo: ed. Paz e Terra, 1999. v. 1. espécie de escavação deliberada de rememoração, de patrimônio impresso na memória, e constituem material propício a uma compreensão fenomenológica que articula as significações à consciência que as formula, a partir de associações com o passado, com a própria experiência, em processos que entrelaçam experiências individuais a uma teia comum de relações da esfera coletiva em dado tempo e lugar.

Propõe-se aqui, a partir das referências mencionadas de distintos campos do conhecimento somadas a coleta de dados empíricos de experiências de ativismo urbano realizadas na cidade de São Paulo, suscitar a atenção para os interstícios quase invisíveis da cidade e convidar o cidadão a exercitar uma nova relação com o espaço urbano, um vínculo não puramente utilitário. Criar, assim, condições para que se viabilize o uso compartilhado do espaço, a despeito dos empecilhos, possibilitando uma reação aos habituais comportamentos inspirados pelo medo, indiferença ou conformismo. A partir do êxito de experiências corriqueiras, cotidianas, da retomada de anseios preteridos, ou submersos, pode-se, quem sabe, alcançar valores mais duradouros e, ao mesmo tempo, mais aderentes à experiência concreta dos cidadãos, que possam representar condutas apropriadas para a condução das políticas públicas nos tempos atuais.

[6] Cruz, P.D. Notas sobre o endividamento externo brasileiro nos anos Sessenta. In: Belluzzo, L.G.M. \& Coutinho, R. Desenvolvimento capitalista no Brasil. São Paulo: ed. Brasiliense, 1983. v. 2, p.57-106.

[7] Deleuze, G.; Guattari, F. Mil Platôs: Capitalismo e Esquizofrenia. Rio de Janeiro: Ed. 34,1996, v. 1.

[8] Garcia, A; Lyndon, M. Tactical Urbanism: short-term action for long-term change. London: Island press, 2015.

[9] Gehl, J. Cidades para pessoas. São Paulo: Perspectiva, 2013.

[10] Gershenfeld, N. How to Make Almost Anything: The Digital Fabrication Revolution. In: Foreign Affairs (91), 2012, p. 43-57. 


\section{Gapítulo 14}

\section{RESISTENNCIA E MELHORIA HABITACIONAL: REFLEXÕES SOBRE UMA ATUAÇÃO DIALÓGICA JUNTO À COMUNIDADE INDIANA NA CIDADE DO RIO DE JANEIRO}

Maria Paula Gonçalves Lysandro de Albernaz

Fernando Cesar Negrini Minto

Malu França de Miranda

Huani Quintanilha Felinto

Bruna Garritano Ferreira

Resumo: Este artigo se propõe a refletir sobre as contribuições universitárias na resistência à permanência em assentamentos irregulares e busca por melhorias habitacionais, tendo como premissa o permanente diálogo entre academia e residentes, motivado pela crença na expropriação da discussão sobre a produção do espaço urbano de parte dos atores da cidade. Parte-se do pressuposto de que compartilhar conhecimento técnico e contribuição empírica produz um bem coletivo com sustentabilidade que servirá na mediação entre comunidades e poder público, além de contribuir para estudantes amadurecerem sua compreensão arquitetônicourbanística da produção habitacional e da cidade ao revelar a realidade política, social e geográfica. A experiência na Comunidade Indiana, favela carioca com 887 habitantes, no âmbito de projetos de extensão universitários que vêm sendo realizados há três anos, é o material empírico para reflexão. O Escritório Modelo de Arquitetura e Urbanismo da Faculdade de Arquitetura e Urbanismo da UFRJ, a Comissão de Moradores da Indiana, a Associação de Moradores de Indiana e o Núcleo de Terras e Habitação da Defensoria Pública do Estado do Rio de Janeiro são os parceiros desses projetos. As referências teórico-metodológicas para atuação são o pensamento acerca da pedagogia emancipatória, da prevalência de aspectos sociais na questão da moradia, da necessidade de engajamento e entendimento do contexto político. Para reflexão, apresentam-se as ações desenvolvidas divididas em: resposta a demandas institucionais, construção de vínculos com a população envolvida e processo de planejamento. Comenta-se ao final acerca dos avanços vislumbrados e atuais impasses que impedem uma continuidade no processo. 


\section{INTRODUÇÃO \\ 1.1 APRESENTAÇÃO}

Este artigo se propõe a refletir sobre possíveis contribuições de discentes e docentes universitários na resistência à remoção de moradores dos assentamentos irregulares e na busca por melhorias na habitação, tendo como premissa básica o permanente diálogo entre o meio acadêmico e os residentes em todo processo, motivada pela histórica condição imposta pela trama da produção do espaço urbano que expropria parte dos atores da discussão. É necessário que se construa espaços para o questionamento, entendimento, reflexão e, principalmente, denúncia. Faz-se necessária a construção de um entendimento comum das estruturas políticas (e suas vontades) para que de fato se conheça as estratégias contra as quais se resiste. Parte-se, aqui, do pressuposto de que o compartilhamento do conhecimento técnico e da contribuição empírica produz um bem coletivo com sustentabilidade que servirá de articulação e mediação entre comunidades e poder público. As pessoas envolvidas se tornam agentes ativos na organização espacial do ambiente construído, para realmente entenderem seus padrões de uso e sentirem-se emponderadas nas mudanças através do tempo.

Além disso, numa perspectiva dialógica, o envolvimento de um grupo de estudantes em atuação em assentamentos irregulares também contribui no amadurecimento da sua compreensão arquitetônico-urbanística da produção habitacional e da cidade ao revelar a realidade política, social e geográfica. Apresenta-se uma oportunidade de construir uma ação - oferecida aos estudantes do início até o final da graduação - para uma vivência acadêmica pautada no exercício de um aprendizado de natureza distinta daquele aplicado recorrentemente em sala de aula, fundamentado pelo conhecimento das experiências/ vivências da população destinada, exigindo um engajamento mais amplo e uma abordagem transdisciplinar que extrapolam o conhecimento técnico previsto na grade curricular. Avaliou-se a importância de absorver um aprendizado para além dos limites do conhecimento arquitetônicourbanístico tradicionalmente transmitido, envolvendo um estudo do funcionamento de mecanismos de poder e da importância das relações interpessoais, que por sua vez, repercutem em um enriquecimento do processo projetual, prática profissional da arquitetura e urbanismo.

Neste sentido, a participação do Escritório Modelo de Arquitetura e Urbanismo EMAU/UFRJ foi fundamental. Os Escritórios Modelos de Arquitetura e Urbanismo são uma resposta da iniciativa estudantil, proveniente da discussão no âmbito dos encontros da FENEA - Federação Nacional dos Estudantes de Arquitetura e Urbanismo, a partir do debate acerca da vivência e das práticas dos estudantes de arquitetura durante a graduação, para extrapolar a experiência da sala de aula e encontrar formas de contatos constantes entre sociedade e universidade, de modo que cada indivíduo envolvido entenda a importância dessa relação e a sua responsabilidade pessoal e profissional na mesma. Assim, se propõe a uma prática do campo disciplinar que afirme um compromisso com a realidade social através de uma atuação junto das comunidades mais pobres. O aspecto fundamental a ser buscado é o intercâmbio de saberes de maneira horizontal com as populações envolvidas, sem hierarquização e com o exercício do diálogo entre as partes comprometidas, para encontrar soluções condizentes com as necessidades e demandas em locais não contemplados pelo mercado formal.

O material empírico utilizado para reflexão foi a experiência realizada no âmbito de dois projetos de extensão: "Trocando os saberes: capacitação dialógica entre estudantes e moradores para melhoria de habitações nos assentamentos irregulares", realizado com apoio financeiro do Ministério de Educação e Cultura (MEC) e Universidade Federal do Rio de Janeiro (UFRJ) em 2015; "Projeto Aproxima - transferência de conhecimento pela aproximação entre a graduação em arquitetura e urbanismo e a sociedade civil de baixa renda, através da criação do EMAU e do Canteiro Experimental Integrado da FAU UFRJ", que vem sendo realizado já há três anos com apoio da UFRJ. Essa experiência envolve ações voltadas à permanência dos moradores da na Comunidade Indiana favela carioca com 887 habitantes, e à formulação de propostas urbanísticas e arquitetônicas para melhoria habitacional, tendo como protagonistas o Escritório Modelo de Arquitetura e Urbanismo da Faculdade de Arquitetura e Urbanismo da UFRJ (AbricóEMAU/UFRJ), a Comissão de Moradores da Indiana, a Associação de Moradores de 
Indiana e o Núcleo de Terras e Habitação da Defensoria Pública do Estado do Rio de Janeiro.

No âmbito dos projetos de extensão referidos acima, ações de naturezas distintas já foram realizadas com exercício do diálogo entre as partes comprometidas, ressaltando-se: atualização de levantamentos físicos, estudo da situação de risco das casas, apoio ao cadastro social dos moradores em conjunto com o órgão governamental responsável, proposições para apropriar áreas coletivas, elaboração de pareceres para assistência jurídica, além de eventos de mobilização e interação. Para discussão sobre as possíveis contribuições do meio acadêmico aos setores da sociedade mais vulneráveis dividimos o artigo em blocos correspondentes a naturezas distintas das ações desempenhadas, comentando ao final acerca dos avanços vislumbrados e dos atuais impasses que impedem uma continuidade no processo.

\subsection{O CONTEXTO DA ATUAÇÃO EXTENSIONISTA}

Indiana é uma favela com mais de 50 anos de existência e 298 domicílios(Censo IBGE 2010.), localizada no bairro da Tijuca, Zona Norte da cidade do Rio de Janeiro, em região dotada de privilegiadas condições de infraestrutura e serviços urbanos, e igualmente de oportunidades no mercado de trabalho. Grande parte dos moradores trabalha na região ou mesmo dentro da própria favela, especialmente em atividades de prestação de serviços e no comércio. Está praticamente nas bordas da principal artéria do bairro, com transporte facilitado para toda metrópole, além de proximidade com equipamentos de diferentes naturezas. Situa-se em uma área abaixo do nível do logradouro público que lhe dá acesso, que compreende uma faixa estreita ao longo das margens do Rio Maracanã que se prolonga por um terreno quase plano mais alargado, no qual se concentra um maior número de moradias. Essa área é separada apenas por uma rua do Complexo de Favelas do Borel, um dos maiores da cidade que se estende pelas encostas do Maciço da Tijuca. (Ver figura 1)

Figura 1: Mapa do entorno geral e imediato da Favela Indiana.
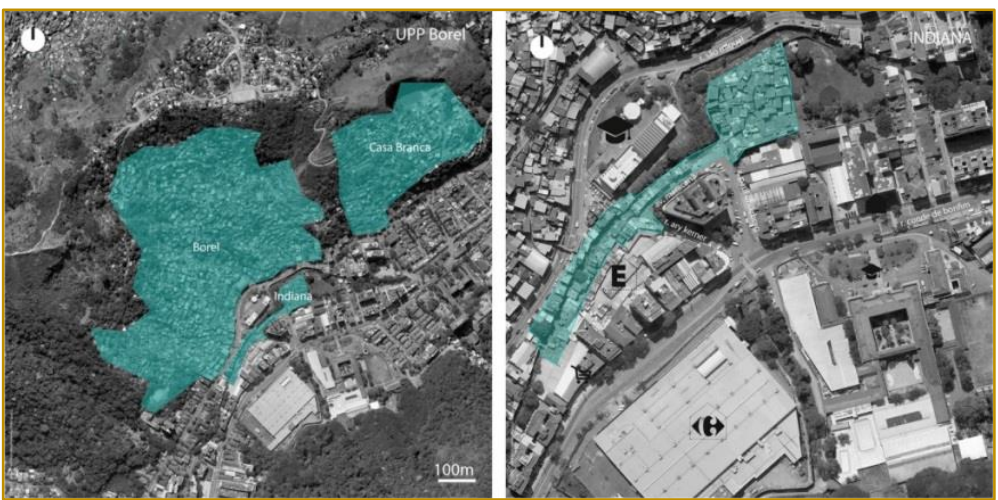

Fonte: banco de dados Abricó EMAU UFRJ

Essas características geográficas são as principais responsáveis pelos conflitos que levaram à atuação da Universidade na Comunidade e também pelos atuais impasses para sua continuidade. A motivação para interação com Indiana originou-se de solicitação à Faculdade de Arquitetura e Urbanismo da Universidade Federal do Rio de Janeiro (FAU-UFRJ) por parte do Núcleo de Terras e Habitação da Defensoria Pública do Estado do Rio de Janeiro, parceira do projeto, para assessoria técnica no atendimento jurídico à Comissão de Moradores em conflito gerado pela oferta de moradias para reassentamento por parte da Prefeitura da Cidade do Rio de Janeiro em 2013 - aceito por alguns, e recusado por outros - e consequente, ameaça de demolir casas e degradar o assentamento. Por depoimentos dos moradores, a iniciativa do executivo municipal - até hoje não totalmente esclarecida - se deveu em grande parte ao interesse pela integração dos terrenos ocupados ao tecido formal contíguo pelo seu alto valor no mercado imobiliário, sobretudo, após a recém-inaugurada estação de metrô Uruguai, distante cerca de dois quilômetros da Comunidade. 
A pressão exercida pelo poder público criou um conflito intenso dentro da comunidade proposital segundo opinião de alguns de seus moradores, já que se constituía em um dos maiores entraves à resistência às remoções. Desde o início da atuação da prefeitura na Comunidade, os moradores se dividiram entre os que resistiam ao reassentamento e queriam ficar na favela, e os que aceitavam a proposta municipal de - mediante a demolição de suas respectivas casas - se mudar para um complexo residencial recém-implantado no âmbito do programa do governo federal "Minha Casa Minha Vida", situado no bairro suburbano de Triagem. O problema levantado pelos que queriam permanecer era o conjunto de espaços residuais gerados com a demolição e seus respectivos entulhos, que entre outros problemas acarretariam a intensificação da poluição do rio Maracanã, a proliferação de vetores e consequente aumento de doenças., e ainda a ameaça de desestabilização estrutural à contiguidade e concentração das casas.

Os conflitos internos gerados pela intervenção municipal que desestabilizaram a união dos residentes da Comunidade, não se restringiram aos embates pela permanência dos moradores. O contágio se deu na divisão da população na tumultuada discussão em torno da destinação de casas desocupadas ou espaços residuais das demolidas. Nessa disputa, origem dos impasses para continuidade da atuação da Universidade, interfere fortemente - segundo depoimentos de moradores - grupos criminosos implantados no Complexo do Borel que têm expressiva presença manifesta no Complexo apesar deste contar com a instalação de uma Unidade Pacificadora da Polícia (UPP) pelo governo estadual.

\subsection{QUADRO TEÓRICO-METODOLÓGICO}

O pensamento relativo à pedagogia crítica na arquitetura social é uma das principais referências téorico-metodológicas para atuação junto à Comunidade Indiana. Nesta perspectiva o potencial emancipatório das relações diaglógicas proposto por Paulo Freire (2001), através da participação, transparência e estrutura da experiência, assume um papel fundamental. O autor reitera que "uma vez a pessoa percebe um desafio, entende ele reconhece a possibilidade de resposta, ele age. A natureza dessa ação corresponde a natureza de sua compreensão." Na obra "Pedagogia da Autonomia" Paulo Freire (2011) também esclarece a necessidade de se negar a "inercia do hábito", numa tentativa de dar margem a novas descobertas. Um grupo externo, muitas vezes provocador, dispara, certamente, reflexões reprimidas pela rotina muitas vezes inebriante. Neste contexto a presença dos estudantes no ambiente da comunidade rompe com o quotidiano e cria tempo e espaço para a reflexão sobre a realidade.

São também preocupações presentes as referentes ao modelo de desenvolvimento brasileiro que produziu ao longo do tempo, cidades caracterizadas em parte pela ilegalidade urbanística, gerando imensos trechos do tecido urbano nos quais o direito à cidade é quase inexistente, como as favelas existentes na cidade do Rio de Janeiro. Como resultado, parcelas significativas da população não têm acesso aos benefícios da urbanização, e vivem em um padrão de crescimento no qual predominam a precariedade e a violência, deixando-as em situação de vulnerabilidade social e política.

Numa perspectiva crítica de compreensão das questões sociais postas ao lidar com grupos da população de menor poder aquisitivo, foi considerada a importante ponderação de Friedrich Engels em seu trabalho clássico "A situação da classe trabalhadora na Inglaterra", quando aponta ser necessário atentar para a origem dos problemas desta classe. Segundo ele, a crise do alojamento se dá, principalmente, pela exploração da classe trabalhadora pela classe dominante. Para tanto, é esta relação exploratória e opressora que deve ser combatida. No contexto de então, o processo migratório do campo para as cidades é que devia ser revisto para que se as moradias tivessem condições salubres e dignas. Uma observação análoga pode ser observada nos apontamentos de Sergio Ferro na obra "Arquitetura e trabalho livre", quando se refere à questão da casa popular que segundo o autor "não será nunca resolvida se não atingirmos o que está mais embaixo ainda, que é o sistema global de exploração global do trabalhador" (FERRO, 2006). Engels e Sérgio Ferro, portanto, deixam bastante claro que a solução para a crise da moradia não se dará apenas com 0 provisionamento habitacional.

Neste sentido, Lefebvre contribui ainda ao comentar que: "Apenas grupos, classes ou 
frações de classes sociais capazes de iniciativas revolucionárias podem se encarregar das, e levar até a sua plena realização, soluções para os problemas urbanos; com essas forças sociais e políticas, a cidade renovada se tornará a obra". (LEFEBVRE, 2001, p.113). Trata-se de desfazer estratégias e ideologias dominantes na sociedade atual.

"Não parece que esses modelos possam resultar seja de um simples estudo das cidades e dos tipos urbanos existentes, seja de uma simples combinatória de elementos. As formas de tempo e de espaço serão, salvo experiências em contrário, inventadas e propostas à práxis. Que a imaginação se descobre, não o imaginário que permite a fuga e a evasão, que veicula ideologias, mas sim o imaginário que se investe na apropriação (do tempo, do espaço, da vida fisiológica, do desejo)". (LEFEBVRE, 2001 p.114)

Esta última afirmação do Lefebvre propicia acrescentar no quadro referencial teóricometodológico uma nova questão colocada por Vitorio Gregotti (2004) acerca do trabalho no campo da arquitetura e urbanismo:

"... a da racionalidade e cientificidade do procedimento projetual e de seus sistemas de controle nas diversas fases de coleta e análise de dados, de sua seleção e utilização, de verificação da eficiência dos resultados, da previsão dos objetivos. Este problema suscita outro mais amplo e geral: o da relação entre pesquisa científica e pesquisa projetual em arquitetura". (GREGOTTI, 2004).

Em última instância o que Gregotti indica é a necessidade de relativizar os dados, de não se deixar levar pela primeira impressão ou qualquer informação sem o exercício da análise, sem o entendimento de um contexto mais amplo, político.

"Devemos, no entanto, duvidar continuamente da objetividade dos dados, pois, estes, de um lado, chegam a nós de algum modo institucionalizados por experiências precedentes e amiúde longínquas, de outro, porque os dados que analisamos adquirem sentido somente a partir da conexão, de sua organização, e o seu modo de chegar a nós é, muitas vezes, o de uma ordenação voltada para objetivos bastante alheios à arquitetura". (GREGOTTI, 2004, p.25).
$\mathrm{Na}$ arquitetura, o espaço entre o desejo e sua satisfação que atribuímos ao projeto, é particularmente amplo e complexo.

\section{RESPONDENDO DEMANDAS INSTITUCIONAIS}

\subsection{ASSESSORIA TÉCNICA NOS TRÂMITES JURÍDICOS}

A ação inicial da Universidade junto à Comunidade Indiana se deu em março de 2014 em resposta ao primeiro apelo de assessoramento técnico lançado pelo Núcleo de Terras e Habitação da Defensoria Pública do Estado do Rio de Janeiro. Tratava-se de vistoriar casas identificadas pela prefeitura municipal para demolição com intuito de verificar suas condições de habitabilidade ou seu estado de vulnerabilidade. Um parecer foi elaborado $^{41}$ já apontando na ocasião a ambiguidade e fragilidade de todo o processo de reassentamento, pois se vislumbrou a impossibilidade de discriminação nas diversas das casas listadas para demolição de motivação estrutural ou sanitária que justificasse tal decisão. Observou-se ainda que, mesmo consideradas insalubres, algumas das unidades poderiam passar por um processo de reforma ou melhoria, num custo financeiro e social muito inferior aos da demolição.

Esta primeira fase desencadeou uma nova série de atividades. Num segundo momento o coletivo opta por aprofundar ainda mais no envolvimento com a comunidade. Frente à situação apresentada, o grupo em consenso decide extrapolar as indicações meramente técnicas, relacionadas aos aspectos edilícios, e faz a avaliação crítica, de caráter mais político, com o envolvimento da comunidade. Neste sentido, o apoio à Defensoria Pública exigiu por um lado ampliar o alcance do próprio campo disciplinar, abrangendo, por exemplo, o reconhecimento da área objeto de atuação - a Comunidade Indiana - passando do estudo restrito do seu espaço físico para a análise da sua relação com o bairro, com a região e com a cidade; por outro, estender 0 escopo temático da atuação, para fundamentar o posicionamento a ser compartilhado com a Defensoria em favor da inclusão social e urbana.

41 Realizadas pela professora da FAU-UFRJ Luciana da Silva Andrade e pelo engenheiro José Simões, acompanhados de técnicos da Defesa Civil e da Secretaria Municipal de Habitação da Prefeitura da Cidade do Rio de Janeiro. 
A partir de então, uma nova agenda se fez presente dinamizando a relação entre os representantes da comunidade, discentes, docentes e parceiros dos projetos. Além do escopo inicial, incorporam-se neste novo cenário atividades de compreensão do território e de apreensão dos processos e linguagem utilizados no trabalho. A intenção principal foi a de, durante todo o processo, horizontalizar conhecimentos - tanto os técnicos da assessoria como os conhecimentos pregressos dos não técnicos no intuito tornar o mais equânime possível à capacidade de participação de cada um, dentro de suas competências. Foi também indispensável um trabalho de formação e de capacitação interdisciplinar da equipe técnica. Leituras coletivas por discentes e docentes, participação em oficinas e seminários internos e externos, com a participação de outros parceiros dos projetos $e$ incorporando as questões relativas ao direito à cidade e à moradia aos problemas técnicos arquitetônicos e urbanísticos, foram atividades indispensáveis para responder de forma coerente às demandas de assessoria técnica nos trâmites jurídicos. O apoio oferecido pela Universidade foi por duas vezes - em audiências públicas distintas ocorridas durante a vigência dos projetos de extensão - considerado de grande valia.

$\mathrm{Na}$ primeira audiência, um aspecto inesperado da atuação do meio acadêmico foi o fortalecimento oferecido à parte mais fragilizada, ou seja, à própria defensora e aos moradores, pela simples aliança institucional. A Universidade foi convidada pela Defensoria a ter assento na sala da sessão durante o julgamento. O posterior desinteresse na desocupação da Indiana provocado na prefeitura, revelado até mesmo no descumprimento do prazo e desleixo do material apresentado como plano de demolição das residências, exigência da juíza nessa audiência, pode de certa forma ser atribuído à força obtida.

$\mathrm{Na}$ segunda audiência, o reforço da Universidade se voltou para elaboração de um parecer técnico que se tornou para a Defensoria a peça principal de argumentação em prol do planejamento e projeto urbanístico antecedendo a demolição de casas na Indiana pelo executivo municipal. Também passou a ser utilizado como um material informativo básico do processo jurídico na esfera interna da Defensoria. Atualmente, é ainda considerado um insumo de relevância para reclamar futuramente a regularização urbanística e fundiária da Comunidade. Destaca-se que o teor do parecer não se limita a considerações arquitetônicas e construtivas, como o adensamento, a aeração e iluminação, a reciprocidade estrutural; aborda também com a mesma intensidade, problemas urbanos e ambientais, como o déficit habitacional, a função social da cidade, instrumentos urbanísticos, infraestrutura, equipamento e serviços urbanos.

\subsection{EM BUSCA DA REGULARIZAÇÃO FUNDIÁRIA}

O entendimento da importância dos processos de titulação nos assentamentos precários pelo seu efeito de formalização da segurança de permanência em um contexto vulnerável levou os parceiros governamentais dos projetos de extensão, notadamente a Defensoria Pública do Estado do Rio de Janeiro, a buscar uma regularização fundiária para Indiana. Como bem observa Edésio Fernandes (2002) ao tratar da legislação fundiária:

"Títulos são importantes, sobretudo, quando há conflitos, sejam eles de propriedade, domésticos, familiares, de direito de vizinhança. E também para reconhecer direitos sociopolíticos e para garantir que os ocupantes possam permanecer nas áreas sem risco de expulsão pelo mercado imobiliário, por mudanças políticas que quebrem o pacto sociopolítico gerador da percepção de segurança da posse, ou pela pressão do crime organizado, como tem acontecido em diversas favelas e loteamentos irregulares brasileiros." (FERNANDES, 2002 p. 23)

A tentativa poderia também ao longo do tempo buscar reverter o padrão excludente de crescimento urbano que se dá hoje na Tijuca, com a presença de inúmeras favelas nas encostas que fazem fronteira em ambos os lados da parte plana do bairro, promovendo tanto quanto possível uma integração socioespacial de Indiana no tecido urbano contíguo.

Apesar do reconhecimento das dificuldades implicadas no processo - até hoje são muito poucos os resultados exitosos de regularização fundiária no Estado do Rio de Janeiro (COMPANS, 2003) - logo no início da atuação conjunta da Universidade com os parceiros dos projetos - Defensoria Pública do 
Estado do Rio de Janeiro, Instituto de Terras e Cartografia do Estado do Rio de Janeiro e Comissão de Moradores da Indiana -, em maio de 2014, verificou-se a possibilidade de buscar a regularização fundiária da Indiana. Por se tratar de uma área de propriedade particular, a opção foi aplicar a usucapião administrativa ou extrajudicial, um instrumento mais ágil para declaração de propriedade, previsto na lei federal $\mathrm{n}$ - 11.977/2009, que instituiu o programa governamental "Minha Casa, Minha Vida". Este ato legal prevê encaminhamento do auto de demarcação das terras ao Cartório de Registro de Imóveis para posterior outorga de Termos de Legitimação de Posse, que serão convertidos em usucapião extrajudicial. A alternativa de se judicializar se dá apenas na hipótese de o proprietário notificado impugnar o auto de demarcação urbanística confeccionado pelo órgão responsável pela regularização fundiária.

O cadastramento socioeconômico dos moradores de Indiana foi o primeiro passo considerado necessário para realizar o intuito da regularização fundiária. Este é um procedimento usualmente realizado pelo Instituto de Terras e Cartografia, que não contando na ocasião com um contingente suficiente de funcionários para tal, pediu 0 apoio da Universidade. Alguns aspectos relacionados à atividade e ao resultado aquém do esperado merecem ser destacados: as dificuldades na mobilização dos estudantes para efetivação do apoio, posto sua operacionalização estar sujeita às conveniências de rotina do parceiro governamental responsável pela coordenação, o ITERJ, frequentemente incompatíveis com os compromissos curriculares estudantis; conflito crescente entre aqueles que queriam ser reassentados e os que queriam permanecer na favela, aqueles que eram donos das casas e os que eram inquilinos, apesar dos esforços empreendidos pelos integrantes da Comissão de Moradores da Indiana. No último caso, demonstrando claramente a reprodução do processo de especulação imobiliária ocorrendo na favela, reproduzido por seus próprios moradores, com suas próprias particularidades/ peculiaridades.

Nesta oportunidade, também foi percebido o quanto a planta cadastral da área a ser regularizada - base para reconhecimento das casas da Comunidade, exigência para o cadastramento socioeconômico dos moradores - estava desatualizada, demandando que se procedesse a um levantamento planimétrico. Esta atividade foi realizada por um engenheiro que voluntariamente assistia a Defensoria, com o apoio universitário e da Comissão de Moradores de Indiana. O produto realizado com parcos meios, mas com a assimilação de um conhecimento aprofundado da realidade local, só possível de ser obtido através da contribuição de residentes da Comunidade, foi bastante satisfatório. O material resultante transformou-se em referência obrigatória para qualquer atuação que envolvesse o espaço físico de Indiana.

Simultaneamente ao levantamento planimétrico, os mesmos técnicos envolvidos procederam a um mapeamento da situação de risco das casas da Indiana localizadas nas margens do rio Maracanã, tendo por base estudo feito pelo órgão municipal responsável pela demarcação das faixas de proteção dos cursos d'água na cidade. O mapeamento revelador da urgência de se contar com instrumentos de urbanização nas favelas - se mostrou também uma ferramenta indispensável para se pensar a regularização da Comunidade.

É igualmente importante ressaltar que os alunos buscaram uma alternativa para que a tarefa que lhes coube não se restringisse a um procedimento unicamente operacional uma vez que não houve discussão sobre o teor dos questionários aplicados, prédefinidos no âmbito da instituição parceira. Propuseram uma atividade complementar que correspondesse a um diálogo horizontal mais profícuo com a população local. Desse modo, entenderam o cadastramento não só como um passo inicial do processo de regularização fundiária - que se mostrou nos dois meses transcorridos de operacionalização impossível de ser concretizada -, mas como uma oportunidade de se lançar nos propósitos de compartilhamento do conhecimento técnico e a contribuição empírica e tornar a população local em agentes ativos na organização espacial do ambiente construído, previstos e almejados nos projetos de extensão. 


\section{CONSTRUINDO UMA RELAÇÃO DE CONFIANÇA}

\subsection{APROXIMAÇÃO COM MORADORES}

Desde o início da participação na ação de cadastramento dos moradores da Comunidade Indiana, os estudantes avaliaram que a ferramenta aplicada pelo Instituto de Terras e Cartografia do Estado do Rio de Janeiro - um questionário com perguntas fechadas e restritas ao levantamento de dados pessoais à informação sobre o domicílio na favela, sugerindo respostas curtas e diretas - era muito formal e ia de encontro a uma abordagem prevista em uma atuação extensionista baseada na troca de saberes. Assim, apesar de avaliarem que o esforço serviria para ampliar seu conhecimento acerca do espaço físico e social da Comunidade, julgaram relevante efetuar uma atividade que de fato possibilitasse uma aproximação com os residentes. Deste modo, criaram um questionário paralelo complementar para realizar o que chamaram de uma consulta dos saberes orgânicos dos moradores.

A busca pelos saberes orgânicos dos participantes do cadastramento socioeconômico teve o intuito de informalizar nossa visita acrescentando ao questionário do ITERJ, com perguntas afetivas que mapeavam as relações e habilidades dos moradores muitas vezes desvalorizadas. A senhora que fazia o bolo, o rapaz que gostava de funk e a menina que tinha um coelho em casa, enfim toda informação que dissesse respeito a uma vivência compartilhada na Comunidade era valorizada, na crença que assim se daria o início e um incentivo ao processo de empoderamento comunitário, no qual todos os saberes, habilidades e interesses são importantes para a criação da identidade local. O entendimento foi de que a identificação enquanto parte indispensável do coletivo é o primeiro passo na consolidação futura de uma luta comunitária.

A finalização da ação de cadastramento socioeconômico - inconclusa como mencionado no item 2.2 - e da atividade de consulta dos saberes orgânicos foi coroada com o agendamento de um evento voltado não só à confraternização festiva mas também a um diálogo sobre o problema no qual a Comunidade se encontrava envolvida. O cinema visto como uma mídia bastante eficaz na atração dos moradores foi escolhido como uma ferramenta para tratar de um modo lúdico questões de interesse. O primeiro filme agendado foi o documentário brasileiro "Remoção", dirigido e roteirizado por Luiz Antonio Pilar e Anderson Quack, vencedor da mostra competitiva de longa metragem documental do RECINE 2013 (Festival Internacional de Cinema de Arquivo). O longa mostra o processo de remoção das favelas durante as décadas de 1960 e 1970 na cidade do Rio de Janeiro e as primeiras experiências de criação de conjuntos habitacionais, revelando facetas variadas, em diferentes comunidades e contextos, do mesmo fenômeno no qual a Indiana de certa maneira se encontrava no momento.

A exibição do filme foi organizada em uma tela de projeção armada na rua com cadeiras postas na área de maior afluxo de moradores, à entrada da favela. Após o filme, houve uma discussão acalorada sobre o tema, na qual os moradores que pretendiam ficar na Comunidade e os que pretendiam sair mostraram suas divergências. O conflito dos residentes revelava-se assim uma vez mais nesse evento de confraternização, apresentando-se como uma desestabilização para a resistência dos moradores, pois o desentendimento gerava uma desunião que dificultava a articulação para lutar justamente contra as remoções, e consequentemente dificultava o avanço de um processo colaborativo.

A sessão de cinema foi utilizada também para uma aproximação lúdica, porém educativa, com os moradores infantis - alcançando, no entanto, apenas parcialmente os efeitos desejados. O filme escolhido foi o aclamado longa de animação brasileiro de 2013,"O menino e o mundo", escrito e dirigido por Alê Abreu, exibido no mesmo local utilizado anteriormente. Apesar de retratar uma história e um cotidiano facilmente identificáveis aos da favela, talvez pela estética simplista e inabitual, ou simplesmente por não ser um filme presente nos seus desejos, não conseguiu atrair a atenção das crianças. Mesmo assim, a atividade revelou-se uma forma de aproximação.

Posteriormente ensaiamos outra forma de aproximação, durante um conselho nacional de entidades estudantis de arquitetura e urbanismo. Nessa ocasião, organizamos na entrada da Comunidade uma roda de conversa sobre "cidade". No entanto, apesar de estarmos fora do campus, e dentro da favela, a distância entre academia e população se revelou imensa, talvez devido à 
linguagem empregada naquele momento. A crítica foi construída in loco por uma das estudantes presentes e repercutiu posteriormente em propostas divergentes: adaptar o vocabulário para criar empatia com os moradores ou empregar os termos técnicos com naturalidade para haver uma apropriação dos conceitos com o tempo. A opção adotada foi aplicar as duas estratégias dependendo da sensibilidade na escolha de acordo com o perfil das pessoas com as quais nos comunicávamos, o contexto específico e tendo o cuidado ao inserir novos conceitos, de não recorrer frequentemente a metáforas e analogias.

A experiência nesse evento repercutiu na crítica sobre a linguagem com a qual estávamos habituados a utilizar na academia, para aplicação na extensão. Para trabalhar com a Indiana observamos ser preciso pensar formas de comunicação verbais distintas associadas a formas visuais, só assim há a chance de uma aproximação efetiva. Deste modo, propusemos em outro evento, durante o XXXIX Encontro Nacional de Estudantes de Arquitetura, sediado no Rio de Janeiro, através de uma atividade de forró, voltada para uma consciência corporal e espacial, um jogo sobre a cidade e questões do déficit habitacional. A abordagem lúdica contribuiu para o entendimento dos debates propostos.

Começamos também a investir em atividades nas quais os moradores de todas as faixas etárias desenhassem suas ideias, uma maneira de ver como eles entendiam espacialmente a Comunidade. A partir desses desenhos, conseguimos entender também como é a representação para pessoas alheias ao campo da arquitetura e do urbanismo. No fim, percebemos que todas as atividades desenvolvidas foram afinando a comunicação com a população de Indiana, estreitando os laços com os moradores e construindo ao longo do tempo uma relação de confiança com a comunidade.

\subsection{VÍNCULOS E SOLIDARIZAÇÃO}

Ao longo dos diversos encontros na Indiana o trabalho extensionista universitário junto aos moradores fortaleceu uma relação de confiança, condição essencial, segundo os integrantes do Abricó - Escritório Modelo de Arquitetura e Urbanismo da FAU/UFRJ para o desenvolvimento de um trabalho prazeroso e de qualidade. Entende-se ser fundamental na parceria da Comunidade com a Universidade, independente da produção material, o fortalecimento da luta dos moradores, além da busca pela autonomia dos mesmos, com respeito e incentivo ao saber local, com a construção de uma relação que gere uma mobilização em prol da comunidade. Para além desse pensamento há ainda a considerar aspectos relacionados às condições precárias da população de um modo geral situada nos extratos de mais baixa renda no país. A construção de uma parceria com a Indiana exigiu por vezes prestar solidariedade pela difícil situação de vida atravessada por grupos de pessoas ou toda a população.

Assim uma primeira situação de solidarização da Universidade com a Comunidade se apresentou por iniciativa da Associação de Moradores, que entrou em contato com os alunos do Escritório Modelo de Arquitetura e Urbanismo da FAU/UFRJ para convidá-los para ajudar na organização do dia das crianças na Comunidade Indiana. Naquele período existia um conflito entre associação e alguns moradores que fizeram parte da comissão, esses conflitos vinham enfraquecendo a luta dos moradores de uma maneira geral, mas felizmente ao longo da organização do evento conseguiu-se que essas pessoas que estavam se desentendendo se unissem para que fosse possível acontecer as atividades do dia das crianças.

Com o foco no entretenimento das crianças durante 0 dia os estudantes propuseram algumas atividades que estivessem voltadas principalmente para elas, mas que de certa forma remetesse a questões espaciais da Indiana. Algumas atividades eram de caráter somente lúdico, como o pula-pula montado na rua, disponível durante o dia, mas muitas outras tinham um caráter pedagógico. Foi realizada uma oficina de fotografia e revelação com câmera pinhole. Nela grupos de crianças andavam pela favela buscando lugares interessantes de serem fotografados. Em paralelo aconteceu uma oficina de desenhos e ainda a exposição de uma grande maquete na escala do brinquedo, onde todas as casas estavam representadas e a interação era livre. As casas na maquete podiam ser pintadas e as ruas identificadas. O evento foi complementado com a distribuição de brinquedos para as crianças presentes e foram oferecidos pedaços de dois grandes bolos para todos que estivessem passando pelo local do evento. 
O espírito da solidarização dos estudantes do Escritório Modelo de Arquitetura e Urbanismo da FAU/UFRJ também se deu com o suporte dado aos moradores quando das enchentes ocorridas na cidade do Rio de Janeiro no final do ano de 2015. O impacto das chuvas na comunidade foi grande, principalmente nas casas que se localizam nas margens do rio Maracanã e/ou próximas a um estacionamento contíguo à faixa junto às margens do rio, situado em terreno ocupado ao que tudo indica irregularmente. As águas entraram no interior de algumas das casas, carregando e danificando muitos dos bens dos seus moradores. A adesão à feira de doações programada pelos estudantes não teve o alcance esperado, porém conseguiu demonstrar a solidarização com a Comunidade.

Recentemente, a partir do entendimento construído através de uma reunião aberta com a participação de representantes dos moradores da Indiana e dos estudantes do Escritório Modelo de Arquitetura e Urbanismo da FAU/UFRJ, acerca das dificuldades atuais na Indiana em decorrência da crise econômica e da falta de investimentos públicos, foi organizada uma feira de doações para a Comunidade com o intuito de apoiar o financiamento das obras urbanísticas necessárias na favela. Nessa atividade, considerada bem-sucedida, foram captadas ajudas em termos de materiais de construção utilizados posteriormente pelos moradores para melhorar a pavimentação das vielas. Entretanto, a falta de divulgação do evento no âmbito interno à Comunidade e da própria reunião precedente, por parte da Associação de Moradores da Indiana, deixou clara a dificuldade de transpor problemas que vêm ocorrendo na Comunidade a partir dos desentendimentos entre grupos de liderança internos. Esses são os principais fatores que vêm desmotivando os estudantes a prosseguir com as atividades de campo apesar dos fortes vínculos já construídos com a população local.

\section{INICIANDO UM PROCESSO DE PLANEJAMENTO}

\subsection{MONTAGEM DE DIAGNÓSTICOS}

O diagnóstico, muito mais que uma fase introdutória do processo de planejamento, de levantamento de demandas e necessidades, foi compreendido como um momento chave de capacitação e fortalecimento do grupo de moradores participantes, com potencial transformador das dinâmicas social e espacial do território da Comunidade Indiana. Neste sentido, apoiando-se em atividades de participação e contando com a experiência dos moradores, buscou-se destacar: em termos de abordagem temática, aspectos mobilizadores, voltados para uma visão sobre as potencialidades do território e menos em conflitos sócio-espaciais; em termos de linguagem, ferramentas motivadoras e de fácil apreensão; em termos de atitude, transparência e sensibilidade.

A primeira atividade prática de diagnóstico com a participação dos moradores da Indiana - concebida com o intuito exclusivo de integrar-se nessa fase específica do processo de planejamento - aconteceu durante 0 evento relatado no item 3.2 de comemoração do dia das crianças, apesar das muitas atividades precedentes de observação em campo, reunião com representantes da Comunidade, registros cartográficos e fotográficos e trocas informais com residentes. O material básico de sua realização foi uma maquete executada no laboratório de maquetes da Faculdade. A estratégia pretendida com a atividade foi a de aguçar o reconhecimento espacial dos moradores a partir da exposição e convite ao manuseio do modelo tridimensional. As casas, representadas por peças de madeira, não eram fixadas à base para que os moradores pudessem pegá-las, reconhecê-las, pintá-las e (re) implantá-las na maquete já lhes atribuindo um novo significado. (Ver figura 2)

Foi possível observar maior facilidade nas crianças para identificação de suas casas e dos caminhos que levavam a elas a partir de um ponto de referência - a entrada da Comunidade - sinalizado pelos propositores da atividade. Acredita-se que houve maior resistência dos moradores adultos na interação por se tratar de lidar com algo novo, com o qual eles nunca tiveram contato. $O$ fato é que as crianças intervieram não só nas suas residências, mas conseguiram identificar e pintar as principais casas da Comunidade e indicar aos demais participantes as suas localizações. Ao final da atividade, constatouse que a maquete pelo fato de possuir três dimensões e incorporar o tato na percepção é uma ferramenta em uma linguagem bem mais acessível que o desenho para trabalhar 0 diagnóstico nos processos participativos. Verificou-se que há, no entanto, alguns aspectos a serem considerados 
principalmente tendo em conta que o reconhecimento do lugar não foi imediato. Teria sido interessante a execução de uma maquete em uma escala que permitisse a apresentação dos elementos construídos com detalhes, vegetação ou mesmo alguns pequenos marcos do caminho. De qualquer modo, a presença da maquete propiciou uma grande interação entre os participantes de todas as faixas etárias e um estreitamento de relações entre parceiros dos projetos de extensão.

Figura 2: Atividade com maquete.

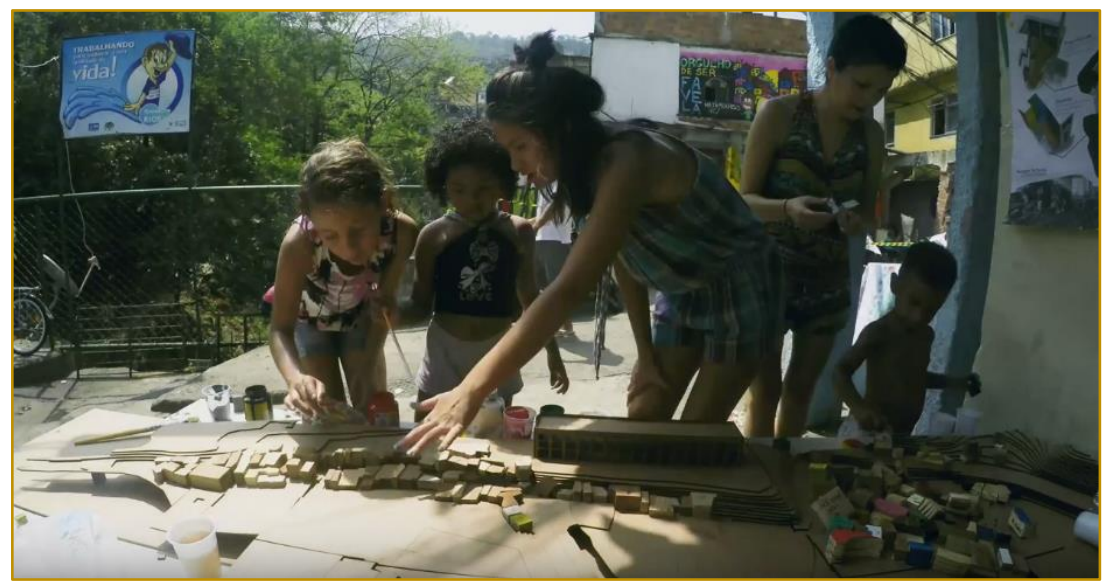

Fonte: banco de dados do Abricó EMAU UFRJ.

Um "desenho a metro da comunidade" foi uma proposta das próprias crianças a partir da sugestão do uso do desenho com temáticas livres. A ideia do grupo infantil foi retratar o espaço em que viviam e as práticas ali exercidas de acordo com suas percepções. Essa atividade espontânea de diagnóstico foi de extrema importância para mostrar aos participantes a visão infantil do espaço da cidade, muitas vezes ignorada pelos adultos. $O$ desenho produzido é otimista, porém real, e foi resultante de um intenso trabalho coletivo de cooperação. Foi possível verificar que o desenho, ferramenta de trabalho para arquitetos e urbanistas, é difícil de ser utilizado pelos adultos para abordar aspectos sobre o imaginário da moradia, do habitar e do coletivo, pois está associado às brincadeiras de crianças. A experiência com essa ferramenta com adultos, entretanto, mostrou, após tímidas tentativas dos participantes, uma ampla compreensão dos trajetos e de aspectos relevantes dos caminhos.

A busca por uma apreensão coletiva dos aspectos sócioterritoriais, geradora de uma visão identitária local, foi trabalhada em uma atividade de diagnóstico utilizando pictogramas que simbolizavam os pontos negativos (em vermelho), positivos (em verde) e propositivos (em amarelo) levantados anteriormente em reunião com os moradores da Comunidade Indiana. As imagens apresentadas aos moradores, facilmente reconhecidas enquanto potencialidades e problemas, foram distribuídas aos participantes que se dividiram em grupos e percorreram os espaços da comunidade colando os pictogramas nos pontos respectivos relacionados. Assim, de forma fácil e lúdica, foi sendo montado um mapa onde se tornou possível identificar potencialidades e fragilidades urbanísticas no território.

\subsection{CONSTRUÇÃO DE PROPOSIÇÕES}

Desde o início da atuação junto aos parceiros governamentais e comunitários verificou-se uma ansiedade muito grande em relação à elaboração por parte da Universidade de um material propositivo que pudesse responder às expectativas de se transformar em um plano de urbanização para Indiana. Muitos mencionavam o caso emblemático da Comunidade de Vila Autódromo, situada em área destinada ao Parque Olímpico na Zona Oeste da cidade do Rio de Janeiro, cuja resistência era atribuída à possibilidade de apresentação nas discussões de um plano de urbanização participativo elaborado em parceria com o Núcleo de Ensino e Pesquisa em Urgência (NEPUR) da Universidade Federal Fluminense (UFF). 
Deste modo, precedendo uma total compreensão do território e das relações estabelecidas, e buscando a criação de novas plataformas e novos suportes para um território transformado e de relações repensadas, dentro de uma realidade imaginada, outra, foram construídas proposições para Indiana no âmbito da academia, em um caráter utópico. Neste sentido, serviu de referência e cautela a afirmação de Lefèbvre:

"A utopia deve ser considerada experimentalmente, estudando-se na prática suas implicações e consequências. Estas podem surpreender. Quais são, quais serão os locais que socialmente terão sucesso? Como detectá-los? Segundo que critérios? Quais tempos, quais ritmos de vida cotidiana se inscrevem, se escrevem, se prescrevem nesses espaços "bem sucedidos", isto é, nesses espaços favoráveis a felicidade? É isso que interessa". (LEFEBVRE, 2001).

Para construir proposições para Indiana foi oferecida uma disciplina inserida na grade curricular da FAU-UFRJ, aumentando o número de estudantes envolvidos e a carga horária disponível de professores e alunos, na qual foi proposto o desenvolvimento de uma dentre três frentes de trabalho, originadas de uma dupla motivação: resistência à remoção e melhoria habitacional. O produto previsto na primeira frente foi um plano de urbanização, pensado enquanto necessária ferramenta de informação aos moradores dos seus direitos à permanência e das limitações à utilização de seu território; insumo para futura discussão com setores governamentais responsáveis pelo projeto de urbanização de Indiana. A segunda frente previa a elaboração de projetos para os espaços coletivos da Comunidade, referência para luta pela permanência com qualidade habitacional e criação de uma identidade coletiva local. O material correspondente à terceira frente eram projetos de melhoria nas moradias, objeto de análise dos requisitos mínimos construtivos e espaciais aceitáveis nas casas e insumo para pleitear ou executar benfeitorias nas habitações.

Os produtos resultantes dessa experiência acadêmica foram expostos aos moradores de Indiana em um evento de aproximação e confraternização. Em termos acadêmicos, a iniciativa correspondeu inteiramente ao interesse dos alunos e se mostrou muito enriquecedora, destacando-se o empenho dos estudantes, apesar de dificuldades inerentes às dinâmicas curriculares. Mesmo considerando o caráter utópico do material elaborado, a interação insuficiente entre alunos e residentes na comunidade e limitações técnicas dos produtos, chama a atenção repercussões relativas a alguns desses produtos junto aos parceiros.

Os projetos para espaços coletivos servem até hoje de argumentação para o grupo da Comissão de Moradores de Indiana que reivindica junto à Associação de Moradores uma apropriação coletiva dos espaços antes ocupados por casas demolidas. A proposição referente ao plano de urbanização expõe claramente uma situação difícil de ser discutida na Comunidade, a situação de risco em que se encontra a maioria das casas implantadas na estreita faixa lindeira às margens do rio Maracanã. Hoje há uma expectativa por parte da Defensoria Pública de abrir uma ação cível em nome dos moradores da Indiana para exigir a elaboração de um plano de urbanização para Comunidade protegendo as famílias sujeitas ao risco.

\section{CONSIDERAÇÕES FINAIS: AVANÇOS E LIMITAÇÕES}

A partir da atuação relatada se constituíram alguns avanços consideráveis para a resistência da população residente na Comunidade Indiana. Consolidaram-se parcerias com as entidades envolvidas, e atendendo as solicitações originárias do processo, as chances de demolição arbitrária das casas se tornaram remotas. A permanência daqueles que o desejassem praticamente se cristalizou. Apesar dos vínculos estabelecidos, os desdobramentos do processo e um aprofundamento no diálogo com a população, entretanto, foram se tornando mais difíceis.

$\mathrm{Na}$ esfera acadêmica, destaca-se a importância da vivência e práticas estudantis durante a graduação compromissada com a realidade social e oferecendo espaço para o debate e a produção aberta à sociedade, condizentes com necessidades e demandas reais e capazes de ser apropriadas pela comunidade. A atuação em Indiana propiciou um amadurecimento nos estudantes que integram o Escritório Modelo de Arquitetura e Urbanismo da FAU/UFRJ, em termos do entendimento das relações sociais envolvidas no projeto de arquitetura e do exercício de trabalho coletivo e da exigência de 
comprometimento, contribuindo efetivamente na sua consolidação. Por fazer parte de uma rede de escritórios modelo de arquitetura e urbanismo de alcance nacional, abriu-se a chance para uma troca intensa de experiências com estudantes de outras escolas de arquitetura e urbanismo na busca de alternativas para desenvolvimento de uma prática projetual distinta da realizada nos estágios em escritórios.

A experiência também permitiu todo o coletivo a questionar a produção do espaço nas cidades, como sugerido por Lefebvre (2001), identificando o papel de atores protagonistas e coadjuvantes - neste processo, correspondendo de certo modo à pedagogia emancipatória preconizada por Freire como indispensável (2001). Explorouse, neste contexto, a necessidade da constituição de um coletivo coeso e com clareza em suas demandas, um grupo capaz, por sua consciência, de propor modificações reais. Esta reflexão trouxe a tona o problema da disjunção destes grupos, destes coletivos e de seus objetivos e agendas.

Apesar das dificuldades no processo participativo de construção de diagnóstico e proposições, por parte do coletivo de um modo geral, houve avanços, pela compreensão clara e com posicionamento crítico, como sugere Vitorio Gregotti (2008). No diagnóstico executado para o território, as informações e dados colhidos foram tratados em conjunto e dentro da complexidade na qual está, cada um, inseridos.

No meio acadêmico, os resultados revelaramse uma oportunidade de experimentar a aplicação de técnicas diferenciadas para leitura sócioterritorial que envolve a população; para os moradores, na apreensão de qualidades territoriais potencializadoras que se contrapõem aos frequentemente mais

\section{REFERÊNCIAS}

[1] Abramo, Pedro (org.). A cidade da informalidade: o desafio das cidades latinoamericanas. Rio de Janeiro: Sette Letras / FAPERJ, 2003.

[2] Compans, Rose. "A regularização de favelas no Estado do Rio de Janeiro". Revista Rio de Janeiro, n. 9, p. 41-53, jan./abr. 2003. http://www.forumrio.uerj.br/documentos/revista_9/0 09_041.pdf. Acesso em 25/11/2016.

[3] Engels, Friedrisch. A situação da classe trabalhadora na Inglaterra. São Paulo: Boitempo, 2008. destacados problemas sócioespaciais a serem remediados. Por um lado, na proposição de uma linguagem sensível e clara, se expressa o exercício de criatividade e inovação; por outro, na atitude aberta e engajada, o entendimento da relevância em buscar a capacitação e o fortalecimento da população envolvida para tomada de decisões.

Não há dúvida que a ação participativa é a base do processo e que seja necessário cada vez mais tentar clarificar os papéis de técnicos e da população. Como coloca Paulo Freire (2001) na estrutura da experiência a transparência é fundamental. O caráter da atuação deve ser integral abarcando múltiplas áreas, desde aspectos físicos, passando por acompanhamento social - um enorme desafio, melhor resolvido através da integração de campos acadêmicos distintos.

Cabe concluir, que no processo da transferência dialógica dos saberes empreendido na Indiana apresentam-se problemas intrínsecos ao dinamismo da realidade, como mudanças na configuração física da favela e reocupação domiciliar, que impõem dificuldades não impedem uma continuidade no processo. O impasse à continuação de uma atuação da Universidade, no entanto, vem acontecendo em decorrência de conflitos externos e internos à Comunidade. A atuação tem sido minada pela contaminação incontrolável de grupos organizados criminosos, e também pelas lutas de poder expressas nas disputas entre Comissão e Associação de Moradores de Indiana. Esses fatores estão relacionados certamente a aspectos políticos mais abrangentes que se interpõem na luta pela emancipação do grupo da população mais pobre da cidade.

[4] Fernandes, Edésio (org.). Direito Urbanístico e Política Urbana no Brasil. Belo Horizonte: Del Rey, 2001.

[5] Ferro, Sérgio. Arquitetura e Trabalho Livre. São Paulo, CosacNaify, 2006.

[6] Freire, Paulo. Educação como prática da liberdade. Rio de Janeiro: Paz e Terra, 2001. 25a ed.

[7] Pedagogia da autonomia: saberes necessários à prática educativa. São Paulo: Paz e Terra, 2011. 43를 ed.

[8] Gregotti, Vittorio. Território da Arquitetura. São Paulo: Ed. Perspectiva, 2010. $3^{\text {a }}$ ed. 
[9] Lefebvre, Henri. O direito à cidade. Tradução Rubens Eduardo Frias. São Pauo: Centauro, 2001.

[10] Santos, Carlos Nelson F. dos. A cidade como um jogo de cartas. Niterói: Universidade Federal Fluminense/ EDUFF; São Paulo: Projeto Editores, 1988. 


\section{Gapítulo 15}

\section{CAMPO DOS ALEMÃES EM SÃO JOSÉ DOS CAMPOS / SP COMO CAMPO DE DISPUTA SIMBÓLICA: O QUE DIZEM OS MUROS.}

\section{Frederico Papali}

Valéria Zanetti

\section{Paula Vilhena Carnevale Vianna}

Resumo: Este trabalho, de caráter exploratório, investiga se o graffiti encontrado nos muros das casas do bairro Campo dos Alemães, periferia de São José dos Campos/SP, apresenta-se como expressão de construção/afirmação de identidades de grupos ou de apropriação/ressignificação de território e da paisagem urbana. Para responder a essa questão, o método utilizado foi a análise de narrativas sobre três Mutirões de Graffiti realizados neste bairro da cidade em 2007, 2010 e 2013. Três tipos de fonte foram consultadas: impressa, formada por panfletos de divulgação e jornais; oral, constituída por depoimento de um dos grafiteiros do bairro e imagética, a partir do recurso do Google Maps, que registrou os trabalhos produzidos nos três Mutirões. Os achados apontam para o graffiti como prática que possibilita a afirmação e mesmo construção de novas identidades em bairros estigmatizados pela exclusão social.

Palavras Chave: Graffiti, Identidades, Território, Arte Urbana, Cidade, Planejamento Urbano. 


\section{INTRODUÇÃO}

O graffiti, surgido no final da década de 1960 e início da década de 1970 na Filadélfia / EUA (FARTHING, 2011) ganhou notoriedade em Nova lorque quando grafiteiros invadiram as ruas da cidade. No início, consistia de "marcas", registros de pseudônimo resumido, estampadas em qualquer espaço público disponível. Essas insígnias evoluíram para grandes e complexas ilustrações caligráficas, feitas com tinta spray. Este tipo de graffiti, conhecido como Tagging, é o tipo mais simples e difundido; em geral é o nome ou assinatura de quem escreve.

O objetivo dos adeptos do tagging é fazer a marcação aparecer em tantos lugares quanto possível. Uma variação desse estilo é a pichação, cuja diferenciação nominal se distingue apenas no Brasil. No resto do mundo, graffiti e pichação são ambos designados como graffiti. Geralmente produzido em uma só cor, era inscrito em paredes, ônibus e trens e, com o tempo, ganhou outros espaços e popularidade. Como uma assinatura estilizada que um escritor marca sobre o meio ambiente, o Tagging nasceu na Costa Leste dos Estados Unidos em 1969 (ALONSO,1998, p. 9, 10), como um componente da cultura Hip Hop. Este estilo de graffiti atraiu a atenção da mídia por causa de sua popularidade entre os jovens. Esta expressão se espalhou e, como o Hip Hop, foi exportado de Nova York para as principais cidades dos Estados Unidos e do mundo.

Inspirado na cultura popular dos desenhos animados, o graffiti foi criando assim uma cultura social e estética. Quando feitas nos vagões do metrô em Nova York, a intenção das marcações era atingir um maior número de pessoas. Alonso (1998, p.10) explica ainda que "[...] para quem faz o tagging, a meta importante é ser reconhecido como um escritor produtivo. Através disso, são adquiridos fama e uma sensação de poder por quantos desenhos são concluídos" e também, "[...] tentativas bem-sucedidas para marcar seu nome no lugar mais inusitado acrescenta a seu autor reconhecimento e fama".

O graffiti apareceu inicialmente na Europa, no auge do movimento estudantil da década de 60, espalhando-se posteriormente por diversos países. Com frases poéticoideológicas, "as escritas urbanas feitas com spray nos muros das cidades europeias, no decorrer da década de 60, eram ousadamente contestadoras e se posicionavam contra o sistema político vigente por meio de frases lúdicas, sutis e plenas de criatividade libertária" (FURTADO, 2009, p. 1283).

O graffiti, o rap e o break, se fundem no Hip Hop, cultura de rua que exprime uma forma de arte e de atitude. Bia Abramo (2001) na orelha do livro "Hip hop: a periferia grita", conta que:

O hip hop é um fenômeno sociocultural dos mais importantes surgidos nas últimas décadas. Ora classificado como um movimento social, ora como uma cultura de rua, o fato é que o hip hop hoje mobiliza milhares de jovens das periferias das grandes cidades brasileiras. Suas formas de expressão - a batida do rap, os movimentos do break e as cores fortes do graffiti - são apenas os signos visíveis de uma enorme discussão que fervilha entre esses filhos das várias e imensas desigualdades da sociedade brasileira a respeito de identidade racial, de possibilidades de inserção social, de alternativas à violência e à marginalidade. Em menos palavras, o hip hop é a resposta política e cultural da juventude excluída.

Gonçalves (2007, p. 15) destaca a relevância dos aspectos relativos à expressividade icônica dos graffiti, quando efetuam um jogo de sentidos, com vistas a dificultar a interpretação de suas imagens e estimular, para além da percepção do visível, a lógica da sensação. Para este autor, o graffiti seria expressão estética capaz de subverter certos códigos por intermédio de seu jogo de signos e sentidos e, nos traçados das linhas perpassam, não somente as ações dos grafiteiros, mas o prolongamento da relação entre as pessoas e as imagens inscritas nas ruas.

O movimento hip hop, que inclui o graffiti, foi explicado da seguinte forma por Rocha (2001, p. 18): "basicamente uma manifestação cultural das periferias das grandes cidades, que envolve distintas representações artísticas de cunho contestatório" e que constitui também:

[...] um estilo musical, o rap - abreviatura de rythm and poetry (ritmo e poesia); uma maneira de apresentar a música que envolve um DJ, abreviatura de disc-jóquei, e um MC, abreviatura de master of ceremony (mestre de-cerimônias); uma dança, o break, (dança de solo, praticada em rodas, como a Capoeira) e uma forma de expressão plástica, 
o graffiti - pintar ou desenhar (com spray ou tinta) muros, painéis, túneis etc., com logotipos ou desenhos relacionados com o movimento hip hop (p. 19).

As manifestações artísticas urbanas como o graffiti continuam, como eram nos seus primórdios, ligadas a formas de contestação impressa nos muros das cidades. Estes desenhos servem à veiculação de ideologias, ao estabelecimento de identidades sociais e à inversão de relações de poder. Apesar de suas origens comuns, o graffiti se difere da pichação, esta última entendida como intervenções na forma de assinaturas, escritas monocromáticas em tinta spray, enquanto o graffiti está diretamente relacionado às artes plásticas, à pintura e à gravura. A primeira intervenção privilegia a palavra e a letra; a segunda, relaciona-se com o desenho, com a representação plástica da imagem.

A pintura urbana, independente de seus rótulos, pode ser entendida como forma de reflexões sobre o mundo ou, simplesmente, ato de exprimir, por meio da arte, o prazer e satisfação de executar traços e preenchê-los com cores e personalidade. Entende-se que estas manifestações são expressões culturais, pois são moldadas pelo sujeito como agente que se impõe exteriorizando-se no espaço. A questão é de que forma essa expressão se transforma em linguagem de poder.

Essas intervenções no espaço, sejam elas agradáveis ou não aos olhos de quem as vê, são produtos da cultura contemporânea, resultado de um processo histórico que promoveu desencantos em suas expectativas de efetivação das políticas promotoras de justiça social. Imersos nesse contexto, permeado de exclusão, muitos jovens viram, na cultura hip hop a resposta para alguns de seus sonhos, manifestados como forma de arte e de atitude (BORGES, 2016).

Na periferia da cidade metropolitana de São José dos Campos, SP, três eventos, promovidos por jovens grafiteiros, nos anos de 2007, 2010 e 2013, coloriram os muros do bairro estigmatizado pela exclusão e violência. O que os teria motivado, quais suas pretensões e produtos? Tentando responder a essa pergunta, o estudo teve como fonte os produtos dos mutirões de graffiti. Os dois primeiros eventos foram realizados quando a prática era proibida, perseguida e reprimida. Mesmo criminalizado, o mutirão aconteceu durante três dias, regado a música, dança, encontros e desenhos nos muros das casas e ruas do bairro do Campo dos Alemães, até então, único bairro em que a prática se concentrava.

A reflexão para o entendimento dessas manifestações baseia-se na análise de Pallamin (2000, p. 57) que considera as práticas artísticas como apresentação e representação dos imaginários sociais. Elas evocam e produzem memória e podem, potencialmente, ser um caminho contrário ao aniquilamento de referências individuais e coletivas, que tira o sentido, levando ao esquecimento produzido por um presente produtivista. Dando sentido e qualificando os espaços públicos, a arte urbana pode ser também um instrumento de memória política.

Campos (2007) afirma que a condição social dos atores do graffiti urbano é relevante para a problematização dos processos de construção de identidade, de sua fragmentação e de sua criatividade na confecção desses modelos de cultura à margem dos padrões hegemônicos. Medeiros (2008, p. 109) diz que é o uso do território que faz dele objeto de análise social e que "[...] seu entendimento é, pois, fundamental para afastar o risco de alienação, o risco da perda do sentido da existência individual e coletiva, o risco de renúncia ao futuro" (SANTOS, 1998, p.15).

Neste bairro periférico que concentra 55.152 habitantes (pelo censo de 2010, conforme o Atlas do Desenvolvimento Humano no Brasil 2013), cuja renda e escolaridade médias são inferiores à média municipal e que se apresenta no imaginário da cidade como um campo de pobreza e violência, seria o graffiti uma possibilidade de construção e afirmação de identidades, apropriação e ressignificação do território? Que significado e sentido têm essa expressão para os artistas e que relação ela estabelece com a comunidade?

O método utilizado neste trabalho foi a análise de narrativas, tanto oral, constituída por depoimento de Vespa, um dos grafiteiros do bairro e o organizador dos Mutirões, como também imagética, tendo como fonte o recurso do Google Maps, que registra os trabalhos produzidos nos três Mutirões de Graffiti, realizados neste bairro da cidade de São José dos Campos /SP em 2007, 2010 e 2013. 


\section{O CAMPO DOS ALEMÃES - PRIMEIRA APROXIMAÇÃO E MÉTODO DE PESQUISA}

O bairro do Campo dos Alemães, situado na zona sul da cidade de São José dos Campos, recentemente foi tema de notícias de uma reportagem televisiva, que apresentou a movimentação de carros em uma das ruas do bairro, espaço utilizado pelo tráfico de drogas (NOTICIAS.R7 PLAY, 2016).

O âncora do jornal apresenta a cidade como uma das mais ricas do Estado de São Paulo e como os "bandidos", muitos deles menores de idade, dominam o bairro com a venda de drogas; comércio que acontece em plena luz do dia, no meio da rua. Indignado, o âncora do jornal ressalta: "tem até fila de compradores no chamado drive thru do tráfico (...)" (Idem). O repórter, sobrevoando o bairro, dá notícias da movimentação de carros aos telespectadores:

Num bairro dominado pelos bandidos, muitos deles menor de idade, a venda de drogas acontece durante o dia, no meio da rua. 0 cruzamento está parado. É sempre assim. Na esquina, o carro não avança enquanto esse grupo (dos traficantes) não liberar a passagem (...). Mas esses jovens não entregam balas e doces. $O$ que esses adolescentes tiram das sacolas é droga. As cenas foram registradas em São José dos Campos a $90 \mathrm{Km}$ de São Paulo. É do bairro Campo dos Alemães que funciona um ponto do tráfico de drogas. É um bairro aparentemente tranquilo, com ruas e avenidas largas, mas o que se vê daqui (do helicóptero), é assustador. É o lugar onde a lei não existe. Existe apenas a lei do tráfico.

No sobrevoo, fragrante da impunidade. Os jovens, a serviço do crime organizado, estão espalhados pela avenida principal. Logo, um congestionamento se forma. Aparentemente não tem droga ainda. Repare nessa moto, ela sinaliza para o garoto de azul que corre. Em segundos, ele volta com uma sacola cheia. É o suficiente para que a fila ande (...). Isso em plena luz do dia, 13h20min da tarde.

Eles (os envolvidos no tráfico de droga) dividem as funções. Alguns acenam com a mão para que os motoristas encontrem o ponto, enquanto outros, com telefone celular, cuidam da segurança. São os olheiros. Eles avisam sobre qualquer forma de ameaça. É o que esse faz agora: "Tá normal, tá normal" (grita o olheiro). Ele está certo, está tudo normal por aqui (ironicamente, confirma o repórter). Isso quer dizer que o tráfico está garantido, que não tem polícia por perto. É por isso que o drive thru está garantido. Que não tem polícia por perto. É por isso que o drive thru da droga está movimentado. Veja o que vai acontecer... O traficante grita como se estivesse numa feira. Ele pega o dinheiro, tira os pacotes da sacola: 1, 2,3,4,5 compradores levam a droga em 40 segundos. Isso já virou rotina. Os traficantes agem ao lado dos moradores do bairro que observam tudo, calados. A droga é vendida até na frente de crianças (...). Existe até um pequeno congestionamento (...). É impressionante o que acontece aqui no campo dos Alemães em São José dos Campos. A situação é tão evidente que até mesmo aplicativos que desenvolveram mapas e rotas de ruas no mundo todo, flagraram o que parece um rapaz vendendo droga aqui. Foi em 2011. Mas a situação é a mesma de hoje.

Mas, de repente, uma viatura da polícia militar passa pelo bairro. Do alto, resolvemos acompanhar. Será que esses policiais vão fazer algum tipo de revista? Será que esses policiais vão encontrar alguma atividade suspeita?

O carro passa reto bem em frente ao ponto de vendas de drogas. Por pouco tempo, o local fica vazio (...) Os traficantes aqui parecem ter uma certeza: Esse bairro de São José dos Campo pertence a eles (Idem; grifo dos autores).

Este artigo investiga as questões de pesquisa por meio de uma pesquisa exploratória tendo como fundamentação metodológica a análise de narrativas sobre três mutirões de graffiti realizados no Bairro Campo dos Alemães nos anos de 2007, 2010 e 2013. As fontes utilizadas foram: material impresso (panfletos de divulgação dos eventos e matérias de jornal); fontes orais, constituída por entrevista com dois de seus idealizadores e imagens dos graffiti nos muros, mediada pela internet. As informações veiculadas nos jornais e panfletos de divulgação apoiaram a descrição e caracterização do evento. As entrevistas, semi estruturadas, foram exploradas pela técnica de análise de discurso, situando os sujeitos no contexto sociohistórico de vida e compreendo os enunciados como expressão de certa interpretação do mundo. Buscou-se, também, por meio de entrevista, compreender as motivações do organizador para o encontro, as relações e contatos estabelecidos para sua realização, as expectativas, as satisfações, frustrações e a interpretação que os artistas deram para os 
eventos. Finalmente, a observação dos graffiti nos muros, realizada por meio da ferramenta Google Maps, dialogou com as entrevistas e com o bairro, combinando a linguagem oral à gráfica para explorar os sentidos dessa arte urbana em território de tanta complexidade.

\section{OS MUTIRÕES DE GRAFFITI NO CAMPO DOS ALEMÃES}

No mês de março de 2013 aconteceu, em São José dos Campos, o terceiro Encontro Internacional de Graffiti (Figura 1), primeiro evento do gênero depois da descriminalização da manifestação pelo poder público. Nos dois mutirões anteriores (2007 e 2011), o graffiti era considerado contravenção e proibido por lei, no município. O evento de 2013 foi antecedido por uma mesa de debates, com atividades artísticas e esportivas, apoiado por entidades públicas e privadas. A divulgação teve apoio do jornal regional de maior circulação da cidade que perguntava, em tom convidativo: "Para que muros brancos, se eles podem ser coloridos com obras de arte?" E informava que seriam grafitados "muros de pelo menos 12 ruas da região", desde que autorizados pelos proprietários (MARREIRA, 2013; p. 1).

Figura 1 - Material de divulgação do 3o Mutirão -

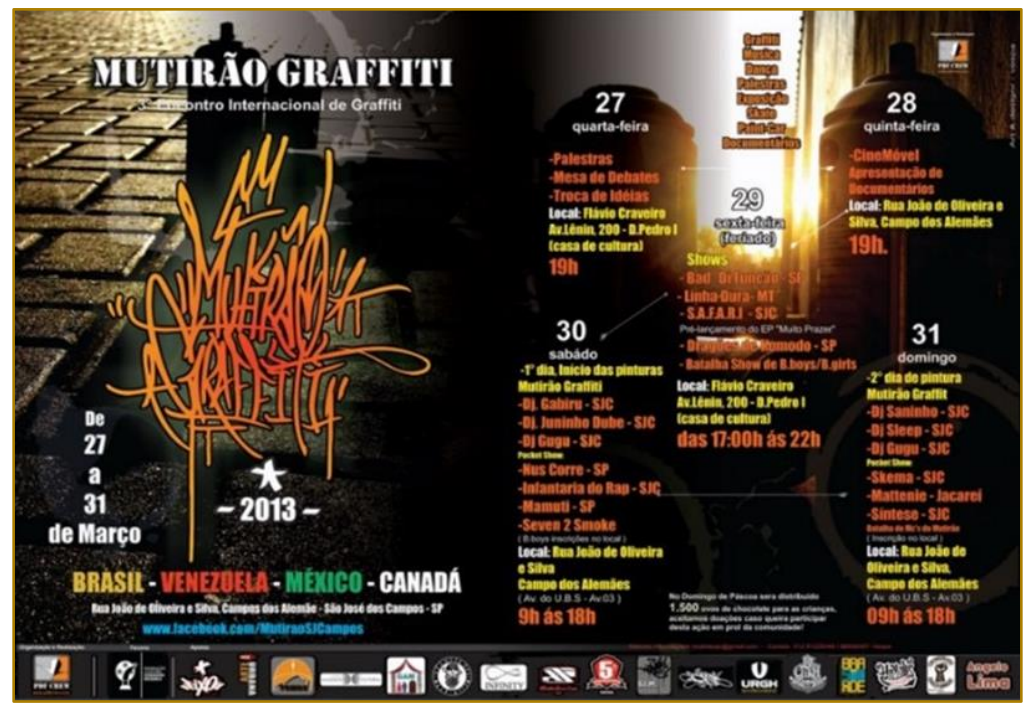

Disponível em:

https://www.facebook.com/MutiraoSjCampos/photos/a.448132538589083.99251.442433702492300/459700354 098968/?type=3\&theater - Acesso: 11 Mai 2016

É da perspectiva da arte urbana como prática social, como definida por Pallamin (2000), que a arte nos muros do bairro será avaliada. Para Pallamin (2000), a arte urbana pode ser tratada como prática social por permitirem "[...] a apreensão de relações e modos diferenciais de apropriação do espaço urbano, envolvendo em seus propósitos estéticos o trato com significados sociais que as rodeiam, seus modos de tematização cultural e política" e ainda (p. 24), que "o relevo dos significados das obras de arte urbana e sua concretização no domínio público dão-se em meio a espaços permeados de interdições, contradições e conflitos".
É um olhar, portanto, apropriado para uma aproximação do espaço do graffiti como uma prática inicialmente contraventora, que ocupa, com singular expressividade, os muros deste bairro de adversas condições sociais, permeado pela problemática da violência. Note-se ainda que se constitui quase que no único espaço urbano onde essa arte acontece com tal expressão na cidade metropolitana de São José dos Campos.

Como pensar a cidade, garantindo a realidade urbana como experiência humana, individual e coletiva? Sobretudo, como pensar essas experiências em São José dos Campos, com tendências de um desenvolvimento baseado no sistema de 
gestão e administração "maquinal" ou "megamáquina moderna", a partir da metáfora de Lewis Mumford (MUMFORD Apud RELPH, 1990, p. 120-21). Como pensar as experiências individuais e coletivas dentro de condições que priorizem as características dos lugares e dos moradores? Em outros termos, é possível pensar a cidade promovendo diálogo com a sensibilidade artística e a racionalidade técnica?

Um espaço, colorido pelo grafitti, se apresenta mais claramente na sua acepção ativa, uma instância da sociedade, um espaço cuja essência, como afirma Santos (2014, p. 1) é social. Isso posto, como um movimento como o Mutirão se relacionaria ao espaço habitado? Que relações se estabelece entre a arte que utiliza os muros e as pessoas que habitam ou que, corriqueiramente, se utilizam desse espaço em seus deslocamentos? Nogueira (2009, p. 3) nos ajuda a entender que,

O que vemos hoje em dia pelas ruas transita entre questões sócio-políticas não só de afirmação como também de protesto. Afirmação no sentido de consolidar aquele espaço como seu, como uma brecha no sistema, quase um espaço-entre, onde é possível penetrar momentaneamente e fazer alguma diferença, fazer algum sentido dentro da sociedade.

O grafiteiro Vespa organizou os três mutirões de graffiti no Campo dos Alemães em São José dos Campos. O primeiro mutirão aconteceu em 2007 e o tema abordado foi "Água"; o segundo, que ocorreu em 2010, teve como tema a "Cultura Brasileira". Estes dois aconteceram quando ainda não existia a lei de liberação da prática do graffiti e não poderia acontecer, mesmo se o grafiteiro tivesse a autorização do dono do imóvel. Portanto, era arte em forma livre, ainda não "domesticada".

O terceiro Mutirão foi também organizado por Vespa, que morou a maior parte de seus 36 anos no bairro. Vespa (2016), no depoimento concedido sobre 0 primeiro evento organizado seis anos antes, assim se manifestou:

O primeiro (mutirão) aconteceu em 2007 e, através de uma conversa com um amigo que eu tinha de que, na verdade, hoje ele faz parte da mesma tribo que eu - (que hoje) mora em Belo Horizonte, (mas já) morou em São José um certo tempo, (e que) depois do mutirão ele veio morar em São José - e aí conversamos e chegamos nessa ideia de fazer um evento na cidade, no bairro onde morávamos, que era ali no Conjunto Ehma, onde acontece a feira e tal. E (sobre) esse evento, a ideia era essa, (a) de a gente poder mostrar para a comunidade esse trabalho que a gente fazia nas ruas, o graffiti, (como) forma de conscientizar, que era uma manifestação cultural, né? E não o que a Prefeitura pregava, que era vandalismo, depredação, e tal (Grifo dos autores).

Essa fala nos remete à relação do grafiteiro com o espaço do bairro, que pode ser compreendido como espaço de poder, como território. Mesmo condenado pela administração pública, o graffiti reuniu não só um grupo de grafiteiros "da mesma tribo" como teve a intenção de "conscientizar" que o graffiti não era crime e sim "manifestação cultural", contrapondo-se à criminalização da prática, abrindo uma "brecha no sistema", construindo o "espaço entre" (Nogueira, 2009, p.3). O depoimento do Vespa nos permite entender o uso que os grafiteiros de São José dos Campos fazem dos espaços da cidade, em específico do lugar onde moram, como espaços de opinião e de diálogo com a comunidade. No confronto com a ordem estabelecida, a prática transgressora do grafitti serve como linguagem e estabelece a democratização da arte, a subversão dessas relações políticas de ocupação e dominação vertical das políticas urbanistas programadas. O grafitti passa a ser o instrumento da fala que possibilita novas práticas sociais.

De acordo com Vespa, a maioria dos participantes do terceiro Mutirão de Graffiti residentes na cidade de São José dos Campos, era originária do bairro Campo dos Alemães e arredores. Sobre a concentração de graffiti no Campo dos Alemães, já verificada antes dos eventos, Vespa atribui o elevado índice de criminalidade que o faria território evitado até mesmo pela polícia e o tornaria local ideal para as manifestações de graffiti quando este era ainda considerado atividade ilícita e proibida; situação que foi alterada em 2011, quando a Lei Federal n. $12.408 / 2011$ descriminalizou o ato de grafitar.

Isso significa que os graffiti do 3 - Mutirão aconteceram depois da liberação e, portanto, não têm característica de transgressão, pois foram praticados em muros com permissão do proprietário. Isso faz o graffiti do $3^{\text {o Mutirão }}$ diferente? $O$ que teria motivado os participantes; o prazer em pintar? E a questão da construção e afirmação de identidade? 
Mas o graffiti é uma das bases do Hip hop e então pode-se perguntar se seus outros componentes, como o rap, que é visto como a voz do povo e o break, que é forma de protesto através do corpo, também não transgridem a cultura vigente?

Como evento organizado, é possível conhecer, pelo material de divulgação do $3^{\circ}$ Mutirão, o total de artistas participantes. Chama a atenção não somente o número (contam-se 285 participantes), como também sua procedência, sendo a maioria paulistas (74), muitos de Belo Horizonte (11), de São José dos Campos (21), constatando-se a manutenção da rede mencionada por Vespa nos primeiros eventos e a presença de estrangeiros em número expressivo, Venezuela (4), Mexico, Canadá e EUA (1 cada).

\section{AS RUAS DO GRAFFITI E A FALA DE VESPA}

Um muro grafitado adquire características próprias e confere, ao entorno em que se situa, uma experiência espacial particular. Para Tuan (1983, p. 1), espaço e lugar são termos familiares que indicam experiências comuns; estamos ligados ao lugar, que é segurança, e desejamos o espaço, que é liberdade. $O$ espaço indiferenciado transforma-se em lugar à medida que o conhecemos melhor e o dotamos de valor; à medida que adquire definição e significação (p. 17). Este valor pode ser evidenciado na prática do graffiti do Campo dos Alemães, valor para os artistas que os produzem, e para a comunidade que convive com eles diariamente.

Carlos (1996, p. 17) afirma que é no lugar que a vida se reproduz, e sua análise, revelada no "plano da vida e do indivíduo", o plano local, pode ser observada a partir da "tríade habitante - identidade - lugar": As relações que os indivíduos mantêm com os espaços habitados se exprimem todos os dias nos modos do uso, nas condições mais banais, no secundário, no acidental. É o espaço passível de ser sentido, pensado, apropriado e vivido através do corpo.

Vespa hoje reside distante do bairro, em seu depoimento, deixa claro que o porta consigo, é seu território, demarcado com graffiti, uma fronteira fluida de spray que se espraiava no entorno, possibilitando à comunidade outras percepções e vivências espaciais, atraindo outros jovens, construindo redes. Vespa caracteriza o bairro que o projetou pela arte do grafitt:

Era aonde a gente morava. E..., e por ser um bairro afastado..., até hoje ainda rola essa visão de..., comunidade, favela, de bairro perigoso, até hoje ainda tem essa..., visão sobre esses bairros. (...) eu cresci ali, eu vivi ali, e faz três anos que eu saí de lá. Então a gente procurava pintar sempre por ali. Graffiti é isso, é demarcar território, né? E a gente pintava onde a gente mora, onde a gente vive compartilhar um pouco disso com a comunidade. Até mesmo a galera que morava em outros bairros, de classe um pouco melhor que a nossa, vinham pro nosso bairro pintar por lá porque era mais tranquilo de pintar, né? Devido a ter pouco policiamento, assim. Então a galera pintava mais por ali.

Percebe-se na fala de Vespa o envolvimento com o lugar, a existência de laços emocionais que conectam pessoa e lugar, o lugar refletido na pessoa.

A programação do 3 o Mutirão se ampliou para um evento de cultura de rua que incluiu a apresentação de grupos de rap e break, além da pintura do graffiti, reforçando a relação com o Hip Hop, caracterizando a cultura de rua como forma de arte e, também, de atitude. Sabe-se da ligação do Hip Hop como estilo de vida, com a afirmação do sujeito social, com a demarcação de território, a valorização da identidade cultural e a ocupação de espaços públicos.

Vespa (2016), que desenhava desde criança, começou a grafitar aos 16 anos, e a aproximação da arte se deu pela dança e viagens por ela proporcionada: "[...] Eu comecei a pintar com 16 anos ..., através da dança. Eu comecei a dançar break em 92 pra 93 e nesse decorrer das viagens que eu tinha pra dançar, eu conheci o graffiti, e já desenhava desde os meus 9 anos de idade". A orientação de Vespa para o graffiti dependeu do estado do sistema das possibilidades que o definiu em relação ao grupo ao qual pertence. Por meio do desenho, Vespa se descobriu grafiteiro e, antes disso, parte integrante de um movimento social cujo campo de atuação é a arte. Sobre sua relação com o desenho, Vespa explicou:

[...] é, o desenhar já sempre existiu. Que eu me recordo, sempre existiu. E..., só foi agregando, né? Aprendendo outras culturas e tudo apaixonado por desenho. Tudo que é 
relacionado com desenho eu gosto. E até que em 97 teve um evento de Hip Hop aqui na cidade e tinha um grafiteiro pintando, de São Paulo. Hoje um deles mora aqui na cidade, também. E aí quando eu vi aquilo eu disse, é isso que eu quero fazer agora, né? Já via em São Paulo, muitos graffiti espalhado, mas não tinha visto alguém fazendo, da forma que eu vi naquele dia, né? Então aquilo me despertou uma vontade maior de aprender, e comecei a pintar em 98. Em 98 que saiu meu primeiro graffiti.

Hall (2005, p.11), tentando entender as identidades que definem o sujeito moderno, com base na concepção sociológica clássica que concebe a formação da identidade na interação entre o eu e a sociedade, considera que o sujeito e sua essência interior seria formado e modificado continuamente num diálogo com os mundos culturais $e$ as identidades que esses mundos oferecem.

O sujeito envolvido com o graffiti, ocupa um espaço determinado, no caso o bairro em questão, território físico e subjetivo, carregado de condições culturais e valores, num processo recíproco de formação de identidade e de construção de lugar, na tríade proposta por Carlos (1996). Vespa (2016) usa com frequência, espontaneamente, os termos território, demarcação atitude, expressão, liberdade: "[...] o acrílico é mais essa atitude de você pintar na rua (...), ele surgiu dessa forma ilegal, né? De demarcar território, de poder pintar na rua, se expressar livremente, sem interferência, sem ter de pedir autorização".

Sobre essa questão, Campos (2007, p. 12) diz que:

O graffiti é, basicamente, uma expressão das culturas juvenis urbanas. Daí que tenhamos de pensar, igualmente, as nossas cidades, o espaço urbano enquanto território edificado habitado por pessoas com lugares e destinos distintos. São essas pessoas que estabelecem vínculos sociais, afetivos, simbólicos, usando diversos recursos para exprimir algo sobre a sua condição. O território e tudo aquilo que este comporta é, desde tempos imemoriais, empregue para comunicar, sendo apropriado por indivíduos e grupos que the emprestam um determinado significado. Daí que uma cidade seja constituída por signos variados, possua uma memória que não é apenas física mas igualmente simbólica. Os jovens que fazem graffiti são exploradores da sua cidade, buscam nas superfícies conhecidas as melhores telas e materiais para nos dizerem algo sobre si e sobre o mundo que os rodeia.

Ainda como definição de território, Haesbaert (2004, p. 01) ressalta: '[...] para aqueles que têm o privilégio de usufrui-lo, o território inspira a identificação (positiva) e a efetiva "apropriação". Entende-se que o graffiti no Campo dos Alemães, para Vespa, permitiu esse usufruto físico e simbólico de um espaço antes estigmatizado: pela arte, mais do que identificado, o território foi apropriado.

Identificado, apropriado, significado, o território se transforma em lugar. Cardoso (2007, p. 15), tratando da noção antropológica de lugar, aponta que este inclui os discursos que por ele circulam, "a linguagem que o caracteriza, bem como os movimentos nele realizados" criando "[...] o que é organicamente social". Ora, o graffiti é linguagem, dialoga com os transeuntes, é denúncia, é provocação. Nas palavras de Vespa, o alcance social da arte aparece explicitado: "[...] esse é um dos poderes que o Hip Hop tem, de conseguir ..., seria o lado social da cultura, né? Do Hip Hop". Mas o graffiti é também possibilidade, libertação, ampliação de fronteiras, como Vespa comenta sobre os efeitos do graffiti na pessoa e no espaço:

[...] oficina de graffiti, que é onde ensina, conta a história, ensina a criançada a manusear a tinta spray, o porquê que..., como que surgiu essa nossa cultura do graffiti, e..., encaminha né? Pro lado bom da situação, resgata as pessoas das favelas, das comunidades precárias assim, e mostra um caminho diferente, que é possível seguir pelo lado certo, né? Através do graffiti, a transformação que o graffiti nos traz. Até mesmo comigo, foi uma das coisas que me resgatou assim, que me fez pensar de uma outra forma, me levou para outros lugares, nunca imaginei sair fora da cidade, naquela época.

\section{DESCOBRINDO O GRAFFITI NO CAMPO DOS ALEMÃES}

Uma das questões dessa pesquisa era investigar o graffiti como dispositivo de afirmação de identidades. Para tal, realizou-se uma narrativa dos muros grafitados no bairro Campo dos Alemães, com recurso do Google Maps, o que permitiu, junto ao depoimento do coordenador dos três mutirões, inferir as 
motivações de um dos líderes do movimento social e artístico ligado ao graffiti e o processo de interpretação das mensagens contidas nos desenhos.

O primeiro mutirão, realizado em 2007 com o tema Água, tingiu de azul muitos muros, como - graffiti mostrado na Figura 2, executada pelo grafiteiro End (identificação bem visível na pintura) da Fhero $3 d$ crew e que resiste até hoje, nove anos depois. A água, fonte de vida, e o azul, cor associada à serenidade, são o pano de fundo para um tubarão que, voraz, mostra sua arcada, carregando, na nadadeira, um inusitado e ambíguo taco de golfe. Interessante observar o tom de azul do muro combinado ao azul da casa, dele separada por uma fileira de cacos de vidro, alinhados tal qual dente de tubarão. No mesmo tom, dois jovens recostados, pés descalços, mão no bolso, convivendo, no cotidiano do bairro, com o lugar criado pelo graffiti, e referência da continuidade deste com o entorno.

Nessa mesma imagem, pode-se ver, na porção direita do muro, agora pintado de branco, parte do graffiti produzido pelo grafiteiro Fernando Pinto, o Fhero, da 3d crew, reproduzido abaixo na sua configuração original quando da realização do 1ำ Mutirão de Graffiti (Figura 3). Nela, o tom de azul, também predominante, contrasta com o vermelho da pintura indígena. Hoje a pintura está parcialmente apagada. O processo de apagamento, feito pelo dono do muro, é encarado com naturalidade pelo artista. Sobre isso Vespa disse: "...eu acho que tá na rua, tá sujeito a tudo, né? ... eu pintei e registrei aquele momento, sozinho ou com amigos que pintou comigo, tirei foto, tá registrado, tá na memória, pode ficar dez anos ali ou pode ficar um dia".

Figura 2 - Graffiti do 1ํ Mutirão de 2007 na Rua Luiz Gonzaga (Rei do BAIÃO) -

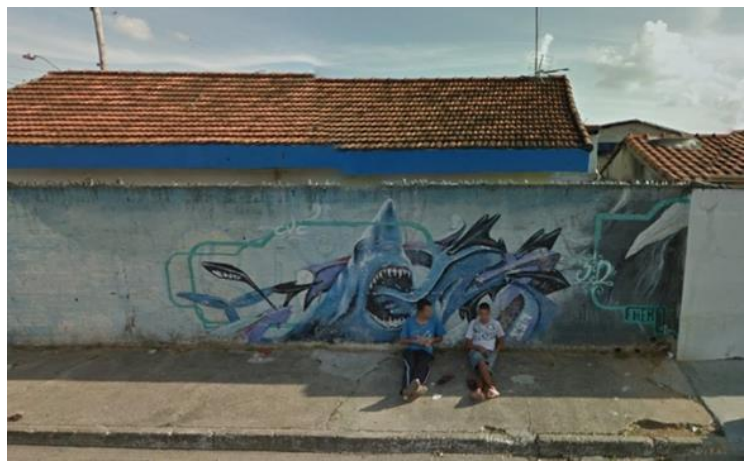

Fonte: Google Maps - Acesso: 11 Mai 2016.

Figura 3 - Graffiti do 1ำ Mutirão na Rua Fernando Antônio Rachid de Paula -

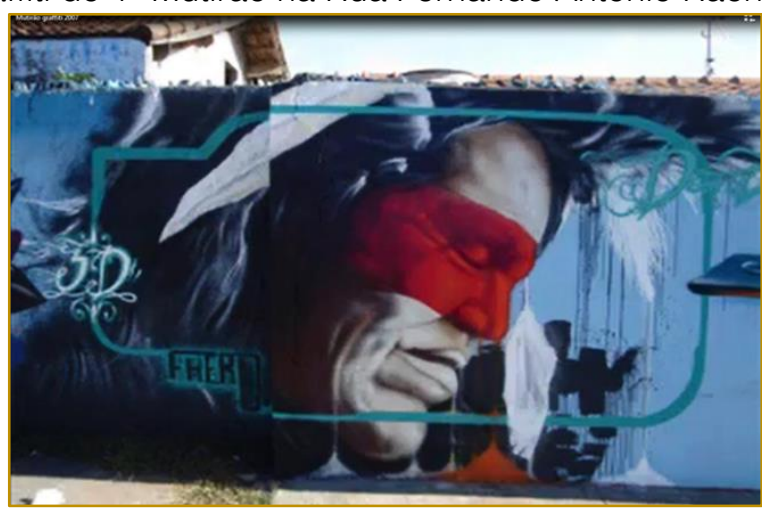

Na Figura 4, também realizada no primeiro mutirão, observa-se o tom mais atenuado de azul, combinado a tons castanhos que se acentuam na pele negra dos jovens, constante presença nas pinturas, da identidade racial, da possibilidades de inserção social, de alternativas à violência e à 
marginalidade e a evidente representação

simbólica da necessidade de expressão.

Figura 4 - Graffiti do 1ํMutirão de Graffiti de 2007, na Rua Fernando Antônio Rachid de Paula -

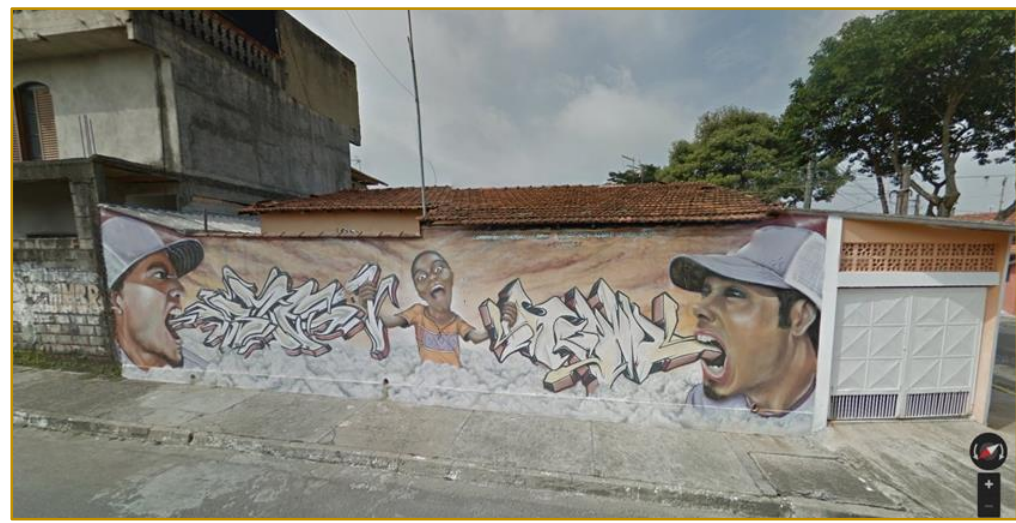

Fonte: Google Maps - Acesso: 11 Mai 2016.

O que pensam os artistas sobre o ato de grafitar, o que os graffiti expressam?

Vespa se pronuncia:

[...] pra mim, o fato de eu poder ter essa liberdade de fazer o que eu quero, de pintar o que eu gosto, independente do que as pessoas vão achar, se vão gostar ou não, isso pra mim é graffiti, de eu ter essa liberdade de me expressar, sem ter que provar algo pra alguém. Eu me sentindo livre, feliz com o que estou fazendo ali, sendo legal, ou não, pra mim isso é graffiti. É..., mas cada um tem uma vivência sobre, né? É..., não tem como eu falar o que é certo e o que é errado, né? Pra mim o que mais conta é isso.

Pode-se verificar no depoimento do grafiteiro a sua motivação para a prática do graffiti, da sua arte, o sentimento de liberdade e o prazer que ela lhe proporciona.

Na Figura 5 abaixo, que mescla imagens e letras, percebe-se a presença de mensagens, o que se observou ser comum neste tipo de graffiti do bairro e que nem sempre tem algum sentido ou caráter contestatório, social ou político.

Figura 5 - Graffiti do 1ำ Mutirão na esquina das ruas Luiz Gonzaga (Rei do Baião) e Maria Ferreira dos Santos.

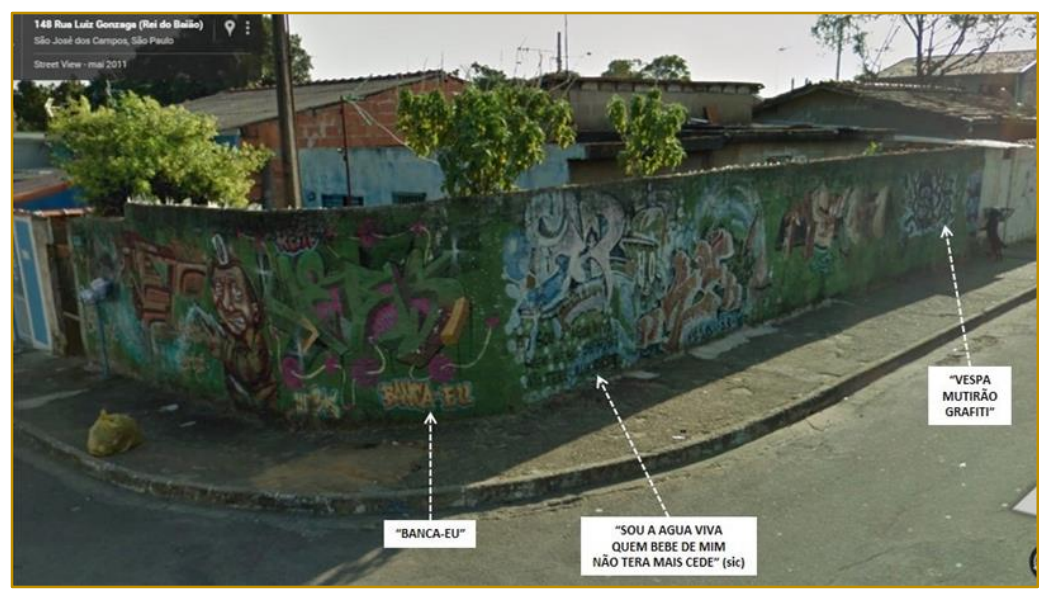

Fonte: Google Maps - Acesso: 11 Mai 2016

Quando indagado se o graffiti é a forma utilizada para se expressar a respeito das questões sociais, Vespa disse:
[...] hoje em dia tem muito disso. Tem artistas grafiteiros que querem passar alguma mensagem do lado social, do lado político, simplesmente do lado artístico de pintar sem 
ter um contexto ali em cima, né? Tem que ter um tema, né? vamos dizer assim. Mas (isso) tem até dividido por partes, hoje. Tem uns que prefere (sic) seguir por esse lado social, que é o (de) ensinar, ou passar mensagens positivas. Outros já usam a pintura mais pra atacar o sistema, pra falar de política, pra falar de algum tema que está acontecendo no momento no país. E todos são graffiti, entende?
Nota-se aqui que Vespa tem conhecimento das questões sociais, mas mostra também que esta não é a única motivação na sua prática.

Observa-se na Figura 6 abaixo que o graffiti no bairro Campo dos Alemães, permitido por seus proprietários, dão colorido a imóveis muito simples, o que é também uma constante do bairro, e se encontram com as pichações na forma de tags.

Figura 6 - Graffiti na Avenida dos Evangélicos -

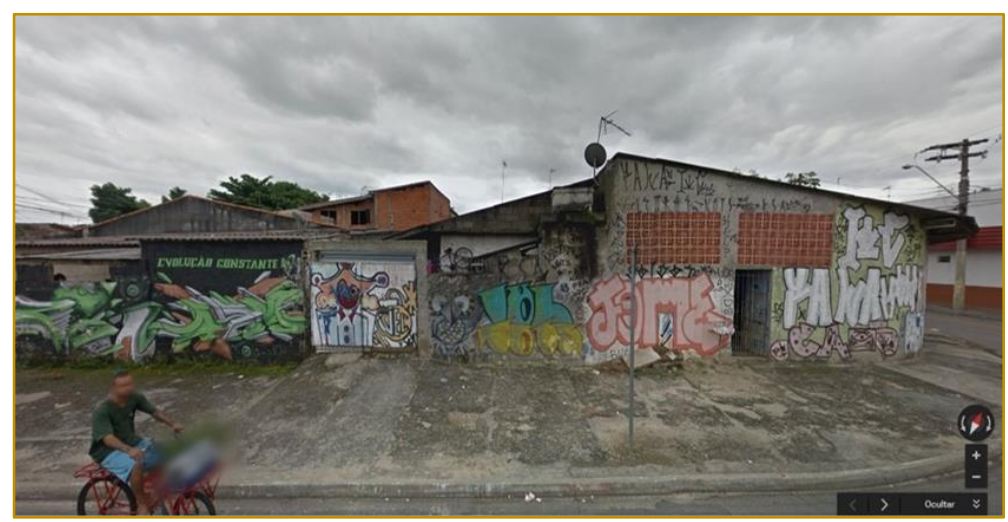

Fonte: Google Maps - Acesso: 11 Mai 2016

Vespa (2016) continua:

[...] Tem momentos que eu escolho um tema. Tem momentos que eu pinto simplesmente pelo prazer de estar com os amigos..., de a gente se reunir e vamos pintar o que? Ah, vamos fazer isso e isso e todo mundo se reúne e pinta. Está ótimo. Eu tenho uma crew também, somos em sete, e ambos, tem momentos pra discutir sobre algum tema, que está acontecendo no momento no Brasil; outras vezes é simplesmente pelo lado artístico, de pintar. Então depende muito do momento, do lugar, com quem está prá poder escolher. Eu não sigo um padrão, de eu só faço isso ou não, vou fazer aquilo. Eu gosto de pintar, eu acho que pra mim é isso.

É possível perceber as diferentes formas de criação, individual e coletiva, bem como as diferentes motivações, que podem ter um caráter de crítica social ou ser de cunho contestatório, ou ser expressão artística mais livre, não temática, orientada pelo prazer, pela prática.

Ainda que possa ser expressão individual, pelo espaço onde se realiza, o graffiti é, por natureza, social. Pode-se notar na Figura 7 abaixo que, durante a prática das pinturas nos Mutirões, é grande o interesse da comunidade que se coloca como espectadora do processo e com ele interage.

Sobre organizar um novo Mutirão, Vespa nos disse que tem vontade e que pensa que pode acontecer ainda em 2016. Mas enfatiza: "Este seria o último", e quando perguntei, porquê? Vespa disse: "por estarmos com uma cabeça diferente". 
Figura 7 - Graffiti do 3ำ Mutirão no Campo dos Alemães em execução

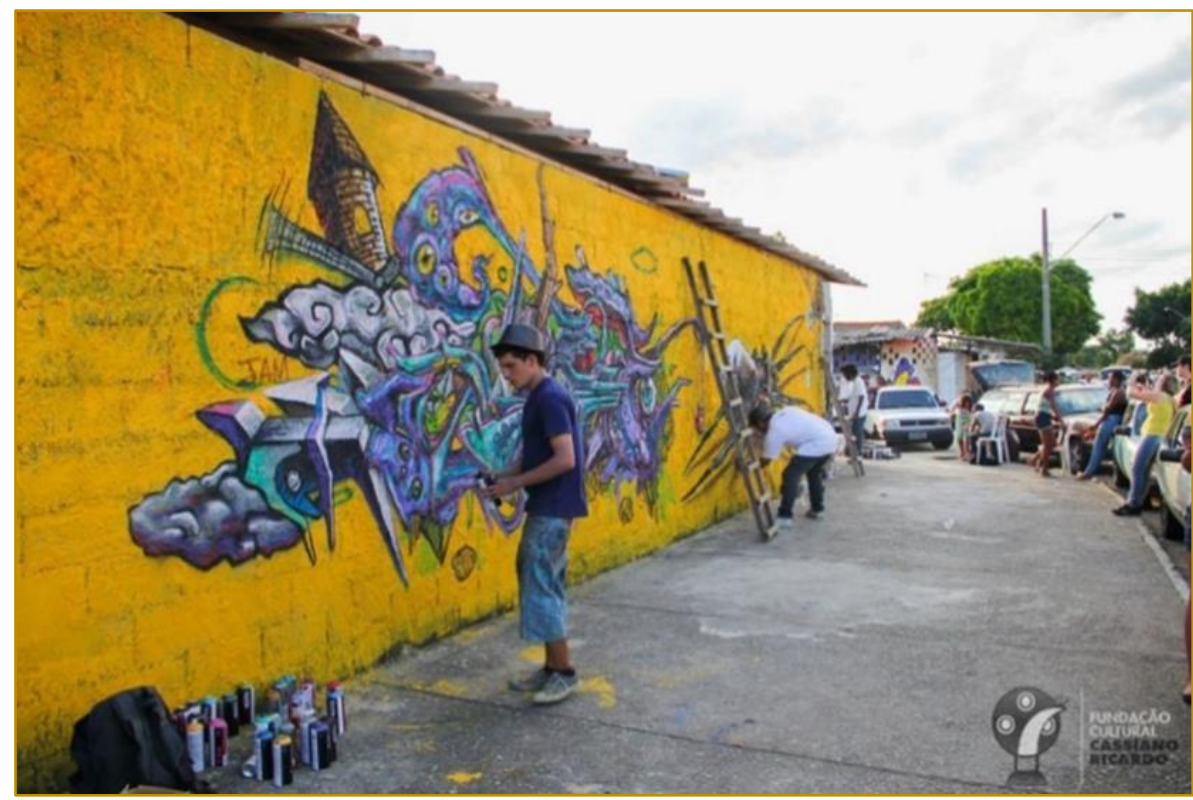

- Disponível em:

https://www.facebook.com/fccrsjc/photos/a.461768823896251.1073741842.146170118789458/4617714138959 92/?type=3\&theater - Acesso: 11 Mai 2016

\section{CONSIDERAÇÕES FINAIS}

O bairro do Campo dos Alemães é disputado como território por diferentes grupos. A cidade sede da Região Metropolitana do Vale do Paraíba e Litoral Norte é pautada por um pensamento contaminado pela ênfase nos negócios que subjuga as dimensões criativas e subjetivas e tolhe a sensibilidade artística como elemento constituinte de proposições sociais e políticas emancipatórias. O país carece de urbanistas que incorporem essa sensibilidade como expressão e meio de direito à cidade. Valorizar a arte urbana 'talvez seja um bom caminho para a edificação de projetos urbanos capazes de articular ética e estética, não apenas em termos de um planejamento normativo, mas instaurativo, capaz de conduzir a outras formas de sociabilidade e remetendo-se ao "direito à cidade"', tal como Henri Lefebvre (1991) definiu, em sua utopia urbana (LIMENA, 2001, p. 39).

Supõe-se que o processo de afirmação ou mesmo de construção de novas identidades, que neguem a tipificação construída pelo senso comum para os habitantes do Campo dos Alemães em São José dos Campos foi favorecido pelo graffiti, como suporte cultural. No plano individual, percebe-se essa construção na narrativa do grafiteiro Vespa, quando refere-se a sua proximidade com o território. Território que o produziu e que ele, por meio de sua arte, transformou por meio da apropriação pela arte.

No plano coletivo, o que significaria a concentração de graffiti no Campo dos Alemães, bairro cuja representação social está relacionada a outra apropriação do espaço, disputado por aqueles que comandam o comércio de drogas e cujo índice de homicídios é o mais alto entre cinco regiões da cidade, conforme dados institucionais constantemente propagados pelas manchetes do jornal local e pela mídia radiofônica em seus noticiários diários?

A arte, seja de que tipo for é carregada de subjetividades e de significados, então ela, da forma que é feita neste espaço, não teria a capacidade de amenizar o estigma que caracteriza o bairro? Ou essa arte é tão diferente daquela elitizada e confinada a quatro paredes a que o Campo dos Alemães não tem acesso? Lefebvre (2011, p. 10) lembra que "[...] as questões relativas à Cidade e à realidade urbana não são plenamente conhecidas e reconhecidas".

Lefebvre (1999, p. 30) diz que "[...] na rua, e por esse espaço, um grupo (a própria cidade) se manifesta, aparece, apropria-se dos lugares, realiza um tempo-espaço apropriado" e os grupos de graffiti fazem isso, se manifestam, aparecem. Afinal ("[...] o espaço urbano da rua não é o lugar da palavra, o 
lugar da troca pelas palavras e signos?" (Idem, p. 30).

Que outra forma senão pela escuta e reflexão das múltiplas narrativas nos abrirmos ao que Bia Abramo (2001) no livro "Hip hop: a periferia grita" diz: "o hip hop é a resposta

\section{REFERÊNCIAS}

[1] Abramo, Bia. In Rocha, Janaina; Domenich, Mirella; Casseano, Patrícia. Hip hop: a periferia grita. Editora Fundação Perseu Abramo, 2001

[2] Alonso, Alex. Urban graffiti on the city landscape. San Diego State University, 1998.

[3] Campos, Ricardo Marnoto de Oliveira. Pintando a cidade: uma abordagem antropológica ao graffitiurbano. 2007.

[4] Cardoso, Ciro Flamarion Santana. Repensando a construção do espaço. Revista de História Regional, v. 3, n. 1, 2007.

[5] Carlos, Ana Fani Alessandri. O lugar no/do mundo. São Paulo: Hucitec, 1996.

[6] Farthing, Stephen. Tudo sobre Arte - Rio de Janeiro; Sextante, 2011.

[7] Furtado, Janaina Rocha; Zanella, Andréa Vieira. Graffiti e cidade: sentidos da intervenção urbana e o processo de constituição dos sujeitos. Revista Mal Estar e Subjetividade, v. 9, n. 4, p. 1279-1302, 2009

[8] Gonçalves, Gesianni Amaral. Inscrições Urbanas: uma cartografia dos processos de subjetivação envolvidos no graffiti. 2007. $152 f$. Dissertação (Mestrado em Psicologia) - PUC Minas Gerais, Belo Horizonte.

[9] Hall, Stuart. A identidade cultural na pósmodernidade. 10ª Edição. Rio de Janeiro. DP\&A, 2005.

[10] Haesbaert, Rogério. Dos múltiplos territórios à multiterritorialidade. Porto Alegre, 2004

[11] Lefebvre, Henri. O direito à cidade. São Paulo, Centauro Editora, 2011.

\section{DEPOIMENTO ORAL}

[1] Vespa, Claudinei F. M. de Oliveira. Depoimento. Ateliê do artista, São José dos Campos. 05 Maio 2016.

\section{VÍDEOS}

[1] Mutirão Graffiti 7 de Julho de 2007 / São José dos Campos - S.P Realização: Vespa conexão virtual crew fhero - 3Dcrew. Disponível em:

$<$ https://www.youtube.com/results?search_query= política e cultural da juventude excluída". Imagina-se que essa possa ser a resposta dos jovens do Campo dos Alemães, também, em muitos aspectos, simultaneamente excluídos e detentores do potencial transformador das práticas cotidianas da vida.

[12] Horizonte. Ed. UFMG. 1999

A revolução urbana. Belo

[13] Paulo, Ed. Moraes, 1991.

[14] Limena, Maria Margarida Cavalcanti. Cidades complexas no século XXI. Ciência, técnica e arte. São Paulo em Perspectiva, 15(3) 2001.

[15] Marreira, F. Grafite sem amarras. O Vale Caderno Viver, São José dos Campos, p. 1, 26 Mar. 2013

[16] Medeiros, Marcelo Matheus. O que dizem os muros da cidade. 2008. Tese de Doutorado. Universidade Federal do Rio de Janeiro.

[17] Nogueira, Cristiana. A (im)permanência do traço: rastro, memória e contestação. PRACS: Revista Eletrônica de Humanidades do Curso de Ciências Sociais da Unifap, v. 2, n. 2, 2009.

[18] Pallamin, V. M. Arte urbana: São Paulo, região central (1945-1998): obras de caráter temporário e permanente. Annablume, 2000.

[19] Relph, E. A paisagem urbana moderna. Lisboa, Edições 70, 1990.

[20] Rocha, Janaina; Domenich, Mirella; Casseano, Patrícia. Hip hop: a periferia grita. Editora Fundação Perseu Abramo, 2001.

[21] Santos, M. Espaço e Método. 5a Edição. 2a reimpr. São Paulo, EDUSP, 2014

[22] Metamorfoses do espaço habitado. São Paulo: Hucitec, v. 4, 1988.

[23] Tuan, Yi-Fu. Espaço e lugar. São Paulo: Difel, p. 01-22, 1983.

mutir\%C3\%A3o+graffiti+2007> - Acesso em: 22 Set 2016.

\section{SITES NA INTERNET}

[1] Borges, Adriana. Hip Hop é cultura, arte e atitude. Publicado em "Música", 2016. Disponível em: <http://obviousmag.org>. Acesso em: 25 Out 2016.

[2] Brasil, Atlas. Atlas do Desenvolvimento Humano no Brasil 2013. Disponível em: 
http://www.atlasbrasil.org.br/2013/pt/perfil_udh/303 30 - Acesso em: 14 Jun. 2016

[3] SP no ar - R7 TV. Disponível em $<$ http://noticias.r7.com/sp-no-ar/videos/drive-thru- de-drogas-provoca-congestionamento-em-saojose-dos-campos-12052016>. Acesso em 23 Out 2016. 


\section{Capítulo 16}

\section{CIDADE CATIVA: ESTRATÉGIAS DE UMA URBANIZACẼO OLIGOPOLISTA EM UMA CIDADE MATO-GROSSENSE}

\section{Livia Maschio Fioravanti}

Resumo : A economia de Primavera do Leste é hoje dinamizada principalmente pelas atividades vinculadas ao chamado "agronegócio". Localizada no sudeste mato-grossense e no entrocamento das rodovias BR- 070 e MT-130, o município se destaca pela produção de soja, seguindo aqueles situados ao longo da BR-163, como Lucas do Rio Verde e Sorriso. O objetivo deste trabalho é investigar de que modo o início da ocupação de Primavera, relacionado com a expansão da fronteira econômica em Mato Grosso a partir da década de 1970, influencia em seus atuais conflitos espaciais. Defendemos a hipótese de que o modo pelo qual a propriedade rural foi dominada e fracionada por grandes empresários do centro-sul brasileiro nas últimas duas décadas do século XX teve como consequência uma dominação também da propriedade urbana, culminando em uma "urbanização oligopolista". O maior domínio sobre a propriedade privada, ainda hoje predominantemente nas mãos das famílias que chegaram no início da expansão da fronteira, gera um maior controle na abertura de loteamentos, no tamanho e no preço dos lotes e imóveis. Essas famílias pioneiras empregam diversas estratégias para controlar a renda da terra e a valorização do solo urbano, como a doação de terrenos e a abertura gradual de novos loteamentos. Por meio de levantamento bibliográfico, realização de trabalhos de campo e de entrevistas, demonstraremos que esse processo tem agravado a segregação espacial em Primavera do Leste.

Palavras Chave: fronteira; urbanização oligopolista; segregação espacial; Primavera do Leste. 


\section{INTRODUÇÃO}

Primavera do Leste, localizada a 234 quilômetros de Cuiabá e cortada pelas rodovias MT-130 e pela BR-070, é uma das cidades brasileiras cujo crescimento econômico está diretamente relacionado à agricultura capitalista mecanizada denominada pelo Estado, pela mídia e pelas empresas de "agronegócio". Se por um lado essas cidades - não apenas em Mato Grosso, mas também nos novos espaços da produção de soja, como oeste da Bahia e sul do Maranhão - parecem esbanjar riqueza, também reproduzem uma população pauperizada das próprias condições de sobrevivência e que tende a apenas encontrar locais de moradia às margens das rodovias ou nas periferias.

Nosso objetivo neste artigo é elucidar que grande parte dos conflitos da produção do espaço primaverense - que envolvem, por exemplo, os espaços para moradia, nos quais se sobrassai o valor de uso, e os espaços utilizados para especulação, com predomínimo do valor de troca - tem como fundamento contradições que se estabeleceram logo no início de sua ocupação, no final da década de 1970. Principalmente a partir deste momento, ligado a um contexto mais amplo de expansão da fronteira do capital rumo ao centro-oeste brasileiro, a propriedade rural e urbana passou a ser dominada e fracionada atendendo, no geral, a interesses de grandes empresários do centro-sul do Brasil.

Partindo da abordagem de Silva (2010), consideramos que houve três momentos da expansão da fronteira em Primavera e no sudeste mato-grossense ligados à produção agrícola: em meados dos anos 1970, com a chegada dos primeiros migrantes do sul e sudeste do Brasil, que passaram a implantar plantações de soja e de arroz; a partir dos anos 1980, com a agroindustrialização da soja; e, por fim, a partir dos anos 1990, com a implantação de grandes grupos empresariais, como a Cargill em Primavera do Leste. A expansão da acumulação do capital nesses três momentos - com continuidades e descontinuidades - apenas foi possível devido ao papel do Estado, seja atuando no início da ocupação da fronteira de modo a favorecer a chegada dos considerados "pioneiros" na década de 1970 por meio de programas federais de ocupação do cerrado e da Amazônia Legal, seja facilitando atualmente a ação dos grandes grupos empresariais via incentivos fiscais. Essa ação do Estado historicamente ocorreu beneficiando grupos de migrantes que tinham recursos para realizarem investimentos na região e hoje também favorece os conglomerados do agronegócio.

A concentração de terra, de poder e de capital no decorrer da implantação e ocupação de Primavera está nos alicerces de uma urbanização controlada por um pequeno grupo de detentores do poder econômico e político - definida, segundo Volochko (2015) e a respeito também de outras cidades dinamizadas pela agricultura capitalista mecanizada, como "urbanização oligopolista".

Esta urbanização é caracterizada por um maior controle da propriedade privada e por uma cidade que é comandada por poucos, os quais frequentemente determinam a abertura de novos loteamentos e manipulam a renda da terra e o processo de valorização do solo urbano a seu bel prazer. Primavera é, nesta perspectiva, uma "cidade cativa", noção aqui desenvolvida a partir da expressão de Martins (2010) de "terra cativa" e que se refere a uma cidade que "tem donos", muitos dos quais passaram a ser detendores de terra, poder e capital há pouco menos de quatro décadas.

Nesta "urbanização oligopolista", o maior controle sobre o preço e tamanho dos lotes resulta em uma dificuldade ainda maior das pessoas de menor renda para o acesso à moradia e à propriedade e se constitui em um dos elementos que nos ajudam a entender o acirramento da segregação espacial em Primavera do Leste.

\section{DESENVOLVIMENTO}

\subsection{UMA FRONTEIRA DO CAPITAL E DA URBANIZAÇÃO}

Para compreender a produção do espaço primaverense é preciso desvendar as estratégias políticas e econômicas que permearam sua concepção e implantação, ainda na década de 1970. Essas estratégias estão diretamente vinculadas à expansão da chamada "fronteira agrícola" - a qual se constitui, na abordagem deste artigo, principamente em uma fronteira da acumulação de capital.

O Estado brasileiro passa a conceber o centro-oeste como fronteira "no sentido de uma disposição política sobre o território derivada das exigências da acumulação 
capitalista" (MARTINS, 1993, p. 23). Surgem, nesse processo, diversos programas de colonização e ocupação da região visando a atender a reprodução do capital. Devido a esses objetivos que impulsionaram a ocupação do centro-oeste a partir deste período, concordamos com a definição do autor de que o conceito de fronteira faça referência a um "espaço submetido a uma contínua redefinição", no qual se sobrepõem relações aparentemente fragmentadas que seriam alteradas pela ação do Estado em função dos interesses em jogo - neste caso, a continuidade da acumulação capitalista. A fronteira envolveria territórios que, por meio de estratégias políticas, passam a ser demandados para o desenvolvimento das forças produtivas (MARTINS, 1993, p. 23). Nesse processo de readequação dos usos do espaço para atender às novas exigências da acumulação, Mato Grosso constitui-se como fronteira principalmente a partir da década de 1970.

O papel do Estado na produção e consolidação da fronteira também é destacado por diversos autores, dentre eles Arruda (2007), Silva (2010), Martins (1993) e Oliveira (2001). Segundo Arruda (2007, p. 78), o Estado foi o "principal agente viabilizador da inserção do espaço mato-grossense à nova lógica de (re) produção capitalista, ou seja, para a expansão da fronteira agrícola". Essa inserção ocorreu sobretudo após o golpe militar de 1964, quando o cerrado passa a ser inserido de modo mais contundente à reprodução do capital através de programas e projetos nos quais as terras eram distribuídas ao capital nacional e internacional via projetos de exploração agropecuária. Esse avanço da fronteira foi possibilitado por meio da construção de rodovias, da implantação de infraestruturas (como rede elétrica), de planos de incentivos governamentais e promoção de políticas de colonização pública ou privadas (ARRUDA, 2007; GIRARDI, 2015). O movimento de expansão da fronteira em Mato Grosso foi, nesse contexto, intensificado com a ampliação da malha viária, principalmente com a abertura das rodovias BR - 364 (Cuiabá - Rio Branco) e BR - 163 (Cuiabá - Santarém). Especificamente, no sudeste mato-grossense, merece destaque também a BR - 070 (Brasília - Cáceres).

Destacando uma das dimensões desse papel do Estado como grande fomentador da expansão geográfica da acumulação de capital em direção às terras mato-grossenses,
Volochko (2013, p. 19) afirma que os planos e programas oficiais implantados durante 0 regime militar - somados à ampliação de infraestruturas - "revelam como o Estado patrocinou o acesso à terra para os grandes grupos econômicos e empresas transnacionais", que utilizavam a terra tanto para produção agropecuária quanto para "a colonização privada fundamentada no loteamento/especulação ${ }^{42 " .}$

Esse processo de dominação e ocupação das terras no centro-oeste - e particularmente no sudeste de Mato Grosso - realizado por grupos empresariais do sudeste brasileiro por meio de incentivos à colonização privada terá, como veremos, profundas implicações na produção do espaço urbano de Primavera do Leste.

Idealizada neste contexto de expansão da fronteira do capital, por grandes grupos econômicos financiados pelo Estado, Primavera do Leste não deve ser vista somente como uma cidade cuja produção do espaço é ritmada por um agrário hegemônico. Conforme destaca Arruda (2007), não é no campo onde está a base produtiva dessas corporações agroempresariais globalizadas, mas na cidade por meio das condições de circulação dos fluxos materiais e imateriais do "agronegócio". $\mathrm{Na}$ cidade, estão concentradas atividades voltadas a atender as demandas do campo, tais como: serviços financeiros e jurídicos, fornecimento de insumos e de máquinas agrícolas, armazéns e indústrias que beneficiam a produção do campo, estabelecimentos comerciais e bancários, assistência técnica especializada.

A cidade, longe de ser um local passivo onde se concentram as atividades vinculadas ao campo, foi a condição para que um campo cada vez tecnificado e financeirizado pudesse se realizar. Além disso, como salienta Volochko (2013, p. 20), devido a essa primazia do urbano para a realização deste

\footnotetext{
${ }^{42}$ A colonização privada tinha como objetivo "atrair uma clientela mais capitalizada, os colonos do sul do país. As terras eram oferecidas muitas vezes a preços irrisórios, sobretudo se comparados às áreas de fronteira agrícola já consolidadas, o que facilitava a aquisição de propriedades de grandes extensões". Já a colonização pública ou oficial foi uma das formas utilizadas para direcionar os movimentos populacionais para regiões de fronteira. Mato Grosso passa a servir como uma alternativa para amenizar os conflitos no campo sem a realização de uma reforma estrutural no campo brasileiro (BERNARDES, 2007, n.p).
} 
agrário, a fronteira não é somente agrícola, ou do capital: é "principalmente uma fronteira da urbanização a partir do agronegócio". É nesse sentido que o autor (2013, p. 24) também afirma que "onde a terra está sendo cultivada como meio de produção das commodities internacionais a serem exportadas (sobretudo carnes e grãos), a extensão das grandes propriedades monocultoras não pode prescindir da centralização urbana". Essa centralização urbana abrange, segundo Volochko, uma centralização técnica (por meio de atividades de controle e gestão da produção); política (por meio de políticas direcionadas ao agronegócio); e econômica (já que é na cidade onde estão as infraestruturas e serviços).

\section{DA TERRA À CIDADE CATIVA}

A ocupação da cidade enquanto projeto iniciou-se no final dos anos 1970. Antes disso, chegaram migrantes com objetivo de desenvolverem atividades ligadas ao campo ou à exploração de riquezas minerais, inclusive atraídos pelo garimpo de diamantes do município de Poxoréo ${ }^{43}$. Há relatos ainda de a região foi rota de bandeirantes no século XVII vindos do que hoje é Mato Grosso do Sul e em busca de riquezas minerais (Câmara Municipal de Primavera do Leste - CMPL, 2016). Contudo, interessa-nos apenas regressar ao momento em que a cidade nasce como uma ocupação planejada e resultado de uma estratégia voltada para atender interesses específicos, isto é, a de possibilitar uma concentração de serviços e infraestruturas capazes de atender inicialmente à demanda exigida pelo agrário, reproduzindo capitais urbanos-industriais do centro sul brasileiro. É neste momento em que está uma potência maior para elucidarmos as

\footnotetext{
${ }^{43}$ Como marcos importantes antes da década de 1970, podemos citar a demarcação de uma linha telegráfica em 1912 ligando Cuiabá à Barra do Garças, passando por Primavera do Leste. Em 1940, houve o desenvolvimento do programa "Marcha para o Oeste", implantado pelo presidente Getúlio Vargas e que abrangia sobretudo a porção sul de Mato Grosso por meio da colonização oficial. O ocupação da Amazônia Legal (na qual se insere o estado de MT) seria intensificada posteriormente a partir da Constituição de 1946 - que previa um plano econômico para viabilizar a ocupação e desenvolvimento econômico da região - e com a implantação de Brasília no governo de Juscelino Kubistchek (SILVA, 2010; CMPL, 2016).
}

contradições e os conflitos atuais da produção do espaço primaverense.

Compreendemos a implantação de Primavera a partir dos incentivos do governo federal propostos para a ocupação da Amazônia Legal - via SUDAM (Superintendência para o Desenvolvimento da Amazônia, implantada em 1966) - e do cerrado brasileiro, via Polocentro (Programa de Desenvolvimento dos Cerrados, criado em 1975). A respeito da migração na constituição da fronteira da acumulação do capital em Mato Grosso, Martins (1993) destaca que é preciso compreender o que chama de "universo pioneiro" 44 para elucidar de que modo houve a expansão do capital para espaços até então considerados como "vazios" ${ }^{45}$. Esse universo estaria "ligado intimamente às exigências de reprodução da sociedade capitalista" (MARTINS, 1993, p. 20).

Aprofundando no que Primavera do Leste apresenta de específico, retomaremos alguns dos momentos de sua produção do espaço, permeado por continuidades como a dominação privada de grandes propriedades nas mãos de grupos empresariais e a manipulação da renda fundiária. Primavera do Leste foi resultado de uma ocupação realizada por uma colonização privada, que, como vimos, atraiu para a região pessoas que já tinham capital para comprar terras e investir. Como salienta Bernardes (2007, n.p.), na década de 1970:

(...) empresários das regiões sul e sudeste, aproveitando as vantagens oferecidas pelos programas governamentais, adquiriram grandes extensões de terras públicas e/ou de terceiros, alguns de maneira ilícita, e investiram na implantação de projetos de colonização privada, que teve caráter seletivo, significando o acesso à terra a existência de recursos próprios.

\footnotetext{
44 Martins se refere em sua dissertação à Chapadão do Sul, Mato Grosso do Sul, mas é possível traçar semelhanças em muitos dos processos constitutivos da produção do espaço desta cidade com Primavera do Leste.

45 Destacamos que a própria ideia de pioneirismo deve ser relativizada e é carregada de um viés ideológico que coloca as pessoas que chegaram naquele momento como as primeiras a se instalarem no local. Considera, desta forma, a região como um "vazio demográfico" e ignora, dentre outras, as populações indígenas. Por isso, empregamos neste artigo o termo (e suas derivações) entre aspas.
} 
Em 1971, Edgar Cosentino, considerado pelos primaverenses como o principal "pioneiro" da cidade, formou a empresa Primavera do Oeste S/A junto com um grupo de empresários paulistas. Desse grupo faziam parte o ex-presidente da General Motors do Brasil e atualmente pecuarista em Primavera do Leste e o ex-dono do grupo "Hermínio Ometto" e da Usina São João, considerada por várias décadas uma das mais importantes do estado de São Paulo no setor sucroalcooleiro $^{46}$. O objetivo desses empresários era desenvolver um projeto agropecuário fomentado pela SUDAM.

Nota-se que que não eram camponeses expropriados do sul do Brasil que chegavam à região. Tratava-se de grandes empresários que expandiam, com recursos próprios e subsidiados pelo Estado, a fronteira do capital. Grande parte de quem chegava à Primavera do Leste tinha conhecimento de como investir e como plantar em grande escala: da família Cosentino chegaram na década de 1970, por exemplo, um engenheiro agrônomo e um economista. Antes mesmo da elaboração do projeto de cidade, Cosentino realizou estudos sobre a viabilidade agrícola nos solos da região em parceria com a Escola Superior de Agricultura da Universidade de São Paulo. Também considerada uma das "pioneiras" da cidade, a família Gasparotto foi a primeira a implantar plantações de arroz, o que apenas foi possível devido ao conhecimento das técnicas de plantio e à relativa disponibilidade de recursos próprios, uma vez que inicialmente não tiveram acesso ao crédito para a compra de maquinário agrícola (CMPL, 2016). Algumas das famílias que chegaram neste momento da expansão da fronteira hoje controlam grande parte das atividades comerciais (como mercados e lojas de equipamentos agrícolas) e de serviços da cidade (com, por exemplo, escritórios de engenharia ou de arquitetura). Além disso, são proprietárias de quantidade significativa de lotes e imóveis na cidade - como detalharemos no próximo item.

Concordamos, neste contexto, com Bernardes (2007) quando afirma que os grupos que comandavam o avanço da fronteira "dispunham de instrumentos técnicos que aumentavam o seu poder, imobilizando importantes recursos de capital, seja em

\footnotetext{
46 Segundo informações pesquisadas pela autora deste artigo. Tratam-se, respectivamente, de André Beer e Hermínio Ometto.
}

termos de instalações, maquinaria e equipamentos, seja em infraestrutura (...)". Como elucida Volochko (2015), as regiões de Mato Grosso em que se realizaram colonizações privadas são consideradas como tendo tido mais êxito em relação àquelas cuja ocupação ocorreu pelas colonizações públicas, no entanto, desde início já eram definidas as condições para quem deveria ter acesso à terra e aos investimentos. Esse processo implicou em um aspecto crucial para nossa investigação, uma vez que ajuda a explicar a transformação de grandes capitalistas também em proprietários, firmando os laços do casamento entre terra e capital estabelecidos desde a Lei de Terras de $1850^{47}$.

Como podemos notar por meio desses "pioneiros" que chegavam à região, na década de 1970 já se traçavam as tramas das relações entre terra, poder e capital esmiuçadas por Martins (1994) e também destacadas por Volochko (2015). As dinâmicas fundiárias do campo e da cidade tendem a ser determinadas pelas relações

\footnotetext{
47 A Lei de Terras foi um marco essencial na questão política fundiária brasileira. Por meio desta Lei, o Estado sacramentava a relação entre terra e capital. Para Martins (2010), assegurava interesses de fazendeiros e comerciantes na iminência de transformações nas condições do regime escravista. A contradição entre capital e escravismo não tinha no Brasil a radicalidade da contradição que opunha capital às relações feudais, como ocorreu em demais países. Dessa forma, os próprios proprietários de terra puderam "personificar as necessidades de reprodução capitalista do capital, não dependendo de uma nova classe" para "viabilizar-se historicamente" (MARTINS, 1994, p. 55). Se a sujeição do trabalhador estava ameaçada, garantia-se, com a Lei de Terras, a sujeição do trabalho. Isso porque determinava a obtenção de terras por compra e venda e legalizava a posse dos títulos das sesmarias de qualquer dimensão não confirmados. Legalizava-se, pela primeira vez na história do Brasil, a grilagem de terras ao se permitir o registro de sesmarias não confirmadas e sem títulos, desde que medidas e registradas. A propriedade privada estava garantida aos grileiros e se garantia mão de obra assalariada à terra agora cativa. A elite, que acumulava riqueza com o monopólio sobre escravo, passou a acumular com o monopólio sobre a terra. A concepção de "renda capitalizada" (MARTINS, 1994) que havia no escravo é transposta, com a Lei de Terras, para a terra. Tanto o escravo quanto a terra enriquecem seus respectivos proprietários mesmo sem produzir ou sem trabalho: cobra-se por aquilo que pode ser produzido.
} 
entre o poder econômico e o político na medida em que terra e capital no Brasil significam poder. As famílias no processo de ocupação de Primavera do Leste começaram a acumular terra e capital. Adquiriram poder em uma sociedade que, como elucida Martins (1994), tem o público atravessado pelo privado $^{48}$. A ocupação das terras em Primavera do Leste, assim como em parcela significativa do restante de Mato Grosso e do território brasileiro, manteve os privilégios econômicos e políticos de oligarquias, permitindo, sempre com incentivos e colaboração do Estado, que grandes empresários fossem também proprietários e participassem do jogo político. Essa relação pode ser observada, por exemplo, no fato de que dois proprietários de fazendas na região de Primavera já foram prefeitos da cidade, cada um, por ao menos três mandatos ${ }^{49}$.

Primavera já nasce como um projeto urbano. Se por um lado era preciso realizá-lo para dar continuidade aos projetos agrários previstos à região, dando vazão aos capitais urbanoindustriais do centro-sul do Brasil e atendendo aos serviços e infraestruturas exigidos pela população e pela atividade agrícola, por outro, transformar-se-á em um projeto tão ou mais importante que a própria produção de grãos. A fronteira da urbanização, neste sentido, não apenas precede a considerada "fronteira agrícola" como se constitui em um grande negócio.

48 O modo pelo qual houve o processo de formação, manutenção e dominação da propriedade privada da terra no Brasil por sujeitos e classes sociais determinados ilumina o que Martins (1994) chama de "poder do atraso". Segundo o autor, o processo de dominação privada da terra por sujeitos sociais específicos e posterior consolidação de uma aliança entre propriedade da terra e capital (em essência, uma aliança entre as classes sociais dos capitalistas e dos proprietários de terra) teceram duras amarras na sociedade brasileira.

${ }^{49}$ Caso emblemático do poder público ocupado por interesses do "agronegócio" é o de Blairo Maggi - empresário da sojicultura, dono do grupo Amaggi e governador do estado de Mato Grosso entre 2003 e 2010. Como destacam Pequeno e Elias (2015, p. 17), "num país onde o imbricamento existente entre os poderes econômico e político é recorrente, acostumamo-nos a ter empresários agrícolas como Ministro da Agricultura, Governador de Estado, além de uma das mais influentes bancadas no Congresso Nacional (a bancada ruralista)". Como salientam, é recorrente no que denominam de "cidades do agronegócio" que os prefeitos também sejam empresários do setor.
O projeto "Cidade Primavera", idealizado por Cosentino e pensado inicialmente omo um grande empreendimento no contexto da interação entre campo e cidade, foi implantado em um local até então conhecido como "Bela Vista das Placas", no entrocamento das rodovias BR- $070 \mathrm{com}$ a MT-130. Essa localização nada teve de acaso: é uma situação geográfica estratégica para escoar a produção agrícola e facilitar os fluxos de mercadorias. O projeto Cidade Primavera foi implantado em 205 hectares dos 1.100 da Fazenda Nova Esperança, adquirida em 1972 por Cosentino, e empreendido com recursos próprios da Construtora e Imobiliária Cosentino Ltda (CMPL, 2016). Cosentino pode ser comparado, utilizando expressão de Martins (1993) ao se referir a um "pioneiro" de Chapadão do Sul, a um "pioneiro estrategista", na medida em que elaborou e empregou estratégias que permitiram a colonização de novos espaços e a expansão da fronteira do capital e da urbanização. O estrategista reuniria "conhecimento e informação para aplicá-los à produção de um espaço concebido", assegurando a "existência de condições para a concretização das estratégias" (MARTINS, 1993, p. 29). Esse "estrategista que se colocava na figura do empreendedor cederia lugar ao loteador de terras". Primavera do Leste também é, ainda segundo noção de Martins (1993), uma "cidade sem infância", já implantada seguindo diretrizes de uma urbanização supostamente coerente e harmônica, seguindo a aplicação de modelos.

Primavera constituiu-se em um negócio previamente estudado e calculado, de modo a tornar possível que os agricultores e empresários que ali chegassem também pudessem investir. A Colonizadora Cosentino foi responsável, até o momento de emancipação política da cidade em 1986, por uma série de investimentos, como a obtenção do gerador de energia elétrica, a implantação da rede telefônica e a construção do primeiro hospital. Como afirma Arruda (2007), referindo-se às cidades em Mato Grosso implantadas para atender aos interesses da agricultura capitalista, as obras de infraestrutura deixam de ser realizadas pelas colonizadoras e passam a ser empreendidas pelo Estado apenas quando a ocupação e expansão já estavam concretizadas e o município emancipado.

O município de Primavera do Leste foi criado em 1986 atendendo às demandas dos 
proprietários e empresários do que até então era um distrito do município de Poxoréo. Segundo Arruda (2007), embora a gestão urbana passe a ser realizada pelo poder público municipal, a colonizadora, agora sob a forma de imobiliária ou incorporadora, ainda tem papel fundamental na produção do espaço dessas cidades ligadas ao "agronegócio", tendo como objetivo "garantir os interesses mercantis, presentes desde o processo inicial de implantação do estabelecimento até os dias atuais, na comercialização dos lotes urbanos e rurais" (ARRUDA, 2007, p. 129).

Neste sentido, o poder que as colonizadoras privadas adquiriram no decorrer do processo de ocupação destas cidades não se extinguiu com as emancipações políticas administrativas de grande parte dos municípios mato-grossenses a partir da década 1970 e 80: o comando da produção do espaço muda apenas formalmente de mãos.

Hoje, a antiga Colonizadora Cosentino - e atual Imobiliária e Incorporadora - é proprietária de grande parte dos terrenos ou casas para venda ou aluguel da cidade, controlando a expansão ou implantação de novos loteamentos juntamente com outras poucas imobiliárias, incorporadoras e construtoras cujos donos ainda são em sua maioria das famílias "pioneiras" no processo de ocupação primaverense. É por meio da dominação de extensas propriedades urbanas, realizada a partir do avanço da fronteira da urbanização realizada por poucos e poderosos grupos privados, que explicamos a "produção oligopolista do espaço" (VOLOCHKO, 2015) nessas cidades movidas atualmente pela agricultura capitalista.

A estrutura oligárquica do campo passa a se reproduzir no urbano, tecendo relações estreitas e totalmente imbricadas uma na outra, de modo que não é possível separar as elites agrárias das elites urbanas. As formas de acumulação capitalista e o processo de dominação e concentração fundiária do campo e da cidade ocorreram de modo concomitante à medida que fazendas eram loteadas para a criação e expansão do núcleo urbano. Assim, a constituição da "terra cativa" - utilizando expressão de Martins (1994) - no decorrer da ocupação da região de Primavera trouxe em seu bojo a produção de uma cidade cativa, como elucidaremos no próximo item a partir da noção de "urbanização oligopolista".

\section{A URBANIZAÇÃO OLIGOPOLISTA EM PRIMAVERA DO LESTE}

Para compreender as contradições do espaço de Primavera do Leste a partir da articulação entre terra, poder e capital é preciso elucidar de que modo ela se realiza também na dinâmica fundiária e imobiliária. A maneira pela qual a propriedade foi se configurando, sendo retalhada em grandes e pequenos pedaços, nos ajuda a compreender os processos constitutivos da produção do espaço primaverense. As contradições espaciais reproduzidas no espaço urbano primaverense estão, portanto, diretamente ligadas à lógica da acumulação capitalista com base na propriedade da terra.

Como vimos, o avanço da fronteira - do capital e principalmente da urbanização - por meio da inserção mais intensa do Mato Grosso nas tramas reprodutivas do capital ocorreu baseado na concentração da propriedade da terra. A "oligopolização do espaço agrário" (ELIAS; PEQUENO, 2007) foi, ao mesmo tempo, uma "oligopolização do espaço urbano" (VOLOCHKO, 2015). Neste movimento da urbanização, "pioneiros" e, posteriormente, grupos do "agronegócio" passam a controlar as terras e investir tanto no campo quanto na cidade. Essa imbricação, iniciada com o avanço da fronteira, continua se reproduzindo atualmente como podemos notar por famílias que atuam tanto em atividades agrárias (por exemplo, na produção, armazenagem ou beneficiamento de grãos) quanto no urbano (notadamente em ramos do setor imobiliário por meio de imobiliárias, construtoras e incorporadoras).

De acordo com Elias e Pequeno (2015), grande parte do capital investido no mercado imobiliário nas cidades dinamizadas pelo "agronegócio" tem sua origem nas transferências de renda do campo e dos lucros vinculados ao agrário. Neste processo, os "antigos pioneiros" e "novos agentes imobiliários ${ }^{50 "}$ direcionam o capital gerado na

50 Quando utilizamos a expressão "antigos pioneiros" nos referimos às famílias que chegaram em Primavera do Leste no decorrer da década de 1970 e 1980 e tiveram importante papel no comando e na determinação das diretrizes que orientaram seu processo de urbanização. Já os "novos agentes imobiliários" são, no geral, empreendedores que não moravam em Primavera, mas viram após a década de 2000 uma possibilidade de expandir na região seus negócios. 
agricultura ou na indústria (ligada principalmente ao beneficiamento das commodities) para investimentos no urbano por meio da compra de loteamentos ou de terrenos, assim como construção de casas ou edifícios para especulação ou venda e posterior obtenção de renda. $\mathrm{O}$ setor imobiliário é uma possibilidade para novos investimentos por, inclusive, permitir - mesmo que de modo provisório - a mobilização de capitais em momentos de crise $^{51}$.

A abertura de novos loteamentos e de investimentos nas parcelas do espaço é seletiva, ou seja, ocorre de modo desigual no tempo e no espaço, valorizando os fragmentos do espaço urbano. Uma vez que são poucos os proprietários de grandes extensões de terra - os quais, com frequência, também detêm o poder econômico e político - há um controle de onde e quando serão abertos loteamentos e, consequentemente, em qual direção a mancha urbana irá se espraiar.

Nas cidades cuja produção do espaço urbano é atravessada pela "urbanização oligopolista", há um controle ainda maior no modo pelo qual o espaço urbano é homogeneizado (tornado mercadoria, com a transformação de lotes rurais em urbanos com claro objetivo presente desde o início da concepção de Primavera de manipulação da renda da terra), fragmentado (com o parcelamento e venda de lotes e terrenos) e hierarquizado (por meio da abertura de loteamentos mais ou menos valorizados) ${ }^{52}$.

No decorrer do processo de ocupação de Primavera do Leste, diversas estratégias foram utilizadas para que fosse possível manipular a renda da terra e valorizar o solo urbano. A Imobiliária Cosentino - até hoje possuindo grande controle sobre a estrutura fundiária urbana - doou inúmeros terrenos para alguns "pioneiros" e para a construção

\footnotetext{
51 Segundo relatos de dois corretores imobiliários de Primavera do Leste, os investimentos de capitais no urbano são ainda maiores quando empresários do agrário (no geral, da sojicultura) já calculam, inclusive pela própria quantidade de chuva prevista para a safra, que as perspectivas de lucro com a soja ficarão abaixo do esperado para o ano.

52 Retomamos aqui a tríade hierarquizaçãohomogeneização-fragmentação exposta por Lefebvre (2000), a qual tem um papel fundamental na compreensão dos processos constitutivos da produção do espaço.
}

de equipamentos públicos. Segundo depoimento de Cosentino para Freitas (2016):

\begin{abstract}
Fizemos investimentos com recursos próprios até que o núcleo foi elevado a município. (...) Fizemos doações, até em forma de sorteios para atrair e despertar nas pessoas o desejo de vir morar em Primavera. Isto porque no início ninguém acreditava no sucesso da criação de uma cidade neste cerrado. Vimos nessa medida uma forma de fixar as pessoas no núcleo.
\end{abstract}

Dentre os terrenos doados pela Cosentino, estão aqueles no loteamento Primavera III, na periferia da cidade, alguns utilizados para creches coordenadas pela Igreja Católica e onze hectares para a CASEMAT (Companhia de Armazéns e Silos do estado de Mato Grosso) (FREITAS, 2016). É interessante destacarmos que a utilização de recursos próprios da Cosentino e a doação de terras tratavam-se também de investimentos para atribuir valor aos terrenos próximos e criar novas frentes de expansão do mercado imobiliário. Observamos, neste caso, uma preocupação não somente em negociar terras, mas principalmente em valorizá-las ${ }^{53}$. Além disso, era preciso garantir a continuidade do investimento cidade Primavera: neste sentido, doar um grande terreno para possibilitar o armazenamento de grãos aparece como um caminho para dinamizar uma economia que pretendia ser movida pelo "agronegócio". Como afirma Martins (1993, p. 165) a respeito de processo semelhante:

(...) a doação de terrenos fez-se acompanhar da deliberação sobre a disposição deles no território, forçando a expansão das redes de serviços implantadas pelo poder público nas áreas que delas ainda se encontravam desprovidas, implicando na 'valorização' dos terrenos, isto é, na incorporação pela renda

\footnotetext{
53 Segundo Ferreira (2008, p. 174), Primavera do Leste em 1979 "apresentava duas obras de alvenaria", sendo uma delas "o escritório de venda da companhia colonizadora". Em 1978, "iniciou-se a venda dos primeiros lotes, inclusive antes da abertura das ruas, da colocação de postes e da instalação da rede elétrica em 1979". O fato de umas das primeiras casas ser um escritório de venda da colonizadora nos leva a refletir sobre um espaço cuja concepção foi desde o início "direcionada para uma ordem especulativa, caracterizada por uma ordem territorial empresarial paulista" (PIRAS, 2007), na qual o objetivo era manipular renda da terra e acumular capital.
} 
fundiária, via elevação dos preços, da parcela da mais-valia social investida pelo poder público, sendo um dos mecanismos privilegiados de concretização da arquiconhecida lógica da especulação imobiliária.

Da mesma forma, a venda de terrenos a preços baixos no início da ocupação foi outra estratégia encontrada para tentar garantir o sucesso do empreendimento Primavera do Leste. Na década de 1990 e 2000, muitos lotes foram negociados a preços baixos visando a incentivar a ocupação e valorizar os demais. São vários os relatos de moradores da cidade de que bastava "dar uma 'Biz' velha para comprar um terreno" (Biz é uma moto popular da Honda, cujos preços variavam em 2016 de 4 mil (usada) a nove mil reais. Esse tipo de transação aparecia como alternativa quando os compradores não tinham disponibilidade imediata de dinheiro.) nos loteamentos mais afastados, como Primavera III e Buritis. Aqui é importante destacarmos que, apesar da negociação a preços relativamente baratos, as terras eram vendidas em grande quantidade e foram obtidas a preços baixos ou doadas no processo de colonização privada. Tal processo também contribuiu para proporcionar uma grande concentração de capital nas mãos dos "antigos pioneiros" da cidade.

Por meio desses mecanismos, era possível manipular a renda capitalista da terra, garantindo a continuidade do projeto de colonização, e atrair novas pessoas - tanto para empreender e investir quanto para se constituir em mão de obra barata para a cidade que crescia.

O fato do loteamento Cidade Primavera ter surgido a partir de uma fazenda de um único proprietário contribui para, segundo Volochko (2015) a respeito de processo semelhante em
Nova Mutum, Mato Grosso: um "controle e uma homogeneidade maiores em relação ao modo como o espaço foi sendo ocupado e produzido, o que se coloca como fundamento da produção espacial que repercute na lógica do planejamento urbano (...)". O domínio da venda dos lotes em uma só pessoa ou empresa - inicialmente, dos Cosentino e, em seguida, com o parcelamento de lotes um pouco mais distantes do núcleo urbano, de outras famílias "pioneiras" - ocorre por meio da própria definição de tamanho (que alcança até 600 metros quadrados nos bairros centrais) e suas formas de aquisição (pagamento à vista ou parcelado, com ou sem financiamento). A imposição de padrões a loteamentos inteiros tende a determinar quem poderá acessá-los, atraindo, no geral, moradores com o mesmo padrão de renda. Em Primavera III, bairro a dez quilômetros do centro da cidade e loteado pela Imobiliária Cosentino, moradores conseguiam obter lotes menores e mais baratos, inclusive com pagamento parcelado e financiado. Já no Jd. Riva, um dos mais caros da cidade, os terrenos são maiores e geralmente vendidos pela família Riva - também "pioneira" no processo de ocupação primaverense através de uma entrada e mais três parcelas.

Essa diferença no tamanho dos lotes e na maneira de aquisição e compra é resultado de estratégias distintas dos loteadores com o mesmo objetivo: a obtenção de renda e a valorização fundiária do que ainda será parcelado e vendido. Ajuda-nos também a explicar, no início da expansão do núcleo urbano, uma maior concentração de pessoas de maior renda ao norte da BR e a oeste da rodovia MT (foto 1) e de moradores de menor renda a sul da BR ou leste da MT (foto 2).

Foto 1. Casa de alto padrão no Jd. Riva

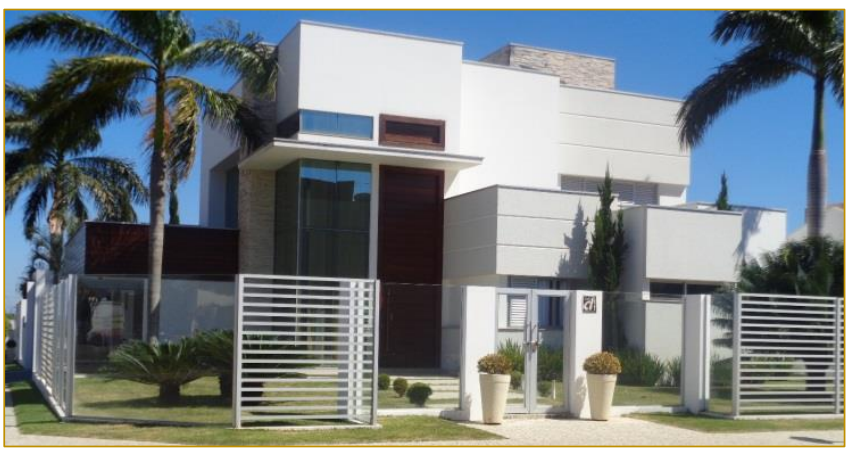


Os muros de vidro seguem modelos adotados em outras casas da cidade: ao mesmo tempo em que delimitam a propriedade, mantêm um padrão arquitetônico que permite que os moradores vejam o lado de fora e tenham, sua casa ao mesmo tempo observada "pelos de fora". Foto da autora. 05 maio 2016.

Foto 2. Rua no Jardim Universitário.

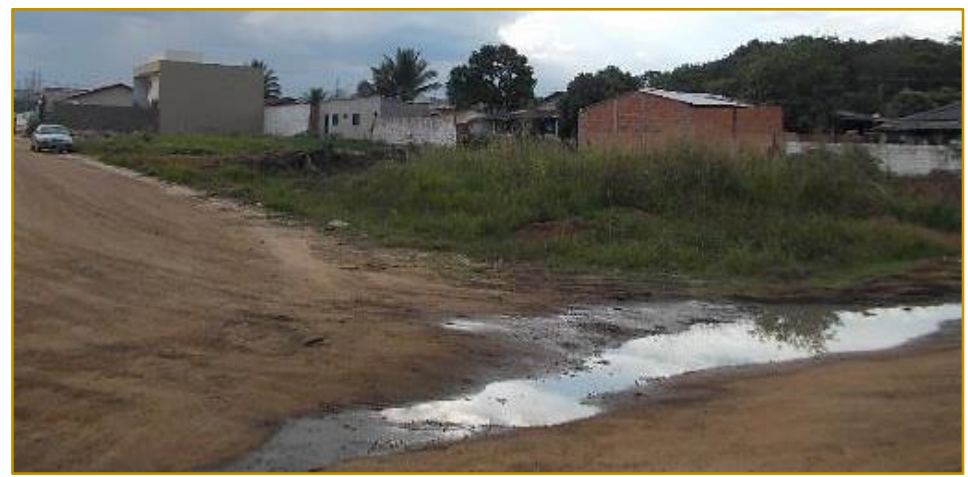

Rua sem asfaltamento e tratamento de esgoto. Foto da autora. 19 set. 2014.

Os "negócios fundiários urbanos" nesses cidades vinculadas mais fortemente ao "agronegócio" podem ser dinamizados com ampliações do perímetro urbano ou modificações no zoneamento (VOLOCHKO, 2015). As discussões sobre a revisão do plano diretor de Primavera do Leste em 2015 envolviam a possibilidade de expansão do perímetro urbano, na qual terrenos rurais passariam a ser considerados urbanos. Mesmo sem a conclusão das discussões sobre o novo plano diretor, a Câmara Municipal sancionou em 2016 uma lei alterando o perímetro urbano e favorecendo, dessa forma, os proprietários das terras contíguas ao núcleo urbano (que passam a auferir ainda mais renda com a venda da terra) $)^{54}$.

Em relação às alterações no zoneamento em Primavera do Leste, caso emblemático é o de um fazendeiro em Primavera do Leste que solicitou a alteração do zoneamento nos lotes atrás da unidade da Cargill - transformando-o de industrial para residencial. Situação similar é a do loteamento Chácara Fontana, na marginal esquerda da MT-130 (sentido Paranatinga) e com 428 lotes, recentemente embargado devido à lei de zoneamento que prevê uso industrial para a região. Uma possível mudança no zoneamento para residencial com a revisão do plano diretor iria,

\footnotetext{
54 Essa mudança, que não contou com a apreciação técnica do Conselho de Desenvolvimento de Primavera do Leste (Codeprim) e teve veto do Poder Executivo, é alvo de uma ação civil pública
}

nesse sentido, favorecer o proprietário no parcelamento e venda dos lotes.

Por meio do mapa $1^{55}$, representamos a concentração fundiária urbana em Primavera do Leste, um dos aspectos da "urbanização oligopolista". Podemos claramente notar que as famílias Cosentino, Riva, Castelli,

\footnotetext{
55 Salientamos que esse mapa é um exercício de aproximação da realidade para que possamos compreender a urbanização oligopolista de Primavera do Leste. Também apresenta generalizações: os Riva e os Cosentino eram proprietários somente incialmente dos bairros selecionados, mas hoje muitos já foram vendidos para terceiros (sobretudo nas áreas centrais da cidade). Da mesma forma, o bairro Buritis (não hachurado no mapa) teve seu loteamento recentemente autorizado para a MarcoVic Loteamentos, mas, possivelmente, Marco A. Kunzler, dono da empresa, pode tê-lo comprado dos Cosentino, por exemplo. Sobre a metodologia empregada na elaboração deste mapa, destacamos as etapas a seguir: autorização para implantação de loteamentos publicadas em portal da Prefeitura Municipal de Primavera do Leste. Foram obtidas informações apenas sobre os novos loteamentos. Sobre as áreas já loteadas pelos Riva e pelo Cosentino, as informações foram obtidas em entrevistas com corretores imobiliários; consultas sobre empresas e seus respectivos sócios em sites como https://www.infoplex.com.br/; http://www.consultasocio.com; delimitação dos loteamentos adquirida também a partir de um mapa base em AutoCad cedido pela Prefeitura Municipal de Primavera do Leste em junho de 2016; relações de parentesco com pessoas com mesmo sobrenome e casamentos foram confirmados em "colunas sociais" locais.
} 
Gasparotto e Freitas detêm grande parte das terras ocupadas e para loteamento no núcleo urbano já consolidado ou com previsão para expansão. Assim, como estamos procurando investigar e expor, a expansão dos loteamentos e o próprio planejamento urbano são ditados por poucas famílias desde o início da ocupação da cidade.

Buscando reiterar que os "antigos pioneiros" permanecem ainda hoje como grandes agentes imobiliários em Primavera do Leste, pesquisamos os anos de fundação das imobiliárias controladas por essas famílias. A maior parte delas foi implantada logo no início da ocupação do núcleo urbano (tabela 1). Além disso, com o objetivo de valorizar as terras e manipular a renda fundiária, os loteamentos são lançados por etapas. A Cosentino lançou o Primavera I ainda entre as décadas de 1980 e 1990, ao passo que o loteamento Primavera IV foi lançando apenas em 2015. O loteamento Castelândia foi um dos primeiros cujos lotes foram vendidos na cidade, no entanto, ainda continua sendo parcelado e já está em sua quarta etapa.

Mapa 1. Urbanização oligoposta em Primavera do Leste - MT.

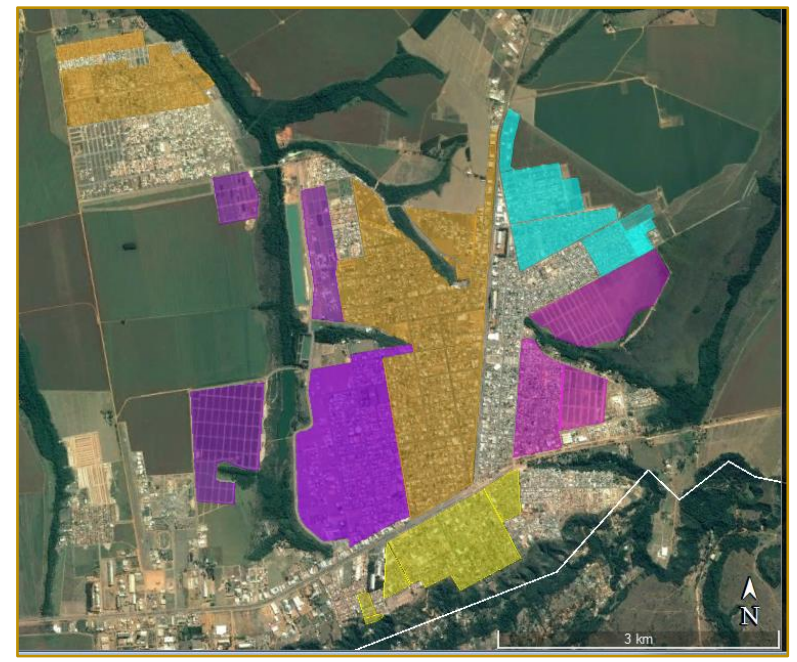

No mapa, observamos extensas parcelas

pela autora em junho de 2016 no do espaço dominadas por uma única software Google Earth Pro.

família (mesma cor). Mapa elaborado

Tabela 1. Relação da urbanização oligopolista em Primavera do Leste com as famílias "pioneiras"

\begin{tabular}{|c|c|c|}
\hline Família & Loteamentos & $\begin{array}{l}\text { Ano de fundação da } \\
\text { imobiliária/empresa }\end{array}$ \\
\hline Castelli & $\begin{array}{c}\text { Castelândia; Castelândia I; Castelândia II; Castelândia III; } \\
\text { Castelândia IV. }\end{array}$ & $07 / 03 / 1984$ \\
\hline Cosentino & $\begin{array}{l}\text { Centro; Primavera I; Primavera II; Primavera III; Primavera IV; } \\
\text { Condomínio Cidade Jardim; Condomínio Porto Seguro; } \\
\text { Condomínio Porto Seguro II; Pq. das Américas. }\end{array}$ & 30/4/1979 \\
\hline Freitas & $\begin{array}{l}\text { Poncho Verde I; Poncho Verde II; Poncho Verde III; Jd. } \\
\text { Luciana; Jd. Luciana II. }\end{array}$ & 12/11/1990 \\
\hline Gasparotto & Pq. Eldorado; Pq. Eldorado - expansão & 06/12/2013 \\
\hline Riva & Jd. Riva; Jd. Riva II; Pq. das Águas; Belvedere; Paraíso. & $17 / 06 / 1988$ \\
\hline
\end{tabular}

Tabela elaborada pela autora a partir da metodologia exposta para elaboração do mapa 1 (consulta ao site $<$ <ttp://www.consultasocio.com/> para obtenção da data de fundação da empresa). Em todos os casos, as famílias tinham mais de uma empresa vinculada a seu nome - escolhemos a empresa mais antiga e vinculada ao mercado imobiliário para mostrar o vínculo com a ocupação da cidade. Exceção pode ser feita à família Gasparotto: na tabela, a empresa responsável pelo loteamento do Pq. Eldorado tinha como data 2013, no entanto, a família chegou a Primavera em 1973 e apresenta empresas no ramo agropecuário desde 1987 
Em 2014, eram aproximadamente 6.732 lotes na cidade aprovados pela Prefeitura e aguardando comercialização, com previsão para abrigarem mais de 22 mil pessoas (mapa 2). Alguns dos loteamentos representados neste mapa são de propriedade dos "antigos pioneiros", os quais não por acaso são aqueles mais próximos do núcleo urbano - como se observa pelas delimitações indicadas pela cor mais clara no mapa. Ainda estão comercializando, portanto, terrenos relativamente próximos ao centro, agora mais valorizados. Além desses "pioneiros" que, como vimos, continuam abrindo loteamentos e no comando da dinâmica do mercado fundiário e imobiliário desde o início da ocupação de Primavera, também foi possível constatar a participação de novos agentes imobiliários.

Mapa 2. Loteamentos previstos para implantação em 2016 e 2017.

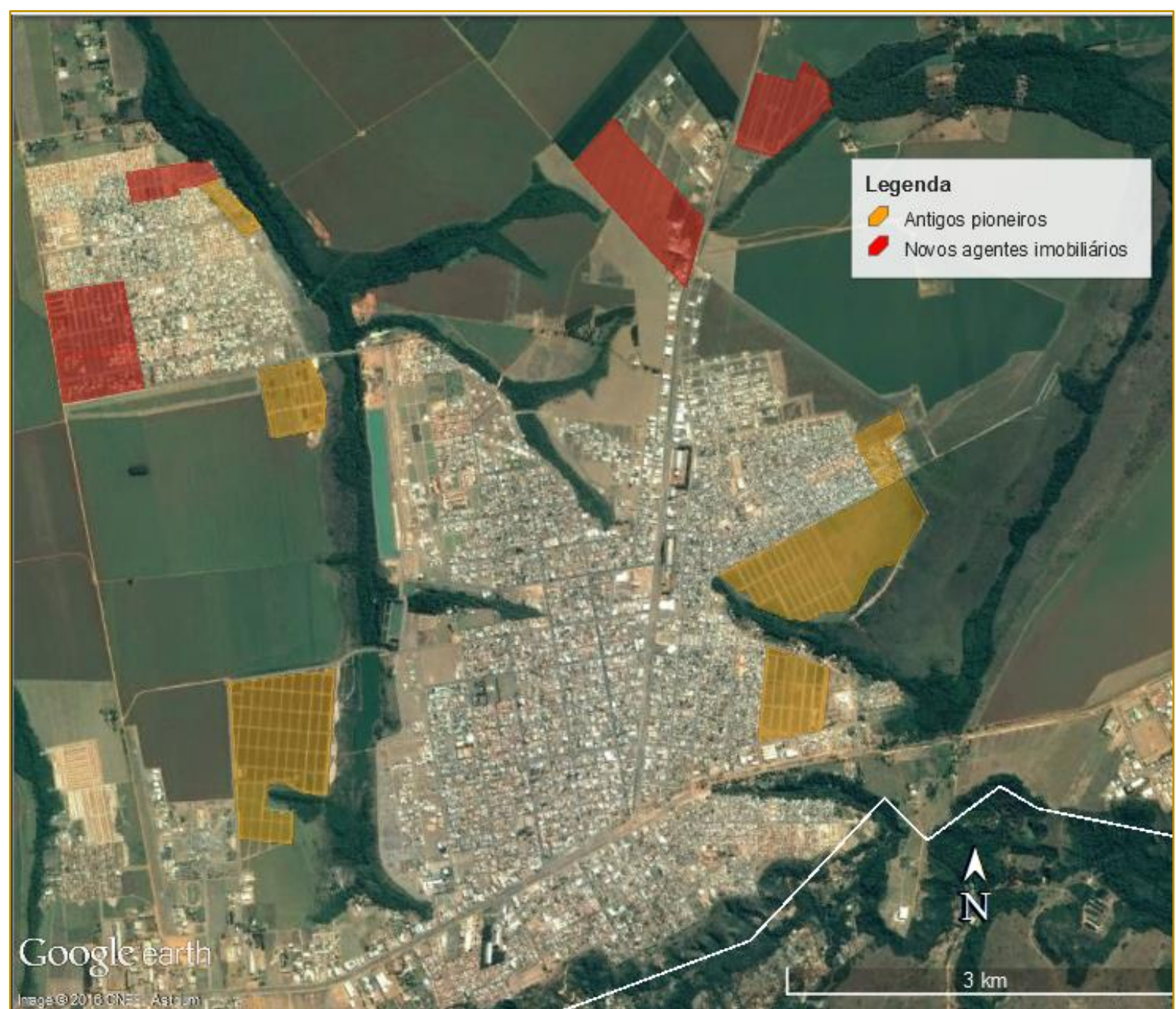

As delimitações dos loteamentos não apresentam absoluta precisão, uma vez que foram traçadas a partir de informações encontradas no Diário Oficial da Prefeitura Municipal e de imagem de satélite (2016). A metologia para investigar os proprietários destes loteamentos foi a mesma da utilizada na elaboração do mapa 1. Mapa elaborado pela autora no software Google Earth Pro. 
Os loteamentos abertos por esses novos agentes imobiliários estão indicados pelos números 1 a 4 no mapa. Aqueles representados pelos números 1 e 2 no mapa, às margens da MT-130 sentido Paranatinga, são, respectivamente, Chácara Fontana e Parque Imperial, aparentemente de investidores que moram em Primavera do Leste. Já o loteamento Três Américas (número 3 no mapa) é de propriedade de um empreendedor que é dono de uma imobiliária e incorporadora também atuante na cidade (responsável pelo lançamento em 2014 de um edifício de alto padrão no centro, com apartamentos de 151 a $173 \mathrm{~m}^{2}$ e preços a partir de 850 mil reais). Este novo loteamento, próximo aos bairros periféricos de Primavera III e Buritis, será destinado à população de menor renda, com lotes de até 200 metros quadrados, possibilidade de financiamento e pagamento em várias parcelas.

Merece destaque, por fim, os dois loteamentos indicados pelo número 4 - Buritis II expansão e Buritis III. O proprietário, Marco A. Kunzler, é administrador de outras cinco empresas no estado de Paraná e cinco em Mato Grosso. A partir de entrevista de Kunzler a Sampaio (2015), sabe-se que Buritis é a denominação utilizada para se referir a conjuntos de loteamentos implantados em
Nova Mutum em 2008 e que atualmente existem também nas cidades matogrossenses de Campo Verde e Sinop (além de Primavera do Leste). Ao todo, de acordo com Sampaio (2015), são mais de 70 empreendimentos no ramo imobiliário ligados à empresa "Buritis Empreendimentos" de Kunzler. Em Primavera, serão 4 mil terrenos nas 4 fases de expansão do loteamento, com previsão para abrigarem $15 \mathrm{mil}$ pessoas. Kunzler mora em Campo Mourão, Paraná, e segundo entrevista, decidiu investir na região por meio de indicação de pessoas de Primavera do Leste (SAMPAIO, 2015).

$\mathrm{Na}$ foto 3, observamos as diferentes fases do loteamento Buritis em Primavera. É importante destacarmos que segundo determinações da Lei de Parcelamento de Solo Urbano do Município de Primavera do Leste, cabe ao loteador ser responsável pela rede de distribuição de energia elétrica, rede de esgoto, de escoamento de águas superficiais e de abastecimento de água. Também fica a seu encargo a terraplanagem, a pavimentação e implantação de meio fios das vias. Se essas medidas por um lado aumentam os custos ao loteador, por outro, também se configuram em um mecanismo para valorizar os lotes que serão comercializados.

Foto 3. Loteamento Buritis - vista aérea.

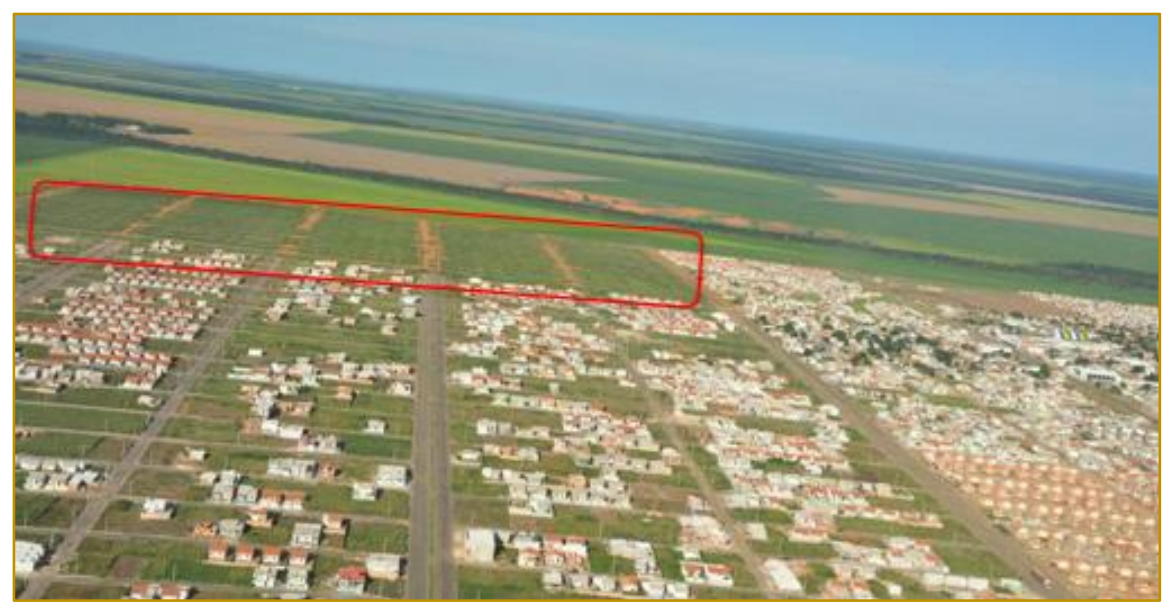

Nota-se uma ocupação mais consolidada à direita e outra ainda esparsa em primeiro plano (duas primeiras fases do Buritis). Ao fundo, em destaque, loteamento Buritis expansão e Buritis III, previstos para implantação em 2016 e $2017 . \quad$ Disponível em http://www.skyscrapercity.com/showthread. Php?p=111002342>.

A disponibilidade de grandes terrenos em Primavera do Leste ou em suas proximidades, neste sentido, pode se constituir um atrativo para incorporadoras e construtoras de fora do estado. Também são do Paraná a Imobiliária Edílio, uma das mais conhecidas da cidade depois da Cosentino, e a construtora Edificatto, que em 2017 entregará dois 
condomínios residenciais de alto padrão na cidade (com apartamentos de até 221,42 $\mathrm{m}^{2}$ cujos preços ultrapassam um milhão de reais) ${ }^{56}$.

A venda desses terrenos, seja pelos "antigos pioneiros" seja pelos "novos agentes imobiários", é movida pela manipulação da renda da terra e controle da valorização do solo urbano a favor desses poucos grupos familiares e empresariais. Nesse processo, em que a terra passa a ser manipulada pelo capital com o intuito de gerar mais capital, há uma inclusão precária de parcela da população que não pode pagar o que é estipulado pelos proprietários e loteadores. Segundo Martins (1993, p. 165):

Nestas condições em que a cidade ganha forma derivada de uma concepção de espaço cujo conteúdo se sustenta na apropriação do trabalhos social sob a forma de renda fundiária, os preços praticados pelo especulador passaram a representar uma interdição crescente às demandas, socialmente diferenciadas, por retalhos desse espaço urbano.

De acordo com reportagem do jornal "O Diário", veiculada no dia 11 de junho de 2015, "o preço médio do metro quadrado vai de $\mathrm{R} \$ 5$ mil a $\mathrm{R} \$ 6$ mil a região central e nos bairros nobres. Já nos bairros a média fica entre $\mathrm{R} \$ 2.200$ a $\mathrm{R} \$ 3$ mil o metro quadrado". Para que possamos ter um parâmetro para comparação, em janeiro de 2015, a cotação média do médio quadrado para venda na cidade de São Paulo era de $\mathrm{R} \$ 8.351^{57}$. Segundo outro índice, no mês de abril de 2016, o preço médio do metro quadrado era

\footnotetext{
56 Conforme informações obtidas no site da empresa e através de corretores imobiliários, o "Rivière", com previsão de entrega para julho de 2017, contará com apartamentos de $95 \mathrm{~m}^{2}$ a 228 $\mathrm{m}^{2}$ de área privativa, e o "Privilège", com 18 apartamentos (2 por andar) e metragem de área privativa de $221,42 \mathrm{~m}^{2}$. Os preços por metro quadrado desses dois empreendimentos variam de $\mathrm{R} \$ 5.273$ a $\mathrm{R} \$ 6.959$.

57 Índice FipeZap, publicado em janeiro de 2015: Metro quadrado avançou 6,7\%, pouco acima da inflação esperada para o ano, segundo o índice FipeZap. Disponível em $<$ http://economia.estadao.com.br/noticias/seuimovel,alta-do-preco-do-imovel-em-2014-quaseempata-com-inflacao,1615809>. Acesso em 24 nov. 2016.
}

de $R \$ 7.355^{58}$. Embora esses valores estejam bem acima daqueles encontrados em Primavera do Leste, o preço nos bairros centrais pode ser comprado àqueles encontrados nos bairros da zona oeste e sul de São Paulo, como Butantã, Mooca e Morumbi59.

Nesse contexto, parcela desses moradores sem condições de arcar com os preços dos terrenos e dos imóveis - e mesmo dos aluguéis - mora às margens da rodovia ou nas periferias, longe dos serviços e equipamentos públicos de infraestrutura urbana. Em Primavera do Leste, há uma favela extremamente precária lindeira à BR070 sentido Barra do Garças, já na saída da cidade (foto 3). As casas compõem uma ocupação extremamente precária de cerca de 90 famílias, formada sobretudo por migrantes alagoanos ou maranhenses.

Já no extremo noroeste da cidade, há o Conjunto Residencial Padre Onesto Costa, inaugurado em 2014 e formado por 500 casas do programa Minha Casa Minha Vida (foto 4). Grande parte de seus moradores está desempregada ou apenas consegue sustentar a família por meio de empregos informais e precários (contraditoriamente, muitos deles gerados, direta ou indiretamente, pelo "agronegócio"). Para o ano de 2017, está a prevista a entrega de outras 750 casas vinculadas ao Minha Casa Minha Vida no loteamento Tuiuiú, também na periferia da cidade. Se a implantação de conjuntos habitacionais na cidade pode garantir, mesmo que minimamente, condições mais dignas de habitação para essa parcela pobre da população, está longe de resolver as contradições geradas pela articulação entre terra, poder e capital que perpassa a produção do espaço primaverense. 
Foto 4. Favela da BR- 07 em Primavera do Leste.

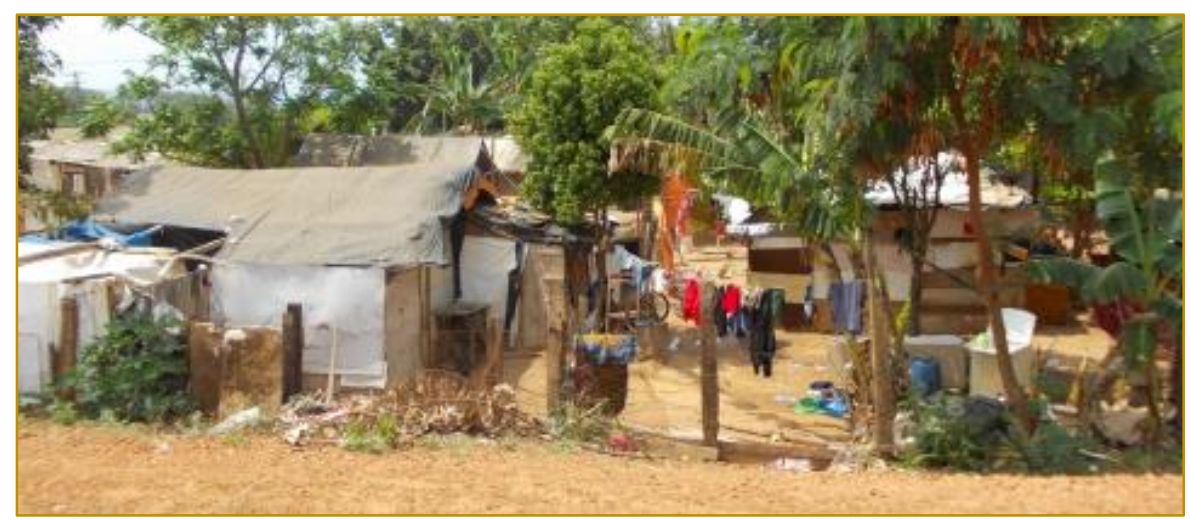

Trecho da favela ao sul da rodovia BR-070, em local próximo a "NutriLara - indústria e comércio de cereais". Observam-se casas de lona e papelão, sem infraestrutura de fornecimento de energia elétrica ou saneamento básico. Foto da autora. 09 de out. 2015.

Foto 5. Fundos das casas da Rua Amendoeira, Conj. Padre Onesto Costa - Primavera III.

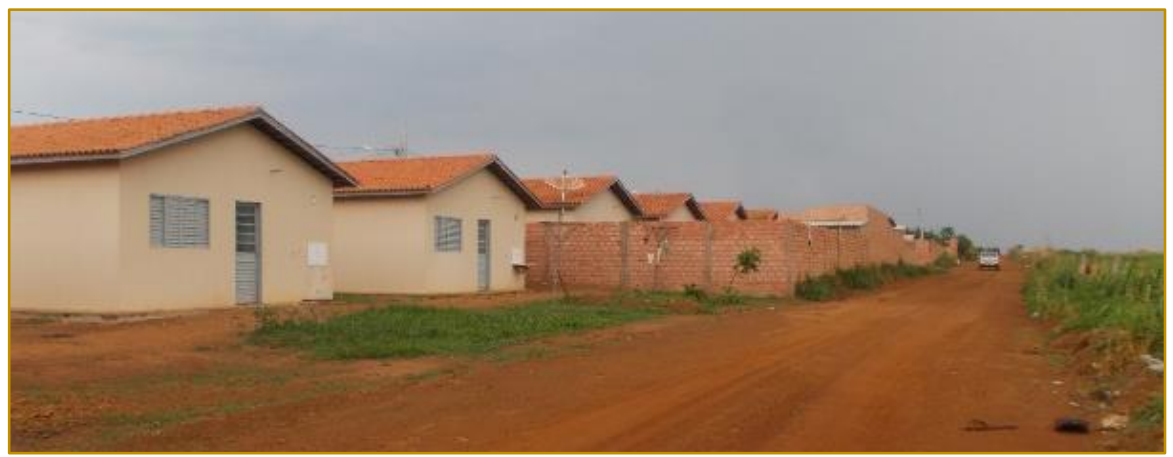

Casas no extremo noroeste da cidade - rua sem asfalto e fundos das casas cujos muros vão sendo erguidos pelos moradores de acordo com a disponibilidade de tempo e dinheiro. Foto da autora. 09 out. 2015.

\section{CONSIDERAÇÕES FINAIS}

O avanço da fronteira do capital e da urbanização no sudeste mato-grossense a partir do final da década de 1970 nos ajuda a iluminar os fundamentos das contradições e dos conflitos espaciais atuais da produção do espaço de Primavera do Leste. O processo de implantação da cidade foi estrategicamente elaborado atendendo aos interesses de uma agricultura capitalista que crescia, dando vazão aos capitais excedentes urbano-industriais. A ocupação de Primavera foi realizada por meio de uma grande concentração da terra, do capital e do poder por "pioneiros", no geral ligados a grandes grupos empresarias do centro-sul brasileiro e com recursos para investir inicialmente na produção agrícola e implantação de infraestruturas urbanas. Hoje, estes "antigos pioneiros" são proprietários dos melhores - e mais valorizados - terrenos da cidade, dividindo uma pequena parcela de sua atuação no mercado imobiliário com novos agentes (no geral, resposáveis pelos loteamentos mais distantes do centro).

$\mathrm{Na}$ produção do espaço primaverense, a dominação e concentração fundiária do campo está diretamente relacionada a da cidade, uma vez que ambas ocorreram concomitantemente à medida que as propriedades rurais eram loteadas para a expansão do núcleo urbano. Essa dominação privada do solo urbano por poucos proprietários tem como uma de suas consequências uma "urbanização oligopolista", na qual implantam-se loteamentos onde e quando é mais 
conveniente e rentável aos interesses fundiários privados (agrários e urbanos).

As estratégias fundiárias e imobiliárias dos "antigos pioneiros" e novos agentes imobiliários - que incluem doação de lotes ou venda de terras a preços relativamente baixos, abertura gradual de loteamentos destinados a padrões determinados de renda, assim como possíveis alterações no zoneamento e perímetro urbano - se realizam desigualmente no urbano e têm profundas implicações no plano social. Contribuem para gerar, junto com a riqueza, pobreza - como se observa a partir da favela às margens da BR-070 e da expansão das periferias.

\section{REFERÊNCIAS}

[1] Arruda, Zuleika Alves de. Onde está o agro deste negócio? Transformações socioespaciais em Mato Grosso decorrentes do agronegócio. Campinas, 2007. Tese (Doutorado em Ciências), Instituto de Geociências, Universidade Estadual de Campinas.

[2] Bernardes, Júlia Adão. Modernização agrícola e trabalho no cerrado brasileiro. IX Colóquio Internacional da Geocrítica, 2007. Disponível em < http://www.ub.edu/geocrit/ 9porto/juliaad.htm>. Acesso em 19 abr. 2016.

[3] Câmara Municipal de Primavera do Leste CMPL. História de Primavera do Leste. Disponível em < http://camarapva.com.br/livro.pdf>. Acesso em abr. 2016

[4] Elias, Denise; Pequeno, Renato. Desigualdades socioespaciais nas cidades do agronegócio. Revista Brasileira de Estudos Urbanos e Regionais. Recife, 2007. v. 9, v. 1, pp. 25-39.

[5]

"(Re) estruturação urbana e desigualdades socioespaciais em região e cidade do agronegócio". GEOgraphia. - ano 17 n. 35 - Dossiê 2015

[6] Ferreira, João Carlos Vicente. Cidades de Mato Grosso: origem e significado de seus nomes. Cuiabá: J. C. V. Ferreira, 2008.

[7] Freitas, Sthephanie. Dr. Edgar Cosentino: fundador de Primavera! Disponível em < http://www.cliquef5.com.br/blogs/blog-primavera30-anos/pva-29-anos/dr-edgard-cosentinofundador-de-primavera/71919 >. Acesso em abril de 2016

[8] Girardi, Eduardo Paulon. Uma leitura da questão agrária em Mato Grosso. Confins [Online], $25 \quad$ I 2015. Disponível em <https://confins.revues.org/ 10446?lang=pt>. Acesso em 30 abr. 2016.
$\mathrm{Na}$ implantação e venda de loteamentos, a manipulação da terra pelo capital com o intuito de gerar mais capital acaba incluindo precariamente aquela parcela da população que não pode pagar o que é estipulado pelos proprietários e pelos loteadores. Nesse contexto, afirmamos que uma das consequências - e ao mesmo tempo condição para sua realização - da "urbanização oligopolista" nesta cidade cativa é o acirramento da segregação espacial, processo que tende a caracterizar as cidades cuja economia é fortemente atrelada ao denominado "agronegócio".

[9] Lefebvre, Henri. A produção do espaço. Trad. do grupo "As (im) possibilidades do urbano na metrópole contemporânea", do Núcleo de Geografia Urbana da UFMG. Do original: La production de l'espace. $4^{\underline{a}}$ ed. Paris: Éditions Anthropos, 2000. Versão tradução de fev. 2006.

[10] Martins, Sérgio Manuel Merêncio. A cidade "sem infância" no universo pioneiro de Chapadão do Sul (MS). São Paulo, 1993. Dissertação de Mestrado (Geografia Humana), Universidade de São Paulo.

[11] Martins, José de Souza. O Poder do Atraso: Ensaios de Sociologia da História Lenta. São Paulo: Hucitec, 1994.

[12] 9a ed. São Paulo: Contexto, 2010

O Cativeiro da Terra.

[13] Oliveira, Ariovaldo Umbelino. A longa marcha do campesinato brasileiro: movimentos sociais, conflitos e reforma agrária. Revista de Estudos Avançados. São Paulo: IEA USP. V. 15, n. 43, p. 185 - 206. Set/Dez 2001.

[14] Piras, Danielle Schimaneski. A territorialização da agricultura moderna em Primavera do Leste. Niterói, 2007. Dissertação (Mestrado em Geografia), Universidade Federal Fluminense.

[15] Prefeitura Municipal de Primavera do Leste. Propostas de alteração da legislação pertinentes ao plano diretor participativo - 2014. Disponível em <http://primaveradoleste.mt.gov.br/ pastaarquivos/69702\%20-\%20RELATORIO \%20PDP\%20\%20AUD.pdf>. Acesso em 09 maio 2016.

[16] Sampaio, Eliane. Buritis empreendimentos: realizando sonhos. 15 agosto 2015. Disponível em $<$ http://www.cliquef5.com.br/primavera-doleste/noticias-de-pva-do-leste/buritis-empreen dimentos-realizando-sonhos/59734>. Acesso em jul. 2016.

[17] Silva, Elias da. Território, cidade e rede: o papel de Rondonópolis na expansão da soja no 
cerrado mato-grossense. São Paulo, 2010. Tese em Geografia Humana - Faculdade de Filosofia Letras e Ciências Humanas - Universidade de São Paulo.

[18] Volochko, Danilo. "Da extensão do campo à centralização do urbano: elementos para o debato da produção do espaço em Mato Grosso".
Revista Mato-Grossense de Geografia. Cuiabá, 2013. n.16. pp. 18-38.

[19

"Terra, poder e capital em Nova Mutum - MT: elementos para o debate da produção do espaço nas 'cidades do agronegócio'”. Rio de Janeiro, 2015. GEOgraphia. Ano 17, n. 35. pp. 40- 67. 


\section{Gapítulo 17}

\section{HABITAÇÃO POPULAR EM CURITIBA/PR: DA CRIAÇÃO DA COHAB À IMPLEMENTAÇÃO DO PROGRAMA MINHA CASA MINHA VIDA}

\section{Fabiana Alves Monteiro}

Resumo: $O$ presente artigo traz algumas considerações a respeito da implementação do Programa Minha Casa Minha Vida em Curitiba, capital do Estado do Paraná e cidade polo da Região Metropolitana de Curitiba (RMC). Inicialmente é analisada a recente articulação entre Estado e mercado imobiliário para produzir habitação popular e em seguida é retomada a discussão sobre as principais transformações ocorridas no espaço urbano de Curitiba nas últimas décadas, a partir do crescimento da informalidade da moradia e da implantação do Planejamento Urbano. Diante desse contexto, é analisado o papel do poder público local na produção de habitação popular, através da COHAB e atualmente por meio da implementação do Programa Minha Casa Minha Vida. Busca-se dessa forma, averiguar se houve mudanças significativas na forma como o poder público local trata a questão da habitação popular ou se permanece a tendência de relegar as camadas sociais de baixa renda às áreas periféricas da cidade e da RMC.

Palavras Chave: Habitação de interesse social, segregação espacial, COHAB, Programa Minha Casa Minha Vida. 


\section{INTRODUÇÃO}

A problemática da moradia no Brasil ainda é um dos maiores desafios a ser enfrentado pelo poder público na atualidade e tem suas raízes no processo de urbanização do Brasil que, de acordo com Santos (1996), ocorreu associado à exclusão social. Assim como afirma Maricato (2000), que chama a atenção para os efeitos perversos dessas transformações no espaço urbano brasileiro ao longo do século passado e reitera que a intensificação da urbanização a partir de 1950 coincidiu com uma nova etapa da industrialização no país e que a crise das décadas de 1980 e 1990, depois de um curto período de crescimento econômico, trouxe um forte impacto social e ambiental, ampliando assim o universo de desigualdade social.

Contudo, Maricato (2000) ressalta que a "tragédia urbana do Brasil" não é produto das décadas perdidas e tem suas raízes em cinco séculos de formação da sociedade brasileira, especialmente a partir da privatização da terra (1850) e da emergência do trabalho livre (1888). Desse modo, afirma que o crescimento urbano do Brasil sempre ocorreu com a exclusão social, fazendo com que, grande parte da população, inclusive àquela regularmente empregada, construísse sua própria moradia em áreas irregulares ou "simplesmente invadidas" (MARICATO, 2000, p.4).

Assim, a partir desta perspectiva e levando em consideração a atual conjuntura socioeconômica do país, o presente artigo discute a articulação entre Estado e mercado imobiliário na implementação do Programa Minha Casa Minha Vida (PMCMV), atualmente o principal programa federal voltado a produzir moradias em massa, tanto para atender a classe média, como a população de menor renda. O Programa, porém, está em fase de estagnação e desde a sua criação foi alvo de inúmeras críticas por parte de estudiosos da área da habitação popular e movimentos sociais envolvidos nessa temática. Muitas das críticas apontam para o fato de que o Programa, ao ser ancorado na iniciativa privada, tende a privilegiar os seus interesses, contribuindo para a padronização dos projetos, a má qualidade das unidades habitacionais e a segregação social, dentre outros problemas.

Dessa forma, o presente trabalho busca traçar algumas considerações a respeito da implementação do Programa Minha Casa
Minha em Curitiba, evidenciando o padrão de localização dos empreendimentos destinados as faixas de menor renda e procurando identificar se a inserção do Programa na capital apresenta algumas especificidades ou vai ao encontro do cenário das demais metrópoles brasileiras.

Para tanto, foi estruturado da seguinte forma: primeiramente é discutido o papel do Estado e do mercado imobiliário nas transformações do espaço urbano brasileiro ao longo do século passado, destacando a recente articulação entre os mesmos para a implementação do referido Programa. Em seguida, são analisadas as características gerais da Região Metropolitana de Curitiba $(\mathrm{RMC})$ e as principais transformações ocorridas nas últimas décadas na capital, principalmente aquelas relacionadas ao aumento da informalidade da moradia. E, em contrapartida, o papel do poder público local nesse contexto, destacando como a implementação do planejamento urbano em Curitiba contribuiu para a segregação espacial.

A parte final discute a atuação do poder público local, através da COHAB na implementação de Habitação Popular em Curitiba, analisando o padrão de localização destes empreendimentos em períodos anteriores e a partir da criação do Programa Minha casa Minha Vida.

\section{ESTADO E MERCADO IMOBILIÁRIO NA PROMOÇÃO DE HABITAÇÃO POPULAR NO BRASIL: A CRIAÇÃO DO PROGRAMA MINHA CASA MINHA VIDA}

Apenas a partir da década de 1960, durante o Regime Militar é que o Brasil vai desenvolver de fato uma política habitacional, conforme afirma Bonduki (1998). Neste contexto, o Estado por vezes assumiu um papel contraditório, no sentido que ao mesmo tempo em que atuava para produzir habitação popular, associava-se também de forma recorrente ao mercado imobiliário para valorizar determinadas porções do espaço urbano brasileiro, contribuindo, dessa forma para a segregação espacial das camadas sociais de menor renda.

A atuação conjunta do Estado e do mercado na transformação do espaço urbano costuma ser comum, conforme afirma Gottdiener (1997, p. 241). O autor coloca que a produção do espaço ocorre "não apenas dos processos 
econômicos, porém, mais especificamente, por causa de uma articulação conjunta Estado-setor imobiliário, que forma a vanguarda das transformações espaciais". O Estado, segundo o autor, intervém em diversas instâncias na produção do espaço urbano, propiciando que o mercado imobiliário obtenha vantagens na sua apropriação. E coloca que essa articulação entre Estado-setor da propriedade se dá através de vários meios como, "mudanças de zoneamento, variâncias, construções de rodovias e outros melhoramentos de infraestruturas e subsídios públicos de todas as espécies" (1997, p. 260).

Cardoso (2005, p. 6), também chama a atenção para o papel do Estado, ao afirmar que o espaço urbano tem seu valor determinado por sua localização, que por sua vez, depende da aglomeração em que se situa e da intervenção estatal para construí-la e equipá-la. E coloca que, "a influência sobre a máquina pública pode render benefícios significativos a quem conseguir direcionar os investimentos do Estado segundo seus interesses de valorização". E que, nas cidades brasileiras a intervenção do Estado foi capaz de produzir de forma recorrente a diferenciação espacial, almejada pelas classes dominantes, sendo que a atuação destas no mercado imobiliário é caracterizada pela disputa para apropriar-se de importantes fundos públicos destinados à urbanização.

Essa articulação entre mercado imobiliário e Estado pode ocorrer também com vistas a promover a habitação social, pois, de acordo com Correa (1989), nos países periféricos, a estratégia dos promotores imobiliários é primeiramente oferecer habitação a demanda solvável da população e se associar ao Estado para "tornar solvável a produção de residências para satisfazer a demanda não solvável" (CORREA, 1989, p. 21/22).

No caso específico do Brasil o autor afirma que,

A existência de uma demanda solvável saturada e de uma não solvável insatisfeita explica o interesse do capital imobiliário em obter ajuda do Estado, de modo a permitir tornar viável a construção de residências para as camadas populares: créditos para os promotores imobiliários, facilidades para desapropriação de terras e créditos para os futuros moradores. A criação de órgãos, como foi o caso do Banco Nacional da Habitação e das Cooperativas de Habitação (COHABs), e a criação de mecanismos jurídicos e financeiros, como o Fundo de Garantia por Tempo de Serviço (FGTS), visam viabilizar a acumulação capitalista via produção de habitações, cujo acesso é agora ampliado (CORREA, 1989, p. 23).

Esta estratégia segundo Correa (1989, p.23), é viável em função da importância da produção da moradia na sociedade capitalista, pois cumpre um papel fundamental, que é "o de amortecer as crises cíclicas da economia através do investimento de capital e da criação de numerosos empregos: daí ter o apoio do Estado capitalista, que por sua vez está fortemente repleto, através de seus componentes, de interesses imobiliários". O autor ressalta ainda que a atuação no espaço dos promotores imobiliários se faz de modo desigual, ao criar e reforçar a segregação residencial que caracteriza a cidade capitalista.

No atual contexto, Rufino (2012, p. 285) coloca que a aproximação do Estado e do mercado imobiliário tornou-se nítida com o Programa MCMV, no qual os financiamentos são articulados a subsídios diretos, além de outros apoios, ofertados, inclusive, na esfera estadual e municipal. Em contrapartida a esse fortalecimento do setor, o Estado se beneficia ao apropria-se integralmente dos resultados do Programa, "incorporando os números da produção de mercado como parte de uma política pública". Dessa forma, essa aliança entre o mercado imobiliário e o Estado tem se mostrado vantajosa para ambos, para o primeiro porque tem vivenciado um enorme crescimento nos últimos anos e para o segundo porque tem garantido uma enorme "capitalização política" com a grande produção do Programa.

O Programa foi criado em 2009 através de Lei Federal e teve como meta inicial a construção de 1 milhão de moradias, destas, 40\% deveriam ser destinadas a famílias com renda mensal de até três salários mínimos, justificado pelo fato da maioria do déficit habitacional do Brasil se concentrar nesta faixa de renda. O Programa nesta primeira fase foi estruturado então, em três faixas de renda, levando em consideração o salário mínimo (s.m.) - Faixa 1: 0 a 3 s. m.; Faixa 2: 3 a 6 s.m. e Faixa 3: 6 a 10 s.m. A partir de 2011, na sua segunda fase, amplia-se a meta e as faixas de renda passam a ser estruturadas em valores nominais - Faixa 1 até $R \$$ 1. 600,00; Faixa 2 até $R \$ 3.275,00$ e Faixa 3 até 5 mil. Já em fevereiro do ano de 
2017, em razão das mudanças no contexto econômico e político do país, o Programa passou por novas alterações: a faixa 1 passou a englobar famílias com renda mensal de até $\mathrm{R} \$ 1,8$ mil; a recém criada faixa 1,5 passou a atender famílias com rendimento de até $\mathrm{R} \$ 2,6$ mil; a faixa 2 com rendimento de até $\mathrm{R} \$ 4$ mil e a faixa 3 passou a atender famílias com renda mensal de até $\mathrm{R} \$ 9$ mil (BRASIL, 2017).

Para cada faixa de renda existem fontes de recursos e subsídios diferenciados que podem chegar até $90 \%$ do valor da unidade habitacional, no caso da Faixa 1. Cardoso e Aragão (2013) sintetizam os princípios que regem a Faixa 1 do Programa,

A produção é "por oferta", o que significa que a construtora define o terreno e o projeto, aprova-o junto aos órgãos competentes e vende integralmente o que produzir para a CAIXA, sem gastos de incorporação imobiliária e comercialização, e sem risco de inadimplência dos compradores ou vacância das unidades. A CAIXA define o acesso às unidades a partir de listas de demanda, elaboradas pelas prefeituras. Os municípios têm como incumbência cadastrar as famílias com rendimento de 0 a 3 salários mínimos, além da participação por meio da doação de terrenos, isenção tributária e desburocratização nos processos de aprovação e licenciamento e também na flexibilização das normas urbanísticas para permitir aumentar os índices de utilização do solo nos empreendimentos do MCMV (CARDOSO \& ARAGÃO, 2013, p. 37).

Nas Faixas 2 e 3 o Programa funciona da seguinte forma:

As construtoras/ incorporadoras apresentam projetos de empreendimentos à CAIXA, que realiza pré-avaliação e autoriza o lançamento e comercialização. Após a conclusão da análise e comprovação da comercialização mínima exigida, é assinado o Contrato de Financiamento à Produção. A comercialização é feita pelas construtoras ou através dos "feirões" da Caixa, havendo a possibilidade de que os pretendentes à aquisição consigam uma carta de crédito na Caixa para ir ao mercado buscar uma moradia para aquisição (CARDOSO \& ARAGÃO, 2013, p. 39).

A segunda fase do Programa, além de incorporar os municípios com menos de 50 mil habitantes que até então eram negligenciados, definiu uma melhoria do padrão construtivo das moradias, de acordo com Cardoso e Aragão (2013), além de viabilizar o uso comercial nos empreendimentos e estimular a utilização de fontes de energia sustentáveis.

Sobre as limitações do Programa, Cardoso e Lago (2013) afirmam, por exemplo, que a regulamentação do Programa definiu que os recursos seriam distribuídos para estados e municípios, de acordo com a participação de cada um no cômputo do déficit habitacional. Dessa forma, "criaram-se cotas, baseadas em um princípio universalista, e evitando a influência de dimensões políticas e relações de clientela na alocação dos recursos". Contudo, como o Programa é ancorado na iniciativa privada, que define quanto, como e aonde construir, acabou por gerar "distorções na distribuição dos recursos entre as unidades da federação" (CARDOSO \& LAGO, 2013, p. 13).

Além disso, conforme Cardoso, Aragão e Jaenisch (2017), o Programa MCMV prioriza a quantidade, não a qualidade das moradias, tendo em vista que o principal propósito da sua criação foi o de conter os efeitos negativos da crise internacional de 2008, que provocou uma desaceleração no mercado imobiliário e no setor da construção civil, que estava em plena ascensão até este momento. Como consequência, o Programa, ao promover a construção de moradias em larga escala, propiciou a criação de empregos e o reaquecimento do setor da construção civil.

Os autores afirmam ainda que o PMCMV foi inspirado nas experiências desenvolvidas no Chile e no México e que eram consideradas pelo empresariado da construção civil como os modelos mais eficientes para dinamizar a produção habitacional. Todavia, ressaltam que o modelo adotado pelo Programa entrou em choque com os princípios do Sistema Nacional de Habitação de Interesse Social (SNHIS), pautados no papel estratégico do setor público, além de ignorar as premissas e debates envolvidos na criação do Plano Nacional de Habitação de Interesse Social (PlanHab).

Um dos impactos mais imediatos sobre os programas desenvolvidos no âmbito do FNHIS diz respeito à eliminação dos repasses de recursos para as ações de provisão habitacional. Dessa forma, desde o lançamento do PMCMV, o FNHIS passou a 
concentrar os seus recursos nas ações de urbanização de assentamentos precários e de desenvolvimento institucional, seguindo orientação do Ministério das Cidades, acatada pelo Conselho Gestor. Além disso, com a consolidação do PMCMV, o Fundo foi completamente esvaziado na administração de Dilma Rousseff (2011-2016), (CARDOSO, ARAGÃO \& JAENISCH, 2017).

Rufino (2015) por sua vez, coloca que a produção do PMCMV para a Faixa 1 tem como principais características a ampla padronização dos projetos e o grande porte dos empreendimentos, desconsiderando as diferentes realidades locais. Além de destacar que a lógica financeira do Programa está pautada em grande parte pelo papel desempenhado pelas empresas de construção, que passam a atuar como proponentes dos empreendimentos junto a Caixa. Dessa forma, a escolha dos terrenos e as características dos projetos pelas empresas são determinantes para tornar os empreendimentos viáveis ou não. Como consequência, a seleção de terrenos mais baratos, a ampliação da escala e a padronização dos empreendimentos tornamse estratégias financeiras determinantes para o desenvolvimento do Programa. Nesse contexto, o papel do Estado se restringe a facilitar a atuação do mercado imobiliário no setor de habitação social.

O desenho institucional adotado pelo programa PMCMV, no entanto, inviabiliza a possibilidade de o poder público atuar como promotor e gestor do empreendimento. A instituição financeira (Caixa Econômica Federal), por um lado, e as empresas, por outro lado, ganham centralidade em detrimento dos órgãos e instituições responsáveis pelas políticas urbanas e habitacionais (RUFINO, 2015, p.55).

A autora ressalta também que, embora as periferias atualmente sejam território muito mais dinâmico e bem equipado, ainda são carentes de atividades econômicas e de empregos, permanecendo caracterizadas pelo predomínio de uso habitacional. De modo que a concentração de empreendimentos do Programa MCMV tende a reforçar essa tendência à monofuncionalidade. Além disso, o Programa, ao optar preferencialmente por condomínios e não priorizar os espaços coletivos e públicos que estimulem a integração e sociabilidade nos empreendimentos e com a vizinhança acaba por reforçar ainda mais uma "urbanização privatizada que tende a exacerbar a segregação e guetificação dos mais pobres na cidade" (RUFINO, 2015, p.69).

Todavia, Cardoso, Aragão e Jaenischi (2017) afirmam que a partir do ano de 2014, com o agravamento da crise política e econômica do país, um novo momento no campo das políticas habitacionais se estabelece, com uma crescente priorização dos interesses do mercado e das camadas de maior renda. Como exemplo dessas transformações, os autores mencionam a diminuição gradativa dos recursos destinados aos programas sociais e as contínuas transformações pelas quais o Programa MCMV vem passando. Dentre estas transformações mais recentes do Programa MCMV os autores destacam o aumento dos juros; a variação constante no limite do valor financiado dos imóveis novos ou usados; o adiamento da terceira fase do Programa; a redução do número de empreendimentos destinados à faixa 1, ao mesmo tempo em que há uma ampliação na oferta de empreendimentos destinados a faixa 3 , ou seja, para famílias com renda mensal de até nove salários mínimos.

Antes, porém, de analisar como o Programa está sendo implementado em Curitiba, discute-se brevemente as recentes transformações da Região Metropolitana de Curitiba e do seu município polo nas últimas décadas, no que se refere à segregação espacial e a atuação do poder público na promoção de habitação de interesse social.

\section{INFORMALIDADE DA MORADIA PLANEJAMENTO URBANO EM CURITIBA}

A Região Metropolitana de Curitiba (RMC), criada em 1973, conta atualmente com 29 municípios e uma população total de 3.223.836 ${ }^{60}$ habitantes (IBGE, 2010). Concentra em seu território cerca de $30 \%$ da população do Estado do Paraná e mantém uma posição de destaque na economia paranaense. Contudo, o território da metrópole é caracterizado pela heterogeneidade e disparidades socioeconômicas. De modo que, os municípios que possuem maior integração a Curitiba, como Araucária, Pinhais e São José dos Pinhais, possuem maior dinamismo econômico e melhores indicadores sociais, o

60 Total da população dos 29 municípios pertencentes à Região Metropolitana de Curitiba. 
que se deve, em parte, a proximidade a eixos viários importantes e a instalação em seus territórios de indústrias e rede de serviços que são capazes de gerar empregos e renda. Porém, outros municípios, mesmo próximos a capital, como Piraquara e Almirante Tamandaré são altamente dependentes de Curitiba e são considerados municípios dormitórios. Além disso, há ainda aqueles que não se inserem no Aglomerado Central e se dedicam primordialmente à agropecuária e ao extrativismo, como Piên e Agudos do Sul.

Moura e Firkowiski (2014) ressaltam esta heterogeneidade, afirmando que o território da RMC é constituído por uma aglomeração metropolitana na porção central, altamente concentrada, urbanizada e ocupada que contrasta com porções tipicamente agrícolas ao sul e com a carência socioeconômica dos municípios do Vale do Ribeira ao norte. Destacam também que essa heterogeneidade não é uma especificidade, pois vai ao encontro do universo heterogêneo e diverso dos municípios que fazem parte das demais Regiões Metropolitanas do país.

A despeito da cidade polo, Curitiba, Silva (2012), coloca que ela é uma das principais metrópoles do Brasil e sua função desempenhada na rede urbana do país é resultado de uma série de transformações socioeconômicas e espaciais ocorridas ao longo das últimas décadas. A autora afirma que 0 primeiro período de grandes transformações pela qual a capital passou, ocorreu entre as décadas de 1970 e 1980, quando se deu a formação da base da estruturação metropolitana vigente. A partir da década de 1990 ocorre o segundo período de grandes transformações, é quando a dinâmica metropolitana se concretiza, desencadeando uma série de processos relacionados às mudanças nos modos de vida e produção, características da atual fase da urbanização mundial.

Entretanto, Silva (2012) ressalta que estes momentos estão relacionados a processos mais abrangentes que se estabeleceram no país em meados do século passado, como a tendência de concentração da urbanização nas metrópoles, bem como a supremacia das atividades dos setores secundário e terciário da economia. Além da expansão do capitalismo a nível mundial, caracterizada por transformações na forma de acumulação.

No que se refere à questão da moradia em Curitiba, verifica-se um aumento da população residente em assentamentos precários ao longo das últimas décadas do século passado. Em 1974, por exemplo, Curitiba contava com 4.083 domicílios informais, no ano de 1996 esse número chegou a 33.778 domicílios e em 2005 já eram 62.267 domicílios informais. O crescimento da informalidade da moradia também ocorreu nos municípios no entorno de Curitiba, sobretudo a partir da década de 1980, quando passaram a abrigar o excedente da população pobre migrante que não conseguiu se estabelecer na capital. O número de domicílios em assentamentos precários na RMC passa então de $54.161 \mathrm{em}$ 1992 para 204.635 domicílios $^{61}$ no ano de 2012 (COHAPAR, 2012; SILVA, 2012).

A Figura 1 a seguir demonstra a localização dos assentamentos precários em Curitiba e Região, bem como a localização dos assentamentos que passam por processo de urbanização através do Programa de Urbanização de Assentamentos Precários do PAC.

Esse aumento, embora tenha acompanhado a conjuntura existente no país, em que se verificou um cenário de crise econômica na década de 1980 e a uma potencialização do mercado informal de terras urbanas (ABRAMO, 2007), bem como um crescente processo de precarização e informalização das relações de trabalho nas ultimas décadas, que resultou numa insuficiência ou insegurança de renda dessa população (CARDOSO, 2007), apresenta certas particularidades na metrópole de Curitiba, de acordo com Silva (2012). A autora destaca que na formação destas áreas nos municípios no entorno de Curitiba, a ação dos proprietários de terra e incorporadores imobiliários teve papel decisivo e que as favelas estão concentradas na capital, que possui também o maior déficit habitacional (50.249 domicílios), bem como a produção de habitação social pelo Estado está centralizada em seu território.
61 O número de domicílios em assentamentos precários para a RMC em 2012 corresponde ao total estipulado para o Escritório Regional de Curitiba, que engloba a RMC e o litoral, totalizando 36 municípios. 
Mapa 1 - Localização dos empreendimentos do PAC Habitação na RMC

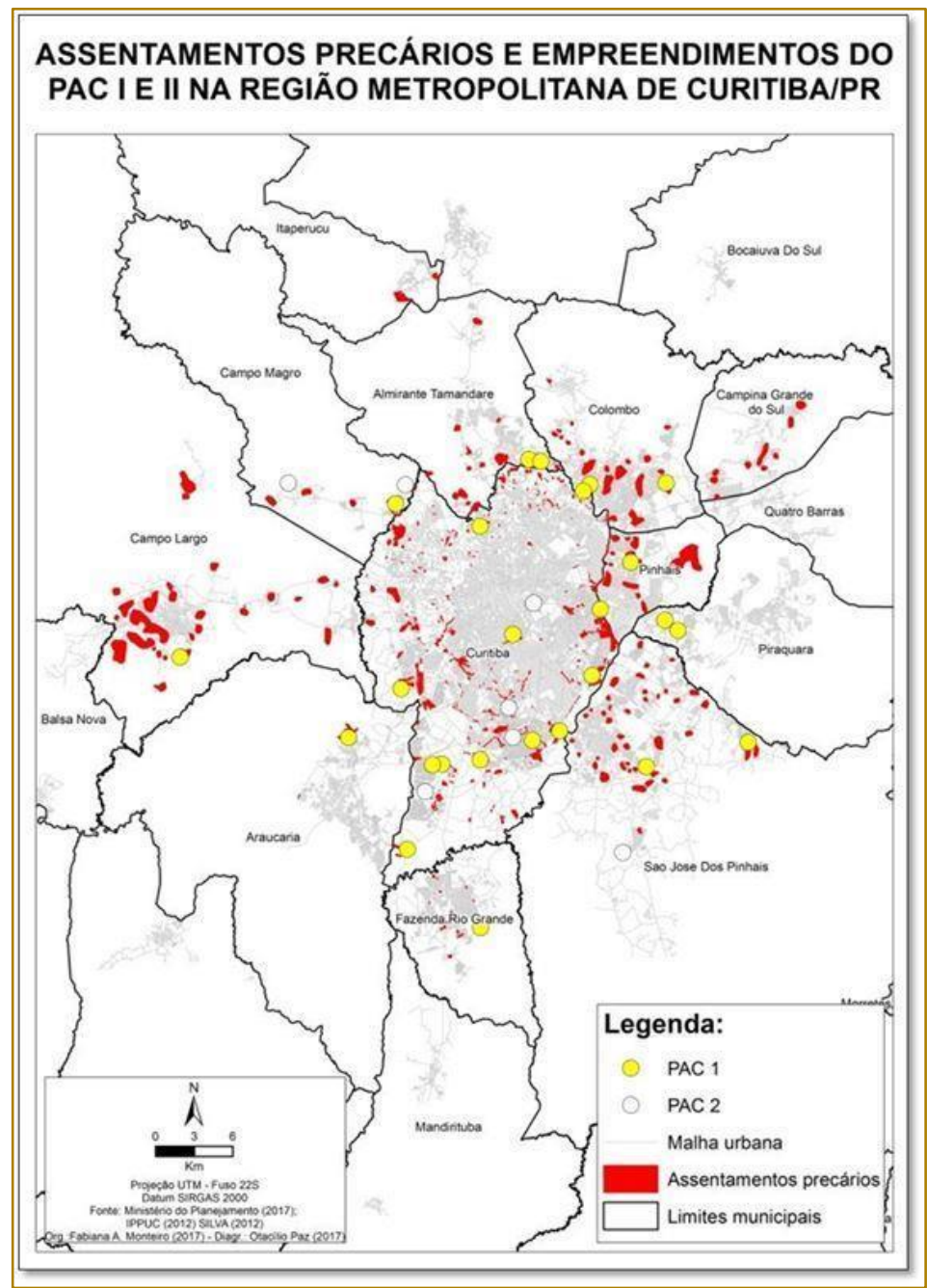

Fonte: BRASIL (2017); IPPUC (2012); SILVA (2012).

Elaboração: Fabiana Monteiro (2017); Otacílio Paz (2017).

É na capital do estado que se localizava também a maioria absoluta das atividades econômicas relevantes, assim como as camadas sociais de alta renda, de acordo com Firkowski (2001), enquanto a população de menor renda está distribuída pelos municípios periféricos. Em tais municípios, conforme Moura e Rodrigues (2009, p.4) o processo contínuo e intenso de ocupação não foi acompanhado de um processo de planejamento e gestão, bem como de políticas públicas para atender as "novas e crescentes demandas".

Nesse contexto, a ação do Estado foi mais no sentido de promover a segregação espacial do que o bem estar social das camadas de menor renda, sobretudo no município polo da RMC. A implementação do Planejamento
Urbano em Curitiba, por exemplo, em muito contribuiu para esta segregação, na medida em que serviu para atender os interesses e demandas das classes de maior renda.

De acordo com Polucha (2009), o tão afamado Planejamento Urbano de Curitiba, criado na década de 1960, mas implementado de fato em 1971, na gestão do Prefeito Jaime Lerner, através do Instituto de Pesquisa e Planejamento Urbano de Curitiba (IPPUC), teve como intervenção mais significativa a implantação de eixos lineares de desenvolvimento (Eixos Estruturais), os quais procuravam ordenar o desenvolvimento da cidade por meio da associação do sistema viário, do transporte coletivo e do adensamento construtivo. Incentivava-se também nestes eixos a habitação e a 
concentração de comércios e serviços. Contudo, estas áreas valorizadas da cidade ficaram restritas as classes de maior renda, enquanto que a população pobre foi direcionada para áreas contíguas ao polo, bem como para os municípios do entorno. Dessa forma, os interesses do mercado imobiliário foram consolidados por meio da Conectora 5 (Ecoville), um prolongamento do Eixo Estrutural Norte.

Segundo Firkowski (2009), o empreendimento Ecoville surgiu da iniciativa de quatro construtoras e da Prefeitura Municipal de Curitiba que alterou a legislação de Uso do Solo, incluindo a Zona Nova Curitiba (onde se encontrava o Ecoville) como um prolongamento do Setor Especial Estrutural, alterando assim as regras de ocupação, construção e uso, no local que inicialmente havia sido destinado a abrigar a classe trabalhadora. Dessa forma, afirma a autora, a legislação foi alterada por pressão dos incorporadores imobiliários que tinham como objetivo construir edifícios de alto padrão e muito acima dos pavimentos permitidos pela legislação anterior.

De modo que a Conectora 5, prevista para ser uma nova frente de expansão da cidade em direção a oeste e acolher a população trabalhadora da recém-criada $\mathrm{CIC}$, teve seu objetivo inicial posto de lado na sua implementação. Pois, das propostas, apenas àquela referente à implantação de infraestrutura viária foi executada pelo Estado, que permitiu que o mercado imobiliário se apropriasse desse espaço e o direcionasse para a elite curitibana posteriormente (POLUCHA, 2009).

Moura \& Rodrigues (2009) também ressaltam os efeitos do Planejamento Urbano de Curitiba na segregação espacial, na medida em que,

(...) criou elementos que valorizaram a terra urbana e a moradia do pólo e elevaram o custo de melhorias e tributos locais, tornando o processo de ocupação seletivo e induzindo o crescimento da ocupação de segmentos mais pobres para áreas periféricas internas e principalmente externas aos seus limites administrativos. Áreas nas quais haviam disponíveis lotes mais compatíveis ao poder aquisitivo desses segmentos, e cuja distância era coberta por um sistema de transporte coletivo que facilitou a comutação diária entre o local de moradia e o de trabalho (MOURA \& RODRIGUES, 2009, p. 3).
Assim como Firkowski, que ressalta que o Planejamento Urbano da capital,

(...) não foi capaz de preparar a cidade para a nova dimensão metropolitana que se apresenta na atualidade, nem tampouco relativizar a ação do capital imobiliário na produção do espaço, priorizando uma cidade socialmente mais justa, como era de se esperar tendo em vista sua 'tradição' em planejamento urbano. Ao contrário, o processo de planejamento fez aprofundar as diferenças sociais, na medida em que valorizou o solo urbano e, consequentemente, restringiu $O$ acesso de certos segmentos sociais (FIRKOWSKI, 2009, p. 23).

Tendo em vista esse cenário de crescimento da precarização e informalidade da moradia em Curitiba e municípios do entorno a partir da década de 1980, em que as ações do Estado na produção do espaço urbano formam mais no sentido de favorecer os interesses do mercado imobiliário e das classes de alta renda, contribuindo desse modo para a segregação espacial, são traçadas algumas considerações a seguir sobre a atuação da Companhia de Habitação Popular de Curitiba (COHAB-CT) no provimento de moradias ao longo das últimas décadas e por outro lado, é analisado a implementação do Programa MCMV na capital.

\section{A CRIAÇÃO DA COHAB E A IMPLEMENTAÇÃO DO PROGRAMA MCMV EM CURITIBA}

Criada em 1965 a COHAB-CT desenvolveu a longo das últimas décadas vários programas para atuar na habitação de interesse social, através da regularização fundiária, urbanização de assentamentos precários, produção de lotes urbanizados e construção de unidades habitacionais (apartamentos ou casas). Tendo concentrada as suas ações na capital, a COHAB produziu um número relevante de moradias, quando comparada a COHAPAR, ao todo foram mais de 124 mil moradias construídas em Curitiba no período entre 1967 a 2010, enquanto que a COHAPAR produziu 190.533 moradias em todo o estado, nesse mesmo período (COHAPAR, 2012).

O período de maior produção da $\mathrm{COHAB}$ ocorreu entre o final de década de 1980 e início da década de 2000, Contudo, Carvalho (2014) afirma que embora esse período tenha sido o de maior produção, a maioria das 
unidades entregues não eram imóveis construídos, mas apenas lotes urbanizados, produzidos, muitas vezes produzidos por empresas privadas. Dessa forma, os custos da produção ficavam a cargo do morador que recorreu na maioria das vezes à autoconstrução.

Além disso, grande parte da produção da COHAB desenvolvida ao longo de sua trajetória ficou restrita a algumas porções da capital, sobretudo nas áreas a sudoeste e ao sul, em bairros como a Cidade Industrial de Curitiba (CIC) e o Sítio Cercado. Estes bairros ao sul se enquadram na tipologia socioespacial popular operário, condição semelhante a dos municípios periféricos da RMC, além disso, estas áreas e incluindo os bairros localizados a leste, como o Cajuru, são as que mais abrigam assentamentos precários em Curitiba. A Figura 2 a seguir demonstra a localização em Curitiba da produção habitacional da COHAB ao longo das últimas décadas.

Figura 1 - Produção da COHAB em Curitiba

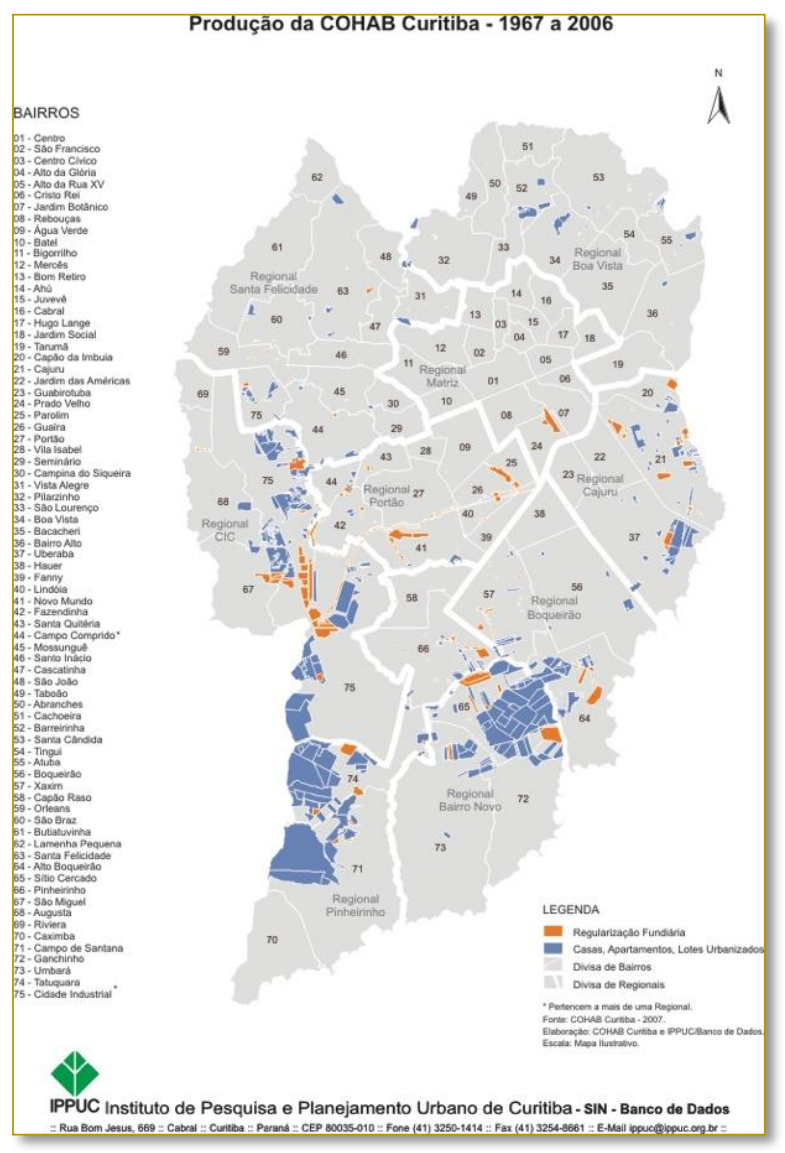

Fonte: IPPUC (2018)

A COHAB atualmente é também a responsável pela execução do Programa Minha Casa Minha Vida em Curitiba, atuando na produção de moradias destinadas as Faixas de Renda 1 e 2. Essa parceria entre a COHAB, a Caixa e a Prefeitura Municipal foi assinada em abril de 2009 e funciona da seguinte forma: a iniciativa privada apresenta os projetos e executa as obras; a Caixa aprova os projetos e libera os recursos; a Prefeitura oferece incentivos fiscais, como isenção de impostos, agiliza o processo de aprovação dos projetos e liberação do alvará de construção; e a COHAB cadastra e identifica a demanda e dá apoio à comercialização das unidades habitacionais (COHAB, 2018).

A destinação destas unidades habitacionais produzidas através da parceria COHAB/PMCMV são comercializadas conforme a faixa de renda: as famílias cadastradas e incluídas na Faixa 1 do PMCMV são selecionadas conforme as normativas do Programa que incluí alguns 
critérios como, famílias de áreas de risco, famílias onde a mulher é a responsável, famílias com pessoa com deficiência, etc. A venda nessa faixa ocorre durante a etapa de obras, com pelo menos $40 \%$ do empreendimento concluído. Já nas Faixas 1,5 e 2 as famílias são convocadas conforme a ordem de inscrição na fila da $\mathrm{COHAB}$ e a comercialização das unidades habitacionais ocorrem início das obras do empreendimento.

Conforme averiguado anteriormente, a COHAB-CT historicamente tem concentrado a produção de habitação social nas porções sul e sudoeste da capital, além de produzir alguns empreendimentos em outros municípios da RMC. Atualmente, essa produção ocorre em parceria como o PMCMV e os municípios que vem abrigando esses empreendimentos são Araucária, Campina Grande do Sul, Fazenda Rio Grande e São José dos Pinhais, conforme se pode verificar na Tabela 1. Segundo a instituição, cerca de 1,5 mil famílias inscritas para ser beneficiadas e enquadradas na Faixa 2 de renda do PMCMV estão sendo convocados para imóveis na RMC e estes empreendimentos construídos fora da capital resultam da parceria da $\mathrm{COHAB}$, da iniciativa privada e das prefeituras destes municípios para atender a demanda da população residente em Curitiba (COHAB-CT, 2017).

Tabela 1 - Empreendimentos da COHAB-CT e do PMCMV na RMC

\begin{tabular}{|c|c|c|c|}
\hline Empreendimento & $\begin{array}{l}\text { Município de } \\
\text { destino }\end{array}$ & $\begin{array}{l}\text { Total de } \\
\text { U. H./Lotes }\end{array}$ & Tipologia \\
\hline $\begin{array}{l}\text { Residencial } \\
\text { Azaleias }\end{array}$ & Araucária & 120 & Apartamentos \\
\hline $\begin{array}{l}\text { Residencial } \\
\text { Canadá I e II }\end{array}$ & Araucária & $\begin{array}{l}\text { I (288) } \\
\text { II (112) }\end{array}$ & Apartamentos \\
\hline $\begin{array}{l}\text { Residencial } \\
\text { Marumbi }\end{array}$ & $\begin{array}{l}\text { Campina Grande } \\
\text { do Sul }\end{array}$ & 47 & Casas \\
\hline $\begin{array}{l}\text { Residencial Green } \\
\text { Park Portugal }\end{array}$ & $\begin{array}{l}\text { Fazenda Rio } \\
\text { Grande }\end{array}$ & 200 & Lotes $\left(120 \mathrm{~m}^{2}\right)$ \\
\hline Residencial Milano & $\begin{array}{l}\text { São José dos } \\
\text { Pinhais }\end{array}$ & 65 & Apartamentos \\
\hline Residencial Safira & $\begin{array}{l}\text { São José dos } \\
\text { Pinhais }\end{array}$ & 224 & Apartamentos \\
\hline
\end{tabular}

Fonte: COHAB-CT (2018)

Elaboração: Fabiana Monteiro (2018)

Contudo, pode-se questionar se é legitimo direcionar esta população de menor renda de Curitiba para outros municípios da RMC, alguns com sérios problemas de infraestrutura urbana e muito distante da capital, como é o caso de Campina Grande do Sul, a 31 km de distância. Além disso, deve-se levar em consideração que estas famílias terão aumento no tempo de deslocamento até o trabalho em Curitiba e que esse incremento populacional pode sobrecarregar os serviços ofertados por estes municípios. Ademais, fica ainda a questão, por que não aproveitar os SEHIS ${ }^{62}$ de Curitiba para implementar estes empreendimentos? Mesmo que estes setores estejam demarcados nas áreas periféricas da cidade, conforme afirma Stroher (2014).

Sobre os resultados da implementação do Programa Minha Casa Minha Vida na RMC, o Quadro 1 traz informações referentes ao número de unidades habitacionais contratadas e entregues nos municípios na Faixa 1. Já o Quadro 2 na sequência, traz os valores nesses municípios referentes as Faixas de Renda 2 e 3 do Programa.

\footnotetext{
${ }^{62}$ Os Setores Especiais de Habitação de Interesses Social (SEHIS) equivalem em Curitiba as Zonas Especiais de Interesse Social (ZEIS), instrumento previsto no Estatuto das Cidades e que foram definidos no Zoneamento da capital do ano 2000 (STROHER, 2014).
} 
Quadro 1 - Unidades Habitacionais do PMCMV - Faixa 1 na RMC 2009-2018

\begin{tabular}{|c|c|c|c|c|c|}
\hline Município & $\begin{array}{c}\text { População } \\
\text { Total (2010) }\end{array}$ & $\begin{array}{c}\text { Total de } \\
\text { empre- } \\
\text { endimentos }\end{array}$ & Modali-dade & $\begin{array}{c}\text { U.H. } \\
\text { Contratadas }\end{array}$ & $\begin{array}{c}\text { U. H. } \\
\text { Entregues }\end{array}$ \\
\hline Agudos do Sul & 8.270 & 3 & Rural & 72 & 48 \\
\hline Balsa Nova & 11.300 & - & - & - & - \\
\hline Bocaiúva do Sul & 10.987 & 2 & Rural & 12 & 5 \\
\hline Campo do Tenente & 7.125 & 4 & Of. Pub./Rural & 80 & 78 \\
\hline Campo Largo & 112.377 & 3 & FAR/Rural & 447 & 17 \\
\hline Campo Magro & 24.843 & 1 & FAR-Urb. & 74 & 70 \\
\hline Cerro Azul & 16.938 & 3 & FAR/Rural & 138 & 138 \\
\hline Colombo & 212.967 & 2 & FAR/Rural & 253 & 253 \\
\hline Curitiba & 1.746 .896 & 34 & $\begin{array}{c}\text { FAR-Urb. } \\
\text { FAR }\end{array}$ & 4.856 & 4.504 \\
\hline Curitiba & - & 5 & Rural & 1.217 & 0 \\
\hline Doutor Ulisses & 5.727 & 2 & Rural & 74 & 74 \\
\hline Fazenda Rio Grande & 81.675 & 2 & FAR/Rural & 509 & 509 \\
\hline Lapa & 44.932 & 5 & FAR/Rural & 336 & 288 \\
\hline Mandirituba & 22.220 & 7 & Rural & 279 & 279 \\
\hline Piên & 11.236 & 3 & $\begin{array}{c}\text { Of. Pub. } \\
\text { Rural }\end{array}$ & 50 & 38 \\
\hline Piraquara & 93.207 & 1 & FAR & 341 & 341 \\
\hline Quatro Barras & 19.851 & 1 & Rural & 7 & 0 \\
\hline Quitandinha & 17.089 & 2 & Rural & 18 & 0 \\
\hline Rio Branco do Sul & 30.650 & 1 & Rural & 7 & 7 \\
\hline Rio Negro & 31.274 & 1 & Rural & 8 & 8 \\
\hline São José dos Pinhais & 264.210 & 10 & $\begin{array}{l}\text { FAR/Rural } \\
\text { FAR-Urb. }\end{array}$ & 1.380 & 1.380 \\
\hline Tijucas do Sul & 14.537 & 1 & Rural & 10 & 10 \\
\hline Total & 3.223 .836 & 93 & - & 10.168 & 8.047 \\
\hline
\end{tabular}

Fonte: BRASIL (2018 - Posição 30/04/2018); IBGE (2010)

Elaboração: Fabiana Monteiro (2018) 
Quadro 2 - Unidades Habitacionais do PMCMV - Faixa 2 e 3 na RMC 2009-2018 (Modalidade CCFGTS)

\begin{tabular}{|c|c|c|c|c|c|c|}
\hline Município & $\begin{array}{c}\text { U.H. } \\
\text { Contratadas }\end{array}$ & $\begin{array}{c}\text { Faixa } 2 \\
\text { U.H. } \\
\text { Concluídas }\end{array}$ & $\begin{array}{c}\text { U. H. } \\
\text { Entregues }\end{array}$ & $\begin{array}{c}\text { U.H. } \\
\text { Contratadas }\end{array}$ & $\begin{array}{c}\text { Faixa } 3 \\
\text { U.H. } \\
\text { Concluídas }\end{array}$ & $\begin{array}{c}\text { U. H. } \\
\text { Entregues }\end{array}$ \\
\hline Agudos do Sul & 3 & 3 & 3 & - & - & - \\
\hline Almirante Tamandaré & 2.074 & 1.184 & 1.134 & 246 & 246 & 244 \\
\hline Araucária & 7.129 & 5.898 & 5.729 & 2.035 & 1.491 & 1.267 \\
\hline Balsa Nova & 3 & 3 & 3 & - & - & - \\
\hline Bocaiúva do Sul & 171 & 171 & 159 & 20 & 20 & 19 \\
\hline Campina Grande do Sul & 2.099 & 2.099 & 2.066 & 243 & 243 & 243 \\
\hline Campo do Tenente & 135 & 135 & 135 & 7 & 7 & 7 \\
\hline Campo Largo & 6.783 & 4.619 & 4.601 & 652 & 652 & 597 \\
\hline Campo Magro & 1 & 1 & 1 & - & - & - \\
\hline Cerro Azul & 1 & 1 & 1 & 19 & 19 & 15 \\
\hline Colombo & 6.537 & 6.149 & 6.007 & 1.190 & 1.190 & 1.050 \\
\hline Contenda & 699 & 677 & 676 & 51 & 51 & 50 \\
\hline Curitiba & 18.808 & 16.790 & 15.479 & 8.077 & 7.821 & 6.047 \\
\hline Doutor Ulisses & 1 & 1 & 1 & - & - & - \\
\hline Fazenda Rio Grande & 16.993 & 15.271 & 15.102 & 1.317 & 1.317 & 1.314 \\
\hline Itaperuçu & 26 & 26 & 26 & 5 & 5 & 5 \\
\hline Lapa & 120 & 120 & 120 & 29 & 29 & 27 \\
\hline Mandirituba & 245 & 245 & 241 & 9 & 9 & 9 \\
\hline Piên & 63 & 63 & 63 & 12 & 12 & 12 \\
\hline Pinhais & 2.289 & 1.661 & 1.506 & 1.029 & 1.026 & 750 \\
\hline Piraquara & 4.075 & 4.075 & 4.058 & 389 & 389 & 389 \\
\hline Quatro Barras & 378 & 378 & 378 & 68 & 68 & 68 \\
\hline Quitandinha & 29 & 29 & 29 & 1 & 1 & 1 \\
\hline Rio Branco do Sul & 14 & 14 & 14 & 2 & 2 & 2 \\
\hline Rio Negro & 272 & 226 & 226 & 34 & 34 & 34 \\
\hline São José dos Pinhais & 13.700 & 10.754 & 10.192 & 5.359 & 4.113 & 3.639 \\
\hline Tijucas do Sul & 525 & 478 & 440 & 6 & 6 & 6 \\
\hline Total & 83.047 & 70.893 & 68.207 & 20.762 & 18.711 & 15.755 \\
\hline
\end{tabular}

Fonte: BRASIL (2018 - Posição 30/05/2018); IBGE (2010)

Elaboração: Fabiana Monteiro (2018)

A partir das informações contidas no Quadro 1, pode-se constatar primeiramente, que o município de Curitiba detém o maior número de contratações de unidades habitacionais voltadas para Faixa 1, com $59 \%$ do total da RMC. É possível identificar também que do total de unidades habitacionais contratadas para todas as faixas de renda (113.977 uni. hab. na RMC) apenas 9\% é destinada a Faixa 1, lembrando que a meta estipulada pelo Programa no ano de 2009, definia que $40 \%$ das unidades habitacionais produzidas deveriam ser destinadas a essa faixa de renda, na qual está concentrado o déficit habitacional do Brasil.

Comparando ainda as contratações por faixa de renda do Programa entre os anos de 2016 e 2018, verifica-se que o número de contratações voltadas a Faixa 1 está praticamente estagnada, eram 9.673 em 2016 e em 2018 esse número é de 10.168 para toda a RMC. Já a Faixa 2 foi a que teve maior número de contratações nesse período, passando de $61.394 \mathrm{em} 2016$ para $83.047 \mathrm{em}$ 2018, enquanto que a Faixa 3 , subiu de 17.448 para 20.762 contratações nesse período, confirmando as observações de Cardoso, Aragão e Jaenischi (2017), sobre o aumento da prioridade dada as camadas de maior renda nos últimos anos, em detrimento daquelas que mais necessitam (BRASIL, 2016, 2018).

Verifica-se também que depois de Curitiba, o município de São José dos Pinhais é o que mais produziu unidades habitacionais para a Faixa 1 - os dois municípios juntos, correspondem a $73 \%$ das unidades habitacionais contratadas para essa faixa de renda, no entanto, os dois municípios não apresentaram nenhuma nova contratação após o ano de 2016, quando correspondiam então a $77 \%$ do número de contratações total.

$\mathrm{Na}$ Faixa 2, Curitiba também aparece na dianteira, mas com um percentual menor, $22 \%$ das unidades produzidas nessa faixa na RMC. Logo em seguida aparece o município 
de Fazenda Rio Grande (20\%) e São José dos Pinhais com $16 \%$ das contratações para essa faixa de renda no ano de 2018.

Contudo, há algumas diferenças na implementação do Programa nestes municípios, enquanto Fazenda Rio Grande concentra a maioria absoluta das contrações na Faixa 2 de renda, em São José dos Pinhais há um número maior de contratações para a Faixa 1 e para aquelas destinadas a Faixa 3 do Programa. Este último município e Araucária são aqueles que mais concentram contratações para a faixa de renda mais elevada do Programa depois de Curitiba, já que os mesmos apresentam também maior renda da população e maior número de empregos na RMC, depois da capital.

Ademais, constata-se que os municípios de Pinhais, Araucária e Almirante Tamandaré não possuem nenhuma unidade habitacional contratada a Faixa 1, que engloba a população de mais baixa renda. Ressaltando que, de acordo com Pereira e Silva (2014), estes são alguns dos municípios da RMC que possuem maior déficit habitacional relativo. Por outro lado, o município de Araucária, possui um número considerável de contratações para as Faixas 2 e 3 . Assim como Colombo, que apesar de apresentar um déficit habitacional elevado e uma população predominantemente de baixa renda, concentra a produção do PMCMV também nestas faixas de renda.

No que diz respeito à conclusão e entrega das unidades habitacionais do Programa na RMC, ambas as faixas de renda possuem índices semelhantes: na Faixa 1, 80\% do total foram concluídas e entregues a população, na Faixa $2(82 \%)$ e na Faixa 3, $75 \%$ do total contratado havia sido entregue em 2018 (BRASIL, 2018).

O Mapa 2 traz a distribuição espacial dos empreendimentos do Programa Minha Casa Minha Vida destinados a Faixa 1 na RMC no ano de 2016.

Mapa 2 - Empreendimentos do PMCMV - Faixa 1 na Região Metropolitana de Curitiba

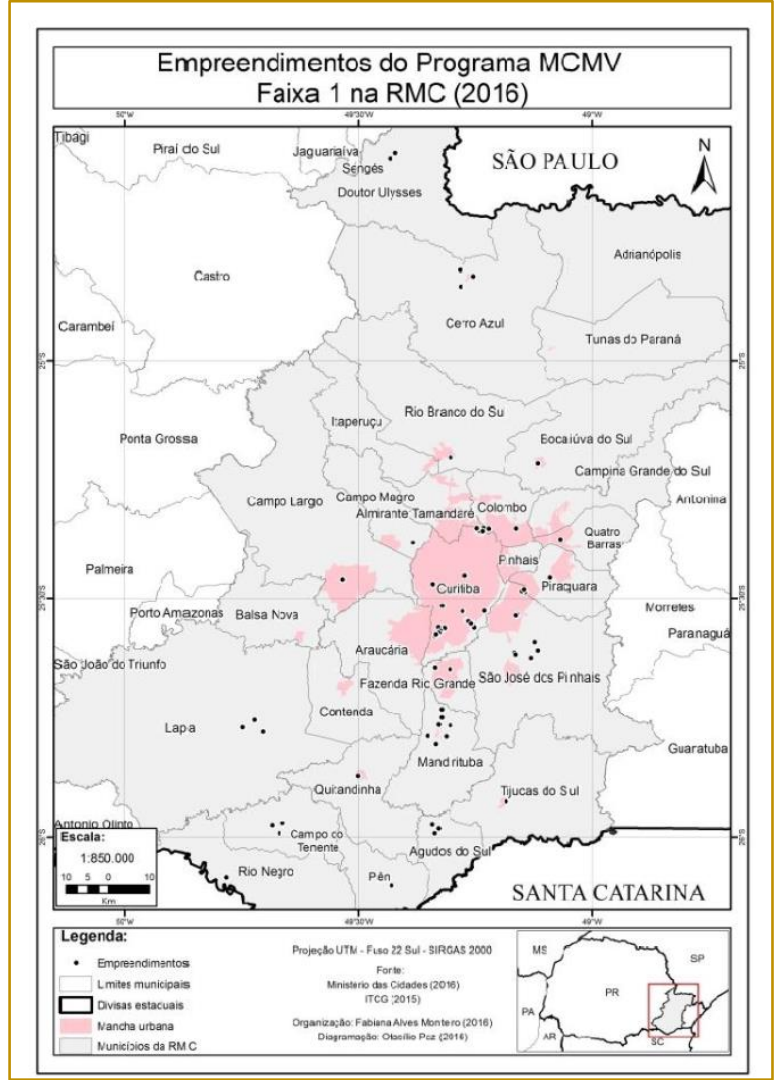

Fonte: Ministério das Cidades (2016); ITCG (2015) - Elaboração: Fabiana Monteiro; Otacílio Paz (2016)

No que diz respeito à implementação do Programa MCMV no município de Curitiba, o Quadro 3 demonstra os empreendimentos contratados para as Faixas 1 e 2 por bairro, já o Mapa 3 na sequência, permite visualizar 
estes empreendimentos no espaço urbano da

capital.

Quadro 3 - Empreendimentos do PMCMV Faixas 1 e 2 por bairro de Curitiba

\begin{tabular}{|c|c|c|c|c|c|c|c|}
\hline Bairro & $\begin{array}{l}\text { Empreendimentos } \\
\text { Faixa } 1\end{array}$ & $\begin{array}{c}\text { U.H } \\
\text { contratadas }\end{array}$ & Modalidade & $\begin{array}{c}\text { U.H. } \\
\text { Entregues }\end{array}$ & $\begin{array}{l}\text { Empreendimentos } \\
\text { Faixa } 2^{63}\end{array}$ & $\begin{array}{c}\text { U.H } \\
\text { contratadas }\end{array}$ & $\begin{array}{c}\text { U.H. } \\
\text { Entregues }\end{array}$ \\
\hline & C. P. Iguaçu I, II, III & 1.411 & FAR & 1.411 & R. Ipê I, II. III e IV & 416 & 416 \\
\hline \multirow{6}{*}{ Ganchinho } & C. R. N. Bairro I, II & 92 & FAR & 92 & R. Araca & 224 & 224 \\
\hline & C. R. N. B. III, IV & 221 & PAC & 221 & - & - & - \\
\hline & R. Buriti & 96 & FAR & 96 & C. N. Bairro V & 336 & 336 \\
\hline & PAC M. Arapoti & 37 & FAR/ Urb. & 37 & R. Rio Negro & 32 & 32 \\
\hline & PAC M. Arroio & 108 & FAR/ Urb. & 0 & R. Cerro Azul & 288 & 288 \\
\hline & - & - & - & - & R. Araucária & 80 & 80 \\
\hline \multirow[t]{6}{*}{$\mathrm{CIC}$} & - & - & - & - & R. Ilha do Mel & 288 & 288 \\
\hline & - & - & - & - & R. Antonina & 160 & 160 \\
\hline & - & - & - & - & R. Morretes & 48 & 48 \\
\hline & - & - & - & - & R. Napoli & 128 & 76 \\
\hline & - & - & - & - & R. Bergamo M. I & 160 & 28 \\
\hline & M. B. Esp. I, II, III & 720 & FAR & 720 & Moradias Laguna II & 40 & 40 \\
\hline \multirow{3}{*}{ Tatuquara } & M. Cerâmica & 194 & FAR & 194 & R. Amendoeiras & 64 & 64 \\
\hline & R. Vila Mariana & 224 & FAR & 224 & - & - & \\
\hline & R. Theo Aterino & 240 & FAR & 0 & - & - & \\
\hline \multirow[t]{5}{*}{$\begin{array}{l}\text { Santa } \\
\text { Cândida }\end{array}$} & $\begin{array}{c}\text { R. Aroeira I, II, III, IV, } \\
\text { V, VI }\end{array}$ & 440 & FAR & 440 & R. Floresta & 192 & 192 \\
\hline & R. Imbuia I, II, III, IV, V & 560 & FAR & 560 & R. V. Trieste & 240 & 240 \\
\hline & R. Pinheiros & 127 & FAR & 127 & R. S. Cryzalis & 120 & 64 \\
\hline & - & - & - & & M. N. do Bosque & 384 & 47 \\
\hline & R. S. Francisco & 48 & FAR & 48 & R. Mandic II & 116 & 51 \\
\hline Sítio & R. Caiobá & 112 & FAR & 112 & Moradias do Sitio & 70 & 70 \\
\hline \multirow[t]{3}{*}{ Cercado } & R. S. Monica & 48 & FAR & 48 & - & - & - \\
\hline & - & - & - & - & R. Palmas de Ouro I, II & 560 & 560 \\
\hline & - & - & - & - & R. Cedros & 544 & 544 \\
\hline \multirow[t]{5}{*}{ Cachoeira } & - & - & - & - & R. Figueiras & 80 & 80 \\
\hline & - & - & - & - & R. Paineiras & 144 & 144 \\
\hline & - & - & - & - & R. Illha dos Pinheiros & 216 & 216 \\
\hline & - & - & - & - & R. Santa Sofia & 208 & 208 \\
\hline & - & - & - & - & R. Cidade de Pavia & 256 & 256 \\
\hline Campo de & - & - & - & - & R. C. de Broni I, II, III & 512 & 512 \\
\hline \multirow[t]{4}{*}{ Santana } & - & - & - & - & R. Cidade de Novara & 208 & 208 \\
\hline & - & - & - & - & R. C. Padova & 419 & 419 \\
\hline & - & - & - & - & Atonina Residencial & 36 & 0 \\
\hline & - & - & - & - & Morretes Residencial & 44 & 27 \\
\hline Novo & - & - & - & - & Villa Pontoni II & 83 & 40 \\
\hline \multirow[t]{2}{*}{ Mundo } & - & - & - & - & R. B. das Palmeiras & 80 & 80 \\
\hline & - & - & - & - & Prime Palladium & 27 & 27 \\
\hline Santa & - & - & - & - & R. V. Genova & 416 & 119 \\
\hline Quitéria & - & - & - & - & R. V. Padova & 224 & 94 \\
\hline \multirow[t]{2}{*}{ Portão } & - & - & - & - & Smart 32 & 17 & 8 \\
\hline & - & - & - & - & Edifício Sessimbra & 64 & 64 \\
\hline Parolin & R. Esperança & 80 & FAR & 80 & - & - & - \\
\hline \multirow[t]{2}{*}{ Alto Boqueirão } & PAC M. Nilo & 70 & FAR/ Urb. & 66 & R. Serra Azul & 96 & 96 \\
\hline & - & - & - & - & - & - & - \\
\hline \multirow[t]{2}{*}{ Pinheirinho } & PAC M. Assai & 28 & FA/Urb. & 28 & R. Liverpool & 64 & 64 \\
\hline & - & - & - & - & Consenza Modulo I & 120 & 4 \\
\hline Fazendinha & - & - & - & - & R. M. do Campo III & 112 & 112 \\
\hline Lindóia & - & - & - & - & Oxford C. Residencial & 20 & 2 \\
\hline Xaxim & - & - & - & - & Premier Residence & 128 & 10 \\
\hline Uberaba & - & - & - & - & Galicia Residencial & 75 & 75 \\
\hline Fanny & - & - & - & - & Connection M1, M2 & 256 & 48 \\
\hline Rural & - & 1.217 & Rural & 0 & - & - & - \\
\hline * & - & - & - & - & R. S. Concord & 142 & 0 \\
\hline * & - & & - & - & * & 5861 & $5.861^{64}$ \\
\hline Total & & 6.073 & & 4.504 & & & \\
\hline
\end{tabular}

${ }^{63}$ Os dados referentes aos empreendimentos Faixa 2 por bairro se referem ao ano de 2016, já que para o ano de 2018 o Ministério das Cidades não informou os valores especificados por bairro. O valor em 2018 do número de unidades habitacionais contratadas para essa faixa de renda em Curitiba é de 18.808 e o total de unidades concluídas e entregues é de 15.479, conforme o Quadro 2 (BRASIL, 2018).

${ }^{64}$ Esse valor engloba empreendimentos e moradias individuais, financiadas tanto pela Caixa Econômica Federal como pelo Banco do Brasil (BRASIL, 2018). 
Mapa 3 - Empreendimentos do PMCMV - Faixa 1 e 2 em Curitiba

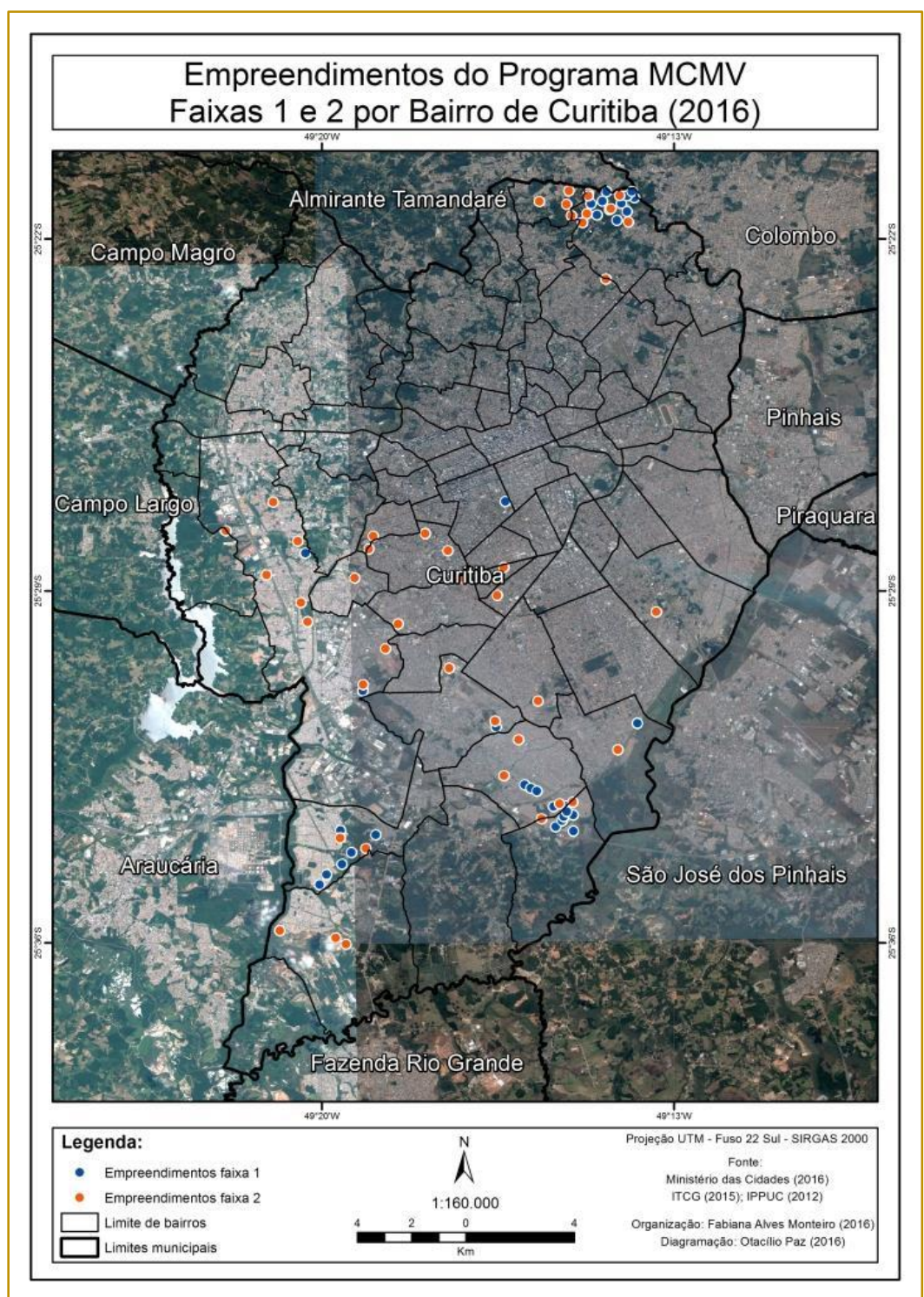

Fonte: Ministério das Cidades (2016); ITCG (2015); IPPUC (2012) Elaboração: Fabiana Monteiro; Otacílio Paz (2016)

A análise das informações contidas no Quadro 3 e no Mapa 3, permite constatar que a produção de unidades habitacionais do Programa MCMV destinada a Faixa 1 está concentrada em apenas 8 dos 75 bairros da capital, localizados sobretudo ao sul, nos limites da malha urbana e que, conforme discutido anteriormente, são tradicionalmente destinados a abrigar os empreendimentos de habitação de interesse social da COHAB, bem como abrigam também a maioria dos assentamentos precários da cidade e a população de menor renda.

Conforme exposto no Quadro 3, o bairro Ganchinho, ao sul, no limite com o município de São José dos Pinhais é o que abriga o maior número de unidades habitacionais destinadas a Faixa 1 do Programa e no total para as duas faixas de renda é o que apresenta também maior número de contratações. O bairro que em 2010 contava com uma população total de 11.178 (IBGE, 2010) é atualmente um dos que apresenta maior crescimento populacional, ocasionado, sobretudo pela implementação de empreendimentos do Programa MCMV. Nos últimos cinco anos, apenas através do Programa foram construídas um total de 2.796 novas moradias, destinadas as Faixas 1 e 2 de renda.

O bairro Santa Cândida, ao norte, no limite da capital com os municípios de Almirante Tamandaré e Colombo ocupa o segundo lugar no número de unidades habitacionais 
contratadas para as duas faixas de renda, são um total de 2.063 novas moradias construídas via PMCMV.

Constata-se que a produção habitacional do Programa MCMV destinada a Faixa 2 de renda, está relativamente melhor distribuída pelos bairros da capital conforme se pode verificar no Mapa 3. Contudo, os empreendimentos localizados nos bairros melhor inseridos na malha urbana e que apresentam melhores condições de infraestrutura e ofertas de serviços e equipamentos públicos são menores e esparsos no território. Enquanto que, os bairros mais periféricos como Cachoeira e Santa Cândida ao norte, CIC a sudoeste e Campo de Santana ao sul, abrigam os empreendimentos com maior número de unidades habitacionais.

O bairro Cachoeira é o que abriga o maior número de unidades habitacionais para a Faixa 2 de renda e o bairro Campo de Santana aparece em segundo lugar no número de contratações. Este último está localizado no extremo sul da capital, no limite com o município de Fazenda Rio Grande, a 24 $\mathrm{km}$ de distância do centro da cidade distância maior do que alguns municípios da RMC, como Pinhais e São José dos Pinhais. Até a década de 2000 apresentava características rurais, porém, de acordo com - IPPUC (2015), a partir desse período passou a sofrer os impactos do adensamento populacional na sua porção oeste.

Finalmente, ao se comparar a produção habitacional atual da COHAB, através do Programa Minha Casa Minha Vida com a de períodos anteriores, fica evidente que as regiões sul e sudoeste continuam sendo o principal destino, contudo, a partir da implementação do Programa em Curitiba a porção norte também passa abrigar empreendimentos destinados à habitação social.

Nos bairros ao sul da capital, onde se localiza a maioria dos empreendimentos do Programa MCMV, especialmente aqueles mais distantes da região central, ainda é deficiente a oferta de infraestruturas e equipamentos públicos e de lazer, reafirmando a colocação de Rufino (2015), de que as periferias ainda são carentes de empregos e a concentração da produção habitacional nestes bairros reforça a sua tendência à monofuncionalidade.

\section{CONSIDERAÇÕES FINAIS}

A partir do exposto, pode-se constatar que o poder público local em muito contribuiu para a segregação espacial na metrópole, especialmente a partir da implementação do Planejamento Urbano em Curitiba. Nesse contexto, os interesses do mercado e das classes de maior renda foram privilegiados na apropriação do espaço urbano.

$\mathrm{Na}$ atuação do poder público local na habitação popular, persistiu a segregação, na medida em que a população pobre foi destinada aos bairros periféricos e que tradicionalmente abrigam a população de menor renda. A implementação do Programa Minha Casa Minha Vida em Curitiba pouco alterou esse cenário, logo que os empreendimentos voltados às famílias de menor renda continuam sendo construídos predominantemente nos bairros que tradicionalmente já abrigavam a produção habitacional da COHAB. Verifica-se que bairros tradicionalmente com população pequena, como Ganchinho e Cachoeira estão sendo os principais destinos dos empreendimentos do PMCMV, o que pode vir a sobrecarregar a infraestrutura existente e a prejudicar a qualidade de vida dos antigos e novos moradores.

Destaca-se, que no cenário da Região Metropolitana de Curitiba, é a capital que detém o maior número de contratações do Programa para as três faixas de renda e assim como em outras metrópoles brasileiras, o Programa tem imposto aqui a padronização das moradias e o padrão de condomínio fechado, uma forma das construtoras aumentarem sua lucratividade, conforme a literatura especializada aponta. Além disso, problemas relacionados à dificuldade dos moradores se adaptarem e arcarem com as despesas dos condomínios, especialmente aqueles provenientes de assentamentos, e a violência dentro dos mesmos, como no caso do Residencial Serra do Mar, em São José dos Pinhais, são noticiados frequentemente na mídia. 


\section{REFERÊNCIAS}

[1] Abramo, Pedro. A cidade Com-fusa. A mão inoxidável do mercado e a produção da estrutura urbana nas grandes metrópoles latinoamericanas. In: Estudos Urbanos e Regionais, V. 9, n.2, 2007.

[2] Bonduki, Nabil. Origens da Habitação Social no Brasil. Arquitetura moderna, Lei do Inquilinato e difusão da casa própria. São Paulo: Estação Liberdade: FAPESP, 1998.

[3] Brasil. Ministério das Cidades. Secretaria Nacional de Habitação. 2016.

[4] Brasil. Ministério das Cidades. Secretaria Nacional de Habitação. 2018.

[5] Ministério das Cidades. Site oficial. Disponível em: <http://www.cidades.gov.brwww/index.php/minhacasa-minha-vida>. Acesso em: 17/09/17.

[6] Cardoso, Adauto Lúcio. Avanços e desafios na experiência brasileira de urbanização de favelas. Cadernos Metrópoles, São Paulo, p. 219-240, 2007.

[7] Cardoso, Adauto Lúcio; Aragão, Themis Amorim. Do fim do BNH ao Programa Minha Casa Minha Vida: 25 anos da política habitacional no Brasil. In: CARDOSO, A. L. (Org.) O Programa Minha Casa Minha Vida e seus efeitos Territoriais. Rio de Janeiro: Letra Capital, 2013.

[8] Cardoso, Adauto Lúcio; Lago, Luciana Corrêa. O Programa Minha Casa Minha Vida e seus Efeitos Territoriais. In: Cardoso, A. L. (Org.) O Programa Minha Casa Minha Vida e seus efeitos Territoriais. Rio de Janeiro: Letra Capital, 2013.

[9] Cardoso, A. L.; Aragão, T. A.; Jaenisch, S. T. Vinte e dois anos de política habitacional no Brasil: da euforia à crise. Rio de Janeiro: Letra Capital: Observatório das Metrópoles, 2017.

[10] Carvalho, André de Souza. Vivendo às margens: Habitação de Interesse Social e o processo de segregação socioespacial em Curitiba. Dissertação (Mestrado em Urbanismo, História e Arquitetura da Cidade). 314 p. Universidade Federal de Santa Catarina. Florianópolis, 2014.

[11] Companhia DE Habitação Popular de Curitiba (Cohab-CT). Site Oficial. Disponível em: <www.cohabct.com.br/>. Acesso em: 20/05/2018.

[12] Companhia de Habitação do Paraná (Cohapar). Plano Estadual de Habitação de Interesse Social do Paraná - PEHIS-PR, Curitiba, $2012 . \quad$ Disponível em: www.cohapar.pr.gov.br/.../Banner\%20Pehis/Pehis... /Pehis_Parte1>. Acesso em 13/08/2017.

[13] Correa, Roberto Lobato. O espaço urbano. São Paulo: Ática, 1989.

[14] Firkowski, Olga Lucia C. de Freitas. A nova territorialidade da indústria e o Aglomerado
Metropolitano de Curitiba. 225 f. Tese (Doutorado em Geografia), Faculdade de Filosofia, Letras e Ciências Humanas, Universidade de São Paulo, 2001.

[15] Firkowski, Olga Lucia C. de Freitas. Considerações sobre o grau de integração da região metropolitana de Curitiba na economia internacional e seus efeitos nas transformações socioespaciais. In: Moura, R.; Firkowski, O. L. C. de F. (Org.). Dinâmicas intrametropolitanas e produção do espaço na Região Metropolitana de Curitiba. Letra Capital: Observatório das Metrópoles. Curitiba, 2009.

[16] Gottdiener, Mark. A produção social do espaço urbano. 2 ed. São Paulo: EDUSP, 1997.

[17] Instituto Brasileiro de Geografia e Estatistica (IBGE). Censo 2010: Disponível em: <http://www.ibge.gov.br>. Acesso em 29/05/2018.

[18] Instituto de Pesquisa e Planejamento Urbano de Curitiba (IPPUC). Site oficial. Disponível em:<http://www.ippuc.org.br>. Acesso em 15/05/2018.

[19] Instituto de Pesquisa e Planejamento Urbano de Curitiba (IPPUC). Nosso Bairro: Cachoeira. 2015

[20] Instituto de Pesquisa e Planejamento Urbano de Curitiba (IPPUC). Nosso Bairro: Campo de Santana. 2015.

[21] Maricato, Ermínia. Urbanismo na periferia do mundo globalizado: metrópoles brasileiras. São Paulo em Perspectiva, v. 14 (4). São Paulo, 2000.

[22] Moura, Rosa; Rodrigues, Ana Lucia. (Org.) Como andam Curitiba e Maringá. Rio de Janeiro: Letra Capital, Observatório das Metrópoles, 2009.

[23] Pereira, Gislene; Silva, Jussara Maria. A rede que se espalha: Programa Minha Casa Minha Vida e acessibilidade urbana. In: Firkowiski, O. L. C.; Moura, R. (Org.) Curitiba: transformações na ordem urbana. 1. ed. - Rio de Janeiro: Letra Capital : Observatório das Metrópoles, 2014.

[24] Polucha, Ricardo Serraglio. Ecoville: A segregação urbana planejada. In: XII Encontro Nacional da ANPUR, Florianópolis, 2009.

[25] Rufino, Maria Beatriz Cruz. Incorporação da Metrópole: centralização do capital no imobiliário e a nova produção do espaço em Fortaleza. 334 p. Tese (Doutorado em de Arquitetura e Urbanismo) Faculdade de Arquitetura e Urbanismo da Universidade de São Paulo, 334 p. São Paulo, 2012.

[26] Rufino, Maria Beatriz Cruz. Um olhar sobre a produção do PMCMV a partir de eixos analíticos. In: AMORE, C. S.; SHIMBO, L. Z.; RUFINO, M. B. C. (Org.) Minha casa... e a cidade? Avaliação do programa minha casa minha vida em seis estados brasileiros. 1. ed. - Rio de Janeiro : Letra Capital, 2015. 
[27] Santos, Milton. A urbanização brasileira. 3 ed. São Paulo: HUCITEC, 1996.

[28] Silva, Madianita Nunes da. A dinâmica de produção dos espaços informais de moradia e 0 processo de metropolização em Curitiba. 259 p. Tese (Doutorado em Geografia) - Setor de Ciências da Terra, Universidade Federal do Paraná, Curitiba, 2012.

[29] Stroher, Laisa Eleonora M., Um balanço crítico da experiência de Planejamento Urbano na grande Curitiba na última década (2004-2014). XVI ENANPUR, Belo Horizonte, 2015. 


\section{Gapítulo 18}

\section{O REFLEXO DA REESTRUTURACÃO PRODUTIVA NAS CIDADES MÉDIAS: O CASO DE VARGINHA/MG}

\section{Helen Ribeiro Rodrigues}

Teresa Cristina de Almeida Faria

Resumo: Este trabalho apresenta uma análise sobre os impactos da reestruturação produtiva no espaço urbano da cidade de Varginha/MG. Parte-se da hipótese de que as mudanças territoriais e socioambientais do município objeto de análise, são decorrentes da atual organização espacial e temporal do setor industrial e logístico na cidade, destacando-se o papel da BR-381 - Rodovia Fernão Dias, do Aeroporto de Varginha - Major Brigadeiro Trompowsky e do Porto Seco Sul de Minas. A pesquisa baseou-se em análise documental da legislação urbanística municipal de Varginha e legislação aplicada aos espaços estudados, e cartográfica, comparando-se a evolução urbana das imagens aéreas do Google Earth, a fim de analisar a influência dos equipamentos urbanos na configuração territorial e socioambiental de Varginha, observando-se o avanço da urbanização e o surgimento de uma nova centralidade, impostos pelos distritos industriais e logísticos.

Palavras Chave: (Reestruturação produtiva; reestruturação urbana; cidade média.) 


\section{CONSIDERAÇÕES INICIAS}

Nas últimas cinco décadas novos padrões de urbanização são observados no Brasil, através de novas dinâmicas espaciais e urbanas. Estes padrões, mesmo reforçando ainda a concentração populacional nos grandes centros urbanos, têm possibilitado o desenvolvimento das cidades médias, através da desconcentração urbano-industrial, promovendo uma nova organização sócio espacial. Este fato é corroborado pelas redes de transportes, comunicação e serviços, integrando uma rede de logística que coloca as cidades médias em outro patamar na rede urbana. (MONTE-MÓR, 2003)

Estas novas dinâmicas na urbanização brasileira são mais evidentes na proliferação de novos centros urbanos articulados, resultantes da localização de indústrias nas periferias destas cidades, ou seja, trata-se de uma urbanização extensiva, com o avanço do tecido urbano sobre o rural, tornando estes limites mais difusos.

As mudanças atuais que observamos na organização territorial é decorrente das transformações dos processos produtivos marcadas pela crise do modelo fordista de produção, por ser este modelo parte integrante de um regime de regulação social, que implicará em formas específicas de organização espacial.

O fordismo foi o modelo de desenvolvimento dominante no Pós-Guerra, iniciado nos EUA, e tinha como princípio a organização do trabalho de forma a implicar em ganhos de produtividade, tendo como contrapartida o aumento dos investimentos provenientes dos lucros e do aumento do poder de compra dos trabalhadores assalariados. (LIPIETZ, 1997)

No final dos anos 1960, o modelo fordista entrou em crise, devido à queda de produtividade e a consequente redução na lucratividade, podendo ser interpretada como uma crise da produção em massa.

Nos anos 1980, contudo, a recessão decorrente das políticas monetaristas dos governos conservadores dos EUA e GrãBretanha resultou na queda dos salários, tendo impacto devastador na política social do Welfare State. Nesse momento, surgem alternativas para superação da crise, através de um sistema produtivo baseado em um regime de acumulação flexível. De um lado, esse sistema é conformado pelo surgimento de empresas inovadoras, com produtos voltados para uma demanda mais sofisticada; de outro, o desenvolvimento do sistema financeiro, apoiado pelo desenvolvimento tecnológico. Em resumo, o regime de acumulação flexível se baseia numa produção industrial fundada na inovação tecnológica e em novas formas de organização da produção. Há ainda o modelo que considera da superação do modelo industrial pelo terciário (Castells) e o das cidades globais, de Saskia Sassen.

A organização flexível da produção ocorre, a nível local, com empresas que estabelecem relações de interação, formando redes de empresas que possibilitam a ampliação dos mercados e uma maior cooperação empresarial, desenvolvendo economias de escala e dinamizando o território de cidades médias e seu entorno, através da reestruturação dos seus espaços intra e inter urbanos. (VÁZQUEZ-BARQUERO, 2001).

Podemos assim destacar que estas dinâmicas de desconcentração espacial das atividades produtivas são mais acentuadas na mudança do fordismo para a acumulação flexível, diretamente afetados pelo papel das cidades médias, ampliado neste novo momento do capitalismo.

Desse modo, nas últimas décadas do século $X X$, muitas das estratégias de produção e reprodução do capital passaram por transformações que influenciaram a organização do espaço da indústria e a localização dos empreendimentos industriais no território mundial e também no Brasil.

Em relação às áreas industriais, a transformação do modelo tradicional de cidade industrial está associada "a uma nova forma de organização do mercado imobiliário: o megaprojeto ou o superespaço multifuncional privado (complexos empresariais e os shopping centers), associado a um esvaziamento e à degradação das áreas de atividade industrial" (ROLNIK, 1994 apudBOTELHO, 2002).

Segundo Botelho (2002), as áreas para onde as indústrias migram, resultam na formação de novos aglomerados industriais articulados à metrópole, novos ramos industriais e novas formas de produzir. Estas áreas também sofrem transformações espaciais, que de acordo com o autor, "acirram as contradições próprias ao modo de produção capitalista em sua fase contemporânea". 
Sassen (s./d.) diz que a dispersão espacial das atividades econômicas associadas à globalização contribuem para uma procura de novas formas de centralização territorial da gestão de operações e controle de alto nível, resultando em novas categorias de lugar e processo de produção.

Com a reestruturação produtiva, as cidades médias têm desempenhado um papel importante tanto em relação à integração quanto ao desenvolvimento regional. Sposito (2007) afirma que as cidades médias desempenham funções de acordo com as relações hierárquicas envolvendo as cidades pequenas que necessitam dos bens e serviços oferecidos pelas cidades médias, e com as cidades grandes que desempenham papéis de integração nacional ou internacional. O autor relata que as cidades médias têm sido escolhidas como "pontos de apoio de diferentes tipos de empresas, sejam de ramos industriais ou de ramos comerciais, em suas políticas de desconcentração das atividades produtivas e de expansão das redes de comercialização de bens e serviços".

No panorama brasileiro, onde a industrialização concentrava-se ao redor da cidade de São Paulo, Caiado (2004) afirma que houve ampliação da área de localização industrial ocasionada pela expansão da produção em setores tradicionais e em menor proporção pela "extrapolação das fronteiras estaduais e localização em estados vizinhos a São Paulo" (especialmente no sul de Minas, norte do RJ e no Paraná), "incorporação de novos espaços produtivos" (Centro-Oeste e alguns Estados nordestinos) e "consolidação de outros" (estados do Sul, Minas Gerais, Espírito Santo, Pará e Amazonas).

\section{A CIDADE DE VARGINHA/MG}

O município de Varginha, fundado em 1882, conta com localização privilegiada e estratégica, equidistante das três principais capitais do Brasil: São Paulo, Rio de Janeiro e Belo Horizonte, em razão de situar-se na região sul do estado de Minas Gerais.

Varginha é a terceira cidade mais populosa do Sul de minas com mais de 123 mil habitantes, sendo a maior parte da população urbana e seu IDH é 0,778 (IBGE, 2010).

Segundo o IBGE, o setor terciário ocupa $53,2 \%$ do total da população economicamente ativa varginhense, o setor secundário ocupa $34,3 \%$ e o setor primário apenas $12,5 \%$. Além disso, o município de Varginha possui o quarto maior PIB da Região do Sul de Minas e um dos maiores do estado de Minas Gerais.

O município possui o Porto Seco Sul de Minas, que consiste em uma estação aduaneira do interior (EADI). $\mathrm{Na}$ cidade, existem diversas empresas que atuam na área de comércio exterior, e que trabalham diretamente com serviços de importação e exportação, fator que influenciou grandes empresas multinacionais a montarem unidades na cidade e região, como PhilipsWalita, Philips Lighting, CooperStander, Coletek, Plascar, dentre outras, resultando em um total de 5.271 empresas atuantes em Varginha.

Figura 1 - Localização estratégica de Varginha em relação às capitais.

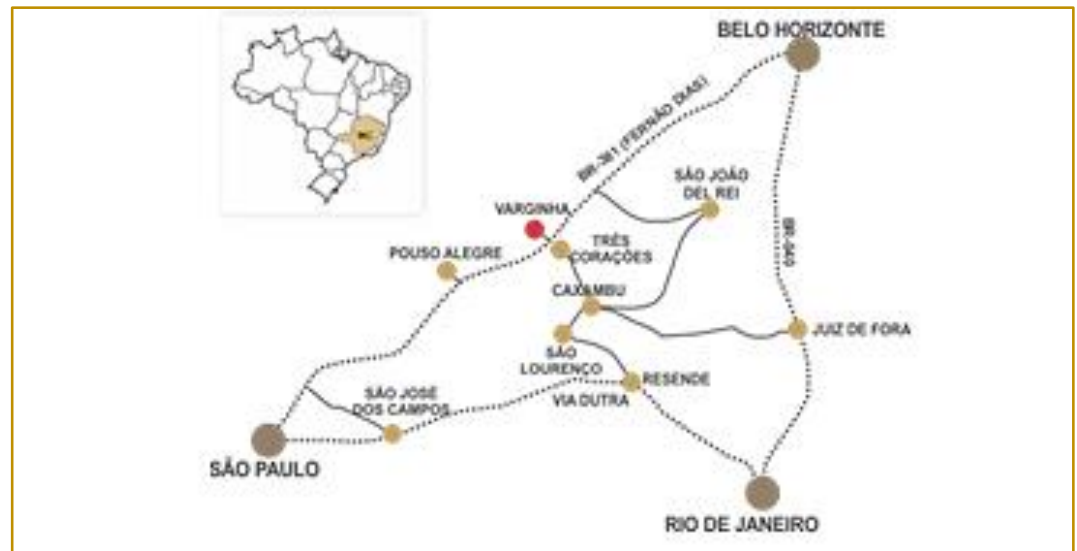

Fonte: elaborada pelas autoras (2016). 


\section{DESENVOLVIMENTO URBANO VARGINHENSE AO LONGO DA HISTÓRIA}

A cidade de Varginha originou-se através da construção de uma pequena capela erguida por bandeirantes que transitavam pelo local como homenagem a companheiros que ali foram sacrificados por índios. No entorno da capela ergueram-se ranchos de pouso para os viajantes que seguiam para a atual cidade de Campanha.

Em 1806, o pequeno arraial, nomeado de Catanduvas, já possuía cerca de mil habitantes e houve a doação de território para o desenvolvimento do núcleo urbano, primeiramente com a construção da capela do Divino Espírito Santo das Catanduvas. Lefort (1950 apud Sales, 2003, p. 219), afirma que o processo de urbanização do povoado foi muito acelerado:

Um progresso ultra-rápido operou-se em Catanduvas. Assim é que em oito anos de existência (1795 a 1803), mais de 70 famílias para ali se locomoveram. Todas, defendendo seus interesses e cuidando de suas atividades.

Os primeiros habitantes do local se dedicavam à garimpagem de ouro, porém, devido à sua inexistência, voltaram suas atividades para a agricultura e criação de gado. Segundo Sales, a evolução de Varginha foi mais acentuada no período de 1850 a 1881, ao serem ali construídas as primeiras obras destinadas ao serviço público como prédios para escola e cadeia, desencadeando assim o primeiro surto desenvolvimentista da cidade. O povoado torna-se vila de Varginha em 1881 e em 1882 é elevada à categoria de cidade. No ano de 1885, inicia-se o cultivo de café na região.

O segundo boom desenvolvimentista da cidade provém do fim da escravidão, em 1888. Para substituir a mão-de-obra escrava, a cidade de Varginha recebeu 1.020 imigrantes italianos.

A inauguração da Estação de Varginha, em 1892, pela Estrada de Ferro Muzambinho, marcou o terceiro surto de desenvolvimento urbano. De acordo com Fonseca \& Liberal (1920 apud Sales, 2003) "com a estrada de ferro recobrou a cidade a sua antiga força comercial". Neste período, a cidade recebeu suas primeiras empresas e várias casas comerciais se instalaram e se consolidaram ao redor da estação. Em 1920, Varginha possuía 113 estabelecimentos de beneficiamento do café. São dessa época duas obras básicas de infraestrutura: as primeiras obras de calçamento e a iluminação pública, de gás acetileno e postes de metal.

No fim da década de 1940, no governo de Getúlio Vargas, foi construído o aeroporto Major Brigadeiro Trompowsky, preparado para prestar informações eficientes a navegação aérea. Suas instalações foram melhoradas em 1951 com a construção do terminal de passageiros que foi reformulado em 1987. A partir de 1984, com o balizamento do aeroporto (iluminação noturna), a cidade passou também a servir de ponto de convergência e vértice do tráfego aéreo.

Com a inauguração da Rodovia Fernão Dias (BR-381), em 1960, observa-se que aos poucos o perfil da economia agrícola foi cedendo espaço, ainda de forma tímida, para a indústria. Nesta época, Varginha possuía trinta estabelecimentos industriais. Além disso, a indústria cafeeira (beneficiamento e exportação) ultrapassou a produção (lavoura) na cidade.

Devido à expansão e mobilidade urbana, em 1982, o terminal rodoviário da cidade, anteriormente localizado na área central, foi deslocado para o local de acesso à rodovia BR-491, visando facilitar a acessibilidade, principalmente para a BR-381 - um dos principais eixos rodoviários nacional, e amenizar o trânsito na região central de Varginha.

A partir da década de 1970, o parque industrial contemporâneo de Varginha começou a tomar forma com empresas como Moinho Sul Mineiro, Café Bom Dia, Pólo Films, Plavigor, FL Smidth, Heatmaster, CBC e Cooper Standard.

Em 1993, Inaugurou-se o Porto Seco Sul de Minas, a primeira Estação Aduaneira do Interior a entrar em funcionamento do país. Diversas empresas, inclusive multinacionais, foram atraídas pela presença do Porto Seco e a facilidade de acessibilidade e transporte local, pois Varginha conta com localização privilegiada e estratégica. O município está situado às margens do Lago de Furnas e equidistante das três principais capitais do Brasil: São Paulo, Rio de Janeiro e Belo Horizonte, além de ser próximo de cidades importantes como Campinas, Ribeirão Preto e região do Vale do Paraíba.

Recentemente foi construído em Varginha o CIT - Condomínio Industrial Tecnológico, um 
parque tecnológico de propriedade do Porto Seco que tem como propósito abrigar empresas de alta tecnologia e centros de distribuição, tendo dentro da área serviços aduaneiros, transporte aéreo e terrestre, escritórios administrativos e incentivos fiscais.

Em 2012, o Porto Seco Sul de Minas foi transferido para o Condomínio Industrial Tecnológico e o aeroporto da cidade está em processo de elevação de categoria para atender o fluxo cargueiro além de passageiros.

A vocação agrícola de Varginha foi sendo substituída pela indústria e prestação de serviços. O mesmo ocorreu com o café. Hoje, os números da torrefação e da exportação do café são extremamente mais expressivos do que a lavoura do município.

Observa-se que Varginha sofre as transformações que vêm ocorrendo nas cidades médias. Há o processo de instalação de indústrias e galpões logísticos na cidade. Em 2016, inaugurou-se o primeiro shopping, Via Café Garden Shopping. Além disso, nota-se a construção de condomínios residenciais de médio e alto padrão. Estas modificações espaciais vêm ocorrendo principalmente nos vetores de expansão provocados pela localização do aeroporto e do Porto Seco Sul de Minas, dos distritos industriais e pelos serviços oferecidos em Varginha, tendo como consequência o crescimento de infraestrutura e urbanização.

\section{NOVAS PERSPECTIVAS DE DESENVOLVIMENTO DO ESPAÇO URBANO VARGINHENSE}

A propagação do meio técnico científico e informacional nas últimas décadas do século $X X$ impôs novos comportamentos, principalmente nos fluxos da produção, do capital, da inovação e das informações, provocando uma reestruturação espacial. Dessa forma, os territórios se reestruturam com base na infraestrutura que sustentam as redes de circulação, interação e de informação.

A reestruturação urbana está baseada na desconcentração populacional e empresarial em direção a novos centros periféricos que passam a se constituir como novas centralidades com poderes econômicos regionais (SILVEIRA; CAMPOS, 2014). Com esse processo observa-se uma tendência a descentralização e dispersão espacial. Neste contexto, compreende-se a reestruturação urbana por um processo de transformação econômica mais profunda da cidade, ocasionado pela reestruturação produtiva, abarcando e promovendo novas relações econômicas, políticas e sociais, que resultam no estabelecimento novas formas de (re)organizar e (re)configurar o espaço da cidade. Este processo, quando concretizado, implica em uma nova relação da rede de cidades, modificando toda a lógica econômica e política preexistente (CARVALHO, 2013).

No entanto, perante o novo cenário da sociedade pós-industrial, compreende-se que o desenvolvimento regional não é somente a instalação de indústrias em determinado local, mas também o importante papel das inovações tecnológicas produzido pela agregação de valor aos produtos e serviços (VASCONCELOS, 2007).

\section{OS DISTRITOS INDUSTRIAIS VARGINHENSES E SUAS INFLUÊNCIAS NA URBANIZAÇÃO}

O conceito de "Distrito Industrial", proposto por Marshall (1890) no século XIX, tinha como intuito caracterizar as aglomerações de pequenas e médias empresas no entorno das grandes indústrias que se situavam nos subúrbios das cidades inglesas. Nestes distritos industriais ingleses, as diversas empresas se implantavam e interrelacionavam, produzindo mercadorias em larga escala visando atender o mercado interno e principalmente o mercado externo.

O fenômeno do desenvolvimento econômico local estimulado pelos distritos industriais, intensificado pela desconcentração produtiva, gerou interesse por parte de pesquisadores e órgãos públicos desencadeando na mudança das políticas públicas de desenvolvimento socioeconômico. Tal panorama resultou na reprodução do modelo dos distritos industriais em diversas partes do território brasileiro, de acordo com as particularidades locais.

Atualmente, o Município de Varginha possui seis distritos industriais, sendo eles: Distrito Industrial Cláudio Galvão Nogueira Condomínio Walita, Distrito Industrial J.K. (Interflex, Metalúrgica Varginha, entre outras), Distrito Industrial Reinaldo Foresti (Plascar, Café Rio Doce, etc.), Distrito Industrial Miguel de Luca (Coleção, KOP, etc.), Condomínio Industrial I (Proluminas, PPPrint, Electroplastic, 
EcoBrasil, etc.) próximo à Fazenda Experimental do Pro-Café, Condomínio Industrial II (Leste Minas, Café Rio Doce, UNICAFÉ, etc) e um Condomínio Industrial Tecnológico (CIT), pertencente ao Grupo Unecom, que atua junto ao Porto Seco e se encontra no entorno do sítio aeroportuário da cidade.

Na figura 2 são apresentados os locais com características predominantemente industriais e logísticas dentro do espaço urbano varginhense

Figura 2 - Distritos industriais do Município de Varginha

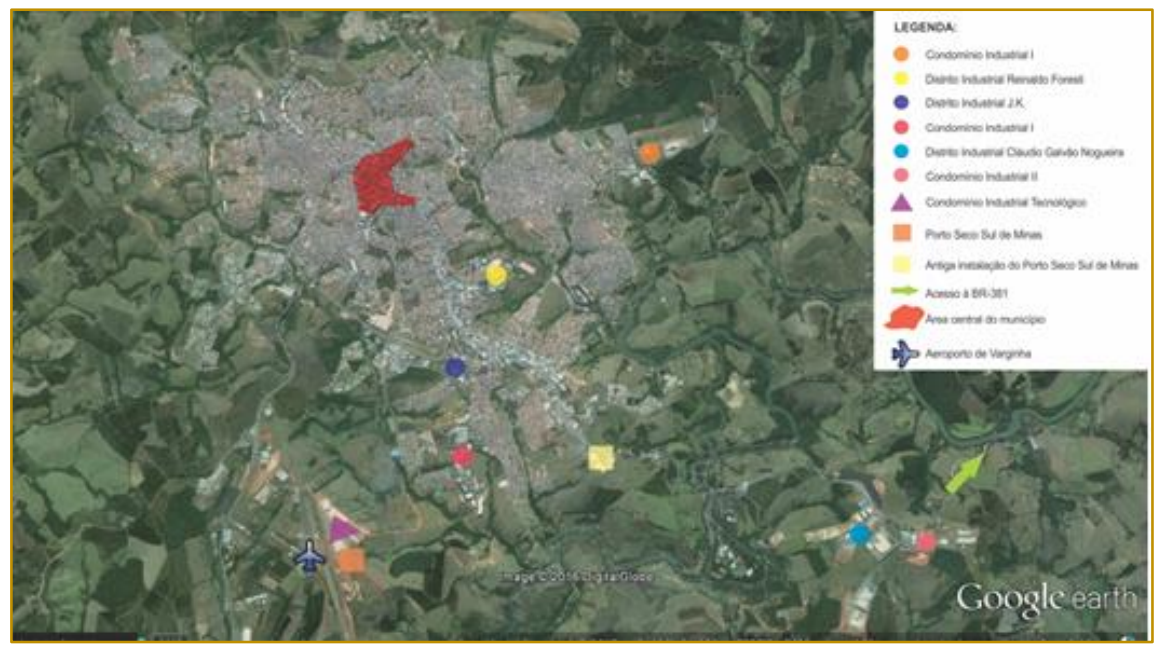

Fonte: figura elaborada pelas autoras, a partir de dados do Google Earth Pro - versão 7.3(2016).

A partir da observação direta, percebe-se que a maioria dos distritos industriais de Varginha localizam-se próximos a rotas de fácil acesso para o aeroporto de Varginha e/ou para a BR381, principal ligação entre as regiões metropolitanas de Belo Horizonte e São Paulo. A rodovia faz parte de um dos mais importantes eixos de transporte de cargas (principalmente carne bovina, produtos industrializados, móveis, veículos, grãos, aço e madeira) e de passageiros de todo o Brasil, passando por municípios de médio porte como Lavras, Varginha, Três Corações, Santa Rita do Sapucaí, Pouso Alegre e Extrema, no Sul de Minas.
Um dos distritos industriais varginhenses que mais vem se destacando devido, principalmente, à sua localização é o Distrito Industrial Cláudio Galvão Nogueira. Este distrito originou-se em 1998 para a implantação de uma filial da indústria Philips do Brasil Ltda, que ocorreu em de 1999. A partir de 2005, por meio da lei municipal n-4379/2005, o local foi ampliado. Outras desapropriações visando a ampliação do distrito ocorreram no decorrer do tempo.

Na figura 3 é possível observar que além da indústria Philips do Brasil Ltda, existiam outras três empresas menores, sendo uma concessionária de caminhões e duas empresas, no ano de 2003. 
Figura 3 - Ocupação e uso do solo no Distrito Industrial Cláudio Galvão Nogueira em 2003.

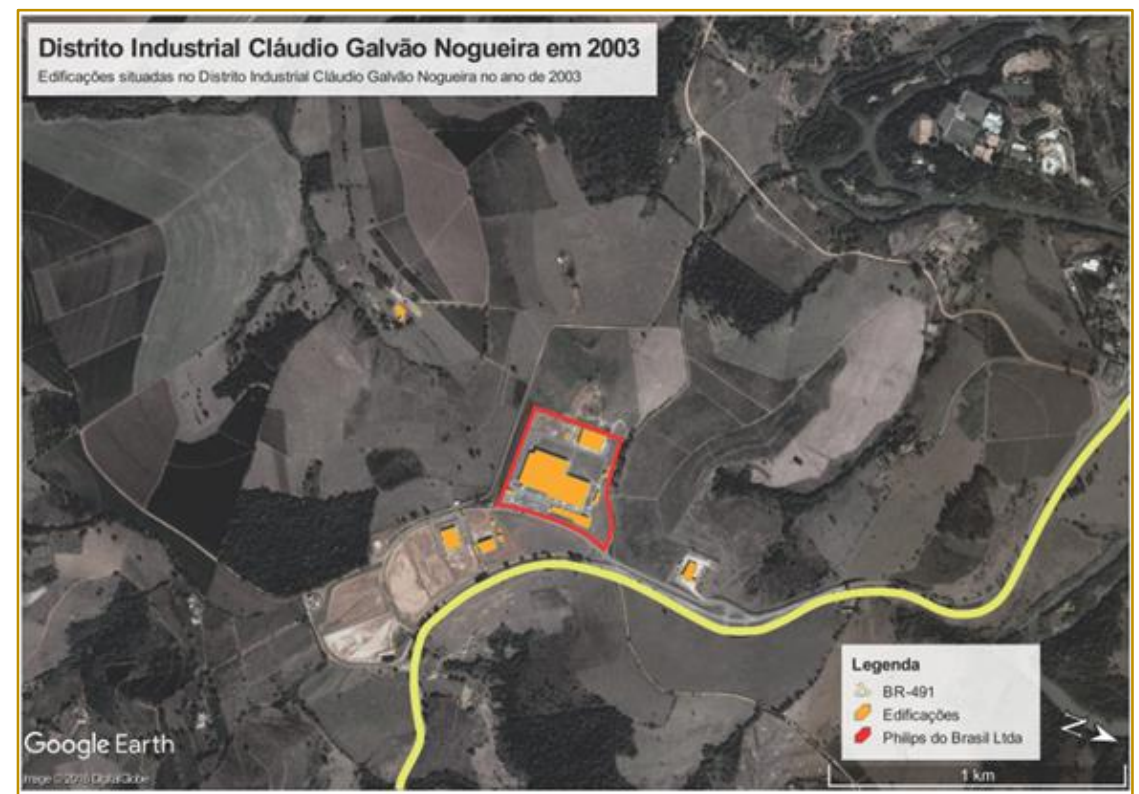

Fonte: figura elaborada pelas autoras, a partir de dados do Google Earth Pro - versão 7.3(2016).

O distrito encontra-se às margens da BR-491 que dá acesso à cidade de Varginha e à Rodovia Fernão Dias (BR-381). Tal localização gerou a atração de empresas de diversos setores para o espaço.
Através da comparação entre configuração espacial do distrito no ano de 2003 (figura 3) e no ano de 2015 (figura 4), é possível observar a expansão territorial do distrito e sua crescente ocupação.

Figura 4 - Ocupação e uso do solo no Distrito Industrial Cláudio Galvão Nogueira e Condomínio Industrial

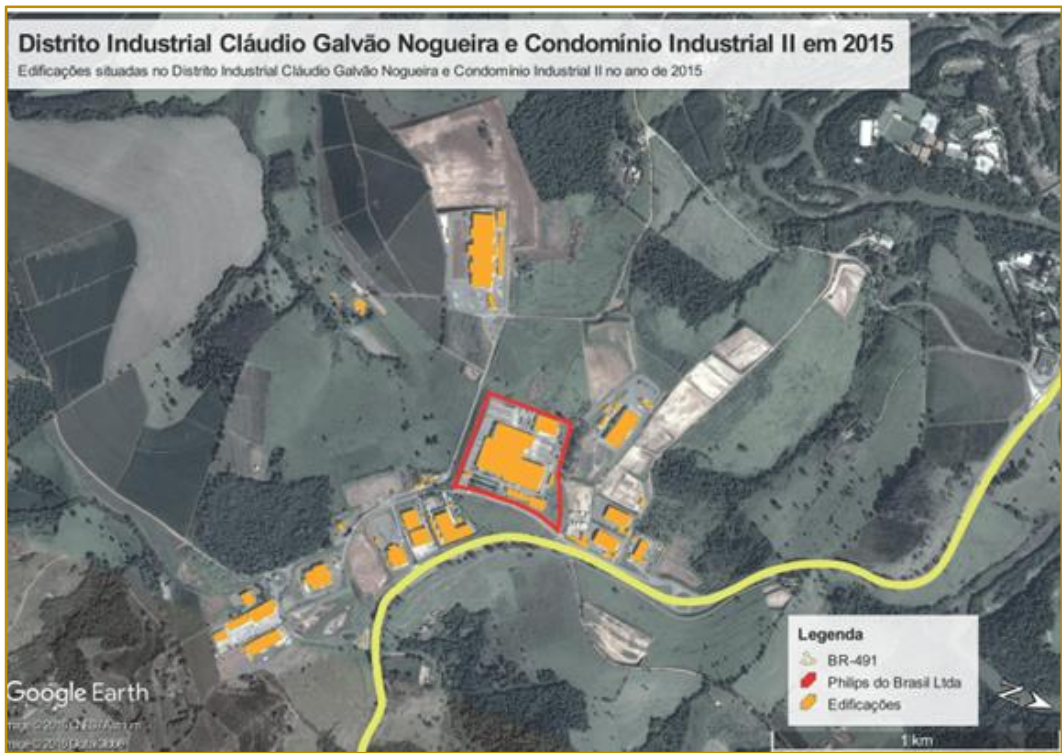

Fonte: figura elaborada pelas autoras, a partir de dados do Google Earth Pro - versão 7.3 (2016).

Atualmente, além do Distrito Industrial Cláudio Galvão Nogueira, foi criado também o Condomínio Industrial II que localiza-se limítrofe ao distrito estudado. O Condomínio Industrial || ou Condomínio Industrial Ouro Verde, construído em uma área de 300 mil m², 
foi ocupado inicialmente por três armazéns de café. As empresas produtoras já possuíam instalações em regiões centrais da cidade, no entanto, o objetivo da transferência foi reduzir o tráfego de caminhões no interior do espaço urbano varginhense, melhorando tanto o trânsito urbano quanto a circulação da produção cafeeira por meio do modal rodoviário.

O espaço delimitado pelos dois ambientes industriais conta com empresas como: Philips do Brasil Ltda-Divisão Walita, Philips Lighting, CRW, Wellus Brasil, FBM Transportes Ltda, Nova Página, Trans-Lume, Dexcom, Enermax Sistema de Energia, Armazéns Gerais Leste de Minas, entre outras.

Devido à localização estratégica de Varginha em relação ao eixo São Paulo - Belo Horizonte - Rio de Janeiro, região de grande importância para o território nacional, aliada à localização do distrito industrial em estudo, percebe-se que houve a atração significativa de indústrias para o local.

Ao analisar as edificações industriais entre os anos de 2003 e 2015, nota-se o crescente investimento em infraestrutura da área, além do aumento e ampliação das ocupações. O ambiente industrial se expande às margens da BR-491, buscando principalmente acessibilidade e conectividade com a BR-381, como forma de otimizar a circulação de matéria prima e produtos finais destas empresas.

O local compreende cada vez mais aspectos relacionados às funções de articulação e a posição geográfica que desempenha na rede urbana regional, nacional e internacional, resultando em um receptor de investimentos públicos e privados instigante para o setor industrial e para a gestão urbana no que tange à urbanização do espaço.

\section{SURGIMENTO DE UM NOVA CENTRALIDADE}

Com intuito de implantar um ponto estratégico à prestação de informações aéreas do território brasileiro, o aeroporto de Varginha, nomeado Major Brigadeiro Trompowsky, foi construído em 1948.

Situado a $5 \mathrm{~km}$ do centro da cidade na direção sudoeste, o sítio aeroportuário tem como acesso principal a Rodovia BR-491 que liga Varginha à Elói Mendes e localiza-se a
925 m de altitude, em posição estratégica, operando no cruzamento das rotas Rio Brasília e Belo Horizonte - São Paulo. Sua pista possui 2.100 metros de extensão por 30 metros de largura, e nela é possível a operação de aviões do porte Fokker-100, com capacidade para 122 passageiros. Devido à sua localização estratégica, o aeroporto de Varginha vem se destacando na região como local de logística adequada para centros de distribuição, empresas de grande porte e comércio exterior.

Através da recente instalação do Condomínio Industrial Tecnológico (CIT) próximo ao sítio aeroportuário, da construção da cidade universitária do UNIS e da locação de grandes empresas relacionadas com o setor agrícola, principalmente cafeeiro, nota-se que há a intenção de ocupar as áreas próximas ao aeroporto com atividades voltadas para o setor de logística das indústrias e do setor agrícola da região. Além disso, existe a conexão com um polo de ensino, configurando assim, o aeroporto como indutor do desenvolvimento da região e criando base para a implantação do conceito de aeroportocidade.

Segundo Vasconcelos (2007), o termo aeroporto-cidade resume o novo perfil aeroportuário do século XXI. O aeroporto é administrado como um negócio com o intuito de desenvolver socioeconomicamente a região na qual está inserido. Ao redor do aeroporto em si são construídos hotéis, shopping centers, parques industriais e tecnológicos, centros de convenções, entre outras edificações, unindo, as atribuições de um terminal aeroportuário com as características de shopping center, com comércio diversificado, restaurantes, áreas de lazer, além de serviços de logística de carga aérea.

No âmbito da infraestrutura de acesso a estes locais, os investimentos em transporte e a diversificação dos modais são válidos, uma vez que a melhoria do transporte poderá gerar um crescimento da região e o desenvolvimento dos municípios ao seu entorno.

Em 2003 já existiam edificações ao redor do sítio aeroportuário (Figura 5). No entanto, tais edificações consistiam em residências, fazendas e apenas alguns armazéns de grande escala. 
Figura 5 - Ocupação e uso do solo no entorno do sítio aeroportuário em 2003.

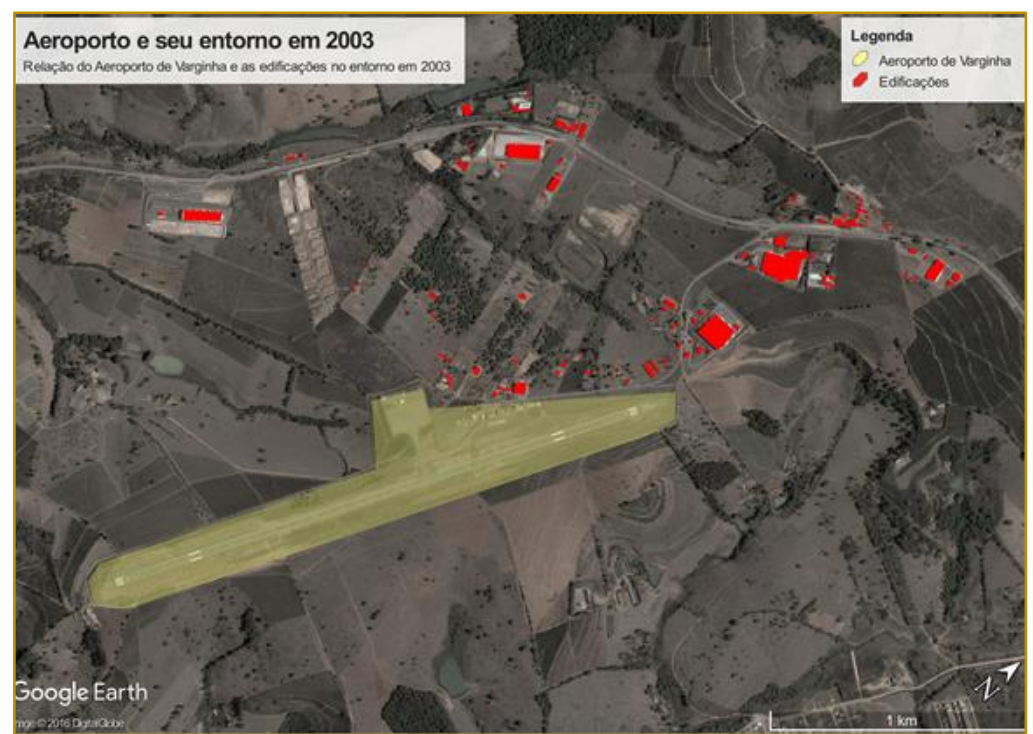

Fonte: figura elaborada pelas autoras, a partir de dados do Google Earth Pro - versão 7.3 (2016).

Com investimentos em infraestrutura aeroportuária e de acessibilidade ao aeroporto, houve o aumento do interesse do setor industrial e logístico na área.

No ano de 2012, com a transferência do Porto Seco Sul de Minas para o entorno do aeroporto e a implantação do Condomínio Industrial Tecnológico, a urbanização da área em estudo foi intensificada.

O Condomínio Industrial Tecnológico (CIT) conta com uma área de aproximadamente $1.300 .000 \mathrm{~m}^{2}$. O CIT é um parque tecnológico que tem como papel abrigar empresas de alta tecnologia, abarcando serviços aduaneiros, transporte aéreo e terrestre, escritórios administrativos e incentivos fiscais. Aliado ao porto seco, o CIT foi construído com o intuito de alavancar as exportações na região e a importação de matéria prima, peças e produtos. Além disso, houve a melhoria das instalações físicas do Porto Seco Sul de Minas que dobrou a capacidade de armazenamento de duzentos e cinquenta para quinhentos containers. Atualmente a estação aduaneira do interior atende cerca de trezentas empresas da região.

A figura 6 apresenta a transformação do espaço urbano varginhense que vem ocorrendo ao redor do aeroporto de Varginha.

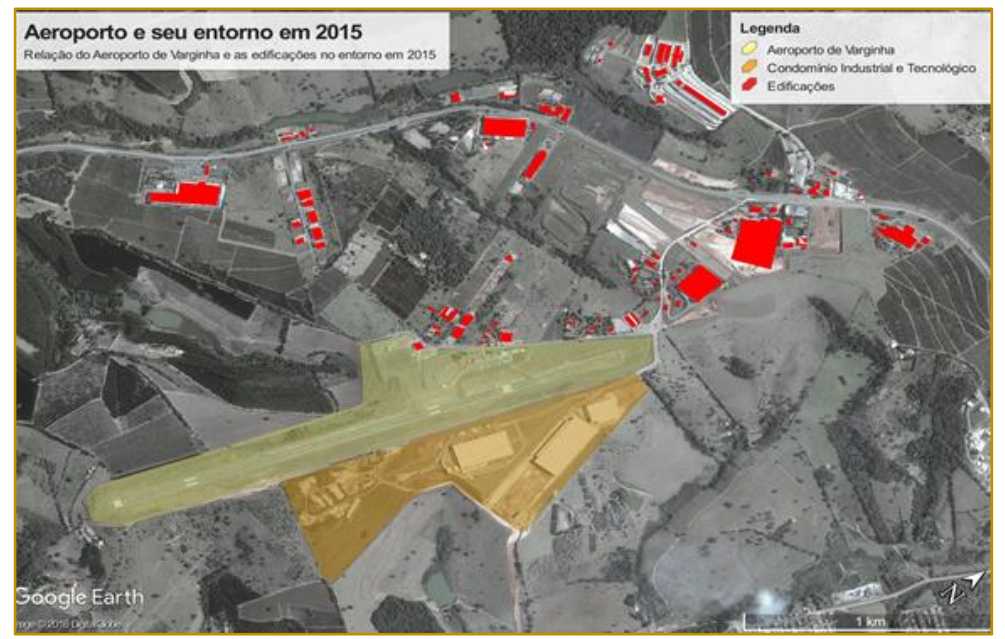

Fonte: figura elaborada pelas autoras, a partir de dados do Google Earth Pro - versão 7.3

Ao comparar as imagens aéreas obtidas nos anos de 2003 e 2015, observa-se que houve a atração de alguns setores para o local. Após a nova configuração espacial dinamizada 
pelo aeroporto e porto seco, diversas empresas logísticas vêm ocupando áreas próximas, e as já existentes ampliaram suas edificações. Além disso, atualmente a cidade universitária do Centro Universitário do Sul de Minas (UNIS) encontra-se implantada à margem oposta da BR-491 em relação ao sítio aeroportuário. Observa-se também, através da figura 6 , que diversos lotes vagos vêm sofrendo intervenções no solo com intuito de construir novas edificações, resultando assim na expansão da urbanização da área.

Os equipamentos situados no local vêm desempenhando o papel de articuladores do espaço, incentivando a ocupação e uso do solo principalmente pelo setor logístico e industrial. Deste modo, atuam como ferramentas logísticas para as empresas da região além de atrair investimentos para este mesmo local. Este novo panorama espacial transforma-o em um elemento precursor do desenvolvimento regional, impulsionando a geração de empregos e rendas e atraindo outros tipos de investimentos decorrentes de prestações de serviços necessárias ao funcionamento de tais equipamentos.

\section{NOVA CONFIGURAÇÃO DO ESPAÇO URBANO VARGINHENSE}

As alterações que vêm ocorrendo no espaço urbano varginhense são impactadas especialmente pela localização geográfica de Varginha. A equidistância entre Varginha e as seguintes capitais: São Paulo $(316 \mathrm{Km})$, Belo Horizonte (313 Km) e Rio de Janeiro (390 Km) favorece a logística industrial, potencializando a atração de investimentos para a economia da região. Além disso, a Rodovia Fernão Dias que localiza-se próxima ao acesso de Varginha, consiste em um importante eixo de distribuição de produtos e equipamentos no eixo São Paulo - Belo Horizonte.

A alta concentração de indústrias no Sul e Sudoeste de Minas Gerais, demanda estratégias de planejamento que visem a otimização da logística de transporte na região. No caso estudado, as indústrias possuem como única alternativa para o escoamento da sua produção o transporte rodoviário através da Rodovia Fernão Dias, que se encontra com sua capacidade saturada.

As atuais instalações do Porto Seco Sul de Minas, importante centro de importação e exportação de produtos (matérias primas e produtos) para as indústrias da região, incentivam o armazenamento no local uma vez que sua utilização torna-se mais barata quando comparada ao valor gasto em portos marítimos (JORNAL DA EPTV, 2015). Aliado ao sítio aeroportuário e considerando o transporte aéreo de cargas como alternativa logística, o espaço é capaz de promover o desenvolvimento regional resultando em um local de atratividade tanto para indústrias quanto para empresas de serviços relacionados o aeroporto e demais empresas para suprir as necessidades destas últimas, pois Varginha é equidistante via aérea das três capitais do Sudeste: São Paulo, Belo Horizonte e Rio de Janeiro. Portanto, o planejamento e adequação do espaço urbano de Varginha alavancaria o desenvolvimento econômico e social do município.

Figura 7 - Localização estratégica de Varginha em relação às capitais - equidistância aérea.

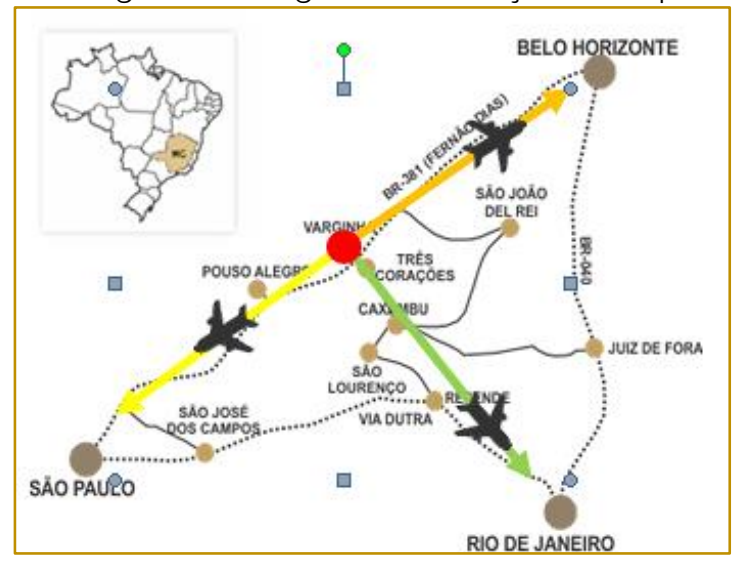

Fonte: elaborada pelas autoras (2016). 
A integração do Município Varginha com as demais cidades da região, promoveria o desenvolvimento regional resultando em um local de atração tanto para indústrias quanto para empresas de serviços relacionados ao aeroporto e demais empresas para suprir as necessidades destas últimas. Neste sentido, o aeroporto como integrante da infraestrutura em transporte (modal rápido e disperso geograficamente por todo o território), é ideal como parceiro das aglomerações industriais. O mesmo pode estimular o crescimento da região oferecendo serviços diferenciados, como é o caso do aeroporto-cidade e ainda suprir as carências de infraestrutura técnica e física da região na qual está inserido.

Segundo MARQUES (2002 apud CAPPA, 2013), para compreender as relações contemporâneas entre cidades e aeroportos e pensar políticas públicas de gestões aeroportuárias, é necessário aplicar os conceitos de aeroporto-cidade e centros de negócios e serviços. Sendo estas relações formadas pela demanda de:

1) Ampliação e modernização dos terminais aeroportuários;

2) Planejamento urbanístico do entorno dos aeroportos;

3) Estarem integrados à dinâmica urbana e econômica das cidades em que estão localizadas por meio de sistema multimodal de transportes;

4) Suas participações nos processos de desenvolvimento das cidades, regiões e países; e por último,

5) Amenizar impactos ambientais.

Os aeroportos, além da função de elos de conexão e integração global, são elementos marcantes na infraestrutura de uma cidade devido à dimensão de suas instalações e à demanda de serviços e infraestrutura urbana do local de sua implantação. Com isso, os mesmos tendem a orientar os vetores de crescimento urbano ou consolidar as tendências existentes, como é o caso do aeroporto-cidade.

Neste contexto, analisando o Plano Diretor de Varginha (Lei Municipal no 2845/1996 e revisada pela Lei no 4530/2006) é notável a intenção de alavancar o desenvolvimento da cidade de forma integrada e torná-la um polo de desenvolvimento para a região do Sul de Minas. O plano (Lei no 2845/1996) delimita ações de política de desenvolvimento municipal objetivando ordenar os processos de adensamento e expansão urbana, de forma a maximizar a utilização da infraestrutura e equipamentos urbanos já implantados e orientar a adequada distribuição dos investimentos públicos. Dentre as diretrizes para o desenvolvimento econômico podemos citar os incisos do Art. 16, 17 e 18: promover a geração e difusão de tecnologia referente à produção da agropecuária; incentivar a ampliação da rede de estocagem de grãos e do parque agroindústria; incentivar a ocupação dos lotes urbanos localizados em áreas destinadas à indústria; desenvolver uma política de consolidação de Varginha como polo regional na área de prestação de serviços; promover a descentralização da área central e induzir a criação de centros de comércio.

Já a revisão do Plano Diretor (Lei $n^{\circ}$ 4530/2006) contém diretrizes para o apoio ao desenvolvimento tecnológico como descrito pelos artigos abaixo:

- Art. 85: A produção tecnológica requer toda uma cadeia de ações no seu preparo e todos esses elos deverão ser apoiados e incentivados;

- $\quad$ Art. 86: Essas atividades encadeadas são: qualificação da mão-de-obra, localização e acessibilidade para as unidades produtivas e de pesquisa, bem como para a população envolvida nas atividades, qualidade ambiental para as áreas de localização, e segurança no transporte da produção;

- Art. 87: Deverão ser implantados Parques Tecnológicos visando à instalação de indústrias de base tecnológica, com alto valor agregado e baixo impacto ambiental;

- $\quad$ Art. 88: Essas atividades também poderão instalar-se em meio ao tecido urbano, desde que não causem conflitos de trânsito e conforto ambiental na vizinhança;

- Art. 89: Os Centros de Pesquisa Tecnológica são atividades de suporte para a expansão dessas atividades;

- $\quad$ Art. 90: A qualificação profissional é outra atividade de suporte a esse tipo de atividade econômica;

- $\quad$ Art. 91: A produção local e regional deve ser objeto de aprimoramento tecnológico.

Além das diretrizes citadas, a revisão ainda inclui diretrizes relacionadas à infraestrutura, 
como pode ser observado no Art. 127 e 128, e à integração regional, Art. 138.

- Art. 127. As infraestruturas aeroportuárias deverão ter seu entorno preparado para a instalação de atividades econômicas que possam beneficiar-se dessa localização, evitando-se a presença de residências, escolas e hospitais;

- Art. 128. Os serviços aduaneiros de interior devem ter áreas no seu entorno reservadas para estocagem e manuseio de cargas;

- $\quad$ Art. 138. Os sistemas de armazenamento e beneficiamento de matérias-primas, bem como as atividades aduaneiras de interior são suportes para o papel de polo regional exercido por Varginha e que poderá ser ampliado com extensão dessas atividades.

No entanto, como a legislação complementar à primeira revisão do Plano diretor de Varginha - o Perímetro Urbano do Município (2.613/1995; 3.128/1999), a Lei de Uso e Ocupação do Solo (3.181/1999), a Lei de Parcelamento (4.990/2008; 2.867/1997; 2.558/1995), o Código de Obras (3.006/1998 obras habitacionais; 3.068/1998 - obras não habitacionais), o Código de Posturas (2.962/1997) e o Plano Municipal de Circulação e Transporte (2.869/1997) - não foi revista em 2006, ou seja permanece a mesma desde a sua elaboração junto com o Plano
Diretor (1996), resulta em empecilhos ao desenvolvimento urbano varginhense. Isto gera como consequência obstáculos a aplicação da legislação de forma efetiva, pois as leis complementares encontram-se em total defasagem temporal e espacial em relação à cidade que existia em 2006 e consequentemente ao cenário atual.

Para que a eficácia do plano seja retomada, é necessário que a próxima revisão institua formas de planejamento e controle do território municipal. Aliadas à segunda revisão, a gestão urbana, a gestão municipal e os munícipes podem utilizar os potenciais e limitações do espaço da cidade. As potencialidades existentes pelas redes de transporte e logística no território varginhense podem alavancar outro vetor de crescimento e desenvolvimento para a cidade. Devem ser incorporados nas discussões da segunda revisão, em processo de elaboração, os diversos agentes sociais, econômicos e políticos que compõem a estrutura urbana, buscando compromissos e definindo ações prioritárias.

Além disso, nas proximidades de Varginha, localizam-se as cidades de Três Corações, Três Pontas e Elói Mendes que possuem uma integração urbana com o município varginhense causada pela localização do aeroporto, do Porto Seco Sul de Minas, dos distritos industriais e pelos serviços oferecidos em Varginha.

Figura 8 - Mapa da cidade.

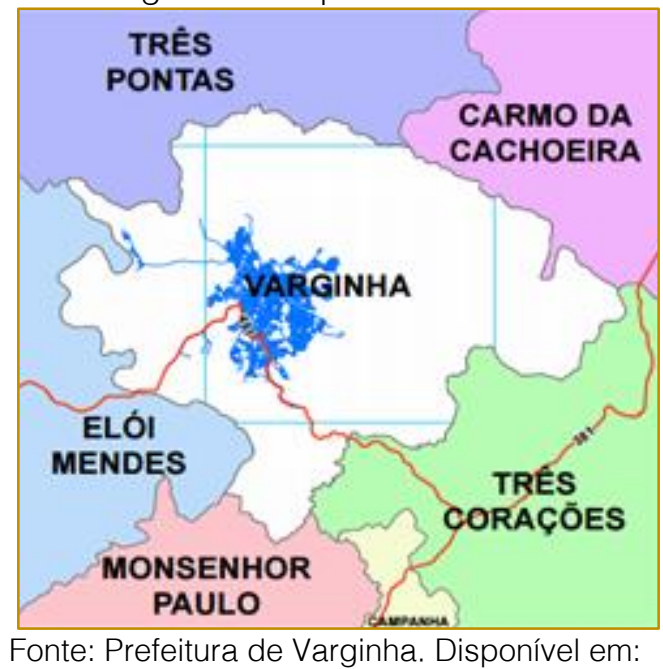

<http://www.varginha.mg.gov.br/Pdfs_e_arquivos_de_leis/Mapa_de_Varginha.pdf>. Acesso em: 07 jun. 2016. 
Esse fato gera como consequência o aumento de infraestrutura e ampliação da cidade de Varginha em direção às três demais cidades citadas de acordo com o tipo de uso do solo próximo a cada uma delas. Três Corações localiza-se próximo à Rodovia Fernão Dias e observa-se o crescimento industrial e logístico de Varginha para tal direção. Elói Mendes está situada próxima ao aeroporto de Varginha e ao condomínio industrial tecnológico, sendo o crescimento da cidade de Varginha no sentido de Elói Mendes baseado em armazéns logísticos e algumas indústrias, além do crescimento educacional associado à construção de um centro universitário no local. Enfim, observa-se que o crescimento de Varginha rumo a Três Pontas, por situar-se mais afastada dos locais caracterizados pelo setor industrial e logístico, é basicamente residencial e ainda bastante rural por concentrar a região produtora de café.

Diante disso, é necessário a adequação e atualização da legislação urbanística de Varginha em relação à configuração espacial em expansão da cidade a fim de evitar futuros contratempos ao desenvolvimento urbano e regional e também incentivar o progresso industrial e logístico local.

\section{CONSIDERAÇÕES FINAIS}

Devido à globalização, o mundo vive uma nova realidade produtiva e tecnológica que inclui novos fatores de concorrência e determina novas condições de localização das atividades de produção. As cidades passam a influir nas opções estratégicas das indústrias a partir de posicionamentos urbanos, fiscais, econômicos e sociais.

Além disso, a preocupação com os fluxos, a acessibilidade de pessoas e mercadorias, a mobilidade interna, entre outros, estão resultando na migração de empresas das

\section{REFERÊNCIAS}

[1] Almeida, E. S. de. A duplicação da rodovia Fernão Dias: uma análise de equilíbrio geral. In: Encontro Nacional de Economia, 32, 2004, Paraíba. Anais... São Paulo: ESALQ, Universidade de São Paulo, 2004;

[2] Botelho, A. Reestruturação produtiva e produção do espaço: o caso da indústria automobilística instalada no Brasil. Revista do Departamento de Geografia, Departamento de Geografia - FFLCH, USP, Vol. 15, 2002, p. 55-64. grandes cidades e metrópoles para cidades menores, uma vez que o avanço das telecomunicações permite o distanciamento entre o centro de decisão - a direção administrativa - e a indústria em si, diminuindo assim os custos de implantação.

Em virtude da localização estratégica associada à rodovia Fernão Dias (BR-381) e proximidade de grandes centros como São Paulo, Rio de Janeiro e Belo Horizonte, empresas de grande porte e de vários setores instalaram unidades na região do Sul de Minas Gerais.

A rodovia Fernão Dias tem uma importância fundamental na região, pois faz parte do mais relevante eixo rodoviário nacional, aliado à BR-116, interligando os três principais estados do Brasil e da região Sudeste, transformando-se em um corredor de transporte tanto para o mercado interno como para a exportação.

O município de Varginha foi um dos mais influenciados pela rede de fluxos estabelecidos pela BR-381, e passou a polarizar uma série de serviços e indústrias, aumentando o seu peso não só na microrregião da qual é centro, mas também na mesorregião do Sul de Minas.

Este trabalho visa compreender a configuração espacial do setor industrial varginhense, pois devido à reestruturação produtiva, observa-se a existência de uma nova conformação do espaço urbano de Varginha no intuito de obter cada vez mais acessibilidade e conectividade com a região e o restante do país.

Através da pesquisa, buscou-se entender o fluxo industrial de Varginha e região e os impactos da reestruturação produtiva no local a fim de criar meios de otimização do planejamento e da gestão urbana do município.

Disponível

em: <http://www.revistas.usp.br/rdg/article/view/47297> . Acesso em: 12 jun. 2016;

[3] Caiado, A. S. C. Reestruturação produtiva e localização industrial: a dinâmica industrial na RMSP entre 1985 e 2000. In: XXXII Encontro nacional de Economia - ANPEC. João Pessoa, PB. Anais... João Pessoa, PB, 2004. Disponível em: $<$ http://www.anpec.org.br/encontro2004/artigos/A0 4A114.pdf>. Acesso em: 12 jun. 2016; 
[4] Cappa, J. Cidades e Aeroportos no Século XXI. Campinas: Alínea. 2013. 226p;

[5] Carvalho, U. M. Reestruturação econômica e urbana no estado de São Paulo: o papel de Mogi Guaçu e Mogi Mirim na complexa rede urbana paulista. 2013. 129 f. Dissertação (Mestrado em Geografia) - Universidade Federal do Rio Grande do Sul, Porto Alegre, RS, 2013. Disponível em: <http://www.lume.ufrgs.br/handle/10183/88002?loc ale=pt_BR $>$. Acesso em: 27 set. 2016;

[6] Instituto Brasileiro de Geografia e Estatística (2016). Disponível em: $<$ http://www.cidades.ibge.gov.br/xtras/perfil.php?la $\mathrm{ng}=\& \operatorname{codmun}=317070 \&$ search $=$ minas -

geraislvarginhalin

fograficos:-informacoes-completas>. Acesso em: 10 jun. 2016;

[7] Jornal da EPTV. Porto Seco de Varginha cria condomínio industrial e logístico para alavancar exportações, Varginha, 14 mar. 2015. Disponível em: <http://g1.globo.com/mg/sul-deminas/jornal-da-eptv-2edicao/videos/v/porto-secode-varginha-cria-condominio-industrial-e-logisticopara-alavancar-exportacao/ 4036015/>. Acesso em: 20 nov. 2016;

[8] Lipietz, A. O mundo pós-fordismo. In: Revista Indicadores Econômicos FEE, Porto Alegre, v.24, n. 4, fev. 1997, p. 79-130. Disponível em: $<$ http://revistas.fee.tche.br/index.php/indicadores/a rticle/view/1256/1613>. Acesso em: 25 nov. 2016;

[9] Monte-MÓR, R. Outra fronteiras: novas especialidades na urbanização brasileira. In: CASTRIOTA, L. B. (org.). Urbanização brasileira: redescobertas. Belo Horizonte: editora C/Arte. 2003. Pp. 260-271

[10] Nunes, A. M. História que fazem a História: Pioneirismo Empresarial em Varginha-MG. Varginha: [s.n.]. 2004;

[11] Porto Seco Sul de Minas (2016). Disponível em: <http://www.portosecosuldeminas. com.br/ps/portugues/default.asp>. Acesso em: 14 jun. 2016;

[12] Prefeitura de Varginha. Disponível em: <http://www.varginha.mg.gov.br/>. Acesso em 20 set. 2016;

[13] Sassen, S. La ciudad global: emplazamiento estratégico, nueva frontera. Disponível em: $<$ http://www.macba.cat/PDFs/saskia_sassen_manol o_laguillo_cas.pdf>. Acesso em: 23 jun. 2016;
[14] Sales, J. R. Espírito Santo de Varginha (MG): 1763 - 1920. Varginha: Gráfica Editora Sul Mineira. 2003.

[15] Silveira, R. L. L.; CAMPOS, H. A.. Reestruturação urbana, valorização do solo e novos produtos imobiliários em Santa Cruz do Sul RS: reflexos na dinâmica socioespacial da capital nacional do tabaco. In: Seminário Internacional da Red Iberoamericana de Investigadores sobre Globalización y Territorio (RII), 13. Anais... 2014. Disponível em:

<http://www.rii.sei.ba.gov.br/anais_xiii/gt6/

Gt6_Heleniza. pdf>. Acesso em: 27 set. 2016;

[16] Sposito, E. S. Reestruturação produtiva e reestruturação urbana no estado de São Paulo. Revista electrónica de geografía y ciencias sociales. Barcelona. Vol. XI, núm. 245 (69), 01 ago. $2007 . \quad$ Disponível em: <http://www.ub.edu/geocrit/sn/sn-24569.htm>. Acesso em: 12 jun. 2016;

[17] Varginha. LEI № 2.845/1996. Institui O plano diretor de desenvolvimento do município de Varginha e dá outras providências;

[18] L Lei № 2869/1997. Dispõe sobre a política municipal do tráfego, trânsito e transporte do município de Varginha;

[19]_. Lei № 3.181/1999. Dispõe sobre o uso e ocupação do solo urbano do município de Varginha e dá outras providências:

[20] Lei № 4.530/2006. Faz a revisão da lei do plano diretor participativo de Varginha e dá outras providências;

[21] Vasconcelos, L. F. S. O aeroporto como integrante de um projeto de desenvolvimento regional: a experiência brasileira. 2007. 149p. Dissertação (Mestrado em Transportes) Universidade de Brasília, Brasília, DF, 2007. Disponível em: < http://repositorio.unb.br/handle/10482/2910>.

Acesso em 29 nov. 2016;

[22] Vázquez Barquero, A. Desenvolvimento endógeno em tempos de globalização. Porto Alegre: Fundação de Economia e Estatística da UFRGS, 2001. Disponível em: $<$ http://www.scielo.br/scielo.php?script=sci_nlinks\& ref $=000142 \&$ pid $=S 1517$ -

4522200400010000800004\&lng

=pt>. Acesso em 25 nov. 2016; 


\section{Gapítulo 19}

\section{SIMULAÇÃO DE ELEVAÇÃO DO NÍVEL DO MAR NA CIDADE DE JOINVILLE (SC)}

\section{Samara Braun}

\section{Juarês José Aumond}

Resumo: Os prognósticos indicam que ao longo deste século as mudanças climáticas ocasionarão o auemnto médio global do nível do mar. Tal alteração ocasionará impactos sobre diversas cidades costeiras. O objetivo deste artigo é de mapear as áreas impactadas pela elevação do nível do mar na cidade de Joinville (SC), uma cidade que surge e se expande sobre uma planície costeira e ecossistemas de mangue. Os mapeamentos foram realizados através de softwares de geoprocessamento e indicam a eleveção do nível do mar impactará ecossistemas naturais e urbanos. Os cenários de prognósticos das mudanças climáticas possibilitam uma análise de possíveis situações futuras, configurando uma ferramenta relevante para o planejamento das cidades. A relevância deste mapeamento inicial consiste em inspirar os planejadores e urbanistas a refletirem sobre as mudanças climáticas e consequentes alterações que irão ser ocasionadas nas dinâmicas locais, para fins de planejamento e construção de uma cidade mais sustentável e resiliente.

Palavras Chave: Mudanças Climáticas; Adaptação; Resiliência; Planejamento Urbano 


\section{INTRODUÇÃO}

Vivemos em um período de grandes transformações climáticas, intensificado ao longo das décadas pela emissão crescente de Gases de Efeito Estufa, provenientes de atividades antrópicas. A biosfera, por se tratar de um sistema dinâmico complexo, manifesta os impactos destas mudanças ocasionadas no clima. Escassez de água, desastres naturais, intensificação das ondas de calor, elevação do nível do mar, entre tantos inúmeros outros impactos decorrentes, que afetam diretamente ao naturais e às comunidades humanas (IPCC, 2014; LABOURIAU, 1998).

Referente à elevação do nível do mar, durante o século XX, foi registrado um aumento médio global do nível de $19 \mathrm{~cm}$, e os modelos climáticos para o final do século XXI identificam a possibilidade de aumento médio de 82 centímetros. Mesmo nos cenários mais otimistas quanto às ações de mitigação das mudanças climáticas, o fenômeno de eustasia (assim denominado o aumento do nível da água dos oceanos) continuaria a ocorrer, impactando zonas costeiras e cidades litorâneas por meio da transgressão marinha. Estima-se que $70 \%$ das zonas costeiras do mundo serão impactadas pelo aumento global do nível dos oceanos (IPCC, 2014)

No contexto das mudanças climáticas, as cidades se encontram em um paradoxo: estão entre as maiores fontes de emissão de Gases de Efeito Estufa e também são as áreas mais sensíveis aos impactos causados pelas mudanças climáticas (BRAGA, 2012; VAGGIONE, 2014). As cidades necessitam ser discutidas no contexto das mudanças climáticas, nas ações de mitigação e de adaptação adotadas, por isso, se faz necessário compreender quais impactos as cidades estão suscetíveis. A cidade de Joinville, localizada na região Nordeste do estado de Santa Catarina, teve seu processo de urbanização iniciado na segunda metade do século XIX e intensificado durante o século XX. A sua ocupação se deu em um sítio plano, com pouca variação altimétrica em relação ao nível do mar, razão pela qual vem sofrendo com inundações decorrentes da influência de marés. Neste aspecto, cabe questionarmos: em cenários futuros, Joinville poderá ser impactada pela eustasia decorrente das mudanças climáticas?

O objetivo deste artigo é de identificar as áreas suscetíveis à elevação do nível do mar, em função das mudanças climáticas, em Joinville. Para tanto, foi realizado um mapeamento das áreas impactadas pela elevação do mar. A cidade é atualmente a mais populosa do estado de Santa Catarina, e com significativos índices de crescimento econômico e de desenvolvimento humano. Devido seu histórico de impactos oriundos da variação das marés, a cidade de Joinville necessita de estudos e prognósticos da elevação do nível do mar na área urbana e áreas adjacentes para 0 planejamento territorial urbano. Este trabalho possibilita uma análise dos impactos da elevação do nível do mar sobre a cidade de Joinville (SC), visto a relevância desta região de zona costeira para - desenvolvimento econômico local e regional. Além do mais, a pesquisa contribui na identificação de áreas de risco socioambiental e para geração de ferramentas para o planejamento territorial.

\section{MUDANÇAS CLIMÁTICAS, EUSTASIA E CIDADES}

O Planeta Terra está em constante transformação, passando pulsações climáticas caracterizadas por uma combinação única, que compõe esse sistema dinâmico de superfície, atmosfera, mares, organismos e ecossistemas. Compõem estes ciclos climáticos (de pulsações e flutuações), como fator comum, alguns fenômenos naturais, como o balanço energético do planeta - que conforma o Efeito Estufa - um complexo sistema interdependente, que por si, busca o equilíbrio ecológico incessante do planeta. Entretanto, o aumento da emissão de Gases de Efeito Estufa (GEE) (5) $^{65}$ com origem nas atividades tem influenciado neste equilíbrio energético, interferindo e acelerando o Efeito Estufa, e ocasionando nestes últimos séculos o aumento acelerado da temperatura média global. A interferência antrópica no sistema climático ocasiona diversas transformações no clima e em inúmeros outros fenômenos e sistemas naturais e socioeconômicos - os quais o clima mantém interação - configurando um ciclo de

\footnotetext{
${ }^{65}$ São alguns dos Gases de Efeito Estufa: Dióxido de Carbono (CO2), Metano ( $\mathrm{CH} 4)$, Óxido Nitroso (N2O), Hexafluoreto de Enxofre (SF6), Hidrofluocarbonos (HFCs) e Perfluorocarbono (PFCs), provenientes de atividades antrópicas como a queima de combustíveis fósseis, produção de energia, processos industriais e agropecuários, alterações de uso do solo.
} 
retroalimentação positiva, que repercute nos elementos componentes do sistema e nos demais sistemas do universo interativo (GELBSPAN, 1999; LABOURIAU, 1998; TAVARES, 2004).

De acordo $\mathrm{cm}$ o 5으 Relatório do Painel Intergovernamental sobre Mudanças Climáticas (do inglês, Intergovernmental Panel on Climate Change - IPCC) de 2014, a influência humana sobre o sistema climático é cada vez mais evidente, sendo muitas mudanças observadas ao longo das últimas décadas, como o aumento da temperaturada atmosfera e dos oceanos - diminuição do volume global de neve e gelo, e o aumento médio global do nível do mar. Entretanto, além das transformações já observadas, e das transformações em curso, a emissão contínua de GEE causará ainda mais aquecimento e mudanças em todos os componentes do sistema climático, ampliando consideravelmente a probabilidade de graves e novos impactos difusos e irreversíveis. Diante deste cenário, fica evidente a vulnerabilidade $^{66}$ e exposição de alguns ecossistemas e sistemas humanos à variabilidade climática. Especificamente em áreas urbanas, as mudanças climáticas interferirão sobre a qualidade de vida por meio dos riscos de estresse ocasionado pelo calor, tempestades e precipitação extrema, inundações costeiras, deslizamentos de terra, poluição do ar, a escassez de água e elevação do nível do mar, tornando ainda mais vulneráveis as localidades desprovidas de infraestrutura básica e serviços, ou em áreas de exposição direta aos impactos.

No intuito de elucidar os impactos decorrentes das mudanças climáticas para as próximas décadas e até o final do século, o $5^{\circ}$ Relatório do IPCC (2014) apresenta quatro possíveis cenários (denominados RCP), que variam desde o cumprimento rigoroso de medidas de mitigação, até o cenário possível caso os modelos vigentes de desenvolvimento e crescimento econômico e populacional se mantenham (IPCC, 2014; MOSS, et al., 2010). Neste sentido, cabe diferenciar os cenários $R C P 2.6$ e RCP 8.5. 0 Cenário $R C P 2.6$ tem por premissa que sejam cumpridas as metas para rigorosa mitigação, com o objetivo de manter o aquecimento

\footnotetext{
66 "A vulnerabilidade indica o quanto existe de inabilidade para lidar com os efeitos adversos das mudanças climáticas e depende da sensibilidade e da capacidade de adaptação dos sistemas" (TAVARES, 2004, p. 70).
}

global em temperaturas não superiores a $2^{\circ} \mathrm{C}$ acima das temperaturas pré-industriais. Já o Cenário RCP 8.5 tem por base que nenhum esforço adicional seria realizado para reduzir as emissões de GEE, além daquelas em vigor atualmente, e considerando o crescimento das emissões globais, impulsionado pelo crescimento da população mundial e atividades econômicas. O quadro a seguir (Quadro 1) apresenta uma síntese dos principais impactos conforme os cenários do IPCC.

Se tratando diretamente da elevação do nível do mar, pelas medições maregráficas, durante o período de 1901 a 2010, constatouse o aumento médio global de $0,19 \mathrm{~m}$. As projeções do IPCC (2014) para o século XXI mostram que o fenômeno será ainda mais acelerado, com previsões de até $0,82 \mathrm{~m}$ até 2100, continuando a subir mesmo que as emissões de GEE sejam reduzidas. Apesar das variações ao longo dos períodos geológicos, nunca a variação foi tão rápida como aquela a que se prevê. Este aumento se espacializa de maneira diferenciada no entorno do globo e cerca de $70 \%$ das zonas costeiras do globo serão impactadas incluindo o litoral brasileiro. A elevação do nível do mar acarretará impactos de formas diferenciadas ao longo das costas, desde simples inundação ao recuo das linhas de orla; o recuo de biota; invasão dos aquíferos de água doce por água salgada (gerando águas mixolinas); interferência na macrodrenagem de águas interiores, ocasionando alagamentos e fenômenos de enchentes; e ainda, poderá interferir nas redes de abastecimento de água e saneamento básico; impacto sobre populações costeiras e ecossistemas, entre outras diversas consequências (GESCH, 2009; IPCC, 2014; KOPP, et al., 2014; LABOURIAU, 1998). 
Quadro 1 - Quadro síntese dos Cenários Futuros das Mudanças Climáticas.

\begin{tabular}{|c|c|c|c|c|}
\hline Impactos & RCP 2.6 & $\mathrm{RCP} 4.5$ & RCP 6.0 & RCP 8.5 \\
\hline $\begin{array}{l}\text { Aumento da temperatura média } \\
\text { global }\end{array}$ & De $0,3^{\circ} \mathrm{C}$ a $1,7^{\circ} \mathrm{C}$ & De $1,1^{\circ} \mathrm{C}$ a $2,6^{\circ} \mathrm{C}$ & De $1,4^{\circ} \mathrm{C}$ a $3,1^{\circ} \mathrm{C}$ & De $2,6^{\circ} \mathrm{C}$ a $4,8^{\circ} \mathrm{C}$ \\
\hline $\begin{array}{l}\text { Ph da superfície dos oceanos - } \\
\text { acidificação dos oceanos }\end{array}$ & $\begin{array}{l}0,06-0,07 \\
\text { (aumento de } 15 \text { a } \\
17 \% \text { da acidez), }\end{array}$ & $\begin{array}{l}0,14-0,15 \text { (38 a } \\
41 \% \text { de aumento } \\
\text { da acidez). }\end{array}$ & $\begin{array}{l}0,14-0,15 \text { (38 a } \\
41 \% \text { de aumento } \\
\text { da acidez) }\end{array}$ & $\begin{array}{l}0,30-0,32 \text { (100 a } \\
109 \% \text { de aumento } \\
\text { da acidez) }\end{array}$ \\
\hline Derretimento das geleiras & 15 a $55 \%$ & & & 35 a $85 \%$ \\
\hline $\begin{array}{l}\text { Aumento médio global do nível } \\
\text { do mar }\end{array}$ & De $0,26 \mathrm{~m}$ e $0,55 \mathrm{~m}$ & & & De $0,45 \mathrm{~m}$ e $0,82 \mathrm{~m}$ \\
\hline
\end{tabular}

Fonte: Elaboração própria, base de dados do IPCC (2014).

A elevação do nível do mar, no contexto das mudanças climáticas, decorre de diversos fatores, como o aquecimento e expansão térmica da água dos oceanos, derretimento das geleiras continentais e alteração das correntes oceânicas e efeito albedo (o derretimento da neve e do gelo revela o oceano mais escuro e a superfície abaixo, absorvendo mais da energia solar e causando mais aquecimento em um ciclo de retroalimentação (ALVES, 2009, p. 155)). Atualmente, cerca de um quinto da população mundial vive num raio de $30 \mathrm{~km}$ do oceano e este aumento irá impactar cerca de $70 \%$ das regiões costeiras do globo, pelo avanço permanente das águas e transgressão marinha, associada à frequência e intensidade de tempestades e inundações, impactando ecossistemas naturais e comunidades (KOPP, et al., 2014; IPCC, 2014; STRAUSS, et al., 2012). O aumento do nível do mar local se distingue do aumento médio global, o que Kopp et al. (2014) destacam como sendo um fato crítico para o planejamento de adaptação e gestão de risco. Dentre os quatro cenários apresentados pelo 5o Relatório do IPCC (2014), especificamente do aumento médio global do nível do mar, tem-se que nesta primeira metade de século, a média global estará entorno de 17 a $38 \mathrm{~cm}$, com alterações significativas no final do século, quando a variabilidade prevista varia entre $26 \mathrm{~cm}$ a 82 $\mathrm{cm}$ (figura 1).

Figura 1 - Tabela de projeção de aumento da temperatura e aumento do nível do mar $\mathrm{p}$ ara o século XXI.

\begin{tabular}{|c|c|c|c|c|c|}
\hline & \multirow[b]{2}{*}{ Scenario } & \multicolumn{2}{|c|}{$2046-2065$} & \multicolumn{2}{|c|}{$2081-2100$} \\
\hline & & Mean & Likely range c & Mean & Likely range c \\
\hline \multirow{4}{*}{$\begin{array}{l}\text { Global Mean Surface } \\
\text { Temperature Change }\left({ }^{\circ} \mathrm{C}\right)^{\circ}\end{array}$} & $\mathrm{RCP2.6}$ & 1.0 & 0.4 to 1.6 & 1.0 & 0.3 to 1.7 \\
\hline & $\mathrm{RCP} 4.5$ & 1.4 & 0.9 to 2.0 & 1.8 & 1.1 to 2.6 \\
\hline & RCP6.0 & 1.3 & 0.8 to 1.8 & 2.2 & 1.4 to 3.1 \\
\hline & RCP8.5 & 2.0 & 1.4 to 2.6 & 3.7 & 2.6 to 4.8 \\
\hline & Scenario & Mean & Likely range d & Mean & Likely range d \\
\hline \multirow{4}{*}{ Global Mean Sea Level Rise $(\mathrm{m})^{\mathrm{b}}$} & $\mathrm{RCP2.6}$ & 0.24 & 0.17 to 0.32 & 0.40 & 0.26 to 0.55 \\
\hline & RCP4.5 & 0.26 & 0.19 to 0.33 & 0.47 & 0.32 to 0.63 \\
\hline & RCP6.0 & 0.25 & 0.18 to 0.32 & 0.48 & 0.33 to 0.63 \\
\hline & RCP8.5 & 0.30 & 0.22 to 0.38 & 0.63 & 0.45 to 0.82 \\
\hline \multicolumn{6}{|l|}{ Notes: } \\
\hline \multicolumn{6}{|c|}{ 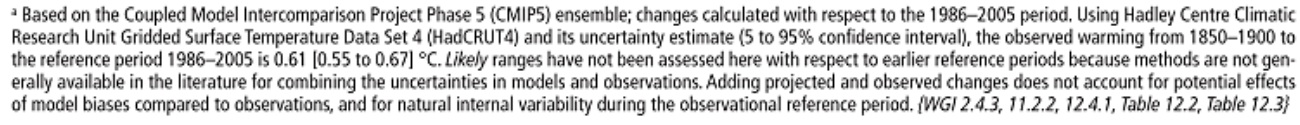 } \\
\hline \multicolumn{6}{|c|}{$\begin{array}{l}\text { b Based on } 21 \text { CMIP5 models; changes calculated with respect to the } 1986-2005 \text { period. Based on current understanding (firom observations, physical understanding and } \\
\text { modelling), only the collapse of marine-based sectors of the Antarctic ice sheet, if initiated, could cause global mean sea level to rise substantially above the likely range } \\
\text { during the } 21 \text { st century. There is medium confidence that this additional contribution would not exceed several tenths of a meter of sea level rise during the } 21 \text { st century. }\end{array}$} \\
\hline \multicolumn{6}{|c|}{$\begin{array}{l}\text { 'Calculated from projections as } 5 \text { to } 95 \% \text { model ranges. These ranges are then assessed to be likely ranges after accounting for additional uncertainties or different levels of } \\
\text { confidence in models. For projections of global mean surface temperature change in 2046-2065, confidence is medium, because the relative importance of natural internal } \\
\text { variability, and uncertainty in non-greenhouse gas forcing and response, are larger than for the 2081-2100 period. The likely ranges for 2046-2065 do not take into account } \\
\text { the possible influence of factors that lead to the assessed range for near term (2016-2035) change in global mean surface temperature that is lower than the } 5 \text { to } 95 \% \\
\text { model range, because the influence of these factors on longer term projections has not been quantified due to insufficient scientific understanding. (WGI 11.3.1\} }\end{array}$} \\
\hline \multicolumn{6}{|c|}{ 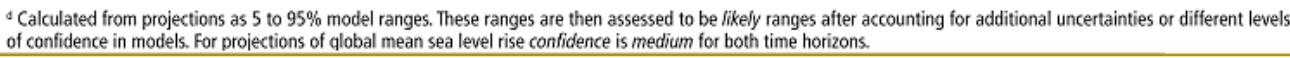 } \\
\hline
\end{tabular}

Fonte: IPCC (2014). 
Kopp et al. (2014) em sua pesquisa levantam diferentes projeções de aumento médio global do nível do mar, tanto para este século como para os próximos. A síntese desta pesquisa é esboçada na figura 2, demonstrando que neste século, as projeções realizadas apresentam resultados próximos, embora, mais elevados que os cenários apresentados pelo relatório do IPCC de 2014.

Figura 2 - Projeções de aumento médio do nível do mar.

\begin{tabular}{|c|c|c|c|c|c|c|c|c|c|c|c|c|c|c|c|}
\hline \multirow{2}{*}{$\begin{array}{l}\text { Table } \\
\mathrm{cm}\end{array}$} & \multicolumn{5}{|c|}{ RCP 8.5} & \multicolumn{5}{|c|}{ RCP 4.5} & \multicolumn{5}{|c|}{ RCP 2.6} \\
\hline & 50 & $17-83$ & $5-95$ & $0.5-99.5$ & 99.9 & 50 & $17-83$ & $5-95$ & $0.5-99.5$ & 99.9 & 50 & $17-83$ & $5-95$ & $0.5-99.5$ & 99.9 \\
\hline \multicolumn{16}{|c|}{ 2100-Components } \\
\hline GIC & 18 & $14-21$ & $11-24$ & $7-29$ & $<30$ & 13 & $10-17$ & $7-19$ & $3-23$ & $<25$ & 12 & $9-15$ & $7-17$ & $3-20$ & $<25$ \\
\hline GIS & 14 & $8-25$ & $5-39$ & $3-70$ & $<95$ & 9 & $4-15$ & $2-23$ & $0-40$ & $<55$ & 6 & $4-12$ & $3-17$ & $2-31$ & $<45$ \\
\hline AIS & 4 & -8 to 15 & -11 to 33 & -14 to 91 & $<155$ & 5 & -5 to 16 & -9 to 33 & -11 to 88 & $<150$ & 6 & -4 to 17 & -8 to 35 & -10 to 93 & $<155$ \\
\hline TE & 37 & $28-46$ & $22-52$ & $12-62$ & $<65$ & 26 & $18-34$ & $13-40$ & $4-48$ & $<55$ & 19 & $13-26$ & $8-31$ & $1-38$ & $<40$ \\
\hline LWS & 5 & $3-7$ & $2-8$ & -0 to 11 & $<11$ & 5 & $3-7$ & $2-8$ & -0 to 11 & $<11$ & 5 & $3-7$ & $2-8$ & -0 to 11 & $<11$ \\
\hline Total & 79 & $62-100$ & $52-121$ & $39-176$ & $<245$ & 59 & $45-77$ & $36-93$ & $24-147$ & $<215$ & 50 & $37-65$ & $29-82$ & $19-141$ & $<210$ \\
\hline \multicolumn{16}{|c|}{ Projections by year } \\
\hline 2030 & 14 & $12-17$ & $11-18$ & $8-21$ & $<25$ & 14 & $12-16$ & $10-18$ & $8-20$ & $<20$ & 14 & $12-16$ & $10-18$ & $8-20$ & $<20$ \\
\hline 2050 & 29 & $24-34$ & $21-38$ & $16-49$ & $<60$ & 26 & $21-31$ & $18-35$ & $14-44$ & $<55$ & 25 & $21-29$ & $18-33$ & $14-43$ & $<55$ \\
\hline 2100 & 79 & $62-100$ & $52-121$ & $39-176$ & $<245$ & 59 & $45-77$ & $36-93$ & $24-147$ & $<215$ & 50 & $37-65$ & $29-82$ & $19-141$ & $<210$ \\
\hline 2150 & 130 & $100-180$ & $80-230$ & $60-370$ & $<540$ & 90 & $60-130$ & $40-170$ & $20-310$ & $<480$ & 70 & $50-110$ & $30-150$ & $20-290$ & $<460$ \\
\hline 2200 & 200 & $130-280$ & $100-370$ & $60-630$ & $<950$ & 130 & $70-200$ & $40-270$ & $10-520$ & $<830$ & 100 & $50-160$ & $30-240$ & $10-500$ & $<810$ \\
\hline \multicolumn{16}{|c|}{ Other projections for 2100} \\
\hline AR5 & 73 & $53-97$ & & & & 52 & $35-70$ & & & & 43 & $28-60$ & & & \\
\hline H14 & & $70-120$ & $50-150$ & & & & & & & & & $40-60$ & $25-70$ & & \\
\hline $\mathrm{J} 12$ & 110 & & $81-165$ & & & 75 & & $52-110$ & & & 57 & & $36-83$ & & \\
\hline $\mathrm{S} 12$ & & & & & & 90 & & $64-121$ & & & 75 & & $52-96$ & & \\
\hline
\end{tabular}

Fonte: (KOPP, et al., 2014, p. 389).

Em ambos os casos se confirma que até o final do século a situação é irreversível e o mar aumentará em seu nível médio global. A variação dependerá exclusivamente de ações que diminuam a emissão de Gases de Efeito Estufa. Mesmo que efetivada estas ações, o mar terá seu nível alterado e regiões continuarão vulneráveis à esta variação, sendo necessário que medidas de adaptação e de resiliência sejam tomadas.

Algumas cidades brasileiras lá lidam com aumento da ocorrência e frequência de ressacas, ocasionando transgressão marinha, erosão e alteração da linha de costa. A cidade de Joinville, numa condição singular por se localizar num estuário e sobre uma planície costeira de pouca variação altimétrica, está suscetível às variações provocadas pela maré, ocasionando remanso e alagamentos. Por vezes, a ocorrência destes fenômenos junto à alta precipitação pluviométrica provoca inundações de maior amplitude, inundando as regiões centrais da cidade. Outro agravante se dá pela tendência de aumento na frequência e intensidade de eventos pluviométricos extremos na região Sul do Brasil, decorrentes do aumento da temperatura que interfere sobre os fluxos de umidade (BRASIL, 2016).

Diante disto, cabe destacar que as cidades são consideradas atualmente as causadoras do maior impacto ambiental. No mundo, as cidades ocupam cerca de $2 \%$ do território, mas geram $75 \%$ do total de emissões de GEE (IPCC, 2014; VAGGIONE, 2014). Mas também, diante das mudanças climáticas, as cidades encontram-se mais suscetíveis aos impactos, pela falta de recursos ou pela exposição direta aos desastres - como secas, intensas precipitações, inundações e transgressão marinha - que ao longo das décadas vem ampliando a ocorrência e a intensidade. Apesar de comunidades humanas demonstrarem ao longo da história a alta capacidade criativa de adaptação ao meio, estamos cada vez mais próximos de situações extremas e de amplo impacto, que demandam planejamento para adaptarmo-nos às situações que se configuram irreversíveis.

No contexto urbano, a adaptação consiste na adoção de medidas de ajuste dos sistemas naturais e socioeconômicos, e que aumentem a capacidade de resiliência, e em estratégias que objetivem reduzir a vulnerabilidade socioambiental às mudanças climáticas 
(IPCC, 2014; VAGGIONE, 2014), fundamentadas numa perspectiva de sustentabilidade e de que cada ambiente demanda soluções singulares. Tais conceitos permeiam o PNA e a Nova Agenda Urbana (Habitat III), compreendendo que o cenário futuro para as cidades demandará uma nova forma de desenvolvimento, que implica em planejamento e tomada de decisões em um contexto de incertezas e num ambiente dinâmico. A baixa capacidade de resposta frente às mudanças climáticas irá refletir diretamente sobre o agravamento da vulnerabilidade socioambiental. Assim a adaptação precisa ser promovida como um indutor da diminuição das vulnerabilidades, principalmente na cidade informal, que devido a fragmentação, ocupa espaços que configuram cenário de suscetibilidade e fragilidade, e diversas vezes, insalubridade (BRASIL, 2016).

Atualmente, já não é mais possível dissociar o ambiente urbano e a sociedade, do modelo de desenvolvimento vigente, pois o modelo de desenvolvimento determina o ambiente a ser construído, e o atual modelo tem produzindo uma instabilidade social desastrosa e levando a um declínio ambiental adicional (CHOAY, 1985; ROGERS; GUMUCHDJIAN, 2005). Em resposta, aliando a noção de sustentabilidade e desenvolvimento, surge a noção de Desenvolvimento Sustentável, que segundo Comissão Mundial sobre Meio Ambiente e Desenvolvimento (1987), é o desenvolvimento que satisfaz as necessidades do presente sem comprometer a capacidade de as gerações futuras satisfazerem as suas próprias necessidades". O planejamento urbano focado na sustentabilidade conduz à adequação do espaço construído aos processos naturais, e também leva a uma ampla reflexão sobre os modelos sociais e econômicos vigentes. A noção de cidade sustentável reconhece que a cidade precisa atender os nossos objetivos sociais, ambientais, políticos e culturais, bem como aos objetivos econômicos e físicos. É um organismo dinâmico tão complexo quanto a própria sociedade e suficientemente ágil para reagir rapidamente às suas mudanças (ROGERS; GUMUCHDJIAN, 2005; SIEBERT, 2012), entretanto, precisa incorporar uma nova dimensão, das mudanças climáticas.

\section{METODOLOGIA}

Para o desenvolvimento do mapeamento foram utilizados softwares de geoprocessamento. A representação virtual de fenômenos ou de dados permite a realização de estudos preditivos e de relações de causa e efeito, o que Moura (2005) denomina de estudo de cenários. A configuração geomorfológica é uma variável fundamental que ajuda a determinar a vulnerabilidade das paisagens costeiras, associado a cartografias de áreas sujeitas a inundação potencial, configuram cenários de grande utilidade para planejadores e gestores preocupados com os impactos da eustasia decorrente das mudanças climáticas (GESCH, 2009).

Para a produção da cartografia foram utilizados os softwares GIS Global Mapper versão 17 e ARCGis versão 9, (ARCGIS, 2016; BLUE MARBLE, 2016). Para ambos os programas se utilizou a base cartográfica do município, disponível na plataforma online SIMGeo (Sistema de Informações Municipais Georreferenciadas) da Prefeitura Municipal de Joinville (PMJ, 2010). A base cartográfica municipal contém em sua base de dados a cobertura aerofotogramétrica, informações de curvas de nível (intervalo de cinco metros), entre outras camadas. Esses dados foram adquiridos na forma de mapas digitais (nos formatos.$d x f$ e .shp). Os dados de cenários utilizados são referentes as previsões do IPCC, publicado no 5o Relatório, de 2014, na atualidade uma referência em dados a respeito das mudanças climáticas. Não foram considerados nesta pesquisa, as questões de precipitações pluviométricas, de variação de marés e de remanso, sendo a análise destes fatores uma das sugestões de continuidade de pesquisa.

O processo realizado em ambos os programas acima citados consiste na inclusão da base de dados, obtenção de um $T N^{67}$ ou Elevation Grid para representação da morfologia da superfície, e a demarcação das alturas especificadas. Dados do tipo Triangulated Irregular Network são baseados em vetores e se constroem mediante a

${ }^{67}$ Dados do tipo Trian Dados do tipo Triangulated Irregular Network são baseados em vetores e se constroem mediante a triangulação de um conjunto de vértices e pontos (como dados de curva de nível e ponto cotado), formando então uma malha triangulada, de tamanhos diversos, contígua e sem sobreposições. 
triangulação de um conjunto de vértices e pontos (como dados de curva de nível e ponto cotado), formando então uma malha triangulada, de tamanhos diversos, contígua e sem sobreposições.. A partir destes modelos, com outros processos, foi possível obter os mapas e visualizações tridimensionais.

\section{JOINVILLE}

Localizado no estado de Santa Catarina, o município de Joinville é polo da microrregião Nordeste do Estado. Junto aos municípios de São Francisco do Sul, Araquari, Balneário Barra do Sul, Garuva e Itapoá, compõe o entorno da Baía da Babitonga, a maior baía navegável do estado, abarcando dois portos (de Itapoá e de São Francisco do Sul). A cidade de Joinville se destaca pelo alto Índice de Desenvolvimento Humano Municipal, de 0,809 (IDHM, 2010) e por ser atualmente a cidade catarinense mais populosa, com 515.288 habitantes (IBGE, 2010). Economicamente, a cidade se destaca como terceiro polo industrial da região Sul (IPPUJ, 2015);

Numa breve análise retrospectiva, sobre a planície costeira de Joinville e entorno já incidiram transgressões marinhas antigas, fenômeno evidenciado pela existência de sítios arqueológicos de povos Sambaquianos e concheiros naturais. Mais recentemente, desde a colonização de Joinville, na segunda metade do século XIX, já havia conhecimento sobre as inundações na localidade, e desde os primeiros anos de colônia, obras de drenagem foram realizadas. Entretanto, a ocorrência de inundações tem ampliado (SILVEIRA, et al., 2009), assim como a expansão sobre áreas suscetíveis às inundações e sobre ecossistemas vulneráveis às mudanças climáticas (SOUZA, 1991; IPPUJ, 2015). Disto, cabe questionarmos, quais áreas de Joinville serão impactadas pela elevação do nível do mar? Para tanto, foram realizadas simulações a partir dos cenários apresentados no $5^{\circ}$ Relatório do IPCC.

\section{MAPEAMENTO DE CENÁRIOS E IMPACTOS}

Dentre os quatro cenários apresentados pelo 5o Relatório do IPCC (2014), especificamente do aumento médio global do nível do mar, tem-se que nesta primeira metade de século, a média global estará entorno de 17 a $38 \mathrm{~cm}$, com alterações significativas no final do século, quando a variabilidade prevista está entre $26 \mathrm{~cm}$ a $82 \mathrm{~cm}$. A simulação se deu com a aplicação direta das cotas previstas nos cenários do IPCC. Foram considerados os cenários RCP 2.6 (0,26m e 0,55 m; "cenário otimista") e $R C P 8.5(0,45 \mathrm{~m}$ e 0,82m; "cenário pessimista"). Foi considerada também a elevação do nível em 1m, como sendo o tailrisk $^{68}$ (os limites de variação que excedem para mais ou para menos as projeções realizadas, a probabilidade de um evento.) (figura 3).

Observa-se na cartografia, que as áreas mais extensas impactadas pela elevação do nível do mar estão no perímetro rural da cidade, em áreas de ocupação agropecuária e de ecossistema de mangues. Na área urbana, são suscetíveis à impactos, direta ou indiretamente, 20 dos 43 bairros.

As figuras 4, 5 e 6 (um recorte da área central e Leste da cidade) ilustram os cenários de elevação do nível do mar, e as diferenças entre as regiões de maior e de menor impacto. Estas planícies são áreas de formação recente (especialmente aquelas áreas de sedimentos quaternários do Holoceno), composta de areias e siltes. Sendo a cidade assentada sobre uma planície, as regiões de calhas de rios (leito secundário) dos cursos do rio Cachoeira e Mathias serão atingidas até na região central, nos cenários de maior elevação.

\footnotetext{
68 TailRisk: os limites de variação que excedem para mais ou para menos as projeções realizadas, a probabilidade de um evento.
} 
Figura 3 - Simulação elevação do nível do mar em Joinville.

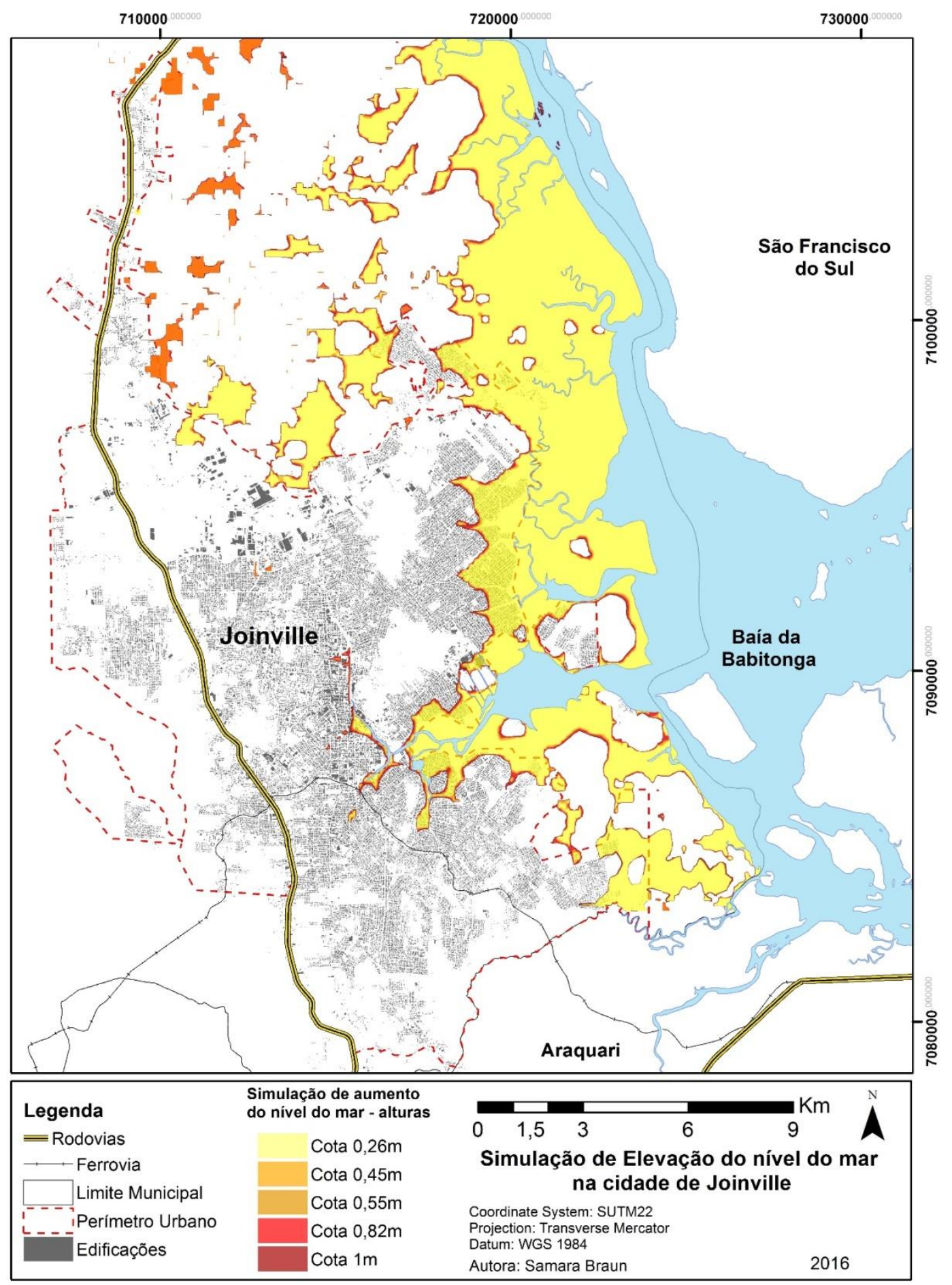

Fonte: A autora (2016). 
Figura 4 - Simulação elevação do nível do mar na região central.

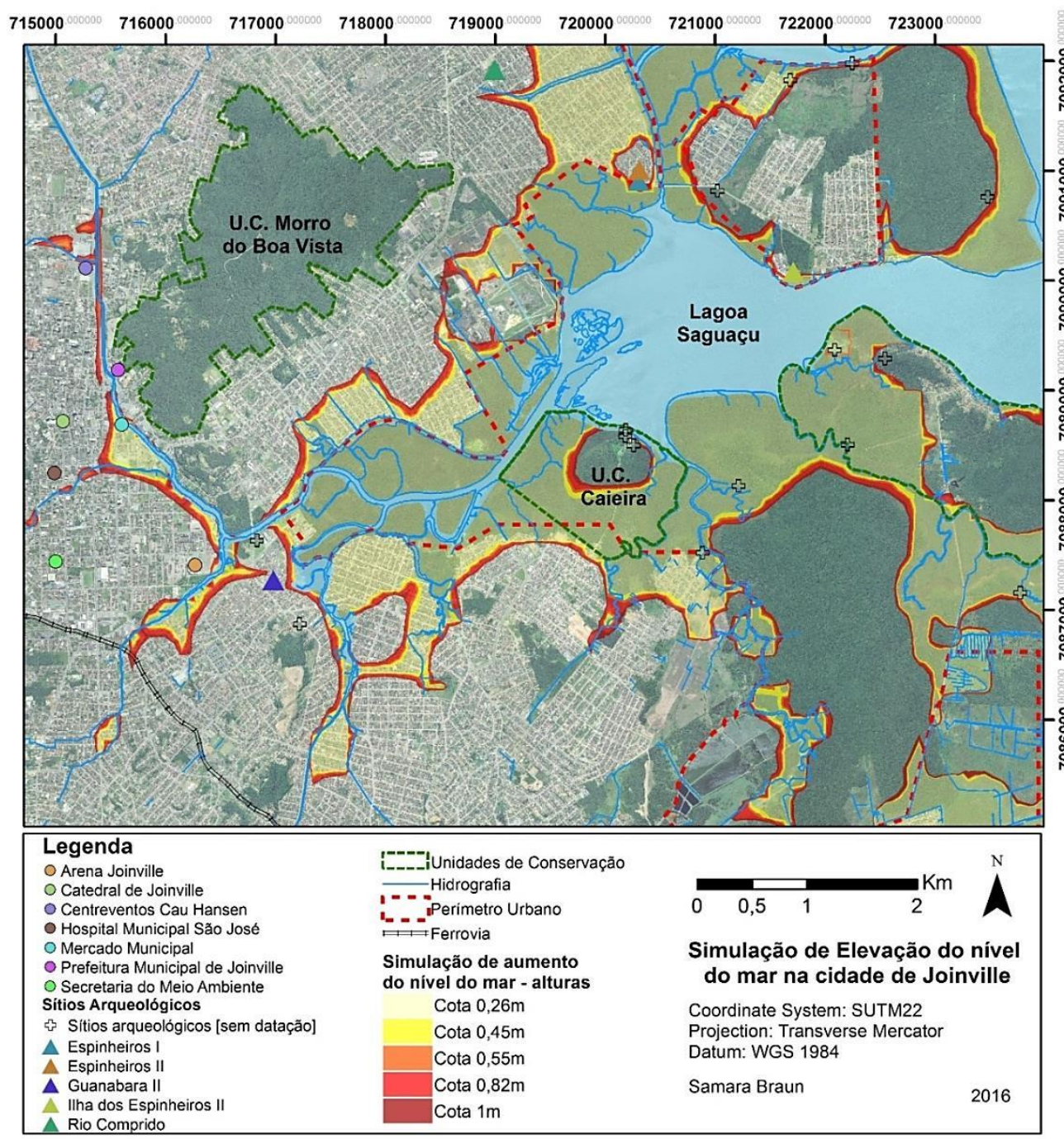

Fonte: A autora (2016).

Figura 5 - Visualização em perspectiva da simulação de elevação do nível do mar em $1 \mathrm{~m}$.

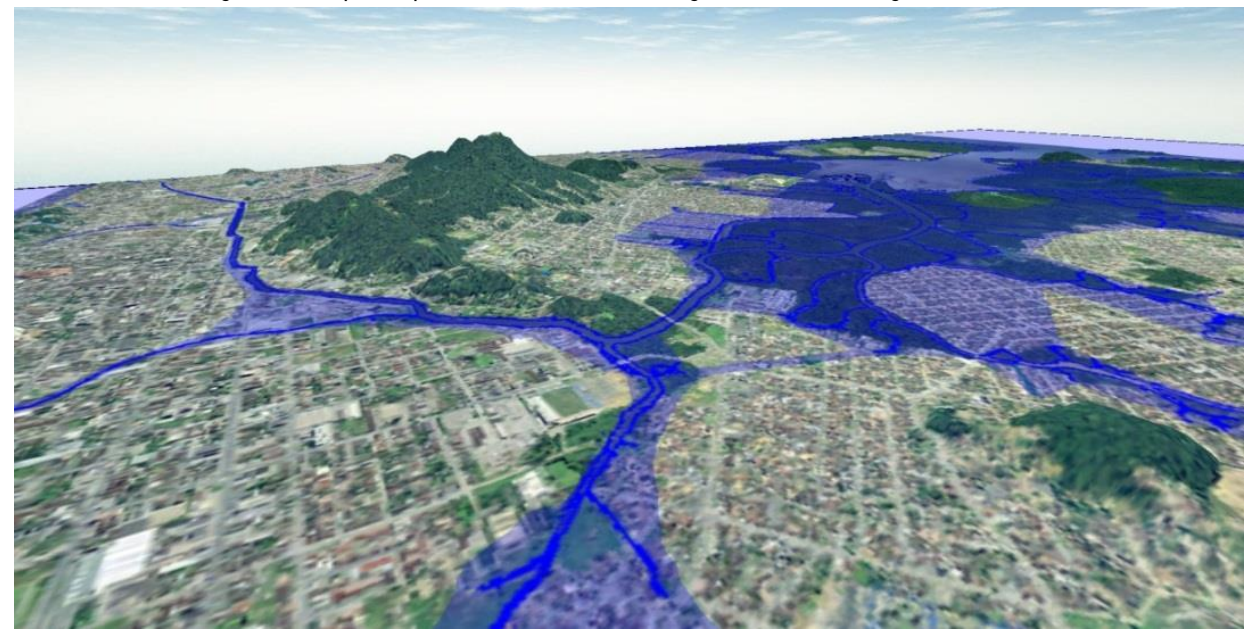

Fonte: A autora (2016) 
Figura 6 - Perfil Esquemático transversal da região central

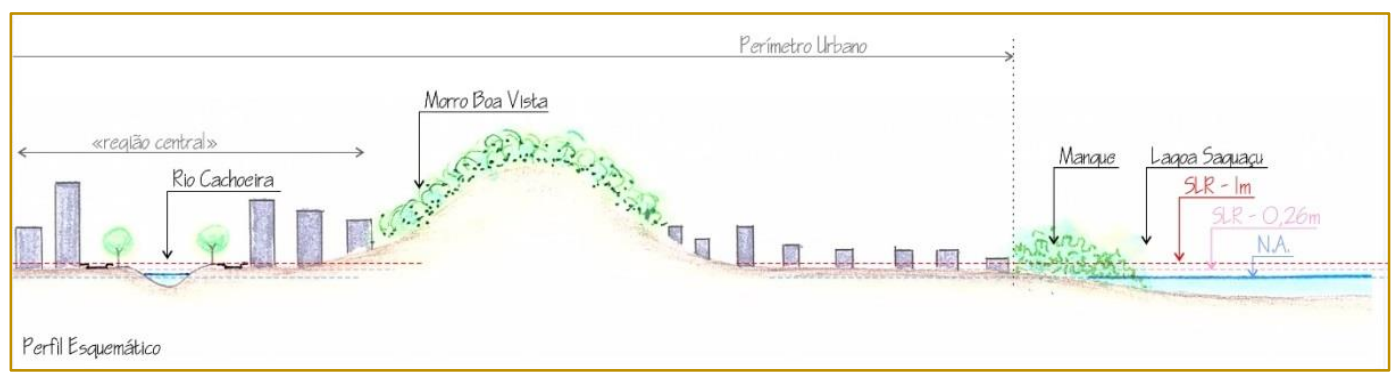

Fonte: A autora (2016)

Este impacto da elevação do nível do mar se expressa no avanço da lâmina d'água e poderá também ser observado por meio de alterações nas dinâmicas de remanso, alteração nos fenômenos de maré alta, na intrusão salina sobre lençóis freáticos, interferência em sistema de drenagem urbana e de saneamento básico, modificação pedológica - tornando os solos mais alagadiços e menos aptos à algumas atividades agropecuárias - e suscetível a danificar infraestruturas - como estradas e infraestruturas subterrâneas.

Neste detalhe da região central da cidade, observa-se a existência de sítios arqueológicos, alguns fora da área de avanço da lâmina d'água. Tratam-se de sítios de Sambaquis, construções artificiais feitas por populações pré-históricas de pescadorescoletores-caçadores que ocuparam a costa brasileira entre 7.000 e 1.000 anos. A existência destes sítios é um dos indicadores das antigas posições dos níveis marinhos, pois parte-se da premissa de que as bases dos sítios, no início de sua construção, estavam em zonas acima da linha de maré alta e em sua maioria sobre substrato seco, mas próximos à linha de costa da época (SCHEEL-YBERT, et al., 2009; BRASIL, 1988).

Cabe destacar também que os ecossistemas de mangues serão impactados pelas mudanças climáticas. Os ecossistemas apresentam certa flexibilidade de adaptação à distúrbios ou interferências, levando o sistema natural de volta ao equilíbrio. Entretanto, as flutuações ecológicas ocorrem entre limites de tolerância (CAPRA, 1996). Neste caso, devido à falta de espaço para migração dos mangues devido a ocupação urbana, a elevação do nível do mar afetará a capacidade de resiliência (capacidade de um mangue migrar naturalmente e de absorver e reorganize-se de forma a manter as suas funções, processos e estrutura (GILMAN, et al., 2008).) e persistência (refere-se a constância ao longo do tempo, independentemente da perturbação ambiental (ALONGI, 2007)) destes ecossistemas, e logo, os serviços ambientais prestados por estes (ALONGI, 2007; KIRWAN, et al., 2010; IPCC, 2014; BRASIL, 2016).

O estresse sobre os mangues da baía poderá causar a supressão deste ecossistema, expondo diretamente as áreas urbanas à processos erosivos, aumento das áreas inundadas e interferência na qualidade de vida, das águas costeiras e biodiversidade da baía, afetando habitats e causando a redução da biodiversidade, impactando inclusive as comunidades humanas que dependem dos serviços ambientais prestados pelos manguezais. A supressão destas áreas de mangues implicará também em liberação de grandes quantidades de carbono armazenado por este ecossistema. Porém, o oposto é de suma relevância. A conservação dos mangues trará benefícios que se estendem às cidades através de alguns dos serviços ambientais prestados, como a capacidade de sequestro de carbono, conservação da biodiversidade, meio de subsistência de comunidades tradicionais e proteção da costa contra erosão e impacto das ondas e diminuição da vulnerabilidade.

\section{CONSIDERAÇÕES FINAIS}

Aprojeção de cenários por meio de cartografia pode ser um meio significativo de representação de situações passíveis de acontecer, diminuindo a 'imprevisibilidade' de certas situações. Assim também os cenários de prognósticos das mudanças climáticas possibilitam uma análise de possíveis situações futuras, configurando uma ferramenta relevante para o planejamento das comunidades e das cidades. A relevância 
deste mapeamento inicial consiste em inspirar os planejadores e urbanistas a refletirem sobre as mudanças climáticas e consequentes alterações que irão ser ocasionadas nas dinâmicas locais, para fins de planejamento e construção de uma cidade mais sustentável e resiliente, tanto para população local, quanto para cidades de entorno e inclusive para o meio ambiente.

É necessário compreender a importância do fator das mudanças climáticas para o planejamento urbano. Diferentemente de outras variáveis, locais e regionais, as mudanças climáticas encontram-se tanto numa escala local quanto global, carecendo de um esforço conjunto para a mitigação e a adaptação, e no caso de Joinville, principalmente para os impactos da elevação do nível do mar.

Destes prognósticos, surgem correntes como a Adaptação Baseada em Ecossistemas $(\mathrm{AbE})$, que partem do princípio de adaptação aos impactos decorrente das mudanças climáticas a partir da inclusão dos serviços ambientais prestados pelos ecossistemas (OLIVIER, et al., 2012). Tal estratégia abarca medidas de conservação, restauração e gestão destes ecossistemas, a partir da noção de sustentabilidade, complementando e até mesmo substituindo obras civis, além dos serviços ambientais prestados, reduzindo a vulnerabilidade socioambiental às mudanças climáticas. A AbE está inclusa no PNA como uma possibilidade de estratégia que possa ser incorporada nas políticas de adaptação setoriais (BRASIL, 2016). À gestão pública, é importante sensibilizar a relevância da abordagem de AbE em ações, planos, estratégias setoriais e integradas, devido principalmente aos que usufruem de tais serviços para a promoção do desenvolvimento sustentável e à resiliência local nas áreas urbanas.

Ressalta-se a importância de um estudo específico de elevação do nível do mar local, considerando as condicionantes locais - como localização geodésica, efeito de marés e interferência pluviométrica - para mapeamentos, e inclusão de outras variáveis como tendências de crescimento da população e da cidade, dinâmicas do mercado imobiliário, fatores econômicos e do meio, inclusão e participação social, entre outros - para fins de planejamento de médio e longo prazo - por exemplo, na escolha de regiões para implantação de equipamentos públicos e institucionais, obras e planos de adaptação e mitigação, obras de drenagem e aterros, e até políticas habitacionais. As estratégias adotadas no presente serão cruciais também a longo prazo. A quantidade de pessoas e de infraestruturas atingidas dependerá dos padrões de desenvolvimento e crescimento estimulados na cidade. Assim, as medidas de adaptação podem ser relevantes para o futuro, mas já no presente serem influentes sobre a qualidade de vida local e na diminuição da vulnerabilidade socioambiental e promoção do desenvolvimento sustentável.

A não consideração do fator das mudanças climáticas nos planos setoriais de desenvolvimento urbano poderá ocasionar, entre outras problemáticas, o custo elevado em infraestruturas de adaptação pós-impacto, diminuição do valor imobiliário em áreas propensas a inundação (devido as alterações nas dinâmicas de maré e consequente inundações), danos às zonas industriais $e$ interferência no setor econômico local, danos às infraestruturas de mobilidade (rodoviárias e ferroviária) com consequente problemas na gestão da movimentação de cargas devido a expansão das zonas de inundação, aumento da necessidade de manutenção de infraestruturas urbanas, entre outras consequências.

Diante do advento das mudanças climáticas, da necessidade de tornar as cidades resilientes, de garantir a qualidade de vida e saúde do ambiente urbano e natural para o desenvolvimento sustentável, o planejamento e as ações sobre o espaço precisam ser compatíveis e dialogadas, e pôr em prática a transição para um sistema integrado. Repensar o desenvolvimento urbano das cidades litorâneas, diante do advento das mudanças climáticas, compreenderá a integração de planos, projetos e gestão, dos mais diversos setores e nas mais diversas escalas, que compreendam tanto a mitigação quanto a adaptação e a resiliência. 


\section{REFERÊNCIAS}

[1] ALONGI, Daniel M. Mangrove forests: Resilience, protection from tsunamis, and responses to global climate change. Australian Institute of Marine Science, ago. 2007.

[2] ARCGIS. ArcGIS. Disponivel em: $<$ http://www.arcgis.com/>. Acesso em: 01 fev. 2016.

[3] ATLAS BRASIL. Perfil Municipal de Joinville, SC. Atlas Brasil, 2010. Disponível em: <http://www.atlasbrasil.org.br/2013/pt/perfil_m/joinv ille_sc>. Acesso em: 16 jun. 2016.

[4] BANDEIRA, Dione da Rocha; ALVES, Maria Cristina. Arqueologia histórica no nordeste de Santa Catarina. Revista Tempos Acadêmicos, Dossiê Arqueologia Histórica, Criciúma, 2012. 6887. n. 10.

[5] BLUE MARBLE. Global Mapper. Blue Marble Geographics. Disponível em: $<$ http://www.bluemarblegeo.com/products/globalmapper.php>. Acesso em: 01 fev. 2016.

[6] BRAGA, Roberto. Mudanças climáticas e planejamento urbano: uma análise do Estatuto da Cidade. Anais do VI Encontro Nacional da Anppas, Belém - PA, set. 2012

[7] BRASIL, Departamento Nacional da Produção Mineral. Mapa geológico do quaternário costeiro dos estados do Paraná e Santa Catarina. Por Louis Martin, Kenitiro Suguio, Jean-Marie Flexor e Antonio E. G de Azevedo. Brasília: Brasil. Departamento Nacional da Produção Mineral, 1988. Mapas - Texto explicativo.

[8] BRASIL, Ministério do Meio Ambiente. Plano Nacional de Adaptação à Mudança do Clima: estratégias setoriais e temáticas. Brasília: MMA, v. 2, 2016.

[9] CAPRA, Fritjof. A teia da Vida: Uma nova compreensão cientifica dos sistemas vivos. São Paulo: Editora Cultrix, 1996.

[10] CHOAY, Françoise. A regra e o modelo: sobre a teoria da arquitetura e do urbanismo. São Paulo: Perspectiva, 1985.

[11] CMMAD, Comissão Mundial para o Meio Ambiente e Desenvolvimento. Nosso Futuro Comum. Geneva, Switzerland: [s.n.], 1987. Disponível em: <http://www.un-documents.net/ocf02.htm\#l>. Acesso em: 27 out. 2016.

[12] GELBSPAN, Ross. O calor vem aí: a batalha contra a ameaça do clima. Tradução de Maria Alice Costa. Lisboa: Editorial Bizâncio, 1999.

[13] GESCH, Dean B. Analysis of Lidar elevation data for improved identification and delineation of lands vulnerable to sea-level rise. Journal of Coastal Research, p. 49-58, 2009. Special Issue No. 53.

[14] GILMAN, Eric. L.; ELLISON, Joanna; DUKE, Norman C.; FIELD, Colin. Threats to mangroves from climate change and adaptation options: A review. Aquatic Botany, n. 89, p. $237-$ 250, 2008

[15] IBGE, Instituto Brasileiro de Geografia e Estatística. IBGE Cidades: Santa Catarina Joinville. Instituto Brasileiro de Geografia e Estatística, 2010. Disponível em: $<$ http://cod.ibge.gov.br/B90>. Acesso em: 17 fev. 2016.

[16] IPCC, Intergovernmental Panel on Climate Change. Climate Change 2014, Synthesis Report: Summary for Policymakers. [S.I.]: [s.n.], 2014.

[17] IPPUJ, Fundação Instituto de Pesquisa e Planejamento para o Desenvolvimento Sustentável de Joinville. Joinville Cidade em Dados 2015. Joinville: Prefeitura Municipal de Joinville, 2015.

[18] KIRWAN, Matthew L.; GUNTENSPERGEN, Glenn R.; D'ALPAOS, Andrea; MORRIS, James T.; MUDD, Simon M.; TEMMERMAN, Stijn. Limits on the adaptability of coastal marshes to rising sealevel. Geophysical Research Letters, v. 37, dez. 2010.

[19] KOPP, Robert E.; HORTON, Radley M.; LITTLE, Christopher M.; MITROVICA, Jerry X.; OPPENHEIMER, Michael; RAUSMUSSEN, D. J.; STRAUSS, Benjamin $\mathrm{H}_{\text {.; }}$ TEBALDI, Claudia. Probabilistic 21st and 22nd century sea-level projections at a global network of tide-gauge sites. Earth's Future, v. 2, p. 383-406, 2014.

[20] LABOURIAU, Maria Lea Salgado. História Ecológica da Terra. 2. ed. São Paulo: Blucher, 1998. 307 p.

[21] MOSER, Liliane. Como o mangue virou cidade: um estudo sobre condições de vida e a organização institucional do espaço urbano nas áreas de mangue em Joinville, SC. Florianópolis: Universidade Federal de Santa Catarina, 1993. Dissertação (Mestrado em Sociologia Política). Programa de Pós-Graduação em Sociologia Política, Centro de Filosofia e Ciências Humanas.

[22] MOSS, Richard. $H$. et al. The next generation of scenarios for climate change research and assessment. Nature, v. 463, p. 747756, fev. 2010

[23] MOURA, Ana Clara M. Geoprocessamento na gestão e planejamento urbano. $2^{a}$. ed. Belo Horizonte: Editora da autora, 2005.

[24] MULLER, Cristiane R.; OLIVEIRA, Francisco H. de.; SCHARDOSIM, Patrícia R. A ocupação em Joinville/SC e o papel da gestão municipal para mitigação de danos causados por inundações. RBPD - Revista Brasileira de Planejamento e Desenvolvimento, 1, jul/ dez. 2012. 23-39. n. 1.

[25] OLIVIER, Julia; PROBST, Kirsten; RENNER, Isabel; RIHA, Klemens. Adaptação baseada nos Ecossistemas (AbE): Uma nova abordagem para antecipar soluções naturais conducentes a uma nova adaptação às mudanças 
climáticas nos diferentes setores. Ambiente e alterações climáticas, Agosto 2012. Disponível em: $<$ https://www.giz.de/fachexpertise/downloads/giz20 13-pt-adaptacao-baseada-nos-ecossistemas.pdf > . Acesso em: 27 out. 2016.

[26] PMJ, Prefeitura Municipal de Joinvlle. Base Cartográfica Municipal de Joinville. SIMGeo, Sistema de Informações Municipais Georreferenciadas, Joinville, 2010. Disponível em: <https://geoprocessamento.joinville.sc.gov.br/> Acesso em: 07 jan. 2016.

[27] ROGERS, Richard; GUMUCHDJIAN, Philip. Cidades para um pequeno planeta. Tradução de Anita Regina Di Marco. Barcelona: Gustavo Gili, 2005

[28] SCHEEL-YBERT, Rita; AFONSO, Marisa Coutinho; GUIMARÃES, Marcia Barbosa; GASPAR, Maria Dulce; YBERT, Jean-Pierre. Considerações sobre o papel dos sambaquis como indicadores do nível do mar. On the role of shell mounds as paleosea-level indicators. Quartenary and Environmental Geosciences, 1, 2009. 3-9. n.1.

[29] SIEBERT, Claudia. Sustentabilidade Urbana: o Pensamento Ambiental e as Cidades. In: SHULT, S. M.; FRANK, B.; SEVEGNANI, L. (Org.). Dimensões institucional, urbana e ecológica das áreas de preservação permanente em margens de rios. Blumenau: Edifurb, 2012

[30] SILVEIRA, Wivian Nereira; KOYBAMA, Masato; GOERL, Roberto Fabris; BRANDENBURG, Brigitte. História das Inundações em Joinville: 1851-2008. Curitiba: Organic Trading, 2009.

[31] SOUZA, Luiz Alberto. O processo de ocupação das áreas de mangues em Joinville: agentes, estratégias e conflitos. Florianópolis: UFSC, 1991. Dissertação submetida ao Curso de Mestrado em Geografia do Centro de Ciências Humanas da UFSC.

[32] TAVARES, Antonio C. Mudanças Climáticas. In: VITTE, A. C.; GUERRA, A. J. T. (Org.). Reflexões sobre a geografia física no Brasil. Rio de Janeiro: Bertrand Brasil, 2004. p. 49-88.

[33] VAGGIONE, Pablo. Planeamiento Urbano para Autoridades Locales. Bogotá: ONU Habitat, Ediciones Screen, 2014.

[34] VENERA, José Isaías; SEVERINO, José Roberto. Joinville: Primeiros Habitantes. Itajaí: Casa Aberta Editora, 2010.

[35] WILHEIM, Jorge. Urbanismo y subdesarrollo. Buenos Aires: Nueva Visión, 1977. 


\section{Bapítulo 20}

\section{PERCEPCEÃO DE IDOSOS BRASILEIROS SOBRE OS FATORES LIMITANTES DE INTERAÇÃO COM O ESPAÇO PÚBLICO: O CASO DAS PRAÇAS NA CIDADE DE FLORIANOPOLIS/SC}

Alba Valeria de Barros e Silva Pinheiro

Fernando Manuel Brandão Alves

Paulo Santos Conceição

Resumo: A abordagem do envelhecimento ativo baseia-se no reconhecimento dos direitos humanos dos idosos e dos princípios estabelecidos pelas Nações Unidas de independência, participação, dignidade, assistência e autorrealização. O espaço público praça é o ambiente físico por excelência para permitir o alcance de boa parte dos objetivos das Nações Unidas para o envelhecimento ativo. Este artigo tem como objetivo identificar a percepção de idosos residentes na cidade de Florianópolis sobre os fatores limitantes da sua interação com o espaço público urbano "praça". Para tanto, foram entrevistados 200 idosos acima de 60 anos sobre aspectos relacionados à sua saúde física e mental, à segurança física e proteção social e financeira, bem como sobre aspectos de sua participação na família e na comunidade onde residem. Dos dados pode-se concluir que os idosos se percebem bem física e mentalmente, protegidos pela seguridade social, mas sem disponibilidade para práticas culturais e de lazer junto à comunidade.

Palavras-Chave: Idoso, Envelhecimento Ativo, Análise de Percepção. 


\section{INTRODUÇÃO}

Atualmente o mundo observa dois fenômenos demográficos sem precedentes: a urbanização e o envelhecimento populacional (RIBEIRO \& PAÚL, 2011; ONU, 2003; OMS, 2009; MUENZ, 2007; KALACHE et al., 1987). O aumento da expectativa de vida é resultado de ganhos fundamentais na saúde pública e nos padrões de vida, no entanto à medida que as cidades crescem, aumentam os desafios dos gestores públicos, em atender satisfatoriamente o novo perfil demográfico que se apresenta, nas áreas sociais, econômicas e de saúde, bem como repensar a infraestrutura das cidades para que sejam seguras, acessíveis e que propiciam qualidade de vida para todos (RIBEIRO \& PAÚL, 2011; OMS, 2009).

Segundo dados da Organização das Nações Unidas (ONU), no ano de 2010, o número de pessoas com mais de 60 anos correspondia a $11 \%$ da população mundial, com projeção de chegar a 21,8\% em 2050. Os dados também mostram que em 2050, 68\% da população mundial viverá nas cidades (OMS, 2009).

Em relação às políticas públicas dirigidas à população idosa foi aprovada no ano de 2002, durante a segunda Assembleia Mundial sobre o Envelhecimento, realizada em Madrid, uma nova declaração política e um novo plano de ação que tem orientado a adoção de medidas normativas sobre o envelhecimento neste século (CAMARANO \&PASINATO, 2004). Este plano está baseado em três princípios:

- Participação ativa dos idosos na sociedade, no desenvolvimento e na luta contra a pobreza;

- Fomento da saúde e bem-estar na velhice: promoção do envelhecimento saudável ao longo da vida;

- Criação de um ambiente propício e favorável ao envelhecimento seguro que promova a solidariedade entre gerações.

Nesta assembleia foi reforçado o conceito de envelhecimento ativo que é "o processo de otimização das oportunidades de saúde, participação e segurança, com o objetivo de melhorar a qualidade de vida à medida que as pessoas ficam mais velhas" (OMS, 2005). Ser um idoso ativo consiste em participar na vida social, cultural, religiosa, econômica e cívica, no ambiente onde está inserido, e não apenas a capacidade de ser fisicamente ativo ou de participar no mercado de trabalho. Este conceito se aplica tanto aos indivíduos quanto aos grupos da população.

Ao envelhecer o indivíduo começa a apresentar limitações que podem influenciar a sua interação com o ambiente no qual está inserido. Cada modificação fisiológica pode acarretar restrições diferentes frente ao uso do espaço e dos equipamentos, porém este processo não impede que os idosos conheçam novos lugares e desenvolvam atividades de lazer, desde que estes espaços sejam seguros, acessíveis e confortáveis (DORNELES, ELY \& PEDROSO, 2006).

O homem busca interagir com seus pares em diversos ambientes, entre eles pode-se destacar o espaço público urbano, que por sua natureza social e coletiva, pode ser utilizado por pessoas de culturas, idades e grupos sociais diversos, o que the atribui um caráter universal e torna-o um espaço multifuncional. Todavia para que estes espaços sejam seguros e acessíveis, faz-se necessário que os elementos que o compõem estejam normatizados e apropriados a todos as idades (FRANCISCO, 2005).

Envelhecer ativamente é um processo no qual todas as pessoas estão inseridas e é uma tarefa ao longo da vida. Cabe à sociedade a responsabilidade de produzir espaços e equipamentos sociais, seguros, variados e acessíveis aos mais velhos, garantir e fomentar a sua participação cívica, em todos os níveis de decisão (PAÚL, 2005).

A evolução histórica do espaço público, de acordo com Alves (2003), nos proporciona uma considerável variedade de espaços diferenciados, de fronteiras bem definidas, inseridos ou desviados dos modelos de localização estratégica, a nível internacional.

As praças, como vazios na malha urbana, marcam a estrutura das cidades e que, associadas a conjuntos arquitetônicos, funcionam como lugares de descompressão ao proporcionarem uma quebra na paisagem urbana. Toda cidade tem uma praça que se destaca como um símbolo urbano, espaço agregador, palco de eventos históricos ou local de confluência social (CALDEIRA, 2007).

Considerando que:

- $\quad$ Os idosos corresponderão a 21,8\% da população mundial em 2050.

- Um dos princípios propostos pela ONU em 2002 é a criação de ambientes 
propícios e favoráveis ao envelhecimento seguro.

- $\quad$ O idoso deve envelhecer ativamente.

- O espaço público urbano é um espaço que promove a interação social entre gerações.

- Toda cidade tem uma praça.

Este capítulo objetiva identificar, na percepção dos idosos, os fatores limitantes da sua interação com o espaço público urbano "praça" na cidade em que residem.

\section{NATUREZA COLETIVA DO ESPAÇO PÚBLICO URBANO}

O Homem, como ser social, interage com seus pares em diversos ambientes e entre estes se destaca o espaço público urbano, que por sua natureza social e coletiva, tornase um espaço de funções diversificadas e que permite a sua utilização por pessoas de culturas e grupos sociais diversos, atribuindoIhe um caráter universal e contribuindo para uma melhor qualidade de vida.
Para Serdoura e Silva (2006), o papel do espaço público, assim como a natureza e o conteúdo da interação social que nele tem lugar varia com a classe, grupo étnico, idade, estruturas e tipo de especialização do bairro onde se localiza e desta forma devem ser acessíveis a todos, independentemente da idade, capacidades, origens ou rendimento, reafirmando a importância universal do espaço público. Quando os indivíduos interagem entre si no espaço público, desenvolvem atividades sociais. Esses locais públicos não devem assumir-se como espaços restritos às necessidades de qualquer setor da sociedade e sim oferecer a possibilidade de escolha, em termos de mobilidade e acesso a diferentes atividades, edifícios e recursos (SERDOURA, 2007).

A Figura 1 apresenta a Praça do Comércio em Lisboa, como um exemplo de espaço público onde decorrem variadas manifestações populares, sejam elas artísticas, políticas, educativas, etc. É um espaço de interação social, acessível a todos. É um espaço público que é palco de manifestações várias.

Figura 1 - O espaço público como palco de manifestações várias

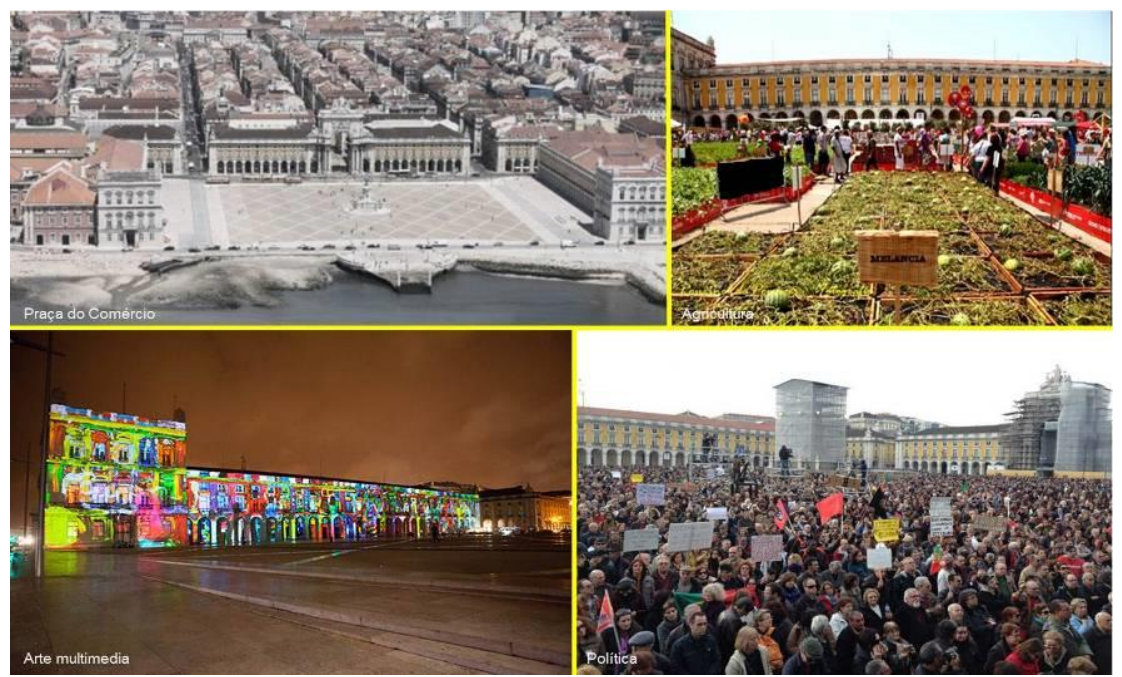

Fonte: Fotomontagem dos autores

Segundo Ferraz (2007), a natureza sociológica do espaço público lança-o além da mera condição funcional e urbanística. O espírito e as atividades do tecido social animam e contextualizam o caráter do espaço público que simultaneamente os reproduz, permitindo ainda a coabitação de populações heterogêneas. Pode proporcionar qualidade de vida à sociedade em todas as suas rotinas e permite o usufruto partilhado do patrimônio coletivo. Esta interação confere ao espaço público um caráter patrimonial, testemunhal, de cujo valor é preciso ter consciência.

"O espaço público é um palco de experiências cívicas; de consagração de acontecimentos de marcante historicidade que imortaliza ambos; a sua imagem e o seu 
usufruto convertem-se em tradição; e, a solidariedade entre todos estes aspetos contribui para a sua perenidade" (FERRAZ, 2007, p. 2).

\section{O IDOSO E O ENVELHECIMENTO ATIVO}

A Organização Mundial da Saúde (OMS) classifica cronologicamente como idosos as pessoas com mais de 65 anos de idade em países desenvolvidos e com mais de 60 anos de idade em países em desenvolvimento (AREOSA \& AREOSA, 2008).

A abordagem do envelhecimento ativo baseia-se no reconhecimento dos direitos humanos dos idosos e dos Princípios estabelecidos pelas Nações Unidas de independência, participação, dignidade, assistência e autorrealização. Segundo a OMS, o planejamento estratégico das políticas de envelhecimento ativo deve abandonar a abordagem "baseada nas necessidades" (que assume que os idosos são alvos passivos) para uma abordagem "baseada nos direitos" que, reconhece os direitos das pessoas à igualdade de oportunidades e de tratamento em todos os aspectos da vida a partir do momento em que se tornam mais velhos (OMS, 2005).

Figura 2 - Determinantes do envelhecimento ativo

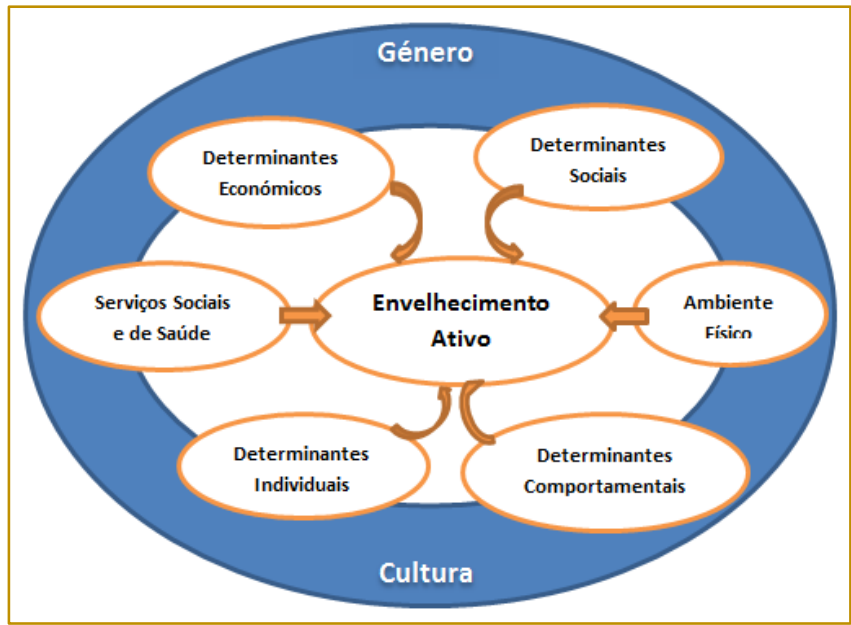

Fonte: OMS, 2009, p.10

A Figura 2 mostra que o envelhecimento ativo depende de uma gama de influências ou determinantes que regulam indivíduos, famílias e países, compreendidos sempre em uma perspectiva de gênero e cultura. Incluem condições materiais e fatores sociais que afetam tipos individuais de comportamento e sentimento. Todos esses fatores, individualmente e combinados uns com outros, exercem um papel importante sobre o envelhecimento de cada indivíduo (OMS, 2009).

\section{METODOLOGIA}

Para a realização da pesquisa foi aplicado um questionário em escala likert junto a 200 idosos, 100 mulheres e 100 homens com idade acima de 60 anos, que frequentam as praças objeto do estudo, quais sejam: praça XV de novembro e praça Getúlio Vargas, na cidade de Florianópolis, estado de Santa Catarina (Figura 3). 
Figura 3 - Localização geográfica das praças na cidade de Florianópolis

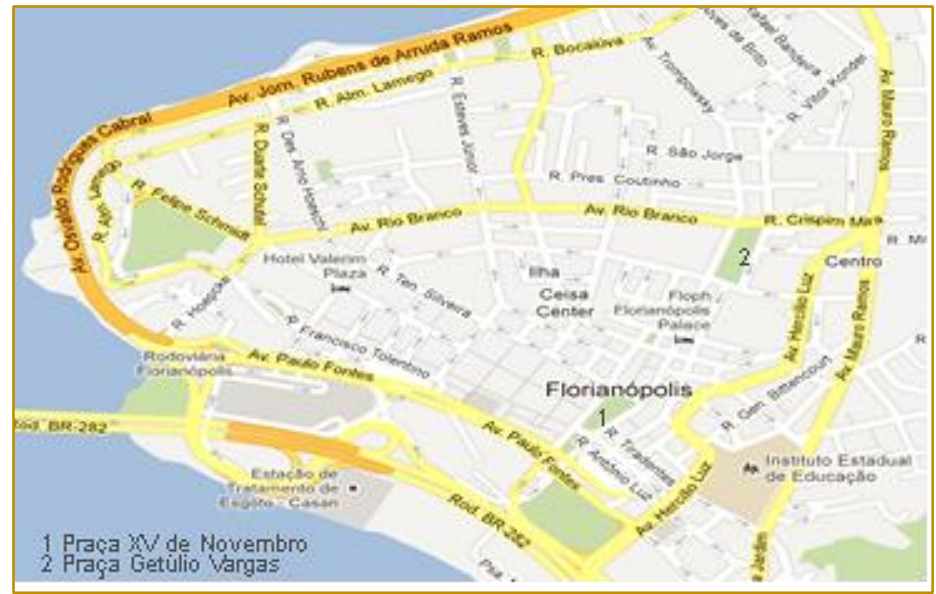

Fonte: https://maps.google.com.br/maps?hl=pt-BR\&q=mapa+de+santa+catarina+e+floripa\&ie=UTF8\&ei=5Wo4UYmXKeHm7AbK1ICwCg\&ved=0CAgQ_AUoAg

A praça XV de novembro localiza-se no centro da cidade de Florianópolis e tem área de $6.655,19 \mathrm{~m}^{2}$. No espaço da praça se distribuem alguns equipamentos, como quiosques para venda de revistas, flores e lanches, além de um espaço para apresentação de corais. O piso da praça é em pedra portuguesa e seus jardins são cercados por uma grade baixa em ferro. No espaço da praça também são realizadas feiras de artesanato e outros eventos ligados a cultura local.

Figura 4 - Equipamentos da praça XV de Novembro, em Florianópolis

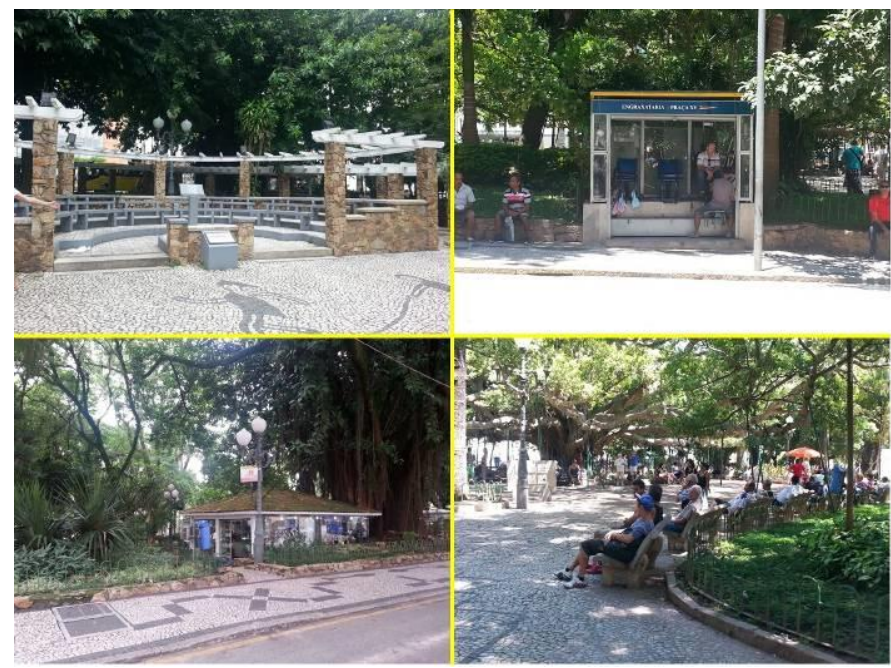

Fonte: dos autores

Também conhecida como "praça dos bombeiros", a praça Getúlio Vargas, tem área de $12.600 \mathrm{~m}^{2}$. Na praça existe uma área de recreação infantil chamada Parque Dona Tilinha e um jardim chamado Gustavo
Richard. No espaço também há um chafariz. A calçada externa tem piso em ladrilho, os caminhos internos da praça são em placa de concreto e do parque infantil é em areia. 
Figura 5 - Equipamentos da praça Getúlio Vargas, em Florianópolis

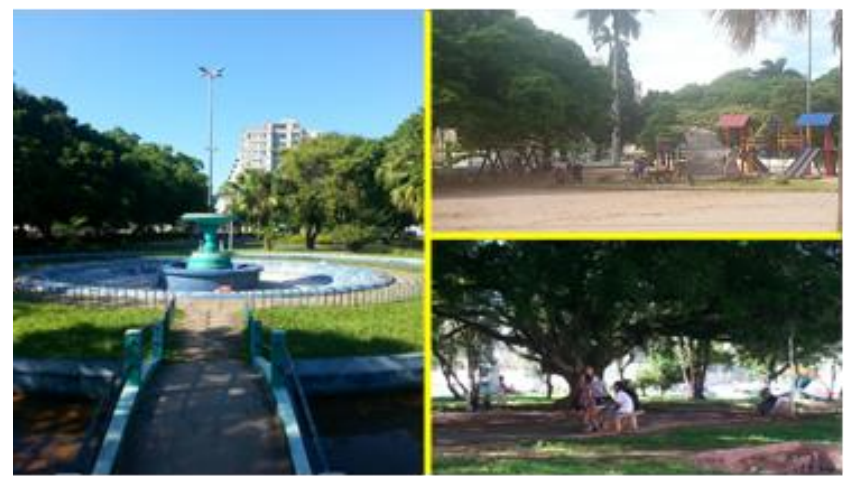

Fonte: dos autores

\section{RESULTADOS E DISCUSSÕES}

Os resultados obtidos na pesquisa de campo, compreendem o perfil socioeconômico dos idosos e sua percepção pessoal ao nível dos três pilares da política de envelhecimento ativo: saúde, segurança e participação social, bem como suas impressões em relação ao espaço público estudado.

\subsection{PERFIL SOCIOECONÔMICO}

Observando a Figura 6 tem-se as seguintes características dos idosos participantes da pesquisa na cidade de Florianópolis:
O perfil dos idosos entrevistados na cidade de Florianópolis/SC/Brasil é composto em sua maioria por idosos entre 60 e 69 anos (65\%), casados $(52 \%)$, seguidos da condição de viúvos (24\%) e que moram com o cônjuge $(49,5 \%)$ ou sozinhos (31\%).

Em relação ao nível de escolaridade dos entrevistados, tem-se que a maioria dos entrevistados, cursou apenas a escola primária $(30,5 \%)$ e apenas $16,5 \%$ tem nível superior completo.

Figura 6. Dados socioeconômicos dos entrevistados

\begin{tabular}{|c|c|c|c|c|c|}
\hline \multirow{2}{*}{ IDADE } & \multicolumn{5}{|c|}{ Florianópolis - Brasil } \\
\hline & Frequência & $\%$ & RENDA & Frequência & $\%$ \\
\hline $60-64$ & 73 & 36,5 & 1Salánio & 51 & 25,5 \\
\hline $65-69$ & 57 & 28,5 & 2Saláios & 50 & 25,0 \\
\hline $70-74$ & 36 & 18,0 & Mais de 3 Salánios & 91 & 45,5 \\
\hline+75 & 34 & 17,0 & Nãosabem & 8 & 4,0 \\
\hline Total & 200 & 100,0 & Total & 200 & 100,0 \\
\hline ESTADOCIVIL & Frequência & $\%$ & AGREGADOFAMIIIAR & Frequência & $\%$ \\
\hline Casado & 104 & 52,0 & Mora com cônjuge & 99 & 49,5 \\
\hline Divorciado & 26 & 13,0 & Mora com filho e neto & 29 & 14,5 \\
\hline Solteiro & 22 & 11,0 & Mora com outra pessoa & 10 & 5,0 \\
\hline Viúvo & 48 & 24,0 & Mora só & 62 & 31,0 \\
\hline Total & 200 & 100,0 & Total & 200 & 100,0 \\
\hline ESCOLARIZAC̣ÃO & Frequência & $\%$ & SITUAC̣ÃOPROFISSIONAL & Frequência & $\%$ \\
\hline Escolaridade 1 & 8 & 4,0 & Aposentado epensionista & 140 & 70,0 \\
\hline Escolaridade 2 & 61 & 30,5 & Empregado & 38 & 19,0 \\
\hline Escolanidade 3 & 39 & 19,5 & Propietáno & 22 & 11,0 \\
\hline Escolanidade 4 & 59 & 29,5 & Sem renda & 0 & 0 \\
\hline Escolaridade 5 & 33 & 16,5 & Total & 200 & 100,0 \\
\hline Total & 200 & 100,0 & & & \\
\hline RESIDÊNCIA NOLOCAL & Frequência & $\%$ & & & \\
\hline Mais de 10 anos & 40 & 20,0 & & & \\
\hline Menos de 10 anos & 4 & 2,0 & & & \\
\hline Outra área & 156 & 78,0 & & & \\
\hline Total & 200 & 100,0 & & & \\
\hline
\end{tabular}

Legenda: Escolaridade 1 refere-se a sem estudo; Escolaridade 2 refere-se a escola primária; Escolaridade 3 refere-se ao ginasial; Escolaridade 4 refere-se ao profissionalizante; Escolaridade 5 refere-se ao ensino superior.

Fonte: Construção dos autores 
Observa-se ainda que $70 \%$ dos entrevistados são reformados ou pensionistas, com renda bruta acima de três salários mínimos (45,5\%), sendo que $25,5 \%$ recebem um salário e $25 \%$ recebem dois salários. Quanto ao tempo de residência junto ao espaço público estudado verifica-se que $78 \%$ moram distantes das praças objeto de estudo.

\subsection{ANÁLISE DA PERCEPÇÃO DOS IDOSOS SOBRE O ESPAÇO PÚBLICO "PRAÇA"}

Para a análise da percepção dos idosos sobre o espaço público de interação social "Praça", aplicou-se o questionário desenvolvido pela pesquisadora tomando como base os pilares da política de envelhecimento ativo da OMS, quais sejam, a otimização das oportunidades de segurança, saúde e participação dos idosos.

\subsubsection{PERCEPÇÃO DOS IDOSOS AO NÍVEL DO PILAR SAÚDE}

O pilar saúde da política de envelhecimento ativo da OMS baseia-se em manter os fatores de riscos comportamentais e ambientais, de doenças crônicas e de declínio funcional, em níveis baixos, elevando-se os fatores de proteção, de modo a promover uma melhor qualidade de vida para os idosos, com saúde e capazes de cuidar de si à medida que envelhecem e os que necessitam de cuidados devem ter acesso a uma gama de serviços sociais e de saúde que atendam às suas necessidades e direitos (OMS, 2005).

Os entrevistados responderam sobre sua percepção em relação a sua própria saúde e autonomia, como a seguir:

A maioria dos idosos entrevistados na cidade de Florianópolis (70\%) estão satisfeitos e 19\% mais ou menos satisfeitos com sua condição de saúde física. Este dado reflete uma independência destes indivíduos para as atividades da vida diária (Figura 7).

Figura 7- Satisfação com saúde e condições para o trabalho

\begin{tabular}{|c|c|c|c|c|c|c|}
\hline \multirow{2}{*}{\multicolumn{2}{|c|}{ Questão }} & \multicolumn{4}{|c|}{ Éscala } & \multirow{3}{*}{$\begin{array}{r}\text { Total } \\
200\end{array}$} \\
\hline & & \multirow{2}{*}{$\begin{array}{c}\text { Insatisfeito } \\
22\end{array}$} & \multirow{2}{*}{$\begin{array}{c}\text { Mais ou Menos } \\
38\end{array}$} & \multirow{2}{*}{$\begin{array}{c}\text { Satisfeito } \\
140\end{array}$} & \multirow{2}{*}{$\begin{array}{c}\text { NSA } \\
-\end{array}$} & \\
\hline \multirow{2}{*}{ Satisfação com saúde física } & Frequência & & & & & \\
\hline & $\%$ & 11 & 19 & 70 & - & 100 \\
\hline \multirow[b]{2}{*}{ Satisfação com saúde mental } & Frequência & 10 & 17 & 173 & - & 200 \\
\hline & $\%$ & 5 & 8,5 & 86,5 & - & 100 \\
\hline \multirow{2}{*}{$\begin{array}{l}\text { Satisfação com sua capacidade } \\
\text { para o trabalho }\end{array}$} & Frequência & 1 & 1 & 142 & 56 & 200 \\
\hline & $\%$ & 0,5 & 0,5 & 71 & 28 & 100 \\
\hline
\end{tabular}

Fonte: Construção dos autores

Quando questionados sobre sua satisfação ao nível de saúde mental, verifica-se que $86,5 \%$ estão satisfeitos e 8,5\% encontram-se mais ou menos satisfeitos com sua saúde mental, refletindo possivelmente alguma perda da autonomia para tomar as decisões sobre a condução de sua vida.

Foi perguntado aos entrevistados se eles ainda teriam capacidade para trabalhar de forma voluntária ou não. Ainda na Figura 7 , pode-se observar que $71 \%$ estão satisfeitos com sua capacidade para o trabalho, no entanto percebe-se que $28 \%$ desconsideraram esta capacidade, quer sejam porque estão já aposentados e/ou porque não se envolvem com as atividades voluntárias na comunidade em que residem.

Atividades do dia-a-dia são consideradas as atividades de vida diária (AVD), que são as tarefas que um indivíduo precisa realizar para cuidar de si, tais como: tomar banho, vestirse, andar, comer, ir ao banheiro, passar da cama para a cadeira, mover-se na cama e ter continências urinária e fecal, e as atividades instrumentais de vida diária (AIVD), que são as habilidades do indivíduo em administrar o ambiente em que vive, tais como: preparar refeições, fazer tarefas domésticas, usar o telefone, tomar medicações, lavar roupas, manusear dinheiro, fazer compras e utilizar os meios de transporte (OKUMA, 1998).

Verifica-se na Figura 8 que os idosos residentes em Florianópolis estão satisfeitos com a realização das AVD (95,5\%), o mesmo se repete quando perguntados sobre sua satisfação com a rotina fora de casa, principalmente atividades de lazer, com 95\%. 
Figura 8- Satisfação com as atividade de rotina diária

\begin{tabular}{|llccccc|}
\hline \multirow{2}{*}{ Questão } & & \multicolumn{4}{c}{ Escala } & \multirow{2}{*}{ Total } \\
\cline { 3 - 6 } & & Insatisfeito & Mais ou Menos & Satisfeito & NSA & \\
\hline $\begin{array}{l}\text { Satisfação com a rotina } \\
\text { diária }\end{array}$ & Frequência & 1 & 6 & 191 & 2,0 & 200 \\
& $\%$ & 0,5 & 3 & 95,5 & 1,0 & 100 \\
\hline Satisfação com a rotina fora de & Frequência & 2 & 7 & 190 & 1,0 & 200 \\
casa & $\%$ & 1,0 & 3,5 & 95 & 0,5 & 100 \\
\hline \multirow{2}{*}{ Satisfação consigo mesmo } & Frequência & 8 & 13 & 179 & - & 200 \\
& $\%$ & 4,0 & 6,5 & 89,5 & - & 100 \\
\hline
\end{tabular}

Fonte: Construção dos autores

Quanto ao grau de satisfação consigo mesmo, verifica-se que $89,5 \%$ dos entrevistados estão satisfeitos e apenas 4\% se encontram insatisfeito consigo mesmo, podendo esta resposta refletir um pouco da perda da autonomia e/ou da capacidade para as atividades da vida diária.

Da análise dos dados apresentados para o pilar saúde, depreende-se que os idosos entrevistados têm uma boa percepção de sua saúde física e mental, e se sentem aptos para contribuir com a família e a comunidade onde estão inseridos.

\subsubsection{PERCEPÇÃO DOS IDOSOS AO NÍVEL DO PILAR SEGURANÇA}

O pilar segurança deve prever que nas políticas e nos programas que abordam as necessidades e direitos dos idosos à segurança social, física e financeira, fiquem asseguradas a dignidade, proteção e assistência aos idosos que não possa mais se sustentar e proteger. As famílias e a comunidade devem receber, por parte do poder público, auxílio no cuidado com os mais velhos (OMS, 2005).
A percepção de segurança e o sentimento de vulnerabilidade constituem dimensões subjetivas críticas do bem-estar do indivíduo na sua relação com a cidade, influenciando a capacidade e motivação do indivíduo para fruir o espaço público e se predispor ao convívio e participação ativa na vida da comunidade. No caso dos idosos, esta percepção, correlacionada ou não com a realidade da prática criminosa no ambiente em que vive, afeta a sua independência, a saúde física, a integração social e o bemestar emocional (PINHEIRO, 2014).

Foi perguntado aos entrevistados se eles se sentiam seguros em sair de casa, considerando a violência urbana. A Figura 9 mostra que $47,5 \%$ dos entrevistados estão satisfeitos. Observa-se porém, que 33\% dos idosos em Florianópolis estão insatisfeitos e 19,5\% mais ou menos satisfeitos.

Segundo o Escritório das Nações Unidas sobre Drogas e Crimes (UNODC), em 2012, o Brasil teve uma taxa de homicídios de 21 por 100 mil habitantes, o que justificaria, em tese, a percepção dos idosos catarinenses sobre a segurança pública.

Figura 9 - Segurança ao sair de casa

\begin{tabular}{|c|c|c|c|c|c|c|}
\hline \multirow{2}{*}{ Questão } & & \multicolumn{4}{|c|}{ Escala } & \multirow{2}{*}{ Total } \\
\hline & & Insatisfeito & Mais ou Menos & Satisfeito & NSA & \\
\hline \multirow{2}{*}{$\begin{array}{l}\text { Satisfação com segurança } \\
\text { ao sair de casa }\end{array}$} & Frequência & 66 & 39 & 95 & - & 200 \\
\hline & $\%$ & 33 & 19,5 & 47,5 & - & 100 \\
\hline \multirow{2}{*}{$\begin{array}{l}\text { Satisfação em caminhar pelos } \\
\text { espaços públicos }\end{array}$} & Frequência & 51 & 43 & 105 & 1,0 & 200 \\
\hline & $\%$ & 25,5 & 21,5 & 52,5 & 0,5 & 100 \\
\hline
\end{tabular}

Fonte: Construção dos autores

Em relação ao trajeto de casa até a praça foi perguntado aos entrevistados se as vias públicas de acesso eram sinalizadas, o piso era adequado, etc. Neste aspecto, 52,5\% dos respondentes disseram estar satisfeitos, 21,5 mais ou menos satisfeitos e $25,5 \%$ estão insatisfeitos.
A discussão da problemática da insegurança urbana requer o envolvimento do conjunto das instituições e organizações sociais, públicas, privadas ou da sociedade civil com responsabilidades na prestação de serviços nos domínios da educação, saúde, justiça, reinserção social, gestão do território, 
transportes, habitação, segurança social, e emprego junto das comunidades (MACHADO et al., 2011).

Perguntou-se aos entrevistados se eles estavam satisfeitos com o apoio que recebiam dos amigos e familiares e se este apoio correspondia ao que eles esperavam. A Figura 10 mostra que $86 \%$ do total da amostra estão satisfeitos, e 71,5\% acreditam receber o apoio que esperam dos familiares e amigos.

Figura 10 - Satisfação com o apoio que recebe dos amigos e familiares

\begin{tabular}{|llccccc|}
\hline \multirow{2}{*}{ Questão } & & \multicolumn{4}{c}{ Escala } & \multirow{2}{*}{ Total } \\
\cline { 3 - 6 } & & Insatisfeito & Mais ou Menos & Satisfeito & NSA & \\
\hline $\begin{array}{l}\text { Satisfação com apoio da } \\
\text { família e amigos }\end{array}$ & Frequência & 12 & 15 & 172 & 1 & 200 \\
& $\%$ & 6,0 & 7,5 & 86 & 0,5 & 100 \\
\hline $\begin{array}{l}\text { Satisfação com o apoio } \\
\text { esperado }\end{array}$ & Frequência & 27 & 27 & 143 & 3 & 200 \\
\hline
\end{tabular}

Fonte: Construção dos autores

Quando perguntados sobre os serviços oferecidos pelo Estado: segurança social, saúde pública, serviços de energia, água e saneamento, etc. Na Figura 11 tem-se que $59,5 \%$ dos entrevistados estão insatisfeitos e que $24 \%$ estão satisfeitos.

Figura 11 - Satisfação com a oferta de serviços

\begin{tabular}{|c|c|c|c|c|c|c|}
\hline \multirow{2}{*}{ Questão } & & \multicolumn{4}{|c|}{ Escala } & \multirow{2}{*}{ Tota } \\
\hline & & Insatisfeito & Mais ou Menos & Satisfeito & NSA & \\
\hline \multirow{2}{*}{$\begin{array}{l}\text { Satisfação com os serviços } \\
\text { oferecidos pelo Estado }\end{array}$} & Frequência & 119 & 33 & 48 & - & 200 \\
\hline & $\%$ & 59,5 & 16,5 & 24 & - & 100 \\
\hline \multirow{2}{*}{$\begin{array}{l}\text { Satisfação com os serviços } \\
\text { oferecidos pela comunidade }\end{array}$} & Frequência & 112 & 40 & 48 & - & 200 \\
\hline & $\%$ & 56 & 20 & 24 & - & 100 \\
\hline
\end{tabular}

Fonte: Construção dos autores

Quando perguntados sobre os serviços oferecidos pela comunidade (centros de convivência, paróquia, associação de moradores, etc.), verifica-se que o grau de insatisfação chega a 56\%, contra $24 \%$ de satisfeitos e $20 \%$ de mais ou menos satisfeitos.

Figura 12 - Satisfação financeira

\begin{tabular}{|ccc|}
\hline \multirow{2}{*}{ Escala } & Florianópolis \\
\cline { 2 - 3 } & Frequência & $\%$ \\
\hline Insatisfeito & 56 & 28,0 \\
Mais ou Menos & 29 & 14,5 \\
Satisfeito & 113 & 56,5 \\
Não se aplica & 2 & 1,0 \\
Total & 200 & 100,0 \\
\hline
\end{tabular}

Fonte: Construção dos autores

Quanto ao grau de satisfação financeira dos entrevistados tem-se na Figura 12 que 56,5\% dos entrevistados estão satisfeitos, $28 \%$ estão insatisfeitos e $14,5 \%$ estão mais ou menos satisfeitos.

\subsubsection{PERCEPÇÃO DOS IDOSOS AO NÍVEL DO PILAR PARTICIPAÇÃO}

O pilar participação social refere-se ao apoio dado pelo mercado de trabalho, o emprego, a educação, as políticas de saúde e sociais e os programas que permitem uma participação integral do idoso em atividades socioeconômicas, culturais e espirituais, garantindo seus direitos humanos 
fundamentais, de modo a contribuírem para a sociedade com atividades remuneradas ou não, enquanto envelhecem (OMS, 2005).

Os entrevistados responderam sobre sua participação social junto à comunidade onde estão inseridos da seguinte forma:

Quando perguntados sobre suas relações pessoais (amigos, família, conhecidos, colegas do trabalho) os entrevistados responderam que $88,5 \%$ estão satisfeitos, e apenas 5,5\% estão insatisfeitos (Figura 13).

Esta percepção pode estar relacionada ao fato de que $64 \%$ dos entrevistados moram com o cônjuge e filhos e netos, ou seja, há grande interação dos idosos na família.

Figura 13 - Satisfação com as relações pessoais

\begin{tabular}{|ccc|}
\hline \multirow{2}{*}{ Escala } & \multicolumn{2}{c|}{ Florianópolis } \\
\cline { 2 - 3 } & Frequência & $\%$ \\
\hline Insatisfeito & 11 & 5,5 \\
Mais ou Menos & 11 & 5,5 \\
Satisféto & 177 & 88,5 \\
Não se aplica & 1 & 0,5 \\
Total & 200 & 100,0 \\
\hline
\end{tabular}

Fonte: Construção dos autores

Foi perguntado aos entrevistados se eles estavam satisfeitos em participar nas atividades culturais, religiosas, de lazer da comunidade onde estão inseridos. A Figura
14 mostra que 55,5\% dos idosos não se interessam, segundo eles, em participar nestas atividades.

Figura 14 - Satisfação com participação na comunidade

\begin{tabular}{|ccc|}
\hline \multirow{2}{*}{ Escala } & \multicolumn{2}{c|}{ Florianópolis } \\
\cline { 2 - 3 } & Frequência & $\%$ \\
\hline Insatisféto & 10 & 5,0 \\
Mais ou Menos & 9 & 4,5 \\
Satisfeito & 70 & 35,0 \\
Não se aplica & 111 & 55,5 \\
Total & 200 & 100,0 \\
\hline
\end{tabular}

Fonte: Construção dos autores

Infelizmente ainda não se tem grandes experiências da participação voluntária de idosos na comunidade, mas tem crescido as oportunidades com a adoção de centros de convívio de idosos.

Perguntou-se aos entrevistados se estavam satisfeitos com os locais disponíveis na cidade para a realização de atividades físicas, culturais e de lazer. Na Figura 15 verifica-se que $10 \%$ não opinaram, $53 \%$ estão satisfeitos, $25,5 \%$ estão insatisfeitos e $11,5 \%$ estão mais ou menos satisfeitos.

Figura 15 - Satisfação com os locais disponíveis para atividades

\begin{tabular}{|ccc|}
\hline \multirow{2}{*}{ Escala } & \multicolumn{2}{c|}{ Florianópolis } \\
\cline { 2 - 3 } & Frequência & $\%$ \\
\hline Insatisfeito & 51 & 25,5 \\
Mais ou Menos & 23 & 11,5 \\
Satisfeito & 106 & 53,0 \\
Não se aplica & 20 & 10,0 \\
Total & 200 & 100,0 \\
\hline
\end{tabular}

Fonte: Construção dos autores 
Quando perguntados se faziam algum exercício físico sós ou acompanhados, os entrevistados responderam, de acordo com a Figura 16 que, 53\% estão satisfeitos, mas
31,5\% consideraram que esta questão não se aplica a eles, seja por incapacidade para a atividade física ou porque não se interessam por este tipo de atividade.

Figura 16 - Satisfação com exercício físico

\begin{tabular}{|ccc|}
\hline \multirow{2}{*}{ Escala } & \multicolumn{2}{c|}{ Florianópolis } \\
\cline { 2 - 3 } & Frequência & $\%$ \\
\hline Insatisfeito & 19 & 9,5 \\
Mais ou Menos & 12 & 6,0 \\
Satisfeito & 106 & 53,0 \\
Não se aplica & 63 & 31,5 \\
Total & 200 & 100,0 \\
\hline
\end{tabular}

Fonte: Construção dos autores

A funcionalidade dos idosos é fortemente afetada pelas Doenças e Agravos Não Transmissíveis - DANT, dificultando ou impedindo o desempenho de suas atividades cotidianas independentes (MACIEL, 2010). Lima-Costa, Barreto e Giatti (2003) investigaram as condições de saúde do idoso brasileiro $(\mathrm{N}=28.943)$. A prevalência de relato de DANT encontrada foi de 69\%. As principais doenças relatadas pelos indivíduos participantes do estudo foram: hipertensão arterial $(43,9 \%)$, artrite $(37,5 \%)$, doenças do coração $(19,0 \%)$ e diabetes (10,3\%). Essas doenças tendem a se manifestar de forma ainda mais expressiva quanto maior for a idade.

\section{CONCLUSÕES}

Os dados coletados com os idosos da cidade de Florianópolis demonstram que eles estão satisfeitos com sua saúde física e mental, o que Ihes permite colaborar com a família e a comunidade onde residem. Em relação ao uso coletivo do espaço público, há uma divisão muito clara nas respostas, onde a maioria se considera insatisfeito com a segurança pública e quase a metade dos

\section{REFERÊNCIAS}

[1] ALVES, FERNANDO BRANDÃO. Avaliação da qualidade do espaço público urbano: uma proposta metodológica. Ed. Fundação Calouste Gulbenkian, Lisboa, 2003.

[2] ANDRADE, A. \& MARTINS, R. Funcionalidade Familiar e Qualidade de Vida dos Idosos. Millenium, 40: 185-199, 2011.

[3] AREOSA, S.V.C. \& AREOSA, A.L. Envelhecimento e dependência: desafios a serem entrevistados relatam dificuldades com a mobilidade pedonal pelas vias públicas, como a qualidade das calçadas e sinalização.

Quanto aos serviços oferecidos pelo Estado e pela comunidade onde estão inseridos, os idosos ouvidos estão bastante insatisfeitos, mesmo acreditando que recebem a apoio de que precisam da família e amigos. Um aspecto a se notar é a satisfação com a condição financeira apontada pela maioria dos entrevistados.

Apesar de se declararem satisfeitos com os locais disponíveis na cidade para a realização de atividades físicas, culturais e de lazer, a maioria não se interessa pela realização de práticas culturais e de lazer nos espaços públicos e boa parte dos consultados não se interessam pela prática de atividades físicas.

$\mathrm{Da}$ análise destes dados pode-se concluir que a percepção de insegurança nos espaços públicos, seja pela violência urbana, seja pela dificuldade de se deslocar até a praça próxima da residência faz com que os idosos não desfrutem destes espaços públicos para atividades culturais, espirituais e de lazer na comunidade, reduzindo consideravelmente suas oportunidades de interação social na comunidade.

enfrentados. Revista Textos \& Contextos. Porto Alegre v. 7 n. 1 p. 138-150, 2008.

[4] CALDEIRA, JUNIA MARQUES. A praça brasileira: trajetória de um espaço urbano - origem e modernidade. Tese. Universidade Estadual de Campinas, São Paulo, 2007.

[5] CAMARANO, A. A. \& PASINATO, M. T. O Envelhecimento Populacional na Agenda das Políticas Públicas.In: Ana Amélia Camarano. (Org.). Os novos idosos brasileiros: muito além dos 60? 1 ed. Rio de Janeiro: IPEA, 2004, v. 1, p. 253-292. 
[6] DORNELES, V.G., BINS ELY, V.H.M. \& PEDROSO, E.S.R. A inserção do idoso no espaço público urbano.In: ENTAC 2006. Anais... Florianópolis. p. 2732-2741.

[7] FERRAZ, S. Compreender o espaço público para requalificar a cidade. Actas do Seminário Estudos Urbanos. Lisboa, 2007. Disponível em: http://seu2007.saau.iscte.pt/Actas/Actas_SEU2007 _files/Susana_Ferraz2.pdf Acesso em 25/05/2011.

[8] FRANCISCO, M. D. Espaço Público Urbano: Oportunidade de Identidade Urbana Participada. Actas $x$ Colóquio Ibérico de Geografia "A Geografia Ibérica no Contexto Europeu" Évora, Universidade de Évora, 2005. Disponível em: http://www.apgeo.pt/files/docs/CD_X_Coloquio_lbe rico_Geografia/pdfs/053.pdf Acesso em $11 / 04 / 2011$

[9] KALACHE, A.; VERAS, R. P.; RAMOS, L. R. O envelhecimento da população mundial: um desafio novo. Rev. Saúde Pública [online], 21(3): 200-210, 1987

[10] LIMA-COSTA, M. F.; BARRETO, S. M; GIATTI, L. Condições de saúde, capacidade funcional, uso de serviços de saúde e gastos com medicamentos da população idosa brasileira: um estudo descritivo baseado na Pesquisa Nacional por Amostra de Domicílios. Caderno de Saúde Publica, 19(3):735-43, 2003.

[11] MACHADO, P.; NEVES, A. V.; ALMEIDA, C.; ESTEVES, N.; VILARES, E.; ROSA, F. Segurança Pública e Desenvolvimento Urbano: a prevenção do crime através do espaço construído. Série Política de Cidades - 7, 2011. Lisboa: DGOTDU.

[12] MACIEL, M.G. Atividade física e funcionalidade do idoso. Motriz, v.16 n.4, p.10241032, out./dez. 2010.

[13] MUENZ, RAINER. Aging and Demographic Change in European Societies: Main Trends and Alternative Policy Options. Hamburg Institute for International Economics. SP Discussion Paper. N. 703. Social Protection, World Bank, 2007.

[14] OKUMA, S. S. O idoso e a atividade física: fundamentos e pesquisas. São Paulo: Papirus, 1998.

[15] ORGANIZAÇÃO DAS NAÇÕES UNIDAS. Plano de ação internacional para o envelhecimento, 2002/ONU. Tradução de Arlene Santos. Brasília: Secretaria Especial dos Direitos Humanos. 2003, 49p.
[16] ORGANIZAÇÃO MUNDIAL DA SAÚDE. Envelhecimento ativo: uma política de saúde. World Health Organization; Tradução Suzana Gontijo. Brasília: Organização Pan-Americana da Saúde, 2005. 60p.: il.

[17] ORGANIZAÇÃO MUNDIAL DA SAÚDE. Guia Global das Cidades Amigas das Pessoas Idosas. Tradução Fundação Calouste Gulbenkian, $2007 . \quad$ Disponivel em: http://www.gulbenkian.pt/media/files/FTP_files/pdfs/ PGDesenvolvimentoHumano/Projldosos_GuiaCidad es2009.pdf Acesso em 12/04/2011.

[18] PAÚL, C. Envelhecimento activo e redes de suporte social. Sociologia - Revista da Faculdade de Letras da Universidade do Porto, 15(1): 275-287, 2005.

[19] PAÚL, C. Envelhecimento e ambiente. In Luís Soczka (org.) Contextos humanos e psicologia ambiental. Lisboa, FCG, 2005. Cap. 8, Pags. 247268.

[20] PINHEIRO, F. A. Índice de Desempenho das Cidades Amigas dos Idosos: Proposta de Modelo. Porto/Portugal: UP. 238p. Tese de Doutorado - Segurança e Saúde Ocupacionais. Faculdade de Engenharia da Universidade do porto, Portugal, 2014.

[21] RIBEIRO, O. \& PAÚL, C. Manual do envelhecimento activo.Porto:Lidel, 2011.

[22] RIBEIRO, R. C. L. et al. Capacidade Funcional e qualidade de vida de idosos. Estud. interdiscip. envelhec., Porto Alegre, v. 4, p. 85-96, 2002.

[23] SERDOURA, F. \& SILVA, F. N. (2006). Espaço Público. Lugar de Vida Urbana. Disponível em:

http://www.civil.uminho.pt/cec/revista/Num27/n_27_ pag_5-16.pdf Acesso em 11/04/2011.

[24] SERDOURA, F. (2007). As dimensões do espaço urbano público. Disponível em: http://www.repository.utl.pt/bitstream/10400.5/1807/ 1/FAUTL_13_D_FSerdoura.pdf Acesso em 16/11/11 as 12:28.

[25] WORLD HEALTH ORGANIZATION. Global age-friendly cities: a guide. Ageing and Life Course, Family and Community Health. French, 2007. ISBN 9789241547307. 


\section{Gapítulo 21}

\section{MICROURBANISMO EFÊMERO: TÁTICAS URBANAS CRIATIVAS}

\section{Tiago Balem}

Resumo: Em muitas cidades do mundo, ações efêmeras têm utilizado terrenos baldios, edifícios abandonados e espaços urbanos degradados para transformá-los em novos lugares por meio de usos temporários. Os lugares que recebem essas intervenções tornam-se cenários para atividades recreativas, clubes comunitários, empresas criativas, economias nômades, mercados informais, bares e vida noturna. Precisamente nesses lugares tem havido, atualmente, uma produção cultural inovadora e eles têm se tornado uma esfera pública vibrante por meio da participação das comunidades. Este artigo apresenta a abordagem do uso temporário de espaços da cidade como alternativa possível para o urbanismo a partir de manifestações contemporâneas de ações promovidas pela sociedade. $O$ artigo investiga essa possibilidade no âmbito do urbanismo e estrutura-se a partir de uma leitura do problema por camadas. A camada 1, Cidade contemporânea em tempos fluidos - uma narrativa, apresenta uma reflexão sobre a sociedade contemporânea, na perspectiva de entendê-la dentro de uma sociedade em rede e fluída. Ainda nessa sessão, aprofundar-se a temática da sociedade contemporânea, aproximando-a de uma noção de um urbanismo também fluído. $\mathrm{Na}$ camada 2, Microurbanismo efêmero - uma prática, esta pesquisa debruça-se sobre as novas teorias, conceitos e estudos de caso que têm se dedicado a compreender ações de usos temporários, ou seja, aquelas que agem sobre espaços degradados por um tempo determinado e contam com a participação cidadã. A camada 3, 0 uso temporário no urbanismo - uma possibilidade, busca estabelecer a relação dessas práticas com a teoria no urbanismo.

Palavras-chave: urbanismo efêmero; práticas urbanas criativas; urbanismo tático. 


\section{INTRODUÇÃO}

Em muitas cidades do mundo, ações efêmeras têm utilizado terrenos baldios, edifícios abandonados e espaços urbanos degradados para transformá-los em novos lugares por meio de usos temporários. Os lugares que recebem essas intervenções tornam-se cenários para atividades recreativas, clubes comunitários, empresas criativas, economias nômades, mercados informais, bares e vida noturna. Precisamente nesses lugares tem havido, atualmente, uma produção cultural inovadora e eles têm se tornado uma esfera pública vibrante por meio da participação das comunidades. Este artigo apresenta a abordagem do uso temporário de espaços da cidade como alternativa possível para o urbanismo a partir de manifestações contemporâneas de ações promovidas pela sociedade.

Os usos temporários estão surgindo onde o Estado falha em atender demandas da sociedade; há flexibilidade no planejamento urbano; reunião de pessoas interessadas em projetos coletivos e áreas nas quais o uso compartilhado é viável. Alguns usos são planejados e formais, outros são informais, acidentais, espontâneos ou até mesmo ilegais. Alguns ocorrem quando uma cidade está encolhendo, outros, quando está crescendo e muitos, ainda, em áreas abandonadas. Alguns usos duram uma noite ou um fim de semana, alguns são sazonais, enquanto outros podem durar cinco anos ou mais. Dada essa ampla gama de características, as atividades temporárias precisam ser definidas com cuidado.

O uso temporário se expressa por meio das mais variadas tipologias formais e funcionais. A maioria dos autores consultados, os quais serão apresentados no decorrer deste artigo, sinalizam a dificuldade em criar critérios de análise e categorias para esses tipos de propostas. Até o momento, esta pesquisa assume, a partir de uma apreciação preliminar, que essas ações conformam-se e definem-se por dois eixos principais: um de caráter social e outro de caráter econômico.

Do eixo social (figura 1, 2 e 3), vê-se emergir inúmeras ações de utilização de todo tipo de espaços urbanos, promovidas por movimentos sociais e coletivos empenhados na construção de melhoria das suas vidas em comunidade. Em sua maioria, as ações produzidas têm caráter de cidadania, política ou arte. Essas ações efêmeras apresentam um vínculo a um determinado contexto, causa ou interesse específico do grupo promotor que constrói ocupações e intervenções urbanas de pequena escala para melhorar a vida coletiva em seu próprio cotidiano.

Figura 1. Jardim público e espaço cultural em terreno baldio em Londres.

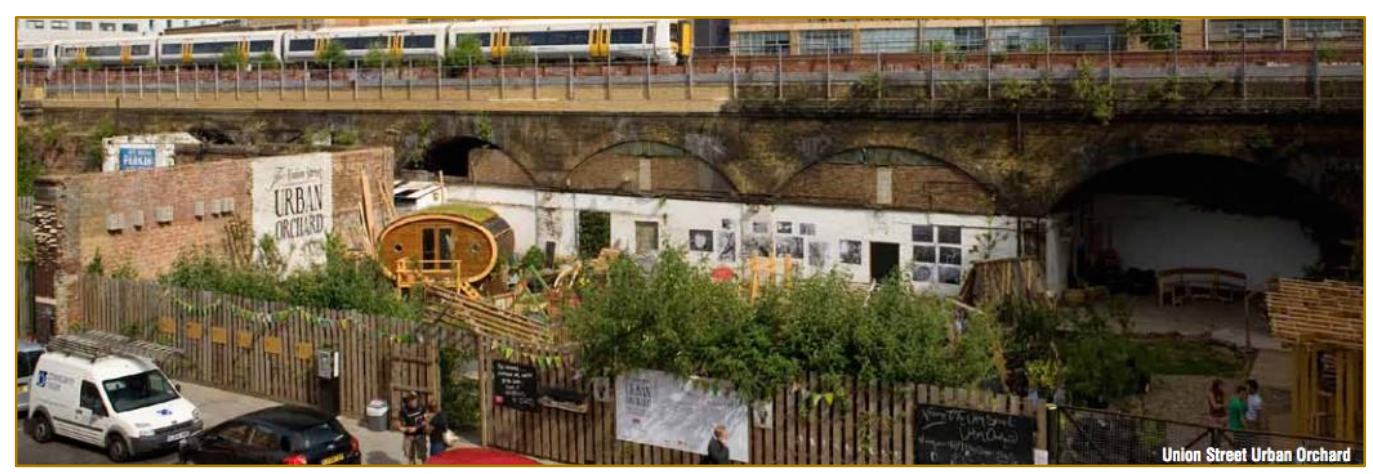

Fotografia: Union Street Urban Orchard

Fonte: www.killingarchitects.com/. Acesso maio 2018. 
Figura 2. Mobiliário construído de forma colaborativa no Largo da Batata, São Paulo.

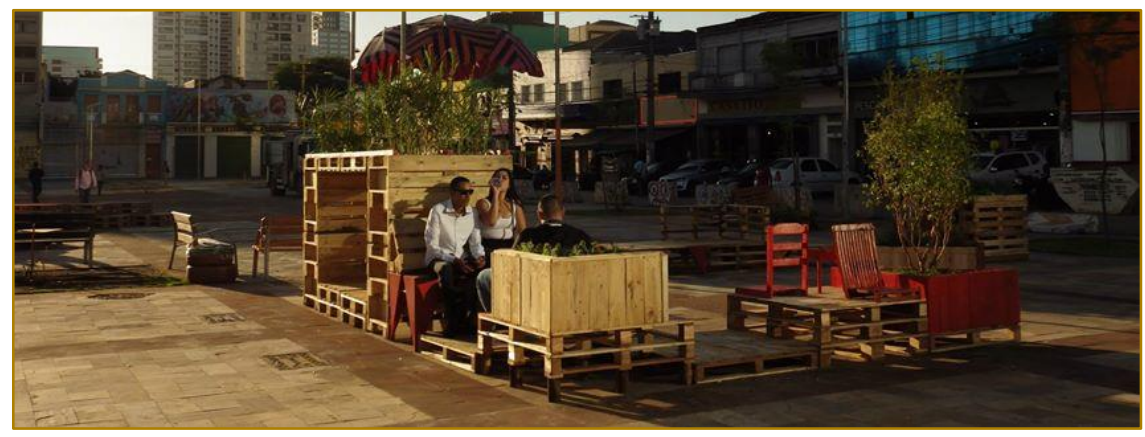

Fotografia: A Batata Precisa de Você. Fonte: http://www.obeijo.com.br/eventos/curso-discuteocupacao-do-espaco-publico-12769917. Acesso maio 2018.

Figura 3. Horta e feira de produtos alimentícios.

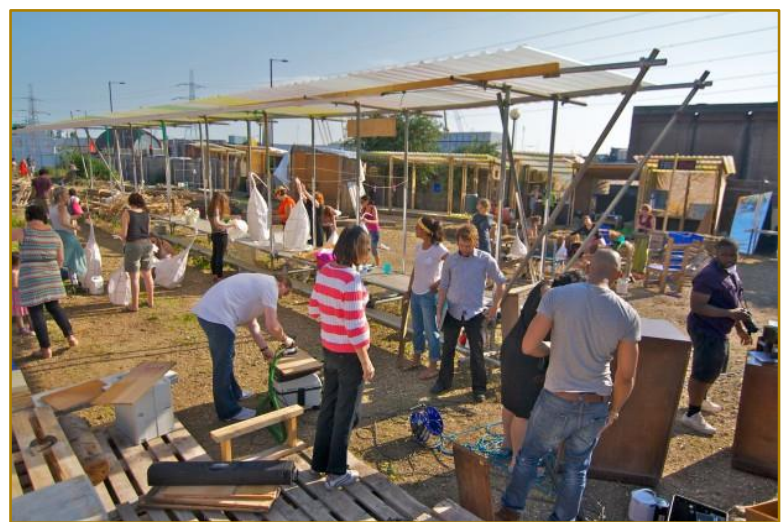

Fonte: http://www.killingarchitects.com. Acesso maio 2018

Por outro lado, no eixo econômico (figura 4 e 5), proliferam ações comerciais temporárias em busca de novos formatos para produção de renda, oportunidades de espaços de criação, visibilidade ao trabalho e experiências de consumo. Os grupos que praticam estas ações investem temporariamente em vazios urbanos, espaços deteriorados, edifícios abandonados ou mesmo em espaços públicos convencionais, valendo-se da condição atmosférica do lugar e de sua vacância como elemento de seu projeto.

Figura 4. The Haus. Galeria de arte de rua em Berlim.

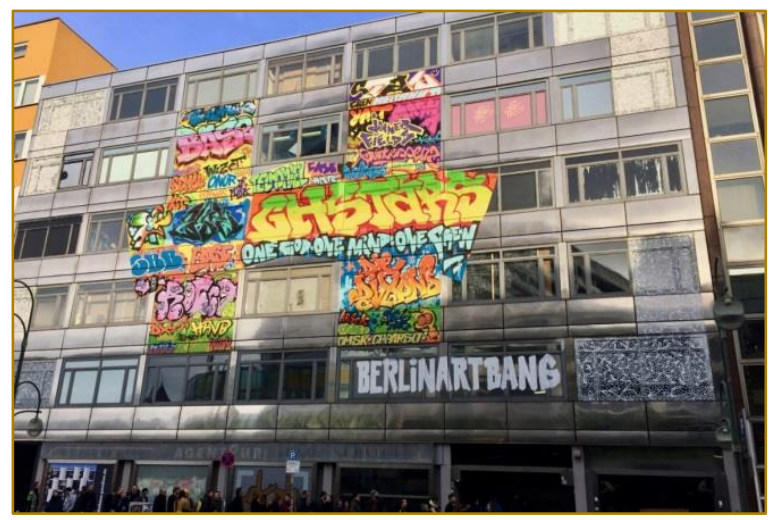

Fotografia: Estilo Palma.

Fonte: http://www.estilopalma.com/2017/05/temporary-art-haus-berlin-iii/. Acesso maio 2018. 
A Figura 5. Mostra a Larkin Square, em Buffalo, Nova lorque que hospeda eventos de food truck e concertos, transformando uma área industrial abandonada em um espaço vibrante.

Figura 5. Larkin Square, em Buffalo, Nova lorque, hospeda eventos de food truck e concertos, transformando uma área industrial abandonada em um espaço vibrante.

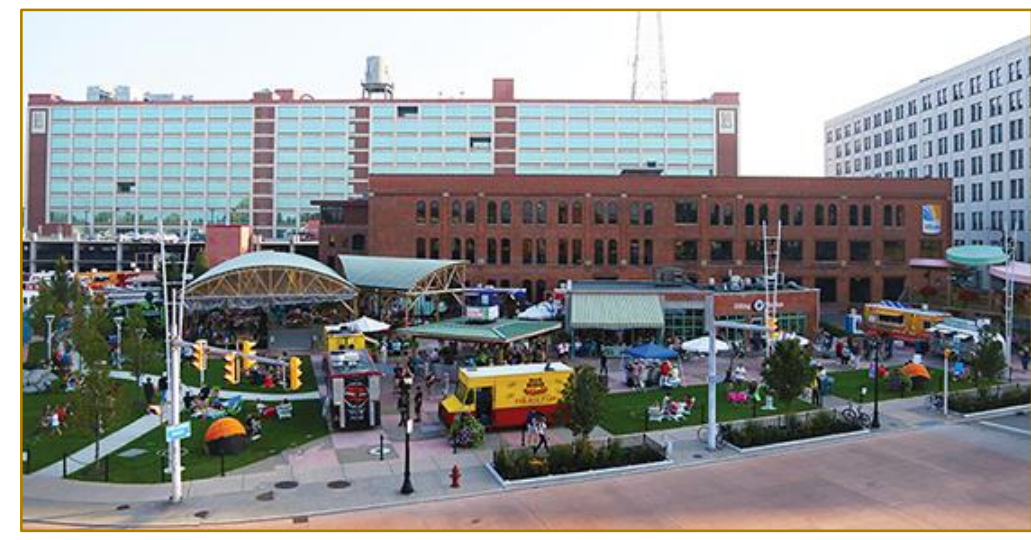

Fonte: https://www.huduser.gov/portal/periodicals/em/winter14/highlight4.html. Acesso maio 2018.

O uso temporário no urbanismo é um assunto relativamente novo. Recentemente, essas práticas vêm recebendo atenção na academia em diferentes partes do mundo a partir de pesquisas e também como temática em congressos sobre espaço público e cidades. Além disso, inúmeras revistas especializadas de arquitetura têm publicado matérias a esse respeito, assim como há diversos blogs de movimentos sociais, sites de escritórios de arquitetura e de empreendedores que produzem tais ações efêmeras. Apesar de já existir um considerável volume de produção científica, a pesquisa ainda tem muito a desenvolver.

Devido ao vasto universo de tipos que comportam, as manifestações efêmeras na cidade contemporânea vêm recebendo diferentes termos para sua definição ou abordagem, como, por exemplo: Placemaking ${ }^{69}$, Playstreet, Guerrilla Urbanism, Selfmade City, Insurgent Public Space ${ }^{70}$, Occupy, Temporary City ${ }^{1}$, Post-it-City ${ }^{2}$,

\footnotetext{
${ }^{69}$ Ver: https://www.placemaking.org.br/ - Acesso em: abr. 2018.

70 Nome de livro editado por Jeffrey Hou, lançado em 2012, com registros de diversos projetos que ocupam espaços públicos investidos com materiais provisórios que redesenham suas funções.

${ }^{71}$ Nome do livro de Peter Bishop e Lesley Williams, 2012, que inclui pesquisa teórica com estudos de casos sobre utilização temporária de espaços urbanos e edifícios.
}

Tactical Urbanism, Handmade Urbanism ${ }^{73}$, Microplanejamento Urbano, entre outros. Pesquisadores estão tateando, ainda, as fronteiras entre um projeto e outro, e tais acepções são usadas conceitualmente para distinguir determinadas especificidades, cujas propostas diferem umas das outras quanto a tipologias formais e funcionais; se têm objetivos políticos, estéticos, sociais ou econômicos; e, ainda, se são casos legais ou não. Mas, dentre todas essas diferenças, pode-se considerar que a temporalidade de suas ações é o cerne que as define. Foi o que concluiu uma das primeiras tentativas de fazer pesquisas neste campo, realizada pelo Urban Catalyst (2013); de acordo com o grupo de pesquisadores de Berlim, um uso é definido como temporário se aqueles que o iniciam e os outros envolvidos esperam que seja de duração limitada.

Além da questão do tempo, outra característica comum desses atos está no fato de que a maioria são propostas desvinculadas de instituições tradicionais e do Estado, promovidas por movimentos coletivos e informais, em um movimento denominado no âmbito do urbanismo como

\footnotetext{
72 Termo cunhado por Giovanni la Varra, nome de livro e site lançado em 2001

${ }^{73}$ Nome de um livro editado por Marcos L. Rosa e Ute E. Weiland, lançado em 2013, em que os autores registram casos que utilizam espaço público carente de equipamentos com "práticas criativas" temporárias.
} 
de abordagem bottom up ${ }^{74}$. Nesses projetos, suas ações baseiam-se firmemente na colaboração do usuário, de modo que, além de alterar a forma de construir projetos urbanos, têm a habilidade de informar desejos da comunidade quando ela passa a ser protagonista por meio de pequenos projetos que, segundo Lydon e Garcia (2015, p. 34), são "capazes de construir um sentido para a comunidade". Além disso, os autores afirmam que as ações de usos temporários de espaços partem da valorização e da construção sobre o que já está no local - por isso o vínculo da comunidade -, sendo suas propostas ações que visam melhorar as suas vidas dentro de sua microescala urbana.

Sophie Wolfrum aponta que este tipo projeto traz uma visão de abordagem arquitetônica para as estratégias urbanas. Seguindo esse enfoque, a autora define que os usos temporários são um "urbanismo performativo", que focaliza "na produção do espaço, na percepção e adoção do corpo individual, bem como a interferência na cidade, com movimento e ocorrência" (ROSA, 2011, p. 214)

A mudança da forma dos usos temporários apresentada pela autora acima, que altera o enfoque das estratégias urbanas, também é afirmada por Peter Bishop e Lesley Williams (2012), que apresentam a ideia de que esse modelo tem processos mais táticos, escalonados, participativos e abertos à colaboração. Assim como eles, muitos pesquisadores se referem ao uso temporário como um trabalho que insere tática no planejamento urbano. De Certeau (2014) faz essa distinção e define estratégia como um trabalho de sistematização - impor uma ordem -, ou seja, o modo padrão desenvolvido pelo urbanismo. Quando essa maneira deve ou precisa ser quebrada e reagrupada, é requerido um modelo tático. As táticas são formas de negociar as estratégias que devem ser estabelecidas e permitem afirmar certa individualidade e autonomia. Atitudes táticas contam com o tempo e estão sempre à espreita de oportunidades que devem ser aproveitadas, ou seja, exatamente

\footnotetext{
${ }^{74}$ Tradução para o português - de baixo para cima. No campo do planejamento, isso significa as ações que são realizadas com a participação dos usuários/comunidades envolvidos em um projeto urbano. É um movimento em contrapartida àquelas ações de aboradagem top down - de cima para baixo, como são a maioria dos projetos urbanos.
}

como os atos de usos temporários se estabelecem.

O uso sazonal, com duração preestabelecida, mostra-se como uma alternativa programada para reativar e reabilitar espaços abandonados que serviriam de base para uma multiplicidade de usos temporários. Aquele vazio não utilizado, um solo em repouso econômico, produto de uma lógica de exploração que o define como capital não utilizado, poderia ser ocupado por funções temporárias que seriam capazes de desempenhar e preencher o vazio, oferecendo locais acessíveis para que as comunidades decidam o seu destino até que um mais perene seja planejado.

O artigo estrutura-se a partir de uma leitura do problema por camadas. A camada 1, Cidade contemporânea em tempos fluidos - uma narrativa, apresenta uma reflexão sobre a sociedade contemporânea, na perspectiva de entendê-la dentro de uma sociedade em rede e fluída. Para tanto, a primeira camada fundamenta-se principalmente em dois teóricos: Castells (1995), (1999) e Baumann (2001), (2002). Ainda nessa sessão, aprofundar-se a temática da sociedade contemporânea, aproximando-a de uma noção de um urbanismo também fluído. Para isso, utiliza-se a teoria formulada por Ignácio Solé-Morales (2002) de arquitetura líquida. $\mathrm{Na}$ camada 2, Microurbanismo efêmero - uma prática, esta pesquisa debruça-se sobre as novas teorias, os conceitos e estudos de caso que têm se dedicado a compreender projetos e ações de usos temporários, ou seja, aqueles que agem sobre espaços degradados por um tempo determinado e contam com a participação cidadã. As principais referências teóricas desta sessão são as pesquisa do coletivo Urban Catalyst (2013); de Lydon e de Garcia (2015); Bishop e Williams (2012); e Rosa (2011), (2016). A camada 3, O uso temporário no urbanismo - uma possibilidade, busca estabelecer a relação dessas práticas com a teoria no urbanismo utilizando como principais autores: Lefebvre (1991), (1999), (2006); Jacques (2003); Certeau (2014); Bishop e Williams (2012), e Rosa (2011), (2016); Urban Catalyst (2013); de Lydon e de Garcia (2015).

\section{A CIDADE CONTEMPORÂNEA EM TEMPOS FLUIDOS - UMA NARRATIVA \\ O período contemporâneo tem sido caracterizado por uma aceleração associada}


às profundas transformações tecnológicas, às novas lógicas de flexibilização das relações de trabalho, à sociedade de consumo de massas e à constituição de um meio técnicocientífico-informacional. Nesse horizonte, acentua-se uma crise das formas de materialização, representação e inteligibilidade das relações mantidas entre os diferentes atores sociais.

Bauman, em Modernidade Liquida (2001), argumenta que, nos últimos cinquenta anos, passou-se de uma "fase sólida da modernidade" para o que chama de uma "fase líquida". O autor assevera que a modernidade caracteriza-se pela capacidade de produzir o "derretimento dos sólidos". Entretanto, a fase sólida foi baseada em uma crença de que era possível fazer um mundo perfeitamente racional, onde os indivíduos que compõem a sociedade poderiam ter a liberdade de construir suas vidas individualmente, mas desde que submetidos a um Estado ordenador e parâmetros sociais estabelecidos. A modernidade sólida não deixava espaços para incógnitas e incertezas, $e$ isso se transmitia por meio do controle sobre a natureza, da criação de burocracias hierárquicas, normas e regulamentos. Esses mecanismos de controle procuravam remover inseguranças pessoais, dando, aos aspectos da vida humana, formas bem ordenadas e familiares. Assim, nessa fase, a modernidade substituía um modelo sólido por outro (BAUMAN, 2001, p. 12).

Bauman (2001) afirma que, agora, vive-se na modernidade líquida - uma fase que, como um líquido, não pode manter sua forma por muito tempo. Já não se acredita em um estado de perfeição: a mudança está aqui para ficar e é uma condição permanente da vida humana. Vive-se em um eterno remodelar-se, o que faz crescer a ambivalência e os sentimentos de incertezas. A passagem global de sólido para líquido da modernidade tem confrontado indivíduos com uma série de novos desafios. Formas sociais e instituições já não têm tempo suficiente para solidificar modelos e não servem de referência para planos de vida a longo prazo. Assim, indivíduos têm de encontrar outras maneiras de organizar suas vidas. Eles têm que unir uma série interminável de projetos de curto prazo que podem não corresponder ao tipo de sequência para que conceitos como "carreira" e "progresso" sejam significativamente aplicados. Isso gera uma forma de "nomadismos", em que se configuram fluxos individuais - seja mudandose de lugares ou empregos, cônjuges ou valores. A modernidade líquida é caracterizada por incerteza, risco e mudança contínua. O que é digno de confiança hoje pode não sê-lo amanhã. Tais vidas fragmentadas sugerem a exigência de indivíduos e sociedades flexíveis e adaptáveis - estar constantemente prontos e dispostos a mudar de tática a curto prazo, a abandonar compromissos e a buscar oportunidades de acordo com sua disponibilidade atual. Podese especular, portanto, que, em tal mundo, poderia ser esperado o florescimento de todos os tipos de atividades temporárias.

Bishop e Williams, em Temporary City (2012), colocam que as crescentes incertezas sobre as condições políticas, econômicas e ambientais, antes assumidas como imutáveis, vêm sofrendo transformações. Desde a derrubada do Muro de Berlim e o fim do comunismo, a forma como se vê o mundo tornou-se mais fluida. Não são mais os grandes blocos de poder que estão em conflito aberto como foi durante a maior parte do século XX. A eliminação dessas barreiras causou o fim de muitas das certezas políticas dessa era. $O$ aquecimento global, a ocorrência de catástrofes naturais - como o tsunami que atingiu a costa do Oceano Índico em 2004, o furacão que devastou Nova Orleans em 2005, os terremotos que atingiram o Haiti e Chile em 2010, ou no Japão, em 2011 - contribuíram para a percepção de que as estruturas feitas pelo homem são mais frágeis e temporárias do que se pensava. A crise financeira de 2008, causada pela especulação e pelo excesso de valorização de ativos do mercado dos Estados Unidos, demonstrou a insuficiência de liquidez no sistema bancário desse país e transformou o boom econômico global que era visto como permanente em uma crise causadora de um colapso financeiro global. Para os autores, os efeitos dessas crises econômicas, dos colapsos geopolíticos e das catástrofes ambientais exigem das pessoas, dos mercados e do planejamento urbano ações com novas visões - mais flexíveis e capazes de lidar com ambientes de incertezas e mudanças constantes.

Castells, em A Sociedade em Rede (1999), anuncia que mudanças vêm reestruturando e influenciando a sociedade por meio da "transformação de nossa cultura material pelos mecanismos de um novo paradigma tecnológico que se organiza em torno da 
tecnologia da informação". Se anteriormente o valor de uma sociedade estava baseado na sua capacidade de produção, hoje, sua medida está muito mais na capacidade de fluxos de informação. O conhecimento como principal fonte produtiva exige do capitalismo uma profunda reestruturação e caracteriza-se por maior flexibilidade de gerenciamentos, individualização e diversificação cada vez maior das relações de trabalho, as quais descentralizam as atividades produtivas (CASTELLS, 1999, p. 49).

Castells, em La ciudad informacional: tecnologias de la información, reestructuración económica y el processo urbano-regional (1995), elabora a tese de que desenvolve-se em todas as sociedades um processo geral de transformação do espaço à medida que elas se articulam, de modo crescente, em um sistema global. O espaço de fluxos ocupa o centro dessa transformação, uma forma de articulação aespacial do poder e da riqueza do mundo de hoje. A localização espacial geográfica (cidades, empresas, governos, moradia) está relativizada pelo espaço de fluxos, que impõe uma lógica que suspende a prioridade da continuidade física na dinâmica das trocas.

Reyes (2005), em Quando a Rua Vira Corpo, afirma que esse novo paradigma traz em si uma nova relação de tempo e espaço. Sendo a informação matéria-prima muito mais flexível e com capacidades de assumir distintas materialidades, "necessita muito pouco de um lugar preciso". A liberação de um lugar fixo tenciona o modelo de configuração das cidade não mais apoiada na territorialização fixa dos espaços construídos. Segundo o autor, "há uma nova concepção de cidade sendo gerida aí: mais flexível e menos territorializada" (REYES, 2005, p. 27).

Duarte, em Crise das matrizes espaciais (2002), expõe que essa mudança do paradigma industrial para o informacional traz reflexos para a conformação das cidades e dos territórios, pois estimula práticas de interconexões e independência do território por meio da possibilidade de ações à distância, desenvolvidas na nova sociedade em rede. O encontro para trocas entre os indivíduos, premissa da origem e existência das cidades, está mediado, hoje, em grande proporção, por cabos e teclados de um computador (DUARTE, 2002).

Se no modelo sólido a indústria e o comércio precisavam do livre acesso para o fluxo de suas produções ocupando a infraestrutura técnica das cidades, atualmente, as redes de comunicação e a outra ordem na produção de mercadorias orientam seus fluxos por canais digitais. Devido às facilidades geradas pelas técnicas, os deslocamentos multiplicam-se, prolongam-se, representando uma forma relativa de autonomia dos habitantes em relação às suas ações no espaço urbano. Isso permite que eles organizem suas existências segundo temporalidades e espacialidades mais pessoais. Dessa forma, quais são os reflexos no espaço urbano e nas inúmeras infraestruturas que servem a esse modelo? Essa pesquisa pretende ater-se aos possíveis fenômenos e considera que parecem surgir daí outros tipos de tecidos urbanos, mais suaves, que se aproximam de possíveis "estruturas líquidas" transpondo a ideia do sociólogo Zigmund Bauman para a arquitetura e o urbanismo.

Solà-Morales, em Territorios (2002), conceituou arquitetura líquida como "aquela que substitue a firmeza pela fluidez e a primazia do espaço pela primazia do tempo" (SOLÀ-MORALES, 2002, p. 127). O autor lembra que, entre os três conceitos vitruvianos definidores da arquitetura - firmeza, utilidade e formosura -, firmeza é o que mais claramente determina que em arquitetura se encontram características físicas, as quais têm a ver com soluções formais, assim como a ideia de estabilidade, delimitação espacial, solidez e, por fim, um "saber e uma técnica ligados à permanência" (SOLÀ-MORALES, 2002, p. 126). Contudo, parece que hoje, mais do que nunca, a sociedade tem abandonado a estabilidade que o mundo fomentou no passado, para, ao contrário, assumir um dinamismo que estimula mudanças e transformações, processos que, segundo o autor, são mais estabelecidos pelo tempo.

Uma "arquitetura líquida" está preocupada em dar configuração não à estabilidade, mas à fluidez cambiante da realidade. Para SolàMorales, arquitetura líquida representa um sistema que não se reduz a uma configuração, mas onde "espaço e tempo estão simultaneamente presentes como categorias abertas, múltiplas, não redutíveis, organizadadoras desta abertura e multiplicidade" (SOLÀ-MORALES, 2002, p. 130). Supõe-se que esse raciocínio não seja restrito à arquitetura, mas estenda-se ao urbanismo, tendo em vista a multiplicidade das experiências abertas pelos espaços dos fluxos e da dilatação dos espaços fixos. Se há 
a necessidade de lidar com a fluidez espacial, que leva ao cabo as atividades diárias a qualquer lugar e a qualquer hora, há a necessidade de se pensar um urbanismo também em estado fluído. As formas fluidas e cambiantes no urbanismo ocorrem no espaço que dá suporte às práticas sociais por meio da co-habitação de múltiplas funções continuamente flexibilizadas e resiginificadas. É essa efemeridade transitória que confere ao espaço urbano contemporâneo seu caráter fluido.

\section{MICROURBANISMO EFÊMERO - UMA PRÁTICA}

Conforme visto anteriormente, há uma série de manifestações de usos temporários acontecendo nas cidades atualmente. Acredita-se que o aumento desse tipo de proposta, tenha uma correlação com um urbanismo em estado fluido. A característica mais comum a todas é que são ações com tempo delimitado; por isso, o primeiro parâmetro que esta pesquisa tomou é a definição proposta por Urban Catalyst (2013), que determina que um uso é definido como temporário se aqueles que o iniciam e os outros envolvidos esperam que seja de duração limitada.

Apesar de delimitar uma das características mais recorrentes desse tipo de projeto, outras especificidades se fazem necessárias para ressaltar e compreender o fenômeno de forma mais abrangente, reconhecer suas facetas e, com isso, alcançar um conceito mais apropriado e operacional para futuras categorias de análises. Para isso, é necessário percorrer outros termos frequentemente utilizados. Em geral, essas outras terminologias estão coladas a nomes de publicações e grupos, cada uma defendendo o conceito/termo que criou. Apesar de serem muito parecidos uns com os outros e definirem praticamente os mesmos tipos de projeto, algumas diferenças complementam o conceito paralelamente tomado. Dada a frequência com que são citados nas pesquisas que estão sendo realizadas dentro desse escopo de trabalho, a seguir, são apresentados os termos mais disseminados, também aqueles mais popularizados pelos produtores dessas práticas, salientando-se, contudo, que isso se dá apenas de forma panorâmica neste momento da pesquisa. Dentre eles, conceitua-se Placemaking, Playstreet,
Insurgent Public Space, Tatical Urbanism, Occupy, Temporary City, Post-it-City, Handmade Urbanism e Microplanejamento Urbano.

Placemaking é uma palavra da língua inglesa e poderia ser traduzida como "fazer lugares". O termo foi cunhado pelo Project for Public Space - PPS ${ }^{75}$, uma organização sem fins lucrativos criada em 1975 e com base em Nova lorque, mas com atuação mundial. Através do Placemaking Leadership Council (Conselho de Lideranças em Placemaking), a PPS está trabalhando na criação de uma rede que conta com cerca de três mil comunidades em quarenta e sete países. Em outubro de 2014, o movimento se instituiu no Brasil com a criação do Conselho Brasileiro de Lideranças em Placemaking.

O processo de Placemaking da PPS partiu do trabalho de William $\mathrm{H}$. Whyte, The Social Life of Small Urban Spaces (1980), cuja proposta foi desenvolvida em pesquisa realizada durante a década de 1970 e consiste em olhar, ouvir e fazer perguntas para as pessoas que vivem, trabalham e frequentam um espaço em particular, com o objetivo de descobrir suas necessidades e aspirações e, junto delas, construir um lugar coletivamente. Segundo o livro Guia do Espaço Público Lugares para Transformar" ${ }^{76}$, de Jeniffer Heemann e Paola Caiuby Santiago (2015), uma adaptação do conteúdo elaborado pela PPS, os lugares produzidos são "espaços públicos que estimulam interações entre as pessoas entre si e entre as pessoas e a cidade, promovendo comunidades mais saudáveis e felizes" (HEEMANN e SANTIAGO, 2015, p.10).

A essa definição, acrescenta-se outra característica importante aos usos temporários: o trabalho coletivo e autoproduzido. Com suas raízes na participação comunitária sugerida por Whyte (1980), o Placemaking abrange o planejamento, o desenho, a gestão e a programação de espaços públicos. Segundo o site de PPS, o Placemaking não quer apenas criar melhorias no desenho urbano, mas facilitar a criação de atividades e conexões (culturais, econômicas, sociais, ambientais) que dariam suporte para a evolução desse espaço.

\footnotetext{
75 https://www.pps.org - Acesso em: abr. 2018.

76 Ver: http://www. placemaking.org.br/home/wpcontent/uploads/2015/03/Guia-do-EspaçoPúblico1.pdf - Acesso em: abr. 2018.
} 
Não por acaso, apresentou-se por primeiro esse termo. Trata-se do mais popular no Brasil, principalmente mencionado entre profissionais e estudantes de arquitetura e urbanismo, mas também entre participantes de coletivos que praticam essas ações, como, por exemplo, grupos que promovem ocupações de vagas de estacionamento e de jardins e hortas urbanas, assim como nos sites populares de arquitetura e urbanismo.

Seguindo o que parecer ser um movimento de ocupações de espaços públicos tradicionais e sua transformação programada por meio de usos temporários, pode-se listar uma série de exemplos e novos termos que surgiram, talvez com inspiração no Placemaking. Os que serão listados a seguir acrescentam outra característica frequente aos usos temporários aos quais esta pesquisa se refere - o caráter ativista.

Por exemplo, o Playstreet, que em tradução livre da língua inglesa para o português poderia ser chamado de "ruas para brincar", consiste em fechar ruas para a circulação de carros e promover ações para recreação com foco nas crianças, mas acaba envolvendo pessoas de todas as idades. Segundo a London Play ${ }^{77}$, uma Organização Não Governamental que promove o Playstreet em Londres, o foco de seu trabalho é devolver o espaço da rua para as pessoas em detrimento do excessivo espaço do carro nas cidades.

Com semelhanças no sentido proposto acima, outros projetos como Massa Crítica $^{78}$, Vaga Viva $^{79}$, Zona Verde, Park(ing) $)^{80}$ e Parklets atuam temporariamente, inserindo ações no lugar do carro. Enquanto o projeto Massa Crítica produz regularmente atos de circulação em grupos de ciclistas pelas ruas das cidades onde atuam, os demais projetos propõem a criação de lugares efêmeros no formato de sala de estar no lugar de uma vaga de estacionamento de carros na rua. Conceitualmente, não há diferenças significativas entre os dois termos. Esse tipo de proposta, com certa pressa, poderia ser

\footnotetext{
${ }^{77}$ Ver: https://www.londonplay.org.uk - Acesso em: mai. 2018.

${ }^{78}$ Ver: https://massacriticapoa.wordpress.com Acesso em: mai. 2018.

79 Ver: http://vadebike.org/2013/08/zona-verdeparklet-vaga-viva/ - Acesso em: mai. 2018.

${ }^{80}$ Ver:

https://en.wikipedia.org/wiki/Rebar_art_and_design _studio - Acesso em: mai. 2018.
}

chamado de um projeto de Placemaking inclusive, grupos de Placemaking fazem Vagas Vivas -, mas tomam-se os referidos termos para essa distinção devido à frequência com que são utilizados. O que interessa frisar, neste momento, é que não há um tipo de projeto de Placemaking, o qual, segundo a definição do PPS, procura criar espaços públicos e conexão de atividades, pessoas e a cidade, mas outros termos são gerados quando um modelo, um grupo ou uma causa específica se estabelece dentro do formato de usos temporários.

Nessa mesma perspectiva de projetos ativistas que usam temporariamente um espaço e se posicionam como uma forma de protesto urbano, há os formatos intitulados de Guerrilla Urbanism e Insurgent Public Space. Não há diferenças conceituais entre os dois termos, ambos podem ser definidos como: ações de usos temporários, espaços de contestação cívica, atividades informais e autoproduzidas por grupos e indivíduos autônomos. Esses termos, também com origem na língua inglesa, são expressões incorporadas em artigos em português como "Urbanismo de Guerrilha" e "Espaços Públicos Insurgentes", respectivamente, e são usados no Brasil como adjetivos de projetos com essa envergadura.

No livro Insurgent Public Space, o autor Jeffrey Hou (2012) reúne vinte estudos de casos ilustrando esses "Espaços Públicos Insurgentes" e demonstra exemplos em várias partes do mundo que vão de jardins comunitários em Seattle e Los Angeles, dança de rua em Pequim, ações de "flash mob" ${ }^{\prime 11} \mathrm{e}$ eventos temporários em Nova lorque até a transformação de estacionamento em parques temporários em São Francisco. A partir de uma coleção de artigos, Jeffrey Hou fornece uma visão crítica de como as questões sociais, políticas, econômicas e culturais contemporâneas estão sendo estruturadas e contestadas no âmbito público atual. Para o autor, espaços públicos insurgentes não se limitam a lugares

\footnotetext{
81 "Flash Mobs são aglomerações instantâneas de pessoas em certo lugar para realizar determinada ação inusitada previamente combinada, estas se dispersando tão rapidamente quanto se reuniram. A expressão geralmente se aplica a reuniões organizadas através de e-mails ou meios de comunicação social, notadamente pelas redes sociais digitais." Fonte: https://pt.wikipedia.org/wiki/Flash_mob - Acesso em: mai. 2018.
} 
convencionais, como parques urbanos, praças, jardins comunitários e outros espaços planejados ou paisagísticos. Para o autor, os espaços urbanos insurgentes expandem, complementam e redefinem o conceito de espaço público ao incluí-los como um novo formato. Ainda, afirma que as atividades insurgentes que ocorrem dentro desses espaços estendem a imaginação do protesto público popular nas cidades.

O espaço público insurgente é, ao mesmo tempo, espontâneo e radical, mas, para Hou (2012), também planejado e progressivo. As ações nessas arenas públicas e urbanas tipicamente não têm nenhum líder particular ou burocracia associada, mas demonstram como grupos marginalizados podem moldar espaços, com propostas que vem de baixo para cima, a partir de um consenso coletivo de base. Para Hou, o urbanismo guerrilheiro, expressão que ele também utiliza, está fomentando espaços públicos "menores, mas maiores" no sentido do alcance simbólico e de coletividade conquistada (HOU, 2012, p. 53).

O autor organizou o livro em seis capítulos baseados em características das intervenções: 1) Appropriating, 2) Reclaiming, 3) Pluralizing, 4) Transgressing, 5) Uncovering e 6) Contesting. O primeiro capítulo, Appropriating (apropriar-se), analisa a forma como as pessoas taticamente usam o espaço aberto para imbuí-lo de um novo significado, enquanto o segundo capítulo, Reclaiming (recuperar), analisa a forma como são subutilizados espaços urbanos frequentemente abandonadas, os quais foram ressuscitados pelas iniciativas coletivas. 0 capítulo Pluralizing (pluralizar) examina como diferentes grupos étnicos interpretam e transformam o significado e a função dentro do espaço aberto, criando um espectro mais heterogêneo de realidades espaciais. Transgressing (transgredir) avalia como os domínios público-privados do espaço aberto foram violados, atravessados e negociados por grupos de pessoas. Uncovering (descobrir) dá exemplos de espaços públicos que foram redescobertos e reconfigurados, revelando memórias latentes e ocultas na paisagem urbana. O capítulo final, Contesting (contestar), traz à luz a luta por identidade e direitos no âmbito público.

De fato, o século XXI tem experimentado um novo movimento no espaço público, que foi transformado e elevado a um sentido coletivo com alcances globais. O movimento de ocupações de espaços públicos como forma de protesto em busca de justiça social e econômica elevou o protagonismo de lugares que passaram a ser reconhecidos em todo o mundo com outras identidades a partir da tomada desses lugares pelas pessoas articuladas sobre um ideal coletivo.

Neste contexto, surge o termo Occupy. Em 2011, o mundo inteiro passou a saber das manifestações que aconteciam diariamente na Praça Tahir, no Cairo, Egito, parte do movimento revolucionário iniciado na Líbia, com repercussão também na Síria e na Tunísia, que ficou conhecido como Primavera Árabe. Em comum, são ações que se concentraram no espaço público e que levaram países ${ }^{82}$ do norte da África e parte do Oriente Médio a depor governos e ditaduras que duravam décadas.

Esses movimentos ativistas tomaram proporções epidêmicas em todo o globo em uma sincronia cosmopolita viral em 2011. Na margem sul do Mediterrâneo, viu-se surgir uma sequência de ocupações espontâneas no espaço público, como, por exemplo, na Espanha, com Los Indignados na Praça Puerta Del Sol; em Portugal, com a Geração Rasca, e na Grécia, com a tomada da Praça Syntagma. A ocupação mais famosa no ocidente aconteceu em Nova lorque, onde o termo Occupy nasceu, com o Occupy Wall Street - um protesto em formato de acampamento de grandes dimensões contra as desigualdades socioeconômicas evidenciadas pela crise econômica global de 2008. À semelhança dessas propostas, surgiram, em seguida, em mais de 90 países, em quase mil cidades do globo, ocupações de espaços públicos. No Brasil, em 2013, assistiu-se as maiores manifestações populares até então, espalhadas por todo o país, denominadas como as Jornadas de 2013.

Muitos pensadores e críticos dessa situação elaboram análises sobre questões e significados das ocupações sob diferentes perspectivas. Alguns exames tomam como fato novo a influência e a força da internet como meio de articulação e mobilização. Outros assumem que o fenômeno surge em meio à falta de uma definição estratégica, programática e teórica dentro de uma crise do capitalismo. Para esta pesquisa, neste momento, o que importa é a questão colocada por David Harvey, que aponta para

82 Tunísia, Argélia, Jordânia, Egito, lêmen, Omã, Sudão, Iraque, Kuwait, Líbia. 
a "união de corpos no espaço público" como o fato importante e a ser valorizado (HARVEY, 2012, p. 10).

É sobre esse ponto, de iniciativas articuladas de baixo pra cima ou bottom up, que surgem outros três termos que, embora definam ações semelhantes, falam de contextos distintos: Tactical Urbanism ou Urbanismo Tático, termo disseminado por Mike Lydon e Anthony Garcia; e Microplanejamento Urbano e Handmade Urbanism, por Marcos L. Rosa e Ute E. Weiland.

Para Lydon e Gracia (2015), Tatical Urbanism ou Urbanismo Tático está relacionado a ações de pequena escala, servindo a um propósito maior ou a um planejamento para alcançar um propósito com respostas intencionais $\mathrm{e}$ flexíveis. Os autores definem o seu conceito como um tipo de planejamento urbano de

[...] abordagem para a construção e ativação de vizinhanças, utilizando intervenções e políticas de curto prazo, de baixo custo e escalonáveis, que utilizam processos de desenvolvimento abertos e interativos, com usos eficientes de recursos e potenciais criativos para a interação social. (LYDON e GRACIA, 2015, p. 2).

Em defesa do conceito a partir do qual estabelecem suas práticas como planejadores urbanos há alguns anos, os autores posicionam as vantagens do Urbanismo Tático para diferentes atores envolvidos nesse tipo de proposta. Segundo eles, para os cidadãos, o Urbanismo Tático permite atender as reivindicações imediatas, com o "redesign ou a reprogramação do espaço público" (LYDON E GRACIA, 2015, p. 2). Para desenvolvedores ou empreendedores, fornece um meio de coletar inteligência do mercado ao qual eles pretendem servir. Para as organizações, é uma maneira de mostrar o que é possível para conseguir apoio público e político. Para o governo, é uma maneira de estabelecer melhores práticas de forma mais precisa.

Assim como em Tatical Urbanism, Handmade Urbanism, de Marcos L. Rosa e Ute E. Weiland, e "Micro-planejamento Urbano" ${ }^{83}$, de Marcos L. Rosa, os autores editaram seus livros incluindo iniciativas conduzidas pelos cidadãos "de baixo para cima", efêmeras e autoproduzidas. A diferença entre as

\footnotetext{
${ }^{83}$ Nome de um livro com diversos projetos desse tipo editado por Marcos L. Rosa, em 2011, com registros semelhantes à nota anterior.
}

publicações, já que conceitualmente entre os termos não há, diz respeito a onde os casos foram coletados: enquanto o primeiro (Tatical Urbanism) deteve-se em casos dos Estados Unidos, o segundo (Handmade Urbanism) registrou exemplos em cidades de países subdesenvolvidos e $\quad 0$ último (Microplanejamento Urbano) somente em São Paulo, e isto diz muito sobre os casos, tendo em vista as diferenças sócio-culturaiseconômicas entre os países.

Handmade Urbanism fala sobre iniciativas comunitárias, do espírito de empreendedorismo, da capacidade de negociar e construir alianças, das capacidades produtivas embutidas, dos modos participativos para cenários futuros, registrados pelos autores em cidades como Mumbai, São Paulo, Cape Town e Istambul. Como dito, até aí não há novidade em relação aos demais termos. O que Rosa e Weiland (2014) atualizam para esta pesquisa é que as práticas que nascem das necessidades cotidianas das comunidades são como um pré-levantamento urbanístico ou, ainda, como os planejadores urbanos gostam de usar, um diagnóstico. Seus projetos manifestam desejos que podem ser interpretados como uma forma de explicação da cidade que emerge das comunidades. Isso fica evidente por meio dos tipos de iniciativas divididas em tipologias que expandem significativamente 0 rol de ações dos usos temporários, considerando que vão de habitação, saúde, cultura e recreação, educação e treinamento profissional, criação de empregos, assistência social, paisagismo e direitos e ativismo. O termo cunhado pelos autores como Handmade Urbanism enfatiza que esses usos temporários falam genuinamente da comunidade, de dentro dela e por ela mesma.

Já o livro Micro Planejamento - Práticas Urbanas Criativas, Rosa (2011) serve para atualizar o sentido dado aos usos temporários ocorridos até então, porque parte do princípio de que eles surgem como um impulso de conexão e coexistência com a escala humana na cidade frente à falta de qualidade dos equipamentos técnicos que o planejamento urbano produz, visto que esses processos surgem exatamente nesses espaços urbanos desperdiçados, vazios, subutilizados, residuais. Para o autor, contudo, são usados como campos para "práticas urbanas criativas", que representam uma "possibilidade de reestruturação urbana comprometida com a escala local" (ROSA, 
2011, p. 16). Essa hipótese é ampliada pelo autor em sua tese de doutorado, defendida em 2016 sob o título: From Modern Infrastructures to Operational Networks - The Qualification of Local Space at Existing Large Scale Utility Infrastructure: A Method for Reading Community-Driven Initiatives.sisp: The Case of São Paulo ${ }^{84}$, em que Rosa (2016) apresenta essa possibilidade de conexão estabelecida por esse tipo de projeto com as infraestruturas urbanas e técnicas, especificamente na cidade de São Paulo. Rosa (2011) define essas ações como "microarquiteturas sobrepostas às estruturas modernas monofuncionais, anexando complexidades capazes de induzir espaços urbanos de qualidade" (ROSA, 2011, p. 22).

Quando essas ações são bem-sucedidas, fazem espaços abandonados voltarem a integrar a cidade e os lugares funcionam como atrativos urbanos. Ou seja, espaços até então desvalorizados e ocultos ganham visibilidade e vitalidade. Em algumas situações, essas "práticas urbanas criativas", como o autor as refere, aparecem como soluções informais para organizar lugares para o encontro - pontos de contato que resistem à desertificação de espaços coletivos de qualidade, com projetos que tencionam limites interdisciplinares à construção de novas pontes para a produção de arquitetura e cidade. Percebe-se que muitos casos revertem a negatividade do lugar, doando valor e visibilidade àquilo que estava oculto.

Coube aos títulos Temporary City e Post-it-City ampliar e colocar os usos temporários também nas tipologias comerciais. Apesar dos livros também tratarem de casos de ativismo cívico, usos comunitários, arte pública, contracultura e instalações de arquitetura, já vistos anteriormente, o que eles expandiram significativamente está no escopo e na abrangência dos tipos de propostas de usos temporários ao inserir a questão da ordem econômica com um vasto número de casos. Tais obras apresentam mais uma faceta não só dos usos temporários, mas de um modelo apetitoso e da comercialização da vida moderna em que se vive: os usos

84 Tradução: Das Infraestruturas Modernas às Redes Operacionais - A Qualificação do Espaço Local na Infra-estrutura Utilitária Existente de Grande Escala: Um Método para Ler Iniciativas Orientadas pela Comunidade. O caso de São Paulo. temporários servindo para a sociedade do consumo.

Explicadas essas definições e utilizações de múltiplos termos, esta pesquisa assume a necessidade de tratar os casos utilizando dois eixos: o econômico e o social. Percebe-se que ambos os eixos criam espaços insurgentes, pois desafiam visões convencionais de como as zonas urbanas são definidas, configuradas e usadas, e como esses espaços podem transformar o ambiente da cidade. Não mais confinados às áreas públicas tradicionais, como parques e praças públicas, lojas e escritórios convencionais, ambos os modos (o social e o econômico) utilizam-se de táticas urbanas $^{85}$ para expressar relações sociais e espaciais alternativas nas cidades.

Na perspectiva do eixo social, aparece esse sentimento de urgência em relação à cidade que parte de dentro da sociedade civil, como um agente gerador e construtor da sua cidade. A auto-organização verificada nos projetos que caracterizam esses usos temporários é impulsionada pela falta de espaços de coexistência com qualidade e representa um potencial para reestruturação urbana comprometida com a comunidade a partir de seus próprios preceitos.

$\mathrm{Na}$ perspectiva do eixo econômico, as propostas comerciais temporárias representam um fenômeno em ascensão que parece tensionar modelos tradicionais ao buscar fomentar o "alternativo", valendo-se de lugares alternativos como simulacros cênicos, transformados, então, em lugares de trocas mercantis. A explosão de lojas, feiras e comércios pop-up ${ }^{86}$ em todo o mundo ${ }^{87}$, vendendo todo tipo de produto, ocupa lugares incomuns para tais práticas, pois insere o comércio em locais com outras funções que não as habituais para esse fim, como, por exemplo, fábricas abandonadas, boates, jardins privados, condomínios, residências, estacionamentos ou mesmo espaços públicos. Mais recentemente podese contabilizar, junto a esses casos, a proliferação das praças de alimentação

\footnotetext{
${ }^{85}$ No sentido formulado por Michel de Certeau em A invenção do Cotidiano (2014).

${ }^{86}$ Loja de duração limitada.

87 Peter Bishop e Lesley Williams (2012). The temporary City.
} 
montadas com food trucks ${ }^{88}$ em todo tipo de espaço público e evento urbano.

Essas descrições ilustrativas de um micromeio criativo de usuários temporários são formadas por pequenas e novas empresas da área chamada economia criativa. Elas operam, em grande medida, à margem do modelo tradicional do setor econômico, pois, independentemente dos ganhos monetizados, cooperam entre si com iniciativas voluntárias e geram considerável contribuição para o equilíbrio social de bairros, onde provocam a promoção e a atratividade de espaços urbanos subutilizados.

Talvez a perpétua busca por novas experiências de consumo seja o fator que tem elevado significativamente o aumento desse setor, associado à exclusividade do "por tempo limitado". Talvez isso também reflita novas tendências no mercado que incorporam os usos temporários como táticas de aproximação de seus públicos para a viabilização de seus negócios. Também pode ser interessante olhar para este fenômeno como uma reconfiguração das cidades com novos modelos de desenvolvimento.

O uso temporário, muitas vezes, é visto como sinônimo de informalidade, mas os inúmeros casos apresentam situações nas quais o efêmero se manifesta de maneira sistemática. Portanto, continuar simplificando este tipo de experiência, afirmando tratar-se apenas de situações informais, correspondentes a determinadas situações esporádicas, é uma definição que fica restrita a somente alguns aspectos do problema. Situações de uso temporário têm uma série de engrenagens sistêmicas que as fazem funcionar e com as quais se pode aprender, inclusive por se tratarem de ações no espaço público ou de problemas urbanos, mas que têm sido deixados de lado como campo de pesquisa.

Essas situações mencionadas são manifestações da cidade e apontam para a necessidade de pensar como planejamento urbano pode abranger tais processos. Se os usos temporários são um fator importante para o desenvolvimento urbano, como eles podem ser incorporados no planejamento e em seu desenvolvimento? Pode-se considerar a dimensão do tempo como elemento e

\footnotetext{
${ }^{88}$ Carros equipados com cozinha e ponto de venda de produtos alimentícios e bebidas, os quais estacionam em todo tipo de espaço urbano público, ou não, agrupados, ou não.
}

matéria para intervenções com vistas à promoção da qualificação urbana?

\section{O USO TEMPORÁRIO PARA URBANISMO - UMA POSSIBILIDADE}

Lefebvre (1991), em 1969, escreveu O Direito à Cidade, um livro-manifesto reivindicando uma condição às pessoas que não fosse somente o direito de ir e vir, mas um direito que abrangesse à possibilidade de vivenciar a cidade para além da sua dimensão produtiva, mas como uma construção coletiva. O direito à cidade seria, então, o direito a transformar e projetar uma nova cidade, na qual predominassem o valor de uso, ou seja, focada nas necessidades das pessoas, pautadas na autogestão em todos os âmbitos da vida.

Em busca da constituição de novas experiências e territorialidades e influenciados por essas teorias, durante a década de 1960, membros da Internacional Situacionista desenvolveram um discurso e práticas em que propunham o resgate às múltiplas formas de vivenciar as cidades - uma alternativa contra a cultura do espetáculo, a alienação da sociedade e como forma de crítica ao pensamento de cidade do Movimento Moderno. O pensamento situacionista urbano não pretendia a formalização de um projeto de cidade; ele estava baseado na construção de situações. Entendia que situações eram experiências que deveriam ser alcançadas coletivamente. Uma situação construída seria, então, um "momento da vida, concreta e deliberadamente construído pela organização coletiva de uma ambiência unitária de um jogo de acontecimentos" (JACQUES, 2003, p. 22).

Para os situacionistas, os habitantes deveriam transformar-se de meros espectadores em vivenciadores de seus próprios espaços - é um manifesto pela participação efetiva da vida urbana. Todo esse discurso está moldado pela utilização do ambiente urbano para induzir à participação e à revolução da vida cotidiana, e, assim, instigar a transformação da própria vida do espectador. Para tentar chegar a essa construção total de um ambiente, os situacionistas propuseram a experiência da deriva. A técnica da deriva seria uma apropriação do espaço urbano pelo pedestre por meio da ação do andar sem rumo. A definição dessa técnica era descrita por Guy Debord como "modo de comportamento experimental ligado às 
condições da sociedade urbana: técnica da passagem rápida por ambiências variadas. Diz-se também, mais particularmente, para designar a duração de um exercício contínuo dessa experiência" (JACQUES, 2003, p. 89).

Esse exercício estava baseado no método chamado de psicogeografia, isto é, uma "geografia afetiva, subjetiva, que buscava cartografar as diferentes ambiências psíquicas provocadas basicamente pelas deambulações urbanas que eram as derivas Situacionistas" (JACQUES, 2003, p. 23). O conjunto dessa teoria formalizava o "Urbanismo Unitário" defendido pelo grupo. Define-se Urbanismo Unitário como uma "teoria do emprego conjunto de artes e técnicas que concorrem para a construção integral de um ambiente em ligação dinâmica com experiências de comportamento" (JACQUES, 2003, p. 24).

Pode-se fazer um paralelo dessas investigações teóricas de Lefebvre e as experiências situacionistas com as propostas dos usos temporários na contemporaneidade. Pois, contra o sistema dominante que organiza e impõe um modelo de produção e configuração urbana, tais propostas inserem suas novas práticas urbanas reivindicando um espaço seu na urdidura do tecido urbano e social da cidade. Através de um modo camaleônico e fugaz, como uma forma alternativa de operar na cidade, os usos temporários implantam um modo tático no jeito de construir a cidade. As ações táticas exploram o potencial dessas aberturas procurando por resultados inventivos desvios do contexto existente que organizam espaços autônomos. Essas definições que se referem à tática como um sistema ou modo de procedimento se aproximam dos métodos utilizados pelos precursores dos usos temporários como método de ação na cidade - o grupo da Internacional Situacionista.

Michael de Certeau (2014), em Invenção do Cotidiano, define tática em diferença à estratégia. De Certeau (2014) esclarece que a estratégia é um trabalho de sistematização impor uma ordem. Quando essa maneira deve ou precisa ser quebrada e reagrupada, é requerido um modelo tático. Para De Certeau, as táticas são maneiras que se usam para negociar as estratégias que são estabelecidas. Enquanto estratégia organiza uma visão macro e a longo prazo, tática ocupa-se da microescala - do particular, podendo referir-se a ações imediatas, a curto prazo. Atitudes táticas estão sempre à espreita de oportunidades que devem ser aproveitadas. De Certeau diz que é por meio de manipulações oferecidas pelas circunstâncias que se configura o desenho tático, ou seja, são ações isoladas ou eventos que tiram proveito de oportunidades oferecidas por aberturas em sistemas estratégicos.

Para o autor, a tática é empregada na experiência militar como forma de designar as tropas no campo de batalha com ordem, rapidez e recíproca proteção, segundo as condições de suas armas e do terreno. No uso militar, uma tática é empregada por uma unidade militar não maior do que uma divisão para implementar uma missão específica e alcançar um objetivo específico ou para avançar em direção a esse objetivo. Uma tática é implementada como uma tarefa capaz de manobrar forças em combate com a habilidade de se apoiar nos recursos disponíveis para alcançar um objetivo.

Os usos temporários estão conectados com as urgências do cotidiano. O urbanismo do dia a dia está em sintonia com intervenções que reforçam as "qualidades heterogêneas não destinadas", espaços pequenos, indistintos e temporários (CHASE, CRAWFORD e KALISKI, 2008, p. 28). Enquanto o planejamento urbano está preocupado em ser estratégico e regulamentar como as cidades devem crescer e ser usadas - e os planos e projetos urbanísticos não são capazes de criar o espontâneo e o inesperado - os usos temporários ordinários são frequentemente o que fazem as cidades terem mais vivacidade. Muitas vezes, justamente porque são concebidas como atividades não planejadas, são o que acabam fornecendo diversidade, dinamismo, atratividade para áreas urbanas.

Se, por um lado, o projeto urbano está no nível da estratégia e é fornecido pelas práticas de planejamento urbano tradicional, por outro, pode haver propostas táticas, expressas por esses microurbanismos efêmeros que atuam nas oportunidades do cotidiano, nas brechas do desenho da cidade e nas necessidades dos usuários. Ambas podem conviver e não se invalidam. A flexibilização dos processos, a capacidade de lidar com o inesperado e saber operar nas frestas abertas pelo status de impermanência das coisas fazem parte do cotidiano de quem trabalha com um programa "temporário". Talvez este seja o aprendizado para o planejamento urbano. O que está em jogo 
nessa questão é borrar o pensamento binário, que só permite ver a distância entre o formal e o informal, o precário e o estabelecido, o efêmero e o permanente.

O Urban Catalyst (2013) defende a incorporação inteligente de usos temporários como uma nova forma de planejamento urbano baseado na formalização do informal e na informalidade do formal. Para os autores, o planejamento urbano sempre se moveu no campo da tensão entre o planejado e o desenvolvimento não planejado, em que a informalidade predomina sobre os processos. Para eles, os usos informais e os usos temporários são tradicionalmente vistos como ameaça aos interesses dos proprietários e desenvolvedores, mas, diferentemente disso, têm se mostrado em diversas cidades do mundo como catalizadores de novos desenvolvimentos, com potencial de influenciar a qualidade urbana. Os autores demonstram que, em terrenos baldios urbanos e outros espaços residuais nos quais o planejamento falha em devolver esses lugares a uma ocupação efetiva, as propostas efêmeras têm se apresentado como uma alternativa que desafia a noção de permanência como condição básica para o planejamento das cidades. Uma proposta efêmera, com ações táticas, não invalida o trabalho da arquitetura que visa o mais perene nem o planejamento que projeta a longo prazo. Uma proposta pode complementar a outra.

Segundo Mehrota (2014, p. 70), quando se dissolvem essas fronteiras entre informal/formal e temporário/permanente, abrem-se oportunidades para novos campos de imaginação e para a fertilização do processo de projeto de urbanismo. Segundo Bishop e Williams (2012), essa dissolução provoca visões mais frouxas dos processos que, em vez de estados finais idealizados, como é o caso do plano para o urbanismo, deixa espaço para as imprevisibilidades. Para os autores, esses tipos de proposições criativas na cidade utilizam-se de fases de

\section{REFERÊNCIAS}

[1] BAUMAN, Zygmunt. Modernidade Líquida. Rio de Janeiro: Jorge Zahar Editor, 2001.

[2]

Comunidade: a busca por segurança no mundo atual. Rio de Janeiro: Jorge Zahar Editor, 2002. desenvolvimento, muitas vezes com uma gama de estágios temporários ao longo de um caminho que, com mais flexibilidade, move-se em direção a uma visão final vagamente definida, em vez de em direção a um estado final absolutamente pronto.

Para esses autores, um dos aprendizados para o planejamento estaria em trabalhar na forma de pacotes escalonados, com pequenas iniciativas que podem ser mais adequadas para desbloquear o potencial de locais. Essa abordagem muitas vezes inclui "estratégias deliberadas em torno de usos temporários que podem mudar a imagem e permitir estágios intercalados para sentir melhor a demanda da área" (BISHOP e WILLIANS, 2012, p. 102). Utilizações temporárias podem criar uma dinâmica urbana e a valorização de um lugar, tanto em aspectos de sociabilidade como de mercado, e podem até mesmo acelerar o seu eventual desenvolvimento "permanente", dando maior segurança para futuros investidores durante um processo mais complexo, como o de um masterplan urbano.

Nessa perspectiva, o planejamento urbano pode ser muito mais eficaz se permitir que o desenvolvimento ocorra em camadas ao longo do tempo. Para os autores, essa abordagem reconhece que, para implementar uma fase, deve-se deixar espaço para o impacto do projeto sobre a área circundante em fases subsequentes de um plano. Por isso, ter como método "táticas adaptativas", comuns aos projetos temporários, pode abrir novas oportunidades para se pensar em curto prazo, especialmente quando elas servem para criar um "ambiente de excitação, um destino e uma nova imagem para a localidade" (Bishop e Willians, 2012, p. 67). Segundo os autores, deve-se aproveitar essa energia e motivação para mudanças e observar o fenômeno como um "open-source de lugares" (BISHOP e WILLIANS, 2012, p. 104).

[3] BISSHOP, Peter; WILLIAMS, Lesley. The temporary city. Londres: Routledge, 2012.

[4] CASTELLS, Manuel. La ciudad informacional: tecnologías de la información, reestructuración económica y el proceso urbanoregional. Madri: Alianza Editorial, 1995. 
[5] A Sociedade em Rede. In: A Era da Informação: Economia, Sociedade e Cultura - Vol I. São Paulo: Paz e Terra, 1999.

[6] CERTEAU, Michel de. A invenção do cotidiano: Artes de fazer. 2. Ed. - Petrópolis: Vozes, 2014.

[7] CHASE, John, CRAWFORD, Margaret, KALISKI, John (Orgs.). Everyday Urbanism. Nova lorque: The Monacelli Press, 2008.

[8] DUARTE, Fábio. Crise das matrizes espaciais. São Paulo: Editora Perspectiva, 2002.

[9] HOU, Jeffrey, Insurgent Public Space. Nova lorque: Routledge, 2012.

[10] HARVEY, David. et al. Occupy. São Paulo: Boitempo Carta Maior, 2012.

[11] JACQUES, Paola Berestein (Org.). Apologia da deriva: escritos situacionistas sobre a cidade/Internacional Situacionista. Rio de Janeiro: Casa da Palavra, 2003.

[12] LEFEBVRE, Henri. A Produção do Espaço. Trad. Grupo "As (im)possibilidades do urbano na metrópole contemporânea”. Belo Horizonte, 2006, no prelo. (orig. 2000)

[13] A Revolução Urbana. White River: Chelsea Green Publishing, 2009.

[14] O Direito à Cidade. São Paulo: Editora Moraes, 1991

[15] LYDON, Mike.; GARCIA, Anthony. Tactical Urbanism: Short-term action for long-term change. Washington: Islandpress, 2015.

[16] PEIXOTO, Nelson Brissac. Artes cidades. São Paulo: Editora SENAC, 1997.
[17] REYES, Paulo Edison Belo. Quando a rua vira corpo [ou a dimensão pública na ordem digital]. São Leopoldo: Editora UNISINOS, 2005.

[18] ROCHA, Heliana Faria Mettig. O Lugar das Práticas Comunitárias Emergentes: Caminhos de Coexistência Socioecológica em Projetos Urbanos. (Tese de Doutorado em Arquitetura e Urbanismo) Faculdade de Arquitetura e Urbanismo da Universidade Federal da Bahia. Salvador, 2017.

[19] ROSA, Marcos.; WEILAND, Ute E. (Orgs.) Handmade Urbanism - From Community Initiatives to Participatory Models. 2a ed. Berlim: Jovis, 2014.

[20] ROSA, Marcos. Micro: Planejamento Práticas urbanas criativas (org). São Paulo: Editora de Cultura, 2011.

[21] From Modern Infrastructures to Operational Networks - The Qualification of Local Space at Existing Large Scale Utility Infrastructure: A Method for Reading Community-Driven Initiatives.ișpiThe Case of São Paulo (Tese de doutorado em Planejamento urbano e regional) Technische Universität München. Munique, 2016.

[22] SOLÀ-MORALES, Ignasi de. Territórios. Barcelona: Gustavo Gili, 2002.

[23] TITTON, Claudia Pauperio. Reestruturação produtiva e regeneração urbana: o caso do IV Distrito de Porto Alegre. Dissertação (Mestrado em Arquitetura e Urbanismo) - Universidade Presbiteriana Mackenzie, São Paulo, 2012.

[24] URBAN CATALYST. The Power of Temporary Use. Berlim: Dom Publishers, 2013.

[25] WHYTE, William H. The Social Life of Small Urban Spaces: Nova lorque: Project For Public Space, 1980. 


$$
\text { Alutary }
$$




\section{MARCO ANTÔNIO COUTO MARINHO (ORGANIZADOR)}

Possui graduação em Geografia pela Pontifícia Universidade Católica (2007), mestrado em Ciências Sociais pela Pontifícia Universidade Católica de Minas Gerais (2012) e doutorado em Ciências Sociais pela Pontifícia Universidade Católica/ Sanduíche/Universidade Nova de Lisboa (2016). Desde maio de 2017 realiza pósdoutorado na Universidade Estadual do Norte Fluminense Darcy Ribeiro, Projeto Mulheres na Pesca. Tem experiência no desenvolvimento de projetos de pesquisas no âmbito da Geografia e das Ciências Sociais, por meio de abordagens e metodologias variadas, com destaque á etnografia em espaços urbanos. De um modo geral, tem experiência em trabalhos relacionados aos seguintes temas: infância, adolescência, juventude, trabalho infantil e escravo, espaço urbano, metrópole, cultura e modos de vida, geografia social, etnografia urbana.

\section{ALBA VALERIA DE BARROS E SILVA PINHEIRO}

Graduada em arquitetura pela Universidade Federal de Pernambuco (1990), especialista em Programação de Ensino em Pedagogia pela Universidade de Pernambuco (1999), mestre em Engenharia Urbana pela Universidade Federal da Paraíba (2005) e doutoranda em Engenharia Civil, na área de Planeamento e Ordenamento do Território, pela Faculdade de Engenharia da Universidade do Porto, Portugal. Atualmente é docente do ensino básico, técnico e tecnológico do Instituto Federal do Sertão Pernambucano, na área de desenho técnico e arquitetura.

\section{AMANDA PEREIRA DE OLIVEIRA DINIZ}

Aluna do Curso de Arquitetura e Urbanismo da Universidade FUMEC

\section{BRUNA GARRITANO FERREIRA}

Estudante de Arquitetura e Urbanismo da Universidade Federal do Rio de Janeiro, integrante dos projetos de Extensão EMAU Abricó (Escritório Modelo de Arquitetura e Urbanismo) e "Entre Cidades de direito e Cidades de privilégio: disputando narrativas na Comunidade Indiana Tijuca" (IPPUR/NIAC/ABRICÓ/UFRJ). Estagiária do NAPP Núcleo de Assessoria, Planejamento e Pesquisa, trabalhando com ênfase em desenvolvimento local e articulação comunitária.

\section{CARLOS FREDERICO BOM KRAEMER}

Possui graduação em Ciências Econômicas pela Universidade Federal do Rio de Janeiro (2003), mestrado em Administração Pública pela Fundação Getúlio Vargas (2005) e doutorado em Ciência Tecnologia e Inovação em Agropecuária pela Universidade Federal Rural do Rio de Janeiro (2018). Atualmente é professor assistente da Universidade Federal Fluminense. Tem experiência na área de Administração, com ênfase em Administração Pública.

\section{CAROLINE GONCCALVES DOS SANTOS}

Arquiteta e Urbanista pela Universidade Federal de Alagoas (2009) e Doutora em Desenvolvimento Urbano pela Universidade Federal de Pernambuco (2017). É professora adjunta na Faculdade de Arquitetura e Urbanismo da Universidade Federal de Alagoas e pesquisadora no Observatório das Metrópoles - Núcleo Recife da Universidade Federal de Pernambuco. Tem experiência na área de Planejamento Urbano e Regional, atuando principalmente nos seguintes temas: política 
habitacional, financeirização do capital imobiliário e Grandes Projetos Urbanos (GPUs).

\section{CESAR AUGUSTO MIRANDA GUEDES}

Professor Titular da Universidade Federal Rural do Rio de Janeiro (UFRRJ, nos Programas de Pós-graduação em Desenvolvimento Territorial e Políticas Públicas (PPGDT) e no Doutorado Binacional em Ciência, Tecnologia e Inovações em Agropecuária (PPGCTIA). Graduado em Economia pela Universidade Federal Fluminense (UFF), Mestre em Engenharia de Produção pela Coordenação dos Programas em Pós Graduação em Engenharia na Universidade Federal do Rio de Janeiro (COPPE/UFRJ) e Doutor pela Escola de Administração de Empresas de São Paulo/Fundação Getúlio Vargas (EAESP/FGV). Pós-doutorado no Instituto Superior de Economia e Gestão da Universidade Técnica de Lisboa (ISEG/UTL).

\section{DANIEL LUCIANO GEVEHR}

Doutor em história (2007) pela Universidade do Vale do Rio dos Sinos (UNISINOS). Possui graduação em história (2000) e mestrado em história (2003) pela mesma Universidade. Autor da Tese Pelos Caminhos de Jacobina: memórias e sentimentos (res)significados, aprovada com grau máximo pela banca examinadora. É Professor Titular II, do Programa de Pós-graduação em Desenvolvimento Regional (PPGDR FACCAT), onde também atua como Líder do Grupo de Pesquisa (CNPq) Instituições, Ordenamento Territorial e Políticas Públicas para o Desenvolvimento Regional.

\section{DINÁ ANDRADE LIMA RAMOS}

É economista pela UFRRJ, mestre em Estudos Populacionais e Pesquisas Sociais pela Escola Nacional de Ciências Estatísticas (ENCE)/IBGE, demografia, Professora Adjunta da UFRRJ, doutoranda em Políticas Públicas no PPGCTIA/UFRRJ, Tem experiência na área de Teoria Econômica, Demografia, Política Pública Territorial Rural, atuando nos seguintes temas: Políticas Públicas, Gestão Social, Desenvolvimento Territorial Rural Sustentável e articulação entre atores locais. Pesquisadora do Programa de Ensino Pesquisa e Extensão em Desenvolvimento territorial e politicas públicas PEPEDT/ICSA/UFRRJ.

\section{ENEIDA DE ALMEIDA}

Professora da Universidade São Judas Tadeu em Regime de Tempo Integral, atua na Graduação e no Mestrado Stricto Sensu em Arquitetura e Urbanismo. Possui doutorado em Arquitetura e Urbanismo pela Faculdade de Arquitetura e Urbanismo da Universidade de São Paulo, FAUUSP (2010), Mestrado em Studio e Restauro dei Monumenti - Università degli Studi di Roma La Sapienza (1987) e Graduação em Arquitetura e Urbanismo pela Universidade de São Paulo, FAU-USP (1981). É coeditora da revista eletrônica arq.urb, do PGAUR/USJT.

\section{ESTHER APARECIDA CERVINI}

Arquiteta, urbanista e artista plástica atuante em São Paulo e Minas Gerais. Graduada em Arquitetura e Urbanismo pela PUC Campinas (1989), mestre em Artes Visuais pelo IA UNESP (1996) e doutoranda em Urbanismo pela PUC Campinas (desde 2016). É docente do Curso de Arquitetura e Urbanismo da PUC Minas campus Poços de Caldas desde 1999, tendo particular interesse sobre teoria da arquitetura e 
paisagem cultural. Atua como profissional liberal em seu próprio Atelier de Arquitetura desde 2010 em Poços de Caldas, MG. Como artista desenvolve vários trabalhos de desenho e pintura participando de exposições individuais e coletivas.

\section{FABIANA ALVES MONTEIRO}

Doutranda em Geografia pela Universidade Federal do Paran. á, Mestrado em Geografia pela Universidade Federal do Paraná, UFPR (2016). Graduação em Bacharelado em Geografia. Universidade Federal do Paraná, UFPR, Curitiba, Brasil.

\section{FERNANDO CESAR NEGRINI MINTO}

Arquiteto e Urbanista, graduado pela FAU UNIMEP. Mestre em Arquitetura e Urbanismo pela FAU-USP, e Doutorando pela FAU UFRJ-PROARQ. É professor na Universidade Santa Úrsula onde coordena o CANTEIRO EXPERIMENTAL e o ateliê Terra/tradição. Atua como arquiteto e urbanista em escritório próprio desde 2001. Foi associado da assessoria técnica USINA de 2006 a 2013. Pesquisador da RED iberoamericana PROTERRA e da rede TerraBrasil. Pesquisador do Laboratório de Culturas Construtivas do Canteiro Experimental Antônio Domingos Battaglia. Atualmente dirige o escritório Matéria Base Arquitetura e Urbanismo e compõe o Coletivo CATÁLISE de Assessoria Técnica no Rio de Janeiro. Atuações principais: tecnologia da construção, habitação de interesse social e arquitetura com terra crua.

\section{FERNANDO MANUEL BRANDÃO ALVES}

Arquiteto. Mestre e Doutor em Planeamento Regional e Urbano pela Universidade de Lisboa. Professor Associado com Agregação, na Faculdade de Engenharia da Universidade do Porto. Investigador sénior do CITTA / Centro de Investigação do Território, Transportes e Ambiente. Membro do Conselho de Departamento de Engenharia Civil. Diretor de Curso de Mestrado em Planeamento e Projecto Urbano FEUP / FAUP. Membro da Comissão Cientifica Estudos Avançados em Reabilitação do Património Edificado. Diretor de Laboratório Planeamento (SPTA-FEUP). Coordenador da Secção de Planeamento do Território e Ambiente (FEUP). Autor e editor de vários livros e artigos científicos publicados em Portugal e no estrangeiro.

\section{FLÁVIO ANTONIO MIRANDA DE SOUZA}

Professor Titular do Departamento de Expressão Gráfica e Professor permanente do Programa de Pós-graduação em Desenvolvimento Urbano (MDU) da Universidade Federal de Pernambuco. Arquiteto e Urbanista pela Universidade Federal de Pernambuco (1990), Mestre em Desenho Urbano pela Oxford Brookes University (1994) e Doutor em Planejamento Urbano pela Oxford Brookes University (1998), possui pós-doutorado em políticas públicas na University of Texas at Austin (2002). Tem experiência na área de Planejamento Urbano e Regional, atuando principalmente nos seguintes temas: políticas públicas, habitação urbana de interesse social, arranjos institucionais e gestão pública, desenvolvimento sustentável, e posse da terra.

\section{FREDERICO PAPALI}

É graduado em Artes Visuais pela Universidade do Vale do Paraíba - Univap e tem Mestrado pelo Programa de Pós-Graduação - Planejamento Urbano e Regional do Instituto de Pesquisa e Desenvolvimento - IP\&D - Univap. 


\section{GABRIEL MAGALHÃES RODRIGUES}

Graduado em Ciências Econômicas pela Universidade Federal de Viçosa (2016), Mestre em Desenvolvimento Territorial e Políticas Públicas pela Universidade Federal Rural do Rio de Janeiro (2018). Tem experiência na área de Economia, atuando principalmente nos seguintes temas: políticas públicas; economia regional/rural; desenvolvimento econômico e territorial; associativismo; economia solidária e cooperativismo.

\section{GERMANA KONRATH}

Arquiteta e urbanista, graduou-se na UFRGS com indicação ao prêmio nacional Opera Prima, em 2008. É doutoranda do PROPUR - UFRGS, onde pesquisa o tempo na prática de projeto urbano. Mestra pelo mesmo programa, teve sua dissertação indicada para publicação, com investigação acerca das contribuições da arte contemporânea para o espaço público urbano. Sua atuação acadêmica e profissional ocorre na intersecção entre arte e cidade. Foi gestora cultural da Fundação Iberê Camargo, de 2014 a 2017. Trabalhou em 6 edições consecutivas da Bienal do Mercosul, destacando-se a coordenação da equipe de museografia da $7^{\text {a }}$ Bienal e a coordenação de produção executiva da $8^{\underline{a}}$ e da $9^{\underline{a}}$ bienais, ao lado de André Severo. Em paralelo, realizou projetos expográficos, de produção executiva e de arquitetura em todo território nacional.

\section{GUILHERME MENDES TENÓRIO}

Formado em História pela Universidade Federal Fluminense (2006), com Especialização em Ensino de História e Ciências Sociais pela mesma instituição. Possui Mestrado em História pela Universidade do Estado do Rio de Janeiro (2009) e Doutorado em História pelo Centro de Pesquisa e Documentação em História Contemporânea do Brasil (2014). Atualmente faz estágio pós-doutoral na PósGraduação em Desenvolvimento e Território da Universidade Federal Rural do Rio de Janeiro e é docente da rede municipal de Duque de Caxias.

\section{HELEN RIBEIRO RODRIGUES}

É graduada em Arquitetura e Urbanismo pela Universidade Federal de Viçosa (2014) e mestre em Arquitetura e Urbanismo (2017) pela mesma instituição. Atualmente é professora substituta no CEFET-MG - Campus Varginha, onde leciona disciplinas para educação profissional e tecnológica e graduação. Tem experiência na área de Arquitetura e Urbanismo, com ênfase em Planejamento Urbano e Regional, atuando principalmente nos seguintes temas: cidades médias, produção do espaço urbano e regional, política urbana, Sistemas de Informações Geográficas e projeto arquitetônico, urbanístico e de habitação.

\section{HIEDA MARIA PAGLIOSA CORONA}

Possui graduação em Ciências Sociais pela Universidade Federal do Paraná (1981), mestrado em Sociologia pela Universidade Federal do Paraná (1999), doutorado em Meio Ambiente e Desenvolvimento pela Universidade Federal do Paraná (2006), pósdoutorado em Desenvolvimento socioambiental pelo Ladyss/Paris X (2012) e pósdoutorado em Desenvolvimento rural pelo PGDR/UFRGS (2013). Professora Permanente e Bolsista-sênior (Fundação Araucária/SETI/PR e Capes) do Programa de Pós-graduação em Desenvolvimento Regional (PPGDR) da Universidade Tecnológica Federal do Paraná (UTFPR). Professora permanente do Programa de Pós-graduação 
em Políticas Sociais e Dinâmicas Regionais da Unochapecó. Editora da Revista Desenvolvimento e Meio Ambiente da UFPR. Lidera o grupo de pesquisa CEPAD/UTFPR - Centro de Pesquisa e Apoio ao Desenvolvimento Regional. Tem experiência na área de Sociologia, atuando principalmente nos seguintes temas: sociologia ambiental, sociologia rural, desenvolvimento socioambiental, interdisciplinaridade.

\section{HUANI QUINTANILHA FELINTO}

Estudante em arquitetura e urbanismo na FAU-UFRJ de 2012 a 2017 e membro do Abricó - Escritório Modelo de Arquitetura e Urbanismo da UFRJ, desde sua reativação em 2013. Atualmente integrante do corpo discente do BASEhabitat na Kunstuniversität Linz. Objetiva contribuir com a produção de arquitetura e urbanismo ambientalmente sustentável e socialmente justa, através da abordagem holística e processos colaborativos.

\section{JACQUES ANDRE GRINGS}

Mestre em Desenvolvimento Regional - FACCAT. Bacharel em Administração de Empresas - FACCAT. Especialista em Mídias na Educação pelo Instituto Federal Rio Grandense - IF SUL. Especialista em Educação a Distância com ênfase na docência e tutoria em EaD pela Pontifícia Universidade Católica do Rio Grande do Sul PUC/RS.

\section{JANE VICTAL FERREIRA}

Professora Titular do Programa de Pós-Graduação em Urbanismo (POSURB PUCCampinas) onde integra as Linhas de Pesquisa Teoria, História e Crítica da Arquitetura e Urbanismo e Projeto, Inovação e Gestão em Arquitetura e Urbanismo da Faculdade de Arquitetura e Urbanismo da Pontifícia Universidade Católica de Campinas. É graduada em Arquitetura e Urbanismo pela Pontifícia Universidade Católica de Campinas (1982), mestre e doutor em Arquitetura e Urbanismo pela Universidade de São Paulo (1999), Pós-Doutorado na King's College London (2016). É consultora ad hoc da FAPESP e CAPES. Foi tutora do Programa de Educação Tutorial (PET) da Secretaria de Educação Superior (Sesu) e interlocutora institucional do mesmo programa, unidade do Ministério da Educação (MEC). Coordenou o Centro Audiovisual (CAV) e o Centro de Documentação (CeDoc) do Centro de Ciências Exatas, Ambientais e de Tecnologias (CEATEC PUC-Campinas). Foi Editor e membro do Conselho Editorial da Revista Oculum Ensaios.

\section{JANE VICTAL FERREIRA}

Professora Titular do Programa de Pós-Graduação em Urbanismo (POSURB PUCCampinas) onde integra as Linhas de Pesquisa Teoria, História e Crítica da Arquitetura e Urbanismo e Projeto, Inovação e Gestão em Arquitetura e Urbanismo da Faculdade de Arquitetura e Urbanismo da Pontifícia Universidade Católica de Campinas. É graduada em Arquitetura e Urbanismo pela Pontifícia Universidade Católica de Campinas (1982), mestre e doutor em Arquitetura e Urbanismo pela Universidade de São Paulo (1999), Pós-Doutorado na Kings College London (2016). É consultora ad hoc da FAPESP e CAPES. Foi tutora do Programa de Educação Tutorial (PET) da Secretaria de Educação Superior (Sesu) e interlocutora institucional do mesmo programa, unidade do Ministério da Educação (MEC). Coordenou o Centro Audiovisual (CAV) e o Centro de Documentação (CeDoc) do Centro de Ciências 
Exatas, Ambientais e de Tecnologias (CEATEC PUC-Campinas). Foi Editor e membro do Conselho Editorial da Revista Oculum Ensaios. Áreas de atuação: Arquitetura e Urbanismo, História Urbana, Patrimônio Cultural, Teoria da Urbanização e Urbanismo Contemporâneo.

\section{JORGE MONTEIRO JUNIOR}

Aluno do Curso de Arquitetura e Urbanismo da Universidade FUMEC

\section{JOZIELI CAMILA CARDENAL}

Jornalista, professora e mestre em Desenvolvimento Regional, pela Universidade Tecnológica Federal do Paraná - UTFPR, com ênfase em Educação e Desenvolvimento (2018). Sua dissertação associa estudos da linguística à concepção do espaço público urbano, demonstrando a materialidade de discursos e a construção social de enunciados. Para tanto, se baseia na teoria da análise dialógica do discurso de Mikhail Bakhtin. Graduada em Comunicação Social, com habilitação em Jornalismo pela Faculdade de Pato Branco - FADEP (2010), é especialista (pósgraduação) em História, Arte e Cultura, pela Universidade Estadual de Ponta Grossa UEPG (2013). Na graduação e na especialização, desenvolveu estudos sobre a manifestação da contracultura em mídias alternativas. Possui, ainda, pós-graduação em Docência no Ensino Superior, pela Faculdade de Pato Branco - FADEP (2018). É membro e pesquisadora do grupo de pesquisa UTFPR-CNPq Linguagem, Atividade e Desenvolvimento Humano (LAD’Humano), coordenado pelo professor doutor Anselmo Pereira de Lima, seu orientador na dissertação de mestrado. Atua como docente titular na Faculdade de Pato Branco - FADEP, no curso de Comunicação Social - Habilitação em Publicidade e Propaganda, em disciplinas que abordam o processo criativo na publicidade, a linguagem na Web, cibercultura, história da comunicação e a produção teórica de trabalhos de conclusão de curso. $\mathrm{Na}$ área da Comunicação, sua atuação enquanto jornalista possui ênfase em assessoria de imprensa e redes sociais.

\section{JUARÊS JOSÉ AUMOND}

Graduado em geologia pela UFRGS; Mestre em geografia pela UFSC; Doutor em Engenharia Civil pela UFSC. Foi diretor técnico de várias empresas privadas de mineração. É especialista e consultor em economia mineral e recuperação de áreas degradadas. Têm publicado uma centena de artigos científicos e capítulos em livros, revistas, congressos e simpósios nacionais e internacionais. Atualmente: Professor da FURB - Fundação Universidade Regional de Blumenau no Doutorado em Desenvolvimento Regional onde leciona as disciplinas Meio Ambiente, Sociedade e Desenvolvimento, Planejamento Urbano e Recuperação de Áreas Degradadas. É pesquisador do Paleoclima e vem estudando e desenvolvendo projetos sobre os impactos das Mudanças Climáticas sobre a sociedade.

\section{JULIANA LAMEGO BALBINO NIZZA}

Mestre em Direito Empresarial. Professora dos Cursos de Engenharia Civil e Engenharia de Produção Civil da Universidade FUMEC 


\section{JULIANA MICHAELLO MACEDO DIAS}

Possui graduação em Arquitetura e Urbanismo pela Universidade Federal de Alagoas, Mestrado em Dinâmicas do Espaço Habitado pelo DEHA/UFAL e Doutorado pelo Instituto de Pesquisa e Planejamento Urbano e Regional (IPPUR) da Universidade Federal do Rio de Janeiro. Professora da Faculdade de Arquitetura e Urbanismo FAU/UFAL. Professora do Programa de Pós-Graduação em Arquitetura e Urbanismo da Faculdade de Arquitetura e Urbanismo da UFAL (PPGAU/FAU/UFAL). Líder do Grupo de Pesquisa Nordestanças (GPN/FAU/UFAL). Coordenou os projetos de pesquisa "Culturas Agrestes: Mapeamento das referências Culturais do Agreste alagoano", financiado por Edital Universal/CNPq (2013-2016) e "Projeto de Salvaguarda do Patrimônio Imaterial de Alagoas", financiado pelo Instituto Histórico e Artístico Nacional (IPHAN) (2015-2017) e o Projeto "Arquitetura enquanto Referência Cultural" (PIBIC-206-2017). Atualmente coordena o projeto "Feiras populares como territórios de persistência: o caso das feiras do bairro da Levada, Maceió-AL" (PIBIC2018-2019). Participou como pesquisadora do projeto de pesquisa "Mapeamento sonoro do sertão alagoano", financiado pelo Edital Universal FAPEAL 13/2016 e é pesquisadora do projeto "Sons da Feira" (PIBIC-2018-2019). Trabalha com projetos de extensão em Políticas públicas da Cultura e Relações entre Cinema e Arquitetura. Organizadora do livro "Letras projetadas sobre fundo em movimento: palavras que dizem cinema" (2014). Diretora de arte dos documentários etnográficos: "A Lapinha de Dudé" , "A saga do menino Canta", "Cavalhadas de Alagoas" e "Carreadas" e da série Cadernos de Viagem: Índia, Austrália, Nova Zelândia, Leste Europeu, Turquia e Nepal. Atua nas seguintes linhas de pesquisa: Cultura, Identidade e Imagem; Identidade, território e poder; Metodologia de mapeamentos culturais e Políticas públicas da cultura. Site do Grupo de Pesquisa: https://www.gpnordestancas.com/

\section{LAMOUNIER ERTHAL VILLELA}

Pós-doutor em Administração Pública - EBAPE/FGV, 2011, Doutor em Economia Aplicada pela Université Paris III (Sorbonne Nouvelle), 1999, Mestre em Planejamento Energético pela COPPE/UFRJ, DEA pela Université de Grenoble II. Professor Adjunto do Departamento de Economia do Instituto de Ciências Sociais Aplicadas - ICSA, Professor permanente do Programa de Pós-Graduação em Desenvolvimento Territorial e Políticas Públicas- PPGDT e Professor permanente do Doutorado em Ciência, Tecnologia e Inovação em Agropecuária - PPGCTIA da Universidade Federal Rural do Rio de Janeiro - UFRRJ. Pesquisa, pública e orienta teses e dissertações focadas nas temática de políticas públicas, ações e governança participativa, redes, gestão social, controle social, desenvolvimento local e territorial sustentável. Experiência acadêmica e profissional como coordenador de programa de pósgraduação; stricto sensu, editoria de revistas científicas. Atual editor da Revista CSDT-Controle Social e Desenvolvimento Territorial. Pesquisador do projeto Prointegração da CAPES coordenado pelo PEGS/EBAPE/FGV. Coordenador do projeto Chamada CNPq/MDA/SPM-PR № 11/2014 - Núcleos de Extensão em Desenvolvimento Territorial da Baia da Ilha Grande- RJ Líder de grupo de pesquisa no CNPq- LPDT- Laboratório de Pesquisa em Desenvolvimento territorial e politicas Desenvolve atividades de extensão universitária em projeto de transferência de tecnologias sociais financiado pela FAPERJ. Membro Associado da Rede Nacional de Pesquisadores em Gestão Social - RGS e da RETE. Coordenador do PEPEDT Programa de Ensino Pesquisa e Extensão em Desenvolvimento Territorial e Políticas Públicas 


\section{LÍVIA MASCHIO FIORAVANTI}

Mestre em Geografia Humana pela Universidade de São Paulo (USP). Bacharel e Licenciada em Geografia pela Universidade de São Paulo. Foi bolsista da Fundação de Amparo à Pesquisa do Estado de São Paulo (Fapesp) durante a graduação e o mestrado. Realizou estágio de pesquisa no exterior no Institut des Hautes Études de IAmérique Latine (Université Sorbonne Nouvelle - Paris). Pesquisadora do Laboratório de Geografia Urbana (Labur) do Departamento de Geografia da USP, estuda, principalmente, temas de Geografia Urbana, como produção do espaço, cidade, urbano, urbanização, diferenciação e segregação socioespaciais. Desde 2014, é doutoranda em Geografia Humana pela USP e docente no Instituto Federal de Mato Grosso (IFMT).

\section{MALU FRANÇA DE MIRANDA}

Estudante em arquitetura e urbanismo na FAU - UFRJ de 2013 a 2017, onde fez parte do Escritório Modelo de Arquitetura e Urbanismo Abricó e integrou o Grupo de Pesquisa Modernidade e Cultura no IPPUR. Hoje estuda na Ecole Nationale Superieure d'Architecture de Strasbourg onde escreve sobre dispositivos de inserção urbana. Estagia no Conseil d'Architecture, d'Urbanisme et de l'Environnement du BasRhin, trabalhando com ênfase em comunicação na relação arquiteto-população.

\section{MARCIO SILVA BORGES}

Doutor em Ciência Tecnologia e Inovação em Agropecuária pela Universidade Federal Rural do Rio de Janeiro - UFRRJ (2014) e Pós-Doutor em Administració d'Empreses i Gestió Econòmica dels Recursos Naturals pela Universitat de Lleida UdL (2018). Professor adjunto no Departamento de Administração e Turismo DAT/UFRRJ e no Programa de Pós-Graduação em Desenvolvimento Territorial e Políticas Públicas - PPGDT/UFRRJ. Tem experiência nos temas de Responsabilidade Social Empresarial, Estratégia Empresarial e Desenvolvimento Rural.

\section{MARIA CAROLINA MAZIVIERO}

Professora em Regime de Dedicação Exclusiva do Departamento de Arquitetura e Urbanismo da Universidade Federal do Paraná - UFPR. Graduada em Arquitetura e Urbanismo pela Universidade Estadual de Londrina (UEL/2003), especialista pela Universidade Católica de Santos - UNISANTOS (2005), mestre (2008) e doutora (2013) em Arquitetura e Urbanismo pela Universidade de São Paulo, FAUUSP, com estágio doutoral no Institute of Urban and Regional Development da Universidade da Califórnia, Berkeley. É pesquisadora do Laboratório de Habitação e Urbanismo (LAHURB/UFPR) e do Grupo Cidade, Meio Ambiente e Políticas Públicas (CIMAPP/UFPR), realizando pesquisa sobre ativismo urbano e insurgências no processo de produção e apropriação do espaço urbano.

\section{MARIA PAULA ALBERNAZ}

Docente do Programa de Pós-Graduação em Urbanismo da Faculdade de Arquitetura e Urbanismo da Universidade Federal do Rio de Janeiro PROURB/FAU/UFRJ e do Departamento de Urbanismo e Meio Ambiente do curso de graduação desta mesma Faculdade. Doutora em Geografia pelo Programa de PósGraduação em Geografia, do Instituto de Geociências da UFRJ. Mestre em Planejamento Urbano e Regional pela UFRJ, e arquiteta pela FAU-UFRJ. Autora de livros sobre história urbana, manuais de arquitetura e urbanismo e um dicionário 
ilustrado de arquitetura. Atualmente leciona em disciplina em ateliê integrado de projeto urbano; desenvolve pesquisa sobre morfologia urbana no Rio de Janeiro e projeto de extensão voltada à valorização e desenvolvimento dos subúrbios cariocas.

\section{MARIANA GALACINI BONADIO}

Arquiteta e Urbanista pela Universidade Federal do Paraná, especialista em Epistemologias do Sul pela Clacso/Ces e Mestra em Sustainable Territorial Development pelo Consortium EMStede (UNIPD; K.U. Leuven; Paris 1 - Sorbonne e UCDB). Com investigações voltadas aos temas de produção do urbano, principalmente às teorias do planejamento em suas dimensões ético-políticas, articuladas por perspectivas feministas, pós-estruturalista e decolonial.

\section{PAULA VILHENA CARNEVALE VIANNA}

É graduada em Medicina pela Universidade Federal de São Paulo (1991), com mestrado em Infectologia pela Universidade Federal de São Paulo (1997) e doutorado em Medicina (Medicina Preventiva) pela Universidade de São Paulo (2004. Atuou na área de Saúde Coletiva no planejamento e organização de serviços de saúde, tanto públicos quanto privados e dedica-se ao estudo da relação saúde/cidade.

\section{PAULO EDISON BELO REYES}

Possui Graduação em Arquitetura e Urbanismo pela UniRitter (1987), Especialização em Design Estratégico pela Unisinos (2008), Mestrado em Planejamento Urbano pela UnB (1992) e Doutorado em Ciências da Comunicação pela Unisinos e pela Universidade Autonoma de Barcelona em um doutorado sanduiche (2004). Foi Coordenador do Curso de Arquitetura e Urbanismo da Unisinos e do Mestrado em Design da Unisinos. Atualmente é Professor Adjunto da Faculdade de Arquitetura da UFRGS no departamento de Urbanismo. É professor e pesquisador no Programa de Pós-Graduação em Planejamento Urbano e Regional PROPUR/UFRGS. Foi Coordenador do PROPUR (Gestão 2016-2018). É consultor ad-hoc da CAPES.

\section{PAULO SANTOS CONCEIÇÃO}

Doutor em Engenharia Civil, pela Universidade do Porto. Professor Auxiliar na Faculdade de Engenharia da Universidade do Porto, Secção de Planeamento do Território e Ambiente do Departamento de Engenharia Civil. Investigador e Secretário do CITTA - Centro de Investigação do Território, Transportes e Ambiente, sendo membro do grupo de investigação sobre planeamento urbano e habitação. Desenvolve investigação no campo das políticas de habitação.

\section{REGINALDO MAGALHÃES DE ALMEIDA}

Doutor em Arquitetura e Urbanismo. Professor dos Cursos de Arquitetura e Urbanismo, de Engenharia Ambiental e Engenharia Civil da Universidade FUMEC

\section{RENATA BAESSO PEREIRA}

Professora Titular da Pontifícia Universidade Católica de Campinas - SP, Membro do corpo docente permanente do Programa de Pós Graduação em Urbanismo (POSURB PUC - Campinas, desde 2012) e da Faculdade de Arquitetura e Urbanismo (FAU PUC Campinas, desde 2008). Membro do grupo de pesquisa "História das Cidades: 
Ocupação Territorial e Ideários Urbanos" do CEATEC PUC Campinas. Doutora pelo Programa de Pós Graduação da FAU USP na área de concentração de História e Fundamentos da Arquitetura e do Urbanismo (2008), mestre em Urbanismo pela Pontifícia Universidade Católica de Campinas (2000) e graduada na Escola de Arquitetura da Universidade Federal de Minas Gerais (1994).

\section{RODRIGO VITORINO ASSUMPÇÃO}

Arquiteto e Urbanista formado desde 2001. Possui Mestrado e Doutorado em Urbanismo pela PucCampinas . Lecionar nas disciplinas de projeto arquitetônico e desenho urbano nas instituições Universidade Cidade de São Paulo ( Unicid) e na FIAM-FAAM Centro Universitário. Atualmente também trabalha com projetos de arquitetura e design de interiores.

\section{SAMARA BRAUN}

Arquiteta Urbanista; MBA em Gestão Pública; Mestre em Desenvolvimento Regional pela FURB - Fundação Universidade Regional de Blumenau Atualmente é Arquiteta Urbanista da Secretaria de Planejamento Urbano e Desenvolvimento Sustentável da Prefeitura de Joinville

\section{SHIRLEI ALEXANDRA FETTER}

Aluna integrante do Projeto de Educação Continuada vinculado ao PPGEDU-UFRGS. Possui Mestrado em Desenvolvimento Regional Pelas Faculdades Integradas de Taquara - FACCAT. Especialização em Mídias na Educação-Instituto Federal de Educação, Ciência e Tecnologia Sul-rio-grandense - IFSUL (2015). Especialização em Gestão Educacional, com ênfase em Orientação e Supervisão Pelas Faculdades Integradas de Taquara - FACCAT (2014). Graduação em Pedagogia Pelas Faculdades Integradas de Taquara - FACCAT (2012).

\section{TERESA CRISTINA DE ALMEIDA FARIA}

Possui graduação em Arquitetura e Urbanismo pela Universidade Santa Úrsula (1983); mestrado (1997) e doutorado (2004) em Planejamento Urbano e Regional pelo Instituto de Pesquisa e Planejamento Urbano e Regional - IPPUR/UFRJ. Atualmente é professora do Departamento de Arquitetura e Urbanismo da Universidade Federal de Viçosa/MG, atuando na graduação e na pós-graduação. Desenvolve pesquisa e extensão na área de Planejamento Urbano e Regional, com foco nos seguintes temas: Política Urbana, habitação, estruturação intra-urbana, mobilidade residencial, irregularidade fundiária e segregação espacial.

\section{TIAGO BALEM}

Graduado em Arquitetura e Urbanismo pelo Uniritter (2004). Mestre em Design pela Unisinos (2010), quando teve sua dissertação premiada e publicada pelo Fumproarte. Doutorando em Planejamento Urbano pelo PROPUR/UFRGS (2016). Foi aluno e ministrante de extensão universitária do International Summer School ? CREED COOPERATION, na Alemanha. É professor de Projeto Arquitetônico na Universidade Feevale. Atua em seu escritório em projetos de arquitetura, expografia e memória. 
É historiadora, graduada pela UFOP (Universidade Federal de Ouro Preto), mestre em História Social pela PUC/RS, doutora em História Social pela PUC/SP, autora do livro Cidade e Identidade: "São José dos Campos, do peito e dos ares". São Paulo: Annablume, 2010; professora do curso de História da Universidade do Vale do Paraíba, membro do Laboratório de Pesquisa e Documentação Histórica do IP\&D; é vinculada ao Grupo de Documentação Histórica (Gedoch) da Univap, docente do Programa de Mestrado em Planejamento Urbano e Regional da Univap.

\section{WALCLER DE LIMA MENDES JUNIOR}

Jornalista, documentarista e músico. Graduado em comunicação Social, Jornalismo, Mestre e Doutor em Planejamento Urbano e Regional pelo IPPUR/UFRJ. Professor de Programa de Pós-Graduação Pleno I 1 (Professor PPG Pleno I 1) no Programa de Pós-graduação em Sociedade, Tecnologias e Políticas Públicas do Centro Universitário Tiradentes. Líder do Grupo de Pesquisa Nordestanças da UFAL, onde atuou como pesquisador do Projeto Universal/CNPQ, Mapeamento do Patrimônio Cultural do Agreste Alagoano e do Projeto de salvaguarda do patrimônio imaterial de Alagoas, financiado pelo Instituto do Patrimônio Histórico e Artístico Nacional - IPHAN entre os anos de 2015 e 2017. Autor dos livros: Brinquedos, rezas e trovas de Alagoas (2017), Rasuras e refrões: Derrida e Deleuze entre bambas, matutos e foliões (2015), O Sujeito arquiautor: conflitos do discurso urbano e midiático (2011). Organizador dos livros: Interreferências, referências culturais em perspectiva (2017) e Letras projetadas sobre fundo em movimento: palavras que dizem cinema (2014). Diretor dos documentários etnográficos: Carreadas (2017); Cavalhadas de Alagoas (2016) Cadernos de Viagem: Nepal (2015), A Lapinha de Dudé (2013), A saga do menino Canta (2012), Cadernos de Viagem: Índia (2012), Cadernos de Viagem: Austrália e Nova Zelândia (2010), Cadernos de Viagem: Leste Europeu e Turquia (2011), Quilombolas da Marambaia (2004). Site: http://gpnordestancas.com. Área de interesse em Etnomusicologia, Cinema, Antropologia da Imagem, Análise do Discurso, Cultura, Regionalismo e Urbanismo. 


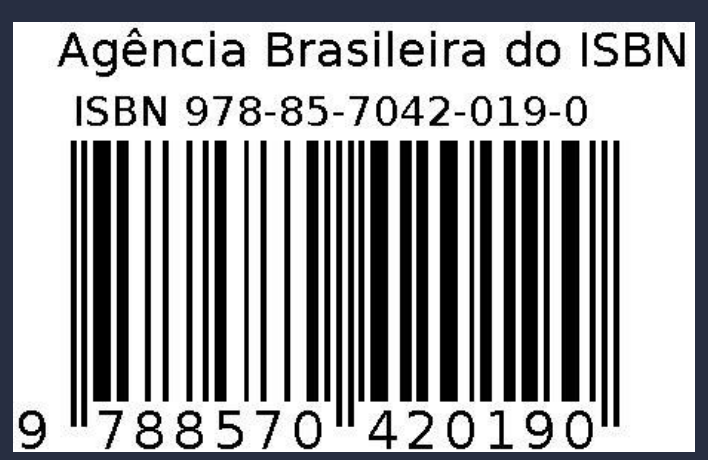

